


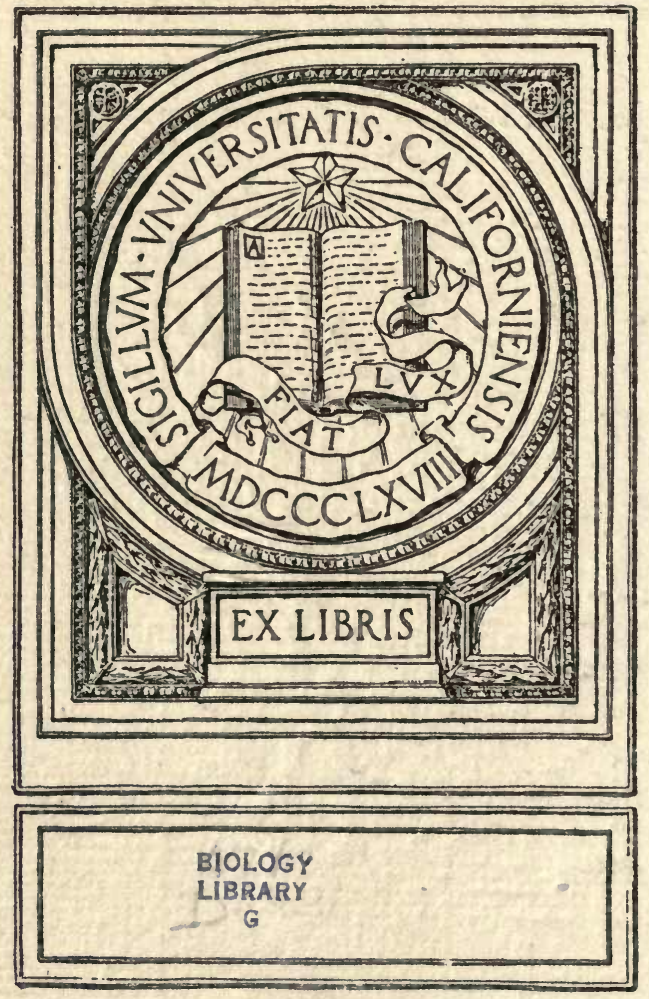






\section{BRITISH ANTS,}

THEIR LIFE-HISTORY AND CLASSIFICATION.

BY

H. Sт. J. K. DONISTHORPE, F.Z.S., ETC.

LATE VICE-PRESIDENT OF THE ENTOMOLOGICAL SOCIETY OF LONDON.

With 18 Plates and 92 Diagrams.

PLYMOUTH :

WILLIAM BRENDON AND SON, LIMITED.

1915. 


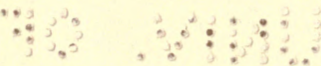

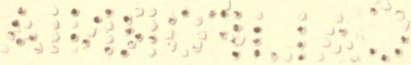


DEDICATED

AS A TOKEN OF ESTEEM AND FRIENDSHIP

To

WILLIAM MORTON WHEELER

Ph.D., Professor of Economic Entomology Harvard University, U.S.A. 


\section{PREFACE.}

THE study of British ants has long been retarded by the want of a comprehensive work. In spite of the great and admitted fascination of the subject very few books have been devoted to it, and of these not one attempts to deal with the whole subject. It is with the object of supplying this long-felt want that the present volume has been written.

The Rev. W. Gould, who may justly be called the Father of British Myrmecology, published a little book-"An Account of English Ants" - in 1747. Although this is of great interest-both as a curiosity and also for the really admirable account of some habits of a few British ants-the author only knew five species, and of course a vast amount of information has accumulated since his time. Lord Avebury's well-known work on "Ants, Bees and Wasps" (1882), which includes most of his earlier papers on these insects, is, as regards ants, almost restricted to experiments on behaviour.

The Rev. Farren-White's small popular book, "Ants and Their Ways" (1883), which touches on ants in general, gives a number of useful notes on British species, but it is neither very scientific nor accurate.

Finally Edward Saunders in his admirable Hymenoptera Aculeata (1896), devoted some twenty-six pages to the British ants. The treatment is almost entirely systematic and naturally after the lapse of so many years requires bringing up to date.

This brief list shows how great is the need for a work which will include all that is now known on our ant fauna.

Such a work I have endeavoured to write, and as I have been studying the habits of ants for over twenty years, have taken all our British species, and have kept most of them in captivity, I feel in some measure justified in undertaking the task.

Scattered throughout and often buried in our literature, are 
large numbers of notes and papers dealing with ants. It would be astonishing if this were not so, considering the deep and wide interest attached to these insects-morphologically, as well as physiologically, bionomically and psychologically. These notes and papers I have endeavoured as far as possible to collect and make available for the reader. This task has indeed been somewhat of a difficulty, and it would have been easier for me to write and possibly more interesting for the student to read, if a continuous account had been given of the habits, etc., of our species as known to me, instead of a narrative continually interrupted by references and by quotations from the records of other writers.

I was at first tempted to adopt the former method, but on reflection it seemed obviously necessary in a scientific work to pay due attention to the historical aspect of the subject.

The facts recorded by Continental and American Myrmecologists on British species which also form part of their fauna have been largely drawn upon in the preparation of the present work. The geographical distribution in Britain is in all cases given as fully and as carefully as $I$ have been able to ascertain it from published records or from personal observation. It is to be hoped that our knowledge of this distribution will be greatly extended when further workers are induced to study these most interesting insects.

With regard to the references quoted in the synonymy-I have mentioned every name that I have found applied to each species of ant, but have not attempted to quote every reference that has been made to them. It appeared better to restrict the synonymic references to the more important notices; for, as has already been explained, there is also a vast mass of quotations and references in the text. Some slight conception of the vastness of the general literature on ants may be gathered from a mere perusal of the references, both synonymic and text, that are to be found in the following pages.

An almost complete list of this literature, up to 1908, will be found in Wheeler's charming book, "Ants, Their Structure, Development and Behavior" (New York, 1910).

In the present work the native genera and species are almost invariably described from a long series of British specimens-my own captures. To this account the full original description is always added in the language of the describer. 
It has been, of course, impossible to describe the introduced species, or to quote many of the references to them; for otherwise this book would have become inordinately long. For the same reason I have for the most part contented myself with a list of the myrmecophiles (other insects, etc.) found with each species of ant. At some future date I hope to write a companion volume entirely devoted to the British myrmecophilous fauna.

A list-as complete as I have been able to make it-of the literature dealing with British ants is printed at the end of the book. This list also includes papers on myrmecophiles, as from these latter I have largely obtained information on the distribution of their ant-hosts. Other notes on ants contained in papers on Hymenoptera, and Entomology generally, will be found in the references under each species.

It may be stated that I have personally verified every reference given in this book. In catalogues, such as Dalla Torre's, etc., dealing with vast accumulations of literature, it is impossible to guard against occasional errors, which are unfortunately copied again and again, and sometimes increased by mistakes in the copying. I can only hope that by much pains I myself have erred as little as possible in this direction.

I must thank most of our Entomologists for kindly sending me ants to name, and allowing me to see their captures. I am deeply indebted to Mr. J. H. Durrant, the Rev. F. D. Morice, and Professor E. B. Poulton for kind encouragement and assistance, Professor E. A. Minchin for dissections of the internal structure, Mr. E. A. Elliott for translations from the Danish and Swedish, and Mrs. Mellor for her kindness in collating and type-writing the Pilot-files, card-indexes, etc., in connection with my extensive myrmecological library.

The following account of twenty years of labour and experience has been brought to a conclusion during the opening months of a supreme national crisis-wellnigh within sound of the guns. At such a time it is too much to hope or even to wish that the problems of biological science should receive their due meed of attention. But later on, when the success of which we cannot be doubtful shall have attended our efforts and those of our Allies, when intellectual pursuits have resumed their sway, it is hoped that the 
present volume will serve both as an inducement and an aid to the study of the most fascinating of all insects.

The figures inserted in the text (except Figs. 45-50) were drawn by the late T. Carreras. Nearly all are from nature; but a few are copies, and in such cases reference is made to the sources from which they were taken.

The drawings for Figs. 45-50, and also the beautiful paintings reproduced on Plate IV, are the work of the accomplished Belgian entomologist and artist, J. Bondroit.

The photographs of eggs, larvae, pupae, and perfect insects are from negatives taken by A. W. Dennis from specimens of my own collecting: those representing nests and their surroundings are from negatives taken by myself, except where otherwise stated.

December 31st, 1914.

HORACE DONISTHORPE. 


\section{CONTENTS.}

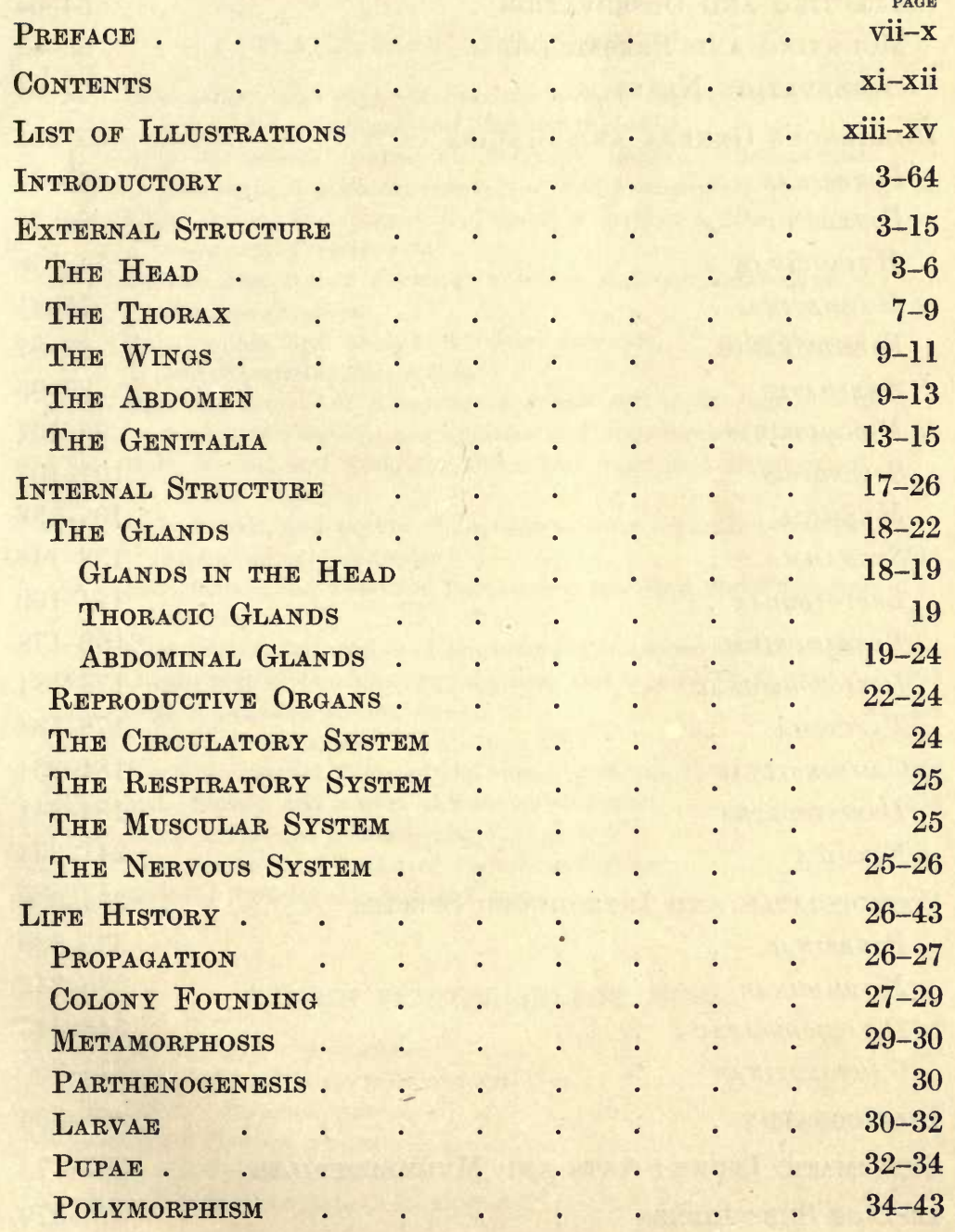


Psychology . . • . . . . . $43-52$

How Ants Know Each Other . . . . 47-48

How Ants Communicate with Each Other • 48-49

How Ants Find their WaY . . . . 49-52

Geographical Distribution . . . . . . 52

Geological Record . . . . . . . $52-53$

Collecting and Observation . . . . . . 54-64

Mounting and Preserving . . . . . 56-57

Observation Nests . . . . . . . 57-64

Indigenous Genera ANd Species . . . . 65-334

Ponerinae . . . . . . . . $65-74$

PONERA . . . . . . . . . 66-74

$M_{Y R M I C I N A E}$. . . . . . . . . $74-178$

MYRMECINA . . . . . . . . $75-81$

FORMICOXENUS . . . . . . . . . $82-87$

ANERGATES . . . . . . . 87-95

Monomorium . . . . . . . . . . 95-101

SOLENOPSIS . . . . . . . . . 101-107

$M_{Y R M I C A}$. . . . . . . . $107-138$

STENAMMA . . .

LEPTOTHORAX . . . . . . . . 144-169

TETRAMORIUM . . . . . . . . 169-178

DOLICHODERINAE . . . . . . . . $178-184$

TAPINOMA . . . . . . . $178-184$

CAMPonotinaE . . . . . . . . . 184-334

DONISTHORPEA . . . . . . . 184-241

FORMICA . . . . . . . . 241-334

Cosmopolitan and Introduced Species . . . 334-350

Ponerinat . . . . . . . . . . $335-336$

MYRMICINAE . . . . . . . . 336-342

DOLICHODERINAE . . . . . . . $342-343$

CAMPonotinaE . . . . . . . $343-350$

BIBLIOGRAPHY . . . . . . . . 351-365

Systematic Index: Ants and Myrmecophiles $367-373$

List OF SUBSCRIBERS . . . . . . $375-379$ 


\title{
LIST OF ILLUSTRATIONS.
}

\author{
PLATES SEPARATELY PRINTED.
}

PLATE

I. Eggs, larvae, and pupae of Ponera coarctata, Myrmecina graminicola, Solenopsis fugax, and Myrmica ruginodis

II. Eggs, larvae and pupae of Anergates atratulus, Monomorium pharaonis, Leptothorax interruptus, and Tetramorium caespitum

III. Eggs, larvae, and pupae of Tapinoma erraticum, Donisthorpea nigra, and Formica rufa

IV. Ergatandromorph of Formica rufibarbis, and Gynandromorph of Formica sanguinea

V. Male, female, and worker of Ponera coarctata, P. punctatissima, and Myrmecina graminicola

VI. Male and female of Anergates atratulus, and male, female, and worker of Formicoxenus nitidulus and Monomorium pharaonis.

VII. Male, female, and worker of Solenopsis fugax and Myrmica sulcinodis

VIII. Male, female, and worker of Leptothorax interruptus, L. acervorum, and Stenamma westwoodi . . . . . . .

IX. Male, female, and worker of Tetramorium caespitum and Tapinoma erraticum

X. Male, female, and worker of Donisthorpea fuliginosa and D. aliena. 184

XI. Carton nest of Donisthorpea fuliginosa and mounds of D. flava . 193

XII. Nest of Donisthorpea umbrata . . . . . . . . 228

XIII. Nests of Formica rufa . . . . . . . . $\quad$. 250

XIV. Nests of Formica rufa v. alpina and F. pratensis. . . . 266

XV. Male, female, and worker of Formica pratensis . . . $\quad 268$

XVI. Nests of Formica pratensis and F. exsecta . . . . . $\quad 273$

XVII. Male, female, and worker of Formica rufibarbis . $\quad . \quad 320$

XVIII. Nests of Formica exsecta and F. picea . . . . . . 333

\section{FIGURES PRINTED IN THE TEXT.}

1. Worker of Formica pratensis

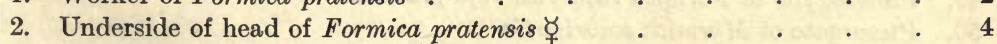

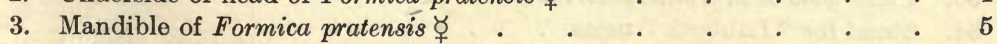

4. Maxilla of Formica pratensis $\not{\uparrow}$. $\quad . \quad$. $\quad . \quad$. $\quad . \quad$. 5

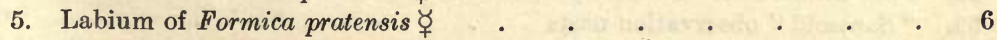

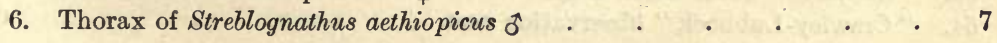


7. Thorax of Formica pratensis 0 . . . 8

8. Fore-wing of Formica (rufa L.) . . . $\quad 10$

9. Fore-wing of Ponera (coarctata Latr.) . . . . 11

10. Fore-wing of Myrmecina (graminicola Latr.) . 11

11. Fore-wing of Formicoxenus (nitidulus Nyl.) ...$\quad 11$

12. Fore-wing of Anergates (atratulus Schenck) . . . . 11

13. Fore-wing of Monomorium (pharaonis L.) . . . . 11

14. Fore-wing of Solenopsis (fugax Latr.) . . . . . . 11

15. Fore-wing of Myrmica (ruginodis Nyl.) . . . . . . 11

16. Fore-wing of Stenamma (westwoodi West.) . . . . . 11

17. Fore-wing of Leptothorax (interruptus Schenck) . . . . 11

18. Fore-wing of Tetramorium (caespitum L.) . . . . . 11

19. Fore-wing of Tapinoma (erraticum Latr.) . . . . . 11

20. Fore-wing of Donisthorpea (aliena Först.) . . . . . 11

21. Abdomen of Ponera coarctata $\not$. . . . . . $\quad$. 12

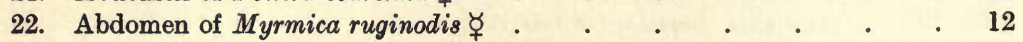

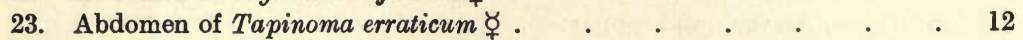

24. Abdomen of Formica pratensis ఫ

25. Abdomen of Formica pratensis ô . . . . . . . . . 13

26. $\delta$ genitalia of Formica rufibarbis (dorsal) . . . . . . $\quad . \quad 14$

27. It genitalia of Formica rufibarbis (ventral) . . . . . $\quad 14$

28. Stipes, volsella, and sagitta of Formica rufibarbis (dissected out) . 15

29. ot genitalia of Ponera punctatissima. . . . . . . 15

30. Ot genitalia of Myrmica scabrinodis . . . . . . . . 15

31. Internal structure of Myrmica rubra ఫ̧ . . . . . 16

32. Gizzard of Formica pratensis $\measuredangle \quad$. $\quad . \quad . \quad . \quad . \quad 17$

33. Gizzard of Tapinoma erraticum $\measuredangle$ (anterior view) . . . $\quad . \quad 18$

34. Poison apparatus of Formica rufibarbis $\not$. $\quad . \quad . \quad . \quad . \quad . \quad 19$

35. Poison apparatus of Bothriomyrmex meridionalis $\not{q}$. . . . 20

36. Poison apparatus of Myrmica laevinodis $\not$ _ . . . . $\quad$. 20

37. Repugnatorial glands of Tapinoma erraticum $\Varangle \quad$. . . . 21

38. Sketch to show position of repugnatorial glands of Tapinoma erraticum ૪. . . . . . . . . . . 22

39. Reproductive organs of Myrmica rubra 우 . . . . . 23

40. Ovaries of pseudogyne of Formica rufa . . . . . . . 23

41. Reproductive organs of Myrmica rubra $\delta^{*}$. . . . . $\quad 24$

42. Brain, etc., of Donisthorpea fuliginosa ఫ్ఛ . . . . . . 25

43. Head of larva of Myrmica scabrinodis . . . . . . . 31

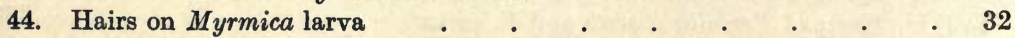

45. Ergatandromorph of Myrmica scabrinodis . . . . . 36

46. Ergatandromorph of Formica sanguinea . . . . . . $\quad$. 37

47. Mermithogyne of Donisthorpea flava . . . . . $\quad . \quad 38$

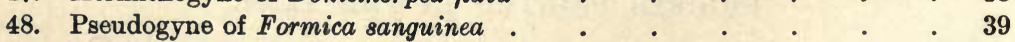

49. Pseudogyne of Formica rufa var. rufo-pratensis _ . . . $\quad$. 40

50. Pterergate of Myrmica scabrinodis . . . . . . . . 41

51. Stand for "Lubbock" nests . . . . . . . . . . 58

52. Four-chambered "Janet" plaster nest . . . . . . . . . 59

53. "Santschi" observation nests . . . . . . . . . . 61

54. "Crawley-Lubbock" observation nest . . . . . . . 61 


\section{LIST OF ILLUSTRATIONS.}

55. "Donisthorpe" observation nest . 63

56. Head of Ponera coarctata 옹 and P. punctatissima 오 . . . . 67

57. Epinotum and pedicel of Myrmecina graminicola $\Varangle \quad$. . . $\quad$. 77

58. Pedicel of Formicoxenus nitidulus $\measuredangle \quad$. . . . . $\quad . \quad 83$

59. Head and thorax of Formicoxenus nitidulus ô . $\quad . \quad . \quad . \quad . \quad 83$

60. Monomorium pharaonis ఛ.$\quad$. . . . . . . . $\quad .97$

61. Antenna of Solenopsis fugax $\Varangle \quad$. $\quad . \quad . \quad . \quad . \quad . \quad . \quad 102$

62. Antenna of Solenopsis fugax ô . . . . . . . . 102

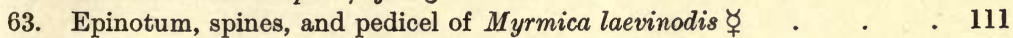

64. Epinotum, spines, and pedicel of Myrmica ruginodis ధॄ _ . . 116

65. Antenna of Myrmica ruginodis ఫ̧ . . . . . . . . . 116

66. Antenna of Myrmica ruginodis ơ . . . . . . . . . 116

67. Antenna of Myrmica sulcinodis $\measuredangle$. . . . . . . . . 122

68. Antenna of Myrmica scabrinodis $\measuredangle$. . . . . . . . . 126

69. Antenna of Myrmica scabrinodis ô . . . . . . . . . . 126

70. Antenna of Myrmica scabrinodis v. sabuleti $\not$. . . . . . 132

71. Antenna of Myrmica scabrinodis v. sabuleti o . . . . . 132

72. Antenna of Myrmica lobicornis ఫ . . . . . . . . 134

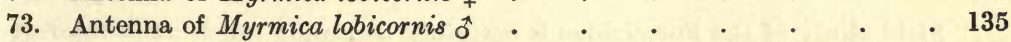

74. Head of Stenamma westwoodi ఫ̧ . . . . . . . . 140

75. Stenamma westwoodi $\Varangle$. . . . . . . . . . . . 140

76. Pedicel of Leptothorax nylanderi o . . . . . . . . . 156

77. Scutellum and epinotum of Leptothorax tuberum + $\quad$. _ . . 163

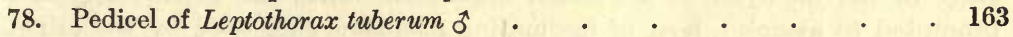

79. Scutellum and epinotum of Leptothorax interruptus 우 . . . 166

80. Pedicel of Leptothorax interruptus ô $4 \quad$. $\quad . \quad$. $\quad . \quad 166$

81. Head and shoulders of Tetramorium caespitum ఫ̧ . . . . 171

82. Donisthorpea fuliginosa 우 with gaster distended with eggs . _ . 189

83. Donisthorpea nigra 오 . . . . . . . . . 201

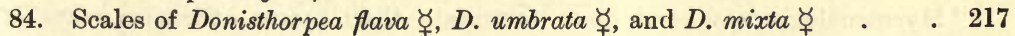

85. Donisthorpea umbrata ㅇ. . . . . . . . . 224

86. D. mixto-umbrata $\Varangle$ with patches of algae on body and legs _ . 235

87. Scale of Formica rufa $\not$. . . . . . . . . . . 246

88. Head of Formica rufa $\not$ and F. rufa v. alpina $\not$ _ . . . $\quad$. 265

89. Head of Formica exsecta $\measuredangle$. . . . . . . . 274

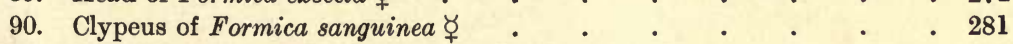

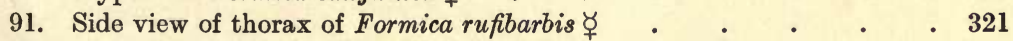

92. Thorax and scale of Formica gagates $\Varangle$ and Formica picea $\Varangle \quad$. $\quad 329$ 
"To him who is satisfied with amassing collections of curious objects, simply for the pleasure of possessing them, such objects can afford, at best, but a childish gratification, faint and fleeting; while he who extends his view beyond the narrow field of nomenclature, beholds a boundless expanse, the exploring of which is worthy of the philosopher, and of the best talents of a reasonable being."-BuRchell, "Southern Africa" 1, 505 (1822).

"Field study of the Formicidae is certainly becoming much more interesting and precise through our increasing knowledge of dulosis and temporary social parasitism, since every ant colony examined no longer represents to the observer merely a meaningless aggregate of individuals, but a definite stage in the life-cycle of a colonial organism. Thus the myrmecologist is prompted to attack a host of fascinating problems suggested by the origin, development and decline, both onto- and phylogenetic, of a living community and the instinctive processes involved in the numerical regulation of its polymorphic components."-Wheeler, "Bull. Amer. Mus. Nat. Hist." 24, 645 (1908).

"Myrmecology has been more fortunate than many other branches of entomology in the men who have contributed to its development. These have been actuated, almost without exception, not by a mania for endless multiplication of genera and species, but by a temperate and philosophical interest in the increase of our knowledge."-WHEELER, "Ants," 1910, p. 123. 


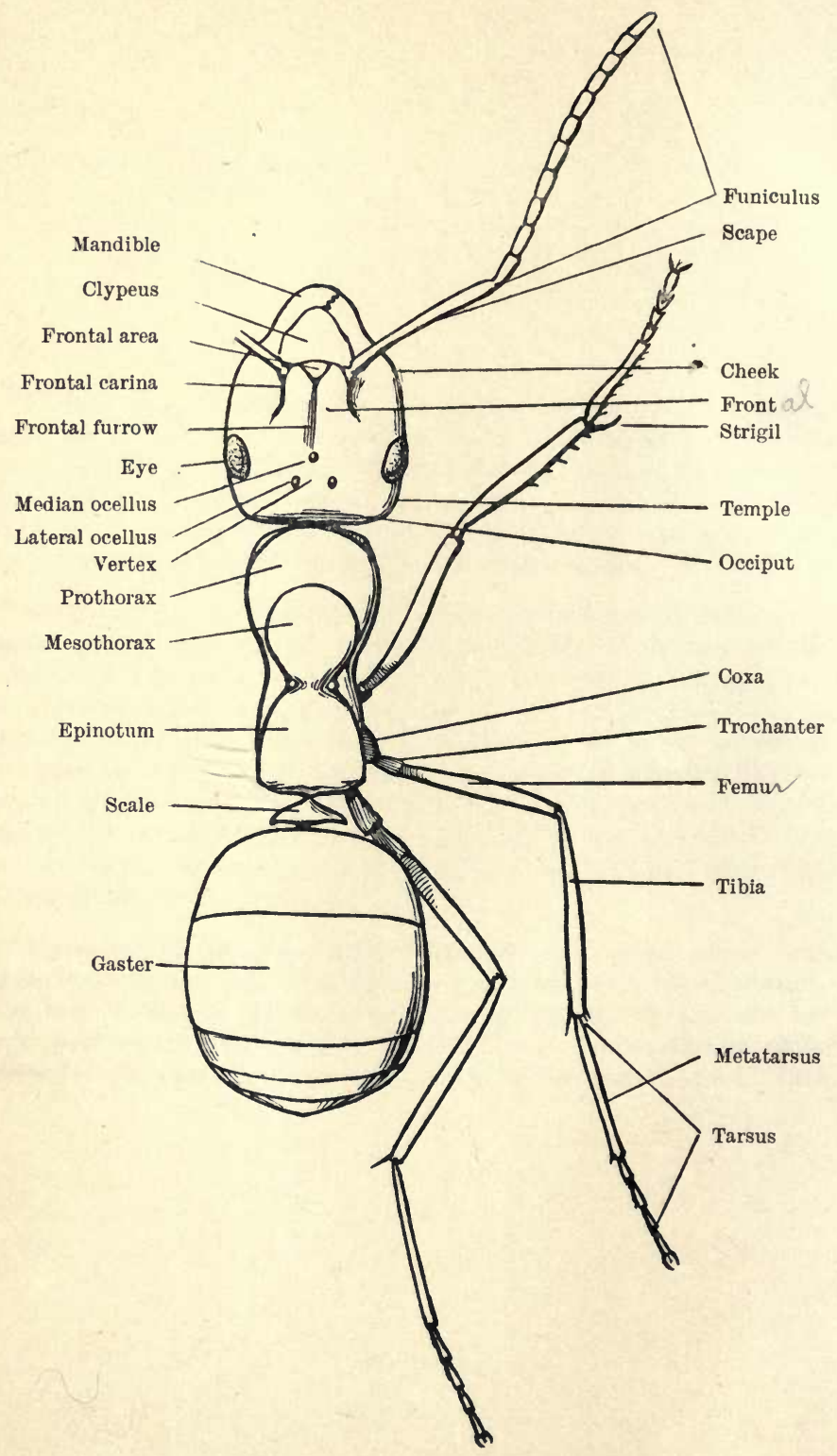

Fig. 1. Worker of Formica pratensis. 


\section{BRITISH ANTS.}

\section{INTRODUCTORY.}

\section{EXTERNAL STRUCTURE.}

ANTs can be distinguished from all the other members of the order Hymenoptera by the construction of the abdomen, which is divided into two very distinct regions, a slender very movable pedicel of one or two joints (the petiole and post-petiole-the petiole with a scale or node on the upper surface), and a larger posterior portion, the gaster.

In certain low forms in the Ponerinae the construction of the abdomen comes nearer to that of some of the Fossores, but such forms, not occurring in Britain, do not concern us here. The consistency of the chitinous integument of the body is very variable, being thicker, harder, and more brittle in species of the more primitive groups, Ponerinae and Myrmicinae, and thinner, softer, and more flexible in the more recently developed groups, Dolichoderinae, Camponotinae, etc.

Some species are glabrous, and shining; others pilose and pubescent, opaque, rugose, punctured, striate, etc.

The hairy covering, when present, consists of (1) pilosity, viz. longer hairs, erect or sub-erect; and (2) pubescence, viz. short closely applied hairs which cover parts, or the whole of the body.

\section{The Head.}

The head varies considerably in shape, it may be three-cornered, four-cornered, round, oval, elongate, transverse, etc. The organs attached to it are the mandibles and other parts of the mouth, the eyes and the antennae.

The head above terminates anteriorly with the clypeus, an immovable plate varying in shape. The genae, or cheeks, are situated on either side of the clypeus extending between the eyes and the mandibles. Posterior to the clypeus in nearly all cases is a 
small space, usually triangular in shape, which is called the frontal area; and behind this an impressed longitudinal line, the frontal furrow, is often present, which runs back towards the base of the head. The front is the region lying between the frontal carinae (a pair of ridges, situated on the inner side of the insertion of the antennae), and is bounded anteriorly by the clypeus. Posteriorly it passes indefinitely into the vertex of the head and the temples; the latter lie above and behind the eyes. The occiput is the short region between the vertex of the head and the narrow opening (the foramen) beneath at its junction with the thorax.

The ventral surface of the head between the labium and the above-mentioned opening is the gula or throat, it is generally divided by a longitudinal suture.

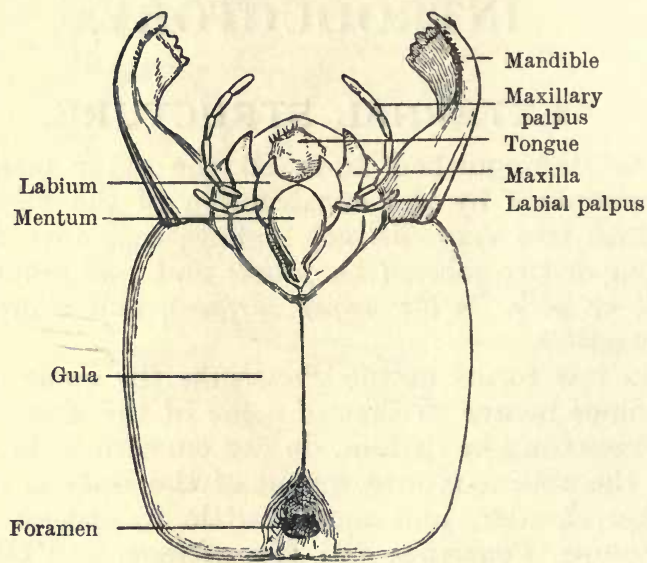

Fig. 2. Underside of head of Formica pratensis $\not$.

The compound or lateral eyes are situated on either side of the head; the simple or median eyes, stemmata, or ocelli, when present, are three in number, and are placed triangularly on the front of the head. Both kinds of eyes are most highly developed in the males, and least in the workers, the ocelli being wanting in the latter of some species.

The facets of the compound eyes vary greatly in size and number in different species. It has been estimated that the lateral eye in the worker of Ponera punctatissima only consists of one facet; in the worker of Solenopsis fugax from 6-9, in the female 200, and in the male 400 ; Tapinoma erraticum-worker 100, female 260, male 400 ; Formica pratensis-worker 600 , female 830 , male 1200.

The mandibles are very variable in structure, being sometimes long, narrow and pointed, but often broad and massive, having three borders, an external, an internal, and a terminal, the latter 
being often more or less strongly toothed. The mandibles can be opened and closed independently of the other parts of the mouth.

The maxillae and labium are situated beneath the very small

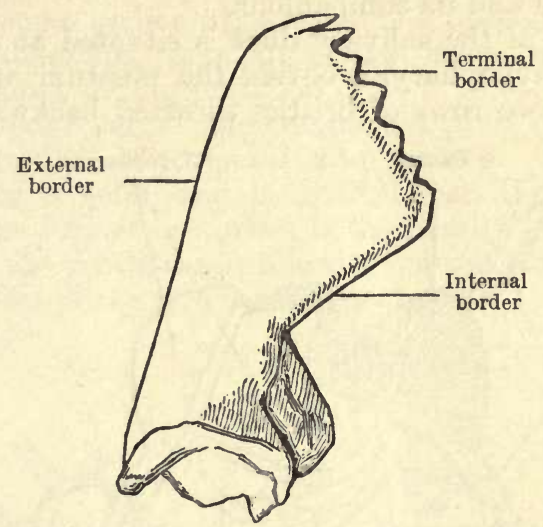

Fig. 3. Mandible of Formica pratensis $\not$.

labrum and keep the mouth completely closed except when the ant is feeding.

The maxillae consist of a cardo or hinge, a stipes or stem, a lacinia or inner-blade, a galea or outer-blade, and a palpus which may consist of from one to six joints.

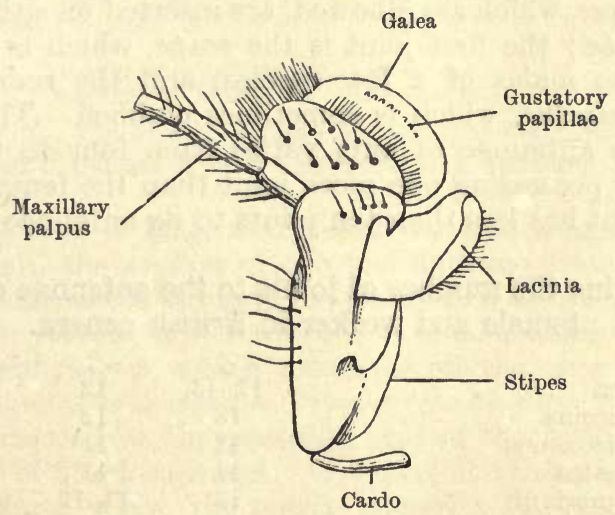

Fig. 4. Maxilla of Formica pratensis

The outer-blade is furnished with gustatory papillae, and a row of bristles used in cleaning the legs, etc.

The labium consists of a submentum or hind-chin, a mentum or chin, the hypopharynx and paraglossae which are double, the glossa 
or tongue, and the labial palpi which may consist of from one to four joints. The tongue is covered with fine transverse ridges ; it can be protruded, and with it the ant rasps and licks up its food, and cleans itself and its companions.

The opening of the salivary duct is situated at the base of the tongue. The hypopharynx covers the mentum and paraglossae, and possesses two rows of bristles directed backwards, which are

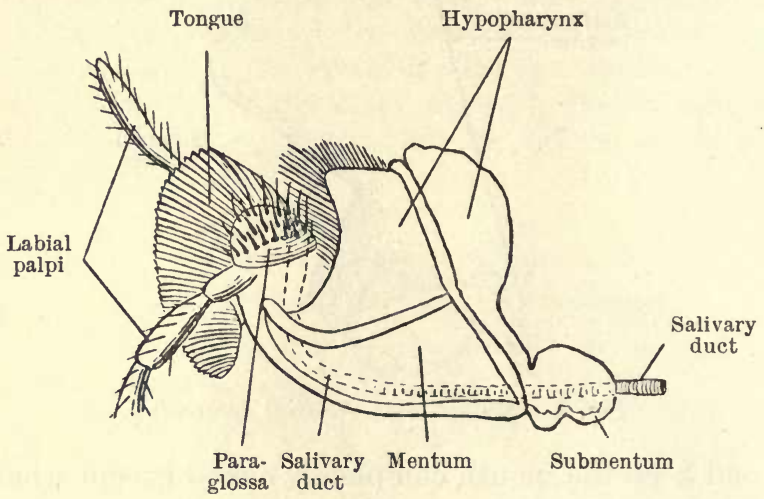

Fig. 5. Labium of Formica pratensis ఫ్ .

used for firmly holding the food. The roof of the mouth is formed by the labrum, which is bilobed, and is concealed by the clypeus.

The antennae, which are elbowed, are inserted on either side of the frontal carinae; the first joint is the scape, which is usually long, except in the males of a few species, and the remaining joints form the funiculus, which is sometimes clubbed. The number of joints in the antennae of ants varies from four to thirteen-the male usually possessing one more joint than the female or worker. No British ant has less than ten joints to its antennae.

Table showing the number of joints to the antennae of the male, female and worker in British genera.

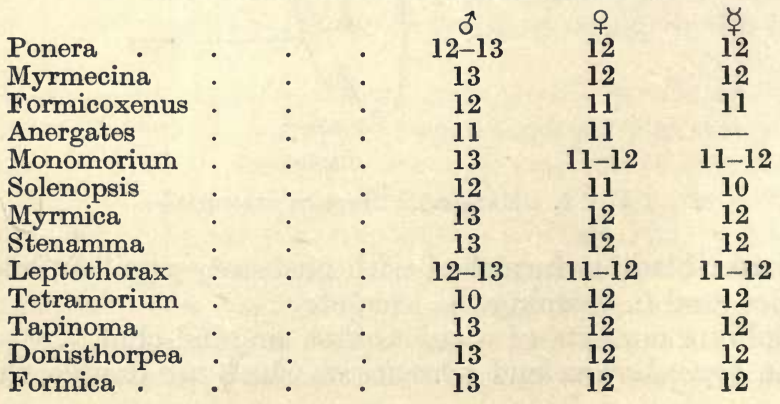




\section{The Thorax.}

The thorax is divided into four segments, the prothorax, mesothorax, metathorax, and epinotum. The epinotum (which is the metanotum of some earlier writers and the propodeum of others) was the first abdominal segment of the larva, which has been fused to the thorax during pupation.

In the primitive form, all the component parts of the thorax of the male ant are distinctly separated by sutures.

The prothorax is small and is divided into the pronotum and prosternum; the former comprises both dorsally and laterally the greater part of the prothorax, while the latter is small and narrow, and to it the coxa of the fore leg is articulated.

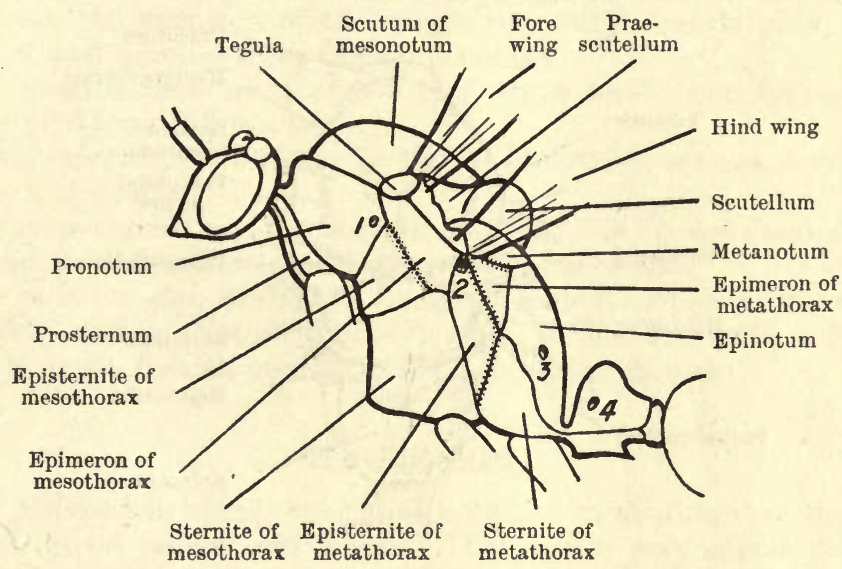

Fig. 6. Thorax of Streblognathus aethiopicus ô. (Emery.)

$1,2,3$, and 4 stigmata of meso- and metathorax, epinotum, and petiole.

The mesothorax is large and bears the fore-wings; its anterior dorsal portion, the scutum of the mesonotum, often spoken of as the mesonotum, bears in many male ants a $\mathrm{Y}$-shaped furrow, called the Mayrian furrow, and on either side is a longitudinal suture, the parapsidal furrow, which separates off the area known as the parapsis. The prae-scutellum (=paraptera of Emery) of the mesothorax, is situated at the posterior end of the scutum behind the articulation of the fore-wings. Covering the insertion of the forewing a chitinous scale, the tegula, occurs. The scutellum, a large semi-circular plate, is situated between the prae-scutellum and the metanotum. The coxa of the intermediate leg is articulated to the mesosternum; between this and the pronotum is the episternite of the mesothorax, and above the latter is the epimeron of the mesothorax.

The metanotum, the dorsal part of the metathorax, consists of a narrow band between the scutellum and the epinotum, and on either 
side between the scutellum and the metanotum lies the postscutellum, or paraptera of the metathorax. The coxa of the hindleg is articulated to the metasternum, and the ventral portion of the metathorax is divided into areas as in the mesothorax, viz. the epimeron, the episternite and the sternite. The hind-wing is inserted between the post-scutellum and the epimeron of the metathorax. The epinotum, which is really the first abdominal segment, is bordered by the epimera of the metathorax above, and the sternites of the metathorax below.

Three stigmata, or spiracles (orifices of tracheae) occur on either side of the thorax, the first close to the junction between the mesothorax and pronotum, the second below the insertion of the hindwing, and the third on the epinotum.

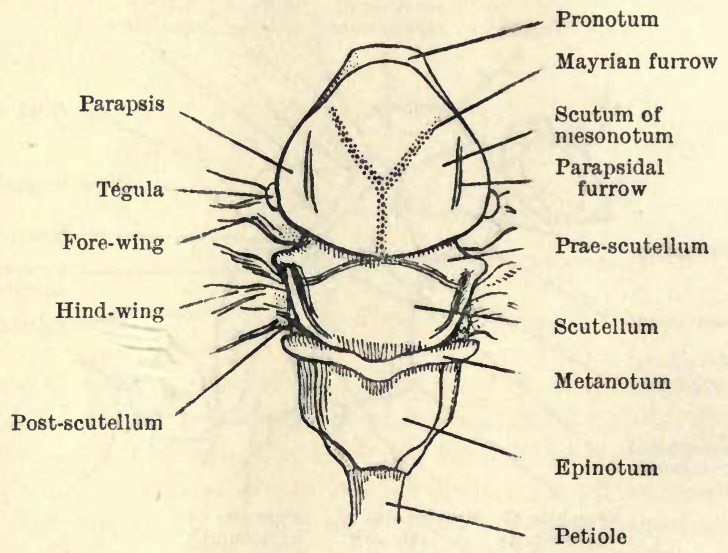

Fig. 7. Thorax of Formica pratensis 0 .

The thorax in the males and females of most ants is generally more simple than in this primitive form on account of the fusion of the epimera and episterna with each other, and also with mesoand metathorax, and epinotum.

The female thorax has the same divisions as the male, but is more robust and the Mayrian furrows are never present. In the workers, being wingless, the meso- and metathorax are greatly reduced, and in the higher and more recent genera, such as Formica, the thorax apparently consists of three segments only, the pronotum, mesonotum and epinotum, owing to the disappearance of the scutellum, the paraptera and the metanotum.

The legs of ants are not very variable and always consist of the same number of joints-the coxa, trochanter, femur, tibia, and a five-jointed tarsus, the first joint of which is always long, especially in the intermediate and posterior legs, and is called the metatarsus. The last joint of the tarsus carries two claws (unguiculi) which 
are generally simple, but sometimes toothed or pectinate. The apices of the tibiae are often armed with movable spurs (calcaria), which may be simple in the intermediate and posterior pairs, but if present are always large and pectinate in the anterior ones. These latter are called strigils, and are curved and fringed with bristles on their inner side. Bristles also occur on the metatarsus, opposite to those on the strigil, and the ants clean their antennae by drawing them between these bristles.

The wings of ants have not been used in classification to the same extent as in other families of the Hymenoptera, chiefly because the workers, which are most often found, are wingless, and the females, which lose their wings after the marriage flight, are more frequently taken in this "deälated" condition; moreover, the venation of the wings may vary considerably, even in males and females from the same colony.

The longitudinal veins of the fore-wings have been named by Emery (1913) as follows :-

Costa, subcosta, pterostigma (=stigma Linnaeus), medius, brachius, radius, and cubitus.

The transverse veins : transversomedialis, basalis (or discoidalis), first and second cubitalis, and recurrens (or medialis).

The cells : costal, median, submedian, radial, cubital 1, 2, and 3, discoidal 1 and 2. Not all, however, of these cells and veins actually occur in most British genera (cf. the following figures).

\section{The Abdomen.}

The abdomen is highly specialized, and in most ants it is sharply divided into a pedicel and gaster. The pedicel may consist of one joint, the petiole, or two joints, the petiole and post-petiole; it is very mobile and is articulated anteriorly to the epinotum and posteriorly to the gaster. When the pedicel is one-jointed it usually consists dorsally of a more or less high scale of variable shape and thickness.

The petiole is morphologically the second abdominal segment, for actually, as we have seen, the epinotum is the first, and consequently the first gastric segment is the third abdominal one. When the pedicel is two-jointed it consists of two nodiform segments, and the first gastric segment is therefore the fourth abdominal one.

The gaster varies in shape, being round, oval, long, or cordiform, etc., and shows five segments in the worker and female, and six in the male when the pedicel is one-jointed, and four in the worker and female and five in the male, when two-jointed. Morphologically the gaster consists of eight segments when the pedicel is onejointed and seven when two-jointed; but the terminal segments are very small and are telescoped into those in front of them.

In those ants which possess the power of stridulating, the sound- 


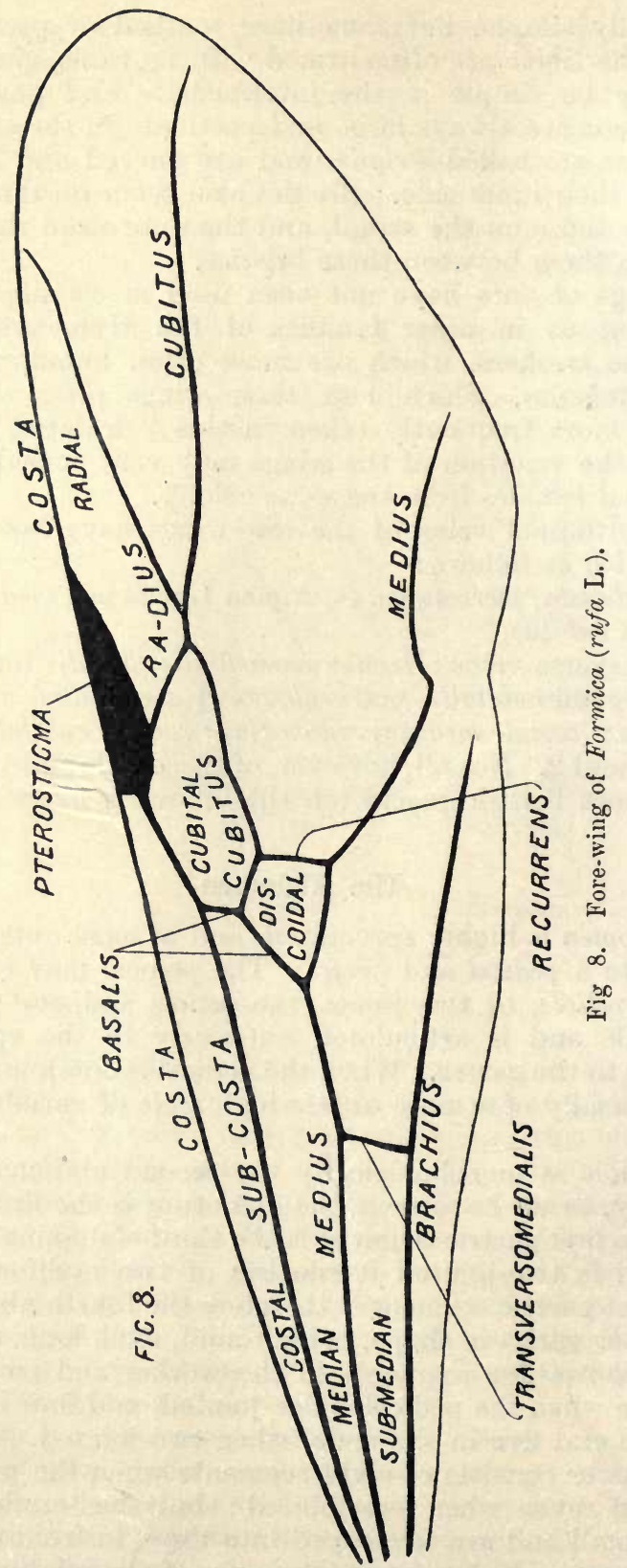




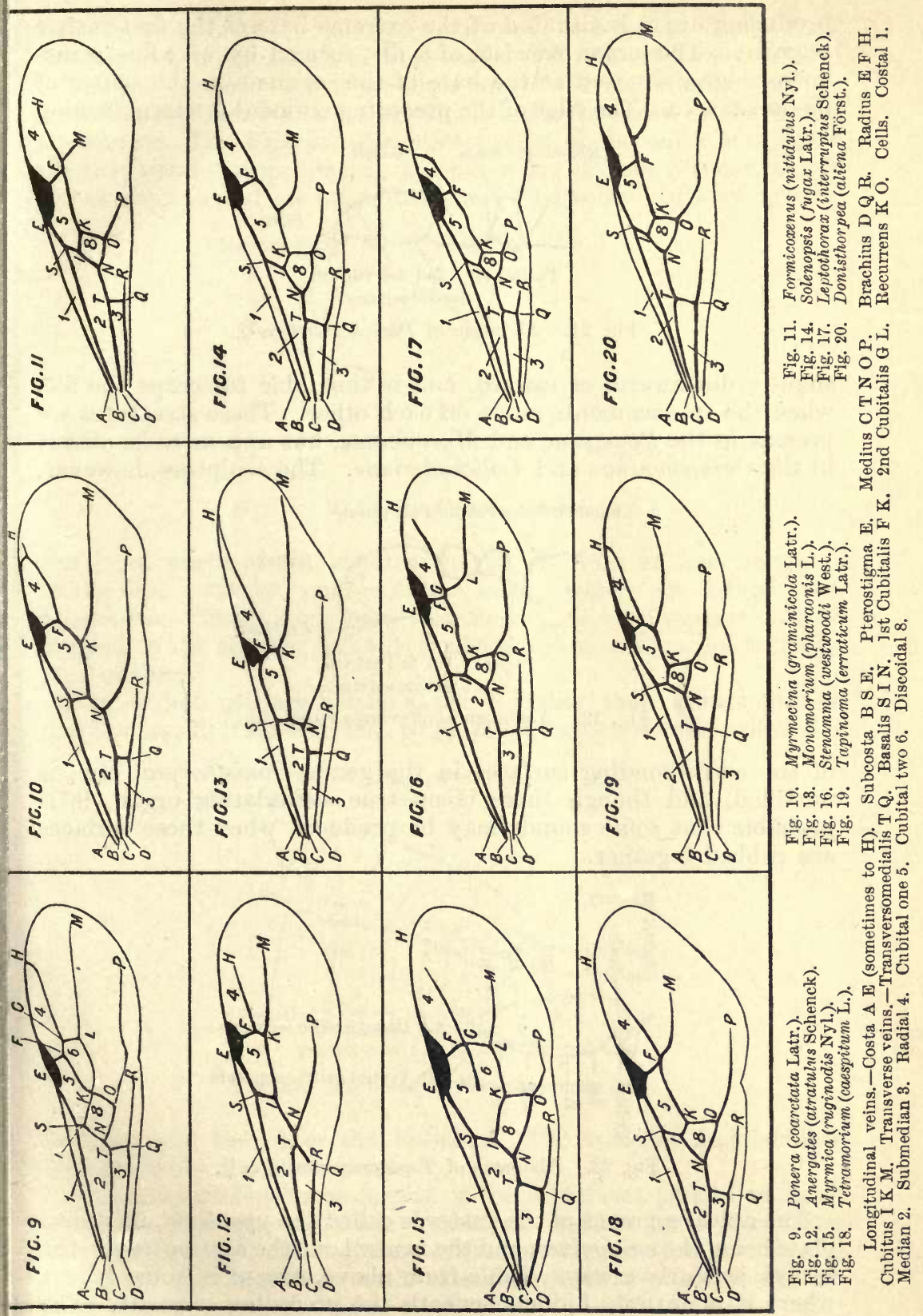


producing organ is situated at the extreme base of the first gastric segment. This organ consists of a file, formed by very fine transverse ridges, situated at the base of the segment, in the centre of its dorsal area. The edge of the preceding segment is sharp, turning

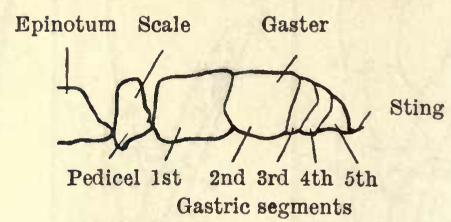

Fig. 21. Abdomen of Ponera coarctata

slightly downward, or inward, and is thus able to scrape the file, when the two segments move on each other. These structures are present in the Ponerinae and Myrmicinae, but appear to be absent in the Camponotinae and Dolichoderinae. The sculpture, however,

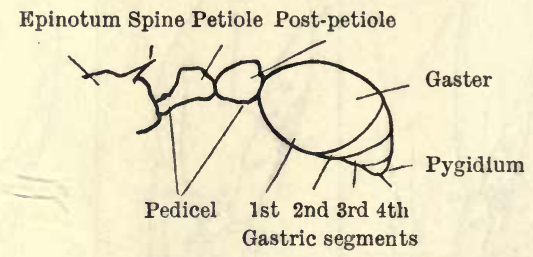

Fig. 22. Abdomen of Myrmica ruginodis $\not{\zeta}$.

of the corresponding surfaces in the genus Donisthorpea, etc., is modified, and though there is no true stridulating organ, it is probable that some sounds may be produced when these surfaces are rubbed together.

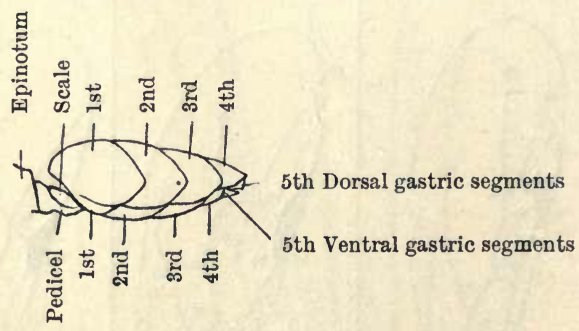

Fig. 23. Abdomen of Tapinoma erraticum $\not$.

The apical segment of the gaster is called the pygidium, its dorsal plate being the epipygium, and the ventral one the hypopygium; the former is nearly always visible from above, except in some genera where it is entirely hidden beneath the preceding segment. The 
last segments hold the genitalia in the two sexes, and also enclose the sting of the females and workers in such ants as possess one.

The genital armature of the male consists of the following parts : The Annular Lamina is a ring which forms the base of the whole apparatus. The External Paramera consist of the outer and intermediate pairs of appendages ; the outer pair are the Stipites, which act as claspers and are often furnished with hairs. In some genera

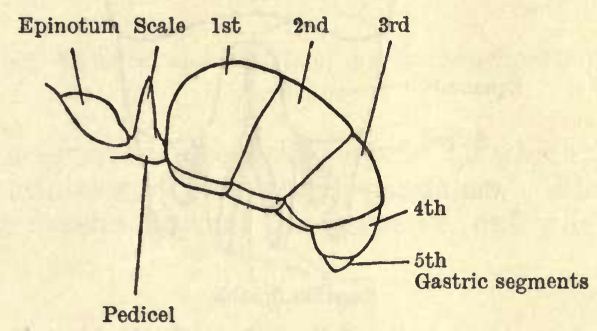

Fig. 24. Abdomen of Formica pratensis ధุ.

the basal parts of the stipites consist of more or less elongate, triangular, oval or semi-circular lobes, which are called the Squamulae. These sometimes look as if they were separate plates applied to the stipites, but this is not the case as they are actually part of them.

The median pair are known as the Volsellae, these are sometimes more or less divided into two pairs, one of which is then called the

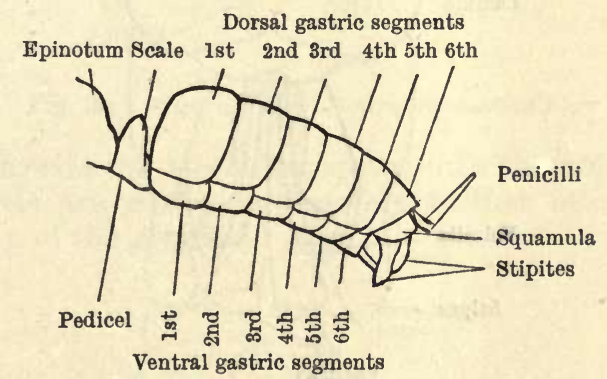

Fig. 25. Abdomen of Formica pratensis ơ.

Laciniae and the other the Volsellae. The volsellae and laciniae also probably act as claspers.

The Internal Paramera consist of the innermost pair of appendages, the Sagittae, which are connected together by a membrane the Spatha; and the sagittae + the spatha function as a penis. The sagittae often have serrated edges which probably serve to hold them in position during copulation. 
Of these three pairs of appendages the stipites enclose the volsellae and the latter enclose the sagittae and spatha.

The Subgenital Lamina is a plate situated beneath the genitalia, and forming in fact the ninth ventral segment of the abdomen.

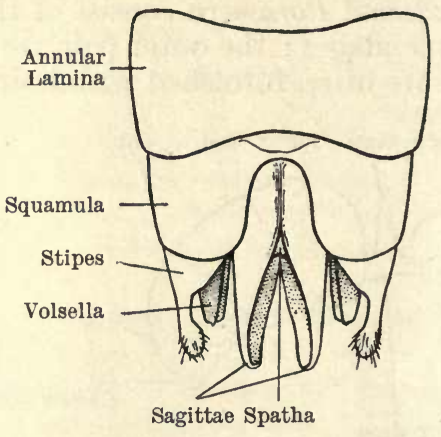

Fig. 26. $\widehat{o}$ genitalia of Formica rufibarbis (dorsal).

(Donisthorpe.)

It is sometimes pointed, forked, or rounded, and presents valuable distinctive characters in some genera.

Finally there are a small pair of hairy appendages, the Penicilli, which are attached to the tenth dorsal segment of the abdomen. They are not present in some genera such as Anergates, Dorylus,

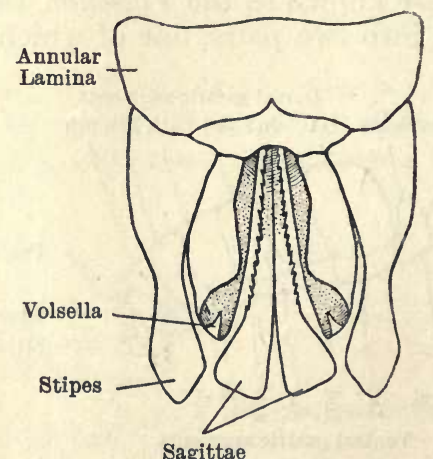

Fig. 27. ô genitalia of Formica rufibarbis (ventral).

(Donisthorpe.)

etc.; and in Prenolepis they are present in some species, and wanting in others, and are consequently valuable for classification purposes. They are stated to represent the Cerci in Blatta (the "Cockroach "), etc., but this does not seem to be absolutely certain.

The sting is retractile, and its size, in different species, varies greatly, not always in proportion to the size of their bodies. It con- 

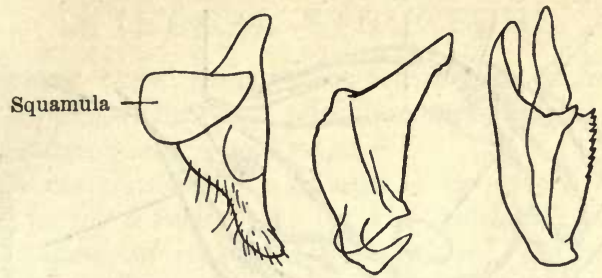

Fig. 28. Stipes, Volsella, and Sagitta of Formica rufibarbis (dissected out). (Donisthorpe.)

sists of a single grooved piece, the gorgeret, on which run the stylets, a pair of smooth, slender, pointed appendages. When at rest the stylets do not extend beyond the gorgeret, but when an ant uses

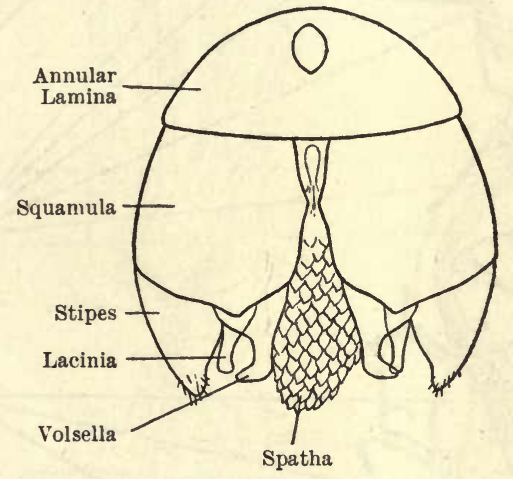

Fig. 29. $\widehat{o}$ genitalia of Ponera punctatissima.

its sting, it thrusts the whole apparatus into the object attacked, and the stylets are pushed alternately further into the wound, beyond the tip of the gorgeret.

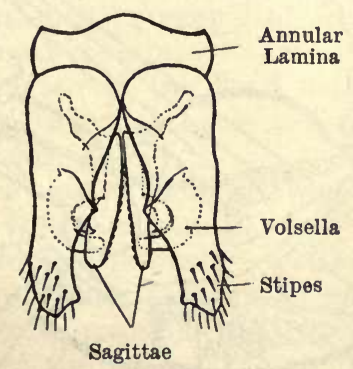

Fig. 30. $\sigma^{\lambda}$ genitalia of Myrmica scabrinodis. (Crawley.) 


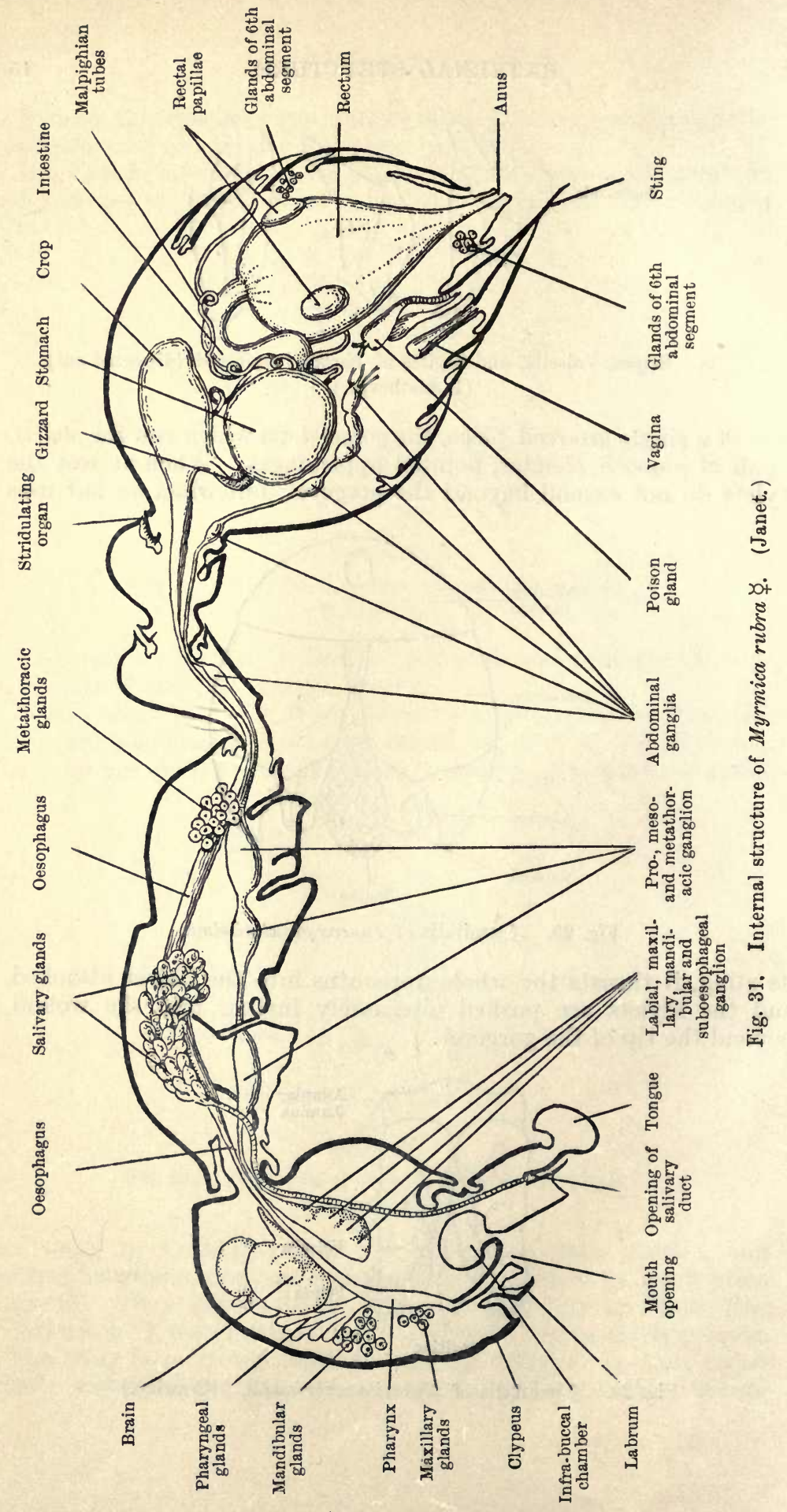




\section{INTERNAL STRUCTURE.}

The alimentary canal consists of a mouth opening and buccal parts, an infra-buccal chamber, pharynx, oesophagus, crop, gizzard, stomach, intestine, rectum and anus.

The infra-buccal chamber is a spherical cavity situated below the pharynx, and forms a receptacle for the solid and semi-solid parts of the food rasped off by the ant's tongue, and also for foreign matter scraped off the ant's body by its tongue and strigils. Any juices that remain in these substances are extracted and sucked

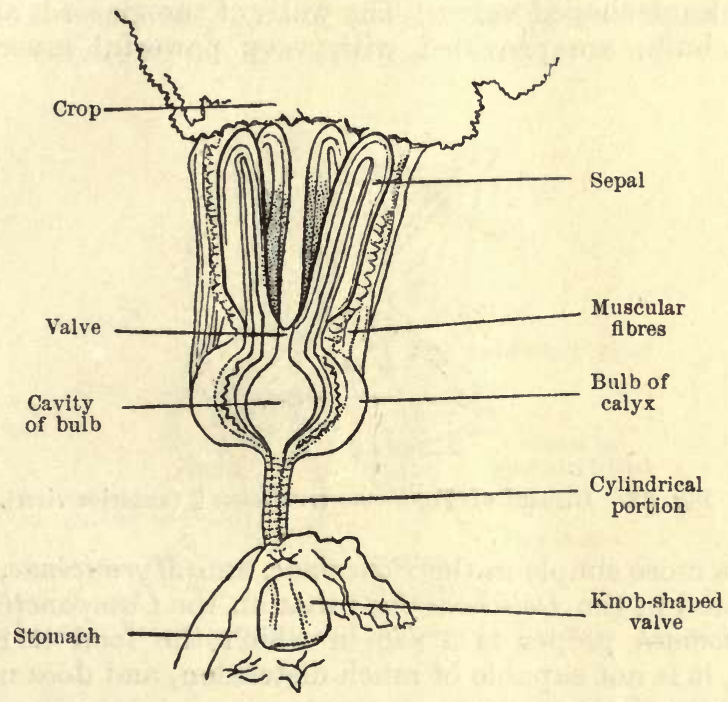

Fig. 32. Gizzard of Formica pratensis ఫ్ఛ. (Forel.)

into the pharynx, the residue being ejected in the form of a solid body, the "Boulettes de nettoyage" of Janet, which retains the shape of the infra-buccal chamber.

The pharynx is situated in the head and is a flattened cavity with very muscular walls which open and shut, forcing the liquid food into the oesophagus.

The oesophagus is a long tube connecting the pharynx with the abdomen ; it is only feebly muscular.

The crop is situated in the gaster, consisting simply of an enlargement of the oesophagus. It forms a reservoir for the retention of the liquid food, and is capable of great distension - the "HoneyAnts of the Garden of the Gods " represent the extreme form of this phenomenon. Forel has called it the social stomach, as the 
food it contains is used to feed the brood, and the other ants of the colony, by regurgitation.

The gizzard connects the crop with the stomach proper, it has been called the pumping-stomach, is very variable in form, and affords valuable characters, which can be used to differentiate genera and even sub-families. It is composed anteriorly of a cupshaped portion, the calyx, the chitinous walls of which are formed by eight bands, the four thicker ones, the sepals, contract at their posterior end to form a valve. The gizzard then becomes dilated into a bulb, the pumping-stomach proper; this is followed by a cylindrical portion which enters the true stomach, where it terminates in a knob-shaped valve. The walls of the gizzard, and especially the bulb, are provided with very powerful muscles. The

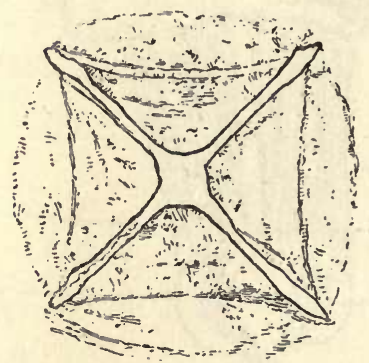

Fig. 33. Gizzard of Tapinoma erraticum $\Varangle$ (anterior view).

gizzard is more simple in the Ponerinae, and Myrmicinae, and more complicated in the Dolichoderinae than in the Camponotinae.

The stomach proper is a sac in which the food it receives is digested, it is not capable of much distension, and does not possess any chitinous lining.

The intestine is a more or less wrinkled tube which connects the stomach with the rectum, and near its anterior end where it forms a valve, the Malpighian tubes or urinary vessels are inserted.

The rectum is large, tapering towards its posterior end where it terminates in the anus; in it the faeces and urinary excretions are collected.

The anus varies in shape in different genera, it is provided with a sphincter muscle, and is sometimes fringed with hairs.

\section{Glands in the Head.}

\section{The Glands.}

The antennary glands consist of a few cells, the slender ducts of which open on a small space, situated in a depression at the base of each antenna.

The maxillary glands comprise two groups of cells placed above 
the buccal tube, their separate ducts opening on a "cribellum " in the lateral wall of the tube.

The mandibular glands are large and consist of a number of cells on either side of the head, their ducts opening separately on a cribellum at the base of the mandibles. These glands supply the cement which ants use in constructing carton, and plastering particles of earth together, etc.

The pharyngeal glands are finger-shaped and consist of two groups, which extend in front of and over the brain, and open by a pair of orifices into the alimentary canal.

\section{Thoracic Glands.}

The labial, or salivary glands, are situated in the thorax, though they really belong to the mouth parts. They are large and paired,

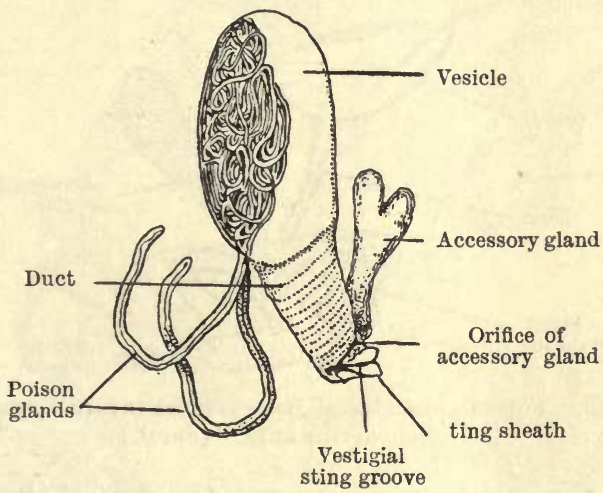

Fig. 34. Poison apparatus of Formica rufibarbis ఫ్ధ. (Forel.)

and are connected by a single duct which opens on the labium. They are derived from the spinning glands of the larva.

The metathoracic glands consist of numerous cells, their ducts opening through a sieve-like membrane into a chamber filled with air. The orifice of this chamber and the cribellum, are sometimes furnished with hairs. Janet has suggested that the secretion from these glands gives to the ant's body the "nest-aura," by means of which the ants in a colony recognize their fellows.

The metatarsal glands are situated in the fore-legs, at the base of the strigil.

\section{Abdominal Glands.}

The rectum is furnished with three rectal papillae, or glands, the central one being situated on the dorsal, the outer pair on the lateral surfaces.

The glands belonging to the sixth abdominal segment (intrasegmental "hautdrüsen" Escherich) consist of small clusters of 
cells, their ducts opening on the dorsal membrane below the segment, and others are found on the ventral membrane.

The poison apparatus is a complicated structure made up of the

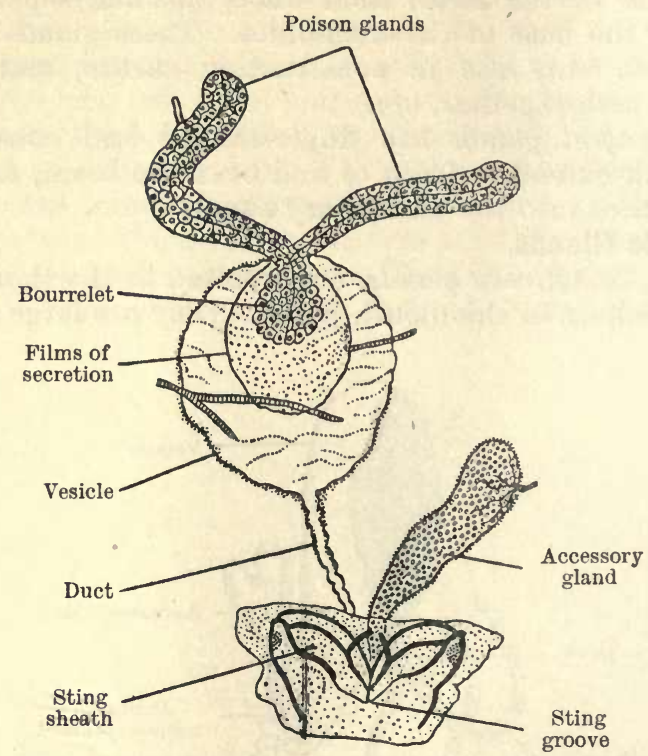

Fig. 35. Poison apparatus of Bothriomyrmex meridionalis $\not$ (a Dolichoderine ant). (Forel.)

poison glands, the vesicle, or poison sac, the duct of the vesicle with, or without, a sting, and the accessory gland. This apparatus occurs in the workers and females of all ants, and is situated in the posterior

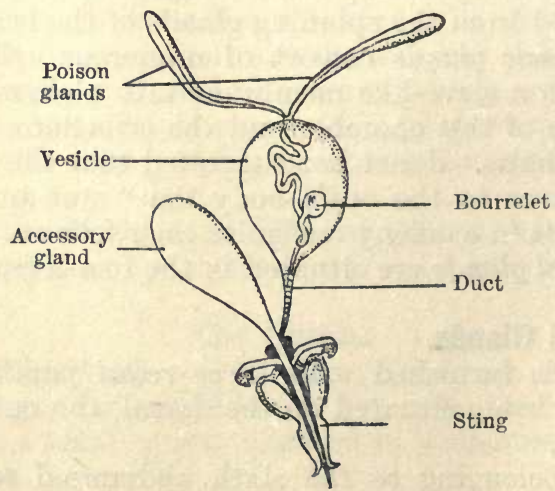

Fig. 36. Poison apparatus of Myrmica laevinodis ఫ̧. (Forel.) 
part of the gaster, below the rectum. Forel distinguished this apparatus into two types-the Pulvinated and the Bourreletedaccording to the form and arrangement of the different parts.

The Pulvinated type is the more complicated, it is confined to the Camponotinae, and in these forms more acid is stored. The two free poison glands enter the distal end of the vesicle, where they become a single tube, which is curled up into innumerable windings, forming a cushion on the inside of the dorsal wall of the

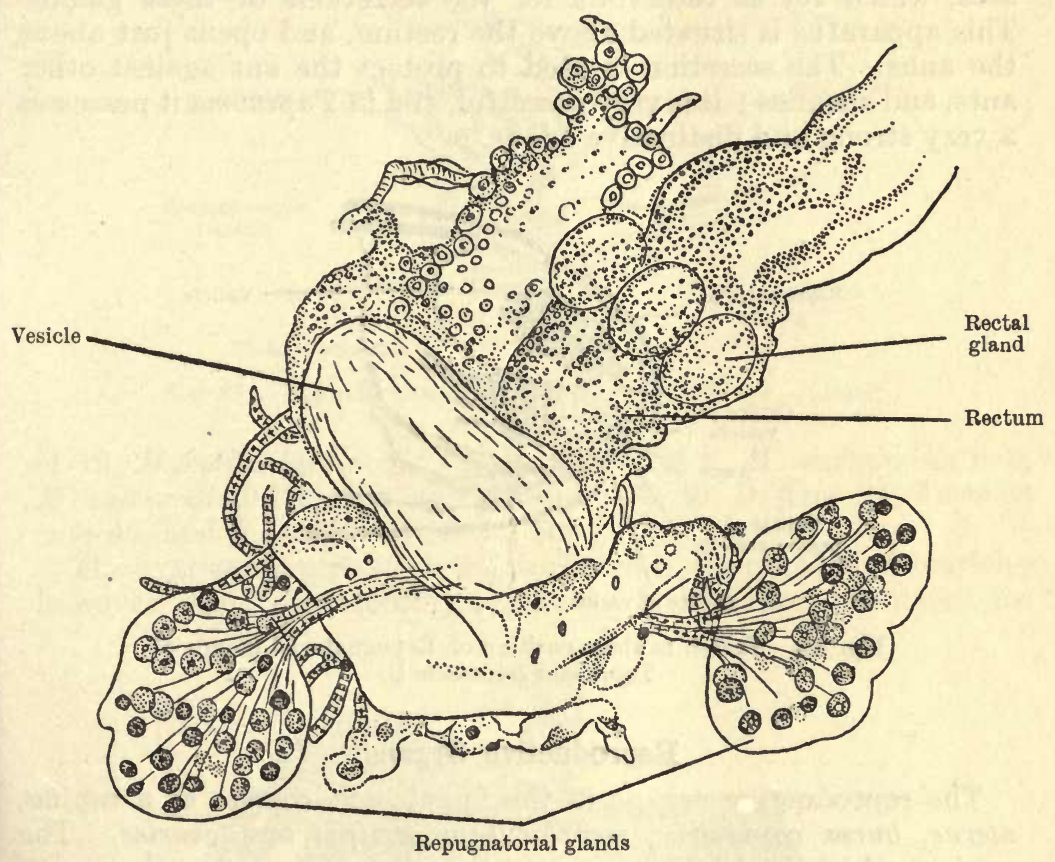

Fig. 37. Repugnatorial glands of Tapinoma erraticum

vesicle. This tube when unravelled is, according to Forel, quite twenty centimetres in length. The duct of the vesicle opens in a large orifice between certain vestiges of the almost obsolete sting. The accessory gland opens into the duct of the vesicle, near its termination. Janet suggests that the secretions of the accessory gland, which are alkaline in character, are used to neutralize the effect of the acid poison which may adhere to the ant's own body, after it has used its poison, or sting, against an enemy.

In the Bourreleted type, the apparatus is much simpler, the vesicle is smaller and more globular, and its duct is more slender. The free poison glands unite and enter the vesicle, where they form 
a not very winding tube which ends in a sort of swelling or "bourrelet."

When a sting is present, the acid is injected directly into the body of an enemy, but when absent, the latter is sprayed over him, or into a wound inflicted by the mandibles.

The anal, or repugnatorial glands, are only present in the workers and females of the Dolichoderinae. They consist of two grapelike clusters of cells; their ducts open into two large vesicles or sacs, which act as reservoirs for the secretions of these glands. This apparatus is situated above the rectum, and opens just above the anus. The secretion is used to protect the ant against other ants, and enemies ; it is very powerful, and in Tapinoma it possesses a very strong and distinctive odour.

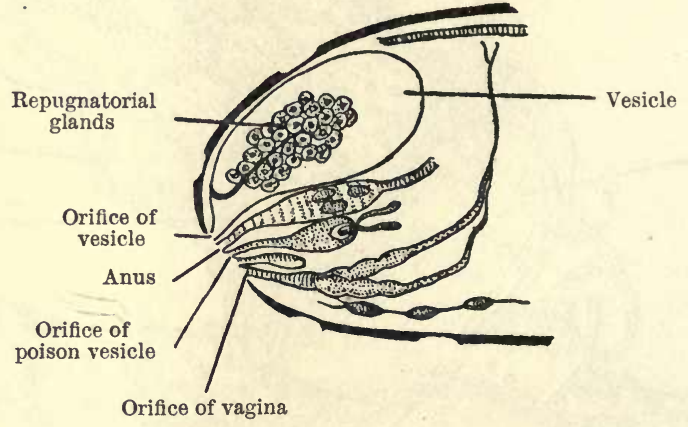

Fig. 38. Sketch to show position of Repugnatorial glands of Tapinoma erraticum \%.

\section{Reproductive Organs.}

The reproductive organs in the female ant consist of a vagina, uterus, bursa copulatrix, receptaculum seminis and ovaries. The vagina, which is short, opens into the uterus, its external opening consisting of a transverse slit situated in front of the sting, or its vestige, on the sternal membrane of the seventh abdominal segment. The bursa copulatrix is a sac, or copulatory pouch situated on the dorsal wall of the vagina. The uterus is formed by the junction of the two oviducts of each ovary, and upon it is placed the receptaculum seminis, which is connected with the uterus by a narrow passage. The receptaculum seminis is a small pocket which is filled with the male element during copulation. A pair of glands are situated at the apex of this receptacle; these secrete a nutritive fluid, which keeps alive for many years the male element, or sperm. The eggs are fertilized during their passage through the uterus by sperm ejected from the receptaculum. The ovaries consist of a number of tubes, the ovarioles, each tapering towards its apex, 
and in these the eggs are formed. The ovarioles are attached at their narrow ends to the pericardium, which lies immediately under the basal tergite of the gaster.

The number of ovarioles in each ovary varies considerably in different species-in the female of Anergates atratulus they consist

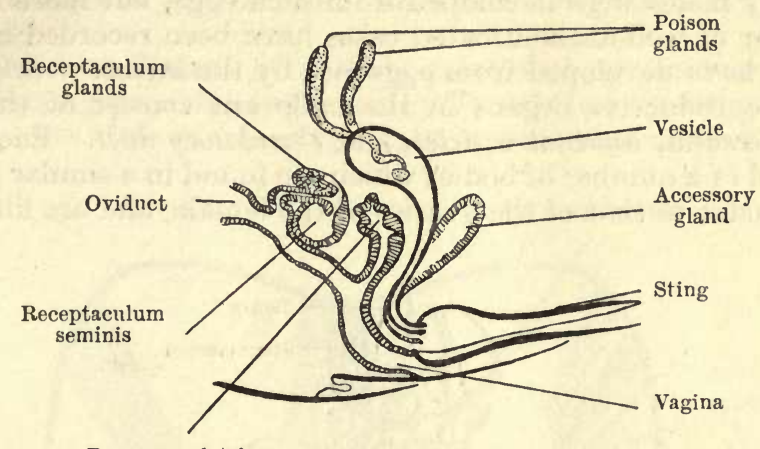

Bursa copulatrix

Fig. 39. Reproductive organs of Myrmica rubra ㅇ. (Janet.)

of 12, Myrmica laevinodis $12, M$. ruginodis $8, M$. scabrinodis 8-9, $M$. sulcinodis 9-11, Donisthorpea nigra 30-40, D. flava 24, Formica rufa 45, and F. rufibarbis 18-20, etc.

The ovaries are present in the worker also, the number of ovarioles however being considerably reduced. It has been estimated for

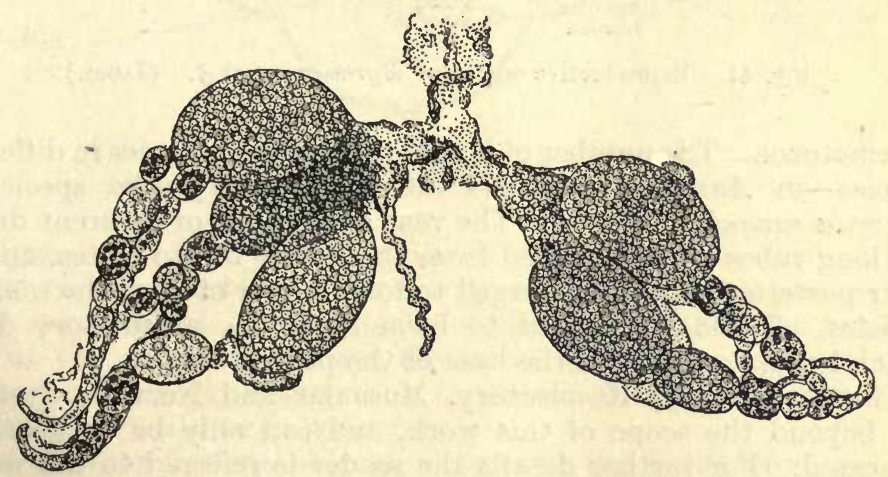

Fig. 40. Ovaries of pseudogyne of Formica rufa,

each ovary in Myrmica laevinodis, ruginodis and scabrinodis as 1, Tapinoma erraticum 1, Donisthorpea fuliginosa 1-2, D. flava 1, Formica rufa 4-10, $F$. pratensis 2-6, $F$. sanguinea 3-6, etc.

The receptaculum seminis is usually wanting in the worker, though 
it has been found present in individual specimens of many species. Copulation between males and workers has not been observed, though the former may sometimes be seen to endeavour to embrace the latter. Eggs laid by workers in captivity have frequently been observed to produce males, and indeed it was formerly supposed that only males were developed from such eggs, but more recently a number of well-authenticated cases have been recorded in which workers have developed from eggs laid by the latter.

The reproductive organs in the male ant consist of the testes, vasa deferentia, seminal vesicles, and ejaculatory duct. Each testis is formed of a number of bodies which are found in a similar position in the gaster to that of the ovaries of the female, and are filled with

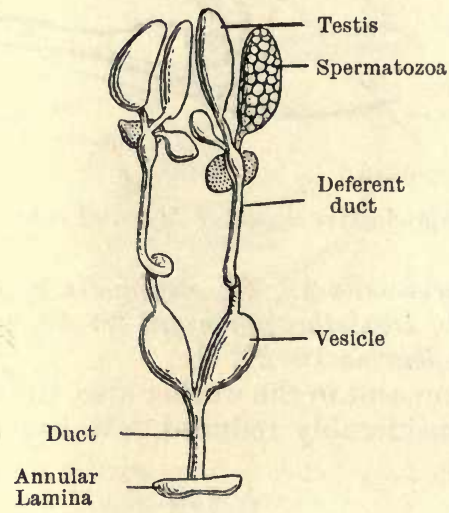

Fig. 41. Reproductive organs of Myrmica rubra $\widehat{\sigma}$. (Janet.)

spermatozoa. The number of bodies to each testis varies in different species-in Anergates atratulus there are 3, Myrmica species 4, Formica sanguinea 21, etc. The vasa deferentia, or deferent ducts, are long tubes which proceed from the bodies of the testes, and at their posterior ends are enlarged to form a pair of sacs, the seminal vesicles. These are united to form a narrow ejaculatory duct, which has its opening at the base of the penis.

The Circulatory, Respiratory, Muscular and Nervous Systems are beyond the scope of this work, and can only be very briefly discussed. For further details the reader is referred to the works of Berlese, Child, Dujardin, Forel, Hicks, Janet, Johnston, Lubbock, Nassonow, Rabal-Ruckard, Wheeler, etc. etc.

The Circulatory System.-The blood, a colourless liquid, is circulated through the body by the contraction and dilatation of the heart, which consists of a tube situated in the mid-dorsal region of the gaster. 
The Respiratory System.-The air is distributed through the system by tracheae or air tubes; these open at the stigmata or spiracles. Ten pairs of spiracles are present, eight of which occur on the eight basal abdominal segments, and, as we have seen, a pair each on the meso- and metathorax. Janet has described and figured elaborate valves with which the stigmatic orifices are furnished.

The Muscular System.-The only point that concerns us here is the interesting fact, demonstrated by Janet, that the wing-muscles in queen ants after the marriage flight become degenerated through

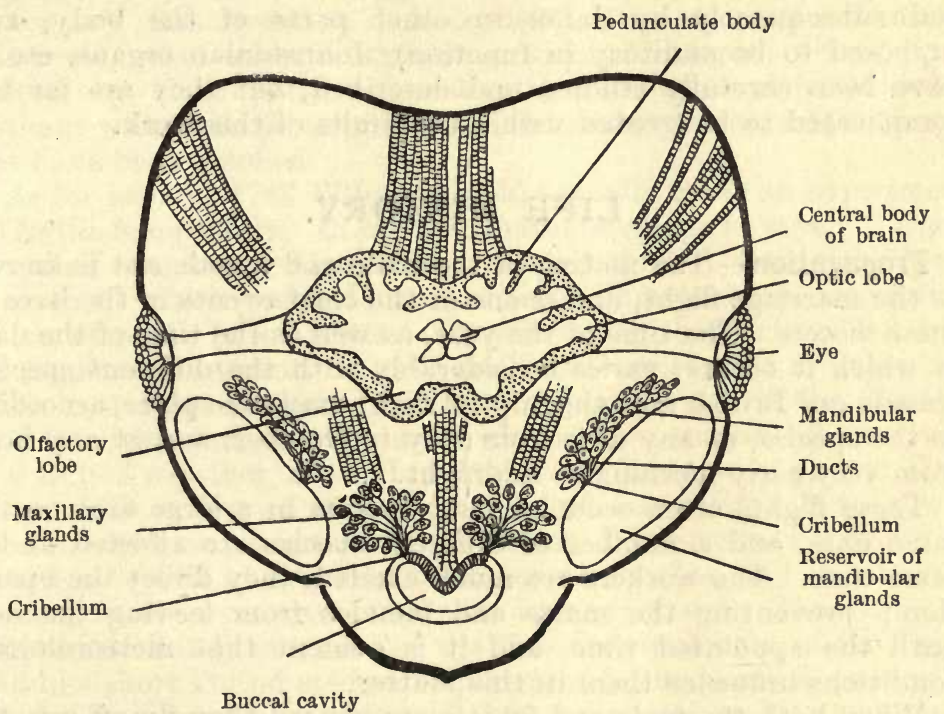

Fig. 42. Brain, etc., of Donisthorpea fuliginosa

histolysis. The fatty and albuminoid substances thus derived are carried to the abdomen in the blood, where they are taken up by the ovaries and assist the growth of the eggs. When the greater part of the wing-muscles has disappeared the thoracic tracheae become considerably enlarged, in consequence of which old queens will float when placed in water, etc.

The Nervous System.-Ganglia occur in the head, pro-, meso-, and metathorax, and abdomen. These are connected by two longitudinal cords, and nerves run from the ganglia to the various organs. The ganglion above the oesophagus is considered to be the brain. The frontal lobes of an ant's brain, which have been compared with the cerebrum of vertebrates, contain two pairs of pedunculate, or mushroom bodies, the corpora pedunculata. The olfactory 
lobes, which have been compared with those of the vertebrates, contain a large number of round bodies, the glomeruli. The pedunculate bodies are often largest in the worker and least developed in the male, and this has been supposed to show that the former was the most, and the latter the least intelligent of the three sexes. Wheeler, however, has shown that the pedunculate bodies may be as highly developed in the female as in the worker, and by no means vestigial in the male, and in any case it is very doubtful if the female is less intelligent than the worker.

Many sense organs - tactile, olfactory, and gustatory sensillae, chordotonal organs (first discovered by Lubbock in the fore tibiae and subsequently by Janet in other parts of the body, and supposed to be auditory in function), Johnstonian organs, etc.have been carefully studied and described, but they are far too complicated to be treated within the limits of this work.

\section{LIFE HISTORY.}

Propagation.-The mating of the male and female ant is known as the marriage flight, and is one of the chief events in the lives of these insects. The time of the year, as well as the time of the day, in which it occurs, varies considerably with the different species. Among our British ants the nuptial flight may take place, according to the species, at any date from May to October, and at any hour from very early morning to midnight.

These flights often occur at many points in a large area on the same date, and a number of different species are affected at the same time. The workers are much excited, they direct the operation; preventing the males and females from leaving the nest until the appointed time, and it is evident that meteorological conditions influence them in this matter.

When both the male and female are winged they fly off into theair, and with those species in which the former is considerably smaller than the latter, copulation takes place on the wing. When however the sexes are of the same size, they either join in the air and fall to the ground, or the male seeks the female on the ground, on trees, bushes, etc., or even in, or on, the nest. When one of the sexes is wingless (no ants are known in which both male and female are wingless, and in Britain no species occurs in which the female is apterous) a "marriage flight" in the strict sense of the word cannot of course take place, but a similar period of excitement is present, and copulation between brother and sister (adelphogamy) in or on the nest, is the rule.

I have, as far as possible, given under each of our species an account of the method of and time for the marriage flight and the appearance of the winged sexes, etc.

After the marriage flight the males do not necessarily die at 
once, as they can be kept alive for months afterwards in observation nests ; nor are they injured when separating from the female, but they wander aimlessly about, without ever returning to their nests, and most of them are probably eaten by birds, or killed by strange ants and other insects.

Many females also share the same fate, but those which escape endeavour to found new colonies-this is brought about in various ways.

Colony Founding. - It is only within comparatively recent years that it has been possible to give anything like a complete and connected account of the origin of the ant colony. For more than a century this question has occupied the attention of many observers, who, though expressing widely divergent views, have helped by their patient investigation to accumulate evidence without which the present state of knowledge on the subject could not have been reached.

As far back as 1747 William Gould actually made an experiment on fertile female ants. In his own quaint language he says : "Upon frequent opening of Mole-Hills, amongst them I met with three, in each of which was a Cluster of large Female Ants, amounting to six or seven in a Cluster. They lay near the Surface, but had no regular Apartment. ... Upon Dissection several of them had Parcels of Eggs in their Insides. I deposited one of the Clusters in a Box with some Earth, under which they concealed themselves, and united together, but did not work any Lodgment. Some Time after, three or four of these Females laid a few Eggs, but did not seem to take any great Notice of them. For Curiosity I placed in the Box, a Cell of Workers of the same Species, and it was surprizing to observe what Fondness was expressed. The Common Ants immediately surrounded the Females, took care of the Eggs, and in a short Period made an Apartment in the Earth fit to receive them. It may also be observed that there were no Common Ants in the Hills where I found the above Clusters."

The above is valuable, not only as showing that fertile females were received by strange workers of their own species, but also because it is the first recorded instance of a number of females after the marriage-flight voluntarily associating together and laying eggs.

P. Huber (1810) carried experiments on fertile females a stage further. He enclosed several fertilized females in a jar full of damp earth, in which they excavated cells. They laid eggs and brought up several fair-sized larvae, which, however, perished owing to his own neglect.

The first who actually demonstrated that females, after the marriage-flight, are capable of bringing up their brood to maturity unassisted, was Lord Avebury, in 1876, whose experiment is referred to under Myrmica ruginodis. 
It was subsequently assumed that all species of ants founded their colonies in this way. Modern researches however have shown that though this is true for the large majority of ants, many species employ very different methods.

Some writers have proposed elaborate classifications of all the different methods of founding a colony, but space does not permit me to discuss them here.

The following table, taken from a paper on the founding of colonies by queen ants read at the Entomological Congress at Oxford by Crawley and myself, briefly shows all the known methods in which a colony may arise :-

I. (a) The female ant, after the marriage-flight, removes her wings, seeks a suitable situation, constructs a cell, and brings up her colony alone.

(b) Several such females may voluntarily associate and found a colony in a similar manner.

II. The female seeks a nest of another species of ant, is adopted willingly or otherwise by the workers, who bring up her brood. In some manner the host-queen, if present, is eliminated. Then either $(a)$ in course of time the host colony dies out, and a pure colony of the female's species remains ; or $(b)$ the mixed character of the colony is kept up by means of slave-raids on nests of the host species by the female's offspring.

III. The female is adopted into a colony of another species and lives side by side with the rightful queen. The intruder's offspring of all sexes, but only workers of the host species, are reared together in the nest.

IV. Differs from II $(a)$ only by the fact that, the species of the alien queen having no worker caste, the colony only lasts for the lifetime of the host workers.

Group I may be considered to represent the normal method, and Groups II, III, and IV the abnormal methods.

In both I and II after the colony has become established, young females reared there may be received back into it, or may enter another colony of their own species after the marriage-flight. The fertilized female removes her wings by working them backwards and forwards, pulling them with her legs and mandibles, or rubbing them against twigs, grass-stalks, or anything handy. In some cases young females which have been fertilized on, or near, their own nest, will be brought back by the workers, who help them to remove the wings.

The shedding of the wings by a fertile female alters her instincts, causing her to become more timid, and to shun the light. Indeed Wheeler has shown that, with some species, the artificial deälation 

Plate I.

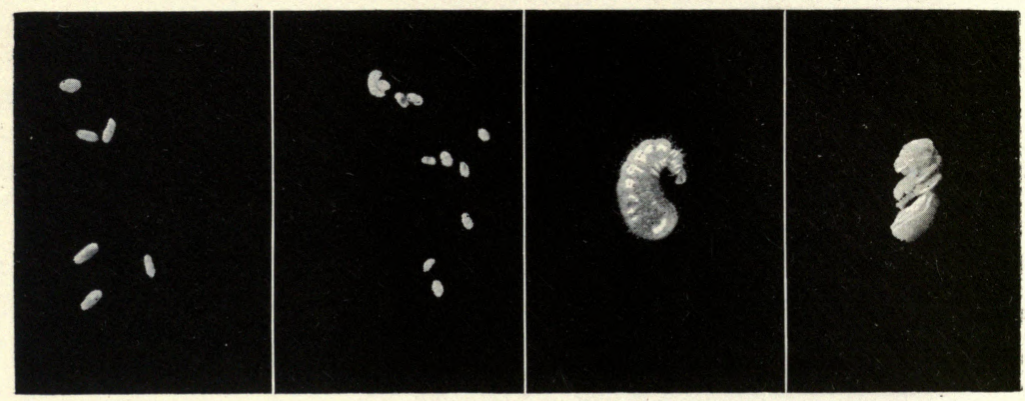

Eggs of Ponera coarctata.
Eggs and small larva, full grown larva, and pupa of Myrmecina graminicola.

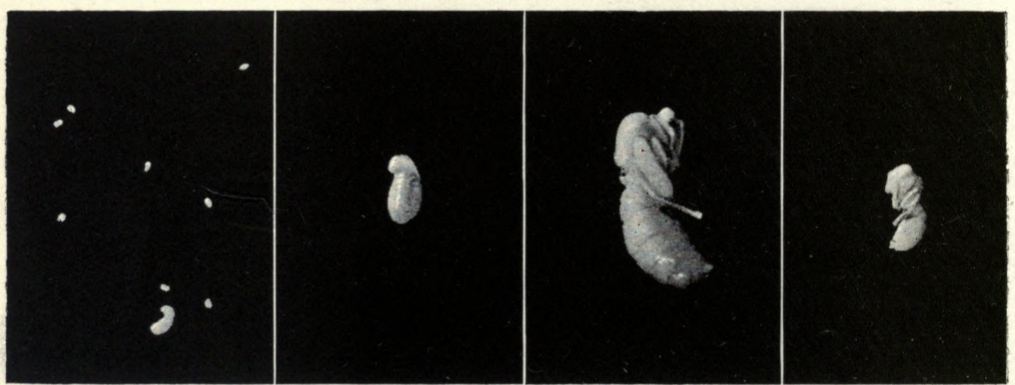

Eggs and small larva, larva, and male and worker pupa of Solenopsis fugax.

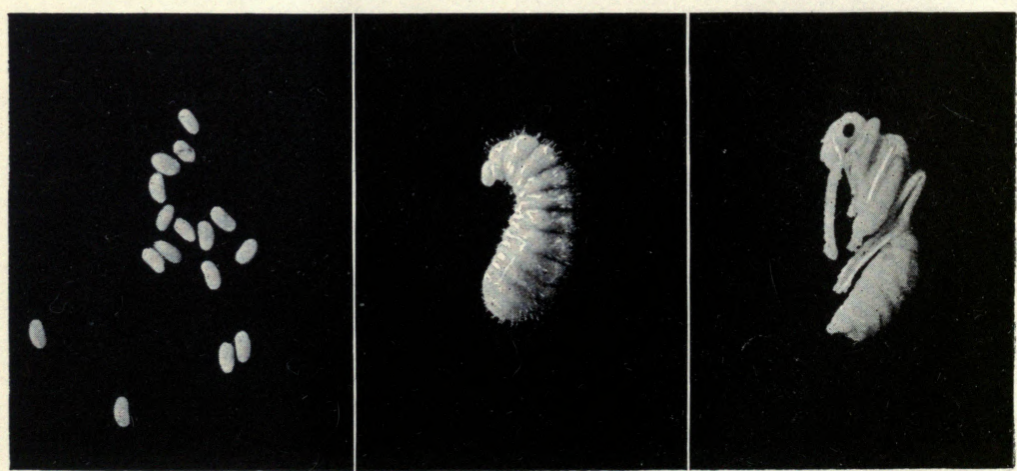

Eggs, larva, and pupa of Myrmica ruginodis. 
of a virgin female has the same effect upon her as the loss of the wings to a fertile one.

It is a remarkable fact that an old queen will, if removed from her nest, again carry out all the labours necessary for the starting of a new colony; although she may have lived an uneventful life for years, being fed and cleaned by her workers, and doing little except lay eggs. Thus an old female belonging to Group I, will under these circumstances excavate a new cell, lay eggs, and bring up a fresh brood; and one belonging to Group II, if introduced into a nest of the host species, will act in the same manner as a young fertile female.

I shall describe, at some length, under each species the colony founding of all the British ants.

Metamorphosis.-The female ant when laying lowers her head and raises her gaster; shortly an egg appears, which is quickly extruded, but remains for some time at the tip of the abdomen until she deposits it on the ground. The workers at once pick up the eggs and collect them in a heap, sometimes even they remove them from the body of the female, drawing them out as they appear. They constantly lick and caress with their antennae the queen's gaster when she is laying. In some cases the queens lay eggs on the march and these are at once picked up by the workers.

Young queens (and also workers which lay) will remove their own eggs, bending the gaster forward between their legs, and pulling out the ovum with their mandibles.

The eggs of ants are quite small, even those of the largest species, in proportion to their size. They are white, or yellow in colour, varying in shape in different species, being round, elliptical, or elongate, and consist of a delicate shell or chorion enclosing a thin liquid yolk.

Ants' eggs are said to grow after they have been laid; this has not been proved by measurements, but from observations in artificial nests it appears to be the case; moreover the ants are constantly licking them and covering them with a coating of saliva, which probably assists in this process.

This salivary coating causes the eggs to adhere together in larger, or smaller, packets, which enables them to be more easily carried about. The coating probably also contains some antiseptic properties against fungoid growths-I have noticed in observation nests that neglected eggs have quickly gone mouldy.

The workers and young queens, and in some cases the old queens as well, continually move and carry about the egg-packets. Many species arrange the eggs, larvae, and pupae, in groups according to their age and condition, as the different stages require different, degrees of moisture and temperature.

Eggs are laid by the young females of some species almost im- 
mediately after fertilization, whereas with others oviposition does not take place until the year after the marriage-flight. The time required for the eggs to mature varies very much both in different species, and also under different conditions. It may only occupy a few days, or it may require six weeks ; and unfertilized eggs take much longer to hatch than fertile ones. A large proportion of the eggs laid are eaten by the ants themselves, chiefly by the workers, though also by the queens, both in new and in long-established colonies.

A young queen eats some of her own eggs, and also feeds her first brood with them.

A large number of the eggs laid by workers in queenless nests are always devoured, and a worker will eat her own egg as soon as she has laid it.

Parthenogenesis.-It was supposed that Dzierzon's theory for the honey-bee, that unfertilized eggs only develop into males, applied to ants also, but although Lord Avebury, Janet, Forel, Miss Fielde and others have shown that this is frequently the case, more recently Tanner, Reichenbach, Mrs. Comstock, Crawley, and myself have proved that unfertilized eggs laid by workers can develop into workers.

Indeed, under certain circumstances-such as the adoption of a Donisthorpea umbrata, or $D$. mixta female into a nest of $D$. nigra or D. aliena-workers only seem to be developed from worker eggs.

Crawley and I have also observed eggs laid by virgin females, but on these occasions, when the eggs have developed, only males were produced.

The particulars of these different experiments-when they concern ants that occur in Britain-will be found under the species in question.

Larvae.-The larvae of ants belong to the vermiform type, being without legs, or any trace of eyes. They are helpless white or yellowish grubs, entirely dependent on the queens and workers, and are usually pear-shaped, or sack-like, being broadest posteriorly, but in a few cases they are cylindrical, or barrel-shaped, i.e. broadest in the middle.

The head is small, but distinct; the neck is narrow and often bent downwards over the ventral surface, considerably more so in some species than in others.

The body, exclusive of the head, usually consists of thirteen segments, three belonging to the thorax and ten to the abdomen; the segmentation being well marked in some species, but considerably less so in others, especially towards the posterior end.

Ten pairs of tracheal openings are present, a pair each to the meso- and meta-thorax, and the remaining pairs to the eight anterior abdominal segments.

The mouth parts are not as a rule strongly developed; they 



\section{Plate II.}

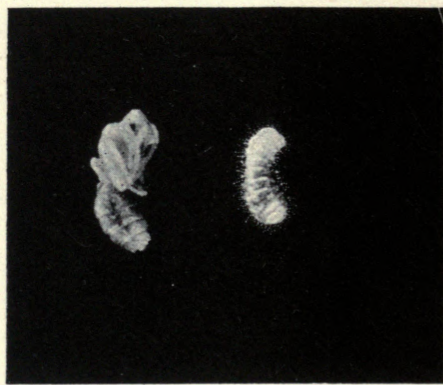

Pupa and larva of Anergates atratulus.

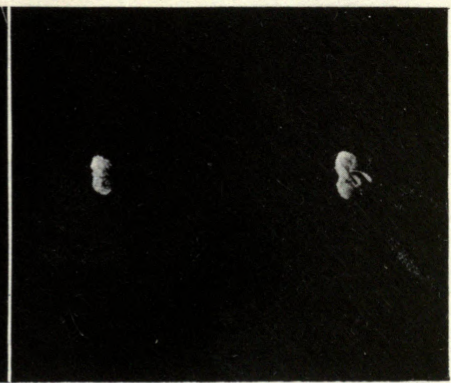

Larva and pupa of Monomorium pharaonis.

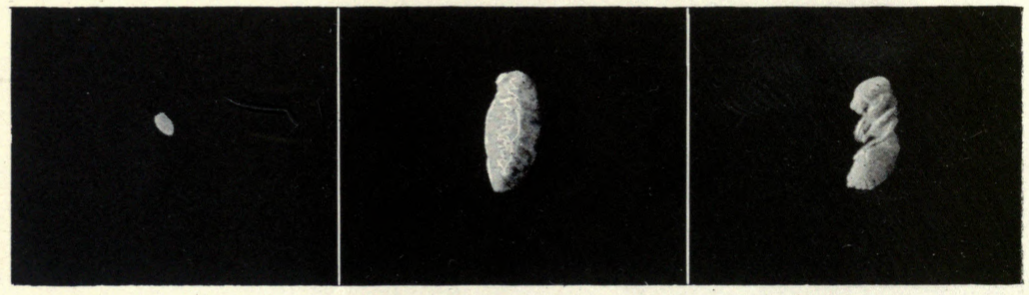

Egg, larva, and pupa of Leptothorax interruptus.

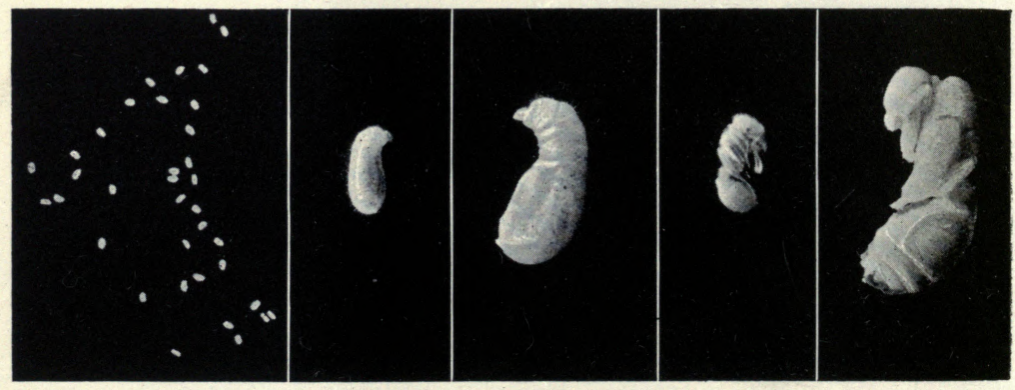

Eggs, small and large larva, worker and male pupa of Tetramorium caespitum. 
consist of a pair of mandibles, a pair of maxillae, and a labium, and usually only the mandibles are more strongly chitinized. The maxillae are furnished on their outer sides with a short blunt chitinous tooth, as is also the labium, and on the latter, two ringlike spots may be seen in some species, being the larval structure which will become the labial palpi of the imago. Although these rings are figured by various writers on ant-larvae, I have not seen any mention of them or suggestion as to their nature. The spinning glands open on the tip of the labium, and are present as well in those species whose larvae do not spin cocoons as in those which do.

The antennae are nearly always wanting in ant-larvae, but Emery has pointed out that in certain exotic species, vestigial antennae are present. I have observed certain rings on the heads (similar to those on the labium before mentioned) of Myrmica larvae, which

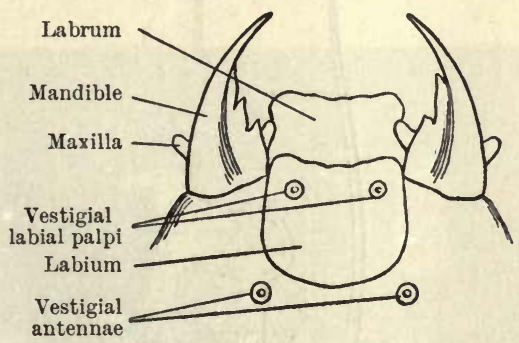

Fig. 43. Head of larva of Myrmica scabrinodis.

are situated in exactly the same position as the rudimentary antennae discovered by Emery in other genera, and these rings no doubt represent antennae of a still more vestigial character.

The larvae of ants are very seldom naked, being furnished with hairs of various kinds, spines, tubercles, etc.

The hairs may be long, or short, simple, serrate, bifurcate, or trifurcate, branched, hooked, or anchor-tipped, etc., and several kinds of hairs may occur on the same larva.

The spines, some kinds of tubercles, and perhaps some hairs, serve to protect the larva against the attacks of its fellows-a hungry larva will sometimes devour another-and also may prevent its body from coming in too close contact with the damp ground. The longer hairs which terminate with a single or double hook (anchor-tipped in the latter case) are used in hanging the larvae on to the walls or roof of their dwelling, and also in causing the younger ones to adhere together in small bundles-some tubercles and probably other hairs also serve for this purpose-so that they can be more quickly moved by the workers.

The long hooked hairs are curved somewhat in the shape of a 
letter $\mathrm{S}$, so that they act as springs, and prevent the delicate skin of the larva from being injured. Thus should an ant quickly seize a larva to remove it from its anchorage, the spring expands, and allows the hair to become unhooked without too great a jerk.

Huber and F. Smith stated that ant-larvae were more thickly clothed with hairs in the winter ; this, however, seems very doubtful, and in my observations all young larvae are more hairy than older ones, being equally so in those species which only rear larvae in the summer, as in those which rear them in the winter. With some species larvae are present practically all the year round.

Ants chiefly feed their larvae with liquid food which is regurgi-

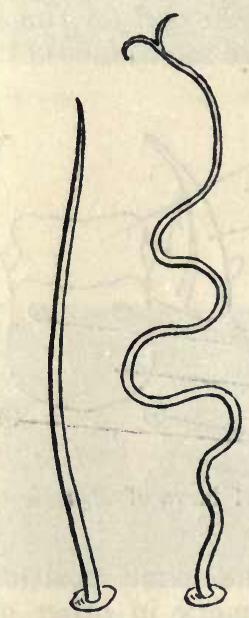

Fig. 44. Hairs on Myrmica larva.

tated into their mouths, but they also supply them with bits of insects, larvae, eggs, etc.; the more solid food being placed by the workers on the bodies of their nurslings or actually held to their mouths that they may feed upon it. Great attention is paid by the nurses to their charges, as they not only feed them, but also continually clean and lick them, and carry them about. The length of time occupied in the larval state varies considerably, both with species and individuals; it may last for only a few weeks, or for many months, or even for over three years, but this extreme length of time is probably due to extraordinary circumstances.

Larvae which hatch from parthenogenetic eggs, take longer to develop than do those from fertile ones.

Pupae.-Ant pupae are either naked, or enclosed in a cocoon, the latter being invariably present in the Ponerinae, often in the 
Plate III.

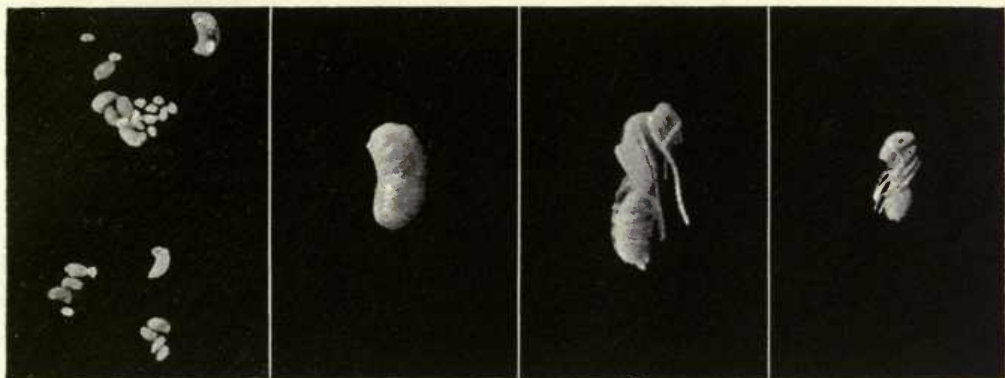

Eggs and small larvae, larva, and male and worker pupae of Tapinoma crraticum.

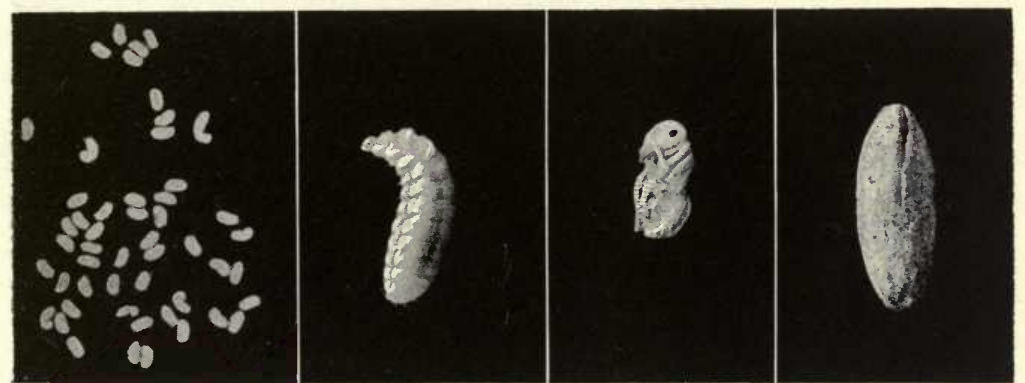

Eggs and small larvae, larva, naked pupa, and cocoon of Donisthorpea nigra.

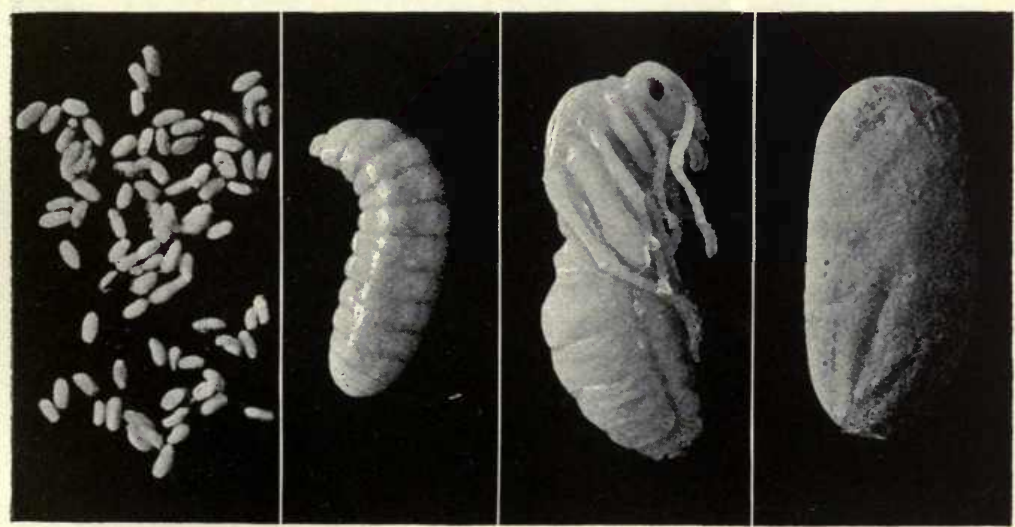

Eggs, larva, naked pupa, and cocoon of Formica rufa. 


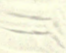


Camponotinae, but not in the Myrmicinae and Dolichoderinae. The fact that the pupae of the most primitive group always possess cocoons, suggests that this habit is an inheritance from solitary ancestors. Wheeler has recorded the presence of the naked pupa of a Dolichoderine ant in Baltic amber, which shows that the absence of a cocoon in this sub-family is not a recent development. In a few genera of the Camponotinae there is no cocoon, but even with those in which one is usually present, naked pupae may often be found, even in nests which also contain pupae in cocoons. It is very difficult to understand this, or to see what, under these circumstances, can be the object of a cocoon at all.

Forel says he has found these naked pupae only in the late autumn, a cocoon always being present with the summer larvae. In England, however, I have found naked pupae of Donisthorpea and Formica species in their nests in June, July, August and September.

When a larva is fully grown it becomes straight and rigid, the legs, wings, etc., which are visible beneath its skin, are packed closely to the body, and it is now a semipupa. The larval skin then splits down the back, and is pushed off posteriorly.

Those larvae which do not remain naked after pupation, naturally spin their cocoon before the semipupal stage is reached. When they are ready to spin, the workers cover them over with little bits of earth, sand, etc., or bury them in shallow holes, to provide them with starting-points on which to commence spinning.

The workers dig up the cocoons when completed, render them clean and smooth by removing all adhering substances, and pile them in a heap.

In observation nests where no earth or sand is present, I have noticed that the workers will make use of bits of plaster, cottonwool, or anything handy, with which to cover a larva when ready to spin.

The colour and texture of the cocoon varies in different species, being white, yellow, buff, or dark brown, and finely or coarsely sculptured, etc.

A black spot is usually to be seen at the posterior end of the cocoon, which consists of the larval excreta, and the larval skin is also present; but with naked pupae these are removed during pupation by the workers.

The workers help the young imago to emerge - the latter before it has acquired the mature coloration has been called a "callow "by biting a hole in the cocoon, and drawing out the ant. Sometimes the workers remove the pupae from their cocoons before they have reached the imago stage.

It was formerly supposed that an ant was unable to get out of its cocoon without assistance, and if left would perish, but this is not always the case. 
The pupal skin, which closely covers the body and limbs, and which of course is the only covering of naked pupae, is also carefully stripped off by the workers, though ants may free themselves from it. If it is not thoroughly removed, it may produce cripples, especially in the winged sexes. I have frequently saved young callows, which had not been properly attended to by their mother, or foster-mothers, in my nests, by carefully removing the remains of the pupal-skin with a wet paint-brush.

The duration of the pupal period is shorter than that of the larval one, and may occupy two or three weeks.

The pupae are kept in drier parts of the nest than are the eggs or larvae, and some species of ants build special incubators of earth, or vegetable detritus, etc., to accelerate their development. Ants kept in plaster-nests in a warm room will pile up their pupae in the chamber nearest to the fire, and watch over them for some time-it is very amusing to observe a worker suddenly seize a pupa and hurry off with it, as fast as she can, back to the cooler chambers, as if it was a joint before the fire, and was just cooked to a turn.

Temperature undoubtedly influences both the period for egglaying and the time required for development of the brood.

In my observation-nests kept in a hot room the queens of some ants, which in nature would not lay before the spring, have commenced to do so as early as December.

The eggs, larvae and pupae of all British ants which $I$ have been able to find will be briefly described below under their respective species or genera.

Polymorphism.-Ants vary exceedingly both in habits and structure, it being almost impossible to lay down rules on any points concerning them, to which exceptions cannot be found. In the following points - and many others might be mentioned-ants vary, not only in different genera and species, but often in the same species itself : the time for the appearance of the sexes, and for the marriage flight; whether the males and females are winged or wingless; whether the former are more abundant than the latter, and whether they are both present at the same time, or in the same nest ; whether the ocelli are present or absent in the wingless forms (worker, male or female); whether the larvae occur in the summer or winter or both; whether the pupae are naked, or enclosed in cocoons; how the colony is founded; in what situations, and under what circumstances the nests will be built, etc. etc.

These variations however are not what is understood by polymorphism in ants.

Polymorphism is possessed by those species in which the sexes -one or both of them-occur in two or more forms; these forms being more or less regularly produced in certain generations, or in each successive generation, which are sprung from the same parents. 

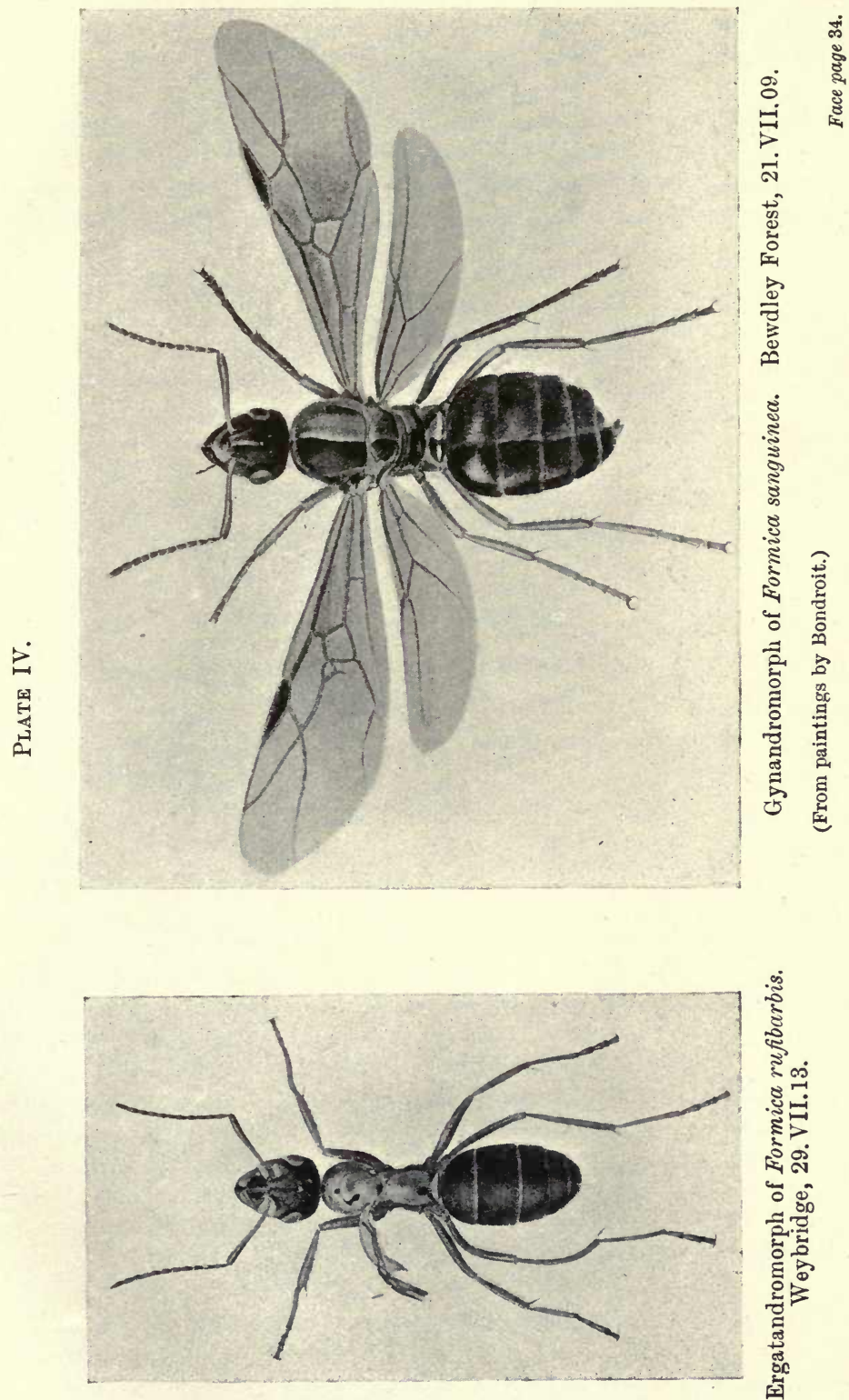
These phenomena are very highly developed in the ants, in most species of which a winged male and female, and a wingless worker are present-in a very few cases only, the worker class is wanting.

These three normal forms are again split up into further " phases," which however are neither as constant, nor as important as the primary ones.

Wheeler has constructed a most valuable table to illustrate the series of different phases known to occur among ants. This table is reproduced here (with a few additions), as although some of the phases have not yet occurred in Britain, and others are peculiar to

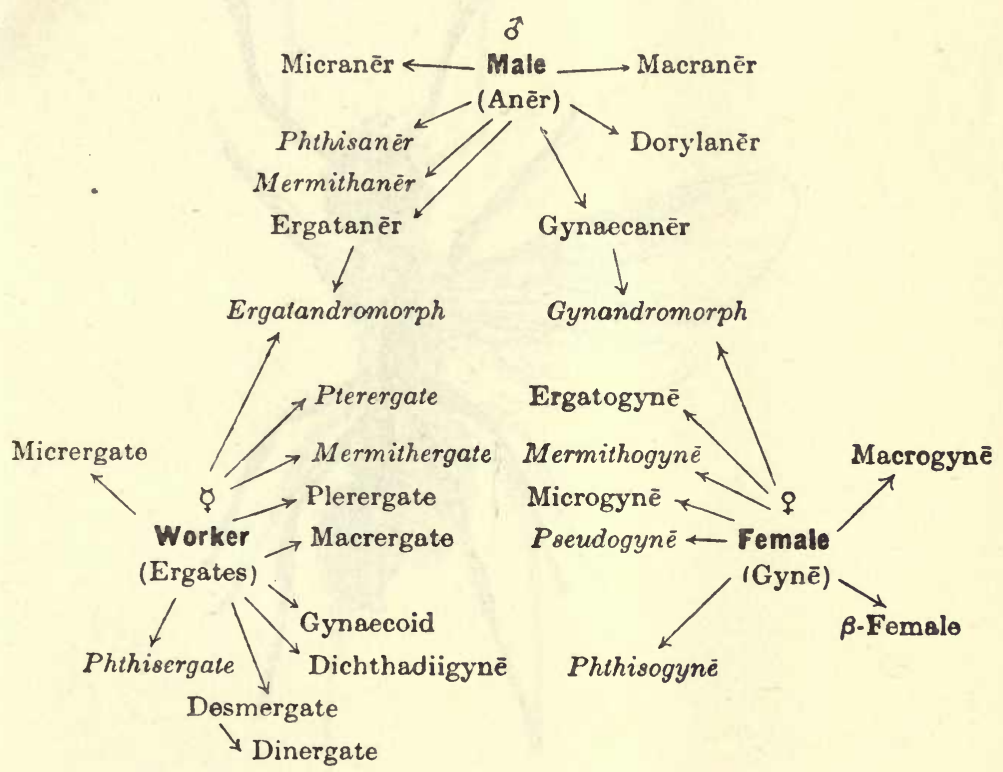

tropical and non-British ants, the table is of so much interest that it would be a pity not to give it in toto.

"The three typical phases are placed at the angles of an isosceles triangle, the excess developments being placed to the right, the defect developments to the left, of a vertical line passing through the middle of the diagram. The arrows indicate the directions of the affinities of the secondary phases and suggest that those on the sides of the triangle are annectant, whereas those which radiate outward from its angles represent the new departures with excess and defect characters."

The typical and atypical phases are printed in Roman type, the pathological phases in italics.

1. The male (anerr) is the most fixed of the three primary phases. 
Typical male ants are always winged, and are often very much alike, superficially, though they may belong to widely separated genera, and even sub-families, in which the females and workers are very diverse.

The body is usually delicate in form, and the colour is often darker than in the female and worker; though in some cases the male may be yellow, or red, etc., when the female is black. The head is usually smaller and rounder, the eyes and ocelli more highly

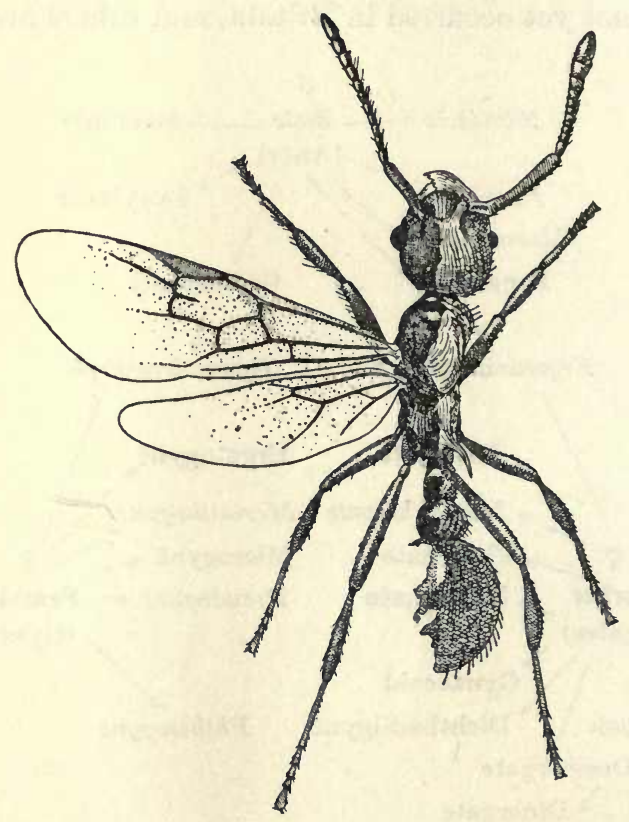

Fig. 45. Ergatandromorph of Myrmica scabrinodis. Ditchling, IX.1909. (Bondroit.)

developed, the mandibles smaller and weaker, and the antennae longer and finer, than in the female and worker.

2. The macraner is larger in stature than the normal male of the species in question, and is occasionally to be met with in populous colonies.

3. The micrane $r$ is smaller in stature than the normal male of the species in question.

4. The dorylanèr is a large form of male peculiar to the Doryline ants. This sub-family does not occur in Britain.

5. The phthisaner is a pupal male which in the larval or semipupal state has had its juices partially extracted by an Orasema 
larva, and is unable to pass on to the imaginal stage. This has not been observed in any British ant, nor have the similar forms which occur in the female and worker.

6. The mermithaner is a male with short wings, caused by the presence of an internal worm of the genus Mermis.

7. The gynaecanèr, or gynaecomorphic male, resembles the female rather than the male. The number of joints of the antennae is

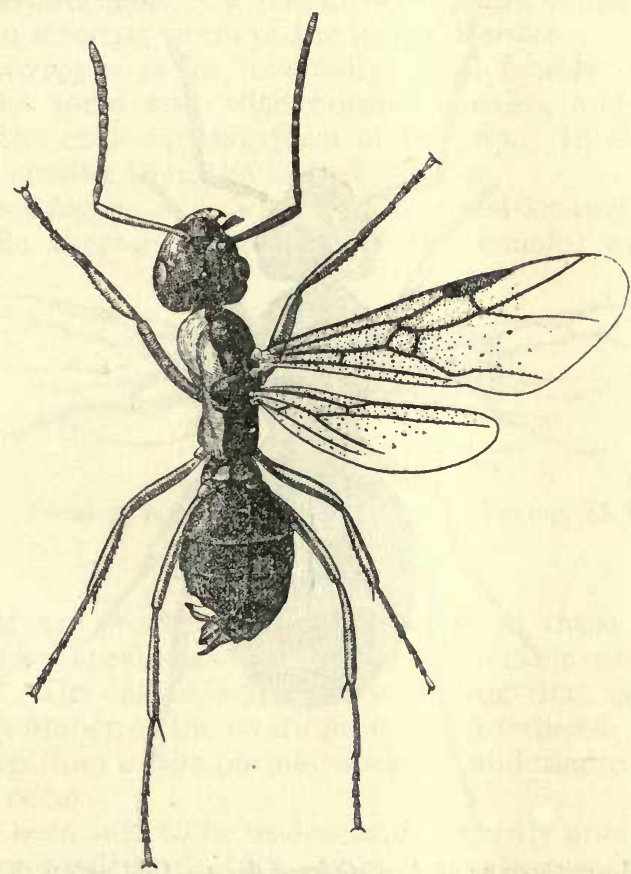

Fig. 46. Ergatandromorph of Formica sanguinea. Bewdley, 20.VII.1909. (Bondroit.)

the same as in the former, but it may be winged, or wingless as in Anergates.

8. The ergataner, ergatomorphic, or ergatoid male, is without wings, and sometimes closely resembles the worker, but may also be more like the normal male. With some species which possess an ergatanēr, a winged form is also present, the male being dimorphic. Some of these wingless males possess only the same number of joints to the antennae as the worker, for example the very ergatoid male of Ponera punctatissima, others possess one more joint, for instance, the male of Formicoxenus nitidulus. 
9. The gynandromorph is an individual in which male and female characters are combined.

10. The ergatandromorph is an individual in which male and worker characters are combined.

11. The female (gyne), queen, or a-female, is the most highly specialized sex. The head and thorax are large; the eyes, ocelli and mandibles well developed, and the gaster is bulky. The legs and antennae are often, and the wings sometimes, shorter and

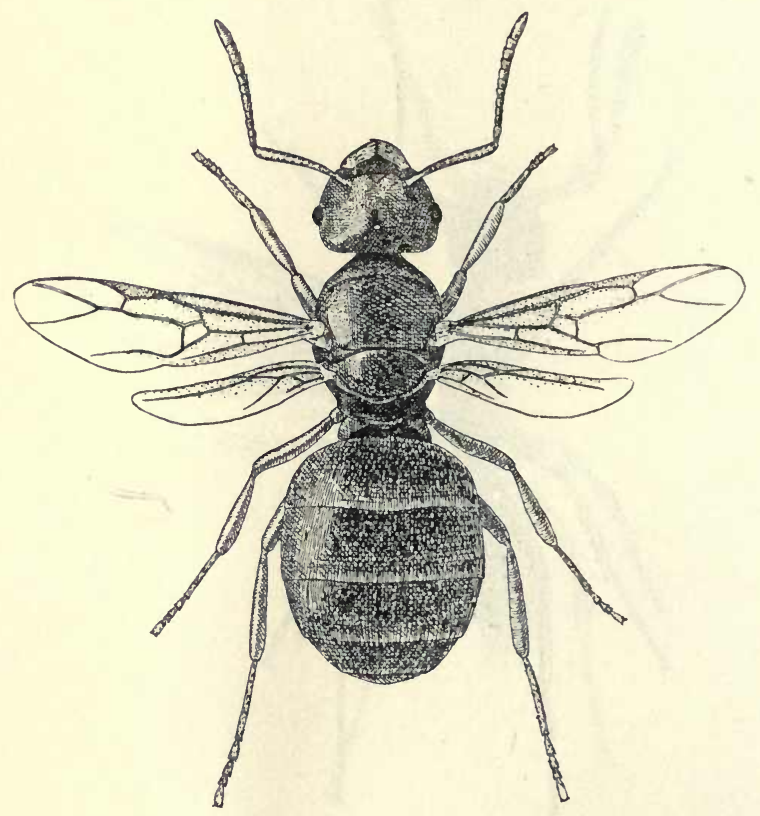

Fig. 47. Mermithogyne of Donisthorpea flava. Oddington, 7.VIII.1900. (Bondroit.)

stouter than in the male. She is usually larger than the male and worker of the same species, and in some exotic genera her size is enormous in comparison with the tiny worker of her own species.

12. The macrogyne is larger in stature than the normal female of the species in question.

13. The ergatogyne, ergatomorphic, or ergatoid female is a wingless form. It possesses ocelli, the eyes and thorax being more like those of the normal female. In some species it is the only form present, in others in which the female is dimorphic, a winged form also occurs. No British species possesses an ergatoid female. (When a wingless female is spoken of, it must be understood that 
this does not refer to the deälated female-i.e. one who has removed or lost her wings after the marriage flight-but to an apterous form which has been born without wings, and whose thorax shows no trace of wing-insertion.)

14. The $\beta$-female is an aberrant form, occurring either with or without the normal female, and characterized by excessive development in the legs, and in the pilosity of the body. This form has not been observed in Britain.

15. The mermithogyne is a female with short wings due to the presence of an internal worm of the genus Mermis.

16. The microgyne is an unusually small female; it may be present in the same nest with normal females, and with some species it is the only existing form of this sex. In either case it may be even smaller than the largest workers.

17. The pseudogyne is a wingless deformed-looking individual, combining the thoracic characters of the female, with the size

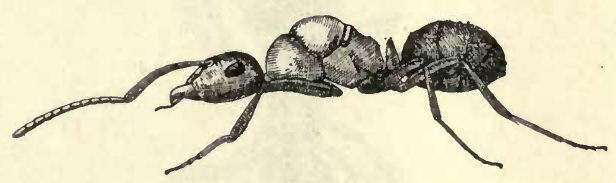

Fig. 48. Pseudogyne of Formica sanguinea. Woking, 21.V.1913.

(Bondroit.)

and gaster of the worker. The characters of these forms vary greatly, no two specimens out of a considerable number being exactly alike. The colour is often much lighter than in the normal female ; the number of the ovarioles is much reduced, being sometimes less even than in the normal worker ; and macro- and micropseudogynes occur.

They have been said to be useless and cowardly ants, but I have found that they will work, bite, spray acid, clean each other, and tend the brood, as do the normal workers.

Wasmann considers that they are brought about-in Formica colonies-by the presence of beetles of the genera Lomechusa and Atemeles, and Wheeler has suggested that they arise from starved female larvae. From my own experience with pseudogynes, I do not consider that either of these hypotheses will always, or alone, account for their presence in a colony; as though both these stimuli may induce this state of things under certain circumstances, under others, some other cause, about which we know nothing at present, may produce the same result.

18. The phthisogyne arises from a female larva under the same conditions as the phthisaner.

19. The worker (ergates) is an imperfectly developed female, 
wingless, and possessing a more simply constructed thorax. The ocelli, which when present are smaller than in the female, are often wanting; the eyes and gaster are small, and the mandibles, antennae and legs are well developed. The largest and smallest workers, in many species, are connected by a series of intermediate forms. With species in which the worker is dimorphic, the intermediate forms have disappeared, and further where only a very small worker is always present, the large worker has also been eliminated.

20 . The pterergate is a worker with vestiges of wings, the thorax being either that of the normal worker, or somewhat approaching that of the female.

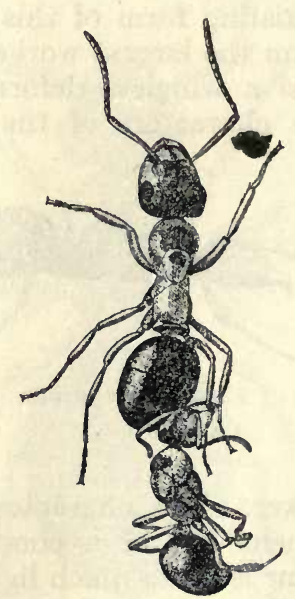

Fig. 49. Pseudogyne of Formica rufa var. rufo-pratensis fastened to the leg of a worker. Nethy Bridge, V.1912 This froves pseudogynes will fight and bite. (Bondroit.)

21. The mermithergate is a somewhat enlarged worker, due to the presence of an internal worm of the genus Mermis. The presence of the parasite in the worker appears to produce excess, instead of defective characters as in the male and female. Thus small ocelli and a tendency towards the female thorax may result from it. This phase has not been discovered in any British worker-ant.

22. The plerergate, replete, or rotund, is a worker which in its callow stage has acquired the habit of distending the gaster with liquid food. The well-known "honey ants" are the best examples, and no such form occurs in Britain.

23. The macrergate is larger in stature than the normal worker of the species in question, and is usually present in populous colonies. 
24. The micrergate is a worker of unusually small size. It is often present in nests which contain macrergates, as well as in moderate colonies. The first brood of a young queen usually consists of this form.

25. The gynaecoid is an egg-laying worker. In some families the queen has disappeared and has been replaced by this form of worker. Should a colony lose its queen, one or more workers may become substitute queens, lay eggs, and be treated accordingly by

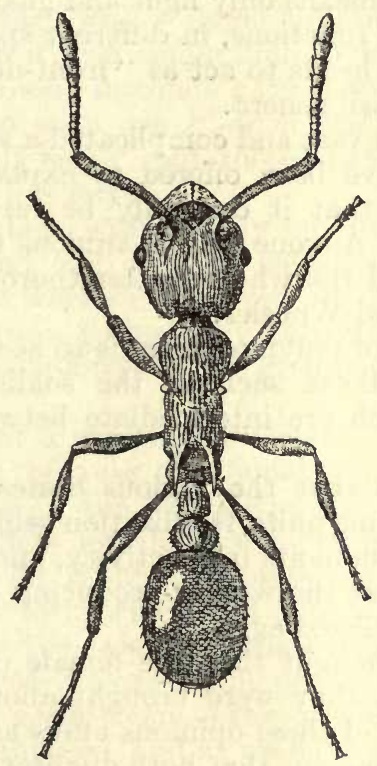

Fig. 50. Pterergate of Myrmica scabrinodis. Yelverton, VIII.1913.

(Bondroit.)

the other workers. I have found such workers in nests of Formica rufibarbis, F. fusca $v$. rubescens, species of Leptothorax, etc.

26. The phthisergate corresponds to the phthisaner and phthisogyne, and arises from the same causes.

27. The dichthadiigyne, or dichthadiiform female, is peculiar to the Dorylinae, and of course is not found in Britain. It is without eyes, ocelli, or wings, and is probably a further development of the gynaecoid worker.

28. The desmergate is an intermediate form between the soldier and the typical worker. Wheeler suggests that the term might also be employed to designate the intermediate forms between the small and large workers in such genera as Monomorium, Formica, 
etc. This does not seem to be a very satisfactory definition, as all the workers in a colony, intermediate between the macrergate and the micrergate, would be called desmergates.

29. The dinergate, or soldier (which is indicated by the symbol for Jupiter- " \& ", to distinguish it from the worker, for which that of Mercury - " $\nvdash "$ is used) is a macrergate with a greatly developed head. The jaws are often very large, long, or massive, and the thorax sometimes approaches that of the female in structure. The name "soldier" is not very happily chosen for these forms, as they by no means only fight and guard the nest, but also perform other special functions, in different species, such as crushing seeds, using their heads to act as "front-doors," etc. They do not occur in any British genera.

Polymorphism is so vast and complicated a subject, and so many different opinions have been offered to explain the origin of its various phenomena, that it can only be further discussed very briefly in this work. Anyone who is anxious to study the subject more deeply, will find the whole matter thoroughly dealt with by Emery, Escherich, and Wheeler.

The chief problem of polymorphism is to account for the various worker forms, and those such as the soldier, pseudogyne and ergatogyne, etc., which are intermediate between the worker and the female.

Weismann believes that the various castes are represented in the egg by corresponding units, fertilization being the stimulus which calls the female determinants into activity, and meagre feeding the stimulus which arouses the worker-producing determinants in the young larva from fertilized eggs.

Herbert Spencer thought that the female castes were not predetermined, but that they were brought about by differences in the feeding. Neither of these opinions offers an adequate explanation; it is certain, however, that both qualitative and quantitative feeding do exercise considerable influence in the matter.

A point that requires explanation is the fact that "queen" ants are not reared in captivity, the only exception being recorded by the late Lord Avebury. He mentions that the nest in question had been richly supplied with animal food, which he says may possibly account for the fact. In my own experience, however well fed my ants may have been, I have never succeeded in getting females produced in my observation nests.*

This would seem to show that either (1) the workers are unable

* Just before going to press a number of winged females have hatched from pupae in my observation nest of Myrmecina graminicola. I have had this colony in my possession for over five years (see page 81); these females must therefore have been produced from eggs laid in captivity! The ants in this nest have been supplied with a large amount of animal food during the last six months. 
to obtain some special food, such as the excreta of Aphidae, etc.; or (2) that they purposely do not bring up females in captivity, as they realize that there is not room for them, and that no marriage flight could take place; or (3) that the queen is unable, or will not, lay eggs in captivity which will produce females. Suppositions 2 and 3 appear to be rather too speculative in our present state of knowledge for serious consideration.

The following appear to be the stages in the phylogeny of ants :-

1. A pre-social stage with a single kind of male and female.

2. A social stage with a single kind of male and female, but the nesting and nursing instincts have developed.

3. A social stage with one kind of male, and two or more kinds of female, all fertile, but those that build and hunt for food are becoming less fertile.

4. The present stage with usually one kind of male, a fertile form of female, and one or more so-called "sterile" females, or workers. These workers, however, are fertile with sufficient frequency to maintain (principally through the male) a representation of their characters in the germ-plasm of the species.

Emery believes that a worker-like wingless form was the oldest type of female both because the females in the Mutillidae are wingless, and because in the Ponerinae, the most primitive subfamily of ants, wingless females are more frequent than in the higher subfamilies. As Escherich points out, however, it is unlikely that a wingless form which had once acquired wings, would again lose them, as in the case of wingless females.

Weismann considered the egg-laying of the workers as too infrequent to influence the germ-plasm of the species. It is not, however, so infrequent as he supposed, and as we have seen under Parthenogenesis, not only males but workers also are produced from these eggs ; so there is no reason why the transmission of characters acquired by this caste should be either impossible or improbable.

\section{PSYCHOLOGY.}

Ants possess the senses of Smell, Touch, Taste, Sight, and probably Hearing in some form or other.

The sense of smell, which is partly combined with that of touch, is of the first importance to these insects, and undoubtedly resides in the antennae. Ants are quickly attracted by some odours and repelled by others; they wave their antennae about when an odorous substance is brought near to them, this being also the case with quite blind species. When tapping anything with the antennae, they probably obtain a combined sensation which 
Forel has called a "contact-odour." Wasmann speaks of the antennae as "touching-noses"; he says ants do not know each other personally, but recognize each other by an intelligent " parole," a recognized form of antennal stroke. Miss Fielde has carried out a number of experiments to prove that each of the different joints of an ant's antennae has a different function. For example she considers the final joint recognizes the home or nest odour, the penultimate recognizes personal relations, the antepenultimate the path or track, etc. She also concludes that the whole nest aura changes every two or three months. Though these experiments are very carefully elaborated, the results are by no means conclusive; the subject being far too difficult and intricate to be settled so easily. It is certain however that if an ant's antennae be removed it can neither find its food-only feeding if it accidentally stumbles on to it-nor its way, nor recognize friends from foes, etc.

Ants possess great delicacy of touch-tactile hairs and sensillae being present all over the body, as well as on the antennae-and this sense is also of great importance to them. Their extreme sensitiveness to light and temperature is probably closely connected with their sense of touch.

The sense of taste is situated in the tongue and maxillae. Ants show distinct preferences for certain foods, and they quickly detect any unpleasant substance-even if odourless-mixed with their food. Wheeler considers that taste is evidently the sense in which these insects approach most closely the higher animals and man.

Sight varies considerably in different species, some being completely blind. The exhibition of " mimicry" in certain myrmecophiles and parasitic ants, shows that their hosts possess the power to discriminate colours and forms. Lubbock demonstrated that ants can perceive, and avoid, the ultra-violet rays of the spectrum, and Forel proved that this was through the eyes-he covered these organs with varnish, when the ants were no longer able to distinguish these rays. Moving objects are more readily observed by ants, but Wasmann has shown that certain species can see an object not larger than a finger, at rest at a distance of five to ten centimetres; smaller objects, such as little beetles, cannot be seen at a greater distance than four to five millimetres. I have frequently observed a worker of Formica rufa when pursuing a small beetle, will lose sight of it and run blindly by it. Exner's theory that the compound eyes form of an object a single picture which is more distinct the greater the number of facets possessed by these eyes and the more convex they are, seems to be generally accepted. In the case of the ocelli, however, it has been suggested that they enable an ant to see better in the dark, but as they are largest and best developed in the male-who can see a flying female at some 
distance-this does not seem to be a satisfactory explanation. Hearing has been denied to ants altogether by some authors, and it is probable that they do not hear, in the ordinary sense of the word. The possession of chordotonal organs in the tibiae (similar to those of crickets, etc.), and other parts of the body, and the fact that numerous ants possess well-developed stridulating organs, seems however to point to some form of hearing. Lord Avebury could never find that ants seemed to hear any noises of a variety of different kinds which he tested them with, but he considered it probable that they might produce sounds entirely beyond our range of hearing.

I tested my ants in captivity with the whistle known as the Galton-Edelmann. The human range runs up to 40,000 to 50,000 vibrations per second, but tested by the sensitive flame this whistle is seen to give off musical notes far above that limit. I tried my ants in every way with it, up to its highest range, before which no sounds whatever could be heard by me, but the ants never appeared to notice anything at all.

Wheeler writes on stridulation :- "Stridulation, at least among the Myrmicinae, Ponerinae and Dorylinae, is an important means of communication, which Bethe has completely ignored and even Forel and other myrmecologists have failed to appreciate. It readily explains the rapid congregation of ants (Myrmicinae) on any particle of food which one of their number may have found, for the excitement of finding food almost invariably causes an ant to stridulate and thus attract other ants in the vicinity. It also explains the rapid spread of a desire to defend the colony when the nest is disturbed."

I have frequently noticed that when fresh honey is placed in the light chamber of a plaster nest, containing a colony of ants in captivity, after one individual has found it, immediately numerous others pour out and the honey becomes completely covered with feeding ants. Often, it is true, the first ant or two which arrive at the honey return to the nest and appear to tell, and to fetch, others; but the appearance of such a large number at once seems only explicable as caused by stridulation. Parker and Miss Fielde found that ants reacted to vibrations reaching them through the soil and other solids. They proved that these vibrations were received through the legs, as when the ant's head, gaster, and any one or two pairs of legs had been cut off, it still reacted to them. They conclude their experiments by pointing out that: "It is misleading to ascribe or deny hearing to ants ; they are very sensitive to the vibration of solids, not to those of air ; their reactions could be as appropriately described as resulting from touch as from hearing."

Several authors however still maintain that ants do perceive aerial vibrations. 
Some writers considered ants to be reasonable, intelligent beings, which possess virtues and morals little behind those of mankind; thus erring as far on the one side as Bethe on the other, who tried to prove that they were purely automatic machines, only performing reflex actions in response to certain stimuli. If the brain of an ant be pierced it remains standing almost as if nailed to the spot; occasionally a quiver runs through the body, and one of the legs is raised in the air from time to time. If irritated, it endeavours to resist, but as soon as it is left alone, it again falls into its former stupor. It does not try to escape, to return to its nest, or to join its companions. It has lost the instincts of fear and self-preservation and has become simply a reflex machine. This alone will prove the falsity of Bethe's theory.

Forel, Wasmann and Wheeler express views intermediate between these two extremes. I agree with Wheeler that ants possess both feelings and impulses, as they undoubtedly experience pleasure and pain, fear and anger, affection and aversion, etc.

That certain of their actions are only reflex ones, just as with ourselves (-Wheeler illustrates this very neatly, he says: "Whether a stinging ant or hornet merely exhibits a pure reflex or has a feeling of anger besides, is a nice problem. I have unintentionally sat on nests of Vespa germanica, and Pogonomyrmex barbatus, and while I have no doubt that I myself acted reflexly under the circumstances, it will take quite an army of physiologists to convince me that these creatures were acting as nothing but reflex machines."-) while others arise from what is called instinct, is evident; but personally from observations on ants both in nature and captivity, I am prepared to grant to them something approaching reasoning power. The following facts appear to support this view: many ants live, comparatively speaking, a very long life, during which time they must learn by experience; they undoubtedly possess memory; under certain circumstances, especially in observationnests, they will break away from their ordinary behaviour, and adapt themselves to new conditions-this plasticity is what Hobhouse defines as "the power of an organism to adapt action to requirement without the guidance of a hereditary method of adjustment," and Wheeler as "action on the basis of individual, i.e. ontogenetic experience, and as such is commonly designated as "intelligence" "-they become far less wild in captivity, for example they soon realize that they are going to be fed when a nest is uncovered, and do not endeavour to escape at once; such species as Myrmecina graminicola which when touched usually roll up and feign death, are with difficulty induced to do so after having been kept for some time, etc.; ants play together, run after each other, pretend to fight, and perform exercises; they have also been noted to assist wounded companions.

Darwin, Belt, Romanes and many other authors have related 
numerous instances in which ants have appeared to exhibit reasoning powers. It is true that some of the examples given, such as ants covering over tar, moisture, or unpleasant substances with earth, or even with their Aphides, etc., to form a bridge as it would appear, are not as conclusive as would be supposed, it being their natural habit to cover up moisture or anything objectionable in their nests.

I have seen workers in my $F$. rufa observation-nest bringing sticks, etc., from their hillock and casting them into the watertrough as if to build a bridge, some individuals having even crossed the water by this means; but it may have only been a similar case to the above.

Ants which are subject to inundations have learnt how to protect their colonies ; Livingstone wrote of ants in Africa: "When all the ant-horizon is submerged a foot deep, they manage to exist by ascending to little houses built of black tenacious loam on stalks of grass, and placed higher than the line of inundation." When an ant colony has been washed out of its nest by sudden heavy rain, or floods, the workers have been observed to collect into a ball with the brood, etc., inside, those on the outside occasionally changing places with the inner layers, and in this way float down the stream, until a place of safety is reached.

I once noticed a somewhat parallel case in my observation-nest of Donisthorpea umbrata. Having filled the water-trough too full, the superfluous water escaped under the glass cover and inundated the chamber in which the brood and most of the ants were situated. The workers immediately clustered round their larvae, enclosing them completely, and remained in this position under the water, until it had all been absorbed by the plaster walls and bottom of the chamber.

As space will not allow us to consider this subject at much greater length, it is best to turn to, and discuss briefly, some of the most striking psychological phenomena exhibited by ants.

\section{Ants know each other.}

Ants in a colony all know each other, but should a strange ant be introduced, it is at once attacked, and killed or driven out. Ants which have been separated for long periods readily recognize each other again; this has been demonstrated by a number of myrmecologists, and I have myself repeatedly found this to be the case with Formica rufa and other species. It has been shown by bathirig ants with the acid, or blood, of strange species, with alcohol, and even only with water, that they are no longer recognized by their friends, at least for a timethis proves that ants possess a special odour by which they are known. It is not present in quite freshly hatched ants; should, 
however, some of these be at once removed from their nest, kept until they are quite mature, and then returned, they will immediately be recognized and accepted. This odour therefore is produced in the individual itself, and does not come from an outside source.

When two ants meet they usually tap each other with their antennae; should one be a stranger, it is immediately threatened with open jaws by the other.

Bethe washed individual ants with alcohol to remove their own odour, and then bathed them in the blood of other species of ants. When he had bathed a strange ant $A$ in the blood of a species $B$, and introduced it into the nest of the latter, it was received in a friendly manner. He then bathed an ant from $\mathrm{B}$ in the blood of $\mathrm{A}$, replacing it in its own nest, when it was treated as an enemy. Wasmann, however, shows that Bethe did not carry the matter far enough, and that after a time ants so treated were again recognized as friends or foes, just as they would have been if they had never been bathed.

The facts that (1) different species of ants behave in different ways; (2) some species bring up strange pupae as slaves; (3) females which are temporary social parasites, and also other ants, do enter strange nests both of their own and other species, and get accepted; (4) myrmecophilous beetles are accepted into other nests of their own host ant, or even into those of other ants-(Wasmann and I have made numerous experiments on this point, and many examples of the other points just mentioned will be found in this book, under the different species)-all prove that how ants know each other is not a mere chemoreflex, but that memory, experience, education, smell, touch, and sight, all enter into the matter.

\section{Ants communicate with each other.}

Though ants cannot be said to converse in the ordinary sense of the word, they actually do communicate with each other; conveying intelligence, wishes, etc.

This is proved by the rapidity with which a mass of ants will pour out from their nest to assist any of their comrades which have been attacked, and congregate on any food that one of their number has found. Any such news may be conveyed by stridulation (as before mentioned), by tapping each other with their antennae, pulling at each other with their mandibles, butting each other with their heads, saluting (as described by Crawley, p. 186), tapping on the floor of the nest with their gasters (as I observed in Leptothorax acervorum, p. 152), etc. Belt also believed ants could communicate the presence of danger, of booty, etc. etc., to a distance by the different intensity or qualities of the odours they gave off.

Some ants when they wish to be fed by their fellows, stroke the 
side of the head of the ant they are begging from with the front feet, also rapidly tapping them with the antennae.

When one ant wishes another to come to a certain locality, it frequently carries it to the desired spot; it is evident that the other understands what is wanted, as it rolls up and allows itself to be carried.

All authors since and including Huber agree, that ants communicate with each other, in great part, by antennal strokes (antennae language). Anyone has only to study the behaviour of ants for himself, to be convinced of this.

Wasmann has enumerated a number of different antennal strokes, conveying different ideas. These depend chiefly on the nature of the stroke, whether quick or slow, heavy or light, at longer or shorter intervals, on the top, or side of the head, or only on the antennae, etc.

Should an ant find something which it desires to carry home to its nest, but which it is unable to move on account of its weight, or for any other reason, it leaves the find, goes to its nest for assistance, and returns with some of its companions. It is of course clear that the finder has conveyed to the others intelligence that something has been found, and that their help is wanted; moreover, although it may be said to be a reflex action when an ant finds food that it should carry it home, this can hardly be said when the ant returns home unladen, to seek for help.

\section{Ants find their way.}

As with nearly every point concerning ants, or their behaviour, it is impossible to generalize as to how they find their way. Bethe fell into this error; he stated ants went to and from their nests in a purely reflex manner, and for his experiments he selected certain species which always follow a trail. He invented a "polarization " theory, and concluded all ants only found their way by odour-contact.

It is true that many ants, such as Donisthorpea species, are chiefly guided in this matter by the sense of smell; but others, such as Formica species, are more indebted to that of sight. The latter sense is obviously of no use to blind ants, which however find their way quite as well as do those which possess eyes.

Many species when returning home to the nest, always follow the same path by which they left it; others make for home in a direct line, no matter how much they may have wandered about on the journey out.

If an obstacle be placed on a track of Donisthorpea fuliginosa, these ants hesitate for a time, all those arriving at this spot clustering together, until one or more crosses it, and the file resumes its march. Should the same experiment be tried with Formica rufa, 
the obstacle is at once crossed, the procession of ants being in no way interfered with-I have observed the similar behaviour of a single " homing" worker of F. rufibarbis (p. 323).

If the eyes of a Donisthorpea be covered with varnish, it finds its way as before, but if a Formica be treated in this manner, it is unable to do so. These facts prove that smell is the predominant feature in some cases, and sight in others.

Memory also helps ants in finding their way-workers of Polyergus rufescens hunting for colonies of Formica fusca will locate various nests, but it may be days or weeks before the slave-makers will raid any particular one of them. No track of any kind could be left, and memory alone must help them to go direct to this nest (the same procedure is noted for Formica sanguinea, p. 290). Again, when an ant finds a suitable place for a new nest at some distance from the old one, returns home, and induces her companions to move to this spot, the ant must remember where the selected spot was ; nor can this be said to be a pure reflex action.

Very many authors, including Bonnet,. Brun, Cornetz, Miss Fielde, Forel, Huber, Lubbock, Santschi, Turner, Viehmeyer, Wasmann and Wheeler, etc., have written at considerable length on this subject, but it is only possible to touch very briefly on some of their views.

Wasmann has clearly demonstrated that Bethe's polarization theory is inaceurate.

Lubbock, Turner and Viehmeyer show that ants are partly influenced, in finding their way, by the rays of light. It is hardly necessary to mention that ants can find their way in the dark, and that some species are nocturnal in their habits.

Cornetz's theory is that ants are endowed with a special sense of what he calls " pure direction," being guided by some mysterious inner impulse. This compels them to move on continuously, up or down, round and round, right or left, and keep on doing so whatever happens, while the impulse lasts. If it is transported elsewhere, no matter, it still moves on as before. He thinks the human mind can only conceive of direction as being aimed towards some particular point of space, but the ant's conception of space may be something quite different, and this may account for its behaviour being sometimes unintelligible to us. Santschi has recently made a number of new experiments; his main points seem to be these :-

1. Cornetz's "pure direction," and all similar hypotheses of a special sense are quite unnecessary.

2. The phenomena which Cornetz sought to explain, can all be explained by natural causes. Without actually seeing distant objects, an ant's visual apparatus may convey to it impressions received from them, which impressions may stimulate and influence the creature's movements.

3. Only one lens of a compound eye can transmit direct rays 
from-say - the sun, and such direct rays must impinge on one particular point of the sensitive surface ; the consequent sensation setting a particular nerve to work.

By so moving as to keep the light in the same direction, it is possible to use the latter as a sort of compass to steer by; and that the ant really does this is borne out by experiments with a mirror (deflect the rays and you upset the insect's steering! Restore the rays, and it can go ahead again !)

4. Differences in the lighting of various parts of the sky, and also of large distant or near spaces and objects, restrictions of the horizon by hills, walls, trees and the like, may all affect the ant's "optics," and through them its whole nervous system and movements thereby originated.

5. X-rays, electric conditions of the atmosphere, etc. etc., may be more or less perceived without any hypothetical special sense for receiving them. Air-movements may be transmitted by sensitive hairs, and become stimuli to movement in some particular direction.

6. Of course many movements of ants are results of actual sight, smell, and the like.

Brun has written a very long and learned paper on "antorientation "; it is full of very many technical and rather unwieldy terms, and I find the language (both as regards his German and his meaning) somewhat difficult to follow. He appears in the main to agree with Santschi, and he rejects all hypotheses of a special sense possessed by ants only. If it is possible to state his views in a few words, they appear to be something of this sort: Ant-orientation is only a special case of "Orientation" in general, viz. a power possessed in some degree by all living protoplasm of maintaining (Static) or altering (Dynamic) the position in space of the whole organism or any of its parts.

Static orientation being a matter of mechanical forces simply, e.g. the weight of the organism, the cohesion of its molecules, and so forth. In Dynamic orientation the organism has power to "orient" movement towards some particular object. If this object is actually present to some sense (e.g. sight or smell) the orientation is direct : if not it is indirect, and in this case, which includes most of the more remarkable movements of ants, it is prompted by memory of past sensation or some sort of inference from present sensation (e.g. fatigue may tell an ant, returning to the nest, "I have expended so much energy on the journey and must be nearing home by this time.") Direct orientation will not explain all movements of ants, as we know that some of their senses are unequal to this, but indirect orientation probably will explain them, without any theory of a special sense. The extent to which any organism possesses the power of indirect orientation depends on its development generally, and more especially on that 
of its nervous system : the power of memory (i.e. recalling past sensations and being "oriented" by them) in greater or less development is hereditable, and includes reflex and instinctive stimulations, differing only in their comparative simplicity or complexity.

Enough has been said to show that ants are not merely reflex machines; they possess senses somewhat similar to ours in effect, though not in degree, and in many of their actions they are influenced by education, experience, and memory.

\section{GEOGRAPHICAL DISTRIBUTION.}

Ants are the most dominant of insects, their species are the most widely distributed, they outnumber in individuals all other terrestrial animals, and they range over the whole world between the extreme Arctic and Antarctic regions. These insects are by far most abundant in the tropics-forming there a powerful factor against which animals and plants have to contend-and becoming less numerous and important the nearer they approach the poles.

The ant fauna of the Palaearctic region proper (i.e. not including the Mediterranean region) is relative to its large size, the poorest in the world. Considerably the largest ant fauna is the Neotropical, and next to it in numbers comes the Hindu-Malayan. A great relationship exists between the ants of the Nearctic and Palaearctic regions, an equally great difference being found between those of the Nearctic and the Neotropical, the Neotropical and the Aethiopian, etc.

It is curious that some species in the extreme northern and southern faunas are very much alike; this is not on account of relationship but has been brought about by convergence, through the effects of a similar climate, etc.

\section{GEOLOGICAL RECORD.}

Fossil ants first make their appearance in the Tertiary period. Sharp states that they are amongst the earliest Hymenoptera, and that remains of these insects in the Lias of Switzerland, and in the English Purbecks have been referred to ants. Handlirsch, however, has shown that those of the former formation certainly do not belong to the Hymenoptera, but presumably to the Homoptera, and that the latter (two wing impressions from the lower Purbecks of Durdlestone Bay, considered by Westwood to belong to ants and described by him in 1854 as Formicium brodiei and Myrmicium heeri) belong to saw-flies.

Still the remains of ants are so numerous in the early Tertiary, where the males, females and workers are as sharply differentiated 
as at the present day, that it seems probable they must have existed as far back as in the Trias, though they have not left any remains. Of the six hundred species of Tertiary Hymenoptera enumerated by Handlirsch, more than half are ants, representing a considerable number of genera many of which are still living. Tertiary ants have occurred in twenty-three localities in Europe and North America; only one of these localities-Bembridge in the Isle of Wight-being situated in Britain.

The remains of three genera-Myrmica, Formica and Camponotus -were found in the Bembridge limestone; the occurrence of the last-mentioned genus is of considerable interest, as no species of Camponotus is living in our country to-day.

The largest number of Fossil ants have been found in the Baltic and Sicilian amber, and the beds of Radoboj, Oeningen, and Florissant.

Emery considers that the study of the ants of the Baltic and Sicilian amber proves that the Arctic fauna went down from the North as a host of conquerors.

Wheeler shows that of the forty genera found in these ambers, thirteen are extinct, and twenty-seven, or more than two-thirds, are still living; moreover, some species of the Baltic amber are almost, if not quite, identical with living species.

Emery accounts for the poverty of the European ant-fauna as follows: "My studies on the ants of the Sicilian amber have demonstrated that at the beginning of the Tertiary, Europe had an ant-fauna of Indoaustralian character, still living and exclusively of this character in Sicily during the formation of the amber ; while to the north of the sea, which at that time extended across Europe, representatives of this fauna, mingled with Formica, Myrmica and other recent holarctic types, lived in the forests of the Samland. After the disappearance of this sea the northern fauna pushed its way southward as far as the Mediterranean. Then came the Glacial epoch, which extinguished the Indian fauna in the north and drove its feeble remnants, mingled with arctic forms, to the warmer localities of southern Europe. From these regions the present ant-fauna wandered back, with the disappearance of the ice, into the middle and northern portions of the continent. But the tropical forms had difficulty in returning, because the Mediterranean, the African deserts and the steppes to the eastward were so many barriers to their progress. The European ant-fauna therefore remains comparatively poor" (Wheeler's translation).

The reader who wishes to study more closely the palaeontology of ants is referred to the works of Er. André, Emery, Handlirsch, Heer, Mayr, and Wheeler. 


\section{COLLECTING.}

Ants occur everywhere; in gardens and fields, in woods and copses, on heaths and open places, on mountains and in valleys, on the cliffs, and even in towns : but sandy and chalky soils appear to be the most productive situations. Colonies may be found under stones, bark, and at the foot of trees, in stumps and fallen branches, in hollow sticks, and galls, in banks, in the nests of other ants; and in houses.

When stray individuals are observed about, but their nest cannot be seen, the latter may often be found by carefully tracking workers returning to their dwelling laden with prey-sometimes over long distances. Some ants return direct to the nest, others wander about for some time, having apparently lost the track. Ants' nests most frequently face the east, and the side of a cliff, valley, or bank which is so situated will be found to be the best.

When a colony has been located, we should first note the situation of the nest, what it is made of, or how it is built, the behaviour of its inhabitants, what prey they bring home, whether any strange ants, parasites, or other myrmecophiles are on or above the nest, etc. The nest must then be treated differently according to whether the myrmecologist wishes to take the colony home, to obtain queens, or myrmecophiles, or only to study the habits, and capture a few of the workers. If a colony be situated under a stone, the latter should be carefully raised and the upper chambers and galleries of the nest examined, and unless it is desired to dig it up, the stone should be replaced in the same position as before. Should queens be required, the nest must be dug up at once and thrown on to a sheet, as if it is interfered with first, the queens may often escape; this is frequently the case with such species as Formica rufa. I have generally found it necessary in the case of $F$. sanguinea, to dig up the whole nest at once with a spade and throw the earth, etc., on to a large sheet. In examining $F$. rufa nests for myrmecophiles, handfuls of débris should be taken from various parts of the nest and put into a bag, the contents of which may then be shaken bit by bit through a sieve over the sheet. All nest materials, etc., should be put back on to the nest, when the ants will quickly rebuild it. A little sugar placed on or near the nest will often prevent the ants from deserting their old quarters, which they frequently do if continually disturbed.

When a colony is to be taken home, it can either be put into a bag-with a few twigs or branches to prevent the ants from being crushed by the earth, etc.-or, if not too large, into tins. I have found it best, if possible, to secure the queen, or queens, separately, and put them into tubes, or glass-topped boxes, when they may be brought home in safety.

When collecting ants, the contents of different nests should 
not be mixed, otherwise much confusion and error may result. To obtain the winged sexes is more difficult, as their times of appearance vary, and also when the collector requires males of a certain species, winged females are often alone present, or vice versa. By carefully noting the situations of nests belonging to species of which the sexes are wanted, and visiting them continually at the times when the winged forms should be present, they may at last be secured. Males and females may also be bred by collecting the larger (sex) pupae or cocoons ; these should be placed with a few workers in tins containing damp earth and a little honey. By these means I have secured the sexes of practically all our British species.

My outfit for collecting consists of a very strong fern-trowel, 12 inches long which fits into a sheath fastened to a leather beltthis is most useful both as a digger, and also to rip off bark, break up wood, etc.; some strong brown holland bags about 18 inches long and 14 inches in circumference ; a white linen sheet, 66 inches long and 60 inches broad, one corner holding a pocket, into which débris, etc., placed on the sheet can be shaken, and the whole rolled up, thus forming a temporary bag; a small sieve with a fairly fine mesh ; a pair of long tweezers with flat round edges, to pick up ants, etc., with; a pocket lens; a small cyanide bottle ; a few glass-topped boxes; some tins, such as have contained cocoa, baking-powder, etc., and a flat tin box containing tubes, half of them empty, in which to bring ants, etc., home alive, the others being filled with the following mixture :-

5 ccs. strong acetic acid.

35 ces. absolute alcohol.

$60 \mathrm{ccs}$. of $\mathrm{a} \frac{1}{50}$ solution of perchlor. mercury in water.

$\overline{100}$

Ants, myrmecophilous coleoptera, etc., can be dropped into this solution, which quickly kills them, preserves them, and also does not render them too stiff to be set.

A note-book should be taken, in which to write down the ants observed, the condition and position of their nests, myrmecophiles present, etc. This note-book I copy out in full into a Journal at the end of each year, a record being thus kept of all observations made on ants from year to year.

I also possess a compact, but strong, two-edged saw-one edge being composed of coarser teeth than the other-to cut through thick roots of trees, etc. Sometimes a spade, and even an axe, are required, but it is best not to carry more than is wanted for the day, or place, in question, as the less one has to carry the more usefully one can work.

A coleopterist's sweeping-net is sometimes of assistance, as any ants swept up indicate that they come from a nest near at 
hand, which may subsequently be traced. The myrmecologist who wishes to take photographs of ants' nests in situ, will also require a good camera. I use a reflex camera, with a good lens which can be mounted, with a ball and socket turn-table, on a very light tripod made of aluminium. The face of the camera can thus be pointed towards the ground, or in any other position required.

\section{Mounting and Preserving.}

British ants should always be completely mounted on cardants should never be pinned, but for a general collection such as the Palaearctic Species, the Ants of the World, etc.- they should not be treated in the British manner, but should be glued on small triangular pieces of card, the body of the ant lying across the narrow end, and a long stout insect pin being run through the broad end, in the continental manner. Three such cards and the data written on a small label may be staged on the same pin.

I personally first mount our species with gum tragacanth on any card stout enough not to curl up, their legs, antennae, and wings being set in the desired position. These cards, with full data written on them, are placed on the boards in my drying cages until the winter, when they are (card, pin and all) dropped into petrol and left there for twenty-four hours-this permanently removes all grease, and revives the colours. They are then removed, and, when dry, remounted on clean cards ; this is easily done with a fine paint-brush and a little water, a drop of strong gum being placed on the underside of the ant only, as sufficient tragacanth remains on the legs, etc., to keep them in position, though it does not show. Each ant is remounted on a single oblong piece of white Bristol board, which has been cut to the required size with a cardcutter, and the locality, date of capture, etc., is written on the underside of the card itself. These cards are fastened into the cabinet drawer with small English "Lill" pins, the top halves of which have been cut off. For the proper study of ants a large series is necessary, I therefore keep two collections. The one is a show collection and is arranged in cabinet drawers; it consists of three or four males, the same number of females (half of the latter being winged, half deälated) and sixteen to twenty workers of each species-for this collection only, specimens are remounted. The other is a duplicate collection, and is kept in a number of storeboxes; specimens of each species (a few mounted on their backs, others dissected, etc.) are present from as many different British localities as possible, and also males, females and workers from the same, as well as from different colonies. I also possess a large collection of the ants of the world, but this does not concern us here.

It is obvious that the cards may be staged on long pins if desired, 
and may be arranged in cabinets, or store-boxes, in any manner the student may prefer.

It is necessary to have a compound microscope as well as a good hand lens-when describing all our genera and species for this work, I have used a binocular microscope and a magnification of 35 diameters.

Ants may be killed with boiling water, in cyanide, laurel, or in the solution before mentioned. In the first case they must be set at once, but if killed in cyanide, or laurel, they can be kept for long periods. For this purpose a large wide-mouthed laurel bottle is convenient, such as is used by the coleopterist; into this the ants are dropped in screws of tissue-paper, with the data written on slips of paper inside each screw. Ants will be found to be in perfect condition for setting, when kept in this way, even after twelve months, or longer.

The instruments for setting such as brushes, setting-needles, tweezers, gum, card, etc., do not require description, as the myrmecologist will select, from experience, those which he finds most suitable to him.

\section{Observation Nests.}

To gain a proper knowledge of the normal conditions under which ants live it is necessary to study their habits as closely as possible in nature, at all times of the day and year, in all weathers, and in different localities. When a nest has been found, it should not be passed over just because it may belong to a common ant, or because the species may be fully represented in the observer's cabinet, as the mere amassing of a collection is only the means to an end, and not the sole object in view-namely to increase as far as possible the knowledge on all points concerning ants.

If a suitable locality exists within easy reach, it should be constantly visited at different times of the year, the situations of the nests of the different species noted, and their contents and the progress of their colonies carefully studied. Such a locality is Weybridge heath, a favourite observation ground of my own, with its sandy soil, fir trees and stumps, young oaks and birch, and heather, etc. Here no less than eighteen of our British species of Formicidae have been found, and many happy hours during the last twenty years and more have been spent in examining their nests and watching their habits.

To observe however the actual doings of the ants in the depths of their dwellings, is naturally almost impossible, as when an ant's nest is disturbed a scene of apparent chaos ensues; the ants all rush about, some attack the intruder, and others hurry off into safety with their brood, etc.

To obviate this as far as possible the myrmecologist must keep ants in captivity, and for this purpose "observation nests" are 
used. Swammerdam in 1737, and Huber in 1810, described artificial nests in which they confined ants, and many observers to the present day have invented, or modified, described, and figured, different forms of nests which they have used for the same purpose; such are : André, Brun, Crawley, Ders, Donisthorpe, Emery, Escherich, Miss Fielde, Forel, Janet, Kneissl, Lubbock, Newell, Overloop, Santschi, Schmitz, Viehmeyer, Wasmann, Wheeler, etc.

The two principal types of observation-nests are Lubbock's glass nests and Janet's plaster nests ; nearly all the others are a modification in some form or other, or a combination of these.

Lubbock describes his nest as follows: "After trying various plans, I found the most convenient method was to keep them in nests consisting of two plates of common window glass, about

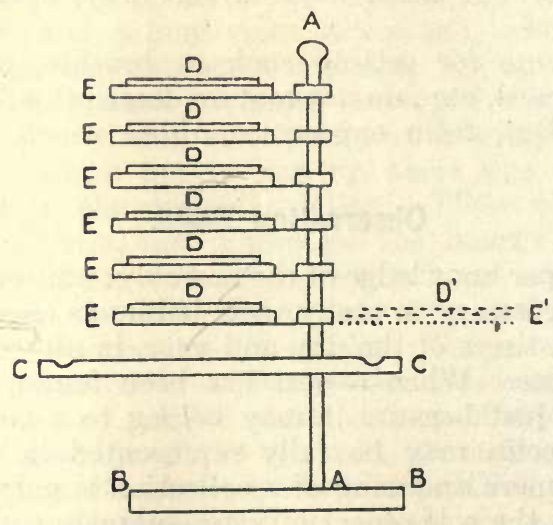

Fig. 51. Stand for nests described by Lord Avebury.

ten inches square, and at a distance apart of from $\frac{1}{10}$ to $\frac{1}{4}$ in. (in fact just sufficiently deep to allow the ants freedom of motion), with slips of wood round the edges, the intermediate space being filled up with fine earth. If the interval between the glass plates was too great, the ants were partly hidden by the earth, but when the distance between the plates of glass was properly regulated with reference to the size of the ants, they were open to close observation, and had no opportunity of concealing themselves. Ants, however, very much dislike light in their nests, probably because it makes them think themselves insecure, and I always therefore kept the nests covered over, except when under actual observation. I found it convenient to have one side of the nest formed by a loose slip of wood, and at one corner I left a small door. These glass nests I either kept in shallow boxes with loose glass covers resting on baize, which admitted enough air and yet was impervious to the ants; or on stands surrounded either by water, 
or by fur, with the hairs pointing downwards. Some of these nests I arranged on stands, as shown in the figure. AA is an upright post fixed on a base $\mathrm{BB}$. $\mathrm{CC}$ is a square platform of wood round which runs a ditch of water. Above are six nests, D, each lying on a platform $\mathrm{E}$, which could be turned for facility of observation, as shown in the dotted lines $\mathrm{D}^{\prime}$ and $\mathrm{E}^{\prime}$. Thus the ants had a considerable range, as they could wander as far as the water ditch. The object of having the platform CC larger than the supports of the nests was that if the ants fell, as often happened, they were within the water boundary, and were able to return home. This plan answered fairly well, and saved space, but it did not quite fulfil my hopes, as the ants were so pugnacious, that I was obliged to be very careful which nests were placed on the same stand. Of course it was impossible to force the ants into these glass nests. On the other hand, when once the right way is known it is easy to induce them to go in. When I wished to start a new nest I dug one up, and brought home the ants, earth, etc., all together. I

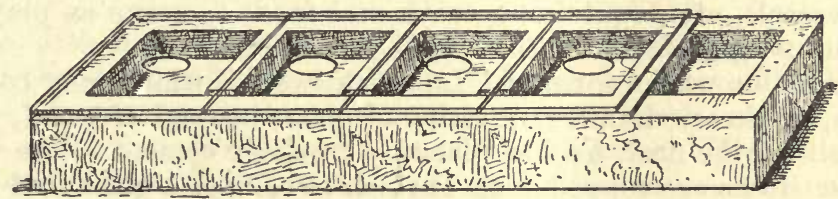

Fig. 52. Four-chambered "Janet" plaster nest.

then put them over one of my artificial nests, on one of the platforms surrounded by a moat of water. Gradually the outer earth dried up, while that between the two plates of glass, being protected from evaporation, retained its moisture. Under these circumstances the ants found it more suitable to their requirements, and gradually deserted the drier mould outside, which I removed by degrees. In the earth between the plates of glass the ants tunnelled out passages, chambers, etc., varying in form according to the circumstances and species. Even between the plates of glass the earth gradually dried up, and I had to supply artificial rain from time to time. Occasionally also I gave them a new nest. They seem, however, to get attached to their old homes, and I have one community which has inhabited the same glass case ever since 1874." (About eight years.) "It is hardly necessary to say that the individual ants belonging to the communities placed on the stands just described, knew their own nests perfectly well."

Janet's type of nest is quite different from the above, it is made of plaster, or some other porous material, with a glass roof, and no earth is employed. His nest consists of three chambers, which are situated in a block of plaster of Paris, and are connected with 
each other by galleries. A fourth space, which is narrower than the other three and is not connected with them, serves as a watertrough. A sheet of glass covers in the three chambers; this has three holes in it, one over each chamber, and other sheets of glass close these holes. Water is poured into the water-trough once or twice a week to keep the nest damp, and the nest is placed on a sheet of glass to prevent the moisture from reaching the table on which it stands. The chamber furthest from the water-trough is naturally the dryest, and is exposed to the light, the other two damper chambers being covered over with some opaque material. The food for the ants is placed in the light dry chamber, which represents the outside world, and the two dark chambers represent the interior of the nest.

The following other observation nests may be mentioned which are used by different myrmecologists.

Wasmann employs two "Lubbock nests," which are connected with each other by a glass tube. The larger of the two-the main nest, which contains the colony of ants-is connected with various glass vessels, etc., containing earth and food, to serve as playingand dumping-grounds for the ants.

Miss Fielde uses a form of "Lubbock nests," which may consist of two, or three, chambers ; strips of glass, instead of wood, form the walls of the nest, held in place by crockery cement. The walls and partitions are topped with Turkish towelling, a glass roof pane for each chamber resting on it. No earth is present, and slices of damp sponge are placed in the one, or two inner dark chambers to supply the necessary moisture.

Wheeler combines a "Janet" and a "Fielde" nest, by constructing the whole of the body of the apparatus of plaster of Paris, the interior being thickly coated with varnish. The glass roof panes rest on Turkish towelling, and the sponges are used, no earth being present.

Emery makes a modified "Janet nest" from tiles which are perforated with holes. The tiles are ground down to the required thickness, the holes on the side which forms the bottom of the nest are closed with plaster of Paris, and the top is covered by a plate of glass.

Brun has substituted a block of peat to take the place of the plaster of Paris walls and partitions of a "Janet nest," the top and bottom being covered with glass.

A small artificial nest for colonies of diminutive ants which have to be kept in very tight receptacles, is constructed by Santschi as follows : "The base of the nest consists of a rectangular glass plate, such as is most conveniently obtained by cleaning an unsuccessfully exposed photographic plate of ordinary dimensions, say $3 \times 4$ or $4 \times 5$ in. Wet plaster of Paris is poured on to this plate in the form of the heavy lines in the accompanying diagrams, which represent 
nests with two or three chambers respectively, connected by galleries. Of course any other design which suggests itself as suitable may be used instead, if desired. Before the plaster has set, a second plate of the same size and shape as the base and previously covered with a film of sweet oil, is pressed down on to the plaster till it forms walls only a few millimetres in height. After the plaster has set, the roof-pane is removed, cleaned and cut into two or more
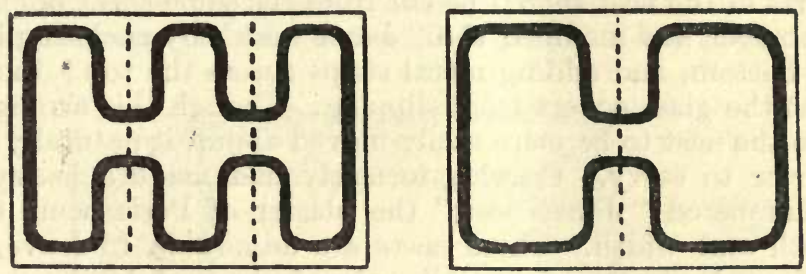

Fig. 53. Small "Santschi" observation nests.

pieces with a diamond along lines (dotted in the figures) which bisect the short galleries, and then replaced as covers of the chambers. The ants can be introduced into the nest by sliding the covers apart a short distance over one of the galleries. The plaster is sufficiently porous to provide for ventilation and a thin slice of wet sponge, or a tuft of wet moss or cotton, placed in one of the chambers will furnish the requisite amount of moisture." Such

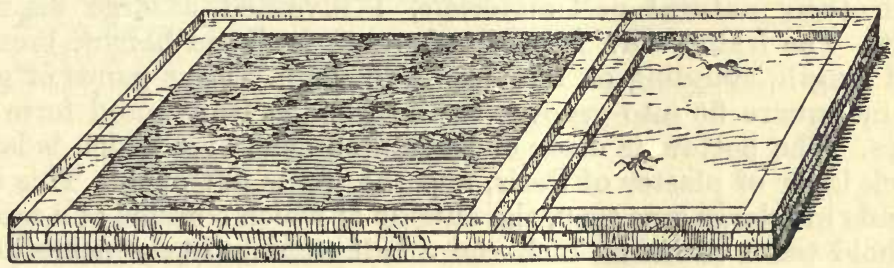

Fig. 54. "Crawley-Lubbock" observation nest.

nests can be placed on the stage of a compound or binocular microscope, and studied under a low objective.

Crawley has improved on the Lubbock type of nest as follows : "The nest consists of two panes of glass, one foot square, with slips of thick glass, $\frac{3}{4}$ in. wide, round the edges, so as to form a frame, leaving a space of néarly $\frac{1}{4}$ in. between the upper and lower glass. On the bottom glass is a layer of plaster of Paris, reducing the interval between the glass panes to $\frac{1}{8}$ in. The space between is filled with fine earth." The earth should be placed on the layer 
of plaster before the latter is dry, and the advantage of this nest is that it retains moisture for a longer period than an ordinary "Lubbock nest." These nests may be made of different sizes if desired ; as in the "Fielde nest," glass strips are used instead of wood, and a second chamber may be added, kept light and without earth, to serve as a feeding and exercise ground. When a second chamber is present the apparatus is entirely shut in and requires to fit more accurately; plate glass $\frac{3}{16}$ or $\frac{1}{8}$ in. thick should be used, and all the parts of the nest should be eut from the same sheet of glass.

Viehmeyer has modified the "Janet nest" by enclosing it with a zinc bottom, and adding metal strips across the top; the latter prevent the glass covers from slipping. Though this arrangement enables the nest to be more easily moved about, it naturally makes it heavier to carry. Crawley formerly had made a heavy large four-chambered "Janet nest," the plaster of Paris being thicker in depth and width. These nests are admirable to leave, when away from home, as when well watered they retain the moisture for a long time.

The nest I most frequently use, and find most convenient on the whole, is a four-chambered "Janet nest," lighter and smaller than the above. This nest is made by Messrs. Doulton and Co., Ltd. (Archtl. Dept.), Lambeth, from directions supplied to them by Crawley and myself, and can always be obtained there. The glass for the roof requires to be purchased separately, and ean be used with, or without, the openings over the chambers. It may be held in position by brass springs, clips, or some other arrangement.

For the reception of such large species as Formica rufa, etc., with their natural nest-materials, I invented a large artificial nest. The frame-work is made of wood, 14 in. in height, breadth and length, standing on four legs $4 \mathrm{in}$. high. Four panes of glass 12 in. square fit into grooves in the wooden frame, and form the sides. The bottom is made of perforated zinc, over which is laid a thick layer of plaster of Paris, and the top is left open. This nest stands in a large zinc tray, the outside of which consists of a trough to hold water about an inch and a half wide and two inches deep. Between the sides of the legs of the nest and the trough there is space about two inches wide. A layer of sand, five or six inches deep, is placed over the plaster in the nest. When a colony is introduced a mass of the materials of the nest, with the ants, etc., just as it was collected, is shot from a bag into the nest. Care must be taken that a queen, or queens have been secured, and these are introduced separately. The ants soon tunnel into the sand, and build up and arrange, the nest materials as in nature. Fresh pine-needles, etc., may be thrown in from time to time, which the ants will add to their hillock, and they use corners of the zine tray for cemeteries and "kitchen middens." Though this form of nest does not enable one to study the behaviour of the ants in 
the interior of the nests - except that they bring the eggs and larvae to the side of the glass pane nearest the sun, or a fire, beneath the nest materials - much may be learnt about their habits by watching it, and many flies and other myrmecophiles may be bred out, which would not occur in "Lubbock" and "Janet" nests. The nest can be enclosed with muslin attached to a wire frame which extends from outside the water-trough over the nest and does not touch it anywhere. In this way any winged creature, which may have hatched out when the observer is not present, will not be lost. (For the same purpose I have used large glass bowls containing

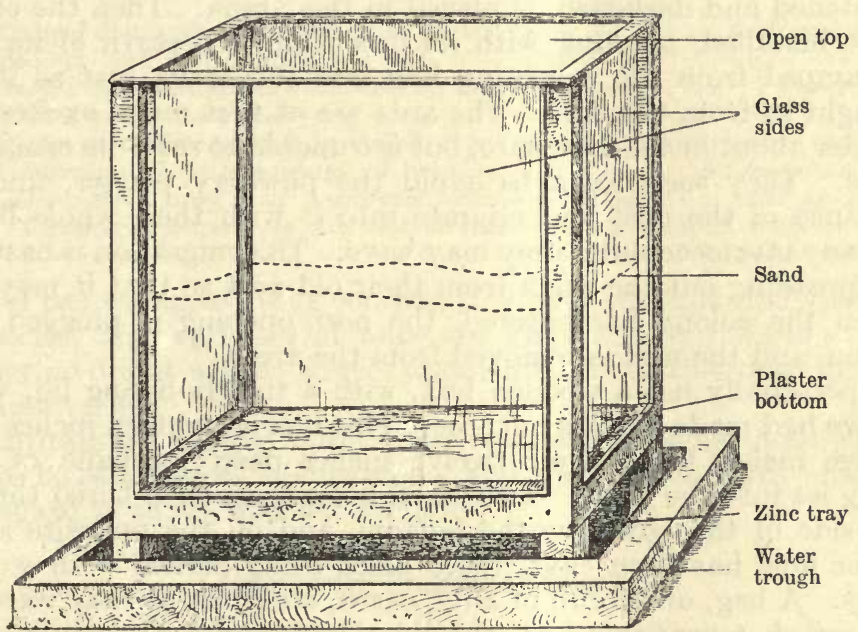

Fig. 55. "Donisthorpe" observation nest.

sand; the earth, or other materials, dug up with the colony, from an ant's nest is shot into them, and the top is covered with muslin. In these bowls I have bred a number of myrmecophiles, which had not been discovered before.)

This nest (and the bowls) occasionally require to be thoroughly watered with a child's watering-can, or some such apparatus.

The water-trough prevents those ants which go down into the tray, where they walk about freely, from escaping into the room. It is not however entirely satisfactory, as some manage to swim across, and when the water gets covered with a film of dust, others walk over it. Some people allow petrol to float on the top of the water; the ants do not like it, but those that may happen to fall in are killed.

Newell, after trying very many different oils and disinfectants, 
etc., for this purpose without success, eventually placed his ants nests on galvanized iron trays, through which running water two inches deep was kept passing day and night. Ants will move with their brood into either "Lubbock" or "Janet" types of nest, if placed with them on a tray or table enclosed with a water moat, or in a "Forel arena." The latter is constructed as follows :" On a table, or large board a circular or elliptical enclosure a few feet in diameter is made by laying down a wall of dry, powdered plaster of Paris about two or three inches broad and an inch high. The inner edge of this wall is made smooth and steep with the aid of a putty or case knife. The artificial nest, with its chambers moistened and darkened, is placed in this arena. Then the colony to be installed, together with its brood and the earth of its nest, is dumped from the collecting bag into the arena just as it was brought in from the field. The ants are at first much excited and wander about in the enclosure, but are unable to scale its crumbling walls. They soon learn to avoid the powdery plaster, find the entrance of the nest and migrate into it with their whole brood, and any myrmecophiles they may have. This migration is hastened by spreading out the earth from their old nest so that it may dry. When the colony has entered, the nest opening is plugged with cotton, and the nest is removed from the arena."

I personally use a wooden box, with a tightly-fitting lid, which I have had made for this purpose. This box is eighteen inches long, twelve inches broad, and twelve inches deep; a pane of glass being let into the front. Two small holes have been bored through one side of the box near the bottom, and on the opposite side a larger hole has been cut; these holes being corked with wooden plugs. A bag, or tin full of ants, earth, etc., just as they were dug up, are shot into this box, the lid closed, and a glass tube fitted to one of the smaller holes. This tube is connected with a watered and darkened plaster nest, and as the contents of the box get dry, the ants soon find their way through the tube into the nest. Should the ants refuse to leave the box, or take too long in migrating, carbon, or cotton-wool dipped in ammonia can be inserted through the larger hole to hurry them up. Prepared "Lubbock" or "Janet" nests can also be placed inside the box previous to the introduction of the ants; this takes the place of a "Forel arena."

This box has the advantage that it can be taken into the field, and the desired ant colony, etc., transferred directly into it-a large carton nest such as that constructed by Donisthorpea fuliginosa is much best treated in this way. I have kept ants in captivity for many years past, including all the British genera, and nearly all the species, besides some continental and exotic ones. 


\section{INDIGENOUS GENERA AND SPECIES.}

THe Formicidae or ants (also called Heterogyna owing to the tendency of the female to assume different phases) form a natural family which is divided into five subfamilies-I Ponerinae Mayr, II Dorylinae Shuckard, III Myrmicinae Mayr, Iv Dolichoderinae Forel, and v Camponotinae Forel.

Only four of these subfamilies occur in the British Isles; these may be distinguished as follows :-

\section{Table of the Subfamilies.}

1 Pedicel distinctly two-jointed in all the sexes.......2 Myrmicinae.

- Pedicel not two-jointed $\ldots \ldots \ldots \ldots \ldots \ldots \ldots \ldots-\ldots$

2 Gaster constricted between its two first segments........ Ponerinae.

(1) Gaster not constricted - $-\ldots \ldots \ldots-\ldots-\ldots$

3 Gaster with five segments visible from above; anal aperture circular

surrounded with a fringe of bristles.......... Camponotinae.

(2) Gaster with only four segments visible from above; anal aperture forming a transverse slit, not circular nor surrounded with bristles - $\ldots \ldots \ldots \ldots \ldots-\ldots \ldots$ Dolichoderinae.

Forel has estimated that considerably over six thousand species, subspecies, and varieties of ants are known in the world; this number no doubt will be largely augmented by further descriptions and discoveries.

In Britain we possess thirty-three species (including those which used to be called races or subspecies, and a few which many authors still regard as such), and ten varieties.

\section{Subfamily Ponerinae Mayr.}

The subfamily Ponerinae comprises many different tribes, by far the larger number of which are to be found in the tropics. In Australia the Ponerinae become a dominant group, where they may be compared with the marsupials and other characteristic animals of that region.

These are the most ancient and primitive forms of ants now living, both in habits and structure; their colonies are mostly small, they are all predaceous and carnivorous, their pupae are always enclosed in cocoons, and a well-developed sting is always present in the worker and female.

We only possess one genus in Britain-Ponera Latreille-the species of which are found in the earth, under stones, in rotten wood, and in vegetable refuse, in both the hot and temperate regions of the whole world.

In 1810 Latreille [Cons. Gén. Crust. Ins. 311 No. 443, 437 (1810)] cited Formica crassinoda (Latr.) F., as the type of Ponera, but he had already in 1805 [H.N. Crust. Ins. 13 257-8 No. 365 (1805)] cited contracta as type. 


\title{
PONERA Latreille.
}

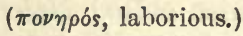

Type: Formica coarctata Latr. (=contracta Latr. ; Latr., 1805).

ఫ Head oblong oval, quadrangular; clypeus triangular, narrow, arched, and produced posteriorly; mandibles long, triangular, with the terminal border dentate and longer than the internal border; maxillary-palpi oneor two-jointed; labial-palpi two-jointed; antennae stout, twelve-jointed, with a four-jointed club, first joint of funiculus longer and broader than the second; frontal-carinae short, convergent, only separated by the frontal furrow; eyes very small, situated in front; ocelli wanting. Thorax narrower than head, convex, truncate posteriorly, with sutures distinct. Pedicel plainly separated from the gaster, furnished with a thick scale which is rounded above, somewhat convex in front, truncate behind, and as high as the gaster. Spurs on all the legs pectinate. Gaster as long as thorax, cylindrical.

ㅇ very like the $\not r ;$ eyes much larger; ocelli present. Fore wings with two cubital and one discoidal cell.

$\hat{\sigma}$ somewhat like the $\measuredangle$; mandibles narrow and short, not dentate; maxillary-palpi four-jointed; labial-palpi three-jointed; antennae twelveor thirteen-jointed, scape a little longer than the first joint of the funiculus, the latter being short and subtransverse, the rest of the joints of the funiculus elongate and filiform; eyes and ocelli larger than in the +. Wings as in the 아, legs longer and more slender than in the $\not$ and ㅇ.

Original description [Latreille Nouv. Dict. d'Hist. Nat. 24 178-9 (1804)] :-

“II. Antennes insérées très-près du bord antérieur de la tête.

1. Antennes grossissant insensiblement vers leur extrémité; premier article faisant presque la moitié de leur longueur, dans les femelles et les mulets; tête épaisse; abdomen ovoïde ou conique; (palpes maxillaires de la longueur au moins des mâchoires, sensibles, de quatre à six articles).

A. Premier article des antennes toujours découvert.

B. Un aiguillon dans les femelles et les mulets.

a. Second anneau de l'abdomen separé au plus du suivant par un léger étranglement: pédicule de l'abdomen n'étant pas formé de deux nœuds très-distincts.

** Mandibules des mulets triangulaires.

Genre Ponère, Ponera.

Mes F. étranglées, à l'exception de la quatrième subdivision.-F. tarsata, clavata Fab."

\section{Table of the Species.}

Two species of Ponera are found in Britain, which may be distinguished as follows :-

Maxillary-palpi two-jointed ; more coarsely punctured .... coarctata Latr. Maxillary-palpi one-jointed; very finely and closely punctured _ - _ - -

우

Eyes not near base of mandibles, smaller; head narrower ... coarctata Latr. Eyes near base of mandibles, larger; head broader punctatissima Roger. 
Winged; antennae 13-jointed; pygidium armed with a spine...........

................................................. Latr. Apterous; antennae 12-jointed; pygidium simple - punctatissima Roger.

\section{Ponera coarctata Latr.}

Formica coarctata Latreille Bull. Soc. philom. Paris 3 No. 57, $65(1802)^{1}$. Formica contracta Latreille Hist. Nat. Fourmis $195(1802)^{2}$. Ponera contracta Latreille Hist. Nat. Crust. Insect. 13257 (1805) ${ }^{3}$; Stephens Ill. Brit. Entom. Sup. $15(1846)^{4}$; F. Smith Trans. Ent. Soc. Lond. (n.s.) $3114(1855)^{5}$ : Ent. Ann. $185734^{6}$ : $185839^{7}$ : Cat. Brit. Foss. Hym. $19(1858)^{8}$ : Ent. Ann. 1866 $128^{9}$; Baly Entom. $6259(1873)^{10}$; Forel Denkschr. Schweiz. Ges. Naturw. $2662(1874)^{11}$; B. Cooke Nat. $573(1879)^{12}$; Parfitt Trans. Devon Assn.
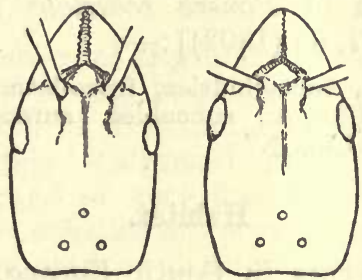

Fig. 56. 1. Head of Ponera coarctata ㅇ.

2. Head of Ponera punctatissima .

Sc-Art $12515(1880)^{13}$; Saunders Trans. Ent. Soc. Lond. $1880212^{14}$; Dale Ent. Mo. Mag. $17236(1881)^{15}$; Lubbock Lin. Soc. Journ. Zool. 2751 (1883) ${ }^{16}$;

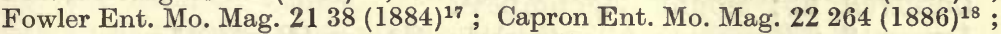
Wasmann Tijdschr. Entom. $3449(1891)^{19}$. Ponera coarctata Dalla Torre Cat. Hym. $738(1893)^{20}$. Ponera contracta D. Sharp Trans. Ent. Soc. Lond. $1893203^{21}$; Farren-White Ants Ways 238 (1895) ${ }^{22}$; Saunders Hym-Acul. $29(1896)^{23}$; Bradley Ent. Mo. Mag. $3346(1897)^{24}$; E. A. Butler Ent. Mo. Mag. $35290(1899)^{25}$; Donisthorpe Ent. Rec. $1416(1902)^{26}$; Chitty Ent. Mo. Mag. $3969^{27}, 283^{28}(1903)$ : $42212(1906)^{29}$; Vic. Hist. Durham 195 $(1905)^{30}$; Vic. Hist. Cornwall $1182(1906)^{31}$. Ponera coarctata Wasmann Arch. Trim. Inst. Grand-Ducal Luxemburg $190613^{32}$. Ponera contracta Vic. Hist. Kent $1116(1908)^{33}$. Ponera coarctata Emery Deutsch. Ent. Zeitschr. $1909369^{34}$; Wheeler Ants $96^{35}, 174^{36}$ (1910); Donisthorpe Ent. Rec. 23 $131911)^{37}$ : Entom. $44389(1911)^{88}$; Emery Gen. Ins. $11890(1911)^{39}$; Donisthorpe Ent. Rec. $244(1912)^{40}: 2561(1913)^{41}$; Crawley and Donisthorpe Int. Ent. Cong. Oxford 1912; $214(1913)^{42}$.

ఫ Dark brown somewhat shining, hairy especially on the gaster, but with scarcely any pubescence, mandibles, clypeus, antennae, legs, and extremity of the gaster reddish yellow-sometimes the whole insect is of a reddish yellow colour.

Head black, duller and more closely punctured than the thorax and gaster ; mandibles with terminal border furnished with three or four stronger teeth in front and indistinctly dentate posteriorly; maxillary-palpi two-jointed, the last joint terminated by a single hair; gaster beneath, strongly rugose transversely at the anterior portion of the second segment. Long, 3-3.5 mm.

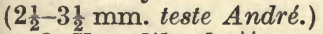

o Very like the $\forall$; eyes about the same distance, or a little further, from the base of the mandibles, as their own length. Long, 4-4.5 $\mathrm{mm}$. (3-3 $\frac{3}{4} \mathrm{~mm}$. teste André.) 

the .

Shining black, legs and antennae brown, puncturation much finer than in

Head trapezoidal, rounded behind ; antennae thirteen-jointed, scape and first joint of funiculus short, somewhat smooth and shining, the other joints of the funiculus elongate and pubescent. Thorax high; scutellum arched; post-scutellum projecting. Pygidium terminating in a spine. Long, $3 \cdot 4-3.8 \mathrm{~mm}$.

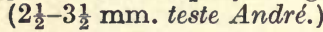

Ovum : long, cylindrical (some individual eggs however appear to be shorter) and yellowish white in colour.

Larva: Head fairly large, with strong horny mandibles, body clothed with bristle capped tubercles, and four pairs of glutinous club-shaped tubercles, situated on the dorsal part of the sixth and following somites.

Pupa : enclosed in somewhat dark cases.

Original description of Ponera coarctata Latreille [Bull. Soc. Philom. Paris 3 No. 57, 65 (1802)] :-

"Operaria. Elongata, subcylindrica, fusco-brunnea; oculis nullis aut obsoletis; squama nodiformis, subcubica, antennis pedibusque flavescentibus. Long. $0,004 .=1$ lig. $\frac{3}{4}$."

\section{Habitat.}

Ponera coarctata occurs in South Europe, the Caucasus, and Algeria, and extends northwards to Paris and Aachen ${ }^{34}$, two varieties occurring in Europe, and three subspecies-in Australia, Africa and N. America ${ }^{39}$.

The British distribution is as follows :-

Cornwall, E.: Mount Edgcumbe ${ }^{31}$.

Devon, S.: Plymouth (Reading) ${ }^{13}$; Exeter $(\text { Parfitt })^{13}$.

Isle of Wight : Ventnor $(\text { Dale })^{15}$; Sandown $(\text { Fowler })^{17}$.

Dorset: Swanage (Nevinson); West Lulworth Cliffs (Haines).

Hants, S. : New Forest (Hamm).

Sussex, E. : Brighton (Power $)^{7}$; Pett (Bennett).

Kent, E. : Deal (Dale $)^{\mathbf{1 5}}$; Doddington (Donisthorpe) ${ }^{26}$; Throwley ${ }^{33}$ Charing ${ }^{27}$ and Chatham ${ }^{28}$ (Chitty); Folkestone (Power VI. 60. Rothney-Coll); Kent, W. : Upnor (Power X. 65, Rothney-Coll); Darenth Wood (Donisthorpe ${ }^{37}$.

Surrey : Mickleham (D. Sharp $)^{9}$; Merton (Power $)^{9}$; Shiere $(\text { Capron })^{18}$; Weybridge (Billups $)^{23}$; Gomshall (E. A. Butler $)^{25}$; Stoat's Nest (W. E. Sharp) ${ }^{37}$; Chipstead (Bedwell); Box Hill

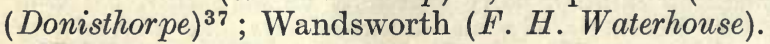

Middlesex : St. James' Park (Westwood) ${ }^{5}$; Kentish Town $(B a l y)^{6}$; Chelsea and Pimlico ${ }^{4}$ (Westwood and Ingpen).

Warwick: Warwick $(\text { Baly })^{10}$; Sutton Coldfield (Bradley) ${ }^{24}$.

Lancashire, S.: Manchester $(\text { Cooke })^{12}$; near Liverpool $(\text { Cooke })^{23}$.

Durham: South Shields ${ }^{30}$.

Ponera coarctata was first discovered in Britain by Professor J. O. Westwood ${ }^{5}$ who captured it in St. James' Park in London. 
It has been suggested that its head-quarters are situated in Kent, east of the Medway ${ }^{28}$, but this is hardly the case since-as has been seen-it ranges from Cornwall as far north as South Shields in Durham.

According to Professor Wheeler ${ }^{36}$ the similarity between our species and Ponera atavia of the Baltic Amber is so intimate that it is impossible to distinguish them by any satisfactory characters -a fact which emphasizes its antiquity.

It is generally sluggish in its movements, and subterranean in habits, forming its nests under stones, etc., but it is often found in moss, when however it is no doubt in search of its food, which consists of small insects and mites, etc. A female was captured by Westwood ${ }^{6}$, attracted to pieces of meat laid in his garden as baits for insects.

It possesses the power of stridulating, the apparatus by which it accomplishes this having been described and figured by Dr. Sharp ${ }^{21}$. The dorsum of the third gastric segment is extremely coarsely and remotely sculptured at its base, while in the middle there is a band of very fine lines, quite unlike the rest of the sculpture. Its colonies are always small, consisting of very few individuals; five or more deälated females may be presentrarely ergatogynes ${ }^{35}$ and more rarely microgynes ${ }^{34}$ occur, though I am not aware of any captures of these two forms in Britain.

Morley found a colony in August, 1903, at Charing under a stone, which contained some twenty-five pupae, a lesser number of workers, and a deälated female. Chitty ${ }^{28}$ who recorded this, thought that this was the first time a nest of this ant had been found in Britain, but Lord Avebury ${ }^{16}$ recorded in $\mathbf{1 8 8 3}$ the discovery of a nest under a stone, the community consisting of about twenty individuals. Later, in August 1903, Chitty ${ }^{28}$ observed a small deposit of pupae and a few workers at Charing, and near Doddington a few workers under a stone, with evident traces of very fine galleries drilled by the ants in the earth. The following nests have been found by me:July 22nd, 1906, when in company with Chitty, two nests under stones at Charing which contained a number of worker pupae ${ }^{28}$; May lst and 8th, 1910 - two small colonies under flints at Box Hill which contained five and three deälated females respectively, and a small number of workers ${ }^{37}$; May 26th, 1911-a small community in moss at Box Hill with two deälated females and a few workers ${ }^{40}$; May 16th, 1913-two more colonies under flints at Box Hill with respectively one and two deälated females and some twelve workers. The nest with the two females consisted of a cell-in which they rested with a packet of eggs - just beneath the stone, built round with earth, through which long narrow galleries stretched in every direction.

The males and winged females are to be found in August and September, and may be swept off herbage in the neighbourhood of 
the nests. Baly ${ }^{6}$ observed a winged female which flew into an open window in his house in Kentish Town, and settled on the page of the book he was reading. Chitty ${ }^{29}$ records males on August 28th, 1904, and September 3rd, 1905, and one winged female on the latter date, all at Charing, and Hamm captured a female on the wing in the New Forest in August, 1908. I have taken five winged females at Darenth Wood on September 27th, $1910^{37}$, and swept many males and one winged female at Box Hill on September 5th, 191241 this female had evidently been fertilized, as she had lost two wings, and when placed in a tube with some males, refused to allow them to embrace her. In September, 1913, none could be found, and on September 2nd, 1914, only one male was swept at the same spot.

Specimens of this ant are frequently found in and about other ants' nests - both Janson ${ }^{22}$ and Shepperd ${ }^{22}$ took workers in company with Donisthorpea fuliginosa, W. E. Sharp ${ }^{37}$ workers with $D$. Alava at Stoat's Nest, and my own captures are as follows:-a worker with Formica fusca at Doddington ${ }^{26}$, May 12th, 1901, five winged females and a few workers in a nest of $D$. fuliginosa at Darenth Wood September 27th, 191037, a worker in the same nest May 26th, 191140, and a number of workers with $F$. fusca Box Hill May 30th, 191241 - some of these were brought home and introduced into two observation nests of $F$. fusca (from Porlock and Tiree) where they lived for more than two months, and were never attacked by the fusca workers, crouching down and remaining motionless when the latter tapped them with their antennae. Wasmann records specimens in the neighbourhood ("Nestbezirke ") of nests of $F$. rufa and $F$. sanguinea in Dutch Limburg ${ }^{19}$, and often with other ants in Luxemburg ${ }^{32}$. It is possible that females of Ponera coarctata may found their small colonies in, or near, the nests of other species of ants for the sake of the food and shelter they may thus obtain ${ }^{42}$.

The following Myrmecophiles have occurred with this ant in Britain :-Drusilla canaliculata F., Lamprinus saginatus Gr., and Bythinus glabratus Rye (Coleoptera), Pseudisobrachium cantianum Chitty (Proctotrupid), Cyphodeirus albinos Nicolet (Collembola), and Ripersia donisthorpei Newstead (Coccid), but Aphidae do not appear to be attended, or kept, by it, as is also pointed out by Forel ${ }^{11}$.

Colonies have not been kept in captivity with much success-the one referred to by Lord Avebury was unfortunately destroyed by a community of Donisthorpea flava ${ }^{\mathbf{1 6}}$; Chitty placed Morley's colony in a small inverted glass shade with earth on August 2nd, when the ants disappeared beneath the earth, and were not seen again till September 20th, when he dug them up and found some twenty workers present, a deälated female and two males ${ }^{28}$ - he states that all the pupae had hatched; but it seems probable that the latter 
were all sex pupae and most of them had been devoured by the workers, since the ants were not observed to have eaten anything; he again kept a small community in damp moss, but this proved a failure, the ants dying and the pupae withering up ${ }^{28}$; four deälated females and some twelve workers were kept by me in a small plaster nest, the ants would not touch the honey given to them, but eagerly devoured small flies, they however all gradually died off, the females not being observed to lay any eggs ${ }^{37}$; another small colony was kept in a glass nest, but most of the ants managed to escape, and the remainder died off ${ }^{40}$; in May, 1913, three females, with a packet of eggs, and twenty-eight workers were placed in a small well-fitting Crawley-Lubbock nest, the females rested in a small cell in the earth in the middle of the nest and the workers tunnelled long narrow winding passages through the earth in all directions, small flies were dragged in and devoured, but the eggs disappeared, probably having also been eaten, and no more were observed to be laid, though the colony seemed in good condition and no deaths had occurred, when in August the nest was placed in a conservatory and the heat killed them all in one day.

\section{Ponera punctatissima Roger.}

Ponera punctatissima Roger Berlin Ent. Zeitschr. 3246 (1859) ${ }^{1} \cdot$ Ponera androgyna Roger Berlin Ent. Zeitschr. $3246(1859)^{2}$. Ponera contracta Meinert Naturv. Afh. Dansk. Vid. Selsk. $550(1860)^{3}$. Ponera punctatissima F. Smith Ent. Ann. $186142^{4}$; Forel Denkschr. Schweiz. Ges. Naturw. 26 $62411(1874)^{5}$. Ponera ochracea Charsley Ent. Mo. Mag. $1469(1877)^{6}$. Ponera tarda Charsley Ent. Mo. Mag. $14162(1877)^{7}$. Ponera punctatissima Saunders Trans. Ent. Soc. Lond. 1880 212 ${ }^{8}$ : Ent. Mo. Mag. 2368 (1886) ${ }^{9}$; Dalla Torre Cat. Hym. $741(1893)^{10}$; Farren-White Ants' Ways 239 (1895) ${ }^{11}$; Saunders Hym-Acul. $29(1896)^{12}$; Vic. Hist. Essex 199 (1903) $^{13}$; Chitty Ent. Rec. $18161(1906)^{14}$; Godfrey Notes Roy. Bot. Gard. Edinb. 1907 No. $17102^{15}$; Vic. Hist. Kent $1116(1908)^{16}$; Donisthorpe Trans. Leicester Lit-Phil. Soc. 12225 (1908) ${ }^{17}$; Emery Deutschr. Ent. Zeitschr. $1909374^{18}$ : Genera Insect. $11891(1911)^{19}$; Donisthorpe Ent. Rec. 2313 (1911)

$\Varangle$ The whole insect is very pubescent especially on the thorax and gaster and is much more finely and closely punctured than P. coarctata, colour variable, a little darker than the darkest forms of the latter, to entirely reddish yellow.

Head a little broader and shorter than in P. coarctata; mandibles with terminal borders furnished with three or four stronger teeth, and with numerous, smaller, irregular teeth posteriorly ; maxillary palpi one-jointed, not terminated by a hair; gaster beneath extremely finely rugose transversely at the anterior portion of the second segment. Long, 2.8-3 mm.

o Very like the $\forall$; Head broader than in $P$. coarctata, with larger eyes nearly touching the base of the mandibles. Long, $3 \cdot 5-3 \cdot 8 \mathrm{~mm}$.

ot Shining reddish yellow, very ergatoid, apterous.

Head larger, broader, and more parallel than in the $\not{\zeta}$; mandibles broader and with stronger teeth than in the $\Varangle ;$ eyes small, situated near base of mandibles; antennae twelve-jointed, scape shorter than in the $\measuredangle$, but much longer than in the $\sigma^{*}$ of $P$. coarctata, funiculus with the last three joints broader, more transverse and more globose than in the $\not$, forming a fairly distinct club. Gaster with seven distinct segments ; pygidium simple. Long, $3.5 \mathrm{~mm}$.

For the very remarkable genital armature see Fig. 29. 
Original description of Ponera punctatissima Roger [Berlin Entom. Zeitschr. 3246 (1859)] :-

" $\Varangle$ Fusca, fusco-brunnea vel rubido-testacea, pube adpressa cinereomicans, mandibulis, antennis, pedibus et apice abdominis pallide rufis, palpis maxillaribus uni-articulatis.-Long, $3 \mathrm{Mm}$. ㅇ Fusca, pube adpressa cinereomicans, ore, antennis, pedibus et apice abdominis pallide rufis, oculis margini

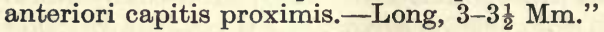

The $\sigma^{\lambda}$ was described by Roger as an abnormal $\not$, under the name of Ponera androgyna, as follows :-

Original description of Ponera androgyna Roger [Berlin Entom. Zeitschr. 3246 (1859)] :-

“ $\Varangle$ Rubido-testacea, nitida, pube adpressa cinereo-micans, antennarum scapo brevi, thorace inter meso- et metanotum sulcato, abdominis segmentis longitudine aequalibus tribus, apice valvulis minutis tribus. Long, $3-3 \frac{1}{2} \mathrm{Mm}$."

\section{Habitat.}

Ponera punctatissima is found in isolated places in England, Germany, France, and Switzerland, and also in the Canary Isles ${ }^{18}$. Three subspecies occur in Madagascar and one on Laysan Island ${ }^{19}$.

Hants, S. : Portsmouth (Donisthorpe and Pool) ${ }^{20}$.

Kent, E. : Whitstable (Chitty and Donisthorpe) $)^{14}$; Deal $(\text { Hall })^{16}$; Queenborough $(\text { Walker })^{17}$; Kent, W.: Bromley (Saunders) $^{9}$.

Essex, N. : Colchester ${ }^{13}$.

Middlesex : London, Burton Crescent (Squire)4, Hampstead Road (Mrs. Varley) ${ }^{4}$, Old Ford (Bedwell).

Oxford : Oxford (Charsley $)^{6}$.

Gloucester, W. : Minchinhampton (Farren-White) ${ }^{11}$.

Glamorgan : Penarth (Hallett).

Cumberland : Nutwich and Great Salkeld (Britten).

Edinburgh : Edinburgh (Stewart) $)^{15}$.

This species was first captured in Britain by Henry Squire in a bake-house near Burton Crescent ${ }^{4}$, where it was again found by Stokes in $1860^{4}$, and several specimens were also taken by Mrs. Varley in the kitchen of her house in Robert Street, Hampstead Road ${ }^{4}$. Charsley next discovered it in a conservatory at Oxford in June, $1877^{6}$, and subsequently described it, as a new species, under the name of $P$. tarda, on account of its slow movements ${ }^{2}$. The ants were found in the earth of a bed in the conservatory, a species of Myrmica inhabiting the same bed, and living in perfect harmony with the Ponera. It is probable that the Myrmica referred to was Tetramorium guineense F., a species frequently found in hot-houses. The Ponera had evidently been long established in this conservatory, as wings and other parts of the insects were found among the dust on ledges which had not been disturbed for years.

It appears to frequent hot-houses, and bake-houses, having 
occurred in the former at Oxford, Minchinhampton-where a large colony was discovered in Mrs. Frith's hot-house by Farren White ${ }^{11}$ - and Edinburgh-where Stewart found a colony in the Royal Botanic Gardens in a propagating frame, the heat of which was about $85^{\circ}$ Fahr. $^{15}$; and in the latter in London ${ }^{4}$, Colchester ${ }^{13}$, and Portsmouth ${ }^{20}$.

It has also occurred away from houses and buildings:- Saunders took a winged female at some distance from any houses at Bromley ${ }^{9}$; Chitty and I found a deälated female and worker in flood refuse at Whitstable ${ }^{14}$; Walker captured workers in the bone-heap at Queenborough ${ }^{17}$; and Hallett swept up a deälated female on June 20th, 1914, within half a mile of Penarth, on mixed herbage at the edge of a field. He tells me this field is about a quarter of a mile, as the crow flies, from the "tip " where the dustmen empty the town refuse.

Its colonies are much more populous than those of $P$. coarctata and the winged females, which occur in July and August, are produced in considerable numbers.

At the end of July, 1910, Pool sent me some winged females which he said were swarming in a scullery at Portsmouth, and in August we visited this scullery together, when the ants were still present in numbers, and this went on for several weeks, these females being chiefly found on a window facing the street. The scullery was connected with a bake-house by a grating and on visiting this a few winged females were also found there. The ants probably emerged from a hole in the masonry of one of the walls, though much search failed to find the nest, and no workers or males were taken. The baker said he had sometimes noticed small ants, crawling about and on the sugar for iceing cakes, some of which may have been the workers, but in the latter case they were probably Monomorium pharaonis L., the "house ant."

Charsley says that the females appeared in June ${ }^{7}$, and Saunders took his winged female when sweeping in a wood on the evening of July 1st, $1886^{\circ}$. Britten captured a male, winged females and workers in a hot-house in Cumberland on April 7th, 1913; and Bedwell took a winged female in the Queenborough Chemical Works on October 3rd, 1914.

Roger found it commonly in Berlin under flower-pots on the borders in pine-apple houses, a colony often consisting of 30,40 , or 50 individuals, which left their nest and came out and ran about in the sunshine ${ }^{1}$.

Forel discovered at Vaux in Switzerland a large colony in an old wall near a stable (no hot-houses being anywhere near) from which on August 16th, 1868, large numbers of winged females were taking flight. The females were unattended by workers, but he found males and workers in the interstices of the masonry of the wall ${ }^{5}$.

The male of this species is always apterous, the description of 
the winged form given by Saunders ${ }^{12}$ is probably taken from Forel, or André, which as pointed out by Emery ${ }^{18}$ refers to $P$. eduardi Forel, a species not known to occur in Britain. Saunders says he has seen specimens of the apterous form (the true male of $P$. punctatissima) from Oxford, but I have been unable to find these specimens, either in his own collection, or at Oxford, or in the British Museum. My description is made from a male taken by Britten in a hot-house at Great Salkeld in Cumberland.

\section{Subfamily Myrmicinae Mayr.}

The subfamily Myrmicinae is divided into ten tribes containing a large number of genera, the majority of which are cosmopolitan. The workers all possess a sting, and the pupae are always naked. Nine genera occur in Britain which may be distinguished as follows :-

\section{Table of the Genera.}

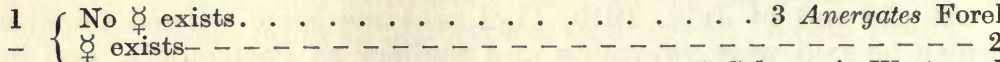

3 Anergates Forel

2 Antennae 10-jointed ........ 5 Solenopsis Westwood

(1) Antennae more than 10-jointed _ $\ldots \ldots \ldots \ldots$

3 Petiole quadrangular ......... 1 Myrmecina Curtis

(2) Petiole not quadrangular $\ldots \ldots \ldots \ldots-\ldots$

4 Post petiole with a spine beneath . . . . 2 Formicoxenus Mayr

(3) Post petiole without spine beneath $\ldots \ldots \ldots \ldots \ldots$

5 Epinotum unarmed. .......... 4 Monomorium Mayr

(4) Epinotum armed with two spines _ _ _ _ _ _ $\ldots \ldots$

6 The three last joints of the funiculus together much shorter than the

rest. . . . . . . . . . . 6 Myrmica Latr.

(5) Not much shorter than the rest $\ldots \ldots \ldots \ldots \ldots$

7 Eyes small, point-like ......... 7 Stenamma West

(6) $\{$ Eyes normal, outstanding $\ldots \ldots \ldots-\ldots-\ldots-\ldots-\ldots$

8 f Shoulders angled. .......... 9 Tetramorium Mayr

(7) 1 Shoulders rounded _ $\ldots \ldots \ldots \ldots$ - $\ldots \ldots$ - $-\ldots$ Lepthorax Mayr

\section{오}

1 Gaster with a broad longitudinal channel . . . . . Anergates Forel.

- Gaster without channel _ _ $\ldots \ldots \ldots \ldots \ldots$

2 Club of antennae large, two-jointed. . . . Solenopsis Westwood.

(1) Club of antennae not two-jointed _ $\ldots \ldots-\ldots \ldots$

3 f Epinotum unarmed ........... Monomorium Mayr.

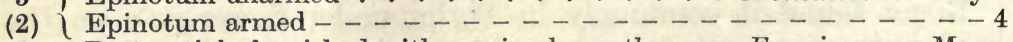

4 Post petiole furnished with a spine beneath . . Formicoxenus Mayr.

(3) Post petiole without spine beneath $-\ldots \ldots-\ldots-\ldots-\ldots-\ldots-5$

5 Petiole quadrangular ............. Myrmecina Curtis.

(4) Petiole not quadrangular _ $\ldots \ldots \ldots \ldots$

6 f Petiole very long ........... Stenamma Westwood.

(5) Petiole not long _ $\ldots \ldots \ldots \ldots \ldots \ldots-\ldots$

7 Hairs not pointed at apex......... Leptothorax Mayr.

(6) Hairs pointed at apex _ $\ldots \ldots \ldots$

8 Spurs simple; size very large in proportion to the $\not$. Tetramorium Mayr

(7) $\{$ Spurs pectinate; size not very large in proportion to the $\Varangle-\ldots$ 


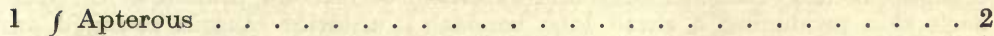

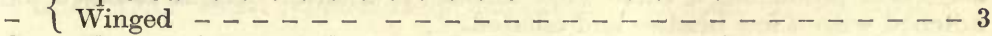

2 The two-joints of the pedicel very large, aspect immature . . . .

(1) . . . . . Anergates Forel.

1) The two joints of the pedicel not large, aspect normal - - - - Formicoxenus

3 f Antennae 10-jointed .......... Tetramorium Mayr.

(1) Antennae more than 10-jointed _ _ _ _ _ $\ldots \ldots \ldots$

4 Forewings with cubital cell half divided by a transverse nervure

(3) ................... Myrmica Latreille.

3) Forewings otherwise - . $\ldots \ldots \ldots \ldots \ldots$

5 Mesonotum without Mayrian furrows. . . . Solenopsis Westwood.

(4) Mesonotum with Mayrian furrows _ _ _ _ $\ldots \ldots \ldots$

6 Epinotum without teeth or tubercles. . . . Monomorium Mayr.

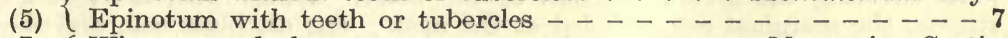

7 f Wings very dark ............. Myrmecina Curtis.

(6) Wings not very dark- _ $\ldots \ldots \ldots \ldots$

8 Frontal area distinct ......... Stenamma Westwood.

(7) Frontal area not distinct _... - . Leptothorax Mayr.

\section{MYRIIECINA Curtis.}

( $\mu \dot{v} \rho \mu \eta \xi$, ant).

Type: Formica graminicola Latr. (=latreillei Curt.; Curt., 1829).

The genus Myrmecina comprises very few species which range over the Palaearctic and Indo-Malayan regions.

$\Varangle$ Head somewhat square, widely but not deeply emarginate at the base, posterior angles rounded; clypeus short with two longitudinal carinae, and two blunt teeth in front: mandibles broad, with two rather strong teeth and a number of smaller ones, when closed a triangular free space is left between them and the clypeus; maxillary palpi four-jointed; labial palpi three-jointed; antennae twelve-jointed, with a three-jointed club; eyes small, situated in front. Thorax short, broad in front, narrowed behind; epinotum furnished with two strong spines, preceded by two small blunt teeth. Petiole quadrangular, longer than broad, the front part cut out and sloping post-petiole subtransverse and subquadrate; gaster oval with very long first segment; sting very small.

o Very like the \& ; head broader; mandiblés larger in proportion. Thorax: epinotal spines more robust. Wings blackish; fore-wings with one radial and one cubital cell.

ot Head globose, much smaller proportionately than in the $\forall$ and $q$; mandibles tridentate, narrow, hidden beneath the labrum; antennae thirteenjointed; scape about as long as the two succeeding joints of the antennae taken together. Thorax high, with the Mayrian furrows on the mesonotum, and impression in front of the scutellum, distinct and crenate, epinotum

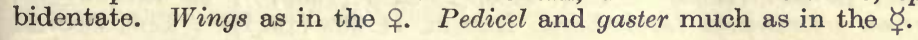

Original description [Curtis Brit. Entom. 6265 (1829)] :-

"Type of the Genus. Myrmecina Latreillii Nob.

Myrmecina Nobis.

Antennae inserted in the middle of the face, remote, longer than the head and thorax, geniculated, hairy; 13-jointed, basal joint short, but twice as long as the second which is subglobose, the third and following oblong, those 
beyond the fifth being rather obovate-truncate, terminal joint the longest, elongate-conic. Labrum large and exserted, coriaceous, dilated at the base, each side producing a small lobe beneath; anterior margin rounded and notched with a few bristles and ciliated.

Mandibles none, at least in the male.

Maxillae large and dilated, terminated by a broad membranous and ciliated lobe, meeting behind the mentum when at rest. Palpi rather long and slender, 4-jointed, basal joint the smallest, second and third of nearly equal length, 4th long subfusiform.

Mentum subovate, truncated at the base, with an arched suture towards the top. Lip none ? Palpi rather long and slender triarticulate, first and second joints nearly of equal length, the third longer and subfusiform.

Head subglobose. Eyes globose. Ocelli very prominent, forming a large triangle. Thorax ovate. Metathorax bidentate. Peduncle biarticulate, second joint the largest and globose. Abdomen ovate-conic, 5-jointed, basal joint covering the greater portion of the body. Wings with a trigonate stigma, the marginal cell pedicled at the apex; one discoidal cell, and the apical nervures obscure. Legs rather long. Thighs long slender, dilated in the middle. Tibiae short, anterior producing a pectinated spine. Tarsi 5-jointed, basal joint as long as the tibia, the remainder oblong. Claws small, pulvilli distinct.

Obs. All the figures and description were taken from a male."

\section{MYRMECINA GRAMINICOLA Latr.}

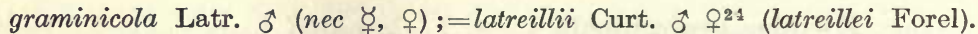
Formica graminicola Latreille Hist. Nat. Fourmis $256(1802)^{1}$. Myrmecina latreillii Curtis Brit. Ent. $6265(1829)^{2}$; [Jenyns MS. Cat. Cambs. Ins. 2

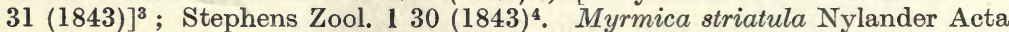
Soc. Sc. Fenn. $340(1849)^{5}$. Myrmica bidens Förster Hym. Stud. 150 $(1850)^{6}$. Myrmecina latreillii Curtis Trans. Linn. Soc. Lond. $21219(1854)^{7}$; F. Smith Trans. Ent. Soc. Lond. (n.s.) 3133 (1855) ${ }^{8}$ : Cat. Brit. Foss. Hym. $36(1858)^{9}$ : Ent. Ann. $186092^{10}$ : $1866128^{11}$. Myrmecina latreillei Forel Denkschr. Schweiz. Ges. Nafurw. $2673^{12}, 352^{13}$ (1874). Myrmicisa latreillii Capron Entom. $1127(1878)^{\mathbf{1 4}}$. Myrmecina latreillei Saunders Trans. Ent. Soc. Lond. $1880222^{15}$; Dale Ent. Mo. Mag. 17236 (1881) ${ }^{16}$; Capron Ent. Mo. Mag. $22229(1886)^{17}$; Swale Ent. Mo. Mag. $2724(1891)^{18}$; Wasmann zusam. Nest. gemischt. Kolon. Ameisen 176 (1891) ${ }^{19}$; Dalla Torre Cat.

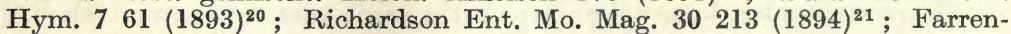
White Ants' Ways 247 (1895) ${ }^{22}$; Saunders Hym-Acul. 32 (1896) ${ }^{23}$. Myrmecina graminicola Emery Öfv. Finsk. Vet. Soc. Förh. $40130(1898)^{24}$. Myrmecina latreillei E. A. Butler Ent. Mo. Mag. $35290(1899)^{25}$. Myrmecina graminicola Wheeler Amer. Nat. $35519(1901)^{26}$. Myrmecina latreillei Martineau Entom. 34232 (1901) ${ }^{27}$; Chitty Ent. Mo. Mag. $3874(1902)^{28}$; Donisthorpe Ent. Rec. $1416(1902)^{29}$; Chitty Ent. Mo. Mag. $39284(1903)^{30}$; Jordain Trans. N-Staff. Nat Field Club $1782(1903)^{31}$; Vic. Hist. Somerset $175(1906)^{32}$; Vic. Hist. Berks $176(1906)^{33}$; Chitty Ent. Rec. 18161 $(1906)^{34}$ : Ent. Mo. Mag. $42212(1906)^{35}$; Donisthorpe Trans. Leicester Lit.Phil. Soc. $12226(1908)^{36}$ : Ent. Rec. $21258(1909)^{37}$ : $2312(1911)^{38}$. Myrmecina graminicola Donisthorpe Entom. 44389 (1911) ${ }^{39}$ : Ent. Rec. 24 $4(1912)^{40}: 2561(1913)^{41}$; Crawley and Donisthorpe Int. Ent. Cong. Oxford $1912214(1913)^{42}$.

$\Varangle$ Blackish brown, hairy; head in front, mandibles, antennae, underside of the thorax and pedicel, the concave surface of the epinotum, and legs reddishsometimes the sides of the thorax, the apex of the spines, and the basal half of the petiole and post-petiole are also reddish.

Head longitudinally rugose; scape bent and curved, a little shorter than the rest of the antennae; the joints between the first joint of the funiculus 
and the first joint of the club strongly transverse, but gradually increasing in length and breadth, the first funicular joint being a little longer and broader than those immediately following. Thorax angled anteriorly,

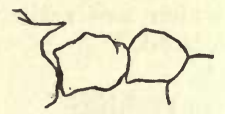

Fig. 57. Epinotum and pedicel of Myrmecina graminicola

strongly rugose longitudinally. Gaster black with apex reddish. Long, 3-3.6 $\mathrm{mm}$.

ㅇ Very like the $\not$ but larger, and often with more red about the body. Wings blackish and pilose. Long, 4-4.2 $\mathrm{mm}$.

o Black, smooth and shining, hairy. Head triangularly raised between the eyes; eyes and ocelli large. Wings as in the $O$, but somewhat more pilose. Petiole and post-petiole somewhat crenate at the base. Legs long, pitchy, with the femora dilated in the middle. Long, 3.4-4 $\mathrm{mm}$.

Ovum : roundish, a little longer than broad, and white.

Larva: mandibles thin and pointed, reddish; head long and narrow, bent over with the three thoracic somites, and the first abdominal, posteriorly towards the ventral surface; the mesothoracic somite is prominent, projecting more forward than the other two somites. Abdomen pyriform, the first somite very prominent. The whole body is clothed with long thin curved hairs, mixed with shorter ones; when young the larva is white, and the somites are not well defined posteriorly, but the full grown larva is distinctly yellowish and all the somites are distinct.

Pupa yellow, becoming the colour of the adult before emergence.

Original description of Formica graminicola Latreille. $\vec{\sigma}$ [Hist. Nat. Fourmis 256 (1802)] :-

" Le mâle ressemble aussi, pour le port, à celui de la fourmi rouge. Il est noir, luisant, pubescent. Les antennes sont d'un brun roussâtre clair avec le premier article noirâtre. La bouche est plus pâle. Le corcelet a deux petits tubercules aigus à son extrémité postérieure. Les pattes sont d'un brun clair, avec les cuisses et les jambes un peu plus foncées. Les ailes sont entièrement noirâtres, avec les nervures noires."

Original description of Myrmecina latreillii Curtis. $\widehat{\alpha}$ [Brit. Ent. 6265 (1829)]:-

"Smooth, shining, piceous black; sparingly clothed with hairs. Eyes black. Head and thorax with a few punctures. Antennae and legs ferruginous, thighs and tibiae piceous in the middle. Wings very iridescent, yellowish fuscous, stigma and nervures brown."

Original description of Myrmecina latreillii Curtis. ㅇ [Trans. Linn. Soc. Lond. 21219 (1854)] :-

"Female black : head suborbicular-quadrate irregularly striated, clypeus bidentate; eyes and ocelli minute, mouth ferruginous: mandibles large and prominent with many minute teeth ; neck distinct, ferruginous : antennae remote, not long, stoutish, geniculated, 12-jointed and clavate, scape long, second joint cup-shaped, seven following transverse, the third being very short, the ninth much longer, the remainder forming a club, the apical joint being long and conical. Thorax not so large as the head, obovate, hollowed and striated before; the scutel, which is smooth, has the suture at the base 
ferruginous; post-scutel very short, punctate, with two short but distinct spines. Petiole ferruginous, elongated, hairy, basal nodule subquadrate or ovate, second broader, transverse, and partially striated : abdomen very smooth and shining, rather broad, slightly depressed and oval, the apex ferruginous. Wings fuscous, exactly like the male. Legs ferruginous, stoutish, especially the anterior, which are rather short: length $1 \frac{2}{3}$, expanse nearly 4 lines. Neuter undiscovered."

\section{Habitat.}

Myrmecina graminicola ranges over the whole of the Palaearctic Region, a variety occurring in Japan, and several subspecies in North America.

The British distribution is as follows:-

Cornwall, E. : Fowey (Dale) ${ }^{23}$; Rame Head (Donisthorpe ${ }^{37}$.

Devon, S.: Tavistock (Swale $)^{18}$; Carn Quarry, Plymouth (Bignell) $^{23}$; Virtuous Lady Mine (Donisthorpe) ${ }^{37}$; Shaldon (Rothney Coll.); Seaton (Crawley); Devon, N.: Ilfracombe and Bideford (Saunders) ${ }^{23}$.

Somerset, N. : Batheaston ${ }^{32}$.

Dorset: Lulworth Cove $(\text { Curtis })^{7}$; Portland ${ }^{23}$, Charmouth ${ }^{23}$, and Cranbourne ${ }^{23}$ (Dale); Wareham and Lyme Regis (Dale Coll.); Weymouth (Richardson) ${ }^{21}$; Swanage (Nevinson).

Isle of Wight: Blackgang Chine $(\text { Curtis })^{7}$; Luccombe and Shanklin (F. Smith) ${ }^{11}$; St. Helens ${ }^{37}$ and Sandown ${ }^{41}$ (Donisthorpe).

Hants, S.: Hurst Castle $(\text { Dale })^{22}$; Hants, N.: Woodhay (Harwood).

Sussex, W.: Worthing (Saunders) $)^{23}$; Sussex, E.: Lewes (E. A. Butler) ; Ditching (Donisthorpe) ${ }^{37}$.

Kent, E. : Sandgate $(\text { Curtis })^{7}$; Charing $^{35}$, Doddington ${ }^{28}$, and Huntingfield $^{30}$ (Chitty); Whitstable (Chitty and Donisthorpe) $)^{34}$; Kent, W.: Greenwich (Curtis) ${ }^{7}$; Down $(\text { Avebury })^{23}$.

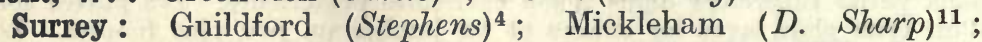
Shiere (Capron) ${ }^{17}$; Gomshall (E. A. Butler) ${ }^{25}$; Box Hill (Donisthorpe $)^{38}$.

Herts : Tring (Donisthorpe) ${ }^{36}$.

Middlesex : Camden New Town and Colney Hatch $(F . S m i t h)^{8}$; Kentish Town ( $F$. Smith Coll.).

Berkshire : Bagley Wood (Young $)^{33}$; Bradfield $(J o y)^{36}$; Aldworth (Harwood).

Oxford : Oddington (Crawley) ${ }^{42}$; Bletchington (Donisthorpe).

Suffolk, E. : Southwold (F. Smith $)^{10}$.

Cambridge : Swaffham Bulbeck (Jenyns) ${ }^{3}$.

Gloucester, W.: Stinchcombe Hill near Dursley and Stone House (Farren White) ${ }^{22}$; Selsby (Martineau) ${ }^{27}$.

Stafford : Colwich ${ }^{31}$ and Cannock Chase ${ }^{31}$ (Martineau).

This interesting little ant was first discovered in Britain about 1829 by Curtis who wrote ${ }^{2}$ " The only specimens I have ever 


\section{Plate V.}

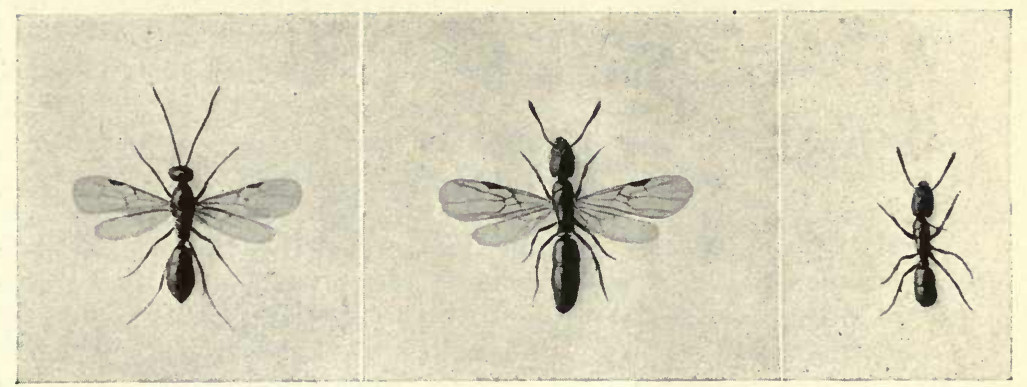

Male, female, and worker of Ponera coarctata.

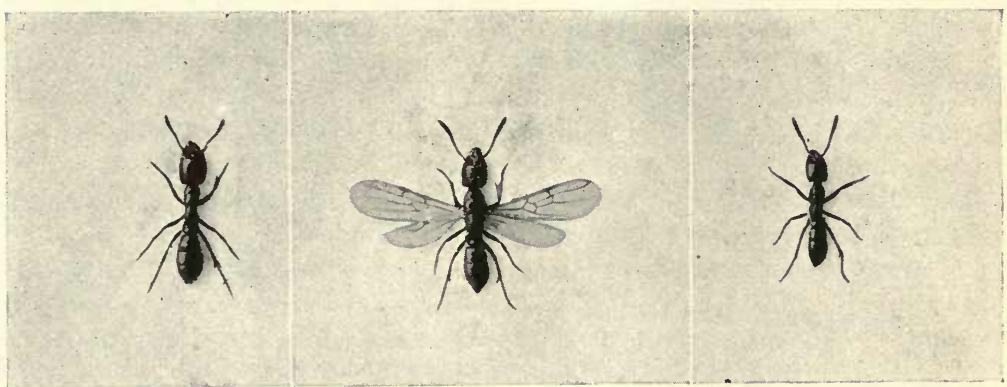

Male, female, and worker of Ponera punctatissima.
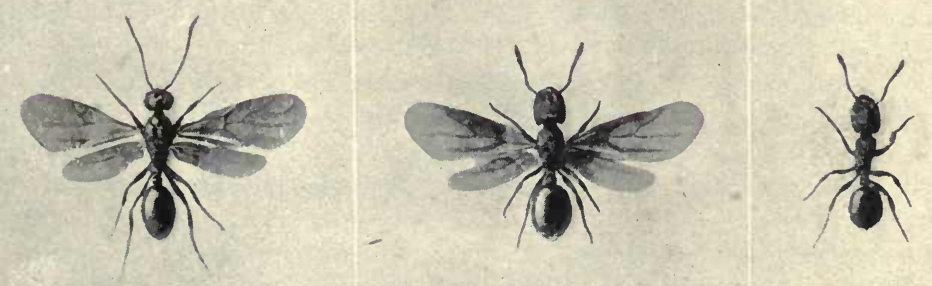

Male, female, and worker of Myrmecina graminicola.

Face page 78. 

seen of this little insect were all males, which I swept off rushes the middle of August and beginning of September, at the back of the Isle of Wight, where they were flying about." In August, 1836, Curtis $^{7}$ discovered the female at Lulworth Cove, and captured males in several other localities.

Stephens ${ }^{4}$ records it from near Guildford in 1842 ; he does not mention the sex, but as Curtis had not then described the female and the worker was unknown, it almost certainly must have been a male. Smith ${ }^{10}$ took a female at Southwold in August, 1859, and remarks how strange it was that no one finds the worker. In September, 1865, the first workers were taken in Britain by Dr. Sharp who found a nest at Mickleham. Smith ${ }^{11}$ recorded this fact and gave a description of the worker. Since then it has been met with in a number of localities, chiefly in the South of England, and appears to range as far north as Staffordshire.

The habits of this ant are subterranean, it nests under stones, in stumps, and at the roots of trees. The colonies are generally small and, at least in this country, have not often been observed. Lord Avebury found a colony near Down ${ }^{23}$ and Farren White ${ }^{22}$ records another which he met with under a stone at the foot of Stinchcombe Hill, near Dursley,-it contained a deälated female, many males, workers, and larvae of all sizes. Jordain ${ }^{31}$ states that Martineau observed colonies in dead tree-stumps at Colwich. I have twice found a small colony in a hollow flint at Box Hill ${ }^{38}$, a very small hole on the under side of the flint giving access to the cavity within - each contained a deälated female and a few workers and brood.

Isolated workers are more frequently met with, and both Richardson ${ }^{21}$ and Farren White ${ }^{22}$ record the fact that they have captured specimens in the centre of half-eaten strawberries.

The males and winged females occur away from the nests in August, September, and October, when they may be swept off grass, rushes, and herbage generally. Forel ${ }^{13}$ records the capture of an isolated winged female on Mont Tendre, but does not mention the date, and Crawley ${ }^{42}$ found a deälated female wandering on the flag-stones in front of his house near Oxford in August.

It is probable that both these specimens, were (after the marriage flight) searching for suitable situations to found colonies-in the latter case the female had already removed her wings. They are probably capable of founding their colonies independently (i.e. without the assistance of workers), as certainly appeared to be the case in the two instances referred to above-the small colonies in the hollow flints.

It is also a fact however that this ant frequently occurs in the nests of other species. Farren White ${ }^{22}$ found it in company with Donisthorpea flava near Dursley, and my own records are as follows :two workers in a nest of $D$. nigra at Doddington in May, $1901^{29}$; a 
single worker with Formica fusca at Rame Head in April, 190937 ; one worker with D. flava in the Meavy Valley in April, 190937; five workers in a nest of $D$. nigra at St. Helens, Isle of Wight, in August, $1909^{37}$; one worker with $D$. flava and three with $F$. fusca at Box Hill in April, $1911^{40}$; one worker with $D$. flava at Sandown Isle of Wight, in September, $1912^{41}$; a small incipient colony consisting of a deälated female and eight workers in a nest of Myrmica scabrinodis at Box Hill in September, 191241,-this colony was situated in a small chamber in the middle of the galleries of the Myrmica nest, which was under a stone; two deälated females and three workers with $D$. flava at Bletchington in May, 1913 ; six workers-some carrying larvae-in a large colony of D. mixta in the root of a tree-stump at Box Hill in May, 1913; and a single deälated female in a similar nest of the same ant in the same locality in September, 1913. Forel ${ }^{13}$ found a colony in Switzerland which had formed a nest by the side of a nest of Formica rufa, and again another connected with a nest of Ponera coarctata. Wasmann ${ }^{19}$ mentions a colony in a hillock of $F$. exsecta at Feldkirch in Vorarlberg. Wheeler ${ }^{26}$ also records the American subspecies-americana Emery, and its variety brevispinosa Emery, and also another subspecies from Texas (subsequently described by him as texana) as being frequently associated with other ants. It is therefore probable that the females sometimes seek the protection of another ants' nest to found their colonies.

This ant has been described as a cowardly species, but I should rather regard it as a lethargic ant, of retiring habits. It is true that when alarmed it rolls up into a ball, the head touching the tail, with the legs and antennae packed close to the body, and feigns death-since its integument is exceedingly hard, it is well protected against ants and other enemies in this position. I have found that the male and female, as well as the worker, make use of this mode of defence ${ }^{40}$. The workers will not tolerate the presence of strange ants of their own species, as instanced by the two colonies found in the flints before mentioned. These were put together in a small observation nest, when the workers of the first colony taken, attacked and killed the female and workers of the second colony and appropriated their brood. I have found also that they will attack and kill ants of other species, and bite at and hold on to a paint brush or tweezers when presented to them; they will eat a little honey, but prefer animal food, devouring the dead bodies of other ants, as well as killing and eating live ones and their brood, and other insects, especially small flies. The ants pass the winter in the larval state and are piled on each other in a heap by the workers. The latter feed the larvae by mouth, but also place cut-up bits of insects and other food on their bodies for them to eat. They pupate in May and attain the perfect state in June and July. 
No Myrmecophiles are known to occur with this ant, though my old friend the late Arthur Chitty suggested that the Proctotrupid Pseudisobrachium subcyaneum Hal., was parasitic on it, as he frequently swept them up together. I have also taken a number of Proctotrupids in this way, with the males of the ant, some having black wings like the latter ${ }^{41}$, but it is not certain that they are really associated. The ants do not appear either to keep, or attend, plant-lice or Coccidae.

Forel $^{12}$ states that this species has a faint raspberry-like smell, which is not however always noticeable, this I have not been able to detect although I have kept a small colony under observation since 1910. The following extracts are from my notes :-

May 1st, 1910 - a small colony consisting of a deälated female, a certain number of workers, eggs, and young larvae, was found in a hollow flint at Box Hill-these were taken home and established in a plaster observation nest. May 8th-another smaller colony was taken in a hollow flint in the same locality, and placed with the first colony, but, as before stated, the latter attacked and killed them. July 10th-more eggs have been laid, and some pupae are present. July 20th-pupae very dark in colour. Ants emerged from all the pupae during August. September 29th-many larvae present in a heap in one corner of the nest, the female and workers resting on the heap. January 1st, 1911-all well, the larvae have not grown during the winter. April 1st-the larvae are larger. May 4 th - some more very small larvae noticed. May 16 th-fresh pupae. May 24th - a fresh bunch of eggs and more pupae. July 5 th-a single male hatched. July 23rd-more eggs laid. July 27 th -all pupae have come to maturity; one worker has the antennae deformed (curled round like horns) - it is a pugnacious little ant, but generally sits by itself away from the others. November 16th - over fifty larvae present-the colony passed the winter quietly and hardly any deaths occurred. June lst, 1912-pupae again present. July 2 nd-callows hatched, and fresh bunches of eggs carried by the workers. September 1st-some hundred workers present (reared during the two years). December 25th-seventythree workers dead-the nest had been allowed to get too dry. January 21st, 1913 - the nest again in good condition - the queen and the remaining workers well, some eggs and many larvae of all sizes present. February 8 th-the ants devour some packets of eggs of Formica rufa given to them. March 31st-the ants kill and cut up a half-drowned $F$. rufa worker given to them. May 6theggs, very small, and nearly full-grown larvae present-no ants have died since February. June 16th-pupae present. July 10th -more pupae, some nearly adult in colour. September lst-all pupae have hatched, many larvae present, only six dead ants. In 1914 a large number of workers were reared. The nest is still under observation. 


\section{FORMICOXENUS Mayr.}

(Formica, ant ; $\xi \dot{\epsilon} \nu$ os, guest).

\section{Type : Myrmica nitidula Nyl. (Mayr, 1855).}

The genus Formicoxenus is confined to the temperate parts of the Palaearctic Region ; three species are known which are found in Europe, only one, $F$. nitidulus Nyl., occurring in Britain.

$\Varangle$ Head oval; clypeus large, triangular; frontal carinae short, parallel, widely separated; frontal area indistinct; mandibles broadest at the extremity, with the terminal border dentate; maxillary palpi four-jointed; labial palpi three-jointed; antennae eleven-jointed, with a three-jointed club; eyes moderate, situated at about the centre of the lateral borders of the head; ocelli generally wanting, sometimes present. Thorax flat; epinotum separated from the mesonotum by a distinet channel, and armed with two blunt teeth. Petiole angled above and below ; post-petiole armed beneath with a distinct spine; gaster oval with very long first segment nearly covering the rest ; sting moderate.

o Very like the $\not$; a little larger ; fore-wings with one cubital cell, and one discoidal cell, the radial cell being open.

ot Ergatoid; antennae twelve-jointed, with a four-jointed club.

Original description [Mayr Verh. Zool. bot. Ver. Wien 5413 $(1855)]:-$

“6

Formica und $\xi \dot{e} v o s$ Gast.

Arbeiter. Der glatte, glänzende Kopf ist länglich viereckig mit stark abgerundeten Ecken, länger als breit und breiter als der Thorax. Die Oberkiefer sind am Ende nicht viel breiter als am Grunde, deren Innenrand ist mit Zähnen besetzt. Die Unterkiefertaster sind viergliedrig. Die Lippentaster sind dreigliederig (scheinbar zweigliedrig), deren erstes Glied ist lang und dünn, das zweite und dritte sind nicht lang aber breit und können bei flüchtiger Untersuchung für ein einziges Glied gehalten werden. Die Oberlippe is vorne abgerundet und in der Mitte des Vorderrandes schwach ausgebuchtet.

Der Clypeus ist gross, ungekielt, von einer Seite zur anderen ziemlich flach, von vorne nach hinten schwach convex. Das Stirnfeld is kaum angedeutet. Die Geissel der eilfgliedrigen Fühler ist keulenförmig. Die Punctaugen sind bei den meisten Individuen vorhanden; merkwürdiger Weise gibt es aber auch manche Exemplare, bei welchen man selbst bei der stärksten mikroscopischen Vergrösserung keine Andeutung von Punctaugen aufzufinden im Stande ist. Die mässig grossen, flachen Netzaugen stehen etwas hinter der Mitte des Kopfes. Der glatte und glänzende Thorax ist hinter dem Mesonotum nicht eingeschnürt, es ist bloss eine feine Furche, welche die Gränze zwischen dem Meso- und Metanotum bildet, vorhanden. Das Metanotum ist mit zwei horizontal stehenden, nach hinten gerichteten, dicken Zähnen bewaffnet. Das erste Glied des Stielchens is vorne nicht stielförmig verlängert, es ist knotenförmig und verlängert sich nach oben in einen stumpfen Kegel, nach unten in einen dicken, starken und stumpfen Zahn; das zweite Glied ist knotenförmig, etwas breiter als lang und an der Unterseite mit einem nach abwärts und vorne gerichteten Dorne versehen. Der Hinterleib ist mässig gross, oval; das erste Segment bedeckt fast den ganzen Hinterleib.

Weibchen. Der Kopf mit seinen Theilen verhält sich ebenso wie beim $\not$, doch sind die drei Punctaugen stets vorhanden. Das Mesonotum ist abgeflacht; das Metanotum ist wie beim $\Varangle$ mit zwei Zähnen bewehrt, die Basalund abschüssige Fläche desselben sind nicht deutlich von einander abgegränzt. Das Stielchen ist so wie beim $\not$, ebenso der Hinterleib. Die Costa transversa 
der Flügel verbindet sich mit der Costa cubitalis nahe an der Theilungsstelle der letzteren, wodurch nur eine geschlossene Cubitalzelle gebildet wird; die Costa recurrens schliesst eine Discoidalzelle ab."

\section{Formicoxenus nitidulus Nyl.}

Myrmica nitidula Nylander Acta. Soc. Sc. Fenn. $21058(1846)^{1}$. Myrmica laeviuscula Förster Hym. Stud. $154(1850)^{2}$. Myrmica lucidula F. Smith Ent. Ann. $185839^{3}$. Myrmica nitidula F. Smith Ent. Ann. $185840^{4}$ : Proc. Ent. Soc. Lond. (n.s.) $4185789(1858)^{5}$. Myrmica (Stenamma) westwoodii F. Smith Trans. Ent. Soc. Lond. (n.s.) 41857281 (1858)6 : Cat. Brit. Foss. Hym. $32(1858)^{7}$. Stenamma (Myrmica) westwoodii F. Smith Ent. Ann. $187298^{8}$. Stenamma westwoodii Forel Denkschr. Schweiz. Ges. Naturw. 26 $82^{9} 227^{10}$ (1874). Stenamma westwoodii Saunders Trans. Ent. Soc. Lond. $1880216^{11}$. Formicoxenus nitidulus Er. André Spec. Hym. Europe 2273 $(1881)^{12}$; Saunders Ent. Mo. Mag. $2016(1883)^{13}$; Adlerz Öfv. Kongl. Vet-Akad Förh. $4143-64$ (1884) $^{14}$; Forel Ann. Soc. Ent. Belg. 30135 (1886) ${ }^{15}$; Wasmann zusam. Nest. gemischt. Kolon. Ameisen 35 (1891) ${ }^{\mathbf{1 6}}$; Dalla Torre Cat. Hym. $762(1893)^{17}$. Stenamma westwoodii Farren-White Ants' Ways $245(1895)^{18}$; Formicoxenus nitidulus Saunders Hym-Acul. $31(1896)^{19}$; Janet Animaux Myr. 54-56 (1897) ${ }^{20}$; Vic. Hist. Worcester. 189 (1901) ${ }^{21}$; Donisthorpe Ent. Rec. $1415(1902)^{22}$; Vic. Hist. Warwick $173(1904)^{23}$; Wasmann Arch. Trim. Inst. Grand-Ducal Luxemburg $190617^{24}$; Donisthorpe Ent. Rec. $18317(1906)^{25}$; Vic. Hist. Berks $176(1906)^{26}$; Bagnall Ent. Mo. Mag. $42140^{27} 210^{28}$ (1906) ; Emery Deutsch. Ent. Zeitscher. 1908 $551^{29}$; Donisthorpe Trans. Leicester Lit-Phil. Soc. $12226(1908)^{30}$; Arnold

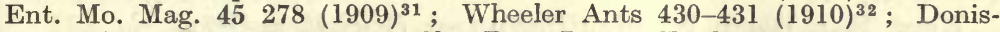
thorpe Ent. Rec. $2562(1913)^{33}$ : Rep. Lancs.-Chesh. Ent. Soc. 361912 $53(1913)^{34}$.

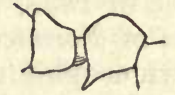

Fig. 58. Pedicel of Formicoxenus nitidulus ఫ.

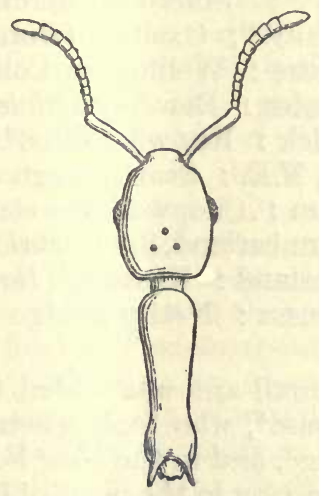

Fig. 59. Head and thorax of Formicoxenus nitidulus of.

$\Varangle$ Smooth and shining, reddish yellow, gaster reddish brown. Mandibles meeting when closed. Post-petiole armed beneath with a small spine. Long. $2 \cdot 8-3 \cdot 4 \mathrm{~mm}$.

ㅇ Very like the $\forall$, a little larger, and darker in colour. Eyes larger ; ocelli present. Post-petiole as in the ర. Long. $3 \cdot 4-3 \cdot 6 \mathrm{~mm}$.

o Very like the $\not{\gamma}$. Mandibles short, unarmed, not meeting when closed; eyes larger; ocelli always present; antennal funiculi more curved. Postpetiole as in ఛ; gaster with one more segment. Long. 2.8-3 mm. 
Original description of Myrmica nitidula Nylander [Acta. Soc. Sc. Fenn. 21058 (1846)] :-

" $\not$ laevis tota nitidissima nuda, rufa, abdomine fusco, oculis atris; antennae 12-articulatae; thorax supra convexiusculus longitudine abdominis (praeter petiolum), metathorax a mesothorace impressione transversali discretus, metanoto in dentem validiusculum horizontalem utrinque exeunte; nodus petioli posterior antice infra spinulâ minutâ instructus. Corpus pilis nonnullis subtilissimis. Statura et magnitudo proxime Myrmicae muscorum. Ab omnibus congeneribus supra allatis abunde discedit haec species jam capite, thorace nodisque petioli politis, propriaeque referenda est subdivisioni Operarium in acervo formicae cujusdam rufae prope Helsingfors invenit ad determinandumque mutuam dedit Stud. F. W. Maeklin. Ex unico specimine notas ulteriores dare nequeo."

\section{Habitat.}

Formicoxenus nitidulus is found in North and Central Europe and West Siberia in the nests of Formica rufa and pratensis. Wasmann discovered a colony with the latter in Luxemburg, all the individuals being of a dark brown colour, to which he gave the varietal name of picea ${ }^{24}$.

Hants, S. : New Forest (G. R. Waterhouse) ${ }^{5}$; Bournemouth $(\text { Jackson })^{25}$.

Kent, E. : Blean Woods (Chitty and Donisthorpe) $)^{22}$.

Surrey : Weybridge (G. R. Waterhouse) ${ }^{5}$; near Guildford (Capron $)^{18}$; Shiere (Capron $)^{19}$; Guildford $(\text { Smith })^{19}$; Esher (Champion) $^{19}$; Oxshott (Bedwell) ; Camberley (Donisthorpe).

Berkshire : Wellington College (Barnes) ${ }^{26}$; Tubney (Collins).

Worcester : Bewdley $(\text { Blatch })^{21}$.

Warwick: Knowle (Ellis) ${ }^{23}$.

Yorks, N.E. : Scarborough (Lawson) ${ }^{8}$.

Durham : Chopwell Woods (Bagnall) ${ }^{30}$.

Northumberland, S. : Corbridge-on-Tyne and Hexham (Bagnall $)^{27}$. Cumberland : Keswick (Day).

Easterness : Nethy Bridge (Donisthorpe) ${ }^{33}$.

This small ant was added to the British list in 1857 , by G. R. Waterhouse ${ }^{5}$, who took specimens in the nests of Formica rufa at Weybridge, and in the New Forest. It is a myrmecophilous species only occurring in the nests of its hosts $F$. rufa and pratensis, though Wheeler ${ }^{32}$ (p. 434) suggests that it may once have been a guest of Myrmica rubida (as Symmyrmica chamberlini Wheeler, an archaic form of Formicoxenius found in Utah, lives with Myrmica mutica, a species closely related to $M$. rubida) and only later became attached to Formica rufa. He goes on to say :- "This is suggested by the fact that the present host belongs to a different subfamily and by the extreme ergatomorphism of the males. This specialization is, at any rate, an interesting example of the more advanced state of development of European as compared with North 
American species belonging to the same or allied genera." However this may be, $M$. rubida is not found in Britain, whereas $F$. nitidulus, as shown above, is widely distributed here, but of course it is possible that the former may have inhabited Britain at some far distant period. The nest of $F$. nitidulus is small and is constructed from the finer materials of which the hosts' nest is composed ; it is generally situated in the interior-more rarely in the upper surface of the hillock-small galleries connecting it freely with its surroundings. Adlerz ${ }^{14}$ found a colony in Sweden situated in the cracks of a rotten oak-stump, over which the host species had built their hillock.

Wasmann ${ }^{16}$ discovered in Holland a small colony, consisting of workers, males, females, and brood, situated in an old cocoon of Cetonia floricola, a beetle which passes its early stages in the nests of $F$. rufa and pratensis.

Its colonies are small, not consisting of more than a hundred individuals, and it is not known how a new colony is founded. The male is apterous, mating taking place on the surface of the nest, and I have suggested that after fecundation the females fly away to other rufa nests to lay their eggs, but some probably reenter their own nest ${ }^{34}$.

The presence of Formicoxenus in the nests of its hosts may no doubt be explained by the fact that it thus obtains safety from enemies, shelter and warmth in which to rear its brood, and also sustenance, though, as Wheeler ${ }^{32}$ remarks, "the nature of its food remains an enigma." It has never been observed to be fed by its hosts, nor to devour the brood of the latter, or their prey-I have noticed they will eat honey and also the larvae of Leptothorax acervorum $^{\mathbf{3 4}}$, and this latter fact is interesting, as Er. André described another species of Formicoxenus ( $F$. ravouxi), taken by him in the south of France in a nest of Leptothorax unifasciatus (vide Bull. Soc. Ent. France 1896367 ). Colonies of $L$. acervorum are frequently found in the nests of $F$. rufa, but it is not suggested that the larvae of the former are the only or proper food of Formicoxenus.

The relationship between guests and hosts is obscure; the Formicoxenus moves freely about among the Formica, but is generally treated with indifference ; the latter sometimes threatening with their jaws, but never actually attacking them. When nitidulus meets a rufa it crouches down and remains motionless, and the rufa generally passes on, though sometimes the host may tap its guest with the antennae.

When the hosts move to another nest, their little guests follow them carrying their fellows and their brood; an interesting instance of this was observed by Fore ${ }^{15}$ in Switzerland. Having several times disturbed a nest of Formica pratensis (which also contained Formicoxenus), the ants deserted it and moved away to an old nest situated at a distance of fourteen metres-on August 
13th he noticed $F$. nitidulus following, in files, in the track of the $F$. pratensis, carrying their winged females, workers, and brood and not experiencing any difficulty in finding the way.

When a Formicoxenus carries another worker, it holds the latter, not (as a Formica would) under its body, but (as other Myrmicinae do) over its back.

Nylander ${ }^{1}$ described $F$. nitidulus so long ago as 1846 , but the male remained unknown until 1884 when it was discovered by Adlerz ${ }^{14}$ in Sweden. This sex was not recorded from Britain till 1906, when Bagnall ${ }^{28}$ captured some ten examples in nests of F. rufa at Corbridge-on-Tyne on August 12th, and in July and August, 1910, more males were taken by Arnold ${ }^{31}$ and Hamm, from what was evidently a large colony, in a rufa nest in the New Forest (there is however an unrecognized male in the Rothney Collection at Oxford, doing duty as a worker of Stenamma westwoodi-this was taken by Dr. Power at Weybridge on July 24th, $1864^{34}$ ). On September 6th, 1912, I secured a number of males from a nest of $F$. rufa at Weybridge ${ }^{33}$, in which Formicoxenus had occurred for many years past. The day was dull and cloudy and the males were observed running about on the surface of the rufa nest; they were easily distinguished from their own workers, by their more active and restless habits, and the bent funiculi of the antennae. These males endeavoured to copulate with the deälated females, and also with the workers, climbing on to their backs and grasping them round the thorax with their short mandibles, both on the surface of the nest and in my tubes-on September 14th six more males were found in this nest ${ }^{34}$. Wheeler ${ }^{32}$ describes the mating of this species, which he observed in the Upper Engadine in July, 1907, as follows:-

"After a cold night, the sun remained behind a mass of clouds at about 9 a.m. when $I$ saw dozens of Formicoxeni of all three phases, but mostly males, running hither and thither over the small twigs and other débris forming the outer covering of an old rufa nest which I had stopped to examine. The males moved very quickly, with feverishly vibrating antennae, and were so amorous that they often seized workers and attempted to mate with them. The few winged females were soon supplied with partners and the supernumerary males continued to hurry about over and among the little sticks of the nest. Then the sun suddenly emerged from the clouds and, as if by magic, all the Formicoxeni disappeared into the nest. I waited for some time and during the remainder of the morning returned repeatedly to the spot, but none of the tiny inquilines reappeared."

It will thus be seen that the males may be found in July, August, and September, and the winged females in July and August-(I have only once taken the winged female-in August, 1906, at Bournemouth). 

Plate VI.

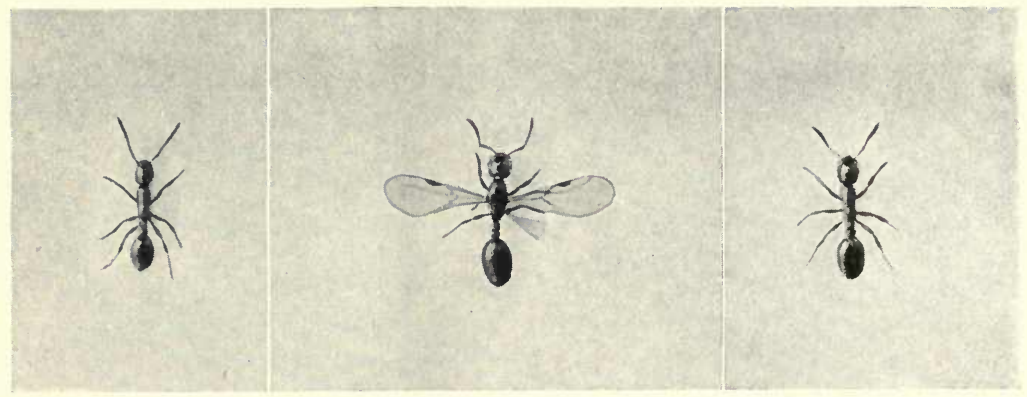

Male, female, and worker of Formicoxenus nitidulus.

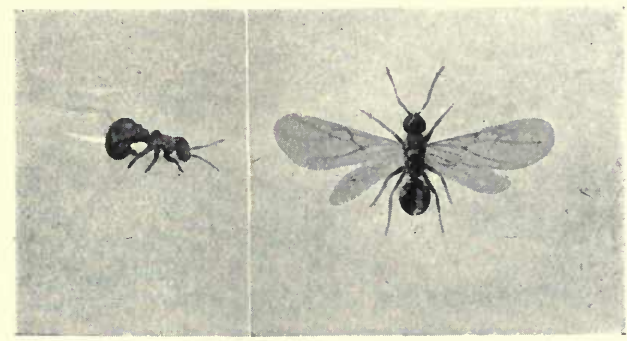

Male and female of Anergates atratulus.

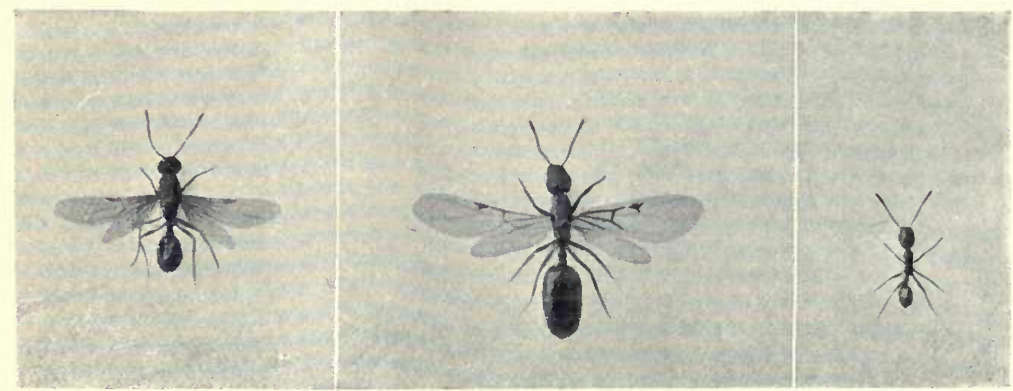

Male, female, and worker of Monomorium pharaonis. 
The following notes on a small community kept in captivity may be of interest :-

September 14th, 1912-a number of workers, several deälated females, and six males, taken in a rufa nest at Weybridge, were established in a plaster nest. September 15th-several workers attacked each other, some being dragged about by the legs and antennae-this occurred at intervals till September 24th. September 20th-two males have died; all the ants crowd round some honey, and simultaneously tap on the ground (when probably stridulating) whilst devouring it ; larvae of Leptothorax acervorum taken in the same rufa nest, also eaten. September 24th-a few workers dead; some fifty left. September 30 th-all the males now dead. October 3rd-introduced a rufa worker, it paid little attention to the Formicoxeni, but eventually picked up one and carried it a little way, setting it down again unhurt; fresh honey being introduced, the rufa went to feed at it, when the little ants crept under it and between its legs to get at the honey; the rufa moved its legs uneasily when the little ants touched against them. November 1st-as the rufa took no further notice of its companions it was put back into its own nest; more Leptothorax larvae introduced, these were collected together into a heap and rested on by the Formicoxeni. December lst-no deaths have occurred since September 30th ; the Leptothorax larvae appear to be treated as if they were the brood of their hosts. December 30th-a few eggs have been laid and placed on the Leptothorax larvae. January 21 st, 1913-a few young larvae present among the Leptothorax larvae. February 8th-introduced a small packet of rufa eggs ; these were never touched, and eventually went mouldy. May lst-all the larvae have disappeared, probably eaten. May 6th-introduced some larvae of Leptothorax affinis (from my nest which was taken at Yvorne, Switzerland), these were collected into a heap as before. June lst-only one deälated female and six workers present, resting on the Leptothorax larvae ; the glass cover of the nest not fitting closely, many must have escaped. July 8 th-on my return home, all the ants were found to have disappeared. These little ants were thus kept in captivity, away from their hosts, for some ten months, and had they not unfortunately escaped, would probably have existed for a much longer period.

\section{ANERGATES Forel.}

(a, negative prefix; $\epsilon \rho \gamma a ́ r \eta s$, worker).

Type : Myrmica atratula Schenck (Forel, 1874).

This extraordinary genus, which is confined to the temperate parts of the Palaearctic Region, only possesses one species, in which the worker phase is absent. 
\& Head strongly emarginate posteriorly; clypeus rounded posteriorly, deeply cut-out anteriorly; mandibles moderate, terminal border short, and furnished with one tooth at the extremity; maxillary palpi two-jointed; labial palpi one-jointed; antennae eleven-jointed, scape cylindrical, broadest anteriorly, funiculus with first joint long, third very short, those following gradually increasing in length, last joint as long as the two preceding taken together, club indistinct, composed of the last three or four joints; eyes large, situated in the centre of the lateral borders of the head; ocelli moderate. Thorax short; epinotum furnished with two distinct tubercles. Forewings with one cubital cell, no discoidal cell, and radial cell open. Petiole transverse, thick; post-petiole twice as broad as long, soldered to the first segment of the gaster; sting wanting, or rudimentary. Legs without spurs on the intermediate and posterior pairs.

ot Head less deeply emarginate posteriorly; clypeus as in the $q$, but less deeply cut out; mandibles narrow, rounded, not distinctly toothed ; maxillary and labial palpi as in the + ; antennae eleven-jointed, but shorter and broader than in the +. Thorax composed of the usual sclerites possessed by winged male ants; pronotum short; mesonotum without Mayrian furrows; a tubercle takes the place of the articulation of the fore wings. Petiole and post-petiole short, very broad and resembling segments of the gaster ; gaster broad, thick and strongly bent beneath the body, convex above, and concave beneath ; genital organs large, prominent.

\section{Original description [Forel Denkschr. Schweiz. Ges. Naturw. 26} $93(1874)]:-$

66

\section{Genus Anergates nov. genus.}

Operaria : Deest.

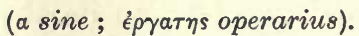

Femina : Petioli articulus primus crassus, obtusus, latior quam longior ; secundus antice convexus, duplo latior quam longior, abdominis segmento primo coalitus. Caput postice valide emarginatum. Palpi maxillares 2, labiales 1 articulati; palporum articuli breves et crassi. Antennae 11 articulatae; scapus cylindricus ; flagelli articulus primus longus, secundus brevior, tertius brevissimus; articuli sequentes sensim usque ad apicem in longitudinem et latitudinem crescunt; articulus ultimus duos praecedentes una sumptos longitudine aequat. Mandibulae haud latae, margine terminali brevi, acuto, apice cum dente uno. Clypeus postice rotundatus, antice in medio usque ad marginem posteriorem profunde lateque excavatus. Clypei partes laterales longitrorsum nequaquam angustatae, ut fieri solet. Laminae frontales breves, elevatae, vix divergentes. Area frontalis et sulcus frontalis variabiles. Oculi ad media capitis latera. Fossa antennalis profunda. Alae superiores cellula cubitali una, discoïdali nulla; costa transversa cum costa cubitali, vel cum ramo cubitali externo conjuncta. Cellula radialis aperta. Metanotum tuberculis elevatis duobus. Pedes non longi. Aculeus inchoatus aut nullus. Pedes medii et posteriores sine calcaribus.

Mas : Allae nullae. Palpi, oculi, ocelli, laminae frontales et fossa antennalis ut in . . Clypeus ut in $ᄋ$, sed excavatione paulo minus profunda. Caput etiam paulo minus postice emarginatum. Area frontalis et sulcus frontalis variabilia. Mandibulae haud latae, ad apicem rotundatae, sine dente et sine margine terminali distincto. Antennae 11 articulatae ut in + , sed breviores et crassiores. Thorax ut in maribus alatis, pronoto brevi, scutello, proscutello et postscutello praeditus. Locus alarum superiorum articulationum protuberantia signatus est. Mesonotum sine sulcis convergentibus. Metanotum in medio paulo concavum, sed absque tuberculis. Pedes breves, crassi. Petioli articuli ambo breves, latissimi, abdominis segmentis simillimi. Abdomen maximum, crassum, infra ita incurvum ut genitalia externa fere sub segmento primo sita sint : abdominis pars dorsalis convexa est, pars ventralis concava. Squamae genitalium externorum fere circulares, magnae, abdo- 
minis segmentum ultimum multo excedunt; valvulae genitales exteriores parvae, triangulares; valvulae genitales mediae inchoatae; valvulae genitales internae maximae, squamas $0,3^{\mathrm{mm}}$ excedentes, apice postice incurvato, caeterum ut in aliis formicis structae."

\section{Anergates atratulus Schenck.}

Myrmica atratula Schenck Jahr. Ver. Naturk Nassau 891 (1852)1. Tetramorium atratulum Mayr Verh. Zool. Bot. Ver Wien $5429(1855)^{2}$. Tomognathus atratulus Mayr Eur. Form. $56(1861)^{3}$. Myrmica atratula Hagens Berlin Ent. Zeitschr. $11106(1867)^{4}$. Anergates atratulus Forel Denkschr. Schweiz. Ges. Naturw. 26 341-344 (1874) $)^{5}$; Er. André Spec. Hym. Europe $2278(1881)^{6}$; Lubbock Ants, Bees, Wasps $89(1882)^{7}$; Adlerz Bih. K. Sven. Vet. Akad. Handl. $11230(1886)^{8}$; Wasmann zusam. Nest. gemischt. Kolon. Ameisen $131(1891)^{9}$; Dalla Torre Cat. Hym. $764(1893)^{10}$. Anergates atratula Dale Entom. $2899(1895)^{11}$. Anergates atratulus Janet Animaux Myr. $56(1897)^{12}$; Donisthorpe Trans. Leicester Lit-Phil. Soc. $12226(1908)^{13}$; Emery Deutsch. Ent. Zeitschr. $1908550^{14}$; Wasmann Biol. Centralb. 28 423-427 (1908) ${ }^{15}$; Adlerz Arkiv Zool. 5 1-6 (1908) ${ }^{16}$; Wheeler Journ. PsyNeur. $13430-432(1908)^{17}$ : Journ. New York Ent. Soc. 17 180-183 (1909) ${ }^{18}$ : Ants 498-503 (1910)19; Donisthorpe Ent. Rec. 246 (1912) ${ }^{20}$; Crawley Ent. Rec. $24218(1912)^{21}$; Donisthorpe Ent. Rec. 2562 (1913) $^{22}$ : Rep. Lancs.Chesh. Ent. Soc. $19123648-52(1913)^{23}$; Crawley and Donisthorpe Int. Ent. Cong. Oxford 19122 68-73 (1913) ${ }^{24}$; Donisthorpe Ent. Rec. 25268 $(1913)^{25}$; Emery Biol. centralb. $33259(1913)^{26}$; Adlerz Myrornas LIV. 238-239 (1913) ${ }^{27}$.

우 Black brown; mandibles, antennae, and legs yellow. The whole body strongly and thickly punctured, distinctly rugose, dull. Wings slightly fuscous. Gaster, in virgin o, deeply channelled longitudinally. Long. $2.5 \mathrm{~mm}$.

$\hat{o}$ The whole insect of a dirty yellowish colour, closely and rugosely punctured. Mesonotum more strongly and less closely punctured. Fore-legs furnished with strigils in specimens from Switzerland, not so in specimens from England, France, Holland and Sweden. Long. $2 \cdot 3 \mathrm{~mm}$.

Ovum : white, roundish.

Larva: yellowish white; when young, hairy; more narrow anteriorly than posteriorly; when older, less hairy and nearly as broad anteriorly as posteriorly, but somewhat attenuate in the middle; head naked; the first four somites of the abdomen furnished with long anchor-tipped hairs; the whole body clothed with both long serrate hairs, and short densely and compactly branching hairs.

Pupa: whitish yellow, becoming the colour of adult when nearly mature.

Original description of Myrmica atratula Schenck [Jahr. Ver. Naturk. Nassau 892 (1852)]:-

"Das W. gegenwärtiger Art ist etwa $1 \frac{1}{2}$ L. lang, ... ; bei den befruchteten ungeflügelten Weibchen, welche man im Frühjahr in den Nesten findet. erreicht der Hinterleib eine beträchtliche Dicke und Grösse. Die Farbe ist tief schwarz, fast glanzlos; der Körper ohne Borstenhaare; Fühler und Beine mit sehr feinen, kurzen Börstchen. Kopf und Thorax sind sehr fein, nur durch die Lupe merklich, gerunzelt, lederartig. Der Kopf ist kurz, ohngefähr von der Breite des Thorax; die Fühler sitzen sehr tief, fast am Mundrande. Unter ihrer Wurzel ziehen sich von den Backen her 2 vornen zwischen den Fühlerwurzeln sich mehr oder weniger nähernde bogenförmige erhabene Ränder. Ueber den Fühlern ist der Kopf flach oder eingedrückt, oft lauft eine tiefe Rinne bis zum mittleren Nebenauge. Ein Kopfschild und ein Stirnfeld sind fast nicht vorhanden. Der Scheitel ist höckerig erhöht, der Hinterkopf eingedrückt und ausgebuchtet. Die Netzaugen sind klein, aber 
stark vorragend, nahe an den Fühlern sitzend; die Nebenaugen vorspringend. Die Backen sind sehr breit, stark nach hinten erweitert; von der Seite gesehen erscheint der Kopf fast viereckig. Die Oberkiefer sind klein und schwach, schwärzlich oder bräunlich, nach dem Ende blässer; die Fühler kurz, heller oder dunkler bräunlich, nach dem Ende blass, braun geringelt; nur 11 gliedrig; der Schaft etwa $=\frac{2}{3}$ der Geissel, das erste Geisselglied etwas verlängert und verdickt, umgekehrt kegelförmig, die 4 folgenden so lang, als breit, fast cylindrisch, die folgenden allmählig dicker, das letzte so lang, als die 2 vorhergehenden, länglich. Der Metathorax hat statt der Dornspitzen zwei nach oben gerichtete Höckerchen, der Raum dazwischen ist vertieft und glatt. Die Knoten sind sehr breit; der zweiter ist weit breiter als der erste, oben fast flach, nicht viel schmähler als der Hinterleib, von demselben nur durch eine Fuge getrennt. Der Hinterleib ist kurz und breit, oben ziemlich flach, im Umkreis rundlich, breiter, aber kürzer, als der Thorax. Die Beine sind kurz, bräunlich, Gelenke und Tarsen gelblich. Die Flügel glashell, etwas graulich, Adern und Randmahl nicht gefärbt, die Unterrander aber schwarz; die Radialzelle offen, die Discoidalzelle fehlt, zuweilen durch den Ansatz einer Querader angedeutet."

\section{Habitat.}

Anergates atratulus has been found in Sweden, Holland, France, Switzerland, Germany, and England; it is also recorded from West Siberia by Emery.

British distribution :-

[Dorset: Charmouth (Dale) $)^{\mathbf{1 1}}$ ?

Hants, S. : New Forest (Crawley and Donisthorpe) ${ }^{24}$.

C. W. Dale ${ }^{11}$ recorded this species as British, stating that it was taken by his father at Charmouth on July 8th, 1835, and that it is the Myrmica maculipes of Curtis' Guide. This name does not however occur in Curtis' Guide, and although I have thoroughly overhauled the Dale Collection at Oxford, there is no label nor ant bearing this name, nor does Anergates occur in the collection under any other name; consequently this record must be dismissed as extremely doubtful.*

On July 23rd, 1912, Anergates was taken in the New Forest by Crawley and myself, in a nest of Tetramorium caespitum, the colony consisting of a large number of Tetramorium workers, all large and dark in colour ; a number of winged female Anergates, three males in copula with winged females, one deälated Anergates female (the

* Curtis writes (Trans. Linn. Soc. Lond. 21216 (1854)) under Myrmica caespitum that he had given the name of maculipes to the female of that species, and that two females agreeing with Nylander's $M$. fuscula [N.B. Myrmica fuscula of Nylander = Tetramorium caespitum L. - see synonymy of that species p. 170] were discovered by Mr. Dale under a stone at Charmouth in July-both had lost their wings. There is a deälated female of Tetramorium caespitum in the Dale collection labelled "Charmouth" in J. C. Dale's handwriting - the name " maculipes" would describe the female of T. caespitum, and there is little doubt that C. W. Dale's record refers to that species. 
queen mother), with the gaster enormously distended, and a number of Anergates larvae and pupae.

Anergates is only found in the nests of $T$. caespitum. In such Anergates-Tetramorium colonies no males, females, nor brood of the host species occur, and Schenck ${ }^{1}$ who discovered the species in Nassau, perhaps naturally took the Tetramorium workers, with which the Anergates occurred, to be those of the latter.

The male of this ant is a most curious object; it walks with difficulty, looking like a cripple, and both it and the female are fed by the Tetramorium workers-they are unable to eat without assistance. The males are licked and carried about by their hosts, but very little attention is paid to the virgin females by the latter. Mating takes place in the nests between brother and sister (adelphogamy), after which the females fly away, presumably to seek other Tetramorium nests; though after fecundation, they soon get rid of their wings in captivity.

The abdominal segments expand enormously some time after the female has lost her wings, becoming so distended with eggs that the chitin which had previously formed segmented rings, is now represented only by small black bars separated by broad spaces of white membrane.

The Tetramorium workers in these mixed colonies are generally large in size, and dark in colour, showing that they have sprung from an old established colony. On June 12th, 1913, I found a colony of $T$. caespitum on the Isle of Lundy ${ }^{25}$, which contained no brood nor queen (whereas in other nests on the Island sex-pupae and a deälated female were found), the workers being the largest specimens I have ever seen, and very dark in colour. This might well have contained a deälated Anergates female, but the ground being very hard and stony, it was impossible to dig up the nest properly.

The males and winged females-which are sometimes very numerous, especially the latter-have been found from May to August. Adlerz has described two extraordinary Gynandromorphs which he reared in an Anergates-Tetramorium colony he had taken in Sweden, and established in an observation nest, as follows ${ }^{16}$ :-

1. Imperfect lateral gynandromorph, with the head largely male on the left, female on the right side, the light colour of the male being sharply marked off only anteriorly from the dark colour of the female. Thorax female in front, with wings equally developed on both sides, but with pale coloration on the left and dark coloration on the right, the line of division neither sharp nor straight and the whole postscutellum blackish brown. Abdomen with irregular arrangement of colour. Petiole black on the right, greyish yellow on the left; post-petiole mostly blackish brown, but with a large greyish yellow spot on the left side of its anterior surface. Third dorsal tergite blackish brown on the right, yellowish on the left side, the remainder of gaster greyish yellow tinged here and there with pale brown. Third tergite with a median longitudinal groove which runs back on to the succeeding segment as in the virgin female. The left side of the abdomen has seven 
complete segments and well-developed genitalia, the right side has only six complete segments, and a membranous incomplete seventh. The genitalia are imperfect, the volsella being represented only by a piece corresponding to its dorsal portion and the stipes is wanting. The legs are female, except the left fore leg, which is male, with a pectinate strigil.

2. Male on left, female on right, resembling the preceding, but with the dark female colour more pronounced on the male side of the head. Wings well developed on both sides, thorax female, though dark on the right and pale on the left, except the epinotum which is entirely greyish yellow. Abdomen almost typically male in colour and form, with the genitalia welldeveloped on both sides, but with a feeble mid-dorsal impression. Legs female, except the left fore one, which is shorter and thicker as in the male, with strigil cleft but not pectinate.

The most interesting problems connected with Anergates are, how the female gets accepted by a Tetramorium colony, and why there are only workers of the latter present in such colonies. It is evident that the female must enter a Tetramorium nest in some way, and be accepted by the workers, when the latter must kill their own queen, or males and winged females if present, since the Anergates female can hardly be strong enough to accomplish this herself. Anergates colonies are everywhere exceedingly scarce and difficult to find, whereas the host species is generally abundant and common where it occurs, and this evidently indicates that the founding of an Anergates colony is by no means a simple matter. Since Anergates is absolutely dependent on the Tetramorium workers, and no more of these can be produced, a colony can only last for the length of the life of the hosts.

Forel, Avebury, and Wasmann express the view that Anergates is descended from a slave-making species, and on this point Lord Avebury writes:- "In Anergates, finally, we come to the last scene of this sad history. We may safely conclude that in distant times their ancestors lived, as so many ants do now, partly by hunting, partly on honey; that by degrees they became bold marauders, and gradually took to keeping slaves; that for a time they maintained their strength and agility, though losing by degrees their real independence, their arts, and even many of their instincts; that gradually even their bodily force dwindled away under the enervating influence to which they had subjected themselves, until they sank to their present degraded condition-weak in body and mind, few in numbers, and apparently nearly extinct, the miserable representatives of far superior ancestors, maintaining a precarious existence as contemptible parasites of their former slaves."

There is nothing in the structure however of this permanent social parasite to prove that it is descended from a slave-making species, and it seems more probable, as pointed out by Wheeler ${ }^{19}$, that it is derived from a temporary parasite, or a guest ant, permanently attached to the nest of another species. Emery believes that Anergates is descended from Monomorium, and that it, or it s 
ancestors, were parasitic on species of the latter genus ${ }^{\mathbf{2}}$. The following observations and experiments may be recapitulated here :-Adlerz ${ }^{8}$ records a few experiments with Anergates females and strange Tetramorium colonies, in Sweden. He introduced several unfertilized females into a strange colony of Tetramorium, when the former moved about almost unnoticed among these ants, and nearly the same results were obtained by introducing unfertilized females into another nest of Tetramorium which possessed a queen and brood of its own species. A number of males, females, larvae, and pupae of Anergates were introduced into an artificial nest which contained a colony of Tetramorium, and all were amicably received.

Wasmann ${ }^{9}$ obtained similar results in Holland, males and females of Anergates being received and not attacked by Tetramorium workers. Janet ${ }^{12}$ placed together in an observation nest a normal colony of Tetramorium with a queen, and an AnergatesTetramorium colony consisting of an obese queen, males, young winged females and Tetramorium workers. Very little fighting took place, but some days later the Anergates queen was dead, though still attended by the Tetramorium workers. Some weeks later all the Anergates had disappeared, an unmixed Tetramorium colony being the result.

Wasmann ${ }^{15}$ found a very strong Anergates-Tetramorium colony in Luxemburg in May which contained an obese female, over 100 winged females, several dozen males, over 1000 Anergates pupae (mostly female), and some 2000 old Tetramorium workers, which were of medium size. The greater part of this colony was placed in an observation nest, when pairing between the sexes was observed, and after fecundation the females endeavoured to leave the nest-Tetramorium worker pupae from a strange nest were given to this colony, but were devoured. He introduced twelve winged but fertilized Anergates females-males being in copula with two of them-into an observation nest containing 100 Tetramorium workers and pupae. One female was attacked and her wings removed, the rest, however, being readily received, but no female was taken as a queen, and all the Anergates had disappeared in a few weeks. Wasmann suggests that a female may be adopted into a queenless old Tetramorium colony or perhaps in a branch nest of an old colony.

Wheeler ${ }^{17}$ discovered near Vaud, on June 6th at 2 p.m., a mediumsized Tetramorium colony from which Anergates females were escaping in considerable numbers and flying away in all directions over the sun-lit grass. Forel having joined him, the nest was excavated with great care, when the obese mother queen of Anergates, several hundred Tetramorium workers, more than a thousand Anergates winged females, a few hundred males, and some larvae and pupae were dug up and placed in a bag for experimental 
purposes. Fertilized females from this colony were placed near the openings of eight nests of Tetramorium in Forel's garden at Chigny, when some of them entered nests without attracting much attention. In other instances females were carried into the nests by the workers, males on the other hand being treated with some animosity, carried away and abandoned. One vigorous colony however behaved differently; males and females placed near the entrance being seized, pulled about, and carried some distance away. Later in the day some of the females that had entered the nests were brought out and thrown away, and the fact that none of these nests finally accepted an Anergates female as their queen was proved by Forel who examined them next year, and found that they contained no Anergates, but male and female Tetramorium pupae were present in all of them.

Several experiments ${ }^{24}$ with Anergates females from the New Forest and Tetramorium colonies in observation nests were carried out by Crawley and myself, these females being attacked and killed by the Tetramorium workers, except in one experiment,- - thus contrary to the results obtained by Adlerz and Wasmann, in which it will be remembered they were readily received. My observation nest contained a fertile deälated female Tetramorium, workers and larvae which had been taken at Whitsand Bay in July, 1911. In one experiment on July 25th, 1912, the Anergates female, when introduced into this nest, seized a Tetramorium worker by the antennae and held on for some time (in all Crawley's experiments the same thing took place), eventually letting go and walking about among the ants-the Anergates was sometimes picked up and carried about by a worker, remaining quite quiet and doubled up, but eventually entering the chamber containing the Tetramorium queen and the greatest number of workers; there she was cleaned by some of the workers and was evidently accepted by them, and quite at home, not having been attacked in any way for some hours, when the nest, having been left in the sun, the workers became unduly excited and the Anergates female was killed and cut in two.

Crawley's observation nest contained a large number of winged female Tetramorium, males, and pupae, besides workers, obtained in June, 1912, at Seaton. Two of the females had recently got rid of their wings in the nest, whether they had been impregnated by their brothers, or not, is unknown, but this point is important in view of the fact that the nest contained no old fertile queen. On July 25th, 1912, an Anergates female holding a Tetramorium worker by the tip of an antenna was introduced into this nest and by next day she was definitely accepted as queen. In a few days' time all the Tetramorium males and females were killed and cut up by the workers and their bodies piled in a heap, and from thence onward the Anergates female was always treated as their 
queen, and her gaster commenced to swell, though unfortunately she died in the early part of next year, without having laid any eggs.

It seems fairly certain from these experiments, that when an Anergates female has entered a Tetramorium nest, and has been accepted by the Tetramorium workers - the seizing of the antennae of the latter by the female being probably an important factor in this acceptance (Adlerz in his recent book also records this fact ${ }^{27}$ ) - the latter then kill their own queen, or males and winged females if present, and devote themselves to the rearing of the offspring of the parasite; but it also seems probable that these acceptances are of rare occurrence, and it should be noted that no Anergates brood has actually been reared in captivity.

\section{MONOMORIUM Mayr.}

[ $\mu \delta$ vos, single ; $\mu \delta \rho\llcorner o \nu$, part (i.e. the maxillary palpi)].

Type : Ionomorium minutum Mayr (Mayr, 1855).

The Genus Monomorium comprises a number of species which are distributed over the whole of the warmer parts of the entire world. Several tropical species have become cosmopolitan, being carried by commerce all over the globe, and inhabiting houses, where they have developed into a serious pest-one of these, Monomorium pharaonis, being the only species thoroughly established in Britain.

$\Varangle$ Head longer than broad, oval, or rectangular; clypeus large, convex, subtriangular, projecting a little over the base of the mandibles, with two obtuse carinae meeting between the base of the antennae; mandibles narrow, terminal border armed with three or four sharp teeth ; maxillary palpi one- to two-jointed; labial palpi two-jointed; frontal carinae short and parallel; antennae eleven, or twelve-jointed ; first joint of funiculus long, the following joints, between the first and the club, short and transverse, club three-jointed as long as the rest of the funiculus, its last joint as long as the two preceding together; eyes oval, generally small. Thorax long and narrow, rounded and a little broader anteriorly; suture between the pronotum and mesonotum obsolete, deeply marked between the mesonotum and epinotum; epinotum unarmed. Petiole cylindrical anteriorly, furnished with a high node posteriorly; post-petiole transverse, its node less high than the petiole; gaster oval, emarginate in front, with distinct anterior angles.

o Head as in the ช. Thorax narrow, higher than broad; mesonotum long, projecting over the pronotum; epinotum unarmed. Wings: fore-wings with one cubital cell and no discoidal cell. Size much larger than in the

ot Head before ocelli flat and broad; clypeus broad and convex; mandibles strong, dentate; antennae thirteen-jointed, scape short, not as long as the first three joints of the antennae together, funiculus with apical joints a little broader not forming a distinct club. Thorax high; mesonotum without Mayrian furrows; epinotum unarmed. Wings as in the o.

Original description [Mayr Verh. Zool. Bot. Ver. Wien 5452 (1855)]:-

66 $\mu$ śvos eines, $\mu \delta \rho$ เov Glied.

Arbeiter: Der Kopf ist länger als breit, und breiter als der Thorax. Die Oberkiefer sind mässig breit, am Innenrande mit grossen, spitzen Zähnen 
bewaffnet. Die Unterkiefertaster sind eingliedrig, an der Spitze mit einer Borste. Die Lippentaster sind zweigliedrig, das erste Glied ist sehr dünn, das zweite sehr dick, beide ziemlich gleichlang. Die Oberlippe ist vorne zweilappig. Der Clypeus reicht zwischen den Fühlern bis hinter dieselben, ist in der Mitte stark gewölbt und von dem höchsten Puncte der Wölbung, welche zwischen den Fühlern liegt, zieht sich eine breite Rinne in der Mittellinie zum Vorderrande des Clypeus, welcher an dieser Stelle schwach ausgerandet ist. Die Fühler sind zwölfgliedrig, die Geissel ist am Ende stark keulenförmig verdickt, die Keule ist aus den drei letzten Gliedern gebildet. Die Punctaugen fehlen. Die Netzaugen sind klein, etwas näher dem Mundrande als dem Hinterrande des Kopfes. Der Thorax hat zwischen dem Meso- und Metanotum eine breite Furche und ist kaum eingeschnürt. Das Metanotum hat keine Dornen und keine Höcker. Das erste Glied des Stielchens ist vorne kurz stiel-hinten knotenförmig; das zweite Glied ist knotenförmig, etwa so breit als der Knoten des ersten Gliedes, aber nicht so hoch ; beide Glieder sind unten ungezähnt. Das erste Hinterleibssegment bedeckt mehr als zwei Drittheile des kleinen, rundlichen Hinterleibes."

\section{Monomorium pharaonis L.}

Formica pharaonis Linnaeus Syst. Nat. Ed. 101580 sp. 7 (1758). ${ }^{1}$ Formica antiguensis Fabricius Entom. Syst. $2357(1793)^{2}$. " Minute Ants" [=Monomorium pharaonis] " J. D." Mag. Nat. Hist. $7369(1834)^{3}$. Formica unifasciata Spence Proc. Ent. Soc. Lond. 1834 XXV (1835)4. Myrmica unifasciata? Bostock Trans. Ent. Soc. Lond. 2 65-67 (1837) ${ }^{5}$ : Proc. 2 XXVIII-XXIX $(1837)^{6}$. Myrmica domestica Shuckard Mag. Nat. Hist. (n.s.) $2626(1838)^{7}$. Myrmica domestica (=M. unifasciata) Shuckard and Bostock Proc. Ent. Soc. Lond. 2 LI-LII $(1839)^{8}$. Myrmica domestica Westwood Gardeners Chron. 1022 p. $340(1850)^{9}$. Atta minuta Jerdon Madras Journ. Lit-Sc. 17105 $(1851)^{10}$. Myrmica domestica Daniel Proc. Linn. Soc. 2 172-177 (1852) ${ }^{11}$; Wakefield Zool. $113810(1853)^{12}$; Curtis Trans. Linn. Soc. $21217(1854)^{13}$. Myrmica (Aecophthora) domestica Nylander Ann. Sc. Nat. Zool. (4) 598 (1856) ${ }^{14}$. Myrmica (Diphlorhoptrum) molesta F. Smith Trans. Ent. Soc. (n.s.) 4284 $(1858)^{15}$. Myrmica (Diplorhoptrum) molesta F. Smith Cat. Brit. Foss. Hym. $34(1858)^{16}$. Diplorhoptrum fugax Lucas Ann. Soc. Ent. France (3) VI LXXXI $(1858)^{17}$. Monomorium pharaonis Mayr Verh. zool. bot. Wien $12752(1862)^{18}$. Myrmica molesta F. Smith Ent. Ann. 1863 59-6319. Diplorhoptrum molesta "H. G. K." [?Knaggs] Science Gossip $1865170^{20}$; F. Smith Ent. Mo. Mag. $229(1865)^{21}$; Shuckard Science Gossip 1866 27222. Myrmica domestica I. Sharp Entom. $4232(1869)^{23}$; Gillam Entom. $583(1870)^{24}$. Diplorhoptrum domesticum Gaskell Ent. Mo. Mag. 13254 (1877) ${ }^{25}$. Myrmica domestica B. Cooke Nat. $573(1879)^{26}$. Diplorhoptrum domesticum Bridgman Trans. Norf. Norwich Nat. Soc. $2621(1879)^{27}$. Diplorhoptrum molesta Parfit Trans. Devon Assn. Sc-Art $12517(1880)^{28}$. Monomorium pharaonis Saunders Trans. Ent. Soc. Lond. $1880222^{29}$; Bignell Young Nat. $3303(1882)^{30}$. †Ciphlorophum domesticum Chappell Young Nat. $863(1887)^{31}$. Monomorium pharaonis Bellevoye Soc. Etud. Sci-Nat. Reims $121-37$ (1891) ${ }^{32}$; Dalla Torre Cat. Hym. $768(1893)^{33}$; E. A. Butler Household Insects 57-61 (1893) ${ }^{34}$. Diplorhoptrum domesticum Farren-White Ants' Ways 246 (1895) ${ }^{35}$. Monomorium

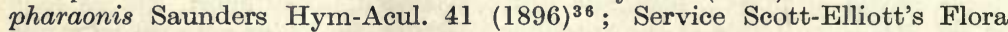
Dumfries XV (1896) ${ }^{37}$; Morley Entom. 3113 (1898) ${ }^{38}$; Evans Ann. Scot. Nat. Hist. $8117(1899)^{39}$; Vic. Hist. Cumberland $1103(1901)^{40}$; Vic. Hist. Essex $199(1903)^{41}$; Godfrey Ann. Scot. Nat. Hist. $12247(1903)^{42}$; Vic. Hist. Warwick $174(1904)^{43}$; Vic. Hist. Durham $195(1905)^{44}$; Vic. Hist. Cornwall $1182(1906)^{45}$; Vic. Hist. Berks $172(1906)^{46}$; Bingham Bull. R. Bot. Gard. Kew (a.s.) 528 (1906) $^{47}$; Vic. Hist. Yorks $1217(1907)^{48}$; Donisthorpe Trans. Leicester Lit-Phil. Soc. $12230(1908)^{49}$; Wheeler Ants $154^{50}$ $573^{51}(1910)$; Forel Int. Ent. Cong. Brux. $1910283(1911)^{52}$; G. Wheeler Proc. Ent. Soc. Lond. 1911 LVI (1912) ${ }^{53}$. 
Dalla Torre ${ }^{33}$ cites Myrmica molesta Say [Boston Journ. N. H. 1 293 (1836)] as a synonym of Monomorium pharaonis L., but Emery and Wheeler both tell me that the former is a Solenopsis and not a Monomorium, and I have seen specimens taken in America by Crawley which had been named Solenopsis molesta Say, by Forel ; these certainly are not $M$. pharaonis $\mathrm{L}$.

$\Varangle$ Reddish yellow, eyes black, gaster blackish posteriorly, with only a few scattered hairs on the pedicel and gaster, pubescence almost wanting. Head, thorax and pedicel closely punctured and dull ; gaster shining. Long. 2-2.4 mm.

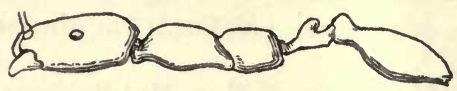

Fig. 60. Monomorium pharaonis ఫ్.

ㅇ A little darker in colour, with eyes considerably larger than in the $\not{\gamma}$. Head slightly blackish. Thorax: mesonotum with a narrow blackish longitudinal patch not quite reaching the middle. Wings slightly fuscous. Gaster more distinctly blackish posteriorly than in the ơ. Long. 4-4.8 $\mathrm{mm}$.

o Black, mandibles, antennae and legs yellow, the femora, scape and apex of the funiculus fuscous.

Eyes very large. Head, thorax and pedicel closely punctured and dull; gaster shining. Wings transparent. Long. $3 \mathrm{~mm}$.

Larva: Short and compact, broadest posteriorly, white. Head transparent, shining, the rest of the body rugose longitudinally, clothed with short, slightly curved, scattered hairs. The whole larva looks superficially like a bit of broken camphor.

Pupa: White, striate transversely; becoming yellow when mature.

Original description of Formica pharaonis Linnaeus [Syst. Nat. Ed. 10. 1580 , sp. 7 (1758)] :-

"F. rufa, abdomine magis fusco. M. L. U.

Habitat in "Aegypto ; minima."

\section{Habitat.}

Monomorium pharaonis has been spread by commerce nearly all over the world, inhabiting houses, bakers' shops, etc., and also living on board ships.

British distribution :-

Cornwall, W. : Falmouth ${ }^{45}$.

Devon, S. : Exeter $(\text { Parfitt })^{28}$; Plymouth $(\text { Parfitt })^{28}$.

Dorset: Dorchester (Haines).

Isle of Wight : Ventnor ( $F$. Smith Coll.).

Hants, S. : Winchester (Wakefield) ${ }^{12}$; Bournemouth (Barnes).

Sussex, E. : Brighton (Spence) $)^{4}$; Hastings (Shuckard $)^{22}$; St. Leonards (Farren-White) ${ }^{35}$.

Kent, E.: Folkestone (Farren-White $)^{35}$; Hythe (Donisthorpe $)^{49}$. Surrey : Southwark (Bostock) $)^{6}$; Crystal Palace (Rothney Coll.); Ewell (Harrison, Saunders Coll.). 
Essex, N. : Colchester and Dovercourt ${ }^{41}$.

Middlesex : London (Bostock ${ }^{6}$, etc.).

Berks : Reading ${ }^{46}$.

Suffolk, E. : Ipswich (Morley $)^{38}$; Wherstead (Morley) ${ }^{38}$.

Norfolk, E.: Norwich (Bridgman $)^{27}$; Norfolk, W.: King's Lynn (Atmore).

Gloucester, W.: Stonehouse and Stroud (Farren-White $)^{35}$; Bristol (Morice Coll.).

Warwick: Birmingham ${ }^{43}$.

Glamorgan : Cardiff (Hallett).

Lancashire, S.: Liverpool $(\text { Bostock })^{8}$; Manchester $(\text { Gillam })^{24}$; Stockport (Gaskell $)^{25}$.

York, S.E. : Hull ${ }^{48}$; York, N.E. : Middlesborough $(I . \text { Sharp })^{23}$; York, N.W. : Leeds ${ }^{48}$.

Durham : Dipton district, etc. ${ }^{44}$; Ryhope near Sunderland.

Cumberland : Carlisle ${ }^{40}$.

Dumfries : Dumfries (R. Service $)^{37}$.

Lanark: Glasgow (J.F.X. King Coll.).

Edinburgh : Edinburgh (Evans) ${ }^{39}$.

Perth, Mid. : Crieff (Godfrey) ${ }^{42}$; Rannoch (Foxcroft, Brit. Mus. Coll.).

Kincardine : Auchniblae near Fordown (Waterston).

Donegal : Ballyshannon (Halbert).

Wicklow: Aghadoe Church (Haliday).

Although Monomorium pharaonis is not a truly indigenous insect to Britain, still it has become firmly established, and, as has been seen, is widely distributed in our Islands, probably inhabiting most of our large towns and sea-ports. Forel ${ }^{52}$, in a paper on the Geographical Distribution of Ants, enumerated eleven cosmopolitan species which have been transported everywhere by ships, this ant being one of them. It has evidently been breeding here for nearly one hundred years-probably longer-and appears to have been first recorded in London in $1828^{22}$. It was notified ${ }^{3}$ as being very abundant in 1833 in the kitchen of a house in Kensington Gravel Pits, and Spence ${ }^{4}$ pointed out in 1834, that it was so numerous in several houses in London and Brighton that the inhabitants had to quit their dwellings. At a meeting of the Entomological Society of London on November 7th, 1836, Bostock ${ }^{6}$ stated that it was inhabiting the kitchen of his house in Upper Bedford Place, and that it extended from Gray's Inn Lane in the east as far as Regent Street in the west, from the commencement of Somers Town to the Strand, and that it occurred in Hampstead and Southwark; Waterhouse remarked that it was to be found in Billingsgate. It has also been recorded from Portman Square in 185211, Regent's Park district in $1853^{12}$, and Russell Square in 1865 ${ }^{20}$. Colonel Bingham ${ }^{47}$ gives it in his list of the ants at Kew 
Gardens, and the writer took it in the Reptile House in the Zoological Gardens ${ }^{49}$ in 1894 - where it is still in abundance-and in a baker's shop in the Earl's Court Road. According to Wakefield ${ }^{12}$ it occurred in thousands in an hotel at Winchester in 1846.

It evidently originated in some tropical country, Smith ${ }^{15}$ suggested that it came from Brazil, where it is common, and Linnaeus ${ }^{1}$ gives its habitat as Egypt. Wheeler ${ }^{50}$ when referring to its presence in America points out that it does not nest out of doors except in southern latitudes. In our own Islands it is confined to houses, etc., though Morley ${ }^{38}$ actually swept a specimen from a hedgebottom on July 2 nd, 1897, at Wherstead, at least a mile from any shop or habitation.

Its colonies are often of vast proportions. Robert Service ${ }^{\mathbf{3 7}}$ mentions that he was called in to see this ant at home in a house in Dumfries which it had overrun from cellar to attic. Its myriads were past comprehension and in some places it distinctly coloured the white wall with its hosts, and Bellevoye ${ }^{32}$ who studied its habits in his house at Reims computes that he captured in twentyfour months, 1,360,000 workers, 1809 deälated females, 34 winged females, and 566 males !

Smith gives August as the time for this ant to swarm²1, and a small colony, sent to me by Blenkarn from Beckenham in August, 1912, which was nesting in a sword case, contained one male, several winged and deälated females, workers and brood; on the other hand, a male and winged female in Saunders' collection were captured by Harrison on June 26th, 1893, at Ewell.

Bellevoye $^{32}$ shows, however, that the males appear rarely at the end of June and continue till the end of October, in which month they are the most abundant, disappearing in November, the winged females occur chiefly in September and October, and the deälated females all the year round, being seen more abundantly in the summer.

He is of opinion that they never use their wings for the marriage flight, but that copulation takes place in the nests or their galleries ; the fertilized females then losing their wings and joining the community, and the males gradually dying off. The latter are quicker in their movements than the females, and use their wings to assist themselves in rapidly gliding along the surface.

This ant is very voracious, eating greedily all kinds of sweets, sugar, cakes, etc., it is very fond of meat and freshly killed insects and will also devour butter and other fats. Daniel ${ }^{11}$ utilized their penchant for meat in the preparation of skeletons-removing the skin and most of the flesh from the small animals he wished to skeletonize, he placed them where the ants could get at them, and thus obtained over one hundred beautiful skeletons of small quadrupeds, birds, reptiles, and fishes, which he gave to the British Museum. 
The Rev. G. Wheeler ${ }^{53}$ stated that some freshly set butterflies in his possession were destroyed by this ant; and he found that they only devoured those specimens which had been killed in the cyanide bottle, whilst others, in the same setting box, into which oxalic acid had been injected were left untouched. This ant has been said to be very destructive to the common "Bed-bug," but Walker found when both species occurred on board a ship in which he was travelling that they lived together in perfect amity ${ }^{53}$.

Tracks are formed from the entrances to their dwellings, which all the ants follow when they go abroad, passing and repassing each other and never deviating from the beaten route. If one of these tracks be watched, deälated females will be observed at intervals amidst the hurrying crowds of workers, and in the course of their progress sometimes laying eggs, which are immediately collected by the workers, and occasionally one of the latter will be seen to carry a larva about with it on the march. Daniel ${ }^{11}$, however, stated that the pupae were carried about by both the males (!) and workers.

They must possess a very remarkable sense of smell, or some other faculty which enables them to discover the whereabouts of any comestible suitable to them :-In August, 1893, when staying at the Seabrook Hotel, at Hythe ${ }^{49}$, I captured workers in the coffee room which were brought up from the kitchens on plates, etc., though I had never seen any sign of them upstairs, but on looking in a box which contained some beetles, freshly killed and set, which I had placed in a drawer in a chest-of-drawers in my bedroom, I was surprised to find it full of these little creatures.

Bellevoye ${ }^{32}$ also gives several instances of this kind-on one occasion he had placed two recently captured spiders in a box on a window-sill on the second étage in his house and on looking at them next day he found the box full of these ants (the abdomens of both spiders had been devoured), and he added, as a rule, were never seen upstairs. He repeated this experiment again with the same result, and at another time having pinned some recently killed dragon-flies in a glass case which was kept upstairs and which had always contained some old dry specimens, the ants soon appeared and cleaned out the bodies of the fresh dragon-flies, leaving the old dry ones untouched.

When once Monomorium pharaonis has become established anywhere it is almost impossible to get rid of it, since it nests in the foundations, in walls and under the floors in houses, and at the back of the ovens in bakeries, etc. Dr. Bostock ${ }^{6}$ had the whole of his kitchen floor taken up, the grate and part of the walls and woodwork removed, and new tiles set in cement fixed on the walls and floor, and even then this pest was not eradicated. Wheeler ${ }^{51}$ suggests pouring, or injecting, boiling water, benzine, gasoline, or preferably carbon bisulphide into the crevices which 
the insects inhabit. Vast numbers can be destroyed by placing pieces of meat, sponges soaked in sugar and water, and bones near the tracks, and when they are covered with ants, plunging them into boiling water, but this only gives temporary relief, since as long as there are a number of fertile females in the nests, the ants thus killed will soon be replaced.

I have several times endeavoured to keep this species in captivity, introducing queens and numbers of workers into plaster nests, but the ants do not appear to be able to live in close confinement, the workers soon dying off in large numbers, and the whole colony eventually perishing.

\section{SOLENOPSIS Westwood.}

[ $\sigma \omega \lambda \dot{\eta} \nu$, channel; $\sigma \psi(s$, face (i.e. the channel on the head)].

\section{Type: Atta geminata F. (=mandibularis West.; West., 1841).}

Solenopsis is a large genus, about half the species of which are proper to America, the remainder being distributed over Asia, Africa, and Australia. Some seven species belong to the Palaearctic Region, of which only two occur in Europe. Dimorphism is very prevalent in the workers of the exotic species, especially the American, soldiers with very large heads being present; the variation in the workers of the Palaearctic species, however, is not nearly so marked. Many species are very hypogaeic in habits, living underground as robbers in the nests of other ants.

$\Varangle$ Head somewhat square, anteriorly with a distinct channel in the middle ; clypeus armed with two teeth on the anterior margin, these teeth converging back between the base of the antennae as carinae; mandibles narrow, terminal border furnished with four teeth; maxillary palpi and labial palpi two-jointed; antennae ten-jointed, with a distinct two-jointed club, the last joint of which is very long; eyes small and flat. Thorax with suture between pronotum and mesonotum obsolete; suture between mesonotum and epinotum distinct and deep; epinotum unarmed. Petiole cylindrical anteriorly, nodiform posteriorly; post-petiole transverse, nodiform, not so high as petiole; gaster oval, with first segment longer than half the gaster; sting very large.

o Much larger than the $\not$. Antennae as in the $\not$, but eleven-jointed; eyes projecting, much larger than in the $\psi$; ocelli present. Wings : fore-wings with a closed cubital cell, and one discoidal cell, radial cell open.

ot Smaller than the ㅇ. Head short; clypeus convex; mandibles narrow, armed with three teeth; maxillary and labial palpi two-jointed; antennae twelve-jointed, scape short, the first joint of the funiculus swollen and globular. Thorax: mesonotum without Mayrian furrows; epinotum unarmed. Wings as in the ㅇ.

Original description [Westwood Ann. Mag. N. H. 686 (1841)]:-

" ( $\sigma \omega \lambda \eta \dot{\nu}$ canalis et $\measuredangle \psi(s$ fascies, ob faciem canaliculatam.)

Characteres e pseudo-foemina desumpti.

Caput maximum subquadratum horizontale posticè emarginatum, suprà linea media longitudinali in duas partes divisum anticè in medio bituberculatum. Oculi parvi laterales ante medium marginis locati. 
Antennae breves graciles prope os in foveolis duabus insertae ; 10-articulatae, articulis duobus apicalibus majoribus.

Labrum parvum inter mandibulas et supra os deflexum bilobum.

Mandibulae magnae valde curvatae crassae apice obliquo, edentulae.

Maxillae et mentum minima fere membranacea, labium subductum.

Palpi maxillares et labiales biarticulati; gracillimi brevissimi, apice seta instructi.

Thorax valde angustus, prothorace mediocri ; mesothorace majori.

Abdomen magnum fere circulare subdepressum segmentis basalibus duobus nodos duos formantibus, segmento proximo maximo.

Pedes graciles tibiis 4 posticis ecalcaratis, unguibus tarsorum simplicibus."

\section{Solenopsis fugax Latr.}

Formica fugax Latreille Ess. Hist. Fourmis France $46(1798)^{1}$. Myrmica flavidula Nylander Acta. Soc. Sc. Fenn. $343(1849)^{2}$. Myrmica fugax Schenck Jahr. ver. Naturk. Nassau 8 107-110 (1852) ${ }^{3}$. Myrmica flavidula F. Smith Proc. Ent. Soc. Lond. (n.s.) 324 (1854)4. Diplorhoptrum fugax Mayr Verh. zool. bot. Ver. Wien 5 450-452 (1855) ${ }^{5}$. Myrmica fugax F. Smith Trans. Ent. Soc. Lond. (n.s.) 3127 (1855) $^{6}$. Myrmica (Diphlorhoptrum) fugax F. Smith Trans. Ent. Soc. Lond. (n.s.) $4283(1858)^{7}$ : Cat. Brit. Foss. Hym. $33(1858)^{8}$. Diplorhoptrum fugax F. Smith Ent. Mo. Mag. $229(1865)^{9}$. Solenopsis fugax Forel Mitt. Schweiz. Ent. Ges. 3 105-128 (1869) ${ }^{10}$ : Denkschr. Schweiz. Ges. Naturw. $26385^{11} 411-412^{12}$ (1874); Saunders Trans. Ent. Soc. Lond. $1880221^{13}$; Er. André Hym. Europe $2388-389(1881)^{14}$; Lubbock Ants, Bees, Wasps $78(1882)^{15}$; Fowler Ent. Mo. Mag. $19139(1882)^{16}$ : 21 37-38 (1884) ${ }^{17}$; Wasmann zusam. Nest. gemischt. Kolon. Ameisen 18-26 $(1891)^{18}$; Dalla Torre Cat. Hym. 775 (1893 $^{19}$; Richardson Ent. Mo. Mag. $30213(1894)^{20}$; Wasmann Krit. Ver. Myr. Ter. Art. $162(1894)^{21}$; FarrenWhite Ants' Ways $246(1895)^{22}$; Saunders Hym. Acul. 41 (1896 ${ }^{23}$; Janet Animaux Myr. 58-60 (1897) ${ }^{24}$; D. Sharp Camb. NH. Insects $2137(1899)^{25}$; Donisthorpe Ent. Rec. $1415(1902)^{26}$ : 20282 (1908) 27 : Trans. Leicester Lit-Phil. Soc. 12228 (1908) ${ }^{28}$ : Ent. Rec. 21258 (1909) ${ }^{29}$; Emery Deutsch. Ent. Zeitschr. $190930^{30}$; Donisthorpe Trans. Ent. Soc. Lond. $1910146^{31}$; Wheeler Ants $427(1910)^{32}$; Santschi Bull. Soc. Sc. Bucarest $19649(1910)^{33}$; Donisthorpe Ent. Rec. $2638(1914)^{34}$.

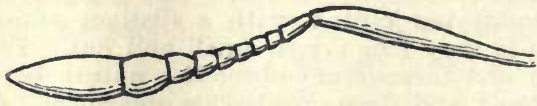

Fig. 61. Antenna of Solenopsis fuğax ל̧.

$\Varangle$ Reddish yellow (the larger examples being darker, almost brown), the first segment of the gaster being usually darker, very finely punctured, smooth, and shining, hairy. Long. $1 \cdot 5-3 \mathrm{~mm}$.

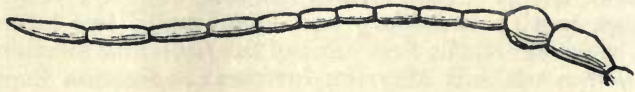

Fig. 62. Antenna of Solenopsis fugax ふָ.

o Black brown with the mandibles, antennae, legs, the posterior borders of each segment and the underside of the gaster yellow, the whole body being shining and very hairy. Head and thorax more coarsely punctured than in the . . Wings very slightly fuscous with the veins and pterostigma yellowish brown. Long. 6-6.5 mm. 
ot Black, shining, with the mandibles, apex of antennae, tarsi, and extremity of gaster yellowish; hairs shorter and more upstanding than in the . . Head (except the clypeus) the pronotum, part of the mesonotum, epinotum and pedicel finely rugose; gaster smooth. Wings as in the + , but more transparent. Long. 4-4.8 $\mathrm{mm}$.

Ovum : Very small, round, white.

Larva : Pyriform, though somewhat narrowed at the extreme base, covered with short curved hairs. The smaller larva (४̧ ?) are yellow, smooth and shining, the larger ones ( 0 \% ?) are white, duller and more rugose.

Pupa : Slightly rugose and dull, white, looking as if they had been cut out of wax. Sex pupae adult colour before emergence.

Original description of Formica fugax Latreille [Ess. Hist. Fourmis France 46 (1798)] :-

\section{" F. fugace. fugax.}

O.t.p. Testacée pâle. Abdomen noir à sa base. Mále. Noir, un peu pubescent, luisant. Antennes, genoux des cuisses, jambes et tarses en grande partie, obcurs. Aîles transparentes. Femelle. Tête, corcelet, nœuds, d'un noir reluisant. Antennes, pattes, d'un brun clair. Anneaux de l'abdomen d'un brun foncé, roussâtres à leur base. Aîles transparentes."

\section{Habitat.}

Solenopsis fugax is found in South and Central Europe, West and Central Asia, and in Japan ; a variety occurring near the Sea of $\mathrm{Aral}^{30}$.

The British distribution is as follows:-

Dorset : Portland (Richardson) ${ }^{20}$; Swanage (Nevinson).

Isle of Wight : Sandown (Fowler) ${ }^{16}$; Blackgang (Donisthorpe $)^{27}$. Kent, E. : Deal (F. Smith $)^{\text {? }}$.

Essex, S. : Shoebury near Southend (F. Smith) ${ }^{4}$.

This ant was first discovered in Britain by Frederick Smith, who exhibited it at a meeting of the Entomological Society of London on September 4th, 1854, under the name of Myrmica flavidula, stating that it was a new species, and that he had taken it at Shoebury near Southend ${ }^{4}$. Subsequently he records that he discovered a colony underground on the shore below Southend in the autumn of 1854, and that he could always find workers by digging, but they never appeared above the surface. Male and female pupae were found in small chambers at the depth of about six inches, though he was never able to rear them ${ }^{6}$; but he captured a female on the Deal sand-hills in the autumn of $1857^{7}$.

It does not appear to have occurred again in England till Easter in 1882, when Fowler found a colony under a stone at Sandown in the Isle of Wight ${ }^{16}$, and again on April 12th, 1884, while collecting at the foot of the Culver Cliffs near Sandown he came across a nest of this ant, and writes as follows-" On pulling at a large stone to remove it from the side of the slope in which it was imbedded, the top, which fitted very closely, came off in my hand, and between 
it and the lower part the Solenopsis had formed its nest : owing to the position of the stone on a slope, the crack was in direct communication with the side of the hill in which it was imbedded, and here a large colony of Formica fusca had settled behind the stone; not one of the latter, apparently, could have got into the crack, but the Solenopsis had, of course, easy access to the $F$. fusca." 17

In June, 1894, Richardson took a dozen workers at Portland under a stone, and he mentions that this stone was situated about half-way between nests of Donisthorpea nigra and D. flava ${ }^{20}$.

I found a colony (on May 4th, 1904), situated in the side of the cliff at Sandown, which was not connected with any other ants' nest ${ }^{28}$, workers only being observed, and in August, 1908, I discovered it at Blackgang Chine at the roots of Arenaria maritima in company with both $D$. nigra and $D$. flava, though in some cases the Solenopsis appeared to be alone ${ }^{27}$, and again at Sandown in 1909 the workers were abundant with $D$. nigra in the sides of the $\operatorname{cliffs}^{29}$.

On August 10th, 1913, Crawley and I took five or six workers in a nest of Formica fusca v. glebaria at "Limpet Run" near Sandown ${ }^{34}$, the only specimens that could be found, but on August 26 th, 1913, I discovered a very large colony at Blackgang ${ }^{34}$. This nest was situated at the foot of the cliffs in a large block of greensand over two feet long by a foot broad, which, when I endeavoured to lift it up, split in two, the whole of the top half coming away bodily in my hands. The surface thus revealed was quite black with the great numbers of males present, and underneath them countless thousands of the small yellow workers occurred. Small chambers had been excavated in the sandstone which contained large numbers of larvae of all sizes, eggs, worker and male pupae, but only one female pupa was found, which was subsequently reared. Only two winged females were observed, and no deälated female could be traced, but as Forel ${ }^{12}$ has pointed out the latter are very difficult to find. There was no other ants' nest in the immediate vicinity, and the most careful investigation failed to produce any myrmecophiles or Aphidae among the Solenopsis.

This little robber ant is subterranean in its habits - the workers, which are nearly blind, very seldom coming up above groundand it generally lives in the nests of other species, where it preys on their brood, building small chambers in or beneath their nests. Very fine galleries allow them to gain access to the runs and dwellings of their hosts, these galleries however being far too narrow to permit the entrance of the latter. Forel ${ }^{10}$ has compared them to mice which live in our dwellings, and Lord Avebury ${ }^{15}$ has pictured the situation as follows-" Solenopsis fugax which makes its chambers and galleries in the walls of the nests of larger species, is the bitter enemy of its hosts. The latter cannot get at 
them, because they are too large to enter the galleries. The little Solenopsis, therefore, are quite safe, and, as it appears, make incursions into the nurseries of the larger ant, and carry off the larvae as food. It is as if we had small dwarfs, about eighteen inches to two feet long, harbouring in the walls of our houses, and every now and then carrying off some of our children into their horrid dens."

The marriage flight takes place in September and October, and although there are a number of males and winged females in the Dale collection at Oxford, taken by him on August 26th and 28th, 1895 , at Portland, these were probably found in the nests, as was the case with my Blackgang specimens.

Schenck $^{3}$ gives September 22nd and October, Mayr ${ }^{5}$ states that large swarms of the males and females may be seen in the air on still warm evenings after rain in the autumn, and Forel ${ }^{12}$ says the males and winged females are to be found in the nests from the beginning of August to September, and records marriage flights towards the end of the afternoon on September 5th, 16th, and 24th. $\mathrm{He}^{10}$ has observed the workers attending the winged forms, when they came out of the nest, as far as the herbage, up which the latter climbed preparatory to flying away, and on the same day he has seen couples on the ground, fallen together after the marriage flight; and he found an isolated fertile female at Vaux on May 9 th, $1871^{12}$.

Santschi describes a curious gynandromorph taken by Montandon at Mangalia in Roumania in which the head and thorax is female and the pedicel and gaster male ${ }^{33}$.

Their colonies are generally very populous, one described by Wasmann ${ }^{18}$ which he found in a nest of Formica pratensis at Roermond consisted of 100,000 workers and 20 queens.

Their food consists of the larvae and pupae of other ants, the juices of insects, etc., and they appear to keep and milk root A phidae, indeed André ${ }^{14}$ considers this to be their principal means of subsistence, though Janet ${ }^{24}$ rather thinks that it consists of the brood of other ants. Both Forel ${ }^{11}$ and Wasmann ${ }^{18}$ found that they milked a rose-coloured root Aphis, and the former ${ }^{10}$ also mentions a small yellow species, whilst once having thrown a large cupful of the cocoons of Formica pratensis among the herbage he observed a number of the workers of Solenopsis come out of the ground and, piercing the cocoons, cut up the pupae ${ }^{11}$. Janet ${ }^{24}$ gave every day to the Solenopsis - in an artificial double nest he had under observation of Solenopsis fugax and-Formica rufibarbis-ten Donisthorpea female cocoons, which he placed near the orifice of the nest. The Solenopsis did not wait long before emerging; they climbed to the number of ten to thirty on to each cocoon, and riddled them with openings, which, uniting together, allowed them to get at the contents. If it contained a pupa the legs and antennae provided 
an easy handle to the mandibles of the Solenopsis, in which case the victim was promptly gashed, sucked, and cut up into quite small particles, which were hastily carried into the interior of the nest. The operation is much more difficult when the contents consist of a larva, as he then saw the Solenopsis convey it into the nest and work at it for twenty-four hours, at the end of which time it was covered with small black contiguous spots, corresponding to the little wounds made by their mandibles, and it commenced to become flabby. A number of individuals were occupied in licking the liquid which flowed from these wounds, but the larva did not decrease in size until after thirty-six hours, when it had been entirely devoured.

Wasmann ${ }^{18}$ observed a number of Myrmica lobicornis female pupae which had been destroyed by Solenopsis, and in the summer of 1887 he found in a hillock of the "black-backed wood ant" (F. pratensis) several cocoons of a "Gold Beetle" (Cetonia floricola) in which a multitude of this little yellow ant were busy eating the dead and half-rotten Cetonia pupae.

Isolated nests appear to be far from common; Forel ${ }^{10}$ in eight years, though continually finding this ant in the nests of other species -indeed he says it was almost impossible to find a nest of Formica fusca which did not contain it-only found three or four such colonies, and suggests that then the host species had deserted the nest, and that it would be very difficult for the Solenopsis to follow it, carrying with them their large female pupae. Wasmann ${ }^{18}$ seldom found them alone in Holland, and then they were nearly always near to the nest of another ant. Janet ${ }^{24}$ who studied the habits of Solenopsis at Beauvais, where it was abundant on a piece of waste ground with hardly any stones, often found isolated colonies, but as he points out, they were never so far from the nests of other ants that they could not easily visit them, or be connected with them.

This is a very courageous little species and will fight fiercely with much larger ants, as has also been recorded by Schenck $^{3}$, Mayr ${ }^{5}$, Forel $^{10}$, Wasmann ${ }^{18}$, and Janet ${ }^{24}$. When a double nest has been disturbed the Solenopsis workers fasten in numbers on to the legs and antennae of the host species, wounding them with their powerful stings. The larger ants, such as species of Formica, do not appear to be able to see them properly, biting at the ground and discharging acid without hurting them; the smaller ones, such as species of Donisthorpea and Tetramorium with its hard chitinous body, being better able to tackle this minute ant. I introduced a number of workers of Solenopsis fugax taken with Donisthorpea nigra at Sandown into a small plaster observation nest which contained workers of Donisthorpea flava from Portland, and they were all killed by the latter, there being no hiding-place for them in the plaster nest ${ }^{31}$. It is evidently a much more common and widely 

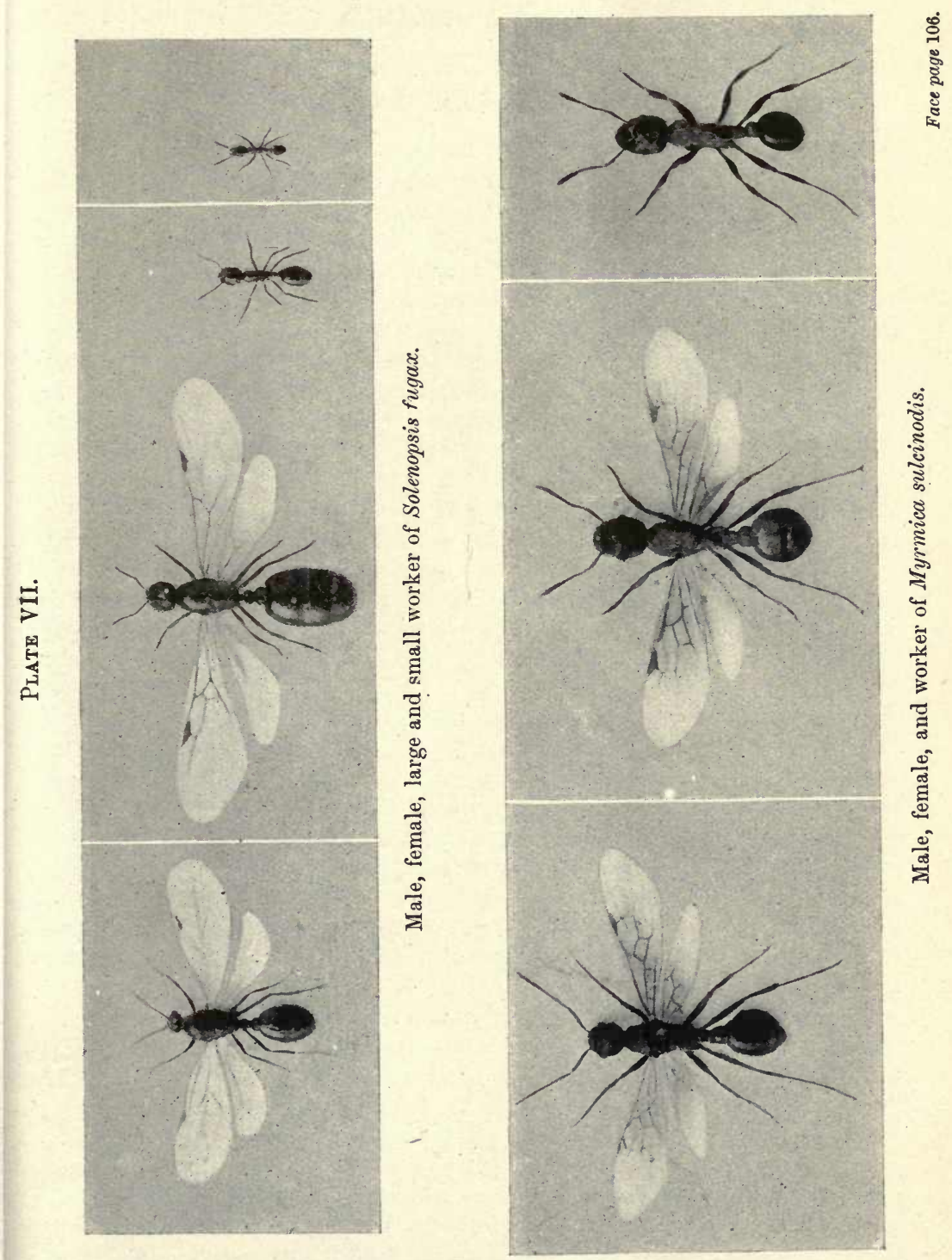
distributed species on the Continent than in England, and is found with many different hosts, occurring in fact with nearly all the larger ants ${ }^{21}$.

MYRIMICA Latreille.

( $\mu u ́ \rho \mu \eta \xi$, ant.)

\section{Type : Formica rubra L. (Latr., 1810).}

The genus Myrmica is common to the Palaearctic and Nearctic Regions, and comprises robust and intelligent ants, which do not fear the light, nor the open air. They nest under stones, in banks and fallen boughs, etc., and also build earth mounds. They are not very quick in their movements, but are deliberate and sure, going out alone on foraging expeditions, also however following each other in files. When these ants carry their fellows, the one that is carried is held by the external edge of one of the mandibles and lies over the back of her carrier with the ventral surface uppermost, the legs and antennae being folded up. They eagerly attend plant-lice out of doors, but also keep a number of species in their nests, and sometimes build special earthen chambers for them; the sweet excreta of these insects forming the principal part of their food. They are the winter hosts of beetles of the genus Atemeles, which they feed, obtaining also a sweet secretion from them.

These ants possess the power of stridulating. The sound is produced by rubbing the post-petiole against the first gastric segment, which is furnished with a file composed of very fine transverse ridges.

The marriage flight takes place in the autumn, and it commences in the air, but as soon as the couples are united they fall to the ground together, because the female is unable to carry the male when on the wing. Copulation only occupies a very short time and one female may be mated with three different males in as many minutes. Much has been written about the marriage flights of these species-Dalglish noticed these ants swarming and dropping like tain on to a greenhouse; Crawley was on one occasion in a hammock in his garden reading, and thought at first it had begun to rain, by the pattering on the leaves of the trees, caused by Myrmica males and females falling down together; Bond described a combat of ants which occurred near Hornsey in the summer of 1828 ; this however was clearly a marriage flight of Myrmica, as he says that they met in mid-air and always fell to the ground in pairs, the one being black and the other red-the former were of course the males and the latter the females.

The winged sexes sometimes occur in such numbers as to give the impression of a cloud of smoke in the air, and it was probably a swarm of these ants which caused the people of Coburg in 1866 to think that the tower of the church of St. Maurice was on fire. 
Farren-White in 1876 observed a swarm of ants near Stonehouse rising and falling over a small beech tree. The effect of those in the air-gyrating and meeting each other in their course, as seen against the deep blue sky-reminded him of the little dodder, with its tiny clustered blossoms and its network of ramifying scarlet threads, over the gorse or heather at Bournemouth. He noticed the swarm about thirty paces off, and it began to assume the appearance of curling smoke; at forty paces he could quite imagine the tree to be on fire. At fifty paces the smoke had nearly vanished into thin air. He captured some and found them to be the males of Myrmica laevinodis. The males generally die shortly after the marriage flight, but Lord Avebury kept two males of Myrmica ruginodis alive from August till the following Spring, one living till May, and Janet had males living from October till the following April. The females are capable of founding their colonies alone, a fact which was first demonstrated by Lord Avebury, who succeeded in rearing a brood from eggs laid by females in captivity; the workers reared in this experiment remained about six weeks in the egg, a month in the larval state, and twenty-five to twentyseven days as pupae. Janet found the times occupied for the development of Myrmica workers to be-eggs, twenty-two to twenty-four days; larvae, thirty to seventy-one days ; and pupae eighteen to twenty-two days: total seventy-one to one hundred and seventeen days. In nature larvae are always present in the winter, and the brood is arranged in different heaps according to size, in observation nests the eggs and young larvae are generally kept in the dampest chambers, and the pupae in the dryer ones.

Their colonies are of medium size, but sometimes very large and also quite small ones occur, the species varying in this respect. Many females may be present in the same nest, and this is caused by the re-seeking of their own colonies by females which have been fertilized near their own nest, an instance of Wasmann's secondary Pleometrose. Microgynes occur in some colonies, and they may also be present in company with ordinary females, intermediate forms not being found. The males and females are of equal size and are not much larger than the workers, the latter varying very little amongst themselves.

In 1810 Latreille [Cons. Gen. Crust. Ins. 312 No. 445, 437 (1810)] cites Formica rubra (L.) F., as the type of the genus Myrmica. Westwood [Mod. Class. Ins. 2 Syn. Gen. 83 (1840)], Girard [Traité Elém. Ent. 21016 (1879)], Bingham [Faun. Brit. India Hym. 2 265 (1903)], and Wheeler [Ann. New York Acad. Sc. 21168 (1911)] also all cite rubra L. as type, and the last-named author [Ann. New York Acad. Sc. 2379 (1913)] adopts Girard's citation.

Emery (Deutsch. Ent. Zeitsch. 1908 169) points out that Linné's words "pessime nostratum pungens" show that when he described his Formica rubra he evidently had before him one, or both, of the 
two forms which Nylander later described as Myrmica ruginodis and laevinodis, since only these two of this group can be described as stinging very badly.

These ants are the "Fourmi rouge" of Huber, and were called "Red Ants" by Gould and other early writers.

We possess five forms which have been considered to be only subspecies by some authors, but I regard them, in company with André, Escherich, and Wheeler, etc., as good though closely allied species.

$\Varangle$ Head oval, rounded posteriorly ; clypeus very convex, rounded posteriorly between the bases of the antennae; mandibles broad, terminal border dentate ; maxillary palpi six-jointed; labial palpi four-jointed; antennae twelve-jointed, with a three- or four-jointed club (in the British species), scape arched or bent at the base, the three last joints of the funiculus, taken together, evidently shorter than the rest; antennal carinae widely separated; frontal area depressed, triangular, pointed posteriorly ; eyes well developed. Thorax rounded anteriorly; suture between pronotum and mesonotum obsolete; suture between mesonotum and epinotum moderately distinct, the thorax somewhat sinuate at this point; epinotum armed with two acute spines. Petiole cylindrical anteriorly, nodiform posteriorly; post-petiole nodiform, transverse; gaster oval; sting very large. Legs : femora clavate, spurs pectinate.

o Characters of the ఫ. Wings : fore-wings with one cubital cell half divided by a transverse vein, and one discoidal cell.

$\hat{o}$ Head smaller in proportion than in the $\Varangle$ and 9 ; clypeus, mandibles, and palpi as in the $\gamma$ and $\$$; antennae thirteen-jointed, scape variable in length; funiculus with the first joint shorter than the second, and a not very distinet four- or five-jointed club; eyes very large ; ocelli prominent. Thorax massive; mesonotum prominent with distinct Mayrian furrows; epinotum only armed with small teeth or tubercles. Wings as in the 9.

Ovum: White, roundish.

Larva: Yellow, narrow anteriorly, broad posteriorly; the segments gradually increasing in width until quite close to the base. The whole body covered with hairs, which are much more abundant in the young larvae. The first to the sixth abdominal segments are furnished on the dorsum with a pair of long anchor-tipped hairs, which are generally absent in the fullgrown larvae. Some of the other long hairs possess a single hook instead of an anchor-tip, some hairs are serrate, and some bifurcate or trifurcate.

Pupa : White, transversely striate; becoming yellow when mature.

Original description [Latreille Nouv. Dict. d'Hist. Nat. 24 178-179 (1804)] :-

“II. Antennes insérees très-près du bord antérior de la tête.

1. Antennes grossissant insensiblement vers leur extrémité; premier article faisant presque la moitié de leur longueur, dans les femelles et les mulets ; tête épaisse; abdomen ovoïde ou conique; (palpes maxillaires de la longueur au moins des mâchoires, sensibles de quatre à six articles).

A. Premier article des antennes toujours decouvert.

B. Un aiguillon dans les femelles et les mulets.

b. Second anneau de l'abdomen en forme de nœud, séparé du troisième par un profound étranglement; pedicule de l'abdomen formé de deux nœuds.

** Mandibles triangulaires.

411. Genre Myrmice, Myrmica.

Mes F. bossues et mes F. piquantes.

$$
\left.\begin{array}{l}
F \text {. rubra } \\
\text { F. cephalotes }
\end{array}\right\} \text { Linn." }
$$


Formica rubra was described by Linnaeus [Syst. Nat. ed. 10580 (1758)] as follows :-

"F. testacea, oculis punctoque sub abdomine nigris."

It is in the twelfth edition [Linn. Syst. Nat. ed. 12963 (1767)] that he uses the words - " pessime nostratum pungens."

\title{
Table of the Species.
}

\author{
ช and $ᄋ$
}

1 f Scape of antennae abruptly bent at base $\ldots \ldots \ldots \ldots \ldots \ldots \ldots \ldots$

- Scape of antennae evenly curved..................... 4

$2 \int$ Scape of antennae ridged or toothed $\ldots \ldots \ldots \ldots \ldots$

(1) Scape of antennae not ridged nor toothed......... sulcinodis Nyl.

3 Scape of antennae with strong transverse ridge at bend-5 lobicornis Nyl.

(2) Scape of antennae with more or less developed lateral tooth at bend

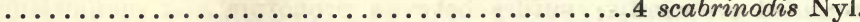

4 Epinotal spines longer than their basal width, transversely striate

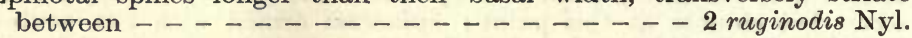

(1) Epinotal spines not longer than their basal width, smooth between ................................. laevinodis Nyl.

\section{ơ}

1 Scape of antennae less than half the length of the funiculus - - -

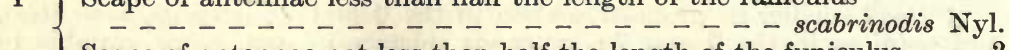

Scape of antennae not less than half the length of the funiculus.....2

2 Scape of antennae abruptly bent at base _ _ _ _ $\ldots$ lobicornis Nyl.

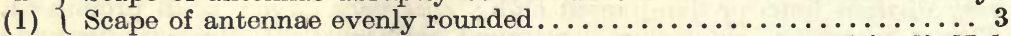

3 f Frontal area longitudinally striate $\ldots \ldots \ldots \ldots \ldots \ldots$ sulcinodis Nyl.

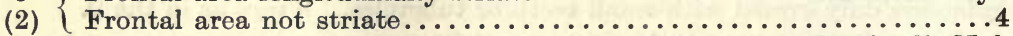

4 f Posterior tibiae with long sub-erect hairs _ . . . . laevinodis Nyl.

(3) Posterior tibiae with short decumbent hairs..........ruginodis Nyl.

\section{Myrmica laevinodis Nyl.}

Myrmica laevinodis Nylander Acta. Soc. Sc. Fenn. $2927^{1} 943$ Pl. XVIII Fig. $4^{2}$ (1846); Curtis Trans. Linn. Soc. Lond. $21213(1854)^{3}$. Myrmica longiscapus Curtis Trans. Linn. Soc. Lond. $21213(1854)^{4}$. Myrmica laevinodis F. Smith Trans. Ent. Soc. Lond. (n.s.) 3118 (1855) ${ }^{5}$. Myrmica longiscapa F. Smith Trans. Ent. Soc. Lond. (n.s.) 3122 (1855) $^{8}$. Myrmica laevinodis F. Smith Trans. Ent. Soc. Lond. (n.s.) $4279(1858)^{7}$ : Cat. Brit. Foss. Hym. $23(1858)^{8}$ : Ent. Ann. $1874147 \mathrm{Pl}$. [I] Fig. $3^{9}$. Myrmica rubra race laevinodis Forel Denkschr. Schweiz. Ges. Naturw. $26271^{10} 380^{11} 414^{12}$ (1874). Myrmica laevinodis Saunders Trans. Ent. Soc. Lond. $1880215^{13}$. Myrmica incompleta Provancher Nat. Canad. $12359(1881)^{14}$. Myrmica laevinodis Er. André Spec. Hym. Europe $2316(1881)^{15}$; Cooke Nat. Yorks $830(1882)^{16}$; Wasmann Stett Ent. Zeitg. 51 $299(1890)^{17}$ : zusam. Nest. gemischt. Kolon. Ameisen $9(1891)^{18}$; Dalla Torre Cat. Hym. $7110(1893)^{19}$; Farren-White Ants' Ways $240(1895)^{20}$. Myrmica rubra race laevinodis Saunders HymAcul. $39(1896)^{21}$. Myrmica laevinodis D. Sharp Cambs. NH. Insect. 2 $148(1899)^{22}$; Escherich Ameise $216(1906)^{23}$; Donisthorpe Trans. Leicester Lit-Phil. Soc. $12227(1908)^{24}$. Myrmica rubra levinodis Emery Deutsch. Ent. Zeitschr. $1908170^{25}$. Myrmica levinodis Wheeler Journ. Econom. Ent. 1 337-339 (1908) ${ }^{26}$. Myrmica rubra subsp. levinodis Wheeler Ants 566 $(1910)^{27}$; Myrmica laevinodis Wasmann Biol. Centralb. $30454(1910)^{28}$. Myrmica levinodis Wheeler Journ. New York Ent. Soc. $19163(1911)^{29}$. 
Myrmica laevinodis Donisthorpe Entom. 44390 (1911) $^{30}$; Crawley and Donisthorpe Int. Ent. Cong. Oxford $1912219(1913)^{31}$; Donisthorpe Ent. Rec. 25 5-6 $(1913)^{32}$.

$\varnothing$ Reddish yellow, shining, with the head and gaster a little darker above, and the rugosity of the whole body less than in any of the other species. Head distinctly striate longitudinally, the interstices very slightly punctured; frontal area smooth and shining; antennae: scape cylindrical at the base, evenly and gradually curved, club more or less distinctly four-jointed. Thorax : epinotal spines not longer than their basal width, smooth and shining between. Petiole slightly punctured, somewhat shining; post-petiole feebly wrinkled longitudinally, shining. Long. 4-5.5 mm. (4-4.5 mm. teste Forel.)

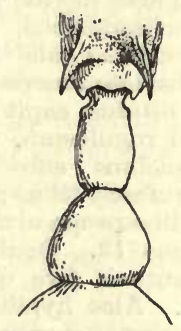

Fig. 63. Epinotum, spines, and pedicel of Myrmica laevinodis

ㅇ Reddish yellow; head above, posterior border of the pronotum, a spot at the articulation of the wings, the scutellum, and often a patch on the gaster blackish brown.

Other characters as in the $\zeta$. Long. 5.5-7 mm. (6.5-7 mm. teste Forel.)

o Blackish brown, mandibles, antennae, legs and apex of the gaster lighter.

Head finely striate longitudinally; antennae with scape as long as half the funiculus, gradually curved near the base ; frontal area smooth and shining, or slightly shagreened. Thorax smooth and shining with the exception of the scutellum and the epinotum anteriorly, which are finely striated. Petiole and post-petiole smooth and shining. Long. 5-5.5 mm.

Original description of Myrmica laevinodis Nylander [Acta. Soc. Sc. Fenn. 2927 (1846)] :-

"Operaria : testaceo-ferruginea sparse flavo-pilosula, capite supra, abdominis dorso in medio et macula ventrali plus minus fuscescentibus; capite et thorace longitudinaliter striatim rugulosis ; metanoto spinis binis validiusculis ; nodis petioli sublaevibus.

$\Varangle$ Long. $1 \frac{3}{4}-2$ lin. Sordide testaceo nitidiuscula, oculis parvis prominulis rotundis atris. Ocelli nulli. Caput vertice et fronte parum obscuratis, totum longitrorsum minus regulariter lateribusque subreticulatim striatulum; lineâ infra longitudinali impressa nigrescente ab ore ad occiput ducta; clypeo supra et areâ triangulari frontis politis; mandibulae subocto-denticulatae, summis apicibus quoque politis ; lamina frontalis marginibus utrinque subrectis, parum arcuatis reflexisque. Antennae scapis ad basin arcuatim parum flexis. Thorax capite angustior, inter mesothoracem et metathoracem parum compressus et in dorso depressum; metanotum ante spinas subtransversim rugulosum. Nodi petiolares sublaeves, nitidiusculi, sparse pilosi. Abdomen longitudine capitis ovatum, supra visum, parum latius, quam a latere visum; dorso plus minus infuscato interdum fere toto fusco; ventre puncto vel macula minori vel majori fusca, interdum obsoleta.

Femina : sordide testaceo-ferruginea sparse flavo-pilosula; capite, 
pronoto et scutello abdomineque supra et infra in medio fuscescentibus; capite thoraceque longitudinaliter striatim rugulosis; metanoto spinis brevibus validiusculis.

o Long. $2 \frac{1}{2}$ lin. Sat similis operariae, sed major, obscurior, rugosior. Ocelli distincti. Caput fuscum, mandibulis testaceis apicibus anguste politis fuscis; antennis testaceis articulorum flagellarium summis apicibus fuscescentibus. Thorax mesonoto, mesopleuris et sterno testaceo-ferrugineis, ceteroquin ferrugineo-fuscescens, spinis metanoti brevibus validiusculis, subdentiformibus. Pedes toti sordide pallide-testacei, pubescentes. Nodi obsolete rugulosi. Abdomen thorace fere longius et nonnihil latius, magis rotundatum quam in $\not{\phi}$, supra et in medio ventris fuscescens. (Alae in nostris speciminibus desunt).

Mas : nigro-fuscus nitidus sparse flavido-pilosulus, mandibulis tarsisque pallide testaceis; antennis, trochanteribus, tibiis et apice abdominis plus minus conspicue fusco-pallescentibus; alis hyalinis obsoletissime cinerascenti-pallescentibus, stigmate obsolete cinerascente.

๙. Long. 2 lin. Fusco-niger nitidus, capite parum opaciori. Caput obsoletissime tenuiter striatulum vel rugulosum, parvum. Palpi et mandibulae testaceae, hae rufescentes apicibus subseptem-denticulatis. Antennae fuscae, flagellis saltem sordide rufescentibus; scapus tertiam partem totius antennae fere excedens, longitudine prope articulorum 7 sequentium flagelli ; articuli antennarum numero sunt 13. Oculi valde prominuli; ocelli distincti. Thorax altus nitidus suturis fere omnibus crenatis; metathorax tuberculo subangulari utrinque. Alae hyalinae inprimis a stigmate versus basin obsoletissime cinereo-pallescentes, nervis et stigmate dilute cinerascentipallidis; area anticarum unica discoidali subrectangulari, nervo radiali nervum transversum apicalem areae primae cubitalis decussante et vel in medio hujus areae desinente vel rarius totam hanc aream percurrente; anticae long. fere $2 \frac{1}{4}$ lin. Nodi et abdomen nitida. Pedes articulationibus et tarsis totis pallide testaceis, tibiis interdum fusco-pallescentibus, tenuiter longiuscule pilosi."

\section{Habitat.}

Myrmica laevinodis occurs in North and Central Europe, further south in mountains, North Asia to East Siberia and Manchuria, also in $\operatorname{Japan}^{25}$, and a variety, probably introduced, is found in Massachusetts ${ }^{27}$. It is very widely distributed in the British Isles, occurring as far north as Elgin, in Scotland, whence I have also records from Dumfries, Ayr, Haddington, Linlithgow, Fife, Kinross, South, Mid, and North Perth, Easterness, Clyde Isles, the MidEbudes and West Ross ; in Ireland from Antrim, Down, Armagh, Monaghan, Donegal, Meath, Dublin, West Galway, Limerick, North Tipperary, South Cork, and Kerry ; and in Wales from Glamorgan, Pembroke, and Denbigh; but I have no records in England for South Wilts, Herts, Bedford, Northampton, East Gloucester, Stafford, Salop, Derby, Mid-Lancashire, South-east, and Mid-west Yorkshire, Cumberland, and Northumberland.

This species prefers to dwell in moist and shady places, nesting under stones, in decayed logs, etc., sometimes making earth mounds, and also inhabiting fields and cultivated land.

$M$. laevinodis-with the exception of $M$. ruginodis-is the most 
warlike of our species and frequent combats occur between different colonies. Forel ${ }^{10}$ describes such a combat which he witnessed in Switzerland between two colonies of $M$. laevinodis, their fury being so great that he was unable to separate them, the ants using their stings with great effect.

Dr. Sharp ${ }^{22}$ states that it lives in perfect harmony with Formica rufa, but this would only be an accidental occurrence, just as were the three colonies-Myrmica laevinodis, Donisthorpea flava, and Formica rufibarbis-found by Wasmann under the same stone in Dutch Limburg ${ }^{18}$. Their colonies are often large and populous, and sometimes they found branch nests, in the same manner as do some species of the Genera Formica and Donisthorpea. In April, 1900, at Oddington, near Oxford, Crawley noticed some workers of $M$. laevinodis crossing a path in a shrubbery, carrying larvae. The ants were traced, and found to be conveying larvae from one nest in a rotten stump to another also in a stump. The first stump was nearly covered with moss, which would most likely account for the desertion. Further investigation showed that the colony, which was of enormous size, occupied four nests, all but one of which were in rotten stumps, and workers were continually crossing from one to another. The space occupied by the nests was roughly 12 yds. by 6 yds. Workers from each nest were placed on the others, which they entered without molestation ${ }^{31}$. There is generally a number of fertile females in the same colony; this is due as has been before stated to the females re-seeking their own colony after having been fertilized near their own nest (Wasmann's Secondary Pleometrose ${ }^{28}$ ).

The winged forms are to be found in the nests from June to September, but I took four females, each with two or three wings, in a colony under a stone at Bletchington near Oxford on May 17th, 1913, which had no doubt remained in the nest since the previous summer.

The wings often vary in this species; Nylander ${ }^{2}$ describes and figures the fore-wing of a male in which the marginal vein entirely divides the cubital cell, B. S. Harwood captured a male at Sydmonton in which the right fore-wing is exactly as in Nylander's figure, and Hallett took another male at Cardiff in which both fore-wings differ from the typical form ${ }^{32}$.

Forel records the capture of some very small virgin females in nests at Vaux in $1868^{12}$ - these would be microgynes, of which I found one in a colony which was sent to me by Hallett, taken by Tomlin at Mathon near West Malvern, situated in an old boot. In this case the female had been fertilized; she only measures five $\mathrm{mm}$. in length, and is smaller than her own workers. Wasmann has also found a number of these small females in colonics at Exaeten in Holland.

Joseph Chappell captured a gynandromorphous specimen of 
M. laevinodis in Dunham Park, Cheshire and presented it to B. Cooke.

It combined characters of male, female, and worker, the right side being entirely worker; on the left side the head being female with an ocellus and antenna exhibiting the female characters; the left side of the thorax is that of the male, the mesothorax exhibiting in front a Mayrian furrow; the epinotum on the left side is destitute of a spine and the legs on the same side are all male.

F. Smith, who recorded and figured this insect as a hermaphrodite, in 1874, stated that it was the first instance of the kind observed in England ${ }^{9}$.

Wasmann ${ }^{17}$ records a mixed ergatandromorph with only the colour of the head like that of the worker, and the ocelli much smaller and more closely aggregated than in the male. In all other respects the species was a normal male.

Wheeler ${ }^{26}$ has shown that $M$. laevinodis has recently been introduced into Massachusetts, and gives good reasons to show it is not indigenous in North America. Early in September, 1908, he found a large colony of this ant in the grass at the edge of the Arnold Arboretum, a few steps from the Bussey Institution at Forest Hills, Mass. The workers were attending plant-lice on a few stalks of Chenopodium album very near their nest. Some days later he discovered a second colony at the edge of Franklin Park, about a mile from the Arboretum, and early in October he saw a third colony on a lawn near the post office in Jamaica Plain. He remarks that though by no means common it is certain that this ant has begun to spread over the country about Forest Hills.

According to Forel $M$. laevinodis understands the cultivation of Aphidae better than all the other species of this genus ${ }^{11}$, and I have taken the following species in its nests-Forda formicaria Heyd., F. furcata Theobald, Pentaphis trivialis Pass., Tycheoides setulosa Pass., and Schizoneura corni F.

The undermentioned myrmecophiles have occurred with this ant in Britain ${ }^{32}$ :-

Coleoptera: Atemeles emarginatus Pk., A. paradoxus Gr., Drusilla canaliculata F., Myrmedonia collaris Pk., and Staphylinas stercorarius $\mathrm{Ol}$.

Ichneumonidae : Pezomachus aquisgranensis var. neesii Först., and Microcryptus nigro-cinctus Gr.

Proctotrupidae : Gonatopus distinctus Kieff.

Heteroptera : Myrmedobia coleoptrata Fall.

Collembola : Cyphodeirus (=Beckia) albinos Nic.

Acarina : Uroplitella ovatula Berl.

Crustacea : Platyarthrus hoffmanseggi Brandt. 
Myrmica laevinodis Nyl. var. ruginodo-laevinodis Forel.

Myrmica rubra race ruginodo-laevinodis Forel Den. Schw. Ges. NW. 26 77-79 (1874)1 ${ }^{1}$. Myrmica ruginodo-laevinodis André Spec. Hym. 2319 (1881) ${ }^{2}$; Forel Ann. Soc. Ent. Belg. $30137(1886)^{3}$. Myrmica laevinodis Nyl. var. ruginodo-laevinodis Dalla Torre Cat. Hym. 7111 (1893)4. Myrmica laevinodis v. laevinodi-ruginodis Escherich Ameise $216(1906)^{5}$. Myrmica ruginodis-

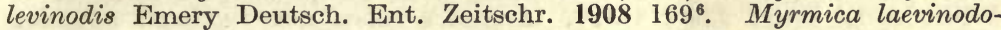
ruginodis Donisthorpe Ent. Rec. $257(1913)^{7}$; Hallett Cardiff Nat. Soc. Trans. $452(1913)^{8}$. Myrmica ruginodis var laevinodo-ruginodis Donisthorpe Ent. Rec. $25267(1913)^{9}$. Myrmica laevinodis var ruginodo-laevinodis Donisthorpe Ent. Rec. $26138(1914)^{10}$.

Forel ${ }^{1}$ pointed out in his admirable work on the Ants of Switzerland that frequent transitions occur between $M$. laevinodis and $M$. ruginodis, in which the length of the epinotal spines, etc., is intermediate, and for which he proposed the name-ruginodolaevinodis. It seems better, therefore, to include all such intermediate forms, whether they come nearer to laevinodis, or to ruginodis, under this name.

Central Europe is given as the habitat of this variety by Dalla Torre ${ }^{4}$, but it probably occurs wherever laevinodis and ruginodis are to be found.

Such forms certainly occur in Britain-Hallett sent me specimens from Glamorgan ${ }^{8}$, which had the spines shorter than in ordinary ruginodis, but the space between rugose, etc. ${ }^{7}$; a similar female specimen was sent to me by S. O. Taylor, who took it at Groby Pool, Leicestershire, in August, 1913, and Hamm has found it at Shotover and Beckley in Oxfordshire, winged females being taken in the former nest on May 5th, 1907. I have taken it in the New Forest and I found a colony on Lundy Island ${ }^{9}$, in which the length of the spines and the rugosity of the whole body is intermediate between laevinodis and ruginodis, the space between the spines being feebly striate transversely. A small deälated female taken in this colony only measures $5.5 \mathrm{~mm}$.

Forel $^{3}$ records finding a colony of $M$. ruginodo-laevinodis which was leaving its old nest, and proceeding to a new one in the moss. The ants were walking very fast, carrying their fellows and their brood, and he noticed that the males being carried were grasped by the thorax with their legs and antennae folded up, in the same way that the pupae are carried by the workers.

Wallace-Kew captured two specimens of the beetle Atemeles emarginatus var. nigricollis $\mathrm{Kr}$. in a nest of this variety situated under a large stone at Countisbury near Lynmouth in Devonshire in October, $1912^{10}$.

\section{Myrmica ruginodis Nyl.}

Myrmica ruginodis Nylander Acta. Soc. Sc. Fenn. 2929 (1846). ${ }^{1}$ Myrmica diluta Nylander Acta. Soc. Sc. Fenn. $341(1849)^{2}$. Myrmica vagans Curtis Trans. Linn. Soc. Lond. $2213(1854)^{3}$. Myrmica ruginodis F. Smith Trans. Ent. Soc. Lond. (n.s.) $3116(1855)^{4}: 4279(1858)^{5}$ : Cat. Brit. Foss. Hym. 
$20(1858)^{6}$; Elwin Science Gossip $1871245-248^{7}$; H. Müller Befrucht. d. Blumen $464(1873)^{8}$. Myrmica rubra race ruginodis Forel Denkschr. Schweiz. Ges. Naturw. $26142^{9} 225^{10} 380^{11}$ (1874). Myrmica ruginodis Elwin Science Gossip 1874 58-6012 ; Swinton Ent. Mo. Mag. $14187(1878)^{13}$; Lubbock Journ. Linn. Soc. Zool. $14270(1878)^{14}$; Saunders Trans. Ent. Soc. Lond. $1880214^{15}$; Parfitt Ent. Mo. Mag. 1843 (1881) ${ }^{16}$; Er. André Spec. Hym. Europe $2317(1881)^{17}$; Lubbock Ants, Bees, Wasps $32(1882)^{18}$; FarrenWhite Ants' Ways 239 (1885) ${ }^{19}$. Myrmica rubra race ruginodis Saunders Hym-Acul. $40(1886)^{20}$. Solenopsis fugax Provancher Nat. Canad. 1722 $(1886)^{21}$. Myrmica ruginodis Wasmann Stett. Ent. Zeitg. $51306308(1890)^{22}$ : zusam Nest. u. gemischt. Kolon. Ameisen 16-17 (1891) ${ }^{23}$; Bignell Ent. Mo. Mag. $28135(1892)^{24}$; Dalla Torre Cat. Hym. $7115(1893)^{25}$; Wasmann Biol. Centralb. $1339(1893)^{26}$; Morice Ent. Mo. Mag. $30260(1894)^{27}$. Stenamma westwoodi Malloch Fauna, Flora, Geol. Clyde Area $219(1901)^{28}$. Myrmica ruginodis Donisthorpe Trans. Leicester Lit-Phil. Soc. 12227 $(1908)^{29}$. Myrmica rubra ruginodis Emery Deutsch. Ent. Zeitschr. 1908 171 ${ }^{30}$. Myrmica ruginodis Donisthorpe Entom. 44390 (1911) $^{31}$; Morley Proc. R. Irish Acad. 31 (24) 3 (1911) ${ }^{32}$; Donisthorpe Ent. Rec. 25 6-8 $8^{33} 96^{34}$ (1913); Beare Ent. Rec. $25258(1913)^{35}$.

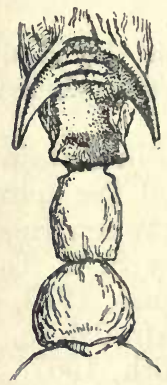

Fig. 64. Epinotum, spines, and pedicel of Myrmica meinodis

$\Varangle$ Reddish yellow; sometimes much darker, the head pedicel and gaster being blackish brown. Very like the preceding but on the average larger, the body being always more rugose.

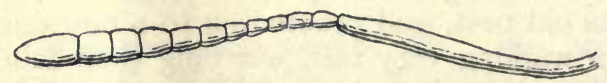

Fig. 65. Antenna of Myrmica ruginodis ఫ̧.

Head a little broader than in laevinodis. Thorax: epinotal spines longer than their basal width, transversely striate between. Petiole and post-petiole longitudinally wrinkled, the latter not, or scarcely, shining. Long. $4 \cdot 5-6 \mathrm{~mm}$. $(5-5 \cdot 5 \mathrm{~mm}$. teste Forel.)

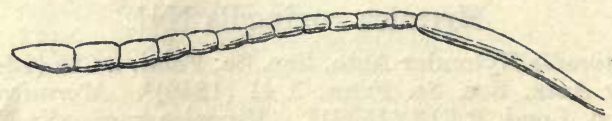

Fig. 66. Antenna of Myrmica ruginodis ô. 
우 Very like laevinodis, sometimes a little darker; characters as in the $\not$. Long. 5•4-6.5 mm. (6.5-7 mm. teste Forel.)

o Very like laevinodis, a little larger on the average; the antennae appear to be a little longer, the sculpture a little stronger, and the epinotal tubercles more pronounced, but laevinodis varies in these particulars. Tibiae furnished with short decumbent hairs. Long, 5-6 $\mathrm{mm}$.

Original description of Myrmica ruginodis Nylander [Acta. Soc. Sc. Fenn. 2929 (1846)] :-

"Operaria: testaceo-ferruginea sparse flavo-pilosula; capite supra, abdominis dorso in medio et macula ventrali plus minus fuscescentibus; capite thoraceque longitudinaliter striatim rugulosis; metanoto spinis binis validiusculis longis; nodis petioli rugosis.

ఛ. Long. 2 lin.-parum ultra. Simillima praecedenti, sed paulo major, rudius fere rugosa, metanoto ante spinas longitudinaliter rugoso, spinis longioribus et nodis longitudinaliter confuse, sed non profunde rugosis. Clypeus supra sat late politus. Cetera ut in praecedente.

Femina: testaceo-ferruginea sparse flavido-pilosula; capite supra, abdominis dorso medio et macula ventrali plus minus fuscescentibus; capite thoraceque longitudinaliter striatim rugulosis; metanoti spinis longiusculis; alis hyalinis obsoletissime cinerascenti-pallescentibus, stigmate distincto cinereo-fuscescente.

ㅇ Long. fere $2 \frac{1}{2}$ lin. Simillima feminae praecedentis, et jam colore et spinis metathoracis duplo longioribus distincta. Caput supra fuscescens, clypeo fusciori, oculis atris; infra pone oculos, mandibulis antennisque testaceoferrugineis; mandibulae apicibus parum fuscescentibus. Striae clypei magis confusae quam in praecedente. Thorax metanoto et pleuris obsoletissime, scutello vero distinctius fuscescentibus; spinis longiusculis. Alae ut supra; anticae long. $2 \frac{1}{2}$ lin. Pedes toti pallide testaceo-ferruginei. Nodi sicut in $\measuredangle$.

Mas : nigro-fuscus nitidus parcissime tenuiter flavido-pilosulus; mandibulis, articulationibus pedum et tarsis testaceo-pallescentibus, antennarum flagellis apiceque abdominis obscure rufescentibus.

$\hat{\sigma}$ Long. $2 \frac{1}{2}$ lin. Mari praecedentis speciei simillimus, at paullo major, robustior, capite inprimis conspicue majori, alarum stigmate distinctiori fusciori, pedibus longe nudioribus. Caput nitidum subtiliter obsolete rugulosum ; clypeus politus aequalis convexiusculus. Alae ut in 웅 anticae long. $2 \frac{1}{3}$ lin. ; pedes tenuiter pubescentes, subnudi."

\section{Habitat.}

The distribution of Myrmica ruginodis in Europe is similar to that of $M$. laevinodis, but it does not appear to range so far east in $\mathrm{Asia}^{30}$. It is very widely distributed in the British Isles, occurring as far as Caithness in the extreme north of Scotland, and is probably to be found all over the country. Morice recorded it from the Shetland Isles as the only ant he could find there ${ }^{27}$, and all ants sent to me from the Shetlands by Waterston have proved to be the same ; it is also abundant on St. Kilda.

In Wales it has been found in Glamorgan, Pembroke, Carnarvon, Denbigh, and Anglesey, and in Ireland in Derry, Antrim, Down, Armagh, Monaghan, Donegal, Louth, Dublin, Kildare, Wexford, Carlow, Westmeath, West Mayo, West and East Galway, North Tipperary, Waterford, South Cork, and Kerry; but I have no records in England for North Somerset, South Wilts, Dorset, 
North Hants, Herts, Cambridgeshire, Bedford, Northampton, East Gloucester, Monmouth, Hereford, Salop, Derby ; and in Scotland for Kircudbrightshire, Wigtown, Selkirk, Roxburgh, North Perth, Forfar, South and North Aberdeen, Banff, the Clyde Isles and South and North Ebudes, East Ross and West Sutherland.

Myrmica ruginodis occurs in uncultivated places, nesting under stones, in rotten stumps, at the edges of woods and roads, etc., and appears to require less moisture than laevinodis (though Fryer sent specimens to me from a colony he had discovered in June, 1912, in Woodwalton Fen, the nest being situated in the peat), and according to Forel ${ }^{11}$ both these species are entirely missing in arid places.

Praeger found specimens of this ant in a Puffin's nest on the Bills Rocks on Clare Island in June, $1910^{32}$.

André points out that ruginodis is often found in higher latitudes than laevinodis, reaching the alpine regions ${ }^{17}$, and Forel says it extends to the region of the fir trees, recording it from Siebenbrunnen at 1460 metres, and Dischmathal at over 1600 metres ${ }^{10}$. Hull found colonies up to $1900 \mathrm{ft}$., at West Allendale in March, $1912^{33}$, Johnson up to $1500 \mathrm{ft}$., on Clare Island ${ }^{32}$, and I have taken it on Snowdon.

Occasionally its colonies are found in close proximity to other ants' nests-Wheeler, when in England in August, 1912, observed a colony close to nests of $M$. laevinodis and $M$. scabrinodis on the hill at the back of Wordsworth's cottage at Grasmere, Morley found it nesting under the same stone as Donisthorpea flava at Killaloe in 1913, and I discovered it in company with the latter species in the same earth mound at Luccombe Chine in August, 1913.

Wasmann ${ }^{23}$ records that in July, 1886, he found colonies of $M$. ruginodis inhabiting the nests of the wood-ants Formica pratensis, and F. rufa. In the first case most of the pratensis had deserted their nest, but in the other it was quite different-here the rufa colony was a very populous one and the ruginodis, which consisted of a fairly strong colony with about one hundred larvae and pupae, had established its nest in a small hollow in the upper part of the former's hillock. They had probably selected this situation to take advantage of the higher temperature they would obtain there to bring up their brood. At first there would have been some fighting between the two species, but eventually, as is the case with strange ants which nest under the same stone, etc., they would become indifferent to each other, and leave each other alone.

M. ruginodis, in common with laevinodis, is a warlike ant and stings fiercely, and Bignell ${ }^{24}$ records what he took to be an instance of its making war on its own species. He states that :- "Rambling 
near the border of Dartmoor, a few miles from Plymouth, on the 10th instant (April, 1892), I caught sight of Myrmica ruginodis carrying something that $I$ could not at first well define ; standing quietly a few moments I saw many others loaded in the same manner. I captured one, and, to my surprise, I found it was another of the same species it was carrying. I have no doubt a raid had been made on a smaller colony, and the victorious party were conveying them off to strengthen their home. The prisoner was grasped by the throat, the abdomen turned over on the top of the head of the carrier."

On this occasion, however, it is certain that the ants were only moving to another nest, carrying their fellows, as is their habit. No strange ant would allow itself to be quietly carried in this manner, and as I have before shown a Myrmica always lies over the back of its fellow when carried, and it would have been the jaws that were grasped, not the throat. As an instance of tenacity of life in this species, a specimen of $M$. ruginodis may be mentioned, which C. Best Gardner had in his possession in 1913, which lived without a head for twenty-one or twenty-two days.

Sometimes colonies of ruginodis occur in which all the individuals are very dark in colour-I found two such colonies on June 14th, 1911, on the mountains at Rannoch, in which some of the workers were nearly black.

It attends and keeps Aphidae, but also feeds on other insects, and will eat honey in captivity. H. Müller ${ }^{8}$ records the capture of both $M$. ruginodis and laevinodis in the flowers of Chrysosplenium and Compositae, where they were no doubt seeking the nectar of the flowers.

Elwin ${ }^{7}$ mentions that a colony he kept in captivity, fed on "blue bottles" and also devoured the remains of a dead sparrow. On September 1st, 1914, I observed an isolated deälated female ruginodis at Weybridge, which was carrying a fly in its jaws. They also collect seeds-when staying with Crawley in July, 1912, at Seaton in Devon, he called my attention to the fact that in his garden the seeds of the blue cornflower (Centaurea cyanus) were collected by workers of $M$. ruginodis and carried to their nest, which was situated just near the front door, the ants bringing the seeds from quite a long distance ${ }^{\mathbf{3 4}}$. They probably devour the elaiosome of the seeds, as Sernander has shown that when it is removed, the seeds are not nearly so attractive to ants.

The stridulating of ruginodis has been noticed by Swinton ${ }^{13}$ and Wasmann ${ }^{26}$. The former observer, having seen specimens of this ant attending Aphidae on thistle heads at Guildford in July, 1877, captured some of them and covered them with an inverted wine-glass. He writes :- "The weather was hot and sultry, and these Myrmicae were probably irascible; for they had not been long left to themselves, when a puny individual was observed, 
placed head downwards, at the side, and near the inverted edge of the glass, rapidly vibrating its abdomen vertically from the pedicle, and simultaneously giving out a continuous singing sound, resembling in tone and intensity the sharp whining of the little dipteron, Syrilla pipiens."

Wasmann having put a strong section of a ruginodis colony into an empty glass vessel, the day being warm, the ants were very excited moving the gasters up and down, and he noticed a chirping noise, which reminded him of the sound caused by the Iris pod beetle, Mononychus pseudacori.

The winged forms are to be found, and the marriage flights occur, at the same times as in laevinodis. Beare records a swarm of this species at Nethy Bridge on August 15th, 1913, at 2.30 p.m., the air temperature being $75^{\circ} \mathrm{F} .{ }^{35}$, Evans observed males and females floating in Loch Ghow, Kinross, on September 11th, 1909, and on April 30th, 1912, I found three small females partly winged, under a stone, in a colony of ruginodis at Hynish in the Isle of Tiree ${ }^{33}$. Wasmann took a number of winged females in a nest of ruginodis at Vorarlberg, Feldkirch in August, 1890, which were smaller than the workers of the same colony ${ }^{22}$.

The same observer records finding a large worker with the head more like that of a female, the rest of the body however being ergatoid, in a colony at Exaeten in Holland ${ }^{22}$.

Forel describes a frontal gynandromorph taken by Frey-Gessner "sur le col du Susten," the body being perfectly symmetrical.

It is rather a male, as the gaster has five segments in addition to the petiole and post-petiole and the external genitalia are male. The epinotum has only two tubercles instead of spines, but the eyes are much smaller than those of the male, and hence more like the female. The head is also a little larger than the head of a male, but both its form and colour are intermediate between the two sexes. Antennae thirteen-jointed as in the male, but in colour and form recalling the antennae of the female. There are also two distinct red bands on the anterior portion of the mesonotum, which are never found in the male. Sculpture of head and epinotum more rugose and less shining than in the male?

The first experiment, in which ants were brought up from eggs laid in captivity, was carried out by Lord Avebury with this species. He writes :- "On August 14, 1876, I isolated two pairs of Myrmica ruginodis which I found flying in my garden. I placed them with damp earth, food, and water, and they continued perfectly healthy through the winter. In April one of the males died, and the second in the middle of May. The first eggs were laid between April 12 and 23. They began to hatch the first week in June, and the first larva turned into a chrysalis on the 27th; a second on the 30 th ; a third on July 1st, when there were also seven larvae and two eggs. On the 8th there was another egg. On July 8th a fourth larva had turned into a pupa. On July 11 th I found there were six eggs, and on the 14th about ten. On the 15 th one of the 
pupae begun to turn brown, and the eggs were about 15 in number. On the 16th a second pupa began to turn brown. On the 21st a fifth larva had turned into a pupa, and there were about 20 eggs. On July 22 the first worker emerged, and a sixth larva had changed. On the 25th I observed the young worker carrying the larvae about when I looked into the nest; a second worker was coming out. On July 28 a third worker emerged, and a fourth on August 5. The eggs appeared to be less numerous, and some had probably been devoured."14

On September 28th, 1912, I found two ruginodis deälated females at Wellington College, side by side in a small hole in the ground, and this suggests that on occasion two females may join together in founding a colony.

Elwin ${ }^{12}$ found larvae and pupae present in a colony in his possession after three years, there being no female present. These would have hatched from eggs laid by the workers; he mentions that no more females were bred, but this is not surprising, since female ants are practically never bred in confinement.

I have taken the following Aphidae in ruginodis nests :-Forda formicaria Heyd., Tycheoides setariae Pass., Brysocrypta lactucaria Pass., B. ranunculi Kalt., Schizoneura corni F., Tetraneura ulmi Geoff. and Aphis plantaginis Schr. Parfitt recorded Hypopi (the young of Acari) on the gasters and antennae of ants of this species in a nest near Exeter ${ }^{16}$.

The following other myrmecophiles have been found with this ant in Britain ${ }^{33}$ :-

Coleoptera: Atemeles emarginatus Pk., Drusilla canaliculata F., Laimprinus saginatus Gr., and Staphylinus stercorarius O].

Ichneumonidae: Pezomachus aquisgranensis Först.

Braconidae : Pachylomma buccata Nees.

Proctotrupidae : Ceraphron myrmicarum Kieffer.

Diptera : Microdon mutabilis L., larva, Apiochaeta (=Phora) conformis Wood and $A$. femorata Wood.

Collembola: Cyphodeirus (=Beckia) albinos Nic., and Smynthurus caecus Tull.

Acarina : Laelaps myrmecophilus Berl.

Crustacea : Platyarthrus hoffmanseggi Brandt.

Myrmica ruginodis Nyl. var. sulcinodo-ruginodis Emery and Forel.

Myrmica rubra race sulcinodis Nyl. (et varr., ruginodis ? et sulcinodisruginodis ?) Forel Den. Schw. Ges. NW. 2677 (1874) $^{1}$. Myrmica sulcinodoruginodis Emery and Forel Mitt. Schweiz. Ent. Gessell. 5461 (1879) ${ }^{2}$; Er. André Hym. Europe 2319 (1881) $^{3}$. Myrmica ruginodis Nyl. var. sulcinodoruginodis Dalla Torre Cat. Hym. $7116(1893)^{4}$. Myrmica sulcinodis-ruginodis Emery Deutsch. Ent. Zeitschr. $19081^{174^{5}}$.

Forel ${ }^{1}$ states that certain varieties of Myrmica sulcinodis are so 
near to $M$. ruginodis that it is almost certain that intermediate forms exist between these two races.

I have seen workers, from a colony, discovered at Leith Hill by Arnold on April 18th, 1909, which may be said to represent this variety.

In these specimens the frontal area is slightly longitudinally striate (which is more pronounced in some individuals than in others), and the scape of the antennae is slightly more bent at the base than in typical ruginodis, otherwise the shape, colour, and general appearance is that of the latter, to which species they are most nearly related.

\section{Myrmica sulcinodis $\mathrm{Nyl}$.}

Myrmica sulcinodis Nylander Acta. Soc. Sc. Fenn. $2934(1846)^{1}$ : 327 $(1849)^{2}$. Myrmica perelegans Curtis Trans. Linn. Soc. Lond. $21214(1854)^{3}$. Myrmica sulcinodis Mayr Verh. Zool. Bot. Ver. Wien $5409(1855)^{4}$; F. Smith Trans. Ent. Soc. Lond. (n.s.) $3119(1855)^{5}$ : 4279 (1858) ${ }^{6}$ : Cat. Brit. Foss. Hym. $24(1858)^{7}$. Myrmica rubra race sulcinodis Forel Denkschr. Schweiz. Ges. Naturw. $2676^{8} 226^{9} 381^{10}$ (1874). Myrmica sulcinodis Parfitt Trans. Devon Assn. Sc-Art. $12515(1880)^{11}$; Saunders Trans. Ent. Soc. Lond. $1880215^{12}$; Er.'André Spec. Hym. 2317 (1881) ${ }^{13}$; Saunders Ent. Mo. Mag. 22116 (1885) ${ }^{14}$; Dalla Torre Cat. Hym. 7117 (1893) $^{15}$; FarrenWhite Ants' Ways $240(1895)^{16}$; Wasmann Biol. Centralb. $15609(1895)^{17}$. Myrmica rubra race sulcinodis Saunders Hym-Acul. $40(1896)^{18}$. Myrmica sulcinodis Johnson Irish Nat. 657 (1897) ${ }^{19}$. Myrmica rubra race sulcinodis Malloch Fauna, Flora, Geol. Clyde Area 219 (1901) ${ }^{20}$; Vic. Hist. Berks 1 $76(1906)^{21}$; Vic. Hist. Cornwall $1185(1906)^{22}$; Myrmica rubra v. sulcinodis Saunders Ent. Mo. Mag. $4261(1906)^{23}$. Myrmica sulcinodis Donisthorpe Trans. Leicester Lit-Phil. Soc. 12228 (1908) ${ }^{24}$; Emery Deutsch. Ent. Zeitschr. $1908173^{25}$; Ellis and Martineau Ent. Rec. 2056 (1908) ${ }^{26}$. Myrmica rubra race sulcinodis Morley Irish Nat. 19185 (1910)27. Myrmica sulcinodis Donisthorpe Ent. Rec. 2311 (1911) ${ }^{28}$ : Entom. 44390 (1911) ${ }^{29}$; Morley Proc. R. Irish Acad. 31 (24) 3 (1911) $^{30}$; Orr Irish Nat. 2076 (1911) ${ }^{31}$; Donisthorpe Ent. Rec. 245 (1912) $^{32}$; Evans Scot. Nat. $1912107^{33}$; Donisthorpe Ent. Rec. $2542(1913)^{34}$; Hallett Cardiff Nat. Soc. Trans. $452(1913)^{35}$.

$\Varangle$ Colour variable; nearly black to all red, in some specimens the thorax and pedicel are pale red, the head and gaster being blackish brown. In the lighter coloured individuals the posterior part of the head is lighter. The mandibles are always of a lighter or darker yellow with the teeth fuscous.

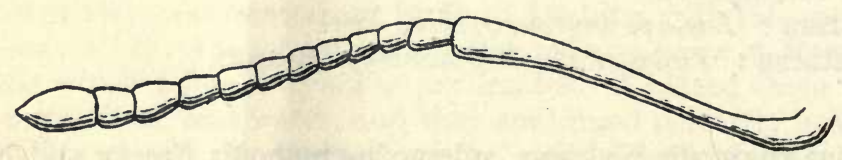

Fig. 67. Antenna of Myrmica sulcinodis $\not$.

Head strongly striate longitudinally, which together with transverse ridges form a network at the sides and base; clypeus rounded and convex; antennae abruptly bent near the base, with a three-jointed club; frontal area longitudinally striate. Thorax coarsely striate longitudinally ; epinotal spines strong, fairly long and somewhat convergent, the space between smooth and shining. Petiole and post-petiole coarsely rugose longitudinally, 
the former high and angled anteriorly, the anterior surface in profile forming an almost straight line to the junction with the thorax. Long. $4 \cdot 3-6 \mathrm{~mm}$.

o Colour and characters as in the $\succ$, the sculpture being a little stronger.

Thorax: mesonotum deeply striate longitudinally. Long. 5.5-6.8 mm. (6.5-7 mm. teste Forel.)

o Blackish brown, shining; mandibles, base and apex of the scape and funiculus of the antennae and the joints of the legs, and sometimes the extremity of the gaster, yellowish; tarsi yellow.

Head longitudinally striate with a faint, smooth, central channel ; frontal area longitudinally striate; scape of antennae about half the length of the funiculus, gradually curved at the base; club of antennae five-jointed, the first joint of which is not so broad as the four following joints. Thorax striate longitudinally, somewhat shining. Petiole finely striate; post-petiole smooth and shining. Long. 5.5-6.5 mm.

Original description of Myrmica sulcinodis Nylander [Acta. Soc. Sc. Fenn. 2934 (1846)] :-

"Operaria: sordide rubida sparse flavo-pilosula, capite et abdomine fusco-nigrescentibus, mandibulis antennisque pallide rufescentibus; capite, thorace et petiolo longitudinaliter striatim profunde exaratis; antennis scapo ad basin parum curvato; metanoti spinis longis.

6. Long. circ. 2 lin. Omnino similis praecedenti, tantum pallidior, antennarum scapis et nodis aliter formatis. Area frontalis obsoleta, striis percurrentibus. Laminae frontalis marginibus infra parum minus dilatatis. Antennae ad basin scapi parum curvatae, magis tamen quam in $M$. laevinodi. Dentes metanoti fere longiores subulati. Nodi longitudinaliter sulcati, sulcis rudibus sub-duodecim in utroque sat ordinatis (nec confusis ut in praecedente).

Femina : sordide fusco-rubescens sparse flavido pilosula, capite et abdomine fusco-nigrescentibus, mandibulis antennisque sordide rufescentibus, pedibus ferrugineo-pallescentibus ; capite, thorace et petiolo profunde longitudinaliter striatim exaratis; antennis scapo ad basin parum curvato; metanoti spinis longis.

‥ Long. $2 \frac{1}{2}$ lin. Similis iterum feminae praecedentis, iisdemque notis a $\not \gamma \mathrm{ab} \not \zeta$ ejusdem dignoscenda. Characteres capitis ut in $\Varangle$. Spinae metanoti longae subulatae, obsolete curvatae. Nodi lateribus imprimis profunde longitrorsum ordinate sulcatis. (Alae desunt.)"

\section{Habitat.}

According to Professor Emery Myrmica sulcinodis occurs in North Europe and North Asia, direct east to Manchuria and Amurland; further south it is a mountain species: Pyrenees, Alps, Apennines, Balkans, and Caucasus 25.

Its distribution in our Islands is as follows :-

Cornwall ${ }^{22}$.

Devon, S. : Lustleigh Cleave and Sandy Gate, St. George's Clist $(\text { Parfitt })^{\mathbf{1 1}}$.

Dorset: Wareham (Dale $)^{16}$; Bloxworth $(\text { Dale })^{18}$; Studland $(\text { Dale })^{18}$; Parley Heath (Dale $)^{18}$; Ringstead (Haines).

Hants, S.: Bournemouth $(\text { Curtis })^{3}$; New Forest $(H a m m)^{32}$; Hants, N. : Fleet (E. A. Butler).

Surrey : Chobham (Saunders) ${ }^{14}$; Woking (Saunders) ${ }^{18}$; Weybridge (Donisthorpe). 
Essex, S. : Epping Forest, Chingford (E. A. Butler).

Berks : Wellington College (Barnes) ${ }^{21}$.

Worcester : Bewdley (Ellis and Martineau $)^{26}$.

Glamorgan : Cwrt-yr-ala (Hallett) $)^{35}$.

Anglesey: Holyhead (J.C. Dale $)^{16}$.

Yorks, Mid. W. : Sherburn (F. Smith Coll.).

Ayr : Irvine Moor (Dalglish) ${ }^{20}$.

Edinburgh : Bavelaw Moss near Balerno (Evans) ${ }^{33}$.

Perth, Mid.: Rannoch (Donisthorpe) ${ }^{32}$.

Aberdeen, S. : Braemar (Donisthorpe $)^{28}$.

Easterness : Nethy Bridge (Donisthorpe $)^{32}$; Nairn (Yerbury $)^{23}$.

Antrim : Belfast Cemetery $(\mathrm{Orr})^{31}$.

Armagh : Poyntzpass (Johnson) ${ }^{19}$.

Donegal : Tory Island, Cratlay Woods, and Glenveagh (Morley) ${ }^{27}$.

Mayo, W. : Achill Sound (Johnson) ${ }^{30}$.

The male of this elegant species was unknown to Nylander when he described the worker and female in $1846^{1}$, and Smith states, in $1855^{5}$, that it is described by himself for the first time, although he quotes Curtis' paper in which the latter described the male, as well as the female and worker, from a colony under a stone on a heath near Bournemouth, under the name of Myrmica perelegans ${ }^{3}$.

$M$. sulcinodis chiefly nests under stones, its colonies being only of moderate size, and its habits appear to be intermediate between those of $M$. ruginodis and $M$. scabrinodis.

Farren-White points out that it has been said to raise a mound like the turf dwellings of Donisthorpea flava, but according to his experience its nest is but very slightly elevated above the surface of the soil ${ }^{16}$.

Nylander ${ }^{2}$ and Mayr ${ }^{4}$ both give mountains for its habitat; and Fore $^{9}$ and André ${ }^{13}$ affirm that it is exclusively an alpine species. The former observer says that it ranges to nearly as high an altitude as does Formica fusca, and is abundant in the highest parts of the Engadine, nesting under stones on high pastures up to the region of the fir trees ${ }^{9}$.

On May 23rd and 25th, 1914, Dr. Chapman found workers attending the larvae of the "Blue Butterfly" (Polyommatus eros Ochs.), at Le Lautaret at an elevation of $7000 \mathrm{ft}$. odd.

Its habits are certainly different in the British Isles-it is true that I have found it under stones on mountains at Rannoch ${ }^{32}$ and Braemar ${ }^{28}$, though only at a moderate height, but it is more abundant down south, on heaths and commons, such as at Woking, Bournemouth, and in the New Forest. The sexes swarm in August and September; Saunders records finding an isolated female, the only time he ever met with this sex, running on the ground at Chobham in August, $1885^{14}$, and I took deälated females in sandpits in the New Forest on May 21st and June 7th, 1908. I found 
male and female pupae in a colony under a stone on a mountain at Rannoch on June 14th, 1911, and also in another situated under a piece of timber on the sandy bank of the Nethy, at Nethy Bridge on June 21st, 1911, which I took home with some of their workers, and from which the winged forms emerged in $\mathrm{July}^{\mathbf{3 2}}$.

Wasmann ${ }^{17}$ records finding, in August, 1891, in a colony of this species at Arlbergpass at a height of 1800 metres, an individual in which the shape of the thorax and size of the body was that of a worker, the gaster however being as well developed as that of a fertilized female, and there did not appear to be any other queen, or female, in the nest.

The following myrmecophiles have occurred with this species in Britain :F. ${ }^{34}$.

Coleoptera: Atemeles emarginatus Pk., and Drusilla canaliculata

Collembola : Cyphodeirus (=Beckia) albinos Nic.

Crustacea : Platyarthrus hofmanseggi Brandt.

\section{Myrmica scabrinodis Nyl.}

Myrmica caespitum Zetterstedt Insect. Lappon. 1450 (1838). ${ }^{1}$ Myrmica scabrinodis Nylander Acta. Soc. Sc. Fenn. $2930(1846)^{2}$ : $1052(1846)^{3}$. Myrmica rubra Curtis Trans. Linn. Soc. Lond. 21213 (1854). ${ }^{4}$ Myrmica scabrinodis F. Smith Trans. Ent. Soc. Lond. (n.s.) 3 115-116 (1855) ${ }^{5}: 4$ $279(1858)^{6}$ : Cat. Brit. Foss. Hym. $21(1858)^{7}$. Myrmica rubra race scabrinodis Forel Denkschr. Schweiz. Ges. Naturw. $2676^{8} 225^{9} 381^{10}$ (1874). Myrmica scabrinodis Saunders Trans. Ent. Soc. Lond. $1880215^{11}$; Er. André Spec. Hym. Europe $2319 .(1881)^{12}$; Lubbock Ants, Bees, Wasps 27 $(1892)^{13}$; Angus Proc. NH. Soc. Glasgow (n.s.) 1 XVIII (1884) ${ }^{14}$; Wasmann Stett. Ent. Zeitg. $51298^{15} 306^{16}(1890)$ : Tijdsh. Entom. $3454(1891)^{17}$; Dalla Torre Cat. Hym. $7116(1893)^{18}$; D. Sharp Trans. Ent. Soc. Lond. $1893206^{19}$; Farren-White Ants' Ways $240(1895)^{20}$. Myrmica rubra race scabrinodis Saunders Hym-Acul. $40(1896)^{21}$. Myrmica scabrinodis Donisthorpe Ent. Rec. $1416(1902)^{22}$. Myrmica rubra Chitty Ent. Rec. 16206 (1904) ${ }^{23}$. Myrmica rubra scabrinodis Wheeler Bull. Amer. Mus. NH. 21 $406(1905)^{24}$. Myrmica scabrinodis Escherich Ameise. $217(1906)^{25}$; Wasmann Tijdschr. Ent. 48 218-219 (1906) ${ }^{26}$. Myrmica scabrinodis, scabrinodis Emery Deutsch. Ent. Zeitschr. $1908 \mathbf{1 7 6}^{27}$. Myrmica scabrinodis Ellis and Martineau Ent. Rec. $2056(1908)^{28}$; Donisthorpe Trans. Leicester LitPhil. Soc. $12228(1908)^{29}$ : Ent. Rec. $21258(1909)^{30}$. Myrmica rubra subsp. scabrinodis Wheeler Ants $566(1910)^{31}$. Myrmica scabrinodis Crawley Ent. Rec. $22155(1910)^{32}$; Donisthorpe Entom. 44390 (1911) ${ }^{33}$ : Ent. Rec. 25 3-4 $4^{34} 43-44^{35}$ (1913); Crawley and Donisthorpe Int. Ent. Cong. Oxford $1912218-19(1913)^{36}$.

ఫ Light reddish yellow, sometimes dark red, with the head and gaster dark brown above, legs and antennae lighter; sculpture sharp and coarse. Head somewhat the same shape as in sulcinodis, with even longitudinal ridges above; frontal area smooth and shining, except at the apex of the triangle, where some of the striae of the front of the head continue on to it ; antennae: scape bent at a right angle at the base, and furnished with a more or less developed lateral tooth at the bend; club three-jointed. Thorax: epinotal spines long and strong, the space between smooth and shining, sometimes 
transversely striate. Petiole rugose, concave anteriorly, forming a distinct angle in profile; post-petiole longitudinally wrinkled. Long. $3.5-5 \mathrm{~mm}$.

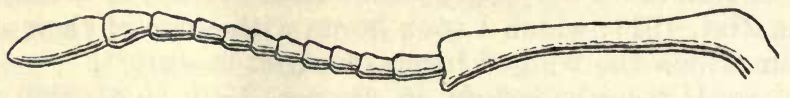

Fig. 68. Antenna of Myrmica scabrinodis

우 Lighter or darker reddish yellow, with dark patches on the thorax, sometimes nearly the whole of the upper surface is dark brown, with lighter mandibles, antennae and legs.

Sculpture stronger, other characters as in the $\not{q}$. Wings fuscous at the base. Long. 5.8-6.5 mm.

$\hat{o}$ Blackish brown, shining, club of antennae, tarsi and apex of gaster yellowish.

Head finely longitudinally striate; antennae: scape short, only as long

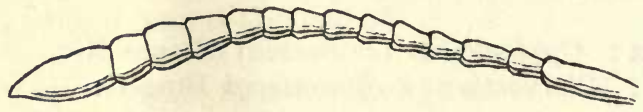

Fig. 69. Antenna of Myrmica scabrinodis ô.

as the three first joints of the funiculus together ; club more or less fourjointed. Wings as in the ㅇ. F'emora thickened in the middle. Long. 4.8-6 mm. (5.5-6 mm. teste Forel.)

Original description of Myrmica scabrinodis Nylander [Acta. Soc. Sc. Fenn. 2930 (1846)] :-

"Operaria: testaceo-ferruginea sparse flavo-pilosula, capite supra et abdominis dorso medio fuscescentibus; capite, thorace et petiolo longitudinaliter striatim profunde rugosis; antennarum scapo ad basin flexo, supra geniculo a lobo oblique-transversim posito; metanoti spinis longis.

૪. Long. $1_{4}^{3}-2$ lin. Simillima iterum praecedenti, sculptura rudiori, area frontali obsoleta et antennarum scapo ut in diagnosi formato. Striae capitis, thoracis petiolique rudes, profundiores quam in praecedentibus, pilositas corporis forte densior et praeterea lamina frontalis aliter constructa, infra nempe margine utrinque aurito-dilatato tenui, processum lamelliformem subsemirotundatum parum elevatum, radices antennarum obtegentem, formante. Area frontalis triangularis parva fere obsoleta. Scapus antennarum basi flexa supra lobo oblique-transverso parvo, subsemirotundato, antice concaviusculo, apice compresso, a parte anteriori viso geniculum parum acutiusculum ostendente. Spinae metanoti longae. Cetera proxime ut in praecedente.

Femina: testaceo-ferruginea sparse flavido-pilosula, capite supra et abdominis dorso medio fuscescentibus, thorace quoque supra et mesopleuris cum sterno parum fuscescentibus ; capite, thorace et petiolo longitudinaliter striatim profunde rugosis; antennarum scapo ad basin geniculatim flexo, geniculo supra angulato; spinis metanoti longiusculis; alis hyalinis obsoletissime cinereo-pallescentibus, stigmate ejusdem coloris distincto.

․ Long. $2 \frac{1}{2}$ lin. sat similis operariae suae, sed major obscurior. Caput fuscum, infra cum genis, mandibulis et antennis ferrugineo-testaceum. Areae triangularis frontis vix vestigium. Scapus flexurâ basis supra angulo subrecto, subtus arcuatâ (lobo distincto nullo). Spinae metanoti ut in specie praecedente sed nodi petiolares rudius sulcatim rugosi. Alae hyalinae albescentes, anticae $2 \frac{1}{2}$ lin. longae, a stigmate versus basin obsoletissime cinereo-pallescentes. Cetera ut in diagnosi vel in praecedente. 
Mas : nigro-fuscus nitidus sparse tenuiter flavido-pilosulus, mandibularum apicibus et tarsis testaceo-pallescentibus, antennis fusco-rufescentibus ; scapo longitudine quintae partis totius antennae; pedibus longe pilosis.

o. Long. $2 \frac{1}{2}$ lin. Similis mari M. laevinodis, antennis vero longitudine tantum flagelli in eadem specie, scapo quintam solum efficiente partem totius antennae, pedibus longe flavido-pilosis. Mandibulae apice sordide pallidae. Antennae obscure rufescentes, longius tenuiusque pilosae quam feminae et operariae; scapus subcylindricus, longitudine tantum trium articulorum insequentium, crassitudinem articuli ultimi superans; pedicellus suborbiculatus crassior quam ullus septem articulorum sequentium, qui sunt longe verticillatim pilosi ; 9,10 et 11 suborbiculati crassiores; ultimus subconicus longitudine fere 10 et 11 (simul sumtorum), sed ejusdem ad basin crassitudinis. Est igitur flagellum ut in feminis fere hujus Generis formatum, at articulis 12. Alae minus albescentes quam in 9 . Pedes longe undique pilosi, pilis his cinerascentibus in tarsis fere longioribus. Anus obsolete pallescens."

\section{Habitat.}

Myrmica scabrinodis is found in North and Central Europe, Siberia, and Turkestan, and varieties ${ }^{31}$ occur in the North and North-eastern States of America, in Alaska and British Columbia.

It is widely distributed in the British Isles, having been recorded as far north as South Aberdeen and Westerness in Scotland, whence I have records from Dumfries, Ayr, Renfrew, Haddington, Edinburgh, Linlithgow, Fife, Kinross, Stirling, South and Mid Perth, Dumbarton, and the Mid Ebudes; and in Ireland from Antrim, Down, Armagh, Tyrone, Donegal, Dublin, Wicklow, Wexford, Carlow, Westmeath, West Mayo, East Galway, Waterford, South Cork, and Kerry. I have no records in England from South Wilts, Cambridge, Bedford, Hunts, East Gloucester, Monmouth, Salop, South-east, South-west and North-west Yorks; and in Wales from Brecon, Cardigan, Montgomery, Merioneth and Flint.

Myrmica scabrinodis nests under stones, on heaths and banks; it does not readily dwell near houses, and on the whole prefers dry sandy places. Indeed $\mathrm{Forel}^{9}$ states it does not occur in woods nor damp places, and never nests in tree trunks, but is to be found on the plains at the edges of woods and roads in dry places, exposed to the south, André12 says it is uniformly established in dry places, Wasmann ${ }^{17}$ gives dry sandy soil on the borders of pine woods, etc., and Escherich ${ }^{25}$ dry places.

On the other hand Bouskell sent me several colonies from Kerry which he had found in the bogs, being all but covered with water $^{34}$, and I found a colony under a stone in a marsh at Studland and several others in clumps of very damp sphagnum in the bogs in the New Forest.

It is stated not to extend to as high an altitude as lobicornis ${ }^{12}$, nor to reach the region of the pines ${ }^{9}$. Hull has sent me scabrinodis from West Allendale taken at a height of $1000 \mathrm{ft}$., and though this 
species may prefer the plains and dry places, it appears to be generally distributed in Britain.

The colonies of this ant are not so populous as those of laevinodis, nor is it as warlike as that species, or ruginodis. Its sting is much more feeble, and though combats take place between colonies of the same species, the mortality is not nearly so great as in the battles of the two above ants.

This Myrmica is a skilful thief, robbing other ants of their prey, even entering their nests for this purpose, and also haunting the battle-fields of larger ants and devouring the dead.

Forel $^{10}$ records that he has seen single individuals enter the nests of Donisthorpea flava, drag out a worker of that species, kill it, and carry it off as a prey. He goes on to say :- "I have seen a scabrinodis worker pull away the dead body of an insect from a rufibarbis worker on the dome of the latter's nest, and in spite of all the efforts of the rufibarbis to retain it. She feigned death, then quickly carried off the prey when the rufibarbis let go, allowed herself to be bitten, but never lost an instant to gain the ground. I saw another catch a cocoon which some rufibarbis, flying before $F$. sanguinea, were carrying. In vain more than twelve rufibarbis workers tried to pull it away, to make her let go, to cut off her head; she remained motionless, clinging to the cocoon with her mandibles. Her patience surpassed that of the rufibarbis, and she ended by carrying off the cocoon so boldly stolen."

Crawley noticed at Oddington, Oxon, where a number of both $M$. scabrinodis and $D$. flava colonies occurred on a lawn, that, at the entrances to the former's nests, an accumulation of a yellow refuse appeared, which kept on increasing. On examination it proved to be composed of vast quantities of the heads of the flava $^{34}$.

The stealing habits of scabrinodis account for the fact that it is frequently met with near nests of flava, and in the nests of other ants. Gould wrote as long ago as 1747- "Very often the Red Ants reside in a distinct part of the Yellow Ant-Hills "F. Smith ${ }^{5}$ says scabrinodis is frequently met with, occupying one side of the same hillock in which flava has formed its habitationFarren-White ${ }^{20}$ records that he has found scabrinodis occupying one side of the raised mound of flava, and also sharing with this species the shelter of the same stone-Fryer sent me specimens of the Myrmica from a colony situated on the top of a large D. Alava mound $1 \mathrm{ft} .4 \mathrm{in}$. high at Woodington $W_{o o d}{ }^{35}$. I have observed the two species together on the following occasions-in the Isle of Wight ${ }^{22}$, at Blackgang, July, 1894 -three colonies of scabrinodis under the same stones as flava at Bletchington on April 9th, 1913 -again at Tenby on April 25th, 1913 - also on Lundy on June 9th, 1913, here the two species were quite mixed, but when the stone was moved they immediately attacked each other. Ellis and 
Martineau record scabrinodis in nests of $F$. sanguinea at Bewdley ${ }^{28}$, and I have frequently found it with the same ant at Weybridge and Woking.

Crawley has found Myrmica scabrinodis (as also $M$. ruginodis and $M$. laevinodis) invariably hostile to strange females ${ }^{32}$, even when fertile and in cases where the colonies possessed no queens of their own, and strange workers were always killed. On the other hand I have known strange colonies of $M$. scabrinodis to amalgamate. Two colonies sent to me by Bouskell in October, 1911, from Miltown, co. Kerry, were arranged in a four-chambered Janet nest, so that each colony occupied two chambers at opposite ends, the passage connecting them being plugged with cotton-wool. One colony contained five females and workers, the other two females, workers and brood. On January 12th, 1912, the cottonwool barrier was removed and the two nests allowed access to each other. No fighting was observed, but on March 2nd some females were dead. Later the remaining females and all the workers occupied the two dampest chambers in common, and the two colonies lived together on perfectly good terms, and in fact became one ${ }^{36}$.

M. scabrinodis (and also ruginodis and laevinodis) will readily accept pupae of their own species from strange nests, and bring them to maturity, but scabrinodis, at any rate, will not rear pupae of the other species.

Angus ${ }^{14}$ records specimens of scabrinodis found in the stomach of a green Woodpecker (Picus viridis) shot in January in North Wales, Wasmann found the remains of thousands of workers in the droppings of this bird in Holland ${ }^{26}$, and Chitty ${ }^{23}$ mentions the Tiger-beetle (Cicindela campestris) feeding on Myrmica rubra (from what he told me the species was probably scabrinodis).

Dr. Sharp ${ }^{19}$ describes the mechanism with which this species stridulates as follows :-

"Myrmica scabrinodis (worker). England. The base or neck, of the segment behind the second node is quite short, and is at the sides covered with sharply raised, quite irregular, rather short, transverse lines; in the middle there is a broad space appearing perfectly smooth and polished, but which, under a high power, proves to be very regularly covered with straight, very fine ridges. The perfect regularity of these fine lines is highly remarkable. The edge, on the hind margin of the second node, by which these lines are scraped is excessively thin."

The males and winged females may be found in the nests from June to September, and the marriage flight takes place chiefly in August and September. Nylander ${ }^{3}$ records a marriage flight of this species at Borgoam in Emsalö on August 22nd, 1846 ; Forel on the summit of Mont-Tendre on August 30th, 1871 ; FarrenWhite ${ }^{20}$ captured a male flying over the cairn which crowns the head of Snowdon in August, 1879; Crawley and I noticed males 
and females leaving their nest and swarming up the grass stems on the cliffs at Sandown, Isle of Wight, on August 12th, 1913, and on August 14th I observed clouds of these ants flying at Shanklin. Scott sent me males and females from a marriage flight, taken at a height of $1000 \mathrm{ft}$. at Landridnod Wells on September 5th, 1912, and Harwood winged females taken flying at Clacton-on-Sea on October 12th, 1912. Wasmann often found in colonies of $M$. scabrinodis at Exaeten, in Holland, single individual workers, nearly double the usual size, with heads the shape of that of a female, though relatively the size of that of a worker, the rest of the body being of the usual form, and no intermediate forms were present ${ }^{16}$.

The same observer records the capture of an ergatandromorph in a colony of this ant, also at Exaeten, in September, 1886, in which a number of males and winged females were present ${ }^{15}$.

It is an approximately lateral ergatandromorph with left half of the body almost entirely that of a worker, whereas the right half is that of a normal male. Left (worker) half of head larger than the right, opaque, coarsely and longitudinally rugose, with a large yellowish red blotch above, sharply delimited on the right side as far as the middle of the face, extending back on the left to the middle of the side of the head as far as the first third of the superior orbit, and anteriorly to the antennal insertion, which is encircled by a black ring. Mandibles, antennae and left half of clypeus yellowish red, the remainder of the head black. Right half of head smaller, more finely longitudinally furrowed and therefore more shining (male). Right eye larger (male), left smaller (worker). Ocellus lacking in that portion of the vertex corresponding to the left side of the head (worker). The two remaining ocelli are present, the median lying rather accurately on the boundary of the black side of the head, but still entirely on that side. Right mandible male in size, shape and number of teeth, but reddish yellow (worker), whereas normally the male mandibles are reddish yellow only at their tips. Left, much more robust, mandible entirely worker. Antennae both alike, thirteenjointed, almost purely male, but very short and sparsely hairy in contradistinction to the long, abundant pilosity of the normal male antennae in Myrmica scabrinodis. They are also lighter in colour, being almost uniformly reddish yellow as in the worker.

Dollman picked up a dead ergatandromorph on a path on the downs at Ditchling ${ }^{30}$ in September, 1909, which he kindly presented to me, and which $I$ have described as follows ${ }^{35}$ :-

"Approximately lateral ergatandromorph, right half of body almost entirely that of a $\forall$, the left being that of a normal $\sigma^{t}$ (the left half being blackish and the right reddish yellow). Right half of head rugosely striate, larger than left, eye smaller; right antennae yellow, club three-jointed; scape with strong lateral tooth at the bend; right half of thorax yellow; epinotum with a strong spine; right half of petiole and post-petiole yellow, rugose and punctured; right half of gaster light fuscous-yellow ; legs on right side yellow, typical $\Varangle$. Left side of head blackish, punctured, not rugosely striate; eye larger; median and left ocelli present; antenna fuscous with four-jointed club; left half of thorax blackish ; epinotum not armed with a spine; petiole and post-petiole fuscous-black, smooth; the greater part of the left half of the gaster has been eaten away, but what remains is of a darker fuscous colour than the right. Legs on left side fuscous, typical $\hat{0}$; wings typical $\hat{0} . "$ 
In this specimen the scape of the left antenna (male) is longer than in typical scabrinodis male, and the tooth on the right antenna (worker) is large, it therefore comes near to the var. sabuleti Meinert.

Wheeler ${ }^{24}$ records the capture of three pterergates in a small colony of a form of Myrmica scabrinodis at Bronxville, New York, on September 5th, 1904. This colony comprised about 150 workers and a deälated female of rather small size. Three of these workers bear vestiges of anterior wings but are in every other respect perfectly normal individuals. In the structure of the thorax, there is not the slightest approach to the female type. Each of the three specimens represents a different condition in the development of the wings. In one the wing vestiges are nearly $1.7 \mathrm{~mm}$. long, spatulate in outline and very slender at their bases where they are furnished with small but distinct tegulae. The appendages are yellowish brown, translucent and covered with minute hairs like those on the normal wings of females, but without any traces of venation. In another worker the wings are barely $4 \mathrm{~mm}$. in length and are merely little opaque pads or sacs, without even a trace of hairs on their surfaces, although they have minute tegulae at their bases. In the third specimen the wings are even more vestigial, the right being represented by a small nodular appendage and its tegula, the left by a minute papilla. Keys found in a colony of scabrinodis at Yelverton, in August, 1913, in which a typical deälated female and males were present, a worker which is a little larger than the other workers from the same nest, measuring $5 \mathrm{~mm}$. in length (the latter being from 4.5 to $4.8 \mathrm{~mm}$. long) the head is rounder and more the shape of a female, and the thorax a little higher, but otherwise that of a normal worker. Two minute chitinous nodules are present on each side of the mesothorax anteriorly.

In July, 1913, I found a form of scabrinodis at Rannoch, in two nests of Formica rufa v. alpina, inhabiting part of the latter's hillocks, but only workers and larvae were found. The scape of the antennae exhibits a slight transverse ridge (more developed in some specimens) reaching across from the lateral tooth, and forming a small point, or angle, opposite to the same. These specimens probably come near the variety scabrinodo-lobicornis Forel, their colour however being that of normal scabrinodis.

I have taken the Aphids-Forda formicaria Heyden, $F$. viridana Buckton, Schizoneura corni F., Trama troglodytes Heyden, T. radicis Kalt., Brysocrypta láctucaria Pass., B. ranunculi Kalt., and Tetraneura ulmi Geoff., in scabrinodis nests.

The undermentioned myrmecophiles have occurred with this species in Britain ${ }^{35}$ :-

Coleoptera: Atemeles emarginatus Pk., Myrmedonia limbata Pk., Drusilla canaliculata F., Homalota analis Gr., Staphylinus 
stercorarius $\mathrm{Ol} .$, Othius myrmecophilus Kies., and Batrisodes venustus Reich.

Formicidae : Myrmecina graminicola Latr.

Ichneumonidae : Pezomachus aquisgranensis Först.

Braconidae : Pachylomma buccata Nees.

Proctotrupidae : Exallonyx fumipennis var. donisthorpei Kief.

Coccidae : Ortheziola vejdovskyi Sulc.

Collembola : Cyphodeirus (=Beckia) albinos Nic.

Araneina: Myrmarachne formicarius De G., and Phrurolithus minimus $\mathrm{C}$. K.

Acarina : Laelaps myrmophilus Mich., $L$. vacuus Mich., and $L$. acutus Mich.

Crustacea : Platyarthrus hoffmanseggi Brandt.

Myrmica scabrinodis Nyl. var. sabuleti Meinert.

Myrmica sabuleti Meinert Kong. Danske. Vidensk. Selsk. Skrift. 5327 (1861) ${ }^{1}$. Myrmica lobicornis Nyl. var. sabuleti Er. André Hym. Europe 2318 $(1881)^{2}$. Myrmica scabrinodis, scabrinodis Nyl. var. sabuleti Emery Deutsch. Ent. Zeitschr. $1908 \mathbf{1 7 6}^{3}$. Myrmica scabrinodis sabuleti Bondroit Ann. Soc. Ent. Belg. 53495 (1909) ${ }^{4}$. Myrmica rubra subsp. scabrinodis Nyl. var. sabuleti Wheeler Ants $566(1910)^{5}$. Myrmica sabuleti Donisthorpe Ent. Rec. 24306 (1912) $^{6}$. Myrmica scabrinodis Nyl. var. sabuleti Donisthorpe Ent. Rec. $2545-46^{7} 62^{8} 267^{9}(1913)$.

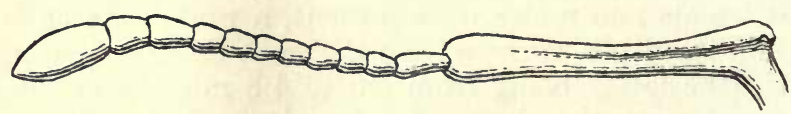

Fig. 70. Antenna of Myrmica scabrinodis v. sabuleti $\not$.

In this variety the worker and female possess a much more developed lateral tooth to the scape of the antennae than in scabrinodis proper, and the longitudinal keel on its upper side is very distinct. The male is to be known by the longer scape, which is as long as the first five joints of the funiculus taken together.

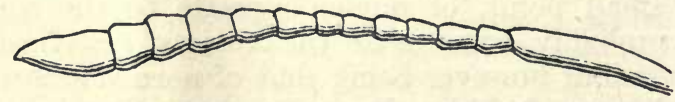

Fig. 71. Antenna of Myrmica scabrinodis v. sabuleti 0 .

In my experience whenever these males with long scapes are found, the females and workers in that colony always exhibit the large development of the lateral tooth, etc., and sabuleti no doubt represents the extreme form of development of scabrinodis in this direction. 
Original description of Myrmica sabuleti Meinert [Kong. Danske. Vidensk. Selsk. Shrift. 5327 (1861)]:-

" Dronning : Ubekjendt.

Arbeider: Rødguul; Bagkroppens Overside mørkere. Antennernes Skaft bøiet i en naesten ret Vinkel, Roden med en Tand og paa Oversiden med en høi, skarp Laengdekjøl. Pandefligene store, øreformige. Pandeegnen heelt eller tildeels rynket. Hovedets Sider med unregelmaessig Sculptur, Midten, Thorax og Stilkens Knuder, de sidste staerkt, laengderynkede. L. 21."'.

Han : Sort ; Antennerne for størte Delen, Bagkroppens Spidse, Benenes Leddemode og Fødderne gule. Antennernes Skaft en tredie Deel af Svøbens Laengde, det sidste Led laengere end de to foregaaende tilsammen, ofte bøiet eller deelt i Midten. Antennerne naesten nøgne; Benene med lange skraat stillede, tildeels naesten lodrette Børster. Stilkens første Knude

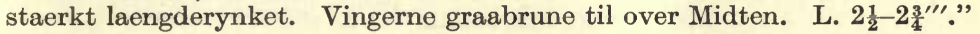

The following is a translation of Meinert's Danish description :-

우: Unknown.

$\Varangle$ : Reddish yellow; gaster darker above. Antennal scape bent almost at right angles, base with a tooth, and on the upper side with a high sharp longitudinal keel. Frontal flaps large, ear-shaped. Frontal portion wholly or partly wrinkled. Sides of head irregularly, thorax and nodes of pedicel distinctly wrinkled longitudinally. Long. $2 \frac{1}{4}$ lin.

$\hat{0}$ : Black; antennae for the greater part, apex of gaster, joints of legs and feet yellow. Antennal scape a third of the length of the funiculus, the last joint longer than the two preceding ones together, often bent or divided in the middle. Antennae almost bare; legs with long, oblique, sub-erect hairs. First node of pedicel wrinkled longitudinally. Wings greyish brown to beyond middle. Long. $2 \frac{1}{2}-2 \frac{3}{4}$ lin.

\section{Habitat.}

According to Emery ${ }^{3}$ this variety extends further south, in the Palaearctic Region, than the type, and Wheeler ${ }^{5}$ records it from the northern states of North America.

In Britain it has occurred in :-

Cornwall, E. : Whitsand Bay (Keys).

Devon, S.: Plymouth district (Keys); Seaton (Donisthorpe) ${ }^{7}$; Devon, N. : Lundy Island (Donisthorpe) ${ }^{9}$.

Isle of Wight: The Landslip near Shanklin (Donisthorpe).

Hants, S. : New Forest (Donisthorpe)?

Surrey : Box Hill (Donisthorpe) ${ }^{\text {? }}$.

Herts : Hitchin (Durrant).

Berkshire : Boar's Hill (Hamm).

Oxford : Shotover $(\text { Hamm })^{8}$; Wolvercote (Collins).

Glamorgan : Cwrt-yr-ala (Hallett).

Pembroke : Tenby (Donisthorpe); St. David's (Allen).

Cheshire : Delamere (Arnold).

Easterness : Loch-an-Eilean (Rothney).

The habits of sabuleti are similar to those of scabrinodis. I found a colony occupying the same mound as Donisthorpea flava in the Isle of Wight in August, 1913, and have taken the males and winged females in the nests in July, August, and September. 
The following myrmecophiles have been captured with $M$. sabuleti in Britain :Gr.

Coleoptera : Atemeles emarginatus Pk., and Lamprinus saginatus

Lepidoptera: Dr. Chapman has taken the larva of the "Blue Butterfly" (Lycaena arion L.) in the nest of this variety in North Devon, and has demonstrated that it devours the ants' larvae.

Collembola : Cyphodeirus (=Beckia) albinos Nic.

Araneina : Harpactes hombergi Sep.

Crustacea: Platyarthrus hoffmanseggi Brandt.

\section{Myrmica lobicornis Nyl.}

Myrmica lobicornis Nylander Acta. Soc. Sc. Fenn. $2932^{1} 1052^{2}$ (1846) :

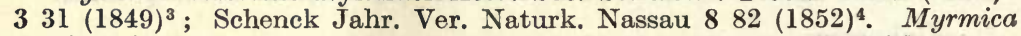
denticornis Curtis Trans. Linn. Soc. Lond. $21215(1854)^{5}$; F. Smith Trans. Ent. Soc. Lond. (n.s.) 3120 (1855) $^{6}$. Myrmica lobicornis F. Smith Cat. Brit. Foss. Hym. 25 (1858) ${ }^{7}$ : Trans. Ent. Soc. Lond. (n.s.) $4279(1858)^{8}$ : Ent. Ann. $186092^{9}$; Meinert Kong. Danske. Vidensk. Selsk. Skrift. $5327(1861)^{10}$; F. Smith Ent. Mo. Mag. $229(1865)^{11}$ : Ent. Ann. $1866128^{12}$; Bold Ent. Mo. Mag. $2234(1866)^{13}$; F. Smith Entom. $3197(1866)^{14}$ : Ent. Ann. $186894^{15}$. Myrmica rubra race lobicornis Forel Denkschr. Schweiz. Ges. Naturw. 26 77-7916 $226^{17} 403^{18}$ (1874). Myrmica lobicornis B. Cooke Nat. 5 $73(1879)^{19}$; Saunders Trans. Ent. Soc. Lond. $1880216^{20}$; Er. André Spec. Hym. Europe $2318(1881)^{21}$. Myrmica nodicornis Chappell Young Nat. 758 $(1886)^{22}$. Myrmica lobicornis Bridgman Trans. Norf. Norwich Nat. Soc. $4394(1886)^{23}$ : $690(1889)^{24}$; Dalla Torre Cat. Hym. $7111(1893)^{25}$; FarrenWhite Ants' Ways $241(1895)^{26}$. Myrmica rubra race lobicornis Freke Irish Nat. 540 (1896) ${ }^{27}$; Saunders Hym-Acul. 40 (1896 ${ }^{28}$; Morley Hym. Suffolk $12(1899)^{29}$; Vic. Hist. Cumberland 1103 (1901) ${ }^{30}$; Vic. Hist. Essex 1102 $(1903)^{31}$; Vic. Hist. Devon $1188(1906)^{32}$. Myrmica lobicornis Escherich $217(1906)^{33}$; Donisthorpe Trans. Leicester Lit-Phil. Soc. $12228(1908)^{34}$. Myrmica scabrinodis lobicornis Emery Deutsch. Ent. Zeitschr. $1908179^{35}$. Myrmica lobicornis Nyl. var. arduennae Bondroit Ann. Soc. Ent. Belg. 55 $12(1911)^{36}$. Myrmica lobicornis Donisthorpe Ent. Rec. $2311(1911)^{37}$ : Entom. 44390 (1911) $^{38}$ : Ent. Rec. 245 (1912) $^{39}$; Evans Scot. Nat. 1912 $108^{40}$; Hallett Trans. Cardiff. Nat. Soc. $452(1913)^{41}$; Donisthorpe Ent. Rec. 25 46-47 (1913) ${ }^{42}$.

$\Varangle$ Lighter or darker brown-red, head and gaster, and sometimes the whole body blackish brown; antennae and legs lighter.

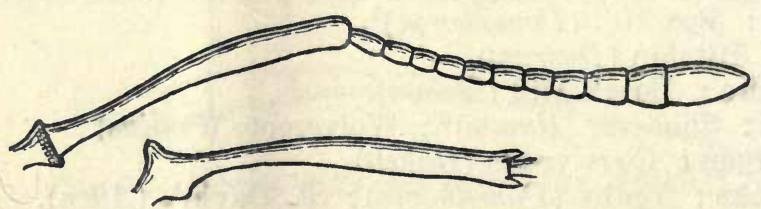

Fig. 72. 1. Antenna of Myrmica lobicornis ధ̧.

2. The same in profile.

Head : frontal area more or less longitudinally striate, sometimes shining and only shagreened; antennae with scape sharply bent at the base, and furnished above at the bend with a strong transverse ridge, which, when seen in profile, has the appearance of a spine.; club of antennae three-jointed. 
Thorax : epinotal spines variable in length, the space between sometimes smooth and shining, sometimes somewhat striate transversely. Long: 4-5 mm. (3.5-5 mm. teste Forel.)

The striation and reticulation of the head, and the rugosity of the thorax and pedicel is variable, often in individuals from the same colony; the denticornis Curtis, and the var. arduennae Bondroit appear to be founded on such varieties.

ㅇ Head and gaster blackish brown, thorax and pedicel red, with some black patches on the former; often the whole body is blackish brown; antennae and legs lighter.

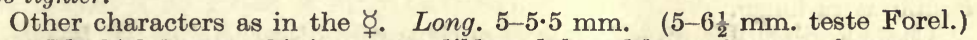

o Blackish brown, shining; mandibles, club and base of scape of antennae, tarsi, femora and tibiae at base and apex, and extremity of gaster yellowish.

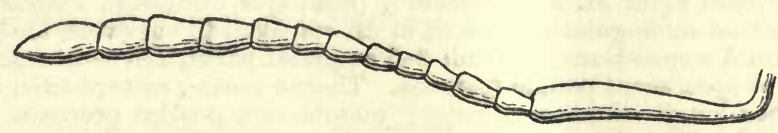

Fig. 73. Antenna of Myrmica lobicornis ô.

Head finely striate, with distinct frontal channel; frontal area finely striate longitudinally, or simply shagreened; antennae with scape abruptly bent at the base, about half the length of the funiculus; funiculus short, with a four-jointed club. Thorax striate; space between epinotal tubercles smooth and shining. Petiole finely striate; post-petiole smooth and shining. Long. 5-5.5 mm. (5-6 mm. teste Forel.)

\section{Original description of Myrmica lobicornis Nylander. ㅎ 우 [Acta} Soc. Sc. Fenn. 2 932-934 (1846)] :-

"Operaria : obscure rubida sparse flavido-pilosula, capite et abdomine fusco-nigrescentibus, mandibulis antennisque rufescentibus; capite, thorace et petiolo longitudinaliter striatim profunde rugosis ; antennarum scapo ad basin curvato, supra lobo transversim posito ; metanoti spinis longis.

ఛ. Long. $1 \frac{2}{3}-2$ lin. Similis praecedenti, at minus forte robusta, colore jam et scapi formatione alia distincta. Mandibulae pallide ferrugineae apice summo fuscescente. Area frontalis conspicua. Lamina frontalis ut in praecedente, marginibus infra utrinque dilatatis parum reflexis. Antennae obscurius, quam mandibulae, rufae; scapus lobo compresso antice parum concaviusculo, formae laminae subsemirotundatae, transversim supra flexuram prope basin posito. (Est hic lobus paullo major, compressior, neque oblique positus, sicut in praecedente). Caput lateribus reticulatim rugosum. Thorax et petiolus longitudinaliter crasse scabri, sordide fuscescenti-rubidi ; nodi sculptura rugosa crassa inaequali longitudinali. Pedes sordide ferrugineo-pallescentes. Abdomen apice obsolete pallescens.

Femina: fusca sparse flavido-pilosula; mandibulis apice, antennis et pedibus pallide rufescentibus; capite, thorace et petiolo longitudinaliter striatim profunde rugosis; antennarum scapo ad basin curvato, supra lobo transversim posito; metanoti spinis longiusculis; alis hyalinis nervis et stigmate dilute cinereo-pallescentibus.

\%. Long. $2 \frac{1}{2}$ lin. Similis quoque feminae praecedentis, sed colore et scapo aliter formato mox distincta. - Mandibulae apicibus late pallide-rufescentibus. Area triangularis, lamina frontalis et scapus antennarum ut in $\breve{q}$. Thorax fuscus, pronoto antice inaequaliter crasse rugoso, ceteroquin longitudinaliter crasse striatus, infra et apice obsolete rubido-rufescens. Nodi fusci infra rubido-rufescentes, crasse sublongitudinaliter rugosi. Alae ut in praecedente, 
sed fere adhuc obsoletius colore cinereo-pallescente dilutissimo tinctae; anticae long. $2 \frac{1}{3}$ lin. Pedes nitidi ferrugineo-pallescentes longe flavo pubescentes. Abdomen apice obscure fusco-rufescente."

The $\hat{o}$ of Myrmica lobicornis was described by Nylander [Acta. Soc. Sc. Fenn. 331 (1849)] as follows :-

"Mas: nigro-fuscus nitidus parce tenuiter flavido-pilosulus, mandibulis, antennis et pedibus testaceo-pallescentibus, scapis, femoribus tibiisque obscuratis ; fronte, pleuris et nodo primo petioli longitudinaliter striatulis ; scapis basi curvatis longitudine tertiae partis totius antennae; alis hyalinis obsoletissime cinereo-pallescentibus; pedibus pubescentibus; corpore fere 5 millimetra longo.

Characteribus illis ab affinibus cognitis statim discernendus, $M$. laevinodi ot paulo minor. Caput subtilissime in fronte longitudinaliter et alibi granulatim rugosum; antennae 13-articulatae sparse breviter pilosulae, paululum longiores quam apud $M$. scabrinodem ô (multoque nudiores), scapus pallide fuscescens basi subangulatim (fere ut in $M$. sulcinodi $\Varangle$ ) curvatus, longitudine articulorum 5 sequentium; articuli 3-6 aequales parvi, 7-8 sensim majores; flagellum et apex scapi pallide testacea. Thorax meso-, metapleuris, scutello et metanoto longitudinaliter striatis ; metathorax postice processu obtuseangulato vel subdentiformi utrinque, spatio excavato laevi nitido. Alae ut in $M$. scabrinodi, fere pallidiores, anticae $4 \frac{1}{2}$ millim. longae. Pedes pubescentes olivaceo-pallidi, articulationibus tarsisque testaceo-pallidis. Nodus petioli anterior longitudinaliter parum striatulus posterior laevis. Abdomen saepe apice et marginibus segmentorum paulo pallescentibus."

\section{Habitat.}

Myrmica lobicornis occurs in North Europe; further south a mountain species (Alps, Apennines); eastwards to Central Asia ${ }^{35}$.

The British distribution is as follows :-

Devon : (Vic. Hist. Devon $)^{32}$.

Somerset, S. : Exmoor (Farren-White) ${ }^{26}$; Somerset, N. : Leigh (Smallcombe).

Hants, S. : New Forest (Donisthorpe) ${ }^{\mathbf{3 4}}$.

Sussex, E. : Seaford $(\text { Rye })^{12}$.

Kent, E. : Dover (F.Smith $)^{11}$; Whitstable (Donisthorpe $)^{39}$.

Surrey : Shirley (Rothney) ${ }^{15}$; Wimbledon Common ${ }^{39}$, Weybridge $^{37}$, and Richmond Park ${ }^{34}$ (Donisthorpe); Chobham ${ }^{20}$ and Woking (Saunders) ${ }^{28}$.

Essex : (Vic. Hist. Essex $)^{31}$; Essex, S. : Chingford and Loughton (E. A. Butler).

Berkshire : Bagley Wood (Hamm).

Oxfordshire : Oxford and Shotover Hill (Hamm); Wolvercote (Collins).

Suffolk, E. : Pakefield ${ }^{9}$ and Lowestoft ${ }^{12}$ (F. Smith) ; Foxhall $(\text { Morley })^{29}$.

Norfolk, E. : Mousehold (Thouless) ${ }^{23}$.

Glamorgan: Pontneathvaughan (Hallett $)^{\mathbf{4 1}}$.

Carnarvon: Aber Waterfall, and Brendon Common (FarrenWhite) ${ }^{26}$.

Denbigh : Llangollen (Chappell $)^{22}$. 
Leicestershire: Groby Pool (S. O. Taylor).

Cheshire : Bowdon (B. Cooke $)^{19}$.

Durham : South Shields $(\text { Bold })^{13}$.

Northumberland, S. : Whitley and Blyth $(\text { Bold })^{\mathbf{1 3}}$.

Cumberland : near Carlisle (Vic. Hist. Cumberland) ${ }^{30}$; Saddleback (Britten).

Haddington : North Berwick (Evans) ${ }^{40}$.

Edinburgh : near Inveresk (Evans $)^{40}$.

Fife and Kinross : N. Queensferry (Donisthorpe) ${ }^{34}$; Kinghorn ${ }^{40}$, St. David's, and Isle of May (Evans).

Perth, S.: Callander (Evans $)^{40}$; Perth, Mid. : Rannoch $(\text { Dale })^{26}$.

Easterness : Nethy Bridge (Donisthorpe).

Ebudes, Mid. : Isle of Mull (Donisthorpe) ${ }^{39}$.

Sutherland, E. : Golspie.(Yerbury).

Armagh : Armagh (Johnson) ${ }^{2}$.

This species was first discovered in Britain by Curtis, who captured males and workers in Scotland in $\mathbf{1 8 2 5 ^ { 5 }}$, and subsequently Dale found a female and workers at Rannoch ${ }^{26}$. F. Smith described Dale's female in $1855^{6}$, but curiously enough when he recorded (in 1860) females taken by himself on the cliffs at Pakefield he stated that it was the first time the female had been found in this country ${ }^{9}$.

$M$. lobicornis lives in small communities, nesting chiefly in sandy places, under stones, in banks, etc. It is the least warlike of our species, possessing a feeble sting, and its habits are somewhat similar to those of $M$. scabrinodis. It prefers to dwell in dry places, but I once found it, on September 14th, 1911, on the Isle of Mull in wet sphagnum in a $\operatorname{bog}^{39}$. According to Forel ${ }^{17}$, Andrée1, and Escherich ${ }^{33}$ this Myrmica is chiefly a mountain species, and the first of these myrmecologists records it on high pastures in the region of the fir trees, rarely occurring in the plains, or as a subalpine species, and states that the alpine forms are smaller and darker.

In Scotland I have found it near the Forth Bridge in the Lowlands, and on the shores of Loch Rannoch and at Nethy Bridge in the Highlands, but never actually on the mountains, and of course in the south of England it occurs on heaths and plains, such as in the New Forest and at Weybridge, etc. Bold when recording it for Northumberland and Durham, speaks of it as a littoralspecies, living on sand-banks ${ }^{13}$.

M. lobicornis, like M. scabrinodis, is sometimes found in, and near, the nests of other ants-Rothney took a female and many workers in nests of Formica sanguinea at Shirley ${ }^{15}$, Hallett records its capture near a nest of $F$. rufa in Glamorgan ${ }^{41}$, and I found two colonies of this ant, at Weybridge on July 22nd, 1911, both situated beneath a nest of $F$. sanguinea ${ }^{39}$.

According to Schenck the marriage flights take place from the 
end of July to the end of September; he first captured a winged female on July 28th, and at the beginning of October he found males and winged females in some numbers in the herbage 4 . Forel witnessed a marriage flight on the summit of Mont Tendre on July 30 th, $1871^{18}$, Nylander captured a winged female at Helsingfors in August, $1846^{2}$, and I have found males and winged females in the nests in July, and August, and on July 21st and September 22nd, 1913, I observed isolated deälated females crawling about on paths at Weybridge. On August 13th, 1914, I found a large colony in a bank in the last mentioned locality which contained a number of workers, three winged females, and between twenty-five and thirty queens.

Meinert described a.mixed frontal gynandromorph, in which the head is female in size, the thorax and external genitalia, as well as the colour and sculpture of the body being male. The wings are intermediate between those of the two sexes ${ }^{10}$.

Bugnion captured a male and female of a small Myrmica in a nest of $M$. lobicornis at Anzeindaz, at a height of 2000 metres in the Swiss Alps, which were first recorded by Forel as a very curious small form of the latter. He remarks however that had they not been taken in company with the males, females, and workers of lobicornis, he would have considered them to belong to another species $^{16}$. He subsequently described them as a new species under the name Myrmica myrmicoxena [Verhandl. 66 Versamm. D. Naturf. Ärzte Wien 143 (1894)]. This ant is probably a workerless parasite, or perhaps a guest-species, living in the nests of $M$. lobicornis.

I have taken the Bracon Pachylomma buccata Nees, and the Dipteron Pseudacteon formicarum Verrall, hovering over workers of lobicornis at Weybridge ${ }^{42}$, and the Collembola Cyphodeirus albinos Nic., in the nests.

\section{STENAMIMA Westwood.}

[ $\sigma \tau \epsilon \nu o ́ s$, narrow ; $\ddot{\alpha} \mu \mu a$, connection (i.e. the petiole)].

Type: Stenamma westwoodi (Steph.) West.; West., 1840.

The genus Stenamma is common to the Palaearctic Region proper, and the Nearctic Region. Its origin is probably not boreal ; it is not found in India, but occurs in Africa. The species are predaceous, they prefer damp places, and are generally found singly. We only possess one species in Britain $-S$. westwoodi West.

$\Varangle$ Head long oval, longer than broad; clypeus furnished with two fine longitudinal carinae, the space between which being somewhat hollowed out; frontal carinae short, divergent ; frontal area deeply impressed, longer than broad; mandibles large, terminal border furnished with eight or nine teeth, which are shorter and blunter posteriorly; maxillary palpi four- 
jointed ; labial palpi three-jointed ; antennae twelve-jointed, the first joint of the funiculus is long, those immediately following being short and transverse, the last joint is about equal in length to the three preceding taken together, and with them forms a not very distinct club; eyes small, pointlike. Thorax with shoulders rounded; the division between the pronotum and mesonotum is obliterated, that between the mesonotum and epinotum being distinctly marked ; epinotum armed with two sharply pointed triangular teeth. Petiole with a long shaft anteriorly, nodiform posteriorly; postpetiole nodiform; gaster oval, with very long first segment.

o Very like the $\forall$, a little larger; eyes larger; ocelli present. Thorax. short and not high. Fore-wings with one cubital cell, and one discoidal cell.

ô Head longer than broad; mandibles broader with four to five teeth on the terminal border, or narrower with only three teeth; antennae thirteenjointed, scape as long as the three following joints taken together, funiculus with a not very distinct four-jointed club, the last joint of which is a little longer than the two preceding taken together; eyes large, situated anteriorly. Thorax not very high; mesonotum with Mayrian furrows; epinotum with two teeth. Pedicel as in the $\not$. Wings as in the 우.

Original description [Westwood Intro. Mod. Class. Insect. 2 Synop. 83 (1840)] :-

"Stenamma Westw. N.G. 92 Steph. Cat. 1 sp. N. G. Westwoodii Steph. Basal joint of antennae long; abdominal peduncle 2-jointed, first joint long, knotted ; max. palpi 4-jointed, labial 3-jointed; mandibles broad, oblique, 5-dentate. My fig. 86 11."

\section{Stenamma westwoodi West.}

Stenamma westwoodii (Stephens) Westwood Introd. mod. Class. Insect. 2226 Synopsis $83(1840) \delta^{11}$. Myrmica lippula Nylander Acta. Soc. Sc. Fenn. 341 (1849) $\nvdash^{2}$. Myrmica debilis Förster Hym. Stud. $152(1850) \delta^{3}$. Myrmica minkii Förster Hym. Stud. 163 (1850) $\Varangle^{4}$. Formica graminicola

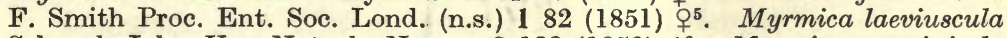
Schenck Jahr. Ver. Naturk. Nassau 8132 (1852) o $^{+6}$. Myrmica graminicola Curtis Trans. Linn. Soc. Lond. 21216 (1854) ధ̧7?. Stenamma westwoodii Curtis Trans. Linn. Soc. Lond. 21217 (1854) o $^{18}$. Myrmica graminicola F. Smith Trans. Ent. Soc. Lond. (n.s.) 3126 (1855) ४̧ ధ9. Stenamma westwoodii F. Smith Trans. Ent. Soc. Lond. (n.s.) 3134 (1855) ${ }^{110}$; Westwood (Proc. Ent. Soc. Lond.) Zool. 134747 (1855) o $^{11}$ : Proc. Ent. Soc. Lond. (n.s.) 392 (1855) $\delta^{12}$. Myrmica minki Mayr Verh. Zool. Bot. Ver. Wien 5415 (1855)

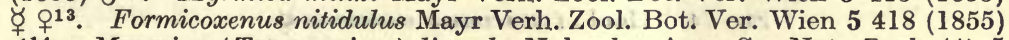
14. Myrmica (Tetramorium) lippula Nylander Ann. Sc. Nat. Zool. (4) 5 88 (1856) ఫ̧15. Myrmica (Stenamma) nitidula Nylander Ann. Sc. Nat. Zool. (4) 594 (1856) j16. Myrmica lippula F. Smith Proc. Ent. Soc. Lond. (n.s.) $488(1857)^{17}$ : Ent. Ann. $185839^{18}$. Myrmica (Tetramorium) lippula F. Smith Cat. Brit. Foss. Hym. 28 (1858) $\measuredangle$ 이․ Myrmica (Stenamma) westwoodii F. Smith Cat. Brit. Foss. Hym. 32 (1858) j $^{20}$. Myrmica (Tetramorium) lippula F. Smith Trans. Ent. Soc. Lond. (n.s.) 4 279-280 (1858) ४ৃ ${ }^{21}$. Myrmica (Stenamma) westwoodii F. Smith Trans. Ent. Soc. Lond. (n.s.) 4281 (1858) i22. Myrmica lippula F. Smith Proc. Ent. Soc. Lond. (n.s.) $4185789(1858)^{23}$ : Ent. Ann. 186092 24. Myrmica nitidula Meinert Kong. Danske. Vidensk. Selsk. Skrift. 5328 (1861) o $^{25}$. Myrmica lippula F. Smith Ent. Ann. 1861 $42^{28}$. ? Tetramorium lippulum Mayr. Europ. Formicid. 61-62 (1861) ל̧ $^{27}$. Asemorhoptrum lippulum Mayr. Europ. Formicid. 76 (1861) ${ }^{28}$. Myrmica lippula F. Smith Ent. Ann. $186359^{29}$ : $1864111{ }^{130}$. Tetramorium lippula F. Smith Ent. Ann. $1864112^{31}$ : Ent. Mo. Mag. 229 (1865) ${ }^{32}$. Asemorhoptrum lippulum v. Hagens Verh. Nat. Ver. Preuss. Rheinl. $2450(1867)^{33}$ : Berlin Ent. Zeitschr. $11102(1867)^{34}: 12268(1868)^{35}$; Forel Denkschr. Schweiz. 
Ges. Naturw. 2680 (1874) $\Varangle$ o $^{36}$. Stenamma westwoodi Forel Denkschr. Schweiz. Ges. Naturw. 2682 (1874) o $^{\mathbf{3 7}}$. Stenamma westwoodii Capron Entom. $11274(1878)^{38}$. Stenamma westwoodi Saunders Trans. Ent. Soc. Lond. 1880216 今39. Asemorhoptrum lippula Saunders Trans. Ent. Soc. Lond. 1880217 ơ 우 뿐. Tetramorium lippula Parfitt Trans. Devon Assn. Sc-Art $12516(1880)^{41}$. Stenamma westwoodi Er. André Spec. Hym. Europe 2312 (1881) 우 우 $\mathbf{0}^{42}$. Tetramorium lippula Bridgman Trans. Norf. Norwich Nat. Soc. $3367(1882)^{43}$. Stenamma laeviuscula Stolpe Entom. Tidskr. 3146 (1882) ช ㅇ․․ Stenamma westwoodi Saunders Ent. Mo. Mag. 20 16, $19(1883)^{45}$. Tetramorium lippula Capron Ent. Mo. Mag. $22264(1886)^{46}$. Stenamma westwoodi Frisby Ent. Mo. Mag. $2682(1890)^{47}$; Wasmann Tijdshr. Entom. $3452(1891)^{48}$ : zusam. Nest. u. gemischt. Kolon. Ameisen $256(1891)^{49}$. Stenamma westwoodii Rothney Ent. Mo. Mag. $2779(1891)^{50}$. Stenamma westwoodi Perkins Ent. Mo. Mag. 27123 (1891) ${ }^{51}$. Stenamma westwoodii

- Fryer Entom. $2550(1892)^{52}$; Dalla Torre Cat. Hym. $7121(1893)^{53}$. Stenamma westwoodi Wasmann Krit. ver. Myr. u. Ter. Art. $162(1894)^{54}$. Tetramorium lippulum Farren-White Ants' Ways 243 (1895) $\Varangle$ ${ }^{55}$. Stenamma westwoodii Farren-White Ants' Ways 245 (1895) o $^{56}$. Stenamma westwoodi Tuck Ent. Mo. Mag. 32155 (1896) ${ }^{57}$; Saunders Hym. Acul. $35(1896)^{58}$; Morley Entom. $3113(1898)^{59}$ : Hym. Suffolk $22(1899)^{60}$. Stenamma westwoodii Vic. Hist. Worcester $186(1901)^{61}$. Stenamma westwoodi Donisthorpe

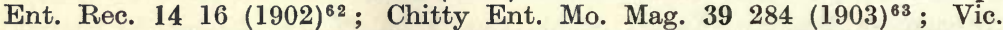
Hist. Cornwall $1182(1906)^{64}$; Escherich Ameise $215(1906)^{65}$; Scharff Europ. Animals $70(1907)^{66}$; Vic. Hist. Kent $1116(1908)^{67}$; Emery Deutsch. Ent. Zeitschr. $1908306^{68}$; Donisthorpe Trans. Leicester Lit-Phil. Soc. $12226(1908)^{69}$ : Ent. Rec. $21258(1909)^{70}$ : Entom. $44390(1911)^{71}$; Emery Rev. Suisse Zool. $21582(1913)^{72}$.

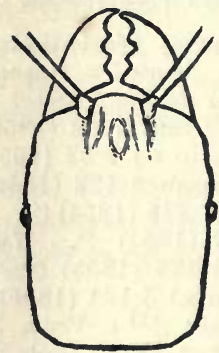

Fig. 74. Head of Stenamma westwoodi $\not$.

ఛ Lighter or darker reddish yellow, antennae, legs and gaster beneath, lighter, sometimes the head, thorax, and pedicel above, and the disc of the gaster are brownish; head and thorax with short, pedicel and gaster with longer, scattered pale hairs. Head with front longitudinally striate, the rest distinctly reticulate; clypeus in centre, and frontal area smooth and shining. Thorax strongly rugose; epinotum posteriorly smooth and shining. Pedicel finely wrinkled longitudinally; gaster smooth and shining. Long. 3.5-4 mm. (3-3.7 mm. teste Emery.)

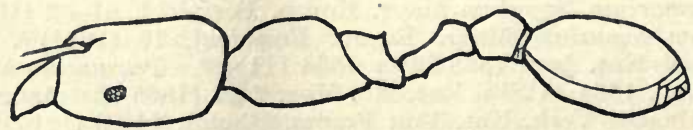

Fig. 75. Stenamma westwoodi 
ㅇ Lighter or darker reddish brown, variable as in the ్. Characters as in the $\forall$. The reticulation of the head is not nearly so marked in some specimens. Wings dirty pale yellow, with light brown pterostigma and nerves. Long. 4.3-4.8 mm. (4-4.6 mm. teste Emery ; $5 \mathrm{~mm}$. teste André.)

ô Blackish brown, mandibles, antennae and legs brownish yellow, apex of antennae, tarsi, and articulations of the joints of the legs lighter. Head longitudinally striate, dull; frontal area smooth and somewhat shining. Thorax a little less strongly striate, and a little more shining than head; epinotum with sides finely striate, shining above and posteriorly. Petiole and postpetiole above, and gaster smooth and shining. Wings as in the ‥ Long. $4 \mathrm{~mm}$. (3.5 mm. teste Emery.)

\section{Habitat.}

Stenamma westwoodi occurs in South and Central Europe; a variety has been described from Italy, and a subspecies from Turkestan. Scharff writes"6_ "It has been found in the southwest of Ireland and in the south of England; nowhere else in the British Isles." As we shall see, however, it occurs as far north as the Midlands and Norfolk (Malloch's record of its capture by Taylor in the Clyde Area was in error, since as pointed out by Evans [Glasgow Nat. 421 (1911)] it really refers to Myrmica ruginodis) :-

Cornwall, W. : The Lizard (H. C. Champion); Truro ${ }^{64}$; Cornwall, E. : Mount Edgcumbe (Dale $)^{58}$.

Devon, S. : Plymouth (Reading) ${ }^{17}$; Bickleigh (Bignell) ${ }^{58}$; Dartmouth (Perkins) ${ }^{51}$; Labrador Shaldon (Rothney) ${ }^{50}$; Seaton $(\text { Dale })^{58}$; Devon, N. : Ilfracombe (Saunders) ${ }^{58}$; Clovelly $(\text { Dale })^{58}$; Lynton (Farren-White) ${ }^{55}$.

Somerset, N. : Weston-super-Mare (Donisthorpe) ${ }^{69}$.

Wilts, S. : Dinton near Wilton (Curtis) ${ }^{\text {? }}$.

Dorset: Godmanstone $(\text { Dale })^{58}$; Corfe Castle $(F \text {. Smith })^{30}$; Studland (Donisthorpe) ${ }^{69}$.

Isle of Wight : Blackgang Chine $(\text { Curtis })^{8}$; Freshwater $(\text { Dale })^{58}$; Parkhurst Forest (Donisthorpe) ${ }^{70}$.

Hants, S.: Portsmouth (Reading, Brit. Mus. Coll.); New Forest (D. Sharp, Camb. Mus. Coll.).

Sussex, E. : Ditchling (Donisthorpe) ${ }^{69}$.

Kent, E. : Maidstone (Frisby $)^{47}$; Doddington $(\text { Chitty })^{63}$; Deal $(\text { Dale })^{58}$; Kent, W. : Tunbridge Wells $(\text { Dale })^{\mathbf{4 0}}$; Charlton (FarrenWhite $)^{55}$; Darenth Wood (Donisthorpe $)^{70}$.

Surrey : Lambeth ${ }^{19}$ and Vauxhall ${ }^{9}$ (Wing); Richmond Park ${ }^{69}$, Box Hill and Oxshott ${ }^{62}$ (Donisthorpe); Esher (Arnold); Woking and Chobham ${ }^{40}$ (Saunders); Shiere (Capron) ${ }^{38}$; Weybridge (F. Smith)?

Essex, S. : Walthamstow, Chingford and Epping Forest (E. $A$. Butler).

Herts : Letchworth (E. A. Butler).

Middlesex : Paddington ${ }^{9}$ and Highgate ${ }^{29}$ (F. Smith); Enfield (Pool and Donisthorpe) ${ }^{69}$. 
Berkshire : Tubney (Donisthorpe) ${ }^{69}$.

Buckinghamshire : Bourne End (Best Gardner).

Suffolk, E. : Bentley Woods (Morley) ${ }^{59}$; Barnby Broad (Bedwell) ; Suffolk, W.: Tostock (Tuck) ${ }^{60}$.

Norfolk, E. : Near Norwich (Bridgman) ${ }^{43}$.

Northampton: Helpston Heath (Morley).

Worcester : Hallow ${ }^{61}$.

Warwickshire : Warwick (Fryer $)^{52}$.

Leicestershire: Ayleston (S.O. Taylor).

Kerry : Kenmare Bay (Halbert) ${ }^{69}$.

The greatest confusion formerly existed in the synonymy of this species, as its male was incorrectly treated as that of Formicoxenus nitidulus, and it was not until Er. André ${ }^{2}$ first pointed out the error, in 1881, that the matter was finally cleared up.

Stenamma westwoodi is a rare species of obscure habits ; according to André ${ }^{2}$ it occurs in shady places in woods and forests, nesting in the earth under moss and dead leaves, the nest being difficult to detect, and $\mathrm{Mayr}^{27}$ states its habits are similar to those of Leptothorax. Nylander ${ }^{15}$ records it in moss in the Forest of Fontainebleau, von Hagens ${ }^{35}$ in all the woods at Cleve, single workers being found in moss and under leaves, and Wasmann ${ }^{48}$ took it occasionally under leaves in Dutch Limburg.

Fore ${ }^{36}$ mentions that Emery discovered it at Prillynear Lausanne, and that they both took a number of workers at roots under dry leaves on the borders of a stream in a wood there in September, 1873 , but no nest was found. I also captured a number of workers, in moss, in company with Myrmica ruginodis, on April 30th, 1905, at Ditchling in Sussex, but could not trace their nest.

Tuck records a specimen in a nest of Bombus terrestris ${ }^{57}$ found at Tostock ${ }^{60}$, and Farren-White the capture of a worker with a dead companion in its mandibles in the Valley of Rocks at Lynton ${ }^{55}$.

Von Hagens ${ }^{34}$ once found an independent colony at Elberfeld, consisting of a deälated female and workers, and Wasmann another, situated under a stone in a wood at Laacher See (Rheinischen Vordereifel) in August 1889, some eighty workers and twelve males being present, no female however being found ${ }^{48} 49$.

This Stenamma has been frequently taken with other ants; von Hagens speaks of it as presumably a guest-ant, the workers occurring preferably in, or near, other ants' colonies ${ }^{33}$, and Escherich as commonly in the neighbourhood of other ants' nests ${ }^{65}$.

André considers its occurrence in such situations as only accidental ${ }^{42}$, and Wasmann is of the opinion that it is not a myrmecophilous species ${ }^{54}$; nevertheless the records with other ants appear to me to be too numerous to be treated as of purely accidental occurrence. F. Smith records its capture amongst a colony of Formica fusca, by Reading in July, 1857, near Plymouth ${ }^{18}$ - twice in 
a nest of Donisthorpea fuliginosa by himself in 185924-by Edwin Shepherd with the same ant in $1860^{26}$, and he points out that E. W. Janson had taken it previously, also with the same Donisthorpea -in 1863 he writes- "This minute ant appears to be a constant resident in the nests of other species, at least in this country; whether it is found invariably in such situations throughout Europe, I am not prepared to say, but I have never found it separated from other ants. Mr. Janson and also Mr. Shepherd, find it in nests of Formica fuliginosa. I have also myself found it in company with the same species, but sparingly. In May last it occurred in some numbers in ants' nests near Highgate, but I have only been successful in taking workers; the only examples I have ever obtained of the other sexes are two females; one was taken on the wing in October, and the other on a Christmas Day, some years ago. I am inclined to believe that M. lippula never constructs its own nest, but resides constantly with species of Formicidae."29 In 1863 he found this species in some abundance in and in the vicinity of a nest of Formica rufa ${ }^{31}$. Von Hagens records workers at Cleve, chiefly with Donisthorpea fuliginosa, singly with Formica sanguinea and D. brunnea ${ }^{34}$. Parfitt found a worker in a nest of F. rufa in Devonshire ${ }^{41}$; Farren-White took it at Charlton in company with D. umbrata ${ }^{55}$, and Saunders near a nest of $F$. rufa and another of $D$. fuliginosa under dead leaves at Chobham in May, $1893^{45} 58$.

Wasmann records it for Dutch Limburg in the neighbourhood of nests of $D$. umbrata, D. brunnea, and $M$. ruginodis ${ }^{48}$.

My own captures of this species in other ants'nests are as follows :Seven specimens at different times in a nest of $D$. fuliginosa at Oxshott ${ }^{62}$ - singly in a nest of $F$. rufa in Parkhurst Forest ${ }^{70}$ (April 26th, 1909), and D. fuliginosa at Darenth Wood ${ }^{70}$ (June 5th, 1909) - a worker in a nest of D. mixta at Box Hill on May 23rd, 1913 - and five workers with D. fuliginosa at Weybridge (September 7 th and 12th, 1914). No winged forms however appear to have been found with other ants, as was also pointed out by von Hagens ${ }^{34}$.

The winged forms occur late in the year, and the marriage flight takes place in September and October.

Curtis captured a male at Blackgang Chine in the middle of October, $1829^{8}$, Wing a female flying at Vauxhall on December 9th, $1850^{5}$, and F. Smith two winged females at Paddington in September $1854^{\circ}$, and whilst sketching the ruins of Corfe Castle a male alighted on his sketch book ${ }^{30}$, on October 6th, 1863.

Von Hagens records a marriage flight at Elberfeld on October 15 th, $1864^{34}$. Capron found a male at Shere on October 15th, $1878^{38}$, Frisby took two winged females at rest on the inside of a half-opened window at Maidstone at the end of August or beginning of September, $1887^{47}$, and Saunders records the capture by 
himself of a male at Ilfracombe in September, and a number of specimens, taken by Dale in various localities, all winged and occurring in October ${ }^{58}$. I captured a winged female by evening sweeping on October 3rd, 1905, at Tubney, males and winged females, at Enfield with Pool, in October, 1906, and an isolated deälated female on the sand-hills at Studland on September 3rd, 1905.

Emery records two specimens in which the wings are abnormalin the one, a female, in both fore-wings a nerve incompletely separates the cubital cell, as in Myrmica; in the other, a male, the right fore-wing possesses a second cubital cell, small and detached from the radial cell ${ }^{72}$.

Perkins records and describes a curious specimen of Stenamma westwoodi which he picked up while walking between Dartmouth and Stoke Fleming in October, 1890. It is an approximately lateral ergatandromorph, the left side being worker, the right side male, and the gaster apparently worker. He described it as follows ${ }^{51}$ :-

"Left Half. Head red, with darker cloud reaching from vertex to eye. Mandible very large with 7 teeth. Antennae 12-jointed, testaceous, with pale hairs ; first joint of flagellum longer than next two together; these and the following joints much wider than long; apical joint very large and stout, as long as two preceding; scape very long and bent, as long as many joints of flagellum. Eye small. Mesothorax red. Second node of petiole lighter. Abdomen from middle line testaceous-brown. Legs shorter and thicker.

"Right Half. Head dark brown. Mandible small (the ant being carded I cannot clearly make out the form of the right mandible). Antennae 13jointed, dark, thin, with pale hairs ; lst joint of flagellum stouter than next, but sub-equal to it; the following joints all much longer than wide; apical joint as long as on left side, but not nearly so stout ; scape short and straight, only about as long as two joints of flagellum, and per se barely half the length of that of left side. Eye larger; more than twice the size of the other, and much nearer to the base of antenna. Mesothorax dark, laterally with two rough projections, apparently tegulae. Second node of petiole darker. Abdomen from middle line dark brown. Legs longer and thinner.

"The form of the abdomen, so far as I can make out in this specimen (set on card) is that of the $\forall$. The shape of the mesothorax is unsymmetrical bilaterally. Length about $3 \mathrm{~mm}$."

This specimen is now in the Cambridge Museum.

\section{LEPTOTHORAX Mayr.}

( $\lambda \epsilon \pi \tau \delta s$, slender ; $\theta \dot{\omega} \rho a \xi$, thorax.)

\section{Type: Leptothorax clypeatus Mayr (Emery, 1912).}

This is a large, widely distributed, homogeneous genus, its species being closely related to each other, and often only separated by somewhat trivial characters. It occurs in Europe, India, Japan, Africa, North America, etc., and comprises very agile, robust, and hard ants, which however are of a timid and adaptable temperament, and not at all warlike in nature. Their habits are singularly 
Plate VIII.
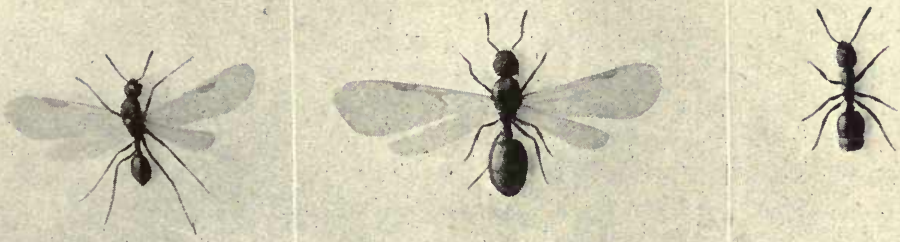

Male, female, and worker of Leptothorax interruptus.
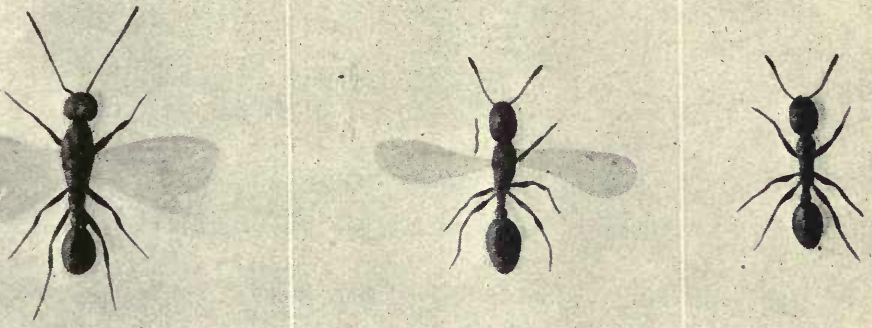

Male, female, and worker of Leptothorax acervorum.

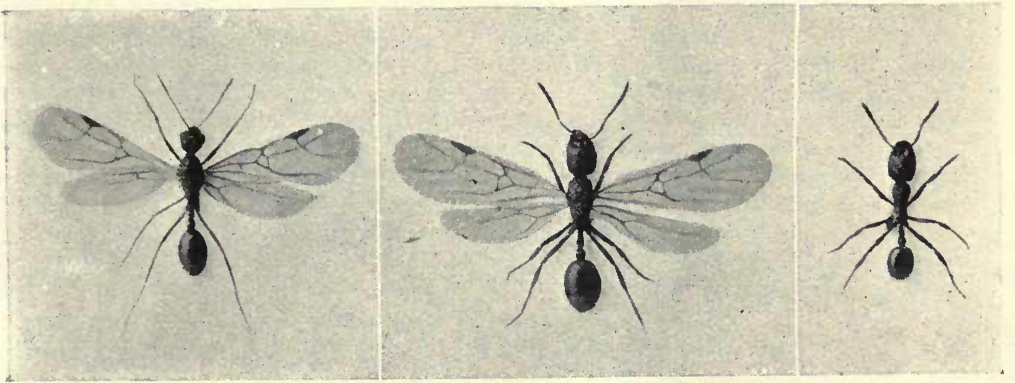

Male, female, and worker of Stenamma westwoodi. 
diverse, and they live in small communities nesting under stones, in the ground, under bark, in moss, in hollow twigs, in rotten branches, in galls and fallen nuts, in the borings of other insects, and between the laminae of stones, etc.

The queens are very little larger than the workers, at least in the large species, and their habits are very similar, both the winged and deälated females carrying about the larvae and pupae in their mandibles.

There is generally more than one fertile female in the same colony, and sometimes the virgin females remove their own wings without leaving the nest. The marriage flight is similar to that of the genus Myrmica, but too few males and females occur to enable it to be called a swarm.

A number of intermediate forms between the females and workers frequently occur, and both microgynes and ergatoid females are often present in the same colony with typical females.

When one of the workers is carried by another, it is seized by the mandibles and swung over the back of the carrier, with the dorsal surface uppermost.

These ants do not keep Aphidae in their nests, nor do they appear to seek them on plants, but they lick the leaves of trees and plants on which honey-dew has fallen.

Many species have a tendency to enter into more or less close symbiotic relations with other ants.

This is the only genus in which the ants are furnished with blunt hairs, which have been called "clubbed hairs," but which in any case are never pointed.

Wheeler designated Formica acervorum Fabricius as the type of the genus Leptothorax [Ann. New York Acad. Sci. 21166 (1911)], but Emery [Ânn. Soc. Ent. Belg. 56271 (1912)] selects L. clypeatus Mayr, both because it was the first species described by Mayr, and because $L$. acervorum Nylander has already been made the type of the subgenus Mychothorax by Ruzsky.

$\Varangle$ Head oblong, rounded posteriorly; clypeus triangular, concave or convex, transverse anteriorly ; frontal carinae short, almost straight; frontal area somewhat impressed, not clearly defined; mandibles broad, terminal margin armed with four or five teeth; maxillary palpi five-jointed; labial palpi three-jointed; antennae eleven-, or twelve-jointed, first joint, and last three joints of funiculus longer than broad, the latter forming a distinct club about as long as the rest of the funiculus, its last joint being equal in length to or a little longer than the two preceding taken together. Thorax long and narrow ; pronotum rounded anteriorly ; suture between pronotum and mesonotum wanting, between mesonotum and epinotum marked, or wanting; epinotum armed with two teeth, or spines. Petiole cylindrical anteriorly, nodiform posteriorly; post-petiole nodiform; gaster oblong oval; sting large.

The body is furnished with short, scattered, blunt hairs.

o Very like the $\not{\gamma}$; gaster longer oval. Wings very pale; fore-wings with one cubital cell, and one discoidal cell.

ô Head triangular; mandibles narrow, flat, unarmed, or furnished with 
four or five teeth; antennae twelve-, or thirteen-jointed; mesonotum with more or less distinct Mayrian furrows; epinotum armed with two tubercles. Wings as in the ㅇ․

Ovum : White, round oval.

Larva: Whitish yellow, slightly pyriform, but the posterior segments not much wider than the anterior ones, clothed with longer and shorter hairs which are more abundant on the younger larvae. The first to the sixth abdominal segments furnished with a pair of long anchor-tipped hairs, on the dorsal surface.

Pupa: Yellow, wax-like, colour of adult when mature.

\section{Original description [Mayr Verh. Zool. Bot. Ver. Wien 5431 $(1855)]:-$ \\ 66 \\ Leptothorax Mayr n.g. \\ $\lambda \epsilon \pi \tau$ os schlank, $\theta \dot{\omega} \rho a \xi$ Brust.}

Arbeiter. Der feingerunzelte Kopf ist langer als breit und breiter als der Thorax. Die Oberkiefer sind breit und gezähnt. Die Unterkiefertaster sind fünfgliedrig, deren letztes Glied ist das längste von allen. Die Lippentaster sind dreigliedrig. Die Oberlippe ist in der Mitte des Vorderrandes schwach stumpwinklig ausgerandet. Der Clypeus ist sehr wenig gewölbt oder vorne concav, bei einer Art undeutlich gezähnt. Die Fühler sind eilf- bis zwölfgliedrig. Die Punctaugen sind wohl meist vorhanden, aber oft sehr undeutlich, ebenso das Stirnfeld. Die Netzaugen sind nicht klein. Der fein gerunzelte und schlanke Thorax is vorne am breitesten und verschmälert sich allmählig nach hinten, er ist oben zwischen dem Meso- und Metanotum nicht eingeschnürt, sondern bloss mit einer Furche versehen. Das Metanotum trägt zwei horizontal nach hinten oder schief nach hinten und aufwärts gerichtete Dornen. Das erste Glied des Stielchens ist vorne kurz stielförmig, hinten knotenförmig ; das zweite Glied ist knotenförmig unten nicht bedornt, der Knoten ist so lang als breit und etwas niedriger als der erste Knoten. Der Hinterleib ist rundlich oder oval und über drei Viertheile desselben werden von seinem ersten Segmente bedeckt.

Weibchen. Der Kopf ist mit Ausnahme der Punct- und Netzaugen so wie beim $\measuredangle$. Der Thorax is von vorne bis zur Mitte ziemlich gleichbreit oder nur unbedeutend in der Mitte breiter. Das Mesonotum ist stark abgeflacht. Das mit zwei horizontal nach hinten oder nach hinten und aufwärts gerichteten Zähnen oder Dornen versehene Metanotum vermehrt die Länge des Thorax um seine eigene Länge und hat eine nur wenig nach abwärts geneigte Basalfläche. Das Steilchen ist so wie beim $\not$, nur ist der zweite Knoten meist unbedeutend breiter als lang. Der Hinterleib ist ei- oder langlicheiförmig, und wenigstens zwei Drittel desselben werden von seinem ersten Segmente bedeckt. Die Flügel sind milchweiss oder sehr schwach gelblich, ebenso deren Rippen. Die Costa transversa verbindet sich mit der Costa cubitalis an deren Theilungsstelle, wodurch bloss eine einzige geschlossene Cubitalzelle entsteht ; der innere Cubitalast ist oft nicht deutlich ausgebildet; die geschlossene Discoidalzelle ist vorhanden.

Männchen. Der Kopf ist kurz und breiter als der Thorax. Die Oberkiefer sind nicht breit, gezähnt oder ungezähnt. Der Clypeus ist schwach gewölbt. Der Schaft der zwölf- bis dreizehngliedrigen Fühler ist kurz, die Geissel ist fadenförmig. Die Punctaugen sind gross, die Netzaugen stehen stark hervor. Das Mesonotum ist mit zwei nach hinten convergirenden Linien versehen. Der Metathorax ist nicht verlängert und das Metanotum ist mit zwei Beulen, selten mit zwei sehr kurzen Zähnchen versehen. Das erste Glied des Stielchens ist hinten knotenförmig verdickt und nach vorne conisch zulaufend; das zweite Glied ist knotenförmig. Das erste Segment des Hinterleibes bedeckt etwa zwei Dritte! des letzteren. Die Flügel sind so wie beim + gebildet." 


\title{
Table of the Species.
}

\author{
૪
}

1 Antennae 12-jointed . . . . . . . . . . . . . . 2

- Antennae 11-jointed (subgen. Mychothorax Ruzsky) - - 1 acervorum F.

2 Club not darker than the rest of antenna . . . . . . . . 3

(1) Club darker than the rest of antenna $\ldots \ldots \ldots \ldots$

3 An impression between mesonotum and epinotum; spines long ...

2) No impression $\cdot \cdot \cdot \cdot \cdot \cdot \cdot \cdot \cdot \cdot 2$ nylanderi Först. No impression between mesonotum and epinotum; spines short - -

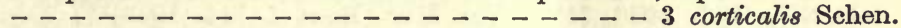

4 f Epinotal spines longer, curved. . . . . . 5 interruptus Schen.

(2) Epinotal spines shorter, not curved _ - - - - -4 tuberum $\mathrm{F}$.

1 f Antennae 12-jointed . . . . . . . . . . . . . 2

- Antennae 11-jointed _ _ _ _ $\ldots \ldots \ldots$ - $\ldots$ acervorum F.

2 Club not darker than the rest of antenna . . . . . . . . . 3

(1) Club darker than the rest of antenna $-\ldots \ldots \ldots$

3 Gaster banded; spines long . . . . . . . . nylanderi Först.

(2) Gaster not banded; spines short _ . . . . - corticalis Schen.

4 Scutellum striate; spines shorter . . . . . . . . tuberum F.

(2) Scutellum smooth and shining in centre; spines longer-

๙ิ

1 Antennae 13-jointed . . . . . . . . . . . . . 2

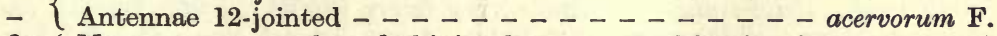

$2\{$ Mesonotum smooth and shining between the Mayrian furrows . . 3

(1) Mesonotum not smooth and shining between the Mayrian furrows - 4

$3\{$ Epinotum armed with small tubercles . . . . . corticalis Schen.

(2) Epinotum without or with very faint tubercles - - nylanderi Först.

4 Joints 2-5 of funiculus as broad as long . . . . interruptus Schen.

(2) Joints 2-5 of funiculus longer than broad - - - - - tuberum F.

\section{Leptothorax acervorum F.}

Formica acervorum Fabricius Ent. Syst. 2358 (1793). ${ }^{1}$ Formica rubra var. acervorum Latreille Hist. Nat. Fourmis $250(1802)^{2}$. Formica graminicola Latreille Hist. Nat. Fourmis 255 (1802) $\zeta^{3}$. Myrmica acervorum Zetterstedt Insect. Lappon. 1451 (1838) 우 ㅇ․ Myrmica lacteipennis Zetterstedt Insect. Lappon. 1452 (1838) $\delta^{5}$. Myrmica acervorum Curtis Trans. Linn. Soc. Lond. $21215(1854)^{6}$; F. Smith Trans. Ent. Soc. Lond. (n.s.) 3 124-125 (1855) Leptothorax acervorum Mayr Verh. Zool. Bot. Ver. Wien $5436(1855)^{8}$. Myrmica (Leptothorax) acervorum F. Smith Brit. Foss. Hym. 29 (1858) : Trans. Ent. Soc. Lond. (n.s.) $41857280(1858)^{10}$. Leptothorax acervorum Forel Denkschr. Schweiz. Ges. Naturw. 2684341403 (1874)11 ; Cameron Proc. NH. Soc. Glasgow $2294(1876)^{12}$ : $390(1876)^{13}: 3105(1877)^{14}$. Myrmica (Leptothorax) acervorum Service Scot. Nat. $563(1879)^{15}$. Leptothorax acervorum Parfitt Trans. Devon Assn. Sc-Art. $12516(1880)^{16}$; Saunders Trans. Ent. Soc. Lond. $1880219^{17}$; Er. André Hym. Europe $2294(1881)^{18}$; Dale Ent.

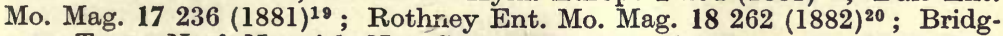
man Trans. Norf. Norwich Nat. Soc. $4690(1889)^{21}$; Wasmann Stett. Ent. Zeit. $51309(1890)^{22}$ : zusam. Nest. gemischt. Kolon. Ameisen $8(1891)^{23}$; Rothney Ent. Mo. Mag. 28 50-51 (1892) ${ }^{24}$; W. Gardner Brit. Nat. 223 $(1892)^{25}$; Dalla Torre Cat. Hym. $7122(1893)^{26}$; Rothney Ent. Mo. Mag. 29 67-68 (1893) ${ }^{27}$; Farren-White Ants' Ways 171 243-244 (1895) ${ }^{28}$; Carpenter Irish Nat. 4257 (1895) $^{29}$; Wasmann Biol. Centralb. 15 618-619 (1895) ${ }^{30}$; Saunders Hym-Acul. 37 (1896) ${ }^{31}$; Service Scott-Elliott's Flora Dumfriesshire 
XV (1896) $)^{32}$; Johnson Irish Nat. 657 (1897) $)^{33}$; Cuthbert Irish Nat. $767^{34}$ $209^{35}$ (1898); Morley Hym. Suffolk 22 (1899) ${ }^{36}$; Saunders Ent. Mo. Mag. $3614(1900)^{37}$; Donisthorpe Ent. Rec. $12176(1900)^{38}$; Vic. Hist. Cumberland $1103(1901)^{39}$; Malloch Fauna, Flora, Geol. Clyde Area $219(1901)^{40}$;

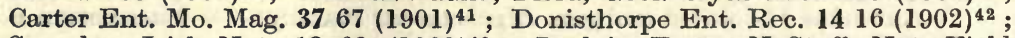
Saunders Irish Nat. $1268(1903)^{43}$; Jordain Trans. N-Staff. Nat. Field Club $1782(1903)^{44}$; Vic. Hist. Sussex $1131(1905)^{45}$; Harwood Ent. Mo. Mag. $41117(1905)^{46}$; Vic. Hist. Berks. $176(1906)^{47}$; Vic. Hist. Cornwall $1182(1906)^{48}$; Rothney Ent. Mo. Mag. $4214(1906)^{49}$; Donisthorpe Ent. Rec. $18317(1906)^{50}$; Escherich Ameise 218 (1906) ${ }^{51}$; Frisby Proc. Holmesdale NH. Club $19067^{52}$; Vic. Hist. Kent $1116(1908)^{53}$; Donisthorpe Trans. Leicester Lit-Phil. Soc. $12227(1908)^{54}$; Morley Ent. Mo. Mag. 44 $215(1908)^{55}$; Silverlock Nat. $191013^{56}$; Wasmann Biol. Centralb. 30 494-495 (1910) $)^{57}$; Donisthorpe Ent. Rec. 23 11-12 (1911) ${ }^{58}$; Orr Irish Nat. $2076(1911)^{59}$; Donisthorpe Entom. 44390 (1911)60: Ent. Rec. 24 $5(1912)^{61}$; Evans Scot. Nat. $1912107^{62}$; J. Taylor Ent. Rec. $2465(1912)^{63}$; Donisthorpe Ent. Rec. 25 62-63 (1913) ${ }^{64}$ : Rep. Lancs-Chesh. Ent. Soc. $36191254(1913)^{65}$; Hallett Trans. Cardiff Nat. Soc. $453(1913)^{66}$; Crawley and Donisthorpe Int. Ent. Cong. Oxford $2191220(1913)^{67}$; Donisthorpe Ent. Rec. 2638 (1914) $^{68}$; Crawley Ent. Rec. 26 91, 95, $97(1914)^{69}$.

$\Varangle$ Reddish yellow with the head, club of antennae, and dorsal surface of the gaster darker, occasionally the whole body is yellow, the darker parts being only slightly darker, or brown with the darker parts brownish black.

Head longitudinally striate; clypeus somewhat concave, smooth and shining; antennae eleven-jointed, club blackish. Thorax more or less rugose ; suture between mesonotum and epinotum distinct; epinotal spines moderately long. Petiole and post-petiole very finely rugose; gaster smooth and shining. Legs : tibiae with erect hairs. Long. $3 \cdot 4-4.5 \mathrm{~mm}$. $(3 \cdot 3-3 \cdot 7 \mathrm{~mm}$. teste Forel.)

ㅇ Very like the $\not{q}$, generally darker in colour, mesonotum often red with black patches.

Antennae eleven-jointed. Tibiae with erect hairs. Wings white, the radial cell open. Long. 4-4.8 mm. (3.5-4.2 mm. teste Forel.)

ot Black, or brownish black; tibiae and tarsi, and the articulations of the legs yellow.

Head rugose; antennae twelve-jointed, the joints of the funiculus only broader at the apex, and not forming a distinct club, second joint of funiculus longer than the scape. Thorax rugose. Petiole finely longitudinally striate; post-petiole and gaster smooth and shining. Wings as in the f. Long. 4.8-5 mm. (3.7-4.8 mm. teste Forel.)

Original description of Formica acervorum Fabricius [Ent. Syst. 2358 (1793)] :-

"F. rufa capite abdomineque nigris, thorace postice bispinoso, petiolo binodi.

Habitat in Daniae nemoribus Mus. Dom. de Sehestedt.

Nimis certe affinis F. tuberum. Caput nigrum antennis mandibulisque rufis. Thorax rufus dorso nigro postice spinis duabus porrectis, validis, acutis. Petiolus ferrugineus, binodis. Abdomen glabrum, atrum, immaculatum. Pedes ferruginei."

\section{Habitat.}

Leptothorax acervorum ranges over the whole of Europe except in the extreme south, and Ruzsky records it from Siberia and Turkestan.

Its distribution in the British Isles is as follows :-

Cornwall, E. : Near Looe ${ }^{48}$. 


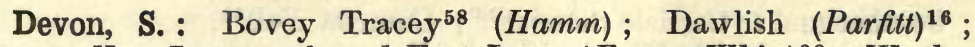
Devon, N. : Lynmouth and East Lynn (Farren-White) ${ }^{28}$; Woolacombe Sands (Parfitt) ${ }^{16}$.

Wilts, N. : Sopworth (Perkins, Cambridge Mus. Coll.).

Dorset: Glanvilles Wootton ${ }^{7}$ and Lulworth ${ }^{7}$ (Dale); Morden, Upper Rockhampton, Puddletown Heath, Tadnoll, and Redbridge (Haines).

Isle of Wight : Parkhurst Forest $(J . \text { Taylor })^{63}$.

Hants, S. : New Forest ${ }^{7}$ (Dale) ; Bournemouth (Farren-White) $^{28}$; Hants, N. : Harewood Forest (Harwood).

Sussex, W. : Harting ${ }^{37}$ (Beaumont) ; Sussex, E. : Guestling ${ }^{45}$ and Bexhill $^{45}$ (Frisby) ; Fairlight ${ }^{38}$ and Camber Sands ${ }^{61}$ (Donisthorpe).

Kent, E. : Hollingbourne ${ }^{53}$; Maidstone ${ }^{31}$ (Frisby); Thurnham (Frisby) $^{53}$; Throwley ${ }^{53}$ (Chitty).

Kent, W. : Birchwood (Power, Rothney Coll.).

Surrey: Shirley (F. Smith $)^{7}$; near Croydon (Saunders) ${ }^{17}$; Box Hill (King) ; Nutfield Marsh (Frisby) ${ }^{52}$; Weybridge (Donisthorpe $)^{42}$; Woking (Saunders) ${ }^{31}$; Woodham (Morice).

Essex, S. : Chingford and Loughton (E. A. Butler).

Middlesex : Enfield ${ }^{50}$ (Pool).

Berks : Wellington College (Farren-White) ${ }^{28}$; Boar's Hill ${ }^{4}$, Bagley Wood and Tubney (Hamm); Greenham (Harwood).

Oxford : Shotover Hill (Hamm).

Bucks : Pollard's Wood, Chalfont St. Giles (Elliman).

Suffolk, W.: Brandon district ${ }^{36}$ (Perkins); Norton Wood ${ }^{36}$ (Tuck).

Norfolk, E. : Earlham (Bridgman $)^{21}$.

Hunts : Monk's Wood ${ }^{55}$ (Chitty).

Gloucester, W.: Stonehouse, Leonard Stanley, Haresfield, Buckstone near Staunton, and the Forest of Dean (Farren-White) ${ }^{28}$.

Hereford: Lydbrook Junction and Symond's Yat (FarrenWhite) ${ }^{28}$.

Stafford : Colwich ${ }^{44}$ (Martineau).

Glamorgan : Cwrt-yr-ala and Ponthneathvaughan (Hallett ${ }^{66}$.

Carmarthen : Carmarthen (E. A. Butler).

Lincoln, N.: Market Rasen (Morley).

Leicestershire : Buddon Wood (S. O. Taylor).

Nottinghamshire : Sherwood Forest (Bedwell).

Derby : Little Eaton (Harwood) ${ }^{46}$.

Cheshire: Bidstone Hill, Birkenhead ${ }^{25}$ (Burns); Delamere Forest (Arnold).

Yorks., N.E.: Goathland (Śaunders's Coll.) ; Normanby, Middlesborough, and Stanghow (Walsh); Lythe (E. A. Butler); Yorks., S.W. : Hebden Bridge (Silverlock) ${ }^{56}$.

Durham : Chopwell (Walsh).

Northumberland, S.: West Allendale ( $\mathrm{Hull}$ ).

Cheviotland: Isle of Lindisfarne (W. E. Sharp). 
Cumberland : Carlisle district ${ }^{39}$; Cumrew Fell ${ }^{39}$.

Dumfries: Mabie Woods (Service) ${ }^{32}$.

Lanark : Coatbridge ${ }^{64}$ (G. Brown).

Peebles : Macbiehill (Evans) ${ }^{62}$.

Haddington : Saltoun (Evans) ${ }^{62}$.

Edinburgh : Salisbury Crags, Polton, Ravensnook near Penicuik, Bavelaw, Ravebrig-toll Moss, Kirknewton, Newpark, and Torduff $\left(\right.$ Evans) ${ }^{62}$.

Linlithgow : Binny Craig (Evans) ${ }^{62}$.

Fife and Kinross : Thornton and Blair Adam (Evans) ${ }^{62}$.

Stirling : Near Falkirk (Evans) ${ }^{62}$

Perth, S. : Near Callander and Kelty Glen, Aberfoyle $(\text { Evans })^{62}$; Perth, Mid. : Comrie (Carter) ${ }^{41}$; Fillans (Rothney) ${ }^{49}$; Ben Lawers

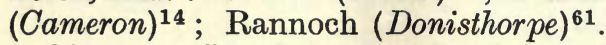

Aberdeen, S. : Braemar (Donisthorpe) ${ }^{58}$.

Elgin : Forres (King).

Easterness : Nethy Bridge (Donisthorpe) ${ }^{54}$; Aviemore (Champion); Kingussie ${ }^{13}$ and Strathglass ${ }^{12}$ (Cameron).

Ebudes, N.: Isle of Skye (R. B. Robertson).

Ross, W. : Kintail (Cameron) ${ }^{12}$.

Down: Newcastle (F.X.King).

Armagh : Rich Hill $(\mathrm{Orr})^{59}$.

Louth : Carlingford ${ }^{31}$ (Johnson).

Dublin : Howth (Halbert).

Wicklow : Bray Head (Johnson) ${ }^{33}$.

Galway, W.: Lough Corrib (Carpenter) ${ }^{29}$.

Kerry : Cromaglaun Mt. (Cuthbert) $)^{35}$; Cloonee ${ }^{35}$ (Halbert); Bull Mount, Killarney (Morley) ; Ballybunion (Cuthbert) ${ }^{34}$; Rossbeigh $^{43}$ and Turner's Rock (Donisthorpe).

The colonies of Leptothorax acervorum are never very populous, and it nests under the bark of tree-stumps-oak and especially fir, etc.-but also under stones, where $I$ have found it on the mountains at Rannoch and Braemar. Parfitt states that this ant constructs little runs by the sides of walls ${ }^{16}$, having found it in such situations at Dawlish ; and I once discovered it at Fairlight, near the "Lovers" Leap," in the cracks of a rock. It will also take advantage of the borings of other insects, Tuck having taken it on a post tenanted by the wasp Odynerus sinuatus ${ }^{36}$ at Norton Wood in Suffolk, and I picked up a fallen "oak-apple" at Weybridge on September 14th, 1912, which contained a small colony of $L$. acervorum consisting of a deälated female, seventy-three workers and some larvae ${ }^{64}$.

André says it is an alpine or sub-alpine species ${ }^{18}$, and Saunders speaks of it as chiefly a northern species in Britain ${ }^{17}$, but it is equally common here in the south.

Forel points out that the alpine variety of acervorum is sometimes nearly entirely brownish black in colour, and lives under stones ${ }^{11}$, 
Cameron records an almost black variety at Kintail ${ }^{12}$, and I have recorded a colony of very dark-coloured specimens found under stones on a mountain at Rannoch ${ }^{61}$.

Saunders states that the males and females appear in September ${ }^{31}$; they are, however, generally to be found much earlier in the year. Cameron recorded males on the top of Ben Lawers in July ${ }^{14}$, Carter males and winged females at Comrie in the same month ${ }^{41}$, and Schenck says that this species swarms in July, and that he found the first winged forms on July 5th at Nassau. Forel observed the copulation of this ant, on a wall on Mont Tendre in Switzerland on July 30 th, $1871^{11}$.

I have found males at Nethy Bridge on June 19th, 1911, males and winged females in the same locality on July 24th, 1907, in the New Forest on July 22nd, 1912, and at Rannoch on July 15th, 1913 , etc.

The queens will carry the larvae in their mandibles, and when a nest is disturbed they may be seen to pick up their brood and hurry off into safety, in the same manner as do the workers, but Hamm has told me that he has actually seen the male perform the same action ${ }^{64}$. Forel has shown that the virgin females in captivity lose their wings in two or three days, removing them themselves, and as females with small gasters are often found in a colony, he suggests that it may be to increase the numbers of the colony, as the workers are not numerous and the females help in the work, and also that they may be fertilized in the nest later on by males produced in it ${ }^{11}$. The female, not being larger than the male, is of course unable to carry him during the marriage flight.

Many microgynes often occur in colonies of Leptothorax acervorum, side by side with ordinary sized females, and Wasmann records a number of instances of small females, and also intermediate forms between the worker and female, in colonies of this ant in Holland.

In Dutch Limburg he found individuals which represented every gradation in size and shape between the female and worker ${ }^{22}$, and he points out that microgynes are much more common than macrogynes ${ }^{30}$.

In a colony at Exaeten in July, 1889, he observed a number of winged females, some with a light yellow-brown thorax, the colour of the worker, and others with the darker colouration of the female, and he records that Dr. Otto Nickerl discovered at Neuhütt in Bohemia a number of light-coloured winged microgynes, which were smaller than the larger workers of the same colony. In August, 1891, in a colony under a stone at Arlberg Wasmann found a number of intermediate winged females, ranging from large dark macrogynes to small light microgynes ${ }^{30}$.

$\mathrm{He}$ also records a number of forms, intermediate in size, colour, and construction of the thorax, between the female and the worker, taken in a colony at Blijenbeck in September, $1884^{30}$. 
On September 14th, 1912, I found in a nest of Formica rufa at Weybridge three very large workers of Leptothorax acervorum, which were light in colour, but each possessed a large gaster and a somewhat larger thorax than that of the ordinary worker.

The female of this species is able to found a colony alone; the small colony in the oak-apple before mentioned was probably an instance of this kind, and I observed a solitary deälated female in a small cavity under a stone at Nethy Bridge on May 19th, $1912^{64}$.

A female may also enter the nest of some other species of ant, as Leptothorax acervorum is often found in such situations.

This ant is of a peaceable and gentle disposition, it does not attack other ants of its own, or different species, and it does not appear to be attacked by them. On March 7th, 1910, I collected two small colonies of this species at Weybridge, which were both situated under the bark of fir stumps-as these two stumps were at a considerable distance from each other, the two colonies could not have been connected in any way-and each consisted of a similar number of workers, a deälated female, and some larvae. When introduced into a small, single-chamber, plaster nest the two colonies were quite friendly together, and joined forces at once, all the larvae were collected into a heap in one corner of the nest, and both the females rested on them ${ }^{58}$. They were kept under observation for nine months, during which time they prospered, eggs were laid, and larvae reared. I have written in my notebook on October 30th- " Introduced a dead house-fly into the nest, much excitement noticed, the workers appear to signal to each other by striking the bottom and side of the plaster nest with their gasters."

A number of instances are on record illustrating how frequently L. acervorum occurs in the nests of other ants of different species:-

Farren-White found a colony at Shirley inhabiting a gorse stump in the centre of a nest of Formica sanguinea ${ }^{28}$; Rothney records specimens in a nest of the same ant in the same locality previous to $1882^{20}$, and in October, 1891, being again at Shirley in quest of nests of $F$. sanguinea, he was indebted, in his success in finding a small colony of that species, entirely to a worker of $L$. acervorum which by careful watching led him some yards straight to the former's secluded retreat, in which he also found other workers of the latter ${ }^{24}$. Again in 1892 the same observer found specimens of the Leptothorax in and about the nest of sanguinea at Shirley, more especially in April and May. He writes-" One worker which I watched entered the nest, remained a few seconds, and came out again in no way interfered with by sanguinea; but a small nest of Myrmica scabrinodis, situated within a foot or two of sanguinea's, which I opened up, was smartly attacked, and the workers dispersed. These observations seem to point to some fixed relations between sanguinea and acervorum."27

Burns took the acervorum in a nest of $F$. fusca at Bidston Hill, 
Birkenhead $^{25}$, Morice found it in a nest of the same ant at Woodham near Byfleet, Hamm discovered a strong colony in a nest of $F$. exsecta at Bovey Tracey ${ }^{58}$, Pool took males, winged females, and workers in a rufa nest at Enfield ${ }^{50}$, and Hull sent me specimens taken in March, 1912, in a nest of $F$. fusca at West Allendale situated at a height of $1100 \mathrm{ft}$.

Escherich states that $L$. acervorum occurs frequently in the neighbourhood of nests of $F$. rufa and $F$. sanguinea in Germany ${ }^{51}$.

Wasmann records it from Holland under bark of fir and oak in connection with Formica rufa, $F$. pratensis, $F$. sanguinea, and $F$. fusca, under the bark of an old oak stump with a strong colony of Donisthorpea fuliginosa, and in company with Myrmica ruginodis under fir bark ${ }^{23}$. He found it at Lippspringe, Westphalia in July, and in August, 1909, also with $F$. truncicola and $M$. laevinodis, but very rarely with $D$. nigra (the Leptothorax being nearer the size of the latter); on July 25th he discovered a small colony consisting of males, winged females, and workers, under the bark of a mossy stump in the middle of a nest of $M$. ruginodis ; and on August 26th another colony of the Leptothorax, containing many queens, in a nest of $F$. sanguinea in a root stump at Hoscheid.

He considers that the "peaceable neighbourhood " with strange ant species is the habitual and original condition of Leptothorax ${ }^{57}$.

My own captures of this species in other ants' nests are as follows :-

In the nest of $F$. rufa at Weybridge previous to $1902^{42}$ - occasionally with $F$. sanguinea at Woking in $1906^{50}$ - males, winged females, and workers in a nest of $F$. rufa at Nethy Bridge in July, 1908 , and continually with $F$. rufa at Weybridge in $1910^{58}-\mathrm{a}$ worker in a nest of $F$. exsecta, and a deälated female in a nest of F. pratensis at Rannoch on June 12th, 1911, and on a mountain there on June 14th, 1911, two colonies under the same stones as colonies of $M$. laevinodis; both species had larvae and pupae, and appeared to be quite friendly, they did not attack each other when disturbed, and if they picked up each other's larvae, or pupae, when taking them into safety, they put them down again ${ }^{61}$ males, winged females, and workers under a stone of a $F$. rufa nest in the New Forest on July 22nd, 191264, and workers and larvae in a nest of $F$. rufa at Weybridge on September 14th, 191265-a deälated female, workers, larvae, and pupae in a nest of $F$. sanguinea at Weybridge on July 12th, 1913, workers in two nests of $F$. rufa v. alpina at Rannoch on July 16th, 1913, and a worker in a nest of $F$. exsecta at Parkhurst Forest on August 23rd, $1913^{68}$.

On July 12th, 1913, I introduced into my observation nest of Formica sanguinea - which is situated in a "Crawley-Lubbock" nest-a deälated female and a few workers of Leptothorax acervorum taken in a sanguinea nest at Weybridge. The acervorum were not attacked by the sanguinea and soon disappeared into the 
nest. They were not observed again for some time, but during the winter of 1913 they were found to have excavated a small cell in the earth in a corner of the nest, removed from their hosts. They occasionally come out and walk about over the nest, and in the wooden box which contains it, and sometimes visit a small hole in a wooden support on the side of the box. When a Leptothorax meets a Formica-either sanguinea, or fusca (slave)-the former stands still and the latter generally runs over it without noticing it, but sometimes just tapping it with the antennae. This tiny colony has lived peaceably in this nest for over nine months.

On June 12th, 1911, I discovered a small colony of Leptothorax acervorum situated under the bark of a log lying in a saw-pit, all the ants of which were observed to be covered with a fungus, but were quite active. The tube in which some of the ants were placed was unfortunately lost, but the fungus was probably a species of Laboulbeniaceae ${ }^{61}$.

I have taken the Coleopteron Drusilla canaliculata F., in company with $L$. acervorum at Fairlight ${ }^{38}$; and Hallett has found the crustacean Platyarthrus hoffmanseggi Brndt., with this ant at Cwrt-yr-ala.

The following forms of Leptothorax with twelve joints to the antennae in the worker and female have been treated by some authorities (Mayr, etc.) as good species, by others as races (Forel, etc.) of $L$. tuberum, or subspecies (Crawley and Donisthorpe, etc.), and again by others as varieties (André, etc.) of $L$. tuberum F.

Without expressing any definite opinion on the subject, I prefer here to treat them as species, as it certainly simplifies matters.

The confusion which has arisen in Britain is chiefly due to the fact that $L$. unifasciatus was supposed to occur in this country, but nearly every British specimen recorded under this name must be referred to L. tuberum $\mathbf{F}$.

Stenamma albipennis Curtis is not distinct from Leptothorax tuberum F., though Dalla Torre erroneously gives it as a synonym of $L$. nylanderi Först.-Curtis describes his albipennis as having the club of the antennae in the worker fuscous, this proves that his insect was not nylanderi-Nylander sinks albipennis Curtis as a synonym of unifasciatus Ltr., and F. Smith recorded L. unifasciatus from Dover on the strength of specimens in Curtis' Collection (these were obviously the Dover specimens described by Curtis as albipennis).

It is evident that both Curtis and F. Smith were aware that considerable confusion existed with regard to the names of the British species of this group, as the former wrote of $L$. tuberum"This species requires investigation," and the latter writes"The unifasciata of British collections is not that which continental Hymenopterists consider to be Latreille's species; in one respect it does not quite agree: the female has, in fact, three bands on the 
abdomen, and the worker has the abdomen nearly entirely fuscous, only the base and apex pale ; it cannot be said to have ' une bande noire transverse sur le bord postérieure du premier segment" "but neither Curtis, Smith, Farren-White, nor Saunders made any attempt to rectify matters.

Saunders determined various specimens as unifasciatus, but I was never able to make these agree with Forel's tables, nor with descriptions of that species, and this led to my arranging in 1912 for the loan of all the specimens standing under the name of unifasciatus in the British, Oxford, and Cambridge Museums, these included the Saunders, Dale, Rothney, and Perkins collections, etc. Crawley and myself took these and others to Dr. Forel on our visits to him, and he determined nearly all these examples (undoubtedly correctly) as $L$. tuberum F., sensu stricto.

In 1914 Crawley published a revision of the British species of Leptothorax, which has added much to our knowledge of this genus. We appear to possess $L$. tuberum $\mathrm{F}$., $L$. nylanderi Förster, $L$. interruptus Schenck, and $L$. corticalis Schenck, but the inclusion of unifasciatus in our list requires confirmation as Crawley and I have seen every specimen captured here, with the exception of those in the Curtis collection (now in Melbourne Museum), and have been unable to detect unifasciatus among them.

Two workers, taken at Hayling Island in 1883 , were presented by Saunders to the Oxford Museum as unifasciatus; these are determined by Forel as affinis, all the other specimens taken by Saunders on Hayling Island are certainly tuberum. The specimens taken in 1883 were recorded by Saunders as occurring under a stone at Hayling, and in 1896 he speaks of large nests of unifasciatus also under stones at South Hayling, whereas Mayr, Forel, and André all record affinis as occurring on tree trunks and under bark. I took it at Yvorne in Switzerland in 1912 in a hollow walnut stick; Dr. Forel told me this is its usual habitat there. It would seem that the two specimens examined by Forel are more probably abnormal forms of tuberum rather than specimens of affinis, a species not actually known to occur in this country, and more material should be collected and examined before we can admit L. affinis Mayr to our list.

\section{Leptothorax nylanderi Först.}

Myrmica nylanderi Förster Hym. Stud. $153(1850)^{1}$; Schenck Jahr. Ver. Naturk. Nassau $8135 \cdot(1852)^{2}$. Myrmica cingulata Schenck Jahr. Ver. Naturk. Nassau 8 104-106 144 (1852) ${ }^{3}$. Myrmica tuberum Curtis Trans. Linn. Soc. Lond. 21216 (1854)4. Leptothorax nylanderi Mayr Verh. Zool. Bot. Ver. Wein 5 447-448 (1855) ${ }^{5}$. Myrmica (Leptothorax) cingulata Nylander Ann. Sc. Nat. Zool. (4) 593 (1856) $)^{6}$. Myrmica (Leptothorax) nylanderi F. Smith Cat. Brit. Foss. Hym. 30 (1858) ${ }^{7}$ : Trans. Ent. Soc. Lond. (n.s.) 4 $1857280(1858)^{8}$. Leptothorax nylanderi F. Smith Ent. Ann. $186894^{\circ}$. Leptothorax tuberum r. nylanderi Forel Denkschr. Schweiz. Ges. Naturw. 26】8410 $340^{11} 416^{12}$ (1874). Leptothorax nylanderi Parfitt Trans. Devon Assn. Sc- 
Art. 12 516-517 $(1880)^{13}$; Saunders Trans. Ent. Soc. Lond. 1880 219-22014 : Ent. Mo. Mag. $1769(1880)^{15}$. Leptothorax tuberum F. v. nylanderi Er. André Spec. Hym. Europe 2300 (1881) ${ }^{16}$. Leptothorax nylanderi Rothney

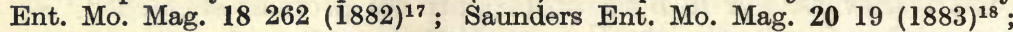
Dalla Torre Cat. Hym. 7125 (1893) $^{19}$; Farren-White Ants' Ways 244 (1895) ${ }^{20}$; Morley Ent. Rec. $6114(1895)^{21}$. Leptothorax tuberum F. race nylanderi Saunders Hym-Acul. 38 (1896) ${ }^{22}$; Morley Hym. Suffolk 22 (1899) $^{23}$. Leptothorax nylanderi Donisthorpe Ent. Rec. $1416(1902)^{24}$ : Trans. Leicester Lit-Phil. Soc. $12227(1908)^{25}$ : Ent. Rec. $20282(1908)^{26}$; Baynes Ent. Rec. $2398(1911)^{27}$; Leptothorax tuberum F., subsp. nylanderi Donisthorpe Entom. $44390(1911)^{28}$. Leptothorax nylanderi Donisthorpe Ent. Rec. 26 $39(1914)^{29}$ Leptothorax tuberum F. subsp. nylanderi Crawley Ent. Rec. $2692,95,107(1914)^{30}$.

$\Varangle$ Yellow, head above often reddish brown, gaster with a broad brown band on the first segment, and sometimes with narrow bands on the succeeding ones. The whole of the antennae, mandibles, and legs yellow.

Head finely longitudinally striate; clypeus as in tuberum; antennae twelve-jointed. Thorax finely rugose, with a distinct impression between the mesonotum and epinotum ; epinotal spines broad at the base, as long as two-thirds of the basal surface of the epinotum. Pedicel finely rugose, gaster smooth and shining. Legs without erect hairs. Long. $2 \cdot 3-3 \cdot 5 \mathrm{~mm}$.

i Yellow, head red to reddish brown, thorax mostly yellow, with two brown patches at the insertion of the wings, and a brown patch at the base of the scutellum, pedicel brownish, gaster yellow with a broad blackish brown band at the base of the first segment, and narrow bands at the base of the other segments; mandibles, clypeus, the whole of the antennae and legs yellow.

Head longitudinally striate; clypeus as in tuberum; antennae twelvejointed. Thorax : mesonotum longitudinally striate, but not so coarsely as in tuberum; scutellum smooth and shining in the centre; epinotal spines long, one-third as long as the basal face of the epinotum. Petiole and postpetiole more finely striate than in tuberum; gaster smooth and shining. Wings clear, radial cell small, closed. Long. $4 \cdot 2-4 \cdot 7 \mathrm{~mm}$.

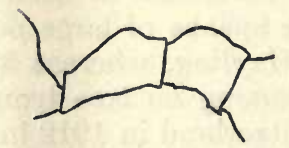

Fig. 76. Pedicel of Leptothorax nylanderi ô.

o Blackish brown, the clypeus, and sometimes the rest of the thorax, reddish brown, mandibles, antennae, legs and extremity of gaster pale dirty yellow. On the whole a little more robust than the male of tuberum.

Head a little more finely rugose than in tuberum; mandibles with four to five teeth*; antennae with joints as in tuberum. Thorax much less rugose than in tuberum ; mesonotum smooth and shining between the Mayrian furrows, the rest of the thorax is shining and smooth with the exception of some fine striae; epinotum without, or with only very faint tubercles. Pedicel smooth and shining ; petiole viewed in profile raised in centre, higher and less strongly rounded than in tuberum; post-petiole about as high as long; gaster smooth and shining. Wings as in the o. Long. 3-3.2 mm. $(2 \cdot 5-3 \cdot 2 \mathrm{~mm}$. teste Forel.)

Original description of Myrmica nylanderi Forster [Hym. Stud. $153(1850)]$ :-

"Mas : Fusco-nigricans, laevis ; capite et metathorace subtilissime rugulosis ; mandibulis et clypeo rufis; palpis, antennis 13-articulatis pedibusque

* Five-toothed in the specimens before me. 
flavis ; metathorace inermi, alis albo-hyalinis, area radiali aperta. Long. $1 \frac{1}{3}$ lin.

Die Färbung dieser Art ist ein mehr oder weniger dunkles Braun, der Kopf und Hinterleib geht mehr in's Schwärzliche. Der erstre erscheint fein runzlig, zwischen der Fühlerwurzel vom Clypeus bis zu den Nebenaugen hinauf mit feinen Längsstreifen. Der Clypeus und die Mandibeln sind roth, diese klein, mit 5 Zähnen, vor der Basis deutlich eingeschnürt, an der Spitze nur mässig erweitert, jener mit schwachen Längsrunzeln, übrigens glatt; ein Stirnfeld nicht deutlich abgesetzt. Die Fühler 13-gliedrig, der Schaft kurz, kaum die Länge der drei folgenden Glieder zusammen genommen übersteigend, an der Geissel das 1-7te Glied ungefähr von gleicher Dicke, das 1, 4, 6, 7te unter sich gleich, aber ein wenig länger als das 2 te 3,5 te, welche unter sich an Länge ebenfalls übereinstimmen; die 4 letzten Glieder bilden eine schwache Keule, deren Glieder allmählig an Grösse etwas wachsen, das letzte Glied is aber völlig so lang und fast etwas länger als die beiden vorhergehenden zusammen genommen. Fühler wie Taster blassgelb, die Nebenaugen sehr gross. Der Kopf in Allgemeinen sehr klein und hinter den stark vortretenden Netzaugen merklich eingeschnürt. Der Mittelleib pechbraun, nicht so dunkel gefärbt wie der Kopf, der Hals etwas röthlich. Von den 3 Lappen des Mesonotum's ist der mittlere fast ganz, die seitlichen aber nach vorne glatt, die Furchen convergiren in der Mitte des Mesonotum's, stossen aber nicht ganz zusammen und von hier aus bis zu dem Schildchen ist dieser Theil des Mittelbrustrückens etwas flach gedrückt und fein längsstreifig-runzlig. Die Mesopleurae und das Mesosternum völlig glatt und stark glänzend. Der Metathorax fein runzlig, unbewehrt, die abschüssige Stelle nur unmittelbar über der Anheftungsstelle des Hinterleibs ein wenig glatt. Die Flügel glashell, mit ganz blassen, unscheinbaren Adern, und eben so gefärbtem Stigma, die Radialzelle sehr schmal, nicht ganz geschlossen, die 1ste Diskoidalzelle ebenfalls nicht augebildet. Die Beine sehr dünn, ganz blassgelb und genau so gefärbt wie die Fühler. Die Schenkel schwach gebogen, das lste Fussglied länger als die 4 folgenden zusammen genommen, an dem vordersten Fusspaar aber an der Basis nur wenig gebogen und dabei etwas verdickt. Der Hinterleib tief schwarzbraun, die Knoten des 1sten Segments glatt, in den Seiten und am Hinterrande fein runzlig, an dem ersten Knoten die vordere sanft abschüssige Seite fast doppelt so lang als die hintere, mehr steil abfallende; die untere Seite nach der Basis hin in eine sehr feine aber auch sehr kurze Spitze ausgezogen. Auch der hintere Knoten zeigt, von der Seite betrachtet, einen stumpfen, wenig in die Augen fallenden Vorsprung Die Spitze des Hinterleibs vom 4ten Segment ab, sowohl auf der Rückenwie auf der Bauchseite röthlichgelb. Der ganze Körper ist mit zerstreuten, ziemlich langen, feinen Härchen besetzt, welche am Hinterrand der Segmente und namentlich an der Spitze des Hinterleibs so wie auf der Bauchseite etwas gedrängter zusammenstehen und daher leichter in die Augen fallen."

\section{Habitat.}

L. nylanderi is found in Central and Southern Europe, in the Caucasus, but is less widely distributed in the north.

Its distribution in Britain is as follows :-

Devon, S. : Stoke and Exeter $(\text { Parfitt })^{\mathbf{1 3}}$.

Isle of Wight: Ryde (Bonisthorpe) ${ }^{26}$.

Hants, S.: Dibden (Crawley).

Kent, W.: Lee, Blackheath (Farren-White $)^{20}$; Bromley (Saunders) ${ }^{22}$.

Surrey: Chobham and Wimbledon (Saunders) ${ }^{\mathbf{1 4}}$; Shirley (Rothney $)^{\mathbf{1 7}}$; Esher and Woking (Champion) ; Claygate, Mickleham 
and Addington Park (Power); Brixton ${ }^{4}$ and Camberwell (Wing) ; Richmond Park ${ }^{25}$, Oxshott ${ }^{24}$ and Box Hill ${ }^{29}$ (Donisthorpe); South Norwood (Rothney Coll.).

Essex, N. : Ardleigh and Colchester (Harwood).

Berks : Wellington College (Donisthorpe) ${ }^{25}$.

Bucks : Burnham (Harwood); near Cookham (Baynes) ${ }^{27}$.

Suffolk, E. : Ipswich (Morley) ${ }^{21}$; Little and Great Blakenham, Bentley Woods, Dodnash Woods, Tattingstone and Whersted $(\text { Morley })^{23}$; Suffolk, W. : Bures (Harwood $)^{22}$; Tostock $(\text { Tuck })^{23}$; Nayland (Harwood).

Gloucester, W. : Near Stonehouse (Davis).

Leptothorax nylanderi prefers to dwell in shady places in woods and coppices, where it chiefly nests in wood, and under bark, in which it excavates small galleries, and it will sometimes appropriate the old borings of other insects. Schenck ${ }^{3}$ says it occurs in moss on trees and rocks, and $\mathrm{Mayr}^{5}$ also mentions that it sometimes nests in moss. It may be found in fallen boughs, and at the foot of old tree trunks, but it never occurs under stones.

Saunders took solitary workers by sweeping at Chobham and Wimbledon ${ }^{\mathbf{1 4}}$, and Morley records it as occurring on Linaria vulgaris (Yellow Toad-Flax) in the summer near Ipswich ${ }^{23}$.

Curtis records that Wing found it under oak-bark at Brixton in April4, and there are specimens in the late Frederick Smith's collection taken under bark at Camberwell in March, 1852. I am inclined to think the latter are from the same source, as a specimen in the British Museum labelled "Camberwell" was also taken by Wing.

Farren-White found a small colony consisting of nine queens and sixteen workers in an old stump at Lee near Blackheath on September 9th, 186120, Harwood found nests at Bures under poplar-bark ${ }^{22}$, Morley took a specimen under the bark of a dead willow at Ipswich on February 13th, 189421, and he says it is common in the winter beneath aspen and maple bark in that district $^{23}$. In October, 1914, I visited Morley's locality near Claydon and found five or more colonies under bark of poplar. These colonies of about fifty workers and one queen in each, were situated under small bits of very close-fitting bark.

Parfitt found a colony in August, 1864, in a hollow stick near Exeter ${ }^{13}$, and I discovered a strong colony, situated in a fallen bough in Richmond Park ${ }^{25}$ in June, 1907, which contained one deälated female and a number of workers and brood.

Parfitt records another colony which occurred in a lane leading from Marypole Head, Exeter, to Cowley Bridge, in an old oak stump which had been bored into by some beetle, probably an Anobium, and in those holes the ants had their runs, their nest being in a larger hole ${ }^{13}$. 
I found specimens occupying the burrows of a beetle, Priobium castaneum, in a broken bough on an old ash at Ryde, Isle of Wight ${ }^{26}$ on October 23rd, 1908, and Baynes discovered a small colony tenanting an old disused burrow of the "Clear-Wing," Sesia andrenaeformis, in a twig of Viburnum lantana near Cookham in Buckinghamshire on June 28th, $1911^{27}$.

Leptothorax nylanderi has also occurred in the nests of other ants -F. Smith wrote in 1868 :- "The Leptothorax nylanderi has never been found in any other situation than in ants' nests, usually those of Formica rufa." not aware of any records of this ant being found in rufa nests, and I think he must have had some other species, probably Formicoxenus nitidulus, in his mind.

There are, however, records of the occurrence of $L$. nylanderi with species other than $F$. rufa-Rothney captured a few specimens in a nest of $F$. sanguinea at Shirley, in $1867^{17}$, and in his collection, now at Oxford, there are specimens taken with Donisthorpea fuliginosa at South Norwood, and by Dr. Power with the same ant at Claygate on May 12th, 1867.

Saunders found it on Whit Monday, 1883, in company with D. fuliginosa on a bank at Chobham ${ }^{18}$, I took both deälated females and workers in a nest of the same ant at Oxshott ${ }^{24}$ in March, April, and May, 1896 and 1897, workers at Wellington College ${ }^{25}$ in April and May, 1906, and on September 7th, 1913, a deälated female in a nest of $D$. mixta in a tree root at Box Hill ${ }^{29}$.

According to Mayr, L. nylanderi swarms in midsummer ${ }^{5}$, Schenck took the winged forms in the nest on August 21st, and in grass on September 25th and October 15th at Nassau ${ }^{3}$, and Forel found males in abundance in nests at Vaux in September, 1867'12. Champion caught winged females by sweeping at Esher on September 20th, 1874, and Morley obtained all three castes beneath poplar bark at Tattingstone in October, $1899^{23}$. On October 10th, 1914, I found two males in a colony under poplar bark near Ipswich.

Forel kept a colony of this species in captivity in April, 1868, which consisted of a deälated female and sixty workers, and many larvae were brought up from the queen's eggs, but he found they would not rear strange larvae. The workers would sometimes devour insects given to them, and males and workers were produced, the former appearing on June 29th and during July ${ }^{11}$.

On October 9th and 10th, 1912, I found two colonies of Leptothorax at Yvorne, Switzerland, each being situated in a hollow walnut stick, the one being $L$. affinis, the other $L$. nylanderi. I brought both sticks home and introduced their contents into a four-chambered "Janet" nest. Each colony consisted of a deälated female, workers, and larvae, but males were also present in the stick belonging to the affinis. The two species joined forces, without any fighting, all the larvae were collected into one heap 
and both females rested on it, eggs were laid and the ants all lived together in amity. The affinis queen died on January 21st, 1913, but the nylanderi queen and a number of workers-which are however nearly all nylanderi-and larvae are still under observation (March, 1914). Workers may often be seen to carry their fellows, when the one that is carried is held by the jaws with the dorsal surface uppermost, above the body of the carrier. Two nylanderi queens, workers, and brood, obtained near Ipswich in October, 1914, were introduced into this affinis-nylanderi nest. Some fighting took place at first, but no deaths occurred; the bulk of the new ants remaining by themselves in one chamber of the nest. After three months they were found to have amalgamated with the old inhabitants, and become one colony, which is still under observation.

In 1906 I took a large worker $(3.5 \mathrm{~mm}$. in length) of Leptothorax nylanderi in a nest of Donisthorpea fuliginosa at Wellington College which has the head more rounded than in the ordinary worker, the gaster longer, and banded as in the female; evidently a similar intermediate form to those before mentioned under $L$. acervorum.

\section{Leptothorax corticalis Schen.}

Myrmica corticalis Schenck Jahrb. Ver. Naturk. Nassau 8100 (1852)1. Leptathorax corticalis Mayr Verh Zool. Bot. Ver. Wien $5440(1855)^{2}$. Myrmica (Leptothorax) corticalis Schenck Jahrb. Ver. Naturk. Nassau 16197 (1861) ${ }^{3}$. Leptothorax tuberum r. corticalis Forel Denkschr. Schweiz. Ges. Naturw. $2685^{4} 227^{5}$ (1874). Leptothorax tuberum var. corticalis Er. André Spec. Hym. Europe $2298(1881)^{6}$. Leptothorax corticalis Dalla Torre Cat. Hym. $7123(1893)^{7}$. Leptothorax tuberum Vic. Hist. Berks. $176(1906)^{8}$. Leptothorax tuberum subsp. corticalis Crawley Ent. Rec. 2463 (1912) ; Crawley and Donisthorpe Int. Ent. Cong. Oxford 1912219 (1913) ${ }^{10}$; Crawley Ent. Rec. 26 92, 95, $106(1914)^{11}$.

$\Varangle$ Reddish brown, mandibles, antennae, articulations of the legs, and tarsi reddish yellow, femora and tibiae red-brown, head above and first segment of the gaster dark brown. The colour is sometimes lighter as in a specimen before me from Munich.

Head finely striate; clypeus as in tuberum; antennae twelve-jointed. Thorax finely striate, but more rugose than in nylanderi, without a distinct impression between the mesonotum and epinotum; epinotal spines very broad at base, horizontal, very short, scarcely as long as a third of the basal face of the epinotum. Pedicel finely striate; gaster smooth and shining. Legs without erect hairs. Long. 2.5-3.2 mm.

o Dark brown, mandibles, antennae and legs yellow-red.

Head longitudinally striate; clypeus as in tuberum; antennae twelvejointed, club no darker than the rest of antennae. Thorax: mesonotum and scutellum finely striate longitudinally; epinotal spines short. Pedicel finely striate; gaster smooth and shining. Long. $3 \cdot 5-4 \mathrm{~mm}$.

đิ I have not seen a typical male; Schenck's description will be found below, and Crawley describes a male in the British Museum collection from Naples labelled "corticalis var." as follows :-

"Joints 2-5 of funiculus much longer than broad. Head rugose; mesonotum smooth and shining between the converging lines; pedicel slightly 
rugose, and shaped as in nylanderi; gaster smooth and shining; epinotum with slight tooth-like tubercles. Too faded to judge of colour."11

Original description of Myrmica corticalis Schenck [Jahrb. Ver. Naturk. Nassau 8100 (1852)] :-

"A. $1 \frac{1}{3}$ bis $1 \frac{1}{2}$ L. Mittelleib und Stiel braunroth, Oberseite des Kopfes und der ganze Hinterleib oben und unten schwarzbraun, letzterer stark glänzend. Oberkiefer, Fühler, Backen, Unterseite des Kopfes sowie die Beine braunroth ; die Fühlerkeule braunroth, die Schenkel bräunlich, oft auch die Knoten. Der ganze Körper mit zerstreuten gelblichen Borstenhärchen besetzt. Die Fühler 12 gliedrig, das erste Geisselglied verdickt und verlängert, die folgenden sehr verkürzt, das achte etwas länger, das neunte und zehnte noch mehr verlängert und verdickt, das letzte am dicksten und so lang, als die drei vorhergehenden, die vier letzten bilden eine Keule. Der Kopf ist fein längstreifig; der Thorax zeigt unter der Lupe schwache unzegelmässige Längsstreifen; der Metathorax hat zwei sehr kurze breite dreieckige wagrechte Dornspitzen; auf jeder Seite das Metathorax zieht sich über und unter demselben ein brauner Rand. Die Knoten sind längsrunzelig, der Hinterleib kurz rundlich. Die Beine sind kahl. Von den A. der zwei vorigen Arten durch die rothe Fühlerkeule, den ganz schwarzbraunen Hinterleib, die kahlen Beine, die kurzen Dornspitzen und die 12 gliedrigen Fühler verschieden.

W. (nur im ungeflügelten Zustande mir bekannt). Fast $2 \mathrm{~L}$. Schwarzbraun, Thorax und Hinterleib glänzend. Oberkiefer, Fühler nebst Keule, Beine braunroth, die Schenkel braunlich. Der Kopf längsgestreift, der Kopfschild mit groben Streifen, deren mittelster sich kielartig erhebt. Der Thorax ist oben breit und flach, Mesothorax und Schildchen fein längsstreifig. Der Metathorax hat zwei kurze, fast wagrechte Dornspitzen. Die Knoten sind längsrunzelig, der Hinterleib breit, kurz, rundlich."

Description of the male of Myrmica (Leptothorax) corticalis Schenck [Jahrb. Ver. Naturk. Nassau 16197 (1861)] :-

" ơ Sehr ähnlich interrupta, glänzend schwarz, Fühler 13 gliedrig, Geisselglied 2 sehr kurz, Schaft viel länger, ohnegefähr so lang als Glied 4 und 5 zusammen, aber viel kürzer, als die halbe Geissel; Fühler hellbraun mit hellerem Endglied, Beine hellbraun; Thorax glatt, ohne Längsstreifen, sehr glänzend ; Flügel wasserhell, etwas ins Milchweisse fällend."

A single worker of a Leptothorax from the Isle of Wight, taken by Perkins, is said by Forel to be "nearly corticalis." It has the antennal club no darker, the short broad spines and coloration of typical corticalis, and Crawley states that he has little doubt that it is corticalis ${ }^{11}$.

(There are also a number of workers in the Cambridge Museum without data except "Perkins Coll.," called by Forel "tuberum with spines almost corticalis." The spines are very short but the antennal club is dark brown, and in other respects the ants are exactly similar to tuberum, and I agree with Crawley that they are only a short-spined variety of tuberum $\mathrm{F}$.)

On April 24th, 1904, Crawley found in a wood at Buckhold Hill near Pangbourne, Berks, a fallen beech-nut, perforated with a small hole, probably by some insect, which contained an incipient colony of a Leptothorax, consisting of a deälated female, one worker, 
and two half-grown larvae? . These were named by Forel "corticalis var. with longer spines," and Crawley describes the female and worker as follows ${ }^{11}$ :-

" $\Varangle$ Thorax finely rugose, less than in nylanderi. Spines very broad at base, long, about two-thirds as long as the basal face of epinotum. Reddish yellow ; mandibles, whole of antennae, and legs of the same colour ; top of head dark brown; whole of gaster as seen from above, except a small patch on the front of the first segment, black-brown. L. $2.3 \mathrm{~mm}$."

" o Mesonotum finely striated longitudinally. Middle of scutellum smooth and shining. Spines long, about one-third as long as basal face of epinotum. Antennae, mandibles, mesonotum, legs, and front of first segment of gaster, entirely reddish yellow; head, scutellum, and remainder of gaster, dark brown. L. $3 \cdot 7 \mathrm{~mm}$."

L. corticalis appears to be rare in the centre and south of Europe, and lives entirely under the bark of trees, sometimes constructing small galleries in the bark.

\section{Leptothorax tuberum F.}

Formica tuberum Fabricius Syst. Ent. $393(1775)^{1}$; Latreille Ess. Hist. Fourmis France $47(1798)^{2}$. Formica tuberosa Latreille Hist. Nat. Fourmis $259(1802)^{3}$. Myrmica tuberosa Latreille Hist. Nat. Crust. Insect. 13259 $(1805)^{4}$. Manica tuberum Jurine Nouv. Méth. Class. Hym. $279(1807)^{5}$. Myrmica unifasciata Shuckard Mag. NH. (n.s.) $2626(1838)^{6}$. Myrmica tuberum Nylander Acta. Soc. Sc. Fenn. 29391057 (1846)? . Myrmica unifasciata Curtis Trans. Linn. Soc. Lond. $21216(1854)^{8}$. Stenamma albipennis Curtis Trans. Linn. Soc. Lond. $21218(1854)^{9}$. Leptothorax tuberum Mayr Verh. Zool. Bot. Ver. Wien $5442(1855)^{10}$. Myrmica unifasciata F. Smith Trans. Ent. Soc. Lond. (n.s.) 3 128-129 (1855) ${ }^{11}$. Stenamma albipennis F. Smith Trans. Ent. Soc. Lond. (n.s.) 3134 (1855) ${ }^{12}$. Myrmica unifasciata F. Smith Ent. Ann. $185839^{13}$ : $186270^{14}$. Leptothorax unifasciata F. Smith Ent. Mo. Mag. 229 (1865) $^{15}$. Myrmica unifasciata F. Smith Ent. Ann. 1868 92 ${ }^{16}$. Leptothorax tuberum Forel Denkschr. Schweiz. Ges. Naturw. $2685^{17}$ $227^{18} 415^{19}$ (1874). Leptothorax unifasciata Saunders Trans. Ent. Soc. Lond. $1880220^{20}$. Leptothorax tuberum Er. André Spec. Hym. Europe $2298(1881)^{21}$. Leptothorax unifasciata Dale Ent. Mo. Mag. 17236 (1881) ${ }^{22}$; Saunders Ent. Mo. Mag. $2087(1883)^{23}$. Leptothorax tuberum Adlerz Bih. Sv. Vet. Acad. Handl. $1182(1886)^{24}$; Fletcher Ent. Mo. Mag. 25 313-314 (1889) ${ }^{25}$. Leptothorax tuberum tuberum Bruyant Fourmis France centr. $58(1890)^{26}$. Leptothorax unifasciata Perkins Ent. Mo. Mag. 27195 (1891)27. Leptothorax tuberum Dalla Torre Cat. Hym. $7127(1893)^{28}$. Leptothorax unifasciata Farren-White Ants' Ways 244-245 (1895) ${ }^{29}$. Leptothorax unifasciatus Saunders Hym-Acul. 38 (1896 $)^{30}$. Leptothorax tuberum Vic. Hist. Worcester $187(1901)^{31}$. Leptothorax tuberum F., race unifasciata Vic. Hist. Sussex 1 $131(1905)^{32}$; Nevinson Ent. Mo. Mag. $4122(1905)^{33}$. Leptothorax tuberum Vic. Hist. Cornwall $1182(1906)^{34}$. Leptothorax unifasciatus (teste Saunders) Donisthorpe Ent. Rec. $19254(1907)^{35}$ : Trans. Leicester Lit-Phil. Soc. $12227(1908)^{36}$. Leptothorax tuberum F. subsp. unifasciata Donisthorpe Entom. 44390 (1911) $^{37}$. Leptothorax unifasciata Donisthorpe Ent. Rec. 24 $5(1912)^{38}$. Leptothorax tuberum Donisthorpe Ent. Rec. $24306(1912)^{39}$. Leptothorax tuberum subsp. tuberum Crawley Ent. Rec. 26 93, 96, $108(1914)^{40}$.

ఫ Yellow, or slightly reddish yellow, the head above anteriorly, sometimes the vertex, and the club of antennae blackish brown. Gaster with an irregular brown patch across the base of the first segment and extending up each side. The legs and the rest of the antennae yellow. 
Head longitudinally striate, and finely rugose; clypeus convex, with a small median ridge, and two or more lateral striae; antennae twelve-jointed. Thorax finely rugose, dorsal surface not interrupted between the mesonotum and epinotum; epinotal spines variable in length, narrow at the base, about half as long as the basal face of the epinotum. Pedicel finely rugose; gaster smooth and shining. Legs without erect hairs. Long. 2:3-3 mm.

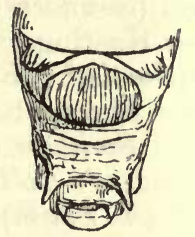

Fig. 77. Scutellum and epinotum of Leptothorax tuberum ㅇ.

오 Dark brown, or reddish brown, club of antennae blackish brown, the rest of the antennae, mandibles, legs, and often a broad patch on the anterior border of the first and second segments of the gaster yellow.

Head more strongly longitudinally striate than in the $\not{\gamma}$; clypeus as in the $\not{\gamma}$; antennae twelve-jointed. Thorax: mesonotum and scutellum longitudinally striate; epinotal spines medium in length, not so long as in nylanderi. Petiole and post-petiole finely striate; gaster smooth and shining. Wings clear; radial cell small and closed. Long. 3.7-4.5 mm.

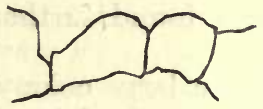

Fig. 78. Pedicel of Leptothorax tuberum $\widehat{0}$.

ô Brownish black, mandibles, antennae, legs, and extremity of gaster, dirty pale yellow.

Head finely rugose; mandibles with terminal border quadridentate; antennae thirteen-jointed, with a narrow, but distinct, four-jointed club, scape much longer than the second joint of funiculus, funiculus with joints two to five twice as long as broad. Thorax: mesonotum rugose; scutellum smooth and shining; epinotum rugose, armed with two blunt tooth-like tubercles. Pedicel finely rugose; petiole viewed in profile slightly raised and rounded in the centre; post-petiole somewhat longer than high; gaster smooth and shining. Wings as in the o. Long. $2 \cdot 5-3 \cdot 2 \mathrm{~mm}$.

Original description of Formica tuberum Fabricius [Syst. Ent. 393 (1775)] :Suecia.

"F. rufa, capite abdominisque fascia nigris, petiolo binodi. Habitat in

Praecedente minor. Antennae rufae, apice nigrae. Thorax ferrugineus, postice bidentatus."

\section{Habitat.}

L. tuberum ranges over Europe in the centre and south and in the Caucasus, but is less widely distributed in the north.

In Britain it is found in the following counties :-

Cornwall : Cornwall ${ }^{34}$. 
Devon, S. : Seaton $(\text { Dale })^{22}$; Stoke Fleming (Perkins $)^{27}$; Torquay $(\mathrm{Hamm})^{36}$.

Dorset : Portland 22, Lulworth"2, and "Burning Cliff" near Weymouth ${ }^{29}$ (Dale) ; Lyme Regis (Nevinson) ${ }^{33}$; Ringstead (Haines).

Isle of Wight : Landslip (Lewis) ${ }^{\mathbf{1 4}}$; Ventnor (Saunders) ${ }^{\mathbf{2 0}}$.

Hants, S. : Hayling Island (Saunders) ${ }^{30}$; New Forest (Dale) ${ }^{11}$.

Sussex, E. : Fairlight near Hastings ${ }^{32}$.

Kent, E. : Near Dover $(\text { Curtis })^{9}$; St. Margaret's Bay (Donisthorpe $)^{35}$; Kent, W. : Lower Shorne near Gravesend $(\text { Baly })^{13}$.

Surrey : Coombe Wood $(F . S m i t h)^{8}$.

Essex, S.: Southend (Saunders's Coll.).

Middlesex : Colney Hatch (F. Smith) ${ }^{11}$.

Worcester : Worcester (Fletcher $)^{25}$; sides of the Teme, Powick, Bransford $^{31}$.

Leptothorax tuberum is found in moss, decaying wood, in and under bark, in old stumps, in the dry stems of brambles, and also under stones.

Latreille recorded it as inhabiting the chinks in walls ${ }^{3}$, and Forel says it is found on the mountains in Switzerland as high as the region of the fir trees, but also on the plains, in dry and rocky places under stones ${ }^{18}$.

$L$. tuberum has not been found further north than Worcestershire in Britain.

Farren-White discovered a large colony between the laminae of a boulder of Portland stone on the Isle of Portland ${ }^{29}$, and Perkins saw the workers running over shale in the hottest sunshine on the cliffs round Stoke Fleming, their nests being situated in cracks between the flakes of shale, the individuals in each nest however being few in number ${ }^{2}$.

In 1857 Baly discovered a colony in a decaying post at Lower Shorne near Gravesend in which there were not less than one hundred and fifty individuals ${ }^{13}$.

Nevinson found, at Lyme Regis, some rotten sticks bored by Osmia leucomelana lying on the ground, and on cutting one of these open to look for the cells of the bee, he came upon a nest of $L$. tuberum with undeveloped eggs. This stick he placed in a box, in the hope of obtaining the sexes. He afterwards found similar nests in the same locality, and introduced eggs from one of them into the box with the others, when he noticed that immediately the workers discovered the new eggs, they felt them with their antennae, seized them about two-thirds down, and carried them into their nest. All the eggs hatched out, and several males and females were obtained ${ }^{33}$.

Forel observed the copulation of $L$. tuberum on the summit of Mont Tendre on August 30th, 1871, and he records isolated fertile females under bark at Vaux and Zurich in the spring ${ }^{19}$. 
Nylander records the capture of a winged female by Dahlbom at Thorsborg on July 14th, $1841^{7}$, Curtis beat two males and two workers out of a privet hedge in the Folkestone road near Dover on July 31 st, $1852^{9}$, and I found the male in a nest at St. Margaret's Bay on August 25th, 1907. On August 23rd having swept workers from the grass on the slope of the undercliff I determined to try and find their nest, and this I succeeded in doing on the 25th, when a small colony was found under a stone in company with Donisthorpea nigra, and on digging up the chalky ground under the stone, a male, deälated female, and a number of workers were secured $^{35}$.

Fletcher bred males from eggs laid by workers in captivity. At the beginning of April, 1887, he found a nest of $L$. tuberum under the bark of a scrubby old maple at Worcester, and collected the colony into a tin, but in doing so he lost the queen, as on reaching home, he only found workers present. 'These he fitted up in a flower-pot partly filled with earth, moss, and pieces of bark, and on examining the nest in July he was astonished to see a number of larvae present, and three weeks later he observed several cocoons (he must have meant pupae, as the pupae of Leptothorax are always naked). Late in September males began to appear, twenty-one in all being reared ${ }^{25}$. Saunders unfortunately records them as the males of $L$. nylanderi ${ }^{30}$, but the specimens, males and workers, are undoubtedly the $L$. tuberum $\mathbf{F}$.

Crawley found a small colony in June, 1912, at Seaton in Devon, in moss under flints on the cliffs, consisting of sixteen workers, one male, several pupae of all castes, and larvae. Specimens from this colony were named by Forel- " $L$. tuberum F. var. approaching interruptus Sch.," but as Crawley says it can only be considered a very slight variety of tuberum, s. str., and he describes it as follows ${ }^{40}:-$

" $\Varangle$ Thorax finely rugose. Spines as in tuberum (s. str). Reddish yellow; club of antennae, front of head, but not vertex, and an irregular patch on the base of first segment of gaster, dark brown. L. $2.5 \mathrm{~mm} .-2.7 \mathrm{~mm}$."

" 0 Joints 2-5 of funiculus much longer than broad, but not so long as in the preceding (tuberum, s. str.) Mandibles quinquedentate. Head, thorax, and pedicel finely rugose; gaster smooth and shining. Epinotum without tooth-like tubercles. Brown-black; mandibles, antennae, and legs paler L. $2 \cdot 7 \mathrm{~mm}$."

\section{Adlerz describes an ergatandromorph of $L$. tuberum $^{24}$ :-}

Incomplete lateral ergatandromorph. Right side exclusively worker, left partly male and partly worker. Left half of head male, pronotum worker, mesonotum, paraptera, scutellum and mesopleurae male; metanotum and epinotum worker; legs male with worker colouring. Petiole and postpetiole between male and worker, but left side darker like that of the male. Gaster as in the worker, but on the left side of tip with an incomplete sternite, representing the seventh segment of the male. There is a projecting, irregular penis, with its genital valves so abortive on the right side as to be recognizable only with difficulty. At the right of the penis is a rather irregular sting. 


\section{Leptothorax interruptus Schen.}

Myrmica interrupta Schenck Jahrb. Ver. Naturk Nassau 8 106-1071 $140^{2}$ $145^{3}$ (1852). Leptothorax interruptus Mayr Verh. Zool. Bot. Ver. Wien 5

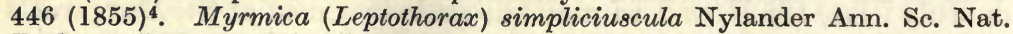
Zool. (4) $592(1856)^{5}$. Leptothorax tuberum r. interruptus Forel Denkschr. Schweiz. Ges. Naturw. $2685^{6} 228^{7} 415^{8}$ (1874). Leptothorax tuberum var interruptus Er. André Spec. Hym. Europe 2299 (1881) ${ }^{\circ}$. Leptothorax interruptus Dalla Torre Cat. Hym. $7124(1893)^{10}$; Bondroit Ann. Soc. Ent. Belg. 55 12-13 (1911) 11. Leptothorax tubero-affinis (teste Forel) Donisthorpe Ent. Rec. 24306 (1912) ${ }^{12}$. Leptothorax tuberum var. tubero-affinis Donisthorpe Ent. Rec. $2563(1913)^{13}$. Leptothorax affino-tuberum Crawley and Donisthorpe Int. Ent. Cong. Oxford 19122 20-21 (1913) ${ }^{14}$. Leptothorax tuberum subsp. interruptus Crawley Ent. Rec. 26 94, 96, $108(1914)^{15}$.

$\Varangle$ Reddish yellow, with the front of the head, and the club of the antennae blackish; gaster with a more or less distinct brown patch at the base of the first segment, often interrupted in the middle, and extending up the sides of the segment, legs, mandibles, and the rest of the antennae yellow, or reddish yellow.

Head rugose, finely striate; clypeus as in tuberum; antennae twelvejointed. Thorax slightly more finely rugose than the head, no impression between mesonotum and epinotum; epinotal spines long, narrow, curved, about two-thirds as long as the basal face of the epinotum. Pedicel a little more finely rugose than the thorax ; gaster smooth and shining. Legs without erect hairs. Long. $2 \cdot 3-3 \cdot 4 \mathrm{~mm}$.

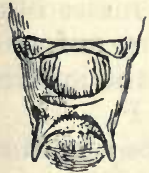

Fig. 79. Scutellum and epinotum of Leptothorax interruptus 오.

ㅇ. Club of antennae, head, thorax, and pedicel black, mandibles, legs, and the rest of the antennae yellow; gaster blackish brown with a narrow yellow band at the apex of all the segments.

Head longitudinally striate, rugose; clypeus as in tuberum; antennae twelve-jointed. Thorax: mesonotum finely longitudinally striate; scutellum smooth and shining in the centre; epinotal spines longer than in tuberum. Pedicel rugose; gaster smooth and shining. Wings clear; radial cell small and closed. Long. $3 \cdot 7-4 \cdot 5 \mathrm{~mm}$.

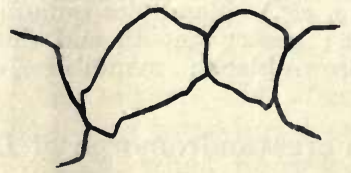

Fig. 80. Pedicel of Leptothorax interruptus $\widehat{0}$.

ô Black, mandibles, antennae and legs pale dirty brownish yellow, with the articulations of the legs and tarsi lighter.

Head finely rugose; mandibles quadridentate; antennae thirteen-jointed, scape as in tuberum, funiculus with joints two to five as broad as long. Thorax finely striate longitudinally; mesonotum at the sides and scutellum in the centre more finely striate than the rest of the thorax, which gives the appearance of being smooth and shining; epinotum armed with two blunt tooth- 
like tubercles. Petiole finely rugose, viewed in profile rising posteriorly to a high point, descending vertically and then continuing horizontally to its junction with the post-petiole ; post-petiole higher than long; gaster smooth and shining. Wings as in the . $^{2}$ Long. $2 \cdot 5-3 \mathrm{~mm}$.

Original description of Myrmica interrupta Schenck [Jahr. Ver. Naturk. Nassau 8106 (૪), 107 (ㅇ), 141 (ઠَ) (1852)] :-

"A. $\frac{3}{4}$ bis 1 L. Gelb oder röthlichgelb, der Vorderleib in der Regel von letzterer Farbe. Kopf vornen nach dem Unterrande hin braun, Scheitel gelb; Fühlerkeule braun; am Ende des Segments befindet sich eine von aussen nach innen verschmählerte, mitten unterbrochene braune Binde (oder zwei dreieckige braune Flecken), oft auch fehlend, oder nur durch eine bräunliche Färbung angedeutet sonst ist der Hinterleib gelb. Der ganze Körper mit abstehenden Borsten besetzt, die Beine kahl. Kopf lang, viereckig, merklich breiter, als der Thorax, fast von der Länge desselben, nicht ausgerandet, fein längsgestreift. Die Fühler 12-gliedrig. Die Stirnlappen sind etwas seitlich verlängert und aufwärts gebogen. Thorax äusserst fein unregelmässig gerunzelt, die Brustseiten sehr fein längsgestreift. Die Dornspitzen des Metathorax lang, schief aufwärtsgerichtet, etwas gebogen. Hinterleib kurz, rundlich, ohngefähr von der Länge des Thorax.

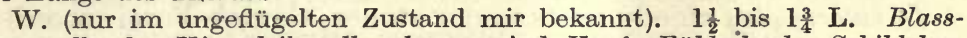
braungelb, der Hinterleib gelb; braun sind Kopf, Fühlerkeule, Schildchen, und eine breite Binde auf jedem Hinterleibsring, fast den ganzen Ring einnehmend, nur am Border- und Hinterrande einen schmahlen gelben Streifen übrig lassend, der am Vorderrand breiter. Kopf vornen ziemlich grob längsrunzelig, neben netzrunzelig, Kopfschild glänzend, weniger gerunzelt ; Stirnfeld nicht deutlich begrenzt ; Stirnlappen seitlich erweitert, aufgebogen. Fühler 12-gliedrig, Keule braun. Thorax fein und dicht längsgestreift, Schildchen mehr oder weniger glatt und glänzend, höchstens am Anfang oder auch noch am Ende hin längsgestreift. Metathorax mit zwei kurzen starken, spitzen Dornen, fast gerade ausgestreckt, zwischen und unter denselben dicht regelmässig quergerunzelt. Hinterleib rundlich, der ganze Körper kurz und gedrungen. Beine gelb, die Schienen mit anliegenden Börstchen."

"Das Männchen ist etwas länger, als der Arbeiter, aber sehr schlank, von der Gestalt des M. der M. unifasciata und cingulata. Tief braun-schwarz, Hinterleib sehr glänzend; Fühler braun Hüftglieder und Schenkel braunschwarz, Schienen braun, Basis und Spitze der Schenkel und Schienen blassgelblich, Tarsen blassgelblich oder bräunlich und nur die Spitzen der Glieder blass. Flügel ganz wasserhell. Der Kopf klein, die Kiefer gelblich; Netzaugen sehr dick, weit unten sitzend, Kopf und Thorax fein längsstreifig. Fühlerschaft ohngefähr dem dritten Theil der Geissel gleich. Der zweite Knoten in den Stiel allmählig verschmählert. Metathorax mit 2 kurzen Zähnchen. Von dem M. der unifasciata und cingulata durch die Farbe der Fühler und Beine verschieden."

\section{Habitat.}

L. interruptus is found here and there in Central and Southern Europe and appears to be rare.

British distribution :-

Hants, S. : New Forest (Crawley and Donisthorpe) ${ }^{\mathbf{1 2}}$.

This pretty little species was discovered by Crawley and myself in the New Forest in a sandy place sparsely covered with fir trees on July 23rd, 1912, when a number of small colonies was found under stones, often in connection with nests of Tetramorium caespitum ${ }^{12}$. 
Many colonies contained males, winged and deälated females, some males, but no winged females, others no winged forms but several deälated females in each, and in one a single deälated female was present.

Several large specimens ( $3.4 \mathrm{~mm}$. in length) occurred among the workers in these nests, in which the head is nearly entirely black above, and more rugose than in the ordinary worker, the gaster long, and the band, interrupted in the centre, on the first segment, distinct, the other segments being also banded.

Specimens sent to authorities on the continent were named $L$. tuberum var. tubero-affinis, and subsequently $L$. interruptus, the latter being undoubtedly correct. As Crawley points out, the form of the pedicel in the male of interruptus distinguishes it from the males of the others, and as the pedicel in the male of affinis is even more elongate than in the male of tuberum, the former is still further removed from the New Forest specimens ${ }^{15}$.

$L$. interruptus chiefly nests under stones, though Forel records it as rare in Switzerland in dead wood and under bark ${ }^{7}$ (but also under stones), Bondroit says it occurs especially under stones, and rarely in moss, and he once found a small colony in an empty snail-shell in Belgium ${ }^{11}$, and Schenck observed it under moss and turf, and running about amongst grass at Nassau ${ }^{1}$.

The winged forms occur in June and July, Forel found males and winged females in the nests at Vaux from June 27th to July $17 \mathrm{th}^{8}$, Schenck observed a winged female, two males, and a number of sex pupae in a nest on the slope of a mountain on June 26th and subsequently, in the same place, many winged females and one male ${ }^{3}$; he also records several deälated females in each nest in the spring and late summer ${ }^{1}$.

Crawley found a deälated female interruptus in the earth of a Tetramorium nest; colonies of the Leptothorax and Tetramorium would not mix in captivity, but he united two colonies of the former in an observation nest, which placed their broods in a single pile, and mingled together without any animosity ${ }^{14}$.

On June 23rd, 1913, when in the New Forest locality, I again found a number of colonies of $L$. interruptus under stones-some in connection with Tetramorium nests-which contained workers, deälated females, and larvae, but no winged forms nor pupae were present. One of these, in which three deälated females were present, I brought home, and established it in a " Crawley-Lubbock" nest, where it has lived ever since. On March 5th, 1914, larvae of Tetramorium caespitum, Myrmecina graminicola, and Leptothorax affinis were placed in the outer part of the observation nest, when the Leptothorax larvae were carried in first, and subsequently the others. The Tetramorium and Myrmecina larvae were partly devoured in a few days and their remains buried in the earth, the $L$. affinis larvae being placed with the $L$. interruptus brood, but 
the former were probably eventually eaten, as I have been unable to detect any affinis workers, though a number of interruptus workers have been reared. Eggs were laid by the interruptus females on May 25th, 1914.

On July 24th, 1914, a number of colonies of interruptus were again observed in the New Forest-one of these, which contained many males and winged females, was found in the centre of a strong colony of Myrmica scabrinodis v. sabuleti situated in a mound-and workers, larvae, and pupae were brought home and placed in the outer part of the 1913 nest. The new workers entered the nest, breaking through the earthen wall constructed by the old inhabitants of the nest and joining forces with them. No fighting took place and the ants have formed one colony.

\section{TETRAMORIUM Mayr.}

[ $\tau \epsilon \tau \rho \alpha$, four; $\mu \delta \rho\llcorner o \nu$, parts (i.e. the joints of the maxillary palpi).]

Type: Formica caespitum L. (Girard, 1879).

This genus is distributed over the whole world, and contains many aphidicolous species. Tetramorium is essentially African, but many species have reached India and New Guinea; Europe has probably acquired its representatives from Southern Asia, and only a few more or less aberrant species are present in America. Two cosmopolitan forms, which have been carried all over the world by commerce, occur in Britain in hot-houses.

Girard [Traité. Élém. Ent. 21016 (1879)] cites Formica caespitum L., as the type of this genus, in which he is followed by Bingham [Faun. Brit. India Hym. 2175 (1903)], and Wheeler [Ann. New York Acad. Sc. 21173 (1911) : 2379 (1913)].

$\Varangle$ Head quadrangular; clypeus triangular, with its posterior margins raised on each side and forming a projecting carina which borders the antennal cavities anteriorly ; frontal carinae projecting, short, wide apart and somewhat divergent posteriorly; frontal area not sharply defined; mandibles broad, with five to seven teeth on the terminal margins; maxillary palpi four-jointed; labial palpi three-jointed; antennae twelve-jointed, funiculus with the last three joints forming a club, which is about as long as the rest of the joints of the funiculus taken together, last joint of club longer than the two preceding taken together. Thorax short; pronotum broad anteriorly, with distinct anterior angles; somewhat depressed between the mesonotum and the epinotum; epinotum armed with two short spines, or pointed teeth. Petiole cylindrical anteriorly, nodiform posteriorly; post-petiole transverse, broader than petiole; gaster oval ; sting large.

o Size large, two or three times that of the $\not{\gamma}$. Characters as in the $\not$, epinotal spines stouter, gaster longer and more robust. Wings: fore-wings with one cubital cell and one discoidal cell.

o Head smaller than in the + ; mandibles flat, terminal margin dentate; maxillary palpi four-jointed; labial palpi three-jointed; antennae tenjointed, scape short, funiculus with the second joint long, longer than scape. Thorax: mesonotum with Mayrian furrows; epinotum slanting, armed with two very feeble teeth, or tubercles. Wings as in the $q$. Size a little smaller than in the ?. 
Original description [Mayr Verh. Zool. Bot. Ver. Wien 5423 (1855)] :-

66

\author{
( $\tau \epsilon \tau \rho a$ vier, $\mu \delta \rho\llcorner o \nu$ Glied.*)
}

Arbeiter: Der Kopf ist ohne Oberkiefer viereckig mit abgerundeten Hinterecken, breiter als der Thorax. Die Oberkiefer sind breit und am Innenrande gezähnt. Die Unterkiefertaster sind vier-, die Lippentaster dreigliedrig. Die Oberlippe ist in der Mitte des vorderen Randes schwach stumpfwinklig ausgebuchtet. Der Clypeus is mässig lang und breit, von vorne nach rückwärts convex, von einer Seite zur anderen fast plan. Die Stirnlappen sind ziemlich schmal. Der Schaft der zwölfgliedrigen Fühler ist nahe am Grunde etwas bogenförmig gekrümmt; die Geissel ist keulenförmig. Das Stirnfeld ist kaum angedeutet. Die Punctaugen fehlen; die Netzaugen sind ziemlich klein, oval und in der Mitte des Seitenrandes des Kopfes gelegen. Der Thorax ist vorne am breitesten und hinten am schmälsten. Zwischen dem Meso- und Metanotum is oben keine Einschnürung, sondern bloss eine feine Furche. Das Metanotum ist mit zwei nach aufwärts und hinten gerichteten Dornen bewehrt. Das erste Glied des Stielchens ist vorne kurz gestielt, oben hinten knotenförmig, welcher Knoten ebenso lang als breit und etwas höher ist als der Knoten des zweiten Gliedes ; das zweite Glied is knotenförmig, breiter als lang und breiter als der Knoten des ersten Gliedes; die Unterseite des Steilchens is unbedornt, höchstens findet man auf dem zweiten Glied einen sehr kurzen, stumpfen, zahnartigen Höcker. Das erster Segment des Hinterleibes bedeckt mehr als dreiviertel Theile des letzteren. Die Beine sind ziemlich dick.

Weibchen : Der Kopf is so wie beim $\not{\gamma}$ mit Ausnahme der hier vorhandenen Punctaugen und der grösseren Netzaugen. ... Der Thorax ist etwas vor den Flügelgelenken am breitesten; das Mesonotum und Schildchen liegen in derselben Ebene und sind flach; das Metanotum ist mit zwei nach hinten und aufwärts gerichteten Dornen oder zahnartigen Höckern versehen. Das Stielchen is so wie beim $\not$. Der Hinterleib ist länglich-eiförmig, dessen erstes Segment bedeckt ein halb bis zwei Drittel desselben. Die Costa transversa verbindet sich mit der Costa cubitalis an deren Theilungsstelle, wodurch nun eine einzige geschlossene Cubitalzelle gebildet wird ; die Costa recurrens ist vorhanden, daher sich auch eine geschlossene Discoidalzelle vorfindet; ...

Mannchen: Der Kopf ist klein, schmäler als der Thorax. Die Oberkiefer sind schmal und gezähnt. Die Kiefertaster und Lippentaster sind so wie bei den vorigen Geschlechtern. Der Clypeus ist mässig gewölbt, ungekielt und reicht bis zwischen die Fühler. Das Stirnfeld ist undeutlich ausgeprägt. Der Schaft der zehngliedrigen Fühler ist so lang als das lange zweite Geisselglied. Die Netzaugen sind gross und hervorstehend. Das Mesonotum, welches zwei nach hinten convergirende Linien eingedrückt hat, überragt bloss das Pronotum, der Metathorax ist nicht verlängert; das Metanotum ist mit zwei äusserst kurzen oft undeutlichen Zähnchen versehen. Das Steilchen is ähnlich jenem des $\not$ und des ․ Der Hinterleib ist eiförmig, hinten zugespitzt und dessen erstes Glied bedeckt die Hälfte desselben. Die Flügel sind so wie beim ㅇ. Die Beine sind dünn und lang."

\title{
Tetramorium caespitum $\mathrm{L}$.
}

Formica caespitum Linnaeus Syst. Nat. Ed. $101581(1758)^{1}$. Formica binodis Linnaeus (Cent. Ins.) Amoen Acad. 6413 No. 94 (1763; 1789)2. Formica caespitum Latreille Ess. Hist. Fourmis France $50(1798)^{3}$. Myrmica caespitum Latreille Hist. Nat. Ins. 13259 (1805)4. Atta caespitum Illiger Mag. Ins. $6194(1807)^{5}$. Formica fusca Leach Zool. Journ. $2290(1825)^{6}$. Myrmica fuscula Nylander Acta. Soc. Sc. Fenn. 29351053 q ơ (1846) ${ }^{7}$. Myrmica

* In Beziehung auf die Unterkiefertaster. 
impura Förster Hym. Stud. $148(1850)^{8}$. Myrmica modesta Förster Hym. Stud. $149(1850)^{9}$. Myrmica fuscula F. Smith Zool. $93248(1851)^{10}$; Schenck Jahr. Ver. Naturk. Nassau 8 86-91 (1852) ${ }^{11}$. Myrmica atratula Schenck Jahr. Ver. Naturk. Nassau 891 (1852) ל⒓ Myrmica fuscula F. Smith Zool. $114080(1853)^{13}$. Myrmica caespitum Curtis Trans. Linn. Soc. Lond. 21 215 (1854) $^{14}$. Myrmica maculipes Curtis Trans. Linn. Soc. Lond. 21216

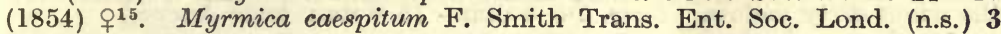
122-124 (1855) ${ }^{16}$ : Ent. Ann. 1855 9717. Tetramorium caespitum Mayr Verh. Zool. Bot. Ver. Wien $5426(1855)^{18}$. Tetramorium atratulum Mayr Verh. Zool. Bot. Ver. Wien 5429 (1855) , ⒈ Myrmica (Tetramorium) caespitum F. Smith Cat. Brit. Foss. Hym. $26(1858)^{20}$ : Trans. Ent. Soc. Lond. (n.s.) $41857279(1858)^{21}$. Myrmica caespitum F. Smith Ent. Ann. 1865 8922. Tetramorium caespitum F. Smith Ent. Mo. Mag. $229(1865)^{23}$ : Ent. Ann. $186895^{24}$. Myrmica caespitum Moggridge Harvesting Ants $63(1873)^{25}$. Tetramorium caespitum Forel Denkschr. Schweiz. Ges. Naturw. $26 \mathbf{7 2}^{26}$ $224^{27} 270^{28} 412^{29}$ (1874); McCook Proc. Acad. Nat. Sc. Philadelphia 1878 $15-19^{30}$ : $1879156-161^{31}$; Saunders Trans. Ent. Soc. Lond. $1880218^{32}$; Parfitt Trans. Devon Assn. Sc-Art. 12516 (1880 ${ }^{33}$; Er. André Spec. Hym. Europe $2285(1881)^{34}$; Lubbock Ants, Bees, Wasps 17 (1882 $)^{35}$; Fowler Ent. Mo. Mag. $19139(1882)^{36}$; Forel Bull. Soc. Vaud. Sc. Nat. $2023(1884)^{37}$; Perkins Ent. Mo. Mag. $27195(1891)^{38}$; Bignell Young Nat. 3255 (1892) ${ }^{39}$; Dalla Torre Cat. Hym. $7131(1893)^{40}$; Farren-White Ants' Ways $6^{41} 95^{42}$ $242^{43}$ (1895); Saunders Hym-Acul. 33 (1896) ${ }^{44}$; Marlatt U.S. Dp. Agr. Div. Ent. (n.s.) Bull. 4 97-99 tf. 45a-g. (1896) ${ }^{45}$; Rothney Ent. Mo. Mag. $3514(1899)^{46}$; Morley Hym. Suffolk $22(1899)^{47}$; Nevinson Ent. Mo. Mag. $3812(1902)^{48}$; Vic. Hist. Surrey $185(1902)^{49}$; Janet Obs. Fourmis $51(1904)^{50}$; Nevinson Ent. Mo. Mag. 4121 (1905) ${ }^{51}$; Vic. Hist. Sussex 1 $131(1905)^{52}$; Pérez Soc. Linn. Bordeaux 61 XXXII-IV $(1906)^{53}$; Vic. Hist. Berks $176(1906)^{54}$; Vic. Hist. Cornwall $1182(1906)^{55}$; Vic. Hist. Somerset $175(1906)^{56}$; Escherich Ameise $117(1906)^{57}$; Vic. Hist. Kent $1116(1908)^{58}$; Wasmann Biol. Centralb. $28353(1908)^{59}$; Donisthorpe Trans. Leicester Lit-Phil. Soc. $12226(1908)^{60}$. Tetramorium caespitum caespitum Emery Deutsch. Ent. Zeitschr. 1909 70061. Tetramorium caespitum Wheeler Ants $154^{62} 278^{63}(1910)$; Donisthorpe Ent. Rec. $2217(1910)^{64}$ : Entom. $44390(1911)^{65}$ : Ent. Rec. 24 5-6 (1912) ${ }^{66}$ : 25267 (1913) ${ }^{67}$; Evans Scot. Nat. $1913116^{68}$; Crawley and Donisthorpe Int. Ent. Cong. Oxford $1912221(1913)^{69}$.

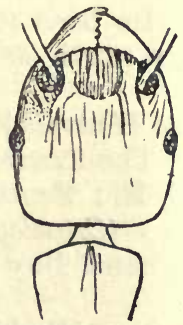

Fig. 81. Head and shoulders of Tetramorium caespitum ధ్.

ఫ Variable in colour, blackish brown to brownish yellow, with the mandibles, antennae, articulations of the legs and the tarsi yellow.

Head and thorax striate longitudinally. Petiole and post-petiole wrinkled longitudinally, but generally smooth in the centre; gaster smooth and shining. Long. 2:4-4 mm.

o Blackish brown, with the mandibles, antennae, legs, and posterior margins 
of the segments of the gaster reddish yellow. The articulation of the legs is often lighter.

Head longitudinally striate. Thorax longitudinally striate; mesonotum smooth and shining anteriorly, but with a few large scattered punctures; scutellum smooth and shining. Petiole and post-petiole broader proportionately than in the $\Varangle ;$ gaster smooth and shining. Pterostigma and nerves of the wings dirty yellow. Long. $7 \cdot 5-8 \mathrm{~mm}$. - (5-8 mm. teste André.)

o Colour as in the ㅇ.

Head striate. Thorax striate; mesonotum transversely striate, with a space between the Mayrian furrows, and a space on each side generally smooth and shining. Petiole and post-petiole finely striate; gaster smooth and shining. Wings as in the o. Long. 5.5-6 mm. (6-7 mm. teste Forel.)

Ovum: Yellowish white, round, oval.

Larva: Yellowish white; whiter and more hairy when young; similar to that of Anergates, the head however is furnished with short hairs, the short branching hairs scattered over the whole body are not so densely, nor compactly branching, and the longer hairs are not serrate. Long anchortipped hairs are situated on the dorsal surface of the second to the sixth abdominal segments.

Pupa : Pale yellow, smooth and shining, as if cut out of wax.

Original description of Formica caespitum Linnaeus [Syst. Nat. Ed. 101581 (1758)] :-

"F. petiolo nodis duobus alternis : posteriore majore.

Habitat in Europae tuberibus."

\section{Habitat.}

Tetramorium caespitum is very common in Europe and Asia, and is also found in Japan; it is rare in North Africa, and is present in North America as an introduced species. A number of subspecies and varieties occur, chiefly in the Mediterranean Regions.

In Great Britain it is most common on the seashores in the south of England, but has also been found in a number of inland localities, and occurs as far north as the Bass Rock and Ailsa Craig :-

Cornwall, W. : Scilly Isles (Farren-White) ${ }^{43}$; Tresco (F. Jenkinson); Tol-Pedn-Penwith ${ }^{55}$; The Lizard (Dale Coll.) ; The Land's End (F. Smith $)^{22}$; Cornwall, E. : Pentire Point (Rothney $)^{46}$; Newquay (Nevinson) ${ }^{48}$; St. Issey (Crawley and Donisthorpe) ${ }^{66}$; Trebetherswick (Hallett); Whitsand Bay (Bignell) ${ }^{39}$; Boscastle and Downderry ${ }^{55}$.

Devon, S. : Stoke Fleming (Perkins) ${ }^{38}$; Dawlish (Hamm) ; Seaton (Crawley) ; Branscombe (Farren-White) ${ }^{41}$; Haldon, Blackdown, Exmouth Warren, and Plymouth (Parfitt $)^{33}$; Devon, N. : Ilfracombe and Morthoe (Saunders Coll.); Lynmouth (FarrenWhite) ${ }^{43}$; Lee Bay (Bagnall) ; Lundy Island (Donisthorpe ${ }^{67}$.

Somerset, N. : Batheaston ${ }^{56}$.

Dorset: Charmouth (Dale $)^{\mathbf{1 5}}$; Lyme Regis (Nevinson) $)^{51}$; Wareham (Dale Coll.); Studland (Morice); Swanage (Nevinson). 
Isle of Wight: Sandown ${ }^{14}$, Shanklin and Luccombe Chines ${ }^{16}$, the Undercliff ${ }^{17}$, and Ventnor ${ }^{20}$ ( $F$. Smith); Landslip (Fowler $)^{36}$; Blackgang Chine (Donisthorpe).

Hants, S.: Bournemouth $(F \text {. Smith })^{22}$; Hayling Island (Saunders) $^{44}$; New Forest (Donisthorpe) ${ }^{66}$; Hants, N.: Fleet (E. A. Butler).

Sussex, E. : Hastings District ${ }^{52}$; Camber Sands (Donisthorpe); Sussex, W.: Arundel Park (F. Smith Coll.).

Kent, E. : Folkestone (F. Smith $)^{\mathbf{1 4}}$; Deal $(F \text {. Smith })^{20}$; Dover $(F \text {. Smith })^{20}$; Sheppey (Champion); Throwley ${ }^{58}$ and Huntingfield (Chitty) ; Kent, W. : Darenth (Curtis) ${ }^{\mathbf{1 4}}$; Plumstead Wood $(F \text {. Smith })^{24}$.

Surrey : Shirley (F. Smith) ${ }^{24}$; Chobham (Saunders $)^{49}$.

Essex, S. : Southend (Curtis) $)^{14}$; Shoeburyness $(F \text {. Smith })^{16}$; Essex, N. : Walton-on-the-Naze (Harwood).

Middlesex : Hampstead Heath (Farren-White $)^{42}$.

Berks : Wellington College (Barnes) ${ }^{54}$; Tubney (Donisthorpe) ${ }^{66}$.

Suffolk, E. : Lowestoft $(F \text {. Smith })^{23}$; Pakefield (Morice) ${ }^{47}$; Dunwich (Farren-White) $)^{42}$; Ipswich (Morley) ${ }^{47}$; Herringfleet (Bedwell) ; Suffolk, W.: Brandon District (Perkins $)^{47}$; Knettish Hall Heath (Morley).

Cambridgeshire : Mildenhall (D. Sharp).

Glamorgan : Horton, Gower (Hallett).

Carmarthen : Llanstephan (E. A. Butler).

Carnarvon: Abersoch (Nevinson).

Pembrokeshire: Tenby (Donisthorpe); St. Davids (Allen.

Denbigh : Deganwy District ( $W$. Gardner).

Haddington: Bass Rock (Evans) ${ }^{68}$.

Clyde Isles : Ailsa Craig (Bagnall).

Tetramorium caespitum prefers to nest in open country and occurs in sandy places, on banks, in fields, etc. Schenck ${ }^{11}$ records it in woods on the Continent, but Forel ${ }^{27}$ states this is seldom the case, and I have never found it in woods in Britain. It occurs in the New Forest, but is there confined to open sandy heaths, where only a few scattered fir trees are present. In Switzerland, according to Forel, T. caespitum ranges as high as the region of the fir trees ${ }^{27}$, and I found it, in October, 1912, on Les Agittes, nesting between the interstices of a wall of rock.

Its nests are often deep in the ground, and are frequently situated under stones, but are sometimes covered with a dome of earth of considerable proportions, and small secondary domes may also be present. Long narrow galleries extend, just beneath the surface, right round these domes, and very small holes, often closed with grains of earth, connect these galleries with the open air.

Mayr ${ }^{18}$ says it not infrequently lives in houses on the Continent, 
and this also appears to be the case in America, where this ant has been introduced from Europe. Wheeler writes-the pavement ant ( $T$. caespitum) of Europe is now common about New York, Washington, and Philadelphia, but it is so sporadic that we must conclude either that it is of comparatively recent importation, or is prevented from spreading by competition with our native ants ${ }^{62}$. Marlatt says the pavement ant of our Eastern Cities is the common meadow ant in Europe, and is very common in the eastern towns and particularly in Washington, having colonies beneath the pavements, and is often a more pernicious and pestilent house nuisance than the true house ant. He goes on to say that it seems to be the species referred to by Kalm in 1748 as often occurring in houses in Philadelphia ${ }^{45}$.

The colonies of this Tetramorium are often very populous, their nests being very extensive, and their enormous females are certainly capable of founding colonies unaided. In July, 1906, Wasmann found a number of deälated females, after the marriage flight, at Hohscheid in Ösling, Luxemburg, some under stones in little cells. He took seven females and put them with damp earth in an observation nest, where they fought each other. On September 4th there was only one female surviving, enclosed in a cell with eggs and small larvae ${ }^{59}$.

The marriage flight takes place chiefly in July, but also occurs from the end of June to well into September according to Schenck ${ }^{11}$. Forel has seen the males and females leaving the nest as early as six o'clock in the morning at Lugano on July 1st, $1871^{29}$. The male and female being nearly the same size, the latter does not carry the former during the marriage flight. I have found males and winged females in the nests in June. July, and the beginning of August.

Forel records quite small larvae in nests on October 9th ${ }^{29}$, Bignell found young larvae on May 6 th at Whitsand Bay ${ }^{39}$, and I have taken young larvae in the nests at Tenby in April, but larvae appear to be present all through the year.

The workers of this ant are very courageous, fierce, and quarrelsome, they are robust and their bodies are very hard, their gait is rather quick, and they follow each other in files, but also go out alone on foraging expeditions. They carry their fellows over the back in the same manner as previously described for Myrmica.

Lord Avebury states that Tetramorium caespitum has the habit of feigning death; he says that this species, however, does not roll itself up, but merely applies its legs and antennae closely to the body ${ }^{35}$. I have not witnessed this, nor have I ever been able to get the ants in my observation nests of this species to exhibit this phenomenon.

These ants are carnivorous, but also like sweet food, Forel having noticed them entering the corollas of Stachys plants to suck the nectar ${ }^{29}$, and they cultivate root Aphidae in their nests, but do 
not appear to seek other species which occur on plants. They also exhibit a tendency to collect and harbour seeds in their nests, more particularly in warm climes such as Algeria, where they construct special chambers to act as granaries. André had sent to him, in the month of December, a number of seeds of a dirty yellow colour, from such a granary of this ant at Oran ${ }^{34}$. Moggridge records that this species may occasionally be seen collecting and carrying seeds into its nests at Mentone and Cannes ${ }^{25}$.

Farren-White says he found this species manifesting harvesting instincts at Branscombe in Devonshire ${ }^{41}$. He noticed the diligent workers filing into their nest with grass-seeds in their mandibles, and on disturbing their habitation he found many seeds scattered among the débris of what he took to be their granary ${ }^{42}$. Janet records that at Beauvais it is not rare to find accumulations of seeds in the nests of this ant, and that at Bois du Montois he found, on September 3rd, a cupful of the little seeds of Mercurialis and Paniscum heaped up in a chamber in a nest situated under a stone. He noticed that those seeds which were deepest in the earth had germinated, whereas the ones which were least exposed to moisture had not done so $^{50}$. Escherich, in the hot summer of 1904 , repeatedly found stores of seeds in the nests of $T$. caespitum at Strasburg, a fact which he had not observed in former years ${ }^{57}$. Wheeler remarks that it is interesting to note that this ant occasionally stores seeds in the chambers of its nests. He has seen the chambers of a colony of this ant near Mamaroneck, N.Y., filled with grass seeds, and he points out that in this case we have apparently either an evanescent or an incipient habit ${ }^{63}$.

In April, 1909, I found a great number of Cardamine seeds (probably either $C$. flexuosa or $C$. hirsuta) in many nests of $T$. caespitum at Whitsand $\mathrm{Bay}^{64}$, again in April, 1911, the same seeds were found in some of the nests of this ant at St. Issey ${ }^{66}$, and in June, 1913, a number of Cerastium seeds were found in three nests of this same ant on Lundy Island ${ }^{67}$. All these nests were situated under stones, and the seeds occurred in chambers just beneath the stone.

Pérez in 1906 records that these ants attack the tubers of potato plants, excavating more or less profound cavities, many young plants being killed in this way. He mentions that the roots of young cabbages and carrots, as well as uncultivated plants, are also injured by $T$. caespitum, and he says it is remarkable that these facts have never been noticed before (" jusqu'a ce jour ") ${ }^{53}$. Linnaeus however in the original description of this species in 1758 writes - "Habitat in tuberibus," 1 and Forel in 1884 observed that young beet-roots were attacked by this same ant at Vaux, many of the plants dying from the injuries received ${ }^{37}$.

Colonies of $T$. caespitum are frequently found in the proximity of other ants' nests, but there is probably no real connection 
between them. Forel states that it is everywhere found in perpetual competition with Donisthorpea nigra, D. Alava, Formica fusca, and species of the genus Myrmica ${ }^{27}$. Fowler records that he discovered $T$. caespitum and $D$. umbrata in company under a stone in the Landslip near Ventnor ${ }^{36}$, and I found a colony under the same stone as $D$. flava on a bank at Tenby.

Battles are frequent between different colonies of $T$. caespitum, which often arise through disputes over booty. Forel graphically describes some of these battles ${ }^{28}$. On April 24th, 1870, he observed an immense combat, which extended over a length of thirty metres on the slope of grass at the entrance to the University of Zurich. The combat was equally violent over this whole space, and he was unable to distinguish whence each party came out. The enemies were identical in colour, size, etc., and the battle was very desperate, thousands of dead strewing the ground. He saw the combatants bending their gasters under to sting each other, and making violent efforts to carry their antagonists off. Generally three or four ants surrounded another, and when they were separated the latter was found to be half dead, having some of its members cut off. These combats lasted for over a month with variable extension and intensity; on May 20th, it being very hot, their vivacity was astonishing, but not many deaths occurred, their fury being less great. In two cases which he observed at Vaux, he was able to distinguish the nest of each party, the one being composed of ants of large size, the other of very small ones. The victorious party arrived in great haste, in a column, without separating from each other, and laid siege to the entrances of the subterranean nest of the vanquished. On one occasion he was able to recognize the cause of the trouble. After the "Amazon Ant" (Polyergus rufescens) had pillaged a small nest of Formica sanguinea, and had retired, he noticed workers of $T$. caespitum coming out of the ground, to cut up, and carry off into their nests, some pupae which were lying on the dome of the sanguinea nest. The workers belonged to two different colonies of $T$. caespitum, and a fierce battle soon started between them.

McCook also records similar battles in Philadelphia; he collected some of the combatants and placed them in a bottle, which contained earth, to form an observation nest. He states that the combat lasted for over two weeks, but that if he introduced a little eau-de-Cologne, it put a stop to the fighting, and caused the combatants to live together in amity ${ }^{30} \mathbf{3 1}$.

I have kept a colony of this ant in captivity, in an observation nest, since July, 1911, and give a few extracts from my notebook for this nest :-

July 8th, 1911, a deälated female and a number of workers and larvae taken under a stone at Whitsand Bay-July 12th introduced into a four-chambered Janet nest-July 27th pupae now 
present-September 9th several callows hatched-September 25th many callows now present-March 2nd, 1912, very few deaths have taken place, a small packet of eggs present; fed with raw meat, bits of which were placed by the workers on the larvaeMarch 29th fed with $F$. rufa larvae and pupae-March 31st very young larvae, which are whiter than the older ones, have hatchedJune 1st callows again present-June 23rd fresh eggs laidJuly 19th many of the larvae are hung on to the plaster walls of the nest (by their anchor-tipped hairs)-July 24th and 25th experiments with Anergates females (previously recorded under Anergates atratulus) - September 15th all well, callows and larvae present-January 31st, 1913, numerous larvae hanging on the walls, have not increased in size during the winter-June lst pupae present-June 17th introduced a number of Paracletus cimiciformis taken in $T$. caespitum nests on Lundy (these did not live longer than a month)-June 24th introduced some large dark $T$. caespitum workers, with larvae and pupae (from a colony found in the New Forest on June 23rd), a little fighting took place-June 25th all well, no dead ants, the strange larvae and pupae have been collected with the old ones, and the strange workers are mixed with the smaller old ones and no further fighting takes place-July 10th a few small callows present, a worker observed to milk a Paracletus, she stroked the hind body of the "Plant-louse" with her antennae and then sucked the anus-September lst a number of mediumsized and small larvae present-February 1st, 1914, only a few dead ants present, medium and small larvae, the female and large and small workers all well.

The nest is still under observation.

The following myrmecophiles have been found with this ant in Britain :-

Coleoptera : Drusilla canaliculata F.; and Staphylinus stercorarius $\mathrm{Ol}$.

Formicidae : Anergates atratulus Schenck.

Proctotrupidae : Tetramopria donisthorpei Kieffer; T. donisthorpei var. femoralis Kieffer; Loxotropa tritoma Thos.; and Gonatopus sociabilis Kieffer.

Aphidae : Paracletus cimiciformis Heyd.; Trama donisthorpei Theob. ; Forda formicaria Heyd.; Pentaphis marginata Koch.; $P$. trivialis Pass. ; and Tetraneura ulmi Geoff.

Coccidae : Ripersia subterranea Newst.

Collembola : Cyphodeirus (=Beckia) albinos Nic.

Araneina: Acartauchenius scurrilis Cbr.; and Micaria pulicaria Sund.

Acarina : Trachyuropoda laminosa C. and B. ; Laelaps equitans Mich.; L. laevis Mich.; L. myrmophilus Mich.

Crustacea : Platyarthrus hoffmanseggi Brandt. 
Tetramorium caespitum L., var. hammi var. nov.

ఫ Dirty yellow-brown, shining, mandibles, antennae, and legs lighter. Head and thorax finely longitudinally striate; epinotal spines very short and pointed. Petiole, post-petiole and gaster smooth and shining. Long. $2 \cdot 4 \mathrm{~mm}$.

Described from a number of specimens taken by Mr. A. H. Hamm in the New Forest on August 25th, 1912.

The sculpture is less rugose, the spines are shorter and less robust, and the petiole and post-petiole are smoother and more shining than in the type.

This variety comes near to the var. schmidti Forel [Rev. Suisse Zool. 1215 (1904)], and the var. semilaeve André [Spec. Hym. Europe $2286(1881)$ ], but it is not so robust as the former, the head, thorax, petiole, and post-petiole are not so broad, and the spines are smaller, finer and more pointed. Compared to the latter it is less yellow, the striation of the head and thorax is a little stronger, and the spines are a little smaller and more pointed. Hamm's specimens were all found walking about on the bare sand, within a few feet in area, but he was not able to find their nest.

\section{Subfamily Dolichoderinae Forel.}

This subfamily comprises a number of genera which are found all over the world, though chiefly in the Tropics ; a very few occur in Europe, of which only one genus (Tapinoma Förster) is present in Britain.

They form a natural, very homogeneous, group, and are more primitive than the Camponotinae.

The gizzard is of a complex and peculiar structure, the sting is vestigial (except in one genus), nearly all the genera possess, in the female and worker, repugnatorial glands which give off a characteristic odour, which is said to resemble that of rotten cocoanuts, and has been called "Tapinoma odour," and the pupae are naked, never being enclosed in cocoons.

TAPINOMA Förster.

[ $\tau a \pi \epsilon i \nu \omega \mu a$, a lowering (i.e. the scale).]

Type : Formica erratica Latr. (=collina Förster ; Först., 1850).

The genus Tapinoma ranges over the hot and temperate regions of the whole globe, with the exception of New Zealand, and contains some twenty-four species. Its colonies are mostly very populous and inhabit dry places; two species being known to live in the nests of Termites.

$\Varangle$ Head scutiform, broadest before base; clypeus broad, with the anterior margin deeply and narrowly excised in the centre; frontal carinae parallel ; frontal area not defined; mandibles long, triangular, the whole terminal 


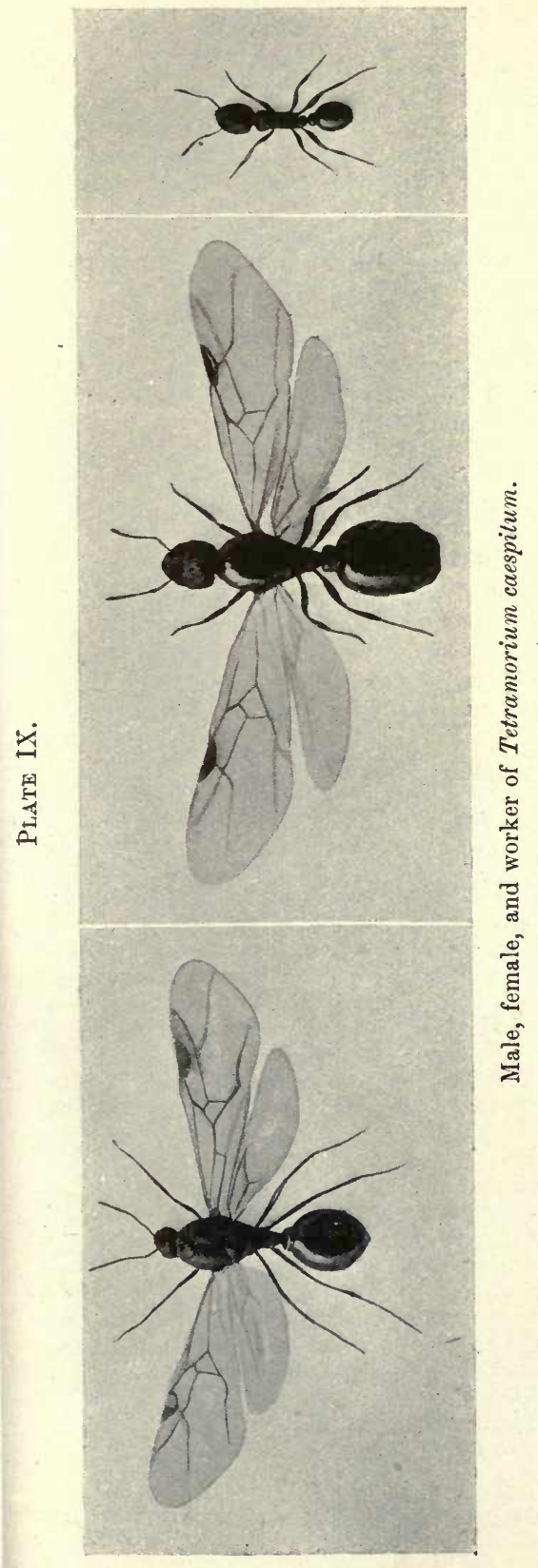

क.

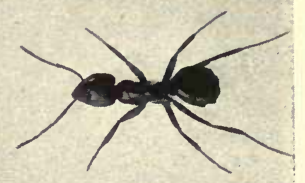

हేँ

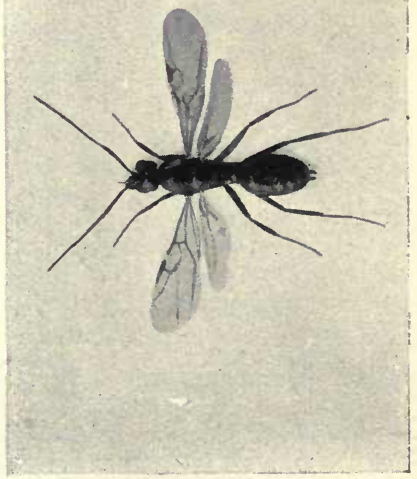



border dentate, with a long tooth at apex; maxillary palpi six-jointed; labial palpi four-jointed; antennae filiform, twelve-jointed, scape long, funiculus gradually and only slightly thickened to apex, first and last joints longer, the ones between shorter and subequal ; eyes large, situated in front ; ocelli wanting. Thorax narrower than head; pronotum rounded, broader than the rest of the thorax; sutures between pronotum and mesonotum, and mesonotum and epinotum distinct; epinotum short, unarmed, flat and slanting posteriorly. Pedicel furnished with a flat scale, which is bent forward; gaster oval, with only four segments visible from above, first segment high, rounded, and prominent, covering the scale, with a fovea in its anterior surface for the reception of the latter.

o Similar to $\not$ but larger ; head broader, eyes larger, ocelli present. Wings : fore-wings with one cubital cell, and one discoidal cell, the latter sometimes wanting.

ô Head triangular; mandibles with terminal border very finely dentate; maxillary palpi six-jointed, labial palpi four-jointed; antennae thirteenjointed, scape as long as the first five joints of the funiculus taken together. Eyes large, prominent; ocelli present. Wings as in the ㅇ. Pedicel broad, rounded above; gaster longer than in the + ; external genital organs large.

\section{Original description [Förster Hym. Stud. 143 (1850)] :-}

$$
\text { “ }
$$

Tapinoma n. gen.*

Palpi maxillares 6-articulati, labiales 4-articulati, dimidia longitudine priorum breviores. Antennae filiformes, infra medium faciei insertae; clypeus mediae magnitudinis, apice medio profunde exciso; squama abdominis segmenti primi oblonga, subrectangularis, depressa, foveola basali segmenti secundi recepta, vix conspicua.

\section{Tapinoma erraticum Latr.}

Formica erratica Latreille Ess. Hist. Fourmis France $44(1798)^{1}$. Formica caerulescens Losana Mem. Accad. Sc. Torino $37314(1834)^{2}$. Formica glabrella Nylander Acta. Soc. Sc. Fenn. $338(1849)^{3}$. Tapinoma collina Förster Hym. Stud. 143 (1850)4 ; Schenck Jahr. Ver. Naturk. Nassau 767 136, 139 (1852) ${ }^{5}$. Tapinoma erratica F. Smith Trans. Ent. Soc. Lond. (n.s.) 3 111-112 (1855) ${ }^{6}$. Formica coerulescens Mayr Verh. Zool. Bot. Ver. Wien 5371 (1855) ${ }^{7}$. Tapinoma erraticum Mayr Verh. Zool. Bot. Ver. Wien $5373(1855)^{8}$. Tapinoma erratica F. Smith Ent. Ann. 1856 96. Micromyrma pygmaea Dufour Ann. Soc. Ent. France 26 (3 s. 5 : 1857) $60(1857)^{10}$. Tapinoma erratica F. Smith Cat. Brit. Foss. Hym. 16-17 (1858) $)^{11}$ : Ent. Ann. $186588^{12}$ : $1866128^{18}$ : $186975^{14}$. Tapinoma erraticum Forel Denkschr. Schweiz. Ges. Naturw. 26 $60^{15} 166^{16} 222^{17} 330-336^{18} 410^{19}$ (1874). Micromyrma Dufourii Perris Ann. Soc. Ent. France 46 (5 s. 7 : 1877) 379-382 (1878) ${ }^{20}$. Tapinoma erratica Parfitt Trans. Devon Assn. Sc-Art. $12514(1880)^{21}$; Saunders Trans. Ent. Soc. Lond. $1880210^{22}$. Tapinoma erraticum Er. André Spec. Hym. Europe 2 222-224 (1881 $)^{23}$. Tapinoma erratica Bignell Young Nat. $3207(1882)^{24}$. Tapinoma erraticum Lubbock Journ. Linn. Soc. Lond. Zool. 20129136 $(1888)^{25}$; Wasmann zusam. Nest. u. gemischt. Kolon. Ameisen $257(1891)^{26}$; Ferton Act. Soc. Linn. Bord. 44 (5 s. 4 : 1890) 341-346 (1892) ${ }^{27}$; Dalla Torre Cat. Hym. $7164(1893)^{28}$. Tapinoma erratica Farren-White Ants' Ways 236-237 (1895) ${ }^{29}$. Tapinoma erraticum Saunders Hym-Acul. 27 (1896) ${ }^{30}$; Service Scott-Elliott's Flora Dumfriesshire XV (1896) ${ }^{31}$. Tapinoma erraticá Saunders Ent. Mo. Mag. $3614(1900)^{32}$. Tapinoma erraticum Escherich 87-88 $218(1906)^{33}$; Santschi Journ. Psychol-Neurol. 13 146-148 (1908) ${ }^{34}$; Donisthorpe Trans. Leicester Lit-Phil. Soc. 12225 (1908) ${ }^{35}$ : Ent. Rec.

* Tapinoma von $\tau a \pi \epsilon i \nu \omega \mu a$ das Erniedrigte.-Der Name enthält eine Andeutung auf die niedergedrückte Schuppe des $1^{\text {sten }}$ Segments." 
$20282(1908)^{36}$ : $21258(1909)^{37}$; Morley Morey's Guide NH. Isle of Wight $303(1909)^{38}$; Donisthorpe Entom. 44390 (1911) $^{39}$ : Ent. Rec. 246 (1912) ${ }^{40}$; Emery Genera Insect. $13740(1912)^{41}$; Crawley and Donisthorpe Int. Ent. Cong. Oxford $1912223(1913)^{42}$; Donisthorpe Ent. Rec. $2563(1913)^{43}$ : $2639(1914)^{44}$.

$\Varangle$ Black, mandibles, and often the antennae and legs dark brown, tarsi and articulations of the joints of the legs yellowish. The whole body covered with white pubescence, very finely punctured, somewhat shining. Long. 2.6-4.2 mm. $(2 \cdot 2-3 \cdot 8 \mathrm{~mm}$ teste Forel.)

o Very like the $\not \gamma$; slightly more pubescent and punctured. Wings somewhat fuscous. Long. $4 \cdot 5-5 \cdot 8 \mathrm{~mm}$. $(4 \cdot 5-5 \mathrm{~mm}$. teste Forel.)

ot Colour, puncturation, and wings as in the + . Long. $3 \cdot 4-5 \mathrm{~mm}$.

Ovum : White, round oval.

Larva: Yellowish white, narrow and pointed anteriorly and posteriorly, with the segments clearly defined. The ventral surface is sharply angled from the first abdominal segment to the pointed apex; the dorsal surface is broadly rounded, the prothoracic segment more prominent. The smaller larvae are almost glabrous, but under a high power short bristles can be seen, chiefly on the ventral surface. The larger larvae are quite glabrous, shining, and more "sausage" shaped.

Pupa: Yellow, transversely striate, wax-like.

Original description of Formica erratica Latreille [Ess. Hist. Fourmis France 44 (1798)] :-

$$
\text { "24. F. errante. erratica. }
$$

O.t.p. Noire, glabre, luisante. Extrémités des cuisses et des jambes, tarses, pâles. Mâle. Tête et corcelet d'un noir clair. Base des antennes, pattes, pâles. Aîles obscures. Femelle. Noire, veloutée. Jambes et tarses testacés. Nervures jaunâtres à la base des aîles antérieures."

\section{Habitat.}

Tapinoma erraticum is found in Central and Southern Europe, on the shores of the Mediterranean, in the Caucasus, and Central Asia. Three varieties and two subspecies occur.

In Britain it is almost confined to the south of England, but has been recorded from Scotland, as F. Smith writes that Dale took workers in Scotland in $1846^{6}$ - the insect he describes is certainly $T$. erraticum - and Service speaks of it as a very scarce species in Dumfries $^{31}$. It is very remarkable that there are no records of its capture further north in England than Surrey.

Cornwall, W. : Scilly Isles $(\text { Dale })^{30}$; Land's End $(F \text {. Smith })^{12}$.

Devon, S. : Bovey Heathfield (Parfitt) ${ }^{21}$; Bovey $(\text { Bignell })^{24}$; Bovey Tracey (Hamm).

Dorset : Lulworth (Farren-White $)^{29}$; Wareham $(\text { Dale })^{30}$; Studland (Morice) ${ }^{35}$; Chapman's Pool (E. A. Butler) $)^{35}$; Ringstead and West Knighton Heath (Haines).

Isle of Wight: Parkhurst Forest $(E . A \text {. Butler })^{38}$.

Hants, S.: Bournemouth. $(\text { Dale })^{6}$; New Forest $(\text { Hamm })^{35}$;

Hants, N. : Harford Bridge Flats (E. A. Butler).

Sussex, W. : Harting (Beaumont) ${ }^{32}$. 
Surrey : Coombe Wood and Weybridge $(\text { Grant })^{9}$; near Guildford (Stevens) ${ }^{11}$; Chobham (Saunders) ${ }^{22}$; Shirley (Farren-White) ${ }^{29}$; near Croydon (Saunders) ${ }^{22}$; Woking (Donisthorpe) ${ }^{35}$.

Dumfries : Dumfries (Service) ${ }^{31}$.

This ant loves dry places exposed to the sun, and occurs chiefly on sandy heaths and commons in Britain. In Switzerland it ranges as high as the sub-alpine regions, Forel having found it at a height of 1200 metres on the Rigi, etc. ${ }^{17}$ It nests in the earth, under stones, on banks, etc., but its subterranean galleries do not extend very deeply into the ground, and temporary domes of variable sizes are built of earth and other materials in order to concentrate heat and to help to hatch the eggs and pupae. These domes sometimes consist of masses of earth built around the stems of grass and other herbage above the chambers of the nest which are underground. A mound nest of Tapinoma erraticum which I found in the New Forest was built of bits of burnt heather, grass, and grains of sand, etc., about six inches high and the same in diameter.

Santschi describes eleven different methods in which this ant constructs its nests in Tunis ${ }^{34}$.

$T$. erraticum has a rather soft body, but is very agile, darting rapidly about in the sunshine, its antennae continuously vibrating, and its gaster, which is very mobile, being raised when the ant is in motion. When the sun is obscured these ants immediately disappear, and on cold and cloudy days very few specimens are to be found away from the nest.

They frequently leave their nesting-place and migrate to a fresh one-generally near at hand, but sometimes at some distance from the old one-when they follow one another in files, carrying their larvae and pupae, the males and winged females following in the procession, the whole process not lasting much longer than an hour. The fertile females carry about the eggs and larvae, and the workers sometimes carry their fellows, in which case the carrier seizes the other ant by the thorax, or a leg, and runs off with her, the latter keeping the legs and antennae closely folded against the body as if she were a pupa.

The pupae (as we have seen is the case with all ants of the subfamily to which this species belongs) are always naked, but F. Smith writes in 1856 - " On the last occasion of Mr. Grant's visiting the colony of Tapinoma, at Coombe Wood, the males and females were in the pupa state, spun up in silken cocoons."9 This undoubtedly shows that on this occasion the ant in question certainly was not Tapinoma erraticum, but most probably Donisthorpea nigra.

This ant is chiefly carnivorous, but will eat a little honey, or sugar; it does not appear to keep Aphidae in its nests in Europe, though Santschi tells me it does so in Tunis; and but rarely visits 
those on plants, though Ferton speaks of it as attending and guarding these insects ${ }^{27}$.

It haunts the battle-fields of larger ants, and carries off the dead bodies of the slain, to be cut up and devoured at home. If these ants, when out hunting, find a dead insect, they immediately seize it and drag it along to their nest, but they will also attack and kill flies and other small insects. They also often feed on dead birds, according to Escherich ${ }^{33}$, and probably any other carrion will occasionally attract them.

The repugnatorial glands possessed by this species enable it to hold its own when coming in contact with other and larger ants, as it ejects the secretion contained in these glands, presenting its mobile gaster in the face of the foe, and smearing the latter with this liquid, which is of a very irritating and fatal nature. The odour of this secretion is exactly similar to that given off by beetles of the genus Myrmedonia, and other Staphylinidae, inhabiting ants' nests, and by which I have shown they protect themselves against the attacks of their hosts.

Forel describes how workers of Formica sanguinea are repulsed when attacking a colony of migrating $T$. erraticum, five or six of the latter applying their gasters to the head of one of the larger ants, which fall back with extraordinary contortions. He also mentions how workers of Tetramorium caespitum treated in the same manner by the Tapinoma, rub the head on the ground, and roll over in great distress ${ }^{18}$. I have experimented with workers of $T$. erraticum and other species of ants in my observation nestswhen introduced into a nest of Donisthorpea fuliginosa and attacked by one of the workers, the Tapinoma poked her gaster into the face of the latter, which immediately fell back, grovelling on the ground, rubbing the chin on the floor of the nest, and behaving as if it had a stroke-another specimen was enclosed in a small box with a worker of Formica rufa; the latter seized the Tapinoma, but quickly let go, and ran round and round in a circle, being evidently much upset-similar experiments with other species produced the same results.

Colonies of $T$. erraticum are sometimes small, but occasionally very populous ones occur; Wasmann records a very strong colony he found in the Brandnertale near Bludenz at the height of 1000 metres $^{26}$, and I found a very large colony at Weybridge on July 29 th, 1913 , the deälated females and the workers in this nest being the largest specimens of this ant I have ever seen ${ }^{44}$.

A number of deälated females are sometimes present in the same nest; Schenck mentions a nest at Nassau which contained between thirty and forty deälated females ${ }^{5}$, and Crawley and I found another in the New Forest, on June 23rd, 1912, in which over twenty such females were present ${ }^{42}$.

The fact that so many queens are found in the same nest indicates 
the reception of females into the parent nest after the marriage flight, or the joining together of several females to found their colony. Sometimes however, as pointed out by Forel ${ }^{19}$, virgin females lose their wings without leaving the nest, and Schenck even suggested that the winged females did not leave the nest at all for the marriage flight ${ }^{5}$.

Judging from the size of the female, it is highly probable that they can found a colony without the aid of any workers.

Males and winged females are to be found in the nests in June, and generally occur in the same nest. In the mound nest before mentioned which I discovered in the New Forest on June 23rd, 1913 - the nest having been traced by carefully watching the workers in the neighbourhood, only a few being out as the day was cold and cloudy - very many winged females, but only a few males, were present; it also contained two deälated females, a large number of workers, male, female, and worker pupae, and some larvae ${ }^{44}$.

The marriage flight takes place in June, though in cold years it is later, occurring in July. Forel saw males and winged females leave a nest at Zurich on June 14th, 1868, and he states that a second generation, of males only, is sometimes produced in September ${ }^{19}$. The male being about as large as the female, he is not carried in the air by the latter during the marriage flight.

The eggs are laid during the first warm days of spring, and the sex pupae appear in the nests in May and June.

I have kept several observation nests of this ant, but they have never been very successful-the ants in a colony without a queen taken at Woking on May 9th, 1909, devoured all their larvae and pupae, and also eggs laid by one of the workers, although plenty of food (honey, caterpillars, and pupae of other ants) was given to them ${ }^{37}$-another colony containing a deälated female taken at Woking on May 18th, 1911, behaved in precisely the same mannera third colony, found under a stone on a bank in the same locality on May 12th, 1912, contained three queens and a number of male and female pupae. In spite of the fact that the ants were supplied with plenty of food, the workers devoured all the sex pupae; workers however were reared, and the colony was kept for some time ${ }^{43}-I$ now possess a colony in captivity, part of the inhabitants of the New Forest mound nest, consisting of the two deälated females and a number of workers. Very few deaths have occurred and all the ants are in good health, but eggs laid by the queens from time to time always disappear.

Forel also records that the male and female pupae in a colony he had in captivity were all devoured by the workers ${ }^{18}$. Dr. Ernst, on the other hand, tells me he has experienced no difficulty in keeping this species in confinement.

Lord Avebury published a figure of one of his ant-cases containing Tapinoma in captivity, in which the earth can be seen to have 
been arranged by the ants into a sort of circular fortification, or zareba, access to which is obtained by one or two tunnels, not visible in the illustration, and to which a pathway leads from the entrance 25 .

The following myrmecophiles have been found with Tapinoma erraticum in Britain :-

Coleoptera : Myrmoecia plicata Er.

Braconidae : Pachylomma buccata Nees.

Diptera : Pseudacteon (=Phora) formicarum Verrall.

Collembola : Cyphodeirus (=Beckia) albinos Nic.

\section{Subfamily Camponotinae Forel.}

This is the highest subfamily; it is very extensive and comprises a number of genera-only two of which, Donisthorpea and Formica, occur in Britain-and very many species.

The pedicel in these species always consists of but a single segment, the petiole, and the sting is transformed into a small vestigial apparatus, consequently these ants are unable to sting, but some of them produce poison copiously, and can eject it to a considerable distance.

Their pupae are usually enclosed in cocoons, but are sometimes naked.

\section{Table of the Genera.}

\section{ఛ̧}

1 Frontal area triangular, distinctly defined; ocelli distinct. 2 Formica L.

- Frontal area rounded behind, not distinctly defined, ocelli not distinct $\ldots \ldots \ldots \ldots \ldots \ldots$ Donisthorpea M. and D.

우

1 Joints 2-5 of funiculus longer than the succeeding ones; frontal area

1 distinctly defined ................ Formica L.

- Joints $2-5$ of funiculus not longer than the succeeding ones; frontal area not distinctly defined _....... Donisthorpea M. and D.

o

1 First joint of funiculus broader than the rest; external genital organs

small ; size much smaller than in the $q$. . Donisthorpea M. and D. - $\begin{gathered}\text { First joint of funiculus not broader than the rest; external genital } \\ \text { organs large; size nearly equal to }\end{gathered}$

\section{DONISTHORPEA Mor. and Drnt.}

$$
=\text { Lasius F. (nec. Jurine). }
$$

Type : Formica nigra L. (Mor. and Drnt., 1915) ; [Mayr, 1861].

The ants of this genus belong to the purely north temperate fauna, being common to the Palaearctic and Nearctic Regions, and species have been found in the Baltic Amber.

They do not stand as high on their legs, and are less active than 

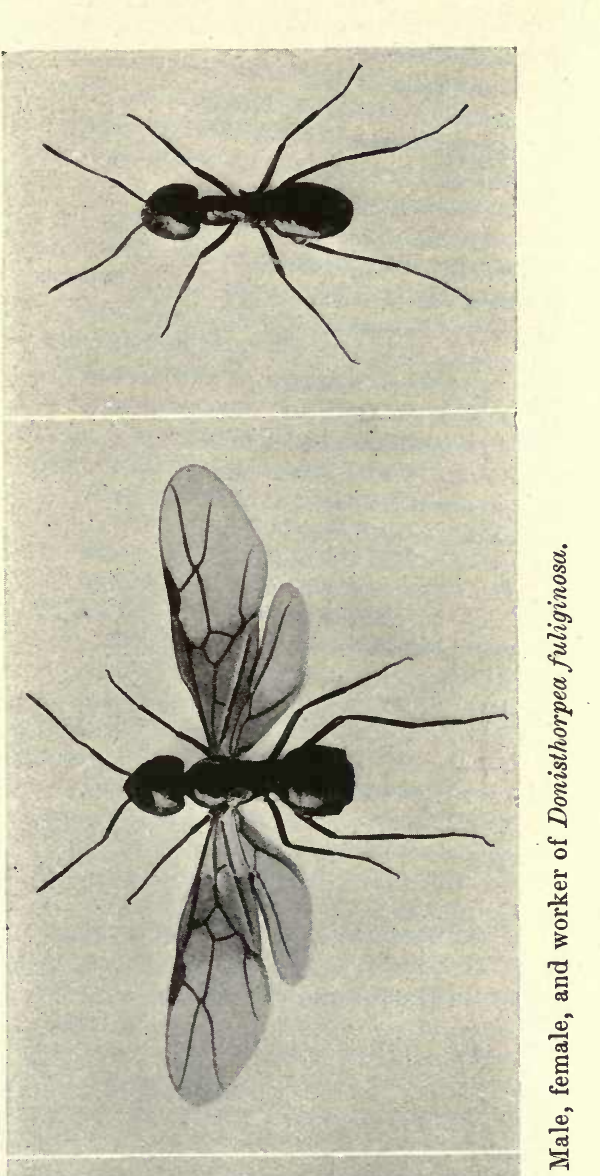

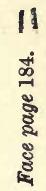
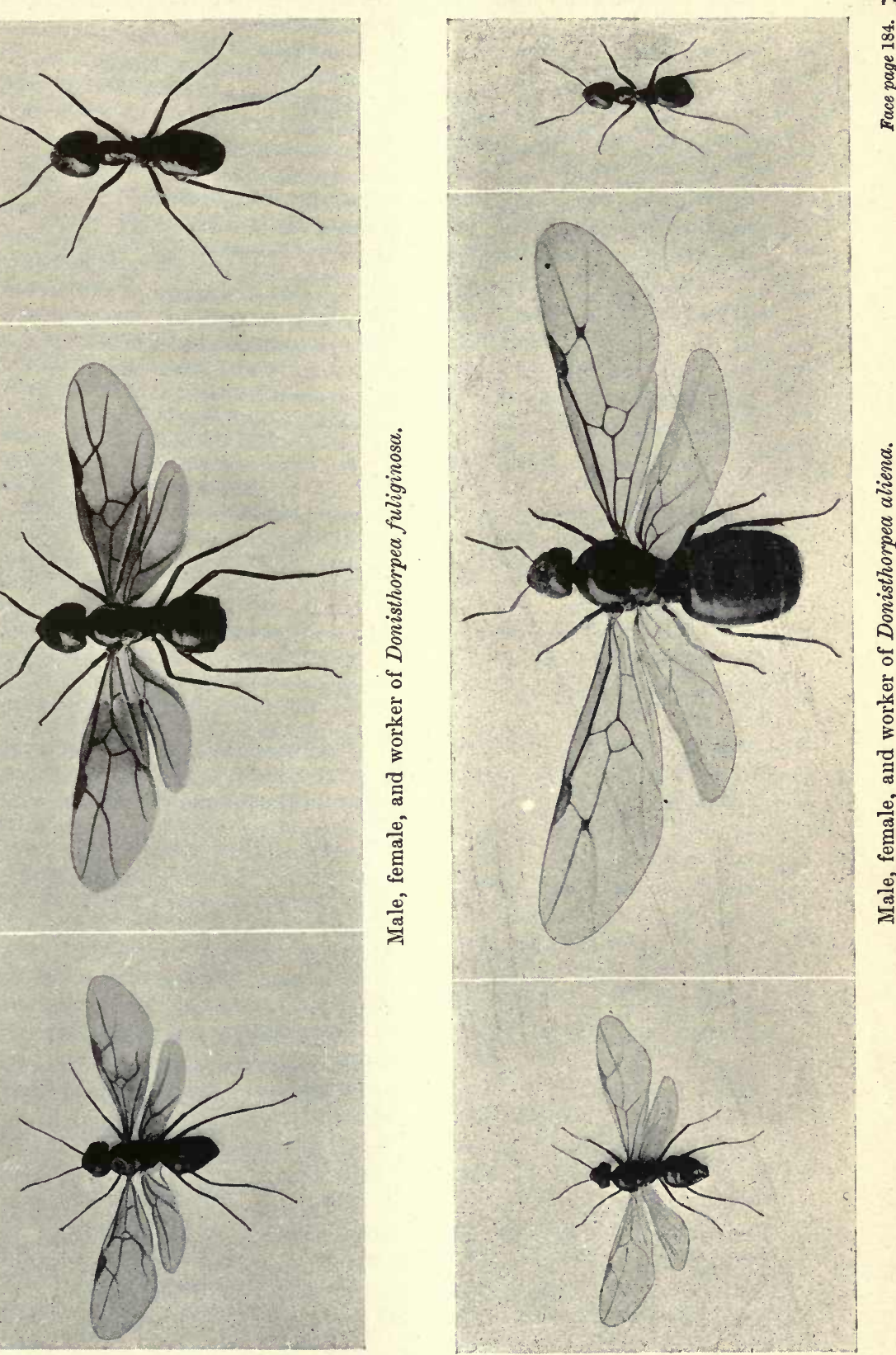

the ants of the genus Formica, the workers follow each other in files, often using well-beaten tracks, and they never carry their fellows.

In finding their way, they do not use their eyes, but rely on the senses of smell and touch.

Some species lead an out-of-door life, but others are very subterranean in their habits, the workers seldom coming above ground.

The nesting habits of Donisthorpea are very diverse, some make carton nests, and they live in holes in trees, in old tree stumps, in roots, under stones, in earth mounds, in banks, and also under the pavements and in masonry in the centre of towns.

These ants are very fond of sweet liquids, but will devour small insects, etc., and also collect the seeds of plants.

They keep droves of Aphids and Coccids, pasturing them on roots and stems of subterranean plants; some species attend Aphidae on plants and trees above ground, and also milk Lycaenid larvae (the caterpillars of the "Blue " Butterflies).

They build covered ways from their nests, and earthen pavilions in which to shelter their plant-lice, etc. They even collect the eggs of Aphidae, storing them in their nests during the winter, and when these hatch, they carry the young plant-lice out and place them on their proper food-plants.

The colonies of Donisthorpea - which are generally large, and often very populous - are founded by some species in the normal manner, and by others, which are temporary social parasites, in one of the abnormal methods.

The fertile females, whose gasters are often enormously swollen with eggs, are always surrounded by a court of workers, being sometimes entirely covered by them, and the latter continually follow their queen, feed and clean her, and carry away her eggs as she lays them.

Crawley and I have shown that the large-bodied females of this genus lay eggs only a few days after fecundation, whereas the temporary social parasites do not lay till the next year.

The males being about the size of the workers, and sometimes even smaller than the largest specimens of the latter, are considerably smaller than the females, and are usually carried by them in the air, when united, during the marriage flight.

Escherich states that the normal period for the marriage flight is July, and that it extends from the middle of that month to the middle of August. But in England August is the principal time, and these marriage flights sometimes commence as early as June and continue till October, swarms during the latter month being probably due to a second generation of the males and females.

The workers in some species are nearly all uniform as regards size, but in others both large and small specimens occur.

The larvae practically occur in the nests throughout the year, 
being always present in the winter, and they take considerably longer to develop than is the case with the larvae of Formica.

The workers feed the larvae with liquid food, but will also give them bits of dead insects, eggs, and other larvae, etc., to eat.

The pupae are generally enclosed in cocoons, and both André and Saunders state that this is always the case; but F. Smith, Mayr, Forel, Janet, and I have all recorded instances where a number of naked pupae have occurred.

These ants are not so warlike, nor so quarrelsome as Formica, and generally act on the defensive, barricading their nests, and the entrances to their subterranean galleries, with grains of earth, when attacked; but occasionally will pour out in vast multitudes, and overwhelm the foe by sheer weight of numbers.

Their method of fighting is for five or six workers to seize the legs of their adversary, and hold on.

Sometimes colonies of different species may be found together, nesting under the same stone, or in close proximity to each other, but it is only in cases where the mixed nest owes its origin to the abnormal method of colony founding that they are really associated. In other cases, where they are living together only by chance, when the nest is disturbed, or the different ants are put into a box, they will at once attack each other.

The method by which ants of this genus salute each other is very characteristic; it has already been described by Crawley, and as far as is known to me he is the only myrmecologist who has published an account of this curious action.

When two specimens of Donisthorpea meet, one of the ants will be seen to make a succession of rapid jerks of the body towards the other, which lasts for several seconds. This motion does not consist in striking the head against the other ant, and the only parts of the body touching at the time are usually the antennae. On uncovering an artificial nest of $D$. flava or nigra and exposing it to the light, almost every ant may be seen thus jerking its whole body to its neighbours. An ant may be seen in an artificial nest to salute nearly every ant it meets. The workers greet young winged females and males in the same manner, and the females sometimes respond, but the males never do. I have seen young winged D. umbrata females frequently salute each other in this manner when they met. A young fertile female will respond to the salutes of her first brood, but an old female in a large nest never does so.

Fabricius [Syst. Piez. 415 (1804)] published a heterotypical genus Lasius for the reception of ten species of ants, but this use of the name is invalid since Lasius (Type A pis quadrimaculata Panz.) had already been used by Jurine for a genus of Bees [Erlangen LittZtg. 1164 No. 33 (1801): Nouv. Méth. Hym. 235-238 No. 33 Pf. 4.33, 11.33 (1807)]. Latreille [Gen. Crust. Ins. 4126 (1809)] sunk Lasius F., as a synonym of Formica, and the Fabrician name 
ceased to be used until 1861, when Mayr [Europ. Formicid. 49 (1861)] revived and re-characterized Lasius F., adopting niger L., F., as his type. Bingham [Faun. Brit. India. Hym. 2338 (1903)] and Wheeler [Ann. New York Acad. Sc. 21165 (1911)] also cite niger as the type. This species was also adopted as the Type by Morice and Durrant [Trans. Ent. Soc. Lond. $1914421-423$ (1915)] who gave the following reasons for the change of name:- "In the Systema Piezatorum Fabricius made use of Jurine's name Lasius, but applied it to a genus of Ants which he separated from Formica L., and later authors have ignored Jurine's Lasius, no doubt because the publication of the Piezatorum (1804) antedates that of the Nouvelle Méthode (1807). But the real date of Lasius Jrn., as we now learn, is May 30th, 1801 (Erlangen List) - \$ Lasius F. (1804) therefore sinks as a homonym of the earlier Lasius Jrn. A new name for $\S$ Lasius F. is necessary, there being apparently no existing synonym, we therefore propose that it be called Donisthorpea in recognition of Mr. H. St. J. K. Donisthorpe's careful investigations into the bionomics of this and other Heterogynous genera."

$\Varangle$ Head cordate; clypeus broad, convex, rounded anteriorly, posterior border distinct ; frontal carinae fairly short ; frontal area indistinctly defined, broader than long, rounded posteriorly ; frontal furrow indistinct or sometimes distinct; mandibles triangular, terminal border dentate; maxillary palpi six-jointed; labial palpi four-jointed; antennae twelve-jointed, funiculus with joints two to five not longer than the succeeding ones; ocelli indistinct. Thorax short; pronotum rounded, suture between pronotum and mesonotum distinct; mesonotum convex; epinotum short, with a flat, sloping surface posteriorly. Petiole with scale vertical, or slightly inclined forward ; gaster oval, flatter than in Formica. Legs shorter than in Formica.

o Head as in the $\not$; ocelli distinct. Thorax robust; pronotum short; mesonotum large, rounded and convex anteriorly, flat posteriorly ; scutellum broad, very slightly convex; epinotum sloping, rounded posteriorly. Wings : fore-wings with one cubital cell, and one discoidal cell, the latter sometimes wanting. Gaster flatter than in Formica. Legs shorter than in Formica.

to Head triangular; clypeus, frontal area and palpi as in the $\measuredangle$; frontal carina short, slightly divergent posteriorly; mandibles broad armed with a single tooth at apex, or with terminal border dentate; antennae thirteenjointed, with the first joint of the funiculus broader, and the last joint longer than the rest. Petiole, with scale as in the small. Wings as in the o. Size generally much smaller than in the o.

Ovum : White, round oval.

Larva: Pale yellowish white, long, very narrow, and curved anteriorly, with the segments distinctly defined, and gradually increasing in breadth till just before the base. The whole body covered with short, slightly curved, yellow hairs of about equal length, which are more abundant in the younger larvae. The body appears to be finely striate transversely.

Pupa: Enclosed in pale reddish yellow cocoons, but sometimes naked.

Original description of Lasius F. [Fabricius Syst. Piez. 415 (1804)] :

"Lasius Os absque lingua.

Mandibula brevis, fornicata, apice rotundata cum acumine.

Labium maxilla brevius.

Antennae medio frontis insertae, fractae." 


\section{Table of the Species.}

\begin{tabular}{|c|c|}
\hline & Colour shining black \\
\hline & $-\ldots-1-1--1--$ \\
\hline & Colour yellow. \\
\hline & Colour brown or blackish brown ------------- \\
\hline & Size variable, generally smaller; scale low, broadest at apex 4 flava F. \\
\hline & Size less variable, larger ; scale higher, not broadest at apex ----4 \\
\hline & $\begin{array}{l}\text { Funiculus thinner, with joints longer than broad; tibiae with outstand- } \\
\text { ing hairs. }\end{array}$ \\
\hline & $\begin{array}{l}\text { Funiculus thicker, with joints not longer than broad; tibiae without } \\
\text { outstanding hairs }-6 \text { mixta Nyl. }\end{array}$ \\
\hline & $\begin{array}{l}\text { cape of antennae and tibiae with outstanding hairs } \cdot 2 \text { nigra L. } \\
\text { cape of antennae and tibiae without outstanding hairs } 3 \text { aliena Först. }\end{array}$ \\
\hline
\end{tabular}

\section{오}

1 Head large, as broad as thorax, emarginate posteriorly . . . . . . 2

- Head small, not as broad as thorax, not emarginate posteriorly - - - 4

2 Colour shining black . . . . . . . . fuliginosa Latr.

(1) $\{$ Colour brown $-\ldots \ldots-\ldots-\ldots$

3 Funiculus thinner, with joints longer than broad; tibiae with outstanding hairs............. umbrata Nyl.

(2) Funiculus thicker, with joints not longer than broad; tibiae without outstanding hairs $\ldots \ldots \ldots \ldots$ - $\ldots \ldots$ mixta Nyl.

4 Underside of head, thorax, and gaster yellowish . . . . flava F.

(1) Underside the same colour as above $-\ldots \ldots \ldots$

5 Scape and tibiae with outstanding hairs ........ nigra L.

(4) Scape and tibiae without outstanding hairs _ _ _ - aliena Först.

$\hat{\sigma}$

1 Mandibles armed with five teeth . . . . . . . . . . . 2

- Mandibles armed with a single tooth $\ldots \ldots \ldots \ldots$

2 Eyes with distinct outstanding hairs . . . . . . umbrata Nyl.

(1) Eyes almost without hairs _ _ _ $\ldots \ldots \ldots \ldots \ldots$ - $\ldots$ mixta Nyl.

3 Colour shining black; gaster with large scattered punctures ....

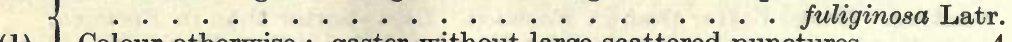

(1) Colour otherwise; gaster without large scattered punctures - - - 4

4 Frontal furrow indistinct; wings slightly smoky . . . . . flava F.

(3) Frontal furrow distinct; wings clear $-\ldots \ldots \ldots$

5 Scape and tibiae with outstanding hairs; mandibles black brown nigra L.

(4) Scape and tibiae without outstanding hairs; mandibles partly yellowish

\section{Donisthorpea fuliginosa Latr.}

["The Jet Ant" Gould Account English Ants $2^{1} 9^{2} 86-90^{3}$ (1747)]. Formica fuliginosa Latreille Ess. Hist. Fourmis France 36 (1798)4. ("La fourmi fuligineuse" Huber Moeurs Fourmis 52318 Pf. 1.3-4 (1810)) Formica fuliginosa Schenck Jahrb. Ver. Naturk. Nassau 8 45-48 $139^{7}$ (1852) ; Mayr Verh. Zool. Bot. Ver. Wien $284^{8} 351^{9}$ (1855); F. Smith Trans. Ent. Soc. Lond. (n.s.) $397^{10} 105-106^{11}$ (1855); Haliday NH. Review 4 $33(1857)^{12}$; F. Smith Cat. Brit. Foss. Hym. $10(1858)^{13}$; Meinert Kong. Danske. Vidensk. Selsk. Skrift. 5 320-321 (1861) ${ }^{14}$. Lasius fuliginosus Mayr Europ. Formicid. 49-51 (1861) ${ }^{15}$. Formica fuliginosa F. Smith Ent. Ann. $1866130^{16}$ : $186895^{17}$; Holt Science Gossip $1868159^{18}$. Lasius fuliginosus Forel Denkschr. Schweiz. Ges. Naturw. $2646^{19} 181-187^{20} 217^{21} 375^{22} 407^{23}$ (1874) ; Lubbock Mo. Mic. Journ. 1877134 Pf. 190.324; Saunders Trans. 
Ent. Soc. Lond. $1880208^{25}$; Er. André Spec. Hym. Europe 2 49-50 191 $(1881)^{26}$. Formica fuliginosa Buckton Mon. Brit. Aphidae $486(1883)^{27}$.

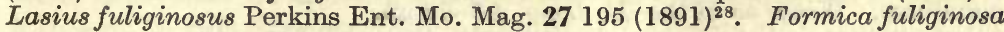
Douglas Ent. Mo. Mag. 28106 (1892) 29. Lasius fuliginosus Dalla Torre Cat. Hym. $7185(1893)^{30}$; D. Sharp Trans. Ent. Soc. Lond. $1893202^{31}$; Sulc Ent. Mo. Mag. 3087 (1894) $^{32}$. Formica (Lasius) fuliginosa FarrenWhite Ants' Ways 234-235 (1895) ${ }^{33}$. Lasius fuliginosus Saunders HymAcul. 23-24 (1896) ${ }^{34}$; Donisthorpe Ent. Rec. $9246(1897)^{35}$; Rothney Ent. Mo. Mag. $3514(1899)^{36}$; Morley Hym. Suffolk 11 (1899) ${ }^{37}$; D. Sharp Camb. NH. Ins. $2138^{38} 153^{39}$ (1899); Wasmann Zool. Anzeig. 22 85-87 $(1899)^{40}$; Lagerheim Ent. Tidskr. 21 17-29 (1900) ${ }^{41}$; Oudemans Allgem. Zeitschr. Ent. $6179(1901)^{42}$; Vic. Hist. Durham $195(1905)^{43}$; Escherich Ameise $94^{44} 112^{45}$ (1906); de Lanoy Ann. Soc. Ent. Belg. 52 47-53 (1908) ${ }^{46}$; Forel Ann. Soc. Ent. Belg. $52180(1908)^{47}$; Emery Ann. Soc. Ent. Belg. $52182(1908)^{48}$; Donisthorpe Trans. Leicester Lit-Phil. Soc. $12224(1908)^{49}$; Wasmann Zool. Anzeig. 35135 (1909) ${ }^{50}$; Wheeler Biol. Bull. $19134(1910)^{51}$; Donisthorpe Ent. Rec. $2217(1910)^{52}$; Crawley Ent. Record $2267(1910)^{53}$; Donisthorpe Trans. Ent. Soc. Lond. 1911 180-181 ${ }^{54}$ : Entom. $44390(1911)^{55}$; Donisthorpe and Crawley Trans. Ent. Soc. Lond. 1911 664-67256 ; Donisthorpe Ent. Rec. $246(1912)^{57}$; Zimmer Zeit. Wiss. Insektenbiol. 832 (1912) ${ }^{58}$; Crawley and Donisthorpe Int. Ent. Cong. Oxford 19122 51-55 $(1913)^{59}$; Donisthorpe Rep. Lanes-Chesh. Ent. Soc. $36191240(1913)^{60}$ : Ent. Rec. 2639 (1914) $^{61}$; J. B. Elliott Trans. Brit. Mycol. Soc. 1914 138-13962.

$\Varangle$ Jet black, shining, funiculus and tarsi yellowish brown, mandibles, scape femora and tibiae reddish brown. The whole body finely alutaceous, and sparsely covered with fine pubescence.

Head large cordiform, emarginate posteriorly; ocelli very small but distinct. Epinotum broad. Scale high, narrowest at apex. Long. 4-6 mm.

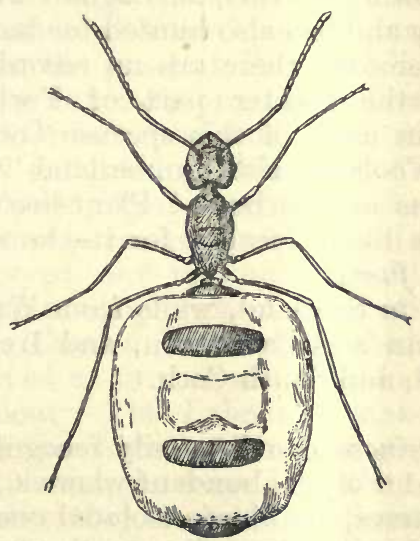

Fig. 82. Donisthorpea fuliginosa ㅇ with gaster distended with eggs.

우 Colour and puncturation the same as in the worker; more pubescent, with short erect hairs.

Head large, as broad as thorax, cordiform, slightly more strongly emar. ginate posteriorly than in the $\forall$. Wings with the anterior half blackish. Long. 6-6.5 mm. (6-8 mm. teste André.)

o Colour as in the , less pubescent, but puncturation more distinct. 
Head finely rugose, widely emarginate posteriorly; mandibles furnished with one large tooth at apex. Mesonotum and gaster with large scattered punctures. Wings as in the o. Long. $4 \cdot 5-5 \mathrm{~mm}$.

Original description of Formica fuliginosa Latreille [Ess. Hist. Fourmis. France 36 (1798)] :-

“* F. fuligineuse, fuliginosa.

O. p. Courte, très-noire, luisante. Antennes, à prendre du coude, genoux et tarses, d'un brun testacé. Tête grosse, échancrée postérieurement. Ecaille petite. Abdomen globuleux. Mâle. Couleurs semblables. Écaille entière, presque ovée. Aîles antérieures obscures à leur base. Femelle. Très-noire, courte. Mandibules, antennes et pattes roussâtres. Aîles et écaille du mâle."

\section{Habitat.}

Donisthorpea fuliginosa ranges over the greater part of Europe ; Ruzsky records it from the Caucasus, Siberia, and Finland, Bingham from Thana in Western India, and it is found in Japan, but Forel considers the Japanese form to be a variety and has recently named it var. nipponensis.

In England it is generally distributed as far north as South Lancashire, and South-West Yorkshire, but I have no records for North Devonshire, South Wiltshire, Bedfordshire, Huntingdonshire, Gloucestershire, Monmouth, Shropshire, or South Lincolnshire. It has been recorded as "not common" in Durham" ${ }^{43}$, but I am rather doubtful about this, as Bagnall who has collected so much in that county and has also hunted for ants' nests, has never come across it; moreover there are no records for Cumberland, Westmorland, nor the greater part of Yorkshire. Buckton's record of Aphidae in nests of this species " on the moors round Alnwick and near Wooler in Northumberland "27 is very doubtful, as D. fuliginosa does not harbour "Plant-lice" in its nests, and the moors are not a likely locality for it-he must have referred to nests of Formica fusca.

It does not occur in Scotland, while from Wales I have records only from Glamorgan and Carnarvon, and Ireland from Dublin, Wicklow, Waterford, and South Cork.

Donisthorpea fuliginosa can be easily recognized by its habits, odour, and nests, and is often abundant where it occurs. It nests in woods, in groups of trees, but also in isolated ones, and may be seen marching steadily along, in long files, on beaten tracks. As long ago as 1747 our countryman Gould described this habit in the following quaint language ${ }^{3}$ :- "There remains a particular Curiosity to be mentioned with regard to the Jet Ants, which not only deserves Admiration, but strongly tends to illustrate the preceeding Observations, and to show that Man is not the only Partaker of Wisdom. It is remarkable of these Ants, that in carrying on their Employments they Form so many Streets or 
different Tracts as are proportionable to the Size and Situation of their Colonies. If the Inhabitants be very numerous, as it usually happens in this Species, they extend their Streets to a considerable Length, (Forty Yards or more) and the Number of them shall amount perhaps to four, besides several less Branches that strike off from the main Tracts. Sometimes there is but one, sometimes two or more grand Streets, besides the little Allies, all which frequently vary in Length. In these Paths the Workers continually make their Progresses to and from the Colony. And you may, with equal Pleasure and Certainty, observe the Variety of their Provisions, their Sedulity in seeking, and Method of bringing it Home. The Tracts are every Moment thronged with Multitudes of industrious Ants; we may (to compare little things with great) not improperly resemble them to the busy Concourse in the Streets of London, - a regular Confusion. Only with this Difference, that not a single Ant is unemployed, or deserves the Title of a Vagrant. All are engaged for the Public Emolument, without Envy, without Complaint. No other Strife, but who shall first return laden with Provisions to sustain the Young. A laudable Emulation! They exert their Labours at the earliest Appearance of Spring, and continue them so long as the Smiles of Autumn give leave. Nothing but Severity of Weather interrupts their Processions. Amongst the many Curiosities this Scene affords us, the Opportunity we have of viewing their Diversity of Aliment is not the least. Numbers of them come Home either with the Spoils of Insects, or the Insects themselves. But far the greatest Part are distended with Juice. I never could discern any fatiguing themselves with the Carriage of Wheat or other Grain; and how such a constant Delusion should arise, if they delighted in Corn, is not easy to conjecture. Their Manner of collecting Provisions is likewise a pleasing Amusement. Their Settlements are generally placed in the Bottom of a Tree somewhat decayed, and in whose Neighbourhood are other Trees more flourishing and verdant. Sometimes the Jet Ants prefer residing in a Garden Wall replenished with Fruit. The Tracts are so contrived as to pass along by such Trees as promise the most Nourishment. The Labourers make Excursions from their main Paths to the Trees, and having gathered what Forage they can meet with, return the same Way they came. In order to facilitate their Progress, they remove any Obstacles that lie in their Road, as Bits of Straw, Sticks, and other Rubbish; and also Bite off the Herbs almost even with the Surface of the Ground. Thus by their indefatigable Pains they suffer not the Grass to grow in the Streets."

This ant possesses a very characteristic, pungent, aromatic odour, which is not unpleasant, though Gould ${ }^{2}$ says-" "It may be remarked that the Jet Ants have a peculiar disagreeable Smell, which, I fancy, is a great Preservative to them against an Enemy" 
-and Farren-White ${ }^{33}$ describes it as a fragrant scent like that of the musk beetle, but it does not remind me of the odour of that insect.

Forel gives reasons to show that the seat of this odour lies in the head more than in any other part of the body ${ }^{22}$, as the heads, when crushed, give off a very violent odour, though the thorax and gaster do not seem to be entirely inodorous.

Landois described a structure in these ants by means of which they can probably stridulate, though Sharp ${ }^{31}$ does not consider it to be a true stridulating organ. It consists of delicate transverse lines sculptured on the dorsal surface in the middle at the base of the third gastric segment, the line of demarcation between the general sculpture and that of the basal portion not being very abrupt. There is however no special contrivance on the overlapping segment to scrape against it, but the friction of the segments together probably produces some sound.

The colonies of $D$. fuliginosa are often very populous, and a number of subsidiary nests may occur in neighbouring trees. Rothney found the nests of this ant were extremely abundant in old oak trees at Barham, and two such trees were situated on the opposite sides of a gravel pathway, beneath which the ants had excavated a tunnel of communication ${ }^{17}$. Consequently they are able to overpower any other ants in the neighbourhood, as they can concentrate in vast numbers very quickly at any desired spot. Forel ${ }^{22}$ placed the contents of ten nests of Formica pratensis near a tree occupied by $D$. fuliginosa, and the latter when besieged, obtained assistance from the inhabitants of other trees near, overwhelmed the pratensis with their numbers and captured all their cocoons. Wasmann ${ }^{40}$, in 1884 , emptied a sack full of $F$. rufa at the entrance to the nest of a strong colony of $D$. fuliginosa in a garden at Exaeten, when the latter swarmed out and drove off the former.

In September, 1913, I placed the large nest I obtained at Oxshott (mentioned presently) in a box on a case with glass sides, open at the top and surrounded by water, which contained a colony of $F$. rufa under observation. In the night a large number of the fuliginosa workers escaped, and, entering the rufa nest, completely routed the inhabitants - some fifty deälated rufa females and all the workers fleeing from the nest.

Huber ${ }^{5}$ and other old writers thought the nests of this species were excavated in wood which was stained black by the ants' acid, but Meinert ${ }^{14}$ and then Fore ${ }^{20}$ proved this not to be the case.

They are really made of carton, consisting of chewed fragments of wood and bark, mixed with earth and cemented together with the secretion from the mandibulary glands, which are greatly developed in this ant (see Fig. 42). Forel ${ }^{20}$ suggests that the liquid from the metathoracic glands helps to soften the wood 



\section{Plate XI}

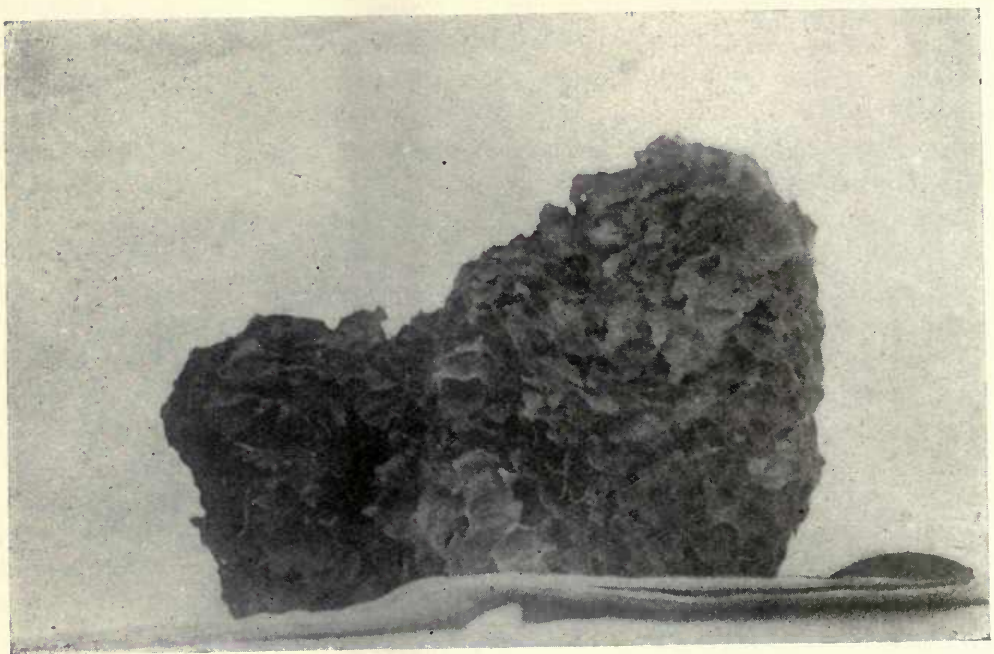

Carton nest of Donisthorpea fuliginosa.

Dug up at Oxshott, 9.IX.13.

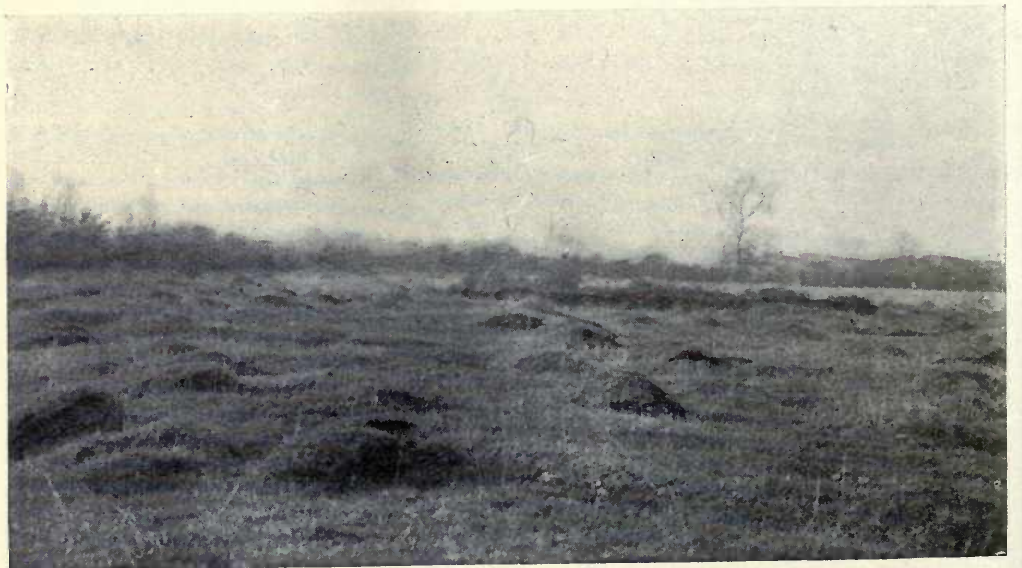

Donisthorpea flava mounds. Oddington, 18.IV.14. 
which the ants chew up; but that of the salivary glands seems more likely for this purpose.

These nests are often very large, having the appearance of a huge sponge, and consist of a number of irregular cells separated from each other by thin carton walls, which are rather brittle and generally black in colour, but sometimes light brown, according to the amount and the colour of the earth used in their construction - the carton of a nest I found in the Isle of Wight was of a light reddish brown colour. The carton contains a quantity of a fungus which was named Septosporium myrmecophilum by Fresenius, Saccardo describes it as Macrosporium myrmecophilum, but considered it might be identical with Cladotrichum, and Lagerheim came to the conclusion that it was really a Cladotrichum, and called it C. myrmecophilum ${ }^{41}$. (I supplied Dr. Jessie Baylis Elliott of the Birmingham University with various samples of $D$. fuliginosa carton, and she has proved, by making cultures, etc., that the fungus it contains is a Cladosporium, and so should be called Cladosporium myrmecophilum ${ }^{62}$.) The "raison d'être" of this fungus is probably twofold, the hyphae may act as food for the ants and their brood-it forms a delicate bluish mould on the walls of the cells and under the microscope it may be seen to have been bitten off by the ants-and the mycelium helps to strengthen the walls of the nest. The ants most probably cultivate this fungus intentionally, as no other species of fungus is found in these nests, but it would not alone supply sufficient food for the teeming myriads that go to form the population of a large colony.

Dr. Sharp says this species lives in decayed wood ${ }^{38}$, but though its nests are generally built in hollow trees, old tree stumps, and posts, they frequently occur in the ground, at the roots of, but also away from, trees, and even in houses and cellars, etc.

On September 9th, 1913, I dug up a nest at Oxshott which was thirteen inches long, nine and a half inches high, and eight and a half inches broad, and was situated under the roots of a large Scots fir some three feet below the surface of the ground. The earth surrounding the nest was of a soft sandy nature, but just below it the ants had excavated small chambers in the ground, and the soil round these was almost as hard as stone.

Smith records it as nesting in a sand-bank at Southend ${ }^{11}$; near Coomb Martin, in the mud walls by the roadside ${ }^{16}$; near Ilfracombe he observed it inhabiting fissures in the rocks ${ }^{16}$; Farren-White ${ }^{33}$ speaks of it as a miner at Clevedon, and White Notley; Perkins ${ }^{28}$ found an enormous colony in a sandy bank at Stoke Fleming in 1891 ; and Rothney ${ }^{36}$ mentions its occurrence in an earth bank on the Headland at Newquay in 1899.

In August, 1914, I observed a number of $D$. fuliginosa workers attending large black Aphidae on some young birch trees on 
Weybridge Heath. It was almost impossible to discover whence they came, but eventually I found the ants had constructed a tunnel, about an inch in diameter, just beneath the surface of the ground. This tunnel extended for six yards, when it entered a sandy bank, and deep in this bank their large carton nest was situated.

Haliday found this Donisthorpea on an undulating expanse of bleached sand off Arklow Head in August, 1856; he says the ants were far away from any trees, but seemed quite busy and happy in the torrid heat ${ }^{12}$.

I have also seen it nesting in the sand near the sea ; the colony in question was situated in a hollow in the sand-dunes at Southport $^{49}$, no trees occurred anywhere near, and the ants entered and left their nest by a hole in the sand.

Schenck ${ }^{6}$ records the occurrence of two nests in the hollow wall of a Garden-house near Homburg, which he says were made of bits of wood and plants, and little stones all fastened together. The one measured two feet in height, two feet in breadth, and half a foot in thickness, and the other was of the same height and thickness, but was only one foot and a half broad. He says a gardener had known of the existence of the ants in this house for about thirty or forty years, and he also mentions another nest in the straw roof of an ice-house.

Holt ${ }^{18}$ in 1868 saw a nest in the floor of a house at Upper Norwood which was built between two of the joists and rested on the ceiling of the cellar below. He says the ants passed in and out of the house under the doorstep, and the nest seemed to be composed of masticated wood. Crawley ${ }^{53} \mathrm{knew}$ of a similar nest in the beams of the cellar in a house he lived in, W. E. Sharp showed me a grating in the wall of his house at Crowthorne where these ants gained access to his cellar, and Nevinson told me a colony had established itself under the concrete floor of a lavatory in his house at Cobham-he has recently had the floor taken up, and he found a nest one foot four inches high, by one foot six inches wide. He showed me the remains of this nest, and the place whence it came, and he assures me that though the ants had lived in his house for some years, they merely took exercise in the hall without hunting for food and they never went out of doors at all. This being the case it would seem that the fungus cultivated by the ants is sufficient to sustain the colony! Also, as will be seen presently, the great difficulty experienced in rearing fuliginosa larvae in captivity-when no carton is present-would seem to show that the fungus is necessary as food, though the ants feed on other substances as well. These remarks will apply in part to D. umbrata also.

Oudemans ${ }^{42}$ has described and figured a nest he found in 1885 in the roof of an ice-shed in Holland which measured thirty-seven 
centimetres in height, thirty-six centimetres in breadth and twenty centimetres in depth, and Zimmer ${ }^{58}$ records the discovery of a nest which was situated in a child's coffin which had been buried for about thirty years, the entire interior of the coffin being filled with the carton made by the ants.

D. fuliginosa often deserts its nests, especially when they have been disturbed, but on the other hand it often remains in the same place for long periods. Bennett has known of a colony, nesting at the foot of a large oak tree at Guestling, for over twenty years.

The food of this ant consists very largely of the excreta of Aphidae which it attends on trees, though it does not harbour them in its nests, and it also visits Coccidae, hunts insects, feeds on the frass of caterpillars, collects seeds, and raids the nests of other ants, carrying off their pupae.

Forel $^{22}$ says they attend plant lice on large trees, especially oaks, and Escherich states they only visit the Aphidae that live on the bark of trees ${ }^{45}$.

Schenck ${ }^{6}$ noticed that this species was very fond of a juice it obtained from a Coccus on oak trees, Douglas ${ }^{29}$ recorded that Dr. Chapman observed it attending Lecanium rubi on bramble stems near Hereford, and Sulc ${ }^{32}$ found three females of Pseudococcus aceris on detached pieces of bark in the runs of $D$. fuliginosa at Prague, which were surrounded and caressed by the ants.

Morley ${ }^{37}$ records it devouring the larvae of Liparis salicis, and carrying Hemerobius stigma in its jaws, and I have frequently watched the workers returning home laden with small insects, though by far the greater number have nothing in their jaws, but their gasters are distended with liquid.

Forel ${ }^{22}$ saw a number of these ants returning home, each with a pupa of a Myrmica in its mandibles, and he concluded they must have raided a large Myrmica nest, and Wasmann ${ }^{40}$ observed on August 7 th, 1898, at Lippspringe a strong colony of $D$. fuliginosa marching over a distance of twenty metres to a nest of $M$. laevinodis, and plundering and carrying home the larvae and pupae of the latter.

In spite of the fact that Gould never saw these ants carrying grain, they do most certainly collect the seeds of plants. Lagerheim has seen them carrying the seeds of Viola odorata, V. hirta, and Melica uniflora in Scandinavia ${ }^{41}$, and in September, 1909, at Darenth Wood I collected a number of the seeds of Melica uniflora which I took from the workers of a colony of $D$. fuliginosa, as they brought them to their nest, which was situated in a large tree stump ${ }^{52}$. These seeds all belong to types which are attractive to ants, by reason of the food stored in them.

The marriage flight takes place in the early afternoon, but also according to Huber ${ }^{5}$ in the middle of the night, which accounts for the fact that Morley took males at electric light in Ipswich ${ }^{37}$. 
Saunders ${ }^{34}$ gives July and August as the months for the swarming of this species, but it also occurs both earlier and later in the year; Schenck ${ }^{7}$ noticed a marriage flight on June 25 th, 1852, at Nassau, and Morley observed males and females swarming on spruce on May 4th, 1907, at Elvedon in Suffolk. Forel records the copulation on June 24th and 29th and July 3rd in Switzerland ${ }^{23}$, and on July 27th, 1911, I observed at Wellington College, in the afternoon, a number of males and females running up the young shoots and boughs growing on a tree stump in which their nest was situated, and copulation took place on these branches ${ }^{57}$. In the case of the large nest before mentioned, which I brought home from Oxshott, copulation took place in September on the top of the nest and in the box in which it was placed. It will thus be seen that females are often fertilized by their brothers from the same nest, and as the male-unlike the other species in the genus-is not much smaller than the female, the latter is probably unable to carry the former during the marriage flight.

The gaster in the fertile female in time becomes distended with eggs and swells enormously, having the appearance of a large sack of white membrane. On August 16th, 1913, I found such a one at Apse Heath in the Isle of Wight; she was lodged in the cells at the top of the carton nest, which was situated just below the turf at the foot of an oak tree, and was surrounded by a large court of workers ${ }^{61}$. Her total length is eleven $\mathrm{mm}$., the gaster alone measuring seven $\mathrm{mm}$. in length, and six $\mathrm{mm}$. in breadth. Crawley and I have shown that the female does not lay till the year after impregnation, and we have proved her to be a temporary social parasite ${ }^{56}$, as will shortly be seen.

The larvae, which are very numerous, occur throughout the year, and the pupae are generally enclosed in cocoons, but both $\mathrm{Mayx}^{8}$ and F. Smith ${ }^{10}$ record finding a number of naked pupae.

D. fuliginosa often founds new colonies by branch nests, which accounts for the fact that many colonies are found in the districts where this ant ocours. After the marriage flight newly fertilized females are received back into the parent and other fuliginosa nests near by. Occasionally, however, deälated females are found wandering about in localities some distance from their nests. Forel records finding a number of deälated females on roads at Soleure on July $21 \mathrm{st}, 1869^{23}$, and Crawley found one at Oddington near Oxford, about one hundred yards from a nest, and others at Esher in August, 189959, and in such cases as these the females would not be likely to be received back into their own nests. However, when isolated they display no desire to found a colony. Crawley and I have both kept in captivity newly fertilized females which get rid of their wings immediately after impregnation;and they never settle down, but endeavour to escape, and soon perish. 
Therefore, from the above facts alone, it seems doubtful whether the female of this species can found a colony unaided.

But further observations in the field point to Donisthorpea umbrata and D. mixta as the host-species of D. fuliginosa. In $1897 \mathrm{I}$ found at Lymington a large colony of $D$. fuliginosa in a hollow tree, and D. umbrata was undoubtedly living with it, as workers of both species were going in and out of the same holes ${ }^{35}$. Crawley in 1898 repeatedly found workers of $D$. umbrata walking unmolested with the workers of a large nest of $D$. fuliginosa established under his house near Oxford ${ }^{53}$. In September, 1900, Tuck sent to me a worker of $D$. umbrata taken in a nest of $D$. fuliginosa at Bury St. Edmunds ${ }^{54}$.

In 1904 de Lannoy ${ }^{46}$ found at Knocke-sur-Mer a few workers of D. mixta in the midst of a large colony of $D$. fuliginosa which were on good terms with the workers of the latter, and in 1906 he again found workers of $D$. mixta in several $D$. fuliginosa nests. Forel $^{47}$, Emery ${ }^{48}$, Wasmann ${ }^{50}$, Wheeler ${ }^{51}$, and $I^{54}$ commented on de Lannoy's observations, and expressed the opinion that the presence of these $D$. mixta workers was due to the fact that fertile D. fuliginosa females had entered nests of the former species and been accepted. The queens of the D. mixta had then died, or had been killed, either by their own workers, or by the $D$. fuliginosa females, and the offspring of the latter were reared by the D. mixta workers. In the course of time many of the latter had died off, and the few found in the nests were the survivors of the original D. mixta colonies.

Crawley and I determined to test this hypothesis by experiments on captive colonies. In July, 1910, a portion of a nest of $D$. fuliginosa was dug up at Darenth Wood, containing a quantity of workers, larvae, males, and winged females, but no queen. The ants and brood were divided into two equal portions and each established in a four-chambered "Janet" nest. (It may be here mentioned that this ant cannot be kept in close confinement, but that if an observation nest be connected by long glass or indiarubber tubes to another plaster nest, or glass bowl, or some other contrivance in which their food is placed, the ants will thus obtain sufficient exercise.) During July all the males died and most of the females, with the exception of about twelve, which were found to be deälated. As some of these latter subsequently laid eggs, from which larvae were reared, it is highly probable that mating had taken place inside the nests.

In the beginning of December, 1910, a nest of D. umbrata without a queen was obtained at Weybridge and divided into two equal portions, which were established in Janet nests.

The first experiment was made on December 10th when one of the deälated female fuliginosa was placed in the light chamber of one of the umbrata nests. She immediately entered the most 
crowded chamber; one worker saluted her and another dragged her further in by a mandible, but eventually she was attacked and killed before evening. On December 13th another deälated female was put into a small plaster nest with some of the workers from the same umbrata nest as in the former experiment. She was slightly attacked but made no resistance, and endeavoured to conciliate her assailants by stroking them with her antennae. When a worker endeavours to bite at the waist of one of these females, she protects it by crossing her hind legs over her back, and when at the neck, by pressing her head back close against the thorax. A few more workers were added, and on December 20 th she was introduced with the workers into the umbrata nest. She was a little attacked by workers who had not seen her before, but the old workers protected her, getting between her and the others, and pulling them away by the leg, but very soon all hostility ceased, and she was evidently accepted. Many workers surrounded her, caressed and fed her, and all went well till April, when, a number of the workers having died off, some four hundred more were obtained from the Weybridge nest and introduced. These new-comers attacked the queen, though they were quite friendly with their sister workers, and as they persistently refused to accept her, she was removed and returned to her own nest on April 21st. The fuliginosa workers were very excited at her appearance in their nest, and she was much pulled about, but eventually lost sight of among the crowds of ants. On July 23rd a female with her gaster enormously dilated was noticed in the fuliginosa nest, with a large pile of eggs and surrounded by workers, which may possibly have been the female of the above experiment.

In the next experiment a female fuliginosa was still more easily received into the other umbrata nest and by December 16th she was completely accepted. On March 22nd, 1911, another fuliginosa was introduced into this nest and was immediately accepted without any hostility whatever, as was the case with two more which were introduced in April, but subsequently removed. The two queens first introduced in this experiment began to lay on May 17th, 1911, for the first time, and these eggs hatched on August 9th. In 1912 they began to lay on June 29th, and laid more eggs than during the previous year, but nothing came of these. Some of the larvae which hatched in August, 1911, were nearly full grown in the summer of 1912, but they remained in this condition until 1914. A larva first pupated on June 23rd, 1914, and several more subsequently, but none of them reached the perfect state. As these were from eggs laid in May, 1911, it will be seen that they took over three years to develop as far as the pupal stage!

In 1913 I made a similar experiment with a nest of Donisthorpea mixto-umbrata obtained at Weybridge on August 11th, 1912, and 
subsequently strengthened with workers of $D$. umbrata from Wellington College. On September 14th, 1913, two fertilized females, from the Oxshott nest before mentioned, which had just removed their wings, were introduced into the mixto-umbrata nest, when they were very little attacked and completely accepted the same day. The one died on October 12th, but the other has been treated by the workers as their queen, having been fed, cleaned, and caressed by them, and is still alive in this nest-she laid her first eggs on July 12 th, 1914.

As the females of $D$. fuliginosa are only slightly larger than the workers, and as their fertility is delayed for so long a period, it is clear that they are unable to found colonies unaided; they are hyper-temporary social parasites, since, as will be seen presently, D. umbrata and D. mixta are temporary social parasites of $D$. nigra and $D$. aliena.

The following species of Myrmecophiles have been taken with this ant in Britain :-

Coleoptera: Homoeusa acuminata Märk., Aleochara ruficornis Gr., Microglossa pulla Gyll., M. gentilis Märk., Oxypoda vittata Märk., O. haemorrhoa Sahlb., Thiasophila angulata Er., T. inquilina Märk., Ilyobates glabriventris Rye, I. bennetti Donis., Myrmedonia haworthi Steph., M. limbata Pk., M. funesta Gr., M. humeralis Gr., M. cognata Märk., M. lugens Gr., M. laticollis Märk., Drusilla canaliculata F., Notothecta confusa Märk., Homalota nitidula Kr., $H$. analis Gr., $H$. exarata Shp., H. consanguinea Epp., Quedius brevis Er., Heterothops sp? (nigra Kr. ?), Xantholinus atratus Gr., Oihius myrmecophilus Kies., Batrisodes venustus Reich., Trichonyx märkeli Aub., Ptenidium myrmecophilum Mots., P. gressneri Er., Dendrophilus punctatus Hbst., and Amphotis marginata F.

Formicidae : Ponera coarctata Latr., Stenamma westwoodi West., and Leptothorax nylanderi Först.

Braconidae: Aspilota nervosa Hal., and Chasmodon apterum Nees.

Proctotrupidae: Hoplogryon myrmecobius K., Teleas myrmecobius K., Tropidopria fuliginosus Wasm., Exallonyx wasmanni K., E. wasmanni K. var. sociabilis K., E. myrmecophilus K., Lagynodes pallidus Boh., Bethylus formicarius Curt., Belyta furcata K. var. formicaria K., Loxotropa formicarum K., Amblyaspis scutellaris K. var. hyalinus K., A. lasiophilus K., A. lasiophilus K. var. rufopetiolatus K., Aclista lasiophila K., and Leptorhaptus myrmecophilus K.

Chalcididae : Spalangia erythromera Först.

Cynipidae : Kleditoma myrmecophila $\mathbf{K}$.

Diptera : Phyllomyza lasiae Collin, Phyllomyza sp ?, Pseudacteon (=Phora) formicarum Verrall, A piochaeta (=Phora) aequalis Wood, A. longicostalis Wood, A. ciliata Zett., Milichia ludens Wahl., Scatopse infumata Hal., S. transversalis L. var., Limosina curti- 
ventris Stnh., L. fungicola Hal., Limosina sp.? and Trineura aterrima $\mathrm{F}$.

Heteroptera : Pilophorus perplexus D. and S., and Myrmedobia coleoptrata Fall.

Coccidae : Newsteadia floccosa Westw.

Collembola: Cyphodeirus (=Beckia) albinos Nic., and Lepidocyrtus cavernarum Mon.

Myriapoda: Julus pulchellus Leach.

Araneina : Tetrilus arietinus Thor., T. recisus Camb., Cryphoeca diverșa Camb., Cicurina cinerea Pz., Drassus troglodytes C.K., Hahnia helvola E. S., Harpactes hombergi Scp., Dysdera cambridgei Thor., Microneta innotabilis Camb., M. viaria Bl., and Micarisoma festiva C.K.

Acarina: Urodiscella ricasoliana Berl., Uroplitella minutissima Berl., Trachyuropoda bostocki Mich., T. excavata Wasm., Antennophorus grandis Berl., and Laelaps cuneifer Mich.

Crustacea : Platyarthrus hoffmanseggi Brdt.

\section{Donisthorpea nigra $\mathrm{L}$.}

["The small Black Ant" Gould Account English Ants (1747)1]. Formica nigra Linnaeus Syst. Nat. Ed. $101580(1758)^{2}$. Formica fusca Christ Naturg. Insekt. $512(1791)^{3}$. Formica nigerrima Christ Naturg. Insekt. $513(1791)^{4}$. Formica fusca Latreille Ess. Hist. Fourmis France $43(1798)^{5}$. Formica nigra Latreille Hist. Nat. Fourmis 156-158 (1802) ${ }^{6}$. Lasius niger Fabricius Syst. Piez. $415(1804)^{7}$. ["La fourmi brune " Huber Mœurs Fourmis (1810) ${ }^{8}$. Formica fusca Förster Hym. Stud. $133(1850)^{9}$. Formica nigra Schenck Jahrb. Ver. Naturk. Nassau $849-51^{10} 144^{11}$ (1852). Formica pallescens Schenck Jahrb. Ver. Naturk. Nassau $855(1852)^{12}$. Formica nigra Daniell Proc. Linn. Soc. Lond. 2 290-291 (1854) ${ }^{13}$; Wakefield Proc. Linn. Soc. Lond. 2 293-294 (1854) ${ }^{14}$; Mayr Verh. Zool. Bot. Ver. Wien $5284^{15} 355^{16}$ (1855); F. Smith Trans. Ent. Soc. Lond. (n.s.) 3 109-110 (1855)17 : Cat. Brit. Foss. Hym. 12-13 (1858) $)^{18}$. ["Common Garden Ant" Spencer Zool. $176697(1859)^{19}$. Formica nigra Eaton Ent. Mo. Mag. $5298(1869)^{20}$. Lasius niger H. Müller Berfrucht. Blumen $464(1873)^{21}$. Lasius niger race niger Forel Denkschr. Schweiz. Ges. Naturw. $2646^{22} 216^{23} 257^{24} 375^{25}$ $406^{26}$ (1874). Lasius niger Lubbock Mo. Mic. Journ. 1877 Pf. 189.1 ${ }^{27}$; Saunders Trans. Ent. Soc. Lond. $1880208^{28}$; Er. André Spec. Hym. Europe 2192 Pf. 4.1-2 (1881) ${ }^{29}$; Lubbock Ants, Bees, Wasps $37^{30} 59^{31}$ (1882) ; Forel Ann. Soc. Ent. Belg. $30206(1886)^{32}$; Lubbock Journ. Linn. Soc. Zool. 20 $136(1888)^{33}$. ["Small Brown Ant" Thomas Rep. Trans. Cardiff Nat. Soc. $\left.20106-109(1888)^{34}\right]$. ["Garden Ant"W.E.G. Science Gossip $1889214^{35}$ ]. Lasius niger Dalla Torre Cat. Hym. $7187(1893)^{36}$. Formica (Lasius) nigra Farren-White Ants' Ways 235 (1895) ${ }^{37}$. Lasius niger Saunders Hym-Acul. $25(1896)^{38}$; Donisthorpe Ent. Rec. $12176(1900)^{38}$; Barnes Ent. Mo. Mag. 38265 (1902) $^{40}$; Reichenbach Biol. Centralb. 22 461-463 (1902) ${ }^{41}$; Wheeler Science (n.s.) 18 830-833 (1903) ${ }^{42}$; Janet Obs. Fourmis $33-34^{43} 38^{44} 51^{45}$ (1904); von Buttel-Reepen Archiv. Rassen Gesells. Biol. 211 (1905) ${ }^{46}$; Southcombe Proc. Ent. Soc. Lond. 1906 LXXV-LXXVII ${ }^{47}$; Mràzek Zeits. Wiss. Insektenbiol. 2 109-111 (1906) ${ }^{48}$; Escherich Ameise 88 Tf. A (1906) ${ }^{49}$; Rayward Entom. 39 219-220 (1906) ${ }^{50}$; Janet Comp. Rend. Acad. Sc. 144 393-396 (1907) ${ }^{51}$; Donisthorpe Ent. Rec. $20281(1908)^{52}$ : Trans. Leicester Lit-Phil. Soc. $12224(1908)^{53}$ : Trans. Ent. Soc. Lond. $1909415^{54}$; Stopes and Hewitt Proc. Manchester Lit-Phil, Soc. 53 1-6 (1909) ${ }^{55}$; Wheeler Ants. 
$174(1910)^{56}$; Donisthorpe Entom. $44390(1911)^{57}$; Crawley Trans. Ent. Soc. Lond. $1911657-663^{58}$; Donisthorpe Ent. Rec. $246(1912)^{59}$ : 2563 $(1913)^{60}$; Crawley Ent. Rec. 25135 (1913) $^{61}$; Crawley and Donisthorpe Int. Ent. Cong. Oxford 19122 26-31 (1913) ${ }^{62}$; Donisthorpe Ent. Rec. 2639 (1914) ${ }^{63}$. Donisthorpea nigra Morice and Durrant Trans. Ent. Soc. Lond. $1914423(1915)^{64}$.

ఫ Lighter or darker black-brown, the thorax sometimes lighter, mandibles, base of the antennae, articulation of the joints of the legs, and the tarsi yellow. Body pubescent, thickest on gaster.

Head not emarginate posteriorly ; frontal furrow indistinct; eyes fairly large; ocelli very small and indistinct; scape and tibiae with outstanding hairs. Long. $3 \cdot 4-5 \mathrm{~mm}$.

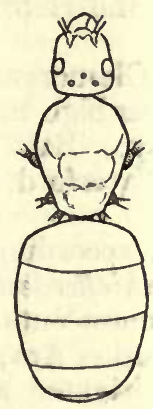

Fig. 83. Donisthorpea nigra 우.

우 Dark brown, or blackish brown, mandibles, scape, tibiae and tarsi reddish. Head small, narrower than thorax, not emarginate posteriorly; scape with outstanding hairs. Thorax narrower than gaster. Gaster large, the same colour beneath as above. Tibiae with outstanding hairs. Wings large, clear. Long. 8-9 mm. (7-10 mm. teste André.)

of Blackish brown with apex of the antennae and tarsi, and the articulations of the joints of the legs lighter.

Head dull; frontal furrow distinct; mandibles with one tooth, blackbrown; scape with outstanding hairs. Thorax narrowly lighter at the insertion of the wings. Tibiae with outstanding hairs. Wings clear. Long. $3 \cdot 5-4 \cdot 7 \mathrm{~mm}$. (3.5-5 $\mathrm{mm}$. teste André.)

Original description of Formica nigra Linnaeus [Syst. Nat. Ed. 10. 1580 (1758)]:-

"F. tota nigra nitida, tibiis cinerascentibus.

Fn. svec. 1022 Formica atra.

Raj. ins. 69. Formica minor e fusco nigricans.

Habitat in Europae terra."

\section{Habitat.}

Donisthorpea nigra ranges over the whole of Europe, and is also found in Japan, Turkestan, the North of Africa, and Madeira. Ruzsky records it from the Caucasus and Siberia. Two varieties occur in the Northern States of America, and a third is found in British America, Alaska, and Colorado. 
Forel states that the Japanese examples are absolutely identical with those from Europe, and that it may be admitted to inhabit the whole of the Northern Hemisphere as far south as the 30th degree of latitude ${ }^{32}$. It probably extends over the whole of the British Isles, but I have no records in England for South Wiltshire, Huntingdonshire, East Gloucestershire, Monmouth, Hereford, Shropshire, South-East and North-West Yorkshire, Cheviotland, Westmoreland, and the Isle of Man, and in Scotland for Peebles, Selkirk, Roxburgh, Forfar, Kincardine, North Aberdeen, Banff, the South, Mid, and North Ebudes, East Ross, East and West Sutherland, Caithness, the Hebrides, the Orkneys, and the Shetlands.

I have only records for Glamorgan, Carmarthen, Pembroke, Merioneth, Carnarvon, and Denbigh in Wales, and Down, Dublin, Wexford, Carlow, West Mayo, East and West Galway, Clare, Limerick, North Tipperary, Waterford, Cork, and Kerry in Ireland.

Donisthorpea nigra, which according to Wheeler is almost indistinguishable from the schiefferdeckeri Mayr of the Baltic Amber ${ }^{56}$, is one of the commonest ants in Europe.

It has been called the "Garden Ant," but it occurs everywhere, in woods, in clearings, in cultivated and uncultivated places, in shady as well as exposed spots, on the seashore and in towns, but is less abundant, however, in fields and meadows than $D$. flava.

Forel records it as occurring as high as the region of the fir trees in Switzerland ${ }^{23}$, and Hull has sent it to me from West Allendale, situated at the height of $1000 \mathrm{ft}$.

D. nigra nests in the earth, in banks, under stones, in old stumps, etc., and frequently occurs under the pavements, and in masonry in towns, and even in houses. I have seen it running about all over the Caledonian Market, and in many other parts of London. S. O. Taylor sent specimens to me from his house in Leicester, and I observed it swarming in a cellar at Southsea.

This ant constructs-though not to the same extent as D. flava - earthen mound nests which in fields are covered with grass; Daniell records such hillocks in grass in his garden at Chobham ${ }^{13}$, Evans found nigra mound nests at Longniddry, and I have seen them at Blankenberge in Belgium, at Woking, and at Sandown in the Isle of Wight, etc.

When nigra nests in tree trunks and stumps it carves out long galleries in the wood, stretching in all directions; André gives figures of a part of a nest of this species carved in the trunk of a dead tree ${ }^{29}$, and I have found it nesting in tree stumps at Tilgate Forest, Parkhurst Forest, etc.

Thomas records finding an interesting nest of " the small brown ant" in a drain-pipe set up as a pedestal for a flower-pot in a garden at Cardiff ${ }^{34}$. The ants had constructed earthen galleries and 
platforms around the whole of the interior of the pipe, their brood being arranged on these platforms. Daniell mentions that nigra will nest in flower-pots, at the roots of the plants ${ }^{13}$, and I once found a small colony in the large hollow root of a Yellow-Horned Poppy at Pett near Hastings. This Donisthorpea has the habit of constructing covered ways from its nests to plants on which Aphidae occur, and also earthen pavilions to shelter and enclose the latter. These constructions, which are very fragile, being made of earth lightly cemented together, may frequently be seen round the stems of plants and at the foot of trees. Step told me that he had seen one of the covered ways of this ant in a greenhouse, which went right up the wall to the roof, and the ants used this tunnel to enter and leave the greenhouse.

Stopes and Hewitt record earthen tents made by Donisthorpea nigra in Japan to enclose A phidae - these tents, which were sausageshaped, made of dark sand, mixed with bits of broken shell and very little cement, were constructed on small branches of an Ilex, on the leaves of which Aphidae were feeding. Nearly the whole twig and its leaves, except the end, were enclosed in a tent, and covered galleries had been built from these tents to communicate with the subterranean nests of the ants ${ }^{55}$.

This species also builds earthen chambers, raised above the ground, round the stems of grass-Escherich gives a good figure of such a structure ${ }^{49}$ - which are used as incubators for the ants' brood; they frequently occur at Weybridge, being made of the fine dry sandy soil there, and are very brittle. I observed a small sand crater at Tenby constructed by this ant at the entrance to its nest which was situated on the sand-dunes, the crater probably having been built to prevent the opening into the nest from being blocked up with sand blown by the wind.

This species may often be seen running in and out of holes in hard paths; and tracks, which are very noticeable, occur on the paths, worn bare by the feet of the ants constantly passing to and fro.

When nesting under stones-sometimes under very large onesD. nigra constructs most beautiful earthen cells between the ground and the stone, with galleries extending down into the subterranean chambers.

If kept in captivity in "Lubbock" nests these ants generally excavate chambers in a particular manner, with a narrow entrance, and a few pillars of earth as supports. Lord Avebury has figured such a nest, showing the entrance, vestibule, main chamber with some pillars, almost as if to support the roof, and inner room; the queen surrounded by workers, one group of pupae, and several of larvae, sorted according to ages; and the blind wood-lice (Platyarthrus hoffmanseggi) ${ }^{33}$.

Huber has beautifully described the manner in which the habita- 
tions of this species are constructed in nature. He writes:"This ant, one of the most industrious of its tribe, forms its nest of stories, four or five lines in height. The partitions are not more than half a line in thickness, and the substance of which they are composed is so finely grained, that the inner walls present one smooth, unbroken surface. These stories are not horizontal : they follow the slope of the ant-hill, and lie one upon the other to the ground-floor, which communicates with the subterranean lodges. They are not always, however, arranged with the same regularity, for these ants do not follow an invariable plan; it appears, on the contrary, that nature has allowed them a certain latitude in this respect, and that they can, according to circumstances, modify them to their wish : but, however fantastical their habitations may appear; we always observe they have been formed by concentrical stories. On examining each story separately, we observe a number of cavities or halls, lodges of narrower dimensions, and long galleries, which serve for general communication. The arched ceilings covering the most spacious places are supported, either by little columns, slender walls, or by regular buttresses. We also notice chambers that have but one entrance, communicating with the lower story, and large open spaces, serving as a kind of carrefour, or cross-road, in which all the streets terminate."8

The ants add to the height of their dwelling during and after rain, by bringing up from below small particles of earth and placing them on the top of the nest, and much of their work is done at night. Huber very carefully watched this operation on one of their ant-hills, which had a round form and rose in the grass. $\mathrm{He}$ says:- "As soon as the rain commenced, they left, in great numbers, their subterranean residence, re-entered it almost immediately, and then returned, bearing between their teeth pellets of earth, which they deposited on the roof of their nest. I could not, at first, conceive, what this was meant for, but at length I saw little walls start up on all sides with spaces left between them. In several places, columns, ranged at regular distances, announced halls, lodges, and passages, which the ants proposed establishing; in one word, it was the ébauche of a new story. ... Each ant, then, carried between its teeth the pellet of earth it had formed, by scraping with the end of its mandibles, the bottom of its abode, which I have often witnessed in open day. This little mass of earth, being composed of particles but just united, could be readily moulded as the ants wished: thus, when they had applied it to the spot where it was to rest, they divided, and pressed against it with their teeth, so as to fill up the little inequalities of their wall. The antennae followed all their movements, passing over each particle of earth as soon as it was placed in its proper position. The whole was then rendered more compact, by pressing it lightly with the forefeet. This work went on remarkably quickly. After 
having traced out the plan of their masonry, in laying here and there foundations for the pillars and the partitions they were about to erect, they gave them more relief by adding fresh materials. It often happened that two little walls, which were to form a gallery, were raised opposite, and at a slight distance from each other. When they had attained the height of four or five lines, the ants busied themselves in covering in the space left between them by a vaulted ceiling. Quitting, then, their labours in the upper part of the building, as if they judged all their partitions of sufficient elevation, they affixed to the interior and upper part of each wall, fragments of moistened earth, in an almost horizontal direction, and in such a way, as to form a ledge which, by extension, would be made to join that coming from the opposite wall. These ledges were about half a line in thickness ; and the breadth of the galleries was, for the most part, about a quarter of an inch. Here several vertical partitions were seen to form the scaffolding of a lodge, which communicated with several corridors, by apertures formed in the masonry ; there, a regularly formed hall, the vaulted ceiling of which was sustained by numerous pillars ; further off might be recognized the rudiments of one of those carrefours of which we have before spoken, and in which several avenues terminate. These parts of the ant-hill were the most spacious ; the ants, however, did not appear embarrassed in constructing the ceiling to cover them in, although they were often more than two inches in breadth. In the upper part of the angles formed by the different walls they laid the first foundations of this ceiling, and from the top of each pillar, as from so many centres, a layer of earth, horizontal and slightly convex, was carried forward to meet the several portions coming from different points of the large public thoroughfare."8

Donisthorpea nigra feeds on a variety of substances, it kills and devours flies and other small insects, etc., harbours numerous subterranean Aphidae and Coccidae in its nests, and also visits other species on plants and shrubs, sucks the nectar of flowers, and collects seeds.

Daniell records seeing nigra kill and drag off a wounded honeybee, and he observed thousands of these ants attending the scale Coccus vitis L., on vines, and others collecting aphides on Calceolarias ${ }^{13}$. He seemed to think the ants killed these plant-lice, because he saw them tearing off the wings of the latter, but ants are known sometimes to remove the wings of these insects to prevent them from escaping. "W.E.G." recorded the "garden ant" milking some black aphides on broad beans in a garden at Bristol ${ }^{35}$, and I have taken many species of Aphidae (and also Coccidae) in numbers on subterranean roots, and at large, in nigra nests under stones. Sich sent me specimens of this ant taken in his greenhouse at Chiswick which were attending the scale Lecanium hesperidum on ferns, and H. Müller records finding the workers in the 
flowers of Chrysoplenium and Rosaceae ${ }^{21}$. Rayward observed D. nigra attending the larvae of the Blue Butterfly (Lycaena bellargus) at Folkestone on August 11th and 12th, $1906^{50}$.

Wakefield in 1854 saw this ant for days and nights togetherhe observed them working at midnight-industriously occupied in dragging to its cells the seeds of the common violet Viola odorata $)^{14}$. Spencer noticed the same habit at Blackheath in 1859, and he saw the ants bring out these seeds from their holes on fine days in July ${ }^{19}$, and Lord Avebury also records the fact that they collect violet seeds ${ }^{31}$. In 1903 Janet frequently found in nests of Donisthorpea nigra near Beauvais seeds of Galium aparine ${ }^{45}$.

D. nigra is a hardy and courageous ant, and it leads an intermediate life between those species which are subterranean in their habits and those which spend most of their time in the open air.

When its nests are disturbed the workers pour out and swarm all over the intruder, and it engages in frequent combats with other ants. It is a deadly enemy to Donisthorpea flava and remains of the latter are constantly to be found in nigra nests. Forel mentions a nest of Formica rufibarbis which he saw encircled and besieged by thousands of $D$. nigra in Switzerland ${ }^{25}$.

It is sometimes found in company with other ants, but these cases are probably only accidental, being due to the gradual encroachment by nigra on the situations occupied by the other species.

Schenck states that it lives not seldom with other ants, for example, flava under the same stone, or near each other in the earth, or in the same earth-hill ${ }^{10}$, and I found a mixed nest of flava and nigra under the same stone at Mickleham ${ }^{39}$ on May 27th, 1900 , and I subsequently pointed out-" As it is unusual for these ants to live together, they were probably encroaching on each other, and eventually the one might exterminate the other." 54

Barnes records that he dug up two deälated females of $D$. nigra in a nest of Formica sanguinea at Wellington College on September 6 th, $1902^{40}$, but it is probable that these females were only sheltering in the earth after the marriage flight, and were not really in the sanguinea nest. The workers of nigra, in common with many other species, will lay eggs, more especially in queenless nests, and it was generally supposed that these parthenogetic eggs always produce males, but Reichenbach has shown that these eggs will produce workers ${ }^{41}$ - Wheeler very ably commented on this and some other known cases ${ }^{42}$ and recently Crawley has proved the same thing by several experiments with colonies in captivity ${ }^{58}$.

The pupae are usually enclosed in cocoons, but Mayr records naked nigra pupae ${ }^{15}$, Janet found naked pupae in a number of nests under large stones at Beauvais ${ }^{44}$, and $I$ found them abundant in a mound nest at Sandown, Isle of Wight, on August 7th, 1913 $3^{63}$. 
Schenck found the winged sexes as early as June 25 th, 1852, at Nassau ${ }^{11}$, and he says the marriage flight takes place from the beginning of July to the beginning of September ${ }^{10}$. Forel gives the middle of July to the middle of August ${ }^{26}$, and Crawley records marriage flights at Seaton on July 14th and September 15th, $1912^{61}$. I have found the winged sexes in the nests from July to September, but I once found a male on April 26th, 1913, under a tin on the sand-hills at Tenby ${ }^{63}$ and I noticed a marriage flight at Woking on September 26th, $1912^{60}$. On August 5th, 1906, Hamm captured a female nigra with short wings-a mermithogyne-at Bovey Tracey in Devonshire.

The marriage flight takes place in the afternoon, and the following description of one I observed at Folkestone on August 9th, 1911, will serve to illustrate the method adopted by the species of Donisthorpea whose males are considerably smaller than the females.

A large colony of $D$. nigra occurred in one of the pillars of a gateway to a house in a street in the town, the ants entering the masonry by a hole in the mortar at the base of the pillar. At five o'clock in the afternoon the workers were much excited, running all over the pavement and up and down the pillar, and a few winged ants were out, going in and out of the entrance to the nest. At six o'clock thousands of males and winged females appeared, emerging from the hole, swarming all over the pillar, and climbing to the top, and on the railings and shrubs in the garden. A few couples were observed in copula, and these flew away together, but most of the winged ants flew off separately, rising straight into the air, and going up so high that they were lost to sight. The workers helped some of them to start, tapping them with their antennae, and pushing them to the edge of the top of the pillar. More females than males occurred. By 6.25 P.M. nearly every winged ant had disappeared, and some few females were already on the ground without wings.

A marriage flight of this species was observed by two of my friends on the same afternoon as the above, at Margate, and Seaview in the Isle of Wight. On August 28th I noticed a marriage flight at Dover, and on my return to Folkestone the same afternoon another was seen there ${ }^{59}$. Marriage flights of $D$. nigra occurred at Weybridge, Putney, Walton, Chobham, and Camberley on August 10th, 1914 (and also of D. flava, D. umbrata, and Myrmica ruginodis at the first-named locality).

Huber says it is requisite that the temperature of the air should be at the $15^{\circ}$ or $16^{\circ}$ Reaumur $\left(67^{\circ} \mathrm{F}\right.$.) to allow of our witnessing the departure of the males and females ${ }^{8}$.

It is evident that the ants are affected by some atmospheric influence which probably extends at the same time over a large area. Eaton records $D$. nigra swarming in the Cactus-house in the 
Botanical Gardens at Cambridge from April 2nd to 8th, $1869^{20}$, but this may have been due to the fact that the ants' nest was situated near to the hot-water pipes, though the temperature in the house during the day was only $60^{\circ}-65^{\circ}$ Fahrenht., and $55^{\circ}-60^{\circ}$ by night.

As an instance of the vast numbers of males and females of D. nigra which are produced a record by F. Smith may be mentioned. He writes :- "In the month of September, 1855, I observed at Dover immense clouds of this ant passing over the town towards the sea ; and subsequently, on passing along the beach, I observed a line of their floating bodies extending from the town at least a mile towards St. Margaret's-the line consisted of males and females, and was about a yard broad."18

Immediately after the marriage flight the females get rid of their wings and seek suitable places in which to lay their eggs, as the females of the large-bodied species of Donisthorpea (D. nigra, aliena, and flava) which are considerably larger than their workers, lay eggs only a few days after fecundation, and are very capable of founding their colonies unaided.

They can live for a considerable time without food, partly subsisting on the muscles, which are completely broken down, as Janet has shown, within a few weeks after deälation ${ }^{51}$. The fatty and albuminoid substances derived from the histolysed wing-muscles are carried in the blood to the abdomen, where they are taken up by the ovaries and, no doubt, contribute greatly to the growth of the eggs.

Deälated females, with small egg-packets, may frequently be met with in the autumn, in small cavities under stones, and in holes and crevices in the earth.

Latreille wrote, in 1802 , of $D$. nigra-one meets often females deprived of the wings, either running on the ground, or hidden, and also alone, under stones 6 . I have frequently met with such females - on October 28th, 1908, many deälated females of Donisthorpea nigra and flava were dug up at Luccombe Chine with their eggs in the little cells they had formed, and in one instance a couple of nigra females were found together in the same cell with a batch of eggs ${ }^{52}$. Wheeler once found two females of Donisthorpea brevicornis together, and he writes-“... under very exceptional circumstances, a couple of females from the same maternal nest may meet after their marriage flight and together start a colony. During August, 1904, I found two deälated females of Lasius brevicornis occupying a small cavity under a clump of moss on a large boulder near Colebrook, Connecticut. They had a few larvae and small cocoons, and a couple of tiny callow workers. . . . Without doubt these twin females were sisters that had accidentally met under the same bit of moss and had renewed the friendly relations in which they had lived before taking their nuptial flight. This case is of considerable 
interest because, as a rule, even sister ants seem averse to such postnuptial partnerships." [Bull. Amer. Mus. NH. 2241 (1906).]

It is probable, however, that two or more nigra females may not infrequently combine in starting a colony, though it is a remarkable fact that colonies of this ant are very rarely found with more than one queen. Crawley once found a colony, in August, 1895, which contained two queens ${ }^{62}$, but it would seem from the experiments in captivity, shortly to be mentioned, that when two or more females have combined together to found a colony, one of them eventually kills the others, and remains the sole queen in the nest.

This species will not receive strange females of its own species into its nests after the marriage flight. Southcombe took some newly-fertilized females of D. nigra in July, 1905, and offered some to wild nests, and others to a captive queenless colony. In every case the females were torn to pieces, the queenless nest in particular showing great ferocity towards the strange females ${ }^{47}$.

A number of colonies have been brought up in captivity by nigra females. Janet found an isolated deälated female, with a small packet of eggs in a little cell, on September 7th, which he placed in an observation nest, the first workers appearing in the following spring; in other experiments which he had carried out in previous years with females of the same species taken after the marriage flight during the first days of August, the first workers were reared by the beginning of October ${ }^{43}$.

In July, 1914, I brought home a deälated nigra female, which I had found walking on a bank at Woking, and established her in a small "Crawley-Lubbock" nest. She blocked up the entrance to her cell, and in a day or so laid eggs. No attention was paid to this nest, but by September lst the female was found to have brought up two small workers. This tiny colony is alive and well to-day, and a number of small larvae are present.

Von Buttel-Reepen took two deälated females after the marriage flight on July 22nd, 1903, and placed them in a glass nest with earth, in which they dug two separate holes and laid eggs by the middle of August. About August 20th one female broke into the cell of the other, brought her eggs, settled with her, and the two females henceforward lived together, heaping their eggs in one bunch. The first larva appeared one month after the eggs were laid, twenty-four in all hatching; some of these pupated after eight months, and the first worker appeared about a year after the females were fertilized. After five workers had hatched, the females ceased to look after the brood. On August 5th the two females commenced to fight, the workers attacking the female that was getting the worst of the combat. This female died the next day, leaving the colony with a single queen ${ }^{46}$.

Mràzek's experiment, though not conclusive, as the females were not actually observed to fight, points to the murder of one female 
by another. In March, 1904, he found two deälated nigra females in a closed cell under a stone, and he established them in a small plaster nest with honey, which they drank. On April 11 th eggs were laid, and by the beginning of June pupae were present which started to hatch at the end of July, and when there were about thirty workers the females no longer attended to the brood. On returning after an absence from home, he found one female dead and cut in pieces $^{48}$.

On July 20th, 1911, Crawley picked up some deälated nigra females after a marriage flight at Sea View, and placed three of them in a small box with earth, when they jointly excavated a cell in the earth and built up a roof covering them completely in. Ten days later the cell was opened and found to contain a quantity of eggs. The three females were then introduced into a fourchambered "Janet" nest with a large number of pupae, when one female immediately began to carry the pupae into a dark chamber, and though assisted for a short time by another female, carried over one hundred herself. Next day each female occupied a chamber to herself with pupae, the energetic female having by far the largest number. On August 2nd one of the other two females was found dead in the same chamber with the energetic one-by this date about one hundred and fifty workers were present, and the females had laid eggs and ceased to work. On August 4th some workers attacked and killed the other female, the energetic one being left as the sole queen of the colony ${ }^{62}$.

In another experiment carried out by Crawley in the same year with three more nigra females, similar results were obtained. After workers had been reared, one of the females killed another and was eventually herself killed by the third, which was left in possession of a thriving colony ${ }^{62}$.

The gaster of a fertile nigra female becomes distended with eggs, though not to such an extent as in fuliginosa; the gaster of a female of the former, which I found in a large colony under a stone at Box Hill on July 30th, 191363 - whose total length is eleven $\mathrm{mm}$.- measures seven $\mathrm{mm}$. in length, and four $\mathrm{mm}$. in breadth.

The following species of Myrmecophiles have been taken with Donisthorpea nigra in Britain :-

Coleoptera : Homoeusa acuminata Märk., Myrmedonia limbata Pk., Drusilla canaliculata F., Claviger testaceus Preys., C. longicornis Müll., and Opatrum sabulosum L.

Formicidae: Ponera coarctata Latr., Myrmecina graminicola Latr., and Solenopsis fugax Latr.

Ichneumonidae : Pezomachus anthracinus Först.

Braconidae : Pachylomma buccata Nees.

Proctotrupidae : Gonatopus myrmecophilus K., Planopria pedestris K., and Loxotropa subterranea $\mathrm{K}$. 
Mymaridae : Litus cynipseus Hal.

Diptera : Pseudacteon (=Phora) formicarum Verrall, and Microdon mutabilis L. (larvae).

Heteroptera: Alydus calcaratus L., Myrmecoris gracilis Sahlb., Nabis lativentris Boh., Myrmedobia coleoptrata Fall., Pilophorus perplexus D. and S., and Systellonotus triguttatus L.

Aphidae : Trama troglodytes Heyd., T. radicis Kalt., Forda formicaria Heyd., Pentaphis marginata Koch, P. trivialis Pass., Geoica carnosa Buckt., G. formicina Buckt., Schizoneura corni F., Aphis plantaginis Schrank, and Macrosiphum sp ?

Coccidae: Lecanopsis formicarum Newst., Ripersia tomlini Newst., $R$. subterranea Newst., $R$. formicarii Newst., and Ortheziola vejdovskyi Sulc.

Collembola : Cyphodeirus (=Beckia) albinos Nicol.

Araneina: Tetrilus arietinus Thor., Evansia merens Camb., Micarisoma festiva C.K., Micaria pulicaria Sund., and Harpactes hombergi Scp.

Acarina : Cillibano comata Leon., Uroplitella minutissima Berl., Trachyuropoda coccinea Mich. var sinuata Berl., T. laminosa Berl., T. excavata Wasm., Antennophorus foreli Wasm., and Laelaps vacuus Mich.

Crustacea : Platyarthrus hofmanseggi Brdt.

Donisthorpea nigra L., var. alieno-nigra Forel.

Lasius niger alieno-niger Forel Denkschr. Schweiz. Ges. Naturw. $2646-47$ $(1874)^{1}$. Lasius alieno-niger Mayr Tijdschr. Entom. $2326(1880)^{2}$. Lasius niger race alieno-niger Er. André Hym. Europe 2194 (1881) ${ }^{3}$. Lasius niger var alieno-niger Dalla Torre Cat. Hym. $7190(1893)^{4}$; Donisthorpe Ent. Rec. $2563(1912)^{5}$ : $2639(1914)^{6}$.

Original description of $L$. alieno-niger Forel :-

"La pubescence des tibias, en se redressant, passe insensiblement aux poils. Souvent un, deux ou trois poils seulement aux tibias et aux scapes. Dans une fourmilière les $\not$ sont plus claires, plus petites, moins pubescentes ; dans l'autre c'est le contraire. Bref, cet intermédiaire est presque aussi commun que les formes typiques." 1

This variety is intermediate in size, colour, and the pubescence on the tibiae and scape, etc., between $D$. nigra and $D$. aliena.

In September, 1912, I discovered several colonies of alieno-nigra at Weybridge situated in sandy banks which contained males and winged females ${ }^{5}$, and in May, $1913 \mathrm{I}$ found a colony under a stone at Bletchington ${ }^{6}$.

Hallett has sent workers to me from Cwrt-yr-ala in Glamorganshire, and Harwood workers from Clacton-on-Sea, as well as males and winged females from a marriage flight which he observed there on October 12th, 1912. 


\section{Donisthorpea aliena Först.}

Formica aliena Förster Hym. Stud. 13671 (1850)1 ${ }^{1}$; Schenck Jahrb. Ver. Naturk. Nassau 8 51-53 (1852) ${ }^{2}$. Lasius alienus Mayr Europ. Formicid. 49 $(1861)^{3}$. Formica aliena F. Smith Ent. Mo. Mag. $230(1865)^{4}$ : Ent. Ann. $1866127-128^{5}$ : $186972^{6}$ : Ent. Mo. Mag. $11111(1874)^{7}$. Lasius niger $\mathrm{r}$. alienus Forel Denkschr. Schweiz. Ges. Naturw. $2646^{8} 216^{9} 376^{10}$ (1874). Lasius alienus Saunders Trans. Ent. Soc. Lond. $1880209^{11}$. Formica aliena Parfitt Trans. Devon Assn. Sc-Art. $12514(1880)^{12}$. Lasius alienus Er. André Spec. Hym. Europe $2192(1891)^{13}$. Lasius niger var. alienus Hall Ent. Mo. Mag. 2491 (1887) ${ }^{14}$. Lasius alienus Perkins Ent. Mo. Mag. 27 195 (1891 $^{15}$; Wasmann Tijdschr. Entom. 3448 (1891) ${ }^{16}$; Dalla Torre Cat. Hym. 7181 (1893)17 ; Janet Bull. Soc. Zool. France $18169(1893)^{18}$. Formica (Lasius) aliena Farren-White Ants' Ways $28^{19} 113^{20} 122^{21} 175^{22} 235-236^{23}$ (1895). Lasius niger race alienus Saunders Hym-Acul. 25 (1896) ${ }^{24}$; Morley Hym. Suffolk 11 (1899) ${ }^{25}$. Lasius alienus D. Sharp Camb. NH. Ins. 2140 $(1899)^{26}$; Donisthorpe Ent. Rec. $12173(1900)^{27}$; Bingham Faun. Brit. India Hym. $2342(1903)^{28}$; Janet Obs. Fourmis $42-45(1904)^{29}$. Lasius niger race alienus Vic. Hist. Sussex $1131(1905)^{30}$. Lasius niger st. alienus Bingham Bull. R. Bot. Gard. Kew (A.S.) $528(1906)^{31}$. Lasius alienus Escherich Ameise $220(1906)^{32}$. Lasius niger race alienus Frisby Proc. Holmesdale NH. Club $190674^{33}$; Halbert Irish Nat. $1644(1907)^{34}$; Donisthorpe Trans. Leicester Lit-Phil. Soc. $12224(1908)^{35}$. Lasius alienus Mràzek Act. Soc. Ent. Bohem. $4139(1908)^{36}$. Lasius niger alienus Bondroit Ann. Soc. Ent. Belg. $53485(1909)^{37}$. Lasius alienus Donisthorpe Ent. Rec. 23 $15(1911)^{38}$. Lasius niger var. alienus Morley Proc. R. Irish Acad. 31243 $(1911)^{39}$. Lasius niger subsp. alienus Donisthorpe Entom. $44390(1911)^{40}$. Lasius alienus Bondroit Ann. Soc. Ent. Belg. $5511(1911)^{41}$. Lasius niger subsp. alienus Donisthorpe Ent. Rec. $247(1912)^{42}$ : $2563(1913)^{43}$. Lasius alienus Crawley and Donisthorpe Int. Ent. Cong. Oxford $1912227(1913)^{44}$; Donisthorpe Ent. Rec. 2639 (1914) $^{45}$; Pinkney Ent. Rec. 2698 (1914) ${ }^{46}$.

$\Varangle$ Lighter or darker brown, mandibles, antennae, and sometimes thorax lighter. Lighter in colour, smaller in size and less pubescent than nigra.

Head not emarginate posteriorly ; frontal furrow indistinct; ocelli very small and indistinct; antennae thinner than in nigra, scape without outstanding hairs. Tibiae without outstanding hairs. Long. $2 \cdot 8-3 \cdot 8 \mathrm{~mm}$. $(2 \cdot 5-4 \mathrm{~mm}$. teste André.)

ㅇ Lighter or darker reddish brown, with mandibles, antennae and legs lighter. Lighter in colour than nigra and less pubescent, the body exhibiting far less "sheen."

Head small, narrower than thorax, not emarginate posteriorly ; scape without outstanding hairs. Thorax narrower than gaster. Gaster large, the same colour beneath as above. Tibiae without outstanding hairs. Wings large, clear. Long. 8-9 mm. (7-9 mm. teste André.)

o Lighter or darker brown, mandibles, antennae, and legs lighter. Lighter in colour and smaller in size than nigra.

Head slightly shining; frontal furrow distinct, though not as distinct as in nigra, with a slight transverse impression before ocelli; mandibles with one tooth, yellowish brown; scape without outstanding hairs. Thorax broadly testaceous at the insertion of the wings. Tibiae without outstanding hairs. Wings clear. Long. $3 \cdot 3-3 \cdot 5 \mathrm{~mm}$. (3.5-4 mm. teste André.)

Original description of Formica aliena Förster [Hym. Stud. 1 36 후 71 ㅇ (1850)] :-

"Operaria : Fusca, nitida, cinerascenti-micans, sparse pilosula, antennarum scapo tibiisque nudis; mandibulis rufis, antennis, tibiis et tarsis pallide testaceis; ocellis minutissimis et linea frontali impressa vix conspicuis ; 
metathoracis dorso abbreviato; squama subrectangulari, parva, supra subrotundata.

Long. 1-1 lin.

Mas: Fusco-niger, parum cinereo-micans, antennarum flagellis, thorace circa scutellum tarsisque ferrugineo-pallescentibus; capite thoraceque pilositate fere obsoleta, scapis pedibusque nudis ; linea frontali impressa, profunda; alis hyalinis, nervis et stigmate pallide flavescentibus; subradio basin versus subfusco; area discoidali parva, subquadrata vel nulla; squama subrectangulari, apice medio leviter emarginato.

Long. 1 $\frac{1}{3}$ lin."

"Femina : Fusca tota undique ciner эо-micans, nitida, corpore toto sparse flavido-pilosulo, antennarum scapis tibiisque praeter pubescentiam adpressam nudis; antennis, tibiis tarsisque ferrugineo-pallescentibus, coxis et femoribus fuscescentibus; mandibulis confertim longitudinaliter rugosis, fortiter punctatis ; clypeo subtiliter punctulato, foveolis lateralibus laevibus; area frontali obsoletissime punctulata, nitida; scutello in circuitu rufescente; alis amplis, hyalinis, nervis cum stigmate pallide flavidis, subradio fusco; squama subcordata, apice subangulatim leviter emarginata.

Lg. $3 \frac{1}{2}$ lin."

\section{Habitat.}

Donisthorpea aliena is widely distributed in Europe, though it does not appear to be as common in the North as nigra. Ruzsky records it from the Caucasus, Siberia, Turkestan, and Finland, and Bingham from the North-West Himalayas up to $9000 \mathrm{ft}^{28}$.

Dalla Torre sinks Formica pallitarsis Provancher [Fauna. Ent. Canada. Hym. 2598 (1883)] as a synonym of D. aliena ${ }^{17}$, but Provancher's description does not agree with aliena, nor does Wheeler in his list of described North American Ants [Ants 561-572 (1910)] give the latter species for North America, where it is represented by $D$. nigra var. americana Emery.

The British distribution is as follows :-

Cornwall, W.: The Lizard (H. C. Champion $)^{43}$; Cornwall, E. : Trebetherick (Hallett).

Devon, S. : High Peak, Sidmouth $(F \text {. Smith })^{\mathbf{1 2}}$; Stoke Fleming (Perkins) $^{15}$; Seaton (Crawley) ${ }^{43}$; Devon, N. : Croyde Bay (Parfitt $)^{12}$; Woolacombe $(\text { Pinkney })^{46}$; Lundy Island (F. Smith) ${ }^{7}$.

Somerset, S.: Minehead (Farren-White) ${ }^{22}$; Somerset, N. : Steepholm $(H u d d)$.

Dorset : The Haven, Poole Harbour (Hamm) ; Studland (Morice); Swanage (Nevinson) ; Lulworth (Farren-White) ${ }^{20}$; Winfrith Heath, Godlingstone Heath, and Morden (Haines).

Isle of Wight : Blackgang ${ }^{27}$, the Landslip, Shanklin, and Sandown ${ }^{43}$ (Donisthorpe); St. Helens (Hamm).

Hants, S. : Bournemouth (Rothney) ${ }^{6}$; Hayling Island (Saunders $)^{11}$; New Forest (J. F. X. King); Hants, N.: Fleet (E. $A$. Butler).

Sussex, E.: Hastings ${ }^{30}$; Sussex, W.: Littlehampton and Arundel Park ( $F$. Smith Coll.).

Kent, E. : Deal (F.Smith $)^{4}$; Buckland near Dover $(\text { Hall })^{14}$; St. Margaret's Bay (Donisthorpe). 
Surrey : Kew (Bingham) ${ }^{31}$; Shirley (Rothney); Wimbledon Common (Morice); Chobham (Saunders) ${ }^{\mathbf{1 1}}$; Reigate Heath $(\text { Frisby })^{33}$; Box Hill, Weybridge ${ }^{42}$ and Woking ${ }^{43}$ (Donisthorpe).

Essex, N. : St. Osyth (Harwood).

Berks : Wellington College (Barnes).

Oxford : Oddington (Crawley) ${ }^{38}$; Bletchington (Donisthorpe $)^{45}$.

Suffolk, E. : Lowestoft (Farren-White) ${ }^{22}$; Kirkley (Morice) ; Blythburgh (Morley); Thorpe by Aldeburgh $(T u c k)^{25}$; Felixstowe (Morley) ${ }^{25}$; Cove Common (Rothney).

Suffolk, W.: Rougham and Mill Heath $(T u c k)^{25}$.

Norfolk, W.: Holme-juxta-Mare (Morley); Lang Mere (H. Scott) ; Blakeney (S. O. Taylor).

Cambridgeshire : Cambridge (D. Sharp); Grantchester (H. Scott) ; Cherryhinton (Fryer).

Gloucester, W. : Stonehouse ${ }^{19}$ and Stinchcombe Hill ${ }^{22}$ (FarrenWhite); Durnham Downs (Smallcombe); Symonds Yat (FarrenWhite) ${ }^{22}$.

Glamorgan : Cwrt-yr-ala (Hallett) ; Rhosilli and Worm's Head (T. W. Allen).

Pembroke : Tenby (Donisthorpe) ${ }^{45}$; St. David's (T. W. Allen).

Carnarvon: Conway Castle (Farren-White) ${ }^{21}$.

Denbigh : Deganwy (W. Gardner).

Dublin : Lambay (Halbert) ${ }^{34}$.

Wicklow : Powerscourt (Dublin Mus. Coll.).

Mayo, W. : Clare Island (Johnson) ${ }^{39}$.

Donisthorpea aliena has generally been considered to be a race or subspecies of $D$. nigra, but I am inclined to agree with Bondroit that it is quite distinct, and should be regarded as a good species ${ }^{41}$.

Although its habits are somewhat similar to those of $D$. nigra, still it differs in many ways; it is not nearly so widely distributed nor so common, it lives a more subterranean life, and is of a much more peaceable disposition.

It prefers to dwell in hot exposed places, on sandy commons, and heaths, and on the cliffs, etc., nesting in the ground under stones and in banks, occurring but rarely in grass, and seldom constructing mound nests. Smith says it has a way of tunnelling under the ground, and of casting up little hillocks after the manner of the mole ${ }^{6}-\mathrm{I}$ have noticed this habit at Weybridge; Farren-White states it usually makes its burrows in sandy places, "with a raised funnel-shaped gate," and he also found it occupying a small mound at Bournemouth ${ }^{23}$ and Bingham recorded two colonies in grass in the Herbarium gardens at $\mathrm{Kew}^{31}$.

Forel says it does not range as high as the sub-alpine regions in Switzerland ${ }^{9}$, Wasmann gives its habitat as heaths in Holland ${ }^{\mathbf{1 6}}$, and Bondroit states it is only to be found in calcareous regions in Belgium ${ }^{41}$.

Parfitt records that he captured, in 1867, specimens of the worker 
and the winged sexes of aliena in a nest on the sands in Croyde Bay, North Devon, which he thought were the first taken in this country ${ }^{12}$, but F. Smith had found it in July, 1865, on the Deal sand-hills ${ }^{4}$, where it is still abundant.

Schenck says he has often met with workers and pupae of $D$. aliena in nests of $F$. sanguinea at Nassau ${ }^{2}$.

Nests of aliena will receive and hatch both worker and female pupae of nigra and vice versa, larvae being even accepted in some instances.

As with nigra, eggs laid by the workers of aliena in captivity will produce workers. I have reared such workers in an observation nest of $D$. aliena-whose queen was a female $D$. mixta-taken at Weybridge on July 10th, 1912. This nest will be referred to again under the latter species, and also under D. umbrata (pp. 232, 240). The winged sexes occur from July to November, though Smith stated that they did not appear before the latter part of August ${ }^{4}$.

Schenck gives July 13th till late in September ${ }^{2}$, FarrenWhite took males in November ${ }^{23}$, and I have found males and winged females in the nests from July 2nd to September 26th.

Mermithogynes occur in this species-D. Sharp mentions that female specimens of aliena have been found with short wings, but he incorrectly treats them as intermediate forms between the winged and wingless females ${ }^{26}$. Mràzek has shown that the virgin females of aliena may become infested with a worm of the genus Mermis and that when this occurs the insects develop abnormally small wings ${ }^{36}$, and Wheeler found on dissecting short-winged females of $D$. neonigra - a species closely related to $D$. alienataken in a colony near Manitou, Colorado, that each contained a large coiled Mermis 53-55 mm. long [Journ. Experim. Zool. 8421 (1910)].

Crawley took several short-winged females of aliena in a nest under a stone at Oddington in $1900^{38}$, and he tells me that all the winged females present in this colony were brachypterous. The wing of one of these females, kindly given to me by the captor, measures $4.5 \mathrm{~mm}$. in length as against $10 \mathrm{~mm}$. in a normal female, from which it differs in no other way.

Schenck says aliena begins to swarm later than nigra, and its swarmings continue after those of the latter have ceased ${ }^{2}$; he records a marriage flight on September $22 \mathrm{nd}^{2}$. Hall noticed another on August 7th, 1887, near Dover. He writes :- "Being a still and sultry evening, the air was literally full of males, and the ground and walls covered by myriads of both sexes; the females had mostly denuded themselves of their wings in order to seek a suitable place for oviposition."14 The females of $D$. aliena are equally well able to found their colonies unaided as are those of nigra.

Farren-White discovered in 1881 under a stone at Lulworth a deälated female and three or four very small-sized pupae enclosed 
in cocoons ${ }^{20}$, which were no doubt the female's first brood, this being an incipient colony.

Janet in 1893 isolated an old queen from a nest of aliena, which he supplied with food, since she was past the age when a female can subsist on her body-fat and wing-muscles. She laid eggs soon after her isolation, and reared twelve larvae and a pupa in sixtyone days, and five pupae and one worker in one hundred and two days ${ }^{18}$. This queen lived in his possession for nine years, and during the first year she reared about fourteen workers, during the second, nineteen, the third, twenty-three, the fifth, sixth, and seventh, a hundred, the eighth, forty, and the ninth, fifteen ${ }^{29}$.

The under-mentioned myrmecophiles have been taken with D. aliena in Britain :-

Coleoptera : Drusilla canaliculata F., and Claviger testaceus Preys.

Braconidae : Pachylomma buccata Nees.

Diptera : Pseudacteon (=Phora) formicarum Verrall, and Peyerimhoffia brachyptera $\mathrm{K}$.

Aphidae: Trama troglodytes Heyd., T. radicis Kalt., Forda formicaria Heyd., F. viridana Buckt., Geoica carnosa Buckt., Tetraneura ulmi Geoff., Aphis alienus Theob., and A. subterranea Walker.

Coccidae : Ripersia subterranea Newst.

Collembola : Cyphodeirus (=Beckia) albinos Nic.

Crustacea : Platyarthrus hoffmanseggi Brdt.

\section{Donisthorpea flava $\mathrm{F}$.}

["The Common Yellow Ant" Gould Account English Ants $2^{1} 11^{2}$ (1747)]. Formica flava Fabricius Spec. Insect $1491(1781)^{3}$. ["La fourmi jaune" Huber Mours Fourmis $319(1810)]^{4}$. Formica flava Schenck Jahrb. Ver. Naturk. Nassau $811^{5} 56^{6}$ (1852); F. Smith Trans. Ent. Soc. Lond. (n.s.) 3 $97^{7} 108-109^{8}$ (1855) : Cat. Brit. Foss. Hym. $15(1858)^{9}$. Lasius flavus Mayr Europ. Formicid. $50(1861)^{10}$. Formica flava Warner Science Gossip 1871 183 11. Lasius flavus Forel Denkschr. Schweiz. Ges. Naturw. $2647^{12} 215^{13}$ $257^{14} 378^{15} 397^{16}$ (1874) ; Lubbock Mo. Mic. Journ. 18 Pf. 189.2 ; 190.1-2 ; 191.1-3 ; 192.1-2, $5(1877)^{17}$; Saunders Trans. Ent. Soc. Lond. $1880210^{18}$; Er. André Spec. Hym. Europe 2195 (1881) ${ }^{19}$; Lubbock Ants, Bees, Wasps $32^{20} 71-72^{21} 91-92^{22}$ (1882); Wasmann Tijdschr Entom. 3448 (1891) $^{23}$; D. Sharp Trans. Ent. Soc. Lond. $1893202^{24}$; Dalla Torre Cat. Hym. 7184 $(1893)^{25}$; Richardson Ent. Mo. Mag. 30213 (1894) $^{26}$. Formica (Lasius) flava Farren-White Ants' Ways $164^{27} 236^{28}$ (1895). Lasius flavus Saunders Hym-Acul. $24(1896)^{29}$. Lasius niger Saunders Irish Nat. $1268(1903)^{30}$. Lasius flavus Ernst Biol. Centralb. 2547 (1905) $^{31}$. Formica flava Rayward Entom. $39197(1906)^{32}$. Lasius flavus Wasmann Naturwiss. Wochenschr. 6 391-392 (1907) ${ }^{33}$; Donisthorpe Trans. Leicester Lit-Phil. Soc. 12224 $(1908)^{34}$ : Ent. Rec. $20281(1908)^{35}$; Wheeler Journ. Psychol-Neurol. 13 $429(1908)^{36}$; Linder Bull. Soc. Vaud. Sc. Nat. 44 303-310 (1908) ${ }^{37}$; Forel Bull. Soc. Vaud. Sc. Nat. 45 341-343 (1909) ${ }^{38}$; Wasmann Biol. Centralb. $30453(1909)^{39}$; Donisthorpe Ent. Rec. 2315 (1911) ${ }^{40}$ : Entom. 44390 $(1911)^{41}$ : Ent. Rec. $247(1912)^{42}$; Crawley and Donisthorpe Int. Ent. Cong. Oxford $1912224-26(1913)^{43}$; Donisthorpe Ent. Rec. $25268(1913)^{44}$ : $2639(1914)^{45}$. 
$\Varangle$ Pale yellow, or yellow with the head, and sometimes the gaster, reddish, and in the larger specimens the whole body is more or less yellowish brown. Size very variable.

Head very slightly emarginate posteriorly; eyes smaller than in nigra and aliena; ocelli very small and indistinct; frontal furrow indistinct; scape without outstanding hairs. Thorax pubescent and hairy above. Scale

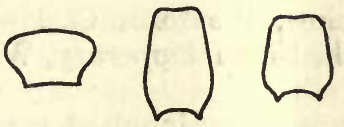

Fig. 84. Scales of (1) Donisthorpea flava ఫ్ధ. (2) D. umbrata ఫ్ధ.

(3) D. mixta ל̧. (Donisthorpe.)

low, broadest at apex, not, or only very slightly emarginate; gaster very pubescent. Tibiae without outstanding hairs. Long. 2.2-4.8 $\mathrm{mm}$. (2-4 mm. teste André.)

ㅇ Brown, mandibles brownish red, cheeks, antennae, underside of the gaster and legs yellow.

Head small, narrower than thorax, very slightly emarginate posteriorly; scape without outstanding hairs. Thorax narrower than gaster. Scale emarginate. Tibiae without outstanding hairs. Wings infuscate at the base for half their length. Long. 7-9.2 mm.

of Blackish brown, shining, antennae and legs brown, with the funiculus tarsi and articulations of the joints of the legs lighter.

Head shining; frontal furrow indistinct, often with a transverse impression before ocelli; mandibles with one tooth (very rarely with a few small teeth on the terminal border), black-brown; scape without outstanding hairs; eyes with a few microscopical hairs. Thorax narrowly testaceous at the insertion of the wings. Tibiae without outstanding hairs. Wings slightly infuscate. Long. $3 \cdot 7-5 \mathrm{~mm}$. (3-4 mm. teste André.)

Original description of Formica flava Fabricius [Spec. Insect. 1 491 (1781)] :-

"F. flaua, abdomine ouato pubescente.

Formica flaua squama petiolari. Degeer. Ins. 2.2.326.

5 tab. 42. fig. 24-28.

Habitat in Europae borealis syluis.

Parua, magnitudine tamen differt."

\section{Habitat.}

Donisthorpea flava ranges over the whole of Europe. Ruzsky records it from the Caucasus and Siberia, and it is represented in North America by the subspecies nearcticus Wheeler. Dalla Torre ${ }^{25}$ sinks Formica ruficornis Fabricius [Syst. Piez. 397 (1804) from India, and Formica mellea Provancher [Nat. Canada 12356 (1881)] from Canada as synonyms of this species, but the descriptions of neither of them agree with $D$. Alava, and the latter is probably synonymous with the nearcticus Wheeler. It is widely distributed in the British Isles, but I have no records in England from South Wilts, Monmouth, South-East and North-West Yorks., Westmoreland, and the Isle of Man ; in Scotland for Dumfries, Kirkcudbright- 
shire, Selkirk, Roxburgh, Forfar, Kincardine, South and North Aberdeen, Banff, Elgin, the North Ebudes, East Ross, East and West Sutherland, Caithness, the Hebrides, the Orkneys, and the Shetlands ; and in Wales for Brecon, Carmarthen, Cardigan, and Montgomery.

I have only the following records for Ireland :-Donegal, Louth, Dublin, Kildare, Wicklow, Wexford, Carlow, West Mayo, West Galway, Clare, Limerick, North Tipperary, Waterford, South Cork and Kerry.

Donisthorpea flava is a very abundant species, but it is not so common nor so widely distributed as $D$. nigra.

It has been called the "turf ant," as it chiefly nests in fields; it is fond of marshy ground, but occurs also in dry situations in the outskirts, rides and clearings (but not in the interior) of woods, rarely occurring in gardens, and never in houses, always nesting in the ground, under stones, etc.

D. flava raises the well-known earth mounds in meadows which look like mole-hills covered with grass-indeed Gould mistook them for such, as he writes:- "The yellow Ants most frequently make Choice of those little Eminencies cast up by Moles, from whom they derive the Name of Mole-hills: But from the Habitation they afford these Creatures are more usually called Ant or Emmet Hills. Thus the Inconveniences produced by one Creature tend to the Service of another." 2 Sometimes they occur in hundreds in one field; I have seen such fields near Balmer Lawn in the New Forest, and at Oddington in Oxfordshire, etc. Wasmann has shown that these hillocks do not occur in the sandy regions of Dutch Limburg ${ }^{23}$.

Sometimes these hills attain very large proportions; I have seen a large earthen mound raised by this ant in a ride in Parkhurst Forest, which was quite three feet in height.

Richardson called attention to the size and number of the anthills of flava near Weymouth in 1894, and he suggested that in a wet spring like the last, the earth (Oxford clay) gets rather sodden, and the ants like to raise their dwellings as high as possible so that they may be drier ${ }^{26}$. The chief reason of these hills, however, is to obtain as much benefit as possible from the rays of the sun, and to act as incubators for the ants' brood.

Huber first pointed out that these ant-hills in the Alps have a peculiar shape, and always face towards the east. He says:"Those little Yellow Ants, that are in possession of the pucerons or aphides, serve the purpose of a compass to the Mountaineers, when they are enshrouded in thick fogs, or have lost their way during the night. Their habitations, which are more common, and more elevated in mountains than elsewhere, take an oblong and almost regular shape. They lie in a direction east and west. Their summit, and the greatest slope, always faces the east : but they 
incline also on the opposite side. I have verified, upon thousands of these ant-hills, this observation of the shepherds. I found a trifling number of exceptions ; but only in those instances, where these hillocks had been deranged by men, or other animals. They do not preserve this form in the plains, where they are more exposed to such accidents." 4

These nests have been called ants' nest compasses, and Tissot ${ }^{33}$, and more recently Linder ${ }^{37}$, have confirmed these observations. The latter has shown that the elongate shape of the mounds is due to the fact that the ants keep extending them in an easterly direction in such a manner that only the extreme easterly and highest portions are inhabited by the insects. Wheeler has observed a similar and equally striking orientation of the mounds of Formica argentata in the sub-alpine meadows of Colorado [Journ. Psychol. Neurol. 13424 (1908)] ; and in 1910 I carried a pocket compass with me wherever I was investigating ants' nests, and whenever it was possible to observe their orientation I found they invariably faced the east [Ent. Rec. 2311 (1911)].

Sometimes the larger workers of flava are darker in colour, and this is especially the case in old colonies, where many of the ants will be found to be large and dark. In 1902 at Rossbeigh, Co. Kerry, I found several colonies of flava, all the ants of which were more or less brown in colour, but they were unfortunately described by Saunders as a race of nigra as follows:- "Lasius niger Linn.-Pale race with tibiae without exserted hairs, but much larger than ordinary alienus." 30 In a colony of D. flava at Bletchington on May 14th, 1913, in which no queen could be found I captured several very large dark workers, many times larger than ordinary workers ${ }^{45}$ which measure $4.8 \mathrm{~mm}$. in length and may be called macrergates.

This is a rather weak ant, and is unable to see very well ; it uses its antennae to find its way, and its workers hardly ever appear above ground, though a few may sometimes be seen, after rain, adding to the height of their mound. When attacked by other ants they block up the entrances to their nest, retiring to the chambers underground, and are generally defeated.

Landois found a structure in the worker of this species similar to that he observed in $D$. fuliginosa which he considered to be a stridulating organ, and D. Sharp describes it as a very short space or ring extending all along the base of the dorsum in the third abdominal segment covered with rather coarse irregular lines. The line of demarcation between this and the general surface of the dorsal plate is abrupt, and there is an extreme difference of texture between the space uncovered and that covered by the overlapping part of the preceding segment ${ }^{24}$.

Very many root Aphidae live in the nests of $D$. Alava, indeed André says this ant lives exclusively on the liquor furnished by these 
insects ${ }^{19}$, and no doubt this is largely the case, but $I$ have found the remains of beetles, etc., in the galleries of flava nests under stones.

If a nest of this ant be dug into in the winter, packets of oblong black eggs will be found in the subterranean chambers, and in the spring these eggs will be seen in the galleries in nests under stones.

Gould (p. 35) thought that these black eggs produced female ants, but young plant-lice hatch from them, which are not however the same species which occur in the nests on roots, but belong to a species which lives on plants outside the nests. These eggs are laid in the autumn, and the ants collect them and carry them into their nests, where they remain the whole winter, and when they hatch the ants carry the young aphides out, and place them on their proper food-plants.

Lord Avebury, who witnessed the latter fact himself ${ }^{21}$, writes :"Such species as Lasius flavus represent a distinctly higher type of social life ; they show more skill in architecture, may literally be said to have domesticated certain species of aphides, and may be compared to the pastoral stage of human progress - to the races which live on the produce of their flocks and herds." 22 I have found four species of Coccidae in the nests of $D$. flava, and these ants also attend larvae of blue butterflies, which they milk.

Rayward records that on June 18th, 1906, he found some thirty or more of the larvae of Lycaena corydon (the " Chalk Hill Blue") at Reigate, nearly all of which had Donisthorpea flava upon them, and two larvae found resting on the leaves of their food-plant on the crown of an ant-hill were literally covered by these ants, more than twenty being counted on one of them ${ }^{32}$.

I have found the winged sexes of $D$. flava in the nests from June to September, and F. Smith records finding a male on November 5 th $^{8}$.

The principal time for the marriage flight of this species is in August; Schenck says it swarms from June to October in Nassau ${ }^{5}$, and Forel gives the end of July to the end of August for Switzerland ${ }^{16}$.

The male settles on the female in the air, and she carries him during the marriage flight, when two or three males may rest upon her at the same time, and Forel states that a female is often fertilized by a number of males in succession ${ }^{16}$.

I have noticed many marriage flights of $D$. flava on the same afternoon as those of D. nigra, D. umbrata, and species of Myrmica, and the procedure is much the same as that described for $D$. nigra.

Crawley observed at Oddington in 1899 and again in 1900 a number of mermithogynes walking on the road in company with a few normal females ${ }^{40}$ - the wings of one of the former which he kindly gave to me measures only $4 \mathrm{~mm}$. in length as against $9 \mathrm{~mm}$. 
in the normal female-and Evans captured one on the Isle of May on September 24th, 1910.

Bondroit kindly presented me with a pterergate which he took in October, 1910, in a colony of $D$. flava at Landelies in the provence of Hainaut, in Belgium. It is a large dark worker measuring $4.8 \mathrm{~mm}$. in length and has a pair of vestigial wings, one on each side of the mesonotum, measuring about $4 \mathrm{~mm}$. in length.

The eggs are laid in the autumn-on September 15th, 1911, I found a colony of $D$. flava under a stone on a small Island in Tobermoray Bay which contained one queen, a number of workers, many of them large and dark, and many packets of eggs ${ }^{42}$. Eggs are laid again in the spring in April or May. F. Smith states that it is a remarkable circumstance that the larvae of $D$. flava, which pass the winter in that state are densely covered with pubescence ${ }^{7}$, but these would be young larvae hatched from eggs laid in the autumn, and all young ant larvae are much more hairy than full grown ones. The females of this species, as we have already stated, are capable of founding their colonies unaided, being many times larger than the workers or males, and abundantly endowed with the necessary reserve force for a protracted fast. Isolated females may frequently be found in the autumn in situations suitable for the formation of their colonies. On October 28th, 1908, I dug up many deälated females from little cells with egg packets in the soft muddy sand of the undercliff at Luccombe Chine ${ }^{35}$, and again on August 26th, 1913, a number of isolated deälated females, some with egg-packets, were seen at Blackgang Chine, in small cells under stones and lumps of soft greensand ${ }^{45}$.

Ernst proved that this species is self-founding in captivity. In October, 1902, he found at Le Chenois a deälated female under a stone, where she had constructed a small cell. This female he took home, and from eggs laid by her on April 22nd, 1903, larvae appeared in August and pupae in October, the first worker hatching on November 9th, eleven months after the finding of the queen ${ }^{31}$.

Ordinarily the fertilized female brings up her brood alone, but sometimes two or more such females may join together to do so. Forel, about 1873, found under a stone on the Saléve a neat cell occupied by two fertile flava females without brood ${ }^{14}$, and Wheeler on June 15th, 1907, while collecting at Sion in Canton Valais, found two deälated queens of Donisthorpea flava under a stone in a small earthen cavity a few $\mathrm{cm}$. in diameter, in which they were nursing a single packet of eggs and young larvae. Both hastened to remove the brood when the stone was lifted ${ }^{36}$.

On April 19th, 1914, Collins and I found a small incipient colony of $D$. Alava under a stone at Bletchington, which consisted of three deälated females, a few very small workers, and a number of little larvae, all three females resting close together on the brood. 
On August 6th, 1904, Crawley found four females together under a stone at Oddington, but as there was no brood and no enclosed cell it was probably only a temporary retreat immediately after the marriage flight and shedding of wings ${ }^{43}$.

Hamm dug up an assembly of no less than 16 queens of flava with about twelve small workers, in the New Forest on April 16th, 1911, which he kept in captivity ${ }^{\mathbf{4 3}}$. No hostility was observed among the females, some of which laid eggs, and larvae were reared, but the whole colony gradually died off, without any workers being brought up.

Wasmann made a discovery in 1909 which seems to indicate that though many females of flava may start a colony together, they eventually split up into groups of not more than two. On September 29th, 1909, he found under a stone in a small cell, at Luxemburg, four females with eggs and a dead mutilated body of a fifth, which he thought might have been killed by the others. After the first larvae had hatched the females split up into two groups of two each ${ }^{39}$. This species being much less pugnacious than nigra, fighting among the females is probably of much rarer occurrence.

It is certainly extremely rare to find more than two queens in a well-established flava colony, and usually only one is present. On May 14th, 1913, I observed two deälated females in a colony at Bletchington ${ }^{45}$, but on June 9th, 1913, I discovered three deälated females in a very large and populous flava colony under a big stone on Lundy Island ${ }^{44}$.

D. flava will not usually receive strange females of its own species into its nest, and, though not so hostile to ants from strange colonies as nigra, yet objects to their presence and drives them from its nests.

Lord Avebury made five experiments, in all of which, nests of flava, both with and without a queen of their own, refused to accept a strange fertile flava female, and he concluded that, at any rate in the case of this species, the workers will not adopt an old queen from another nest ${ }^{20}$. On rare occasions, however, workers of flava may accept a strange queen, or one of their own females after fecundation, as Crawley has made several experiments in which such results have been obtained. To mention one of these : In July, 1897, he had a queenless colony of $D$. flava, containing however ten winged virgin females, in a Lubbock nest. A strange fertile female was then taken and put in a box with four workers from this nest, and as they seemed friendly the box was turned on its side close to the door of the nest. Presently the workers entered the nest, and the female of her own accord followed them; ants saluted her, only two attacked her, and finally she was accepted as queen, shortly after which the workers killed all the winged females in the nest ${ }^{43}$. 
The following species of myrmecophiles have been taken with this ant in Britain :-

Coleoptera : Homoeusa acuminata Märk., Myrmedonia limbata Pk., Drusilla canaliculata F., Homalota analis Gr., Lamprinus saginatus Gr., Staphylinus stercorarius Ol., Othius myrmecophilus Kies,, Medon bicolor Ol., Claviger testaceus Preys., Trichonyx märkeli Aub., and Hetaerius ferrugineus $\mathrm{Ol}$.

Formicidae : Ponera coarctata Latr., Myrmecina graminicola Latr., and Solenopsis fugax Latr.

Braconidae : Pachylomma buccata Nees.

Proctotrupidae: Gonatopus striatus K., Paragryon myrmecophilus K., Loxotropa subterranea K., and L. donisthorpei K.

Diptera : Pseudacteon (=Phora) formicarum Verrall.

Heteroptera : Nabis sp? larva.

Aphidae: Paracletus cimiciformis Heyd., Trama troglodytes Heyd., T. radicis Kalt., Forda formicaria Heyd., $F$. viridana Buckt., F. hexagona Theob., Tycheoides setariae Pass., T. setulosa Pass., T. hirsutum Theob., Pentaphis trivialis Pass., Geoica carnosa Buckt., G. pellucida Buckt., Tetraneura ulmi De G., Schizoneura corni F., Aphis plantaginis Schr., A. ranunculi Kalt., A. leontodoniella Theob., and Macrosiphum formicarium Theob.

Coccidae : Ripersia tomlini Newst., $R$. subterranea Newst., $R$. formicarii Newst., and Ortheziola vejdovskyi Sulc.

Collembola : Cyphodeirus (=Beckia) albinos Nic.

Acarina : Cilibano comata Leon., Uroobovella obovata C and B., Urodiscella philoctena Trou., Uroplitella ovatula Berl., Trachyuropoda laminosa $\mathrm{C}$ and B., T. celtica Halb., Urotrachytes formicarius Lubb., Antennophorus pubescens Wasm., and Laelaps styliferus Halbert.

Crustacea : Platyarthrus hoffmanseggi Brndt.

\section{Donisthorpea umbrata Nyl.}

Formica umbrata Nylander Acta. Soc. Sc. Fenn. $21048(1846)^{1}$; Förster Hym. Stud. $139(1850)^{2}$. Formica mixta Förster Hym. Stud. $14172(1850)^{3}$. Formica umbrata Schenck Jahrb. Ver. Naturk. Nassau 859139 (1852) $^{4}$; F. Smith Trans. Ent. Soc. Lond. (n.s.) 3 106-108 (1855) ; Mayr Verh. Zool. Bot. Ver. Wien $5365(1855)^{6}$; F. Smith Cat. Brit. Foss. Hym. $14(1858)^{7}$. Lasius umbratus Mayr Europ. Formicid. 50 (1861) $^{8}$. Formica umbrata F. Smith Ent. Ann. $18658588^{9}$; Hardy Hist. Berwick Nat. Club 6394 (1872)10. Lasius umbratus r. umbratus Forel Denkschr. Schweiz. Ges. Naturw. $2647^{11}$ $216^{12} 379^{13} 407^{14}(1874)$ : Bull. Soc. Vaud. Sc. Nat. $1460(1875)^{15}$. Formica umbrata Hardy Hist. Berwick Nat. Club $7127(1876)^{16}$; B. Cooke Nat. 5 $73(1879)^{17}$; Parfitt Trans. Devon Assn. Sc-Art $12514(1880)^{18}$. Lasius umbratus Saunders Trans. Ent. Soc. Lond. $1880209^{19}$; Er. André Spec. Hym. Europe $2195(1881)^{20}$; Fowler Ent. Mo. Mag. $19139(1882)^{21}$. Formica umbrata Hardy Hist. Berwick Nat. Club 12446 (1890) ${ }^{22}$. Lasius umbratus Dalla Torre Cat. Hym. $7191(1893)^{23}$. Lasius flavus Michael Journ. R. Mic. Soc. $1894303^{24}$. Formica (Lasius) umbrata Farren-White Ants' Ways $208^{25} 236^{26} 243^{27}$ (1893). Lasius flavus Adlerz Entom. Tijdschr. 17131 
$(1896)^{28}$. Lasius umbratus Harrison Entom. $29375(1896)^{29}$; Saunders

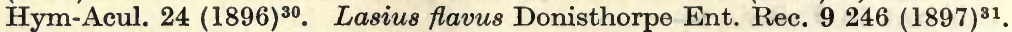
Lasius umbratus Morley Hym. Suffolk 11 (1899) ${ }^{32}$; Evans Ent. Mo. Mag. $36265(1900)^{33}$; Crawley Science Gossip (n.s.) $6365(1900)^{34}$; Vic. Hist. Worcester 189 (1901) $^{35}$; Barnes Ent. Mo. Mag. 38265 (1902) $^{36}$; Jordain Trans. N. Staffs. NF. Club $3782(1903)^{37}$; Tuck Trans. Norf. Norwich Nat. Soc. $7526(1903)^{38}$; Vic. Hist. Warwick $173(1904)^{39}$; Vic. Hist. Sussex $1131(1905)^{40}$; Vic. Hist. Cornwall $1182(1906)^{41}$; Wasmann Archiv. tri. Instit. Grand-Ducal Luxemburg $190612^{42}$; Vic. Hist. Yorks 1216 (1907) ${ }^{43}$; Vic. Hist. Kent $1116(1908)^{44}$; Donisthorpe Trans. Leicester Lit-Phil. Soc. $12224(1908)^{45}$; Morley Guide NH. I. of W. $303(1909)^{46}$; Crawley Ent. Mo. Mag. $4595(1909)^{47}$; Wasmann Zool. Anzeig. $35133^{48}$ $137^{49}(1909)^{50}$. Lasius flavus (?.L. umbratus) Crawley Ent. Record 2267 $(1910)^{51}$. Lasius umbratus Wheeler Psyche 17 235-243 (1910)52; Donisthorpe Ent. Rec. $2311^{53} 59^{54} 237^{55}$ (1911) : Entom. 44390 (1911)56; Trans. Ent. Soc. Lond. $1911180^{57}$; Evans Scot. Nat. $1912106^{58}$; Hallett Trans. Cardiff Nat. Soc. 442 (1912) ${ }^{59}$; Donisthorpe Ent. Rec. $2592(1913)^{60}$ : Rep. Lancs-Chesh. Ent. Soc. $36191240(1913)^{61}$; Crawley and Donisthorpe Int. Ent. Cong. Oxford $1912247-51(1913)^{62}$; Crawley Ent. Rec. 25135 $(1913)^{63}$; Brun Biol. Centralb. 3327 (1913) $^{64}$; Adlerz Myrornas 63 (1913) ${ }^{65}$; Donisthorpe Ent. Rec. 26 39-40 (1914) ${ }^{66}$; Pinkney Ent. Rec. 2698 (1914) ${ }^{67}$; Crawley Ent. Rec. $26142(1914)^{68}$; J. B. Elliott Trans. Brit. Mycol. Soc. $1914139-142^{69}$.

$\Varangle$ Usually clear yellow, sometimes reddish, but the whole body of the same colour, size not very variable.

Head very slightly emarginate posteriorly ; eyes small, as in flavus ; ocelli very small and indistinct; frontal furrow indistinct; funiculus of antennae with joints longer than broad. Thorax hairy, pubescent. Scale high, narrowest at apex, slightly emarginate; gaster pubescent and hairy. Tibiae with outstanding hairs. Long. $3 \cdot 8-5 \cdot 5 \mathrm{~mm}$.

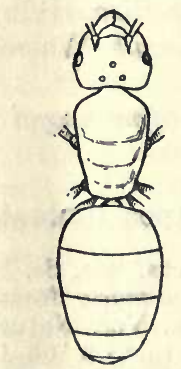

Fig. 85. Donisthorpea umbrata 우.

ㅇ Reddish brown, with the mandibles, antennae, and legs lighter.

Head large, as broad as thorax, emarginate posteriorly; funiculus of antennae with joints longer than broad. Thorax pubescent and hairy, only slightly narrower than gaster. Scale emarginate at apex; gaster pubescent and hairy. Tibiae with outstanding hairs. Wings infuscate at the base for half their length, the colour considerably darker than in flavus. Long. 7-8 $\mathrm{mm}$.

o Blackish brown, antennae and legs lighter, funiculus and tarsi yellowish. Head large; mandibles armed with five teeth; frontal furrow distinct; eyes

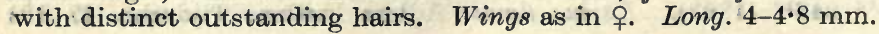


Original description of Formica umbrata Nylander [Acta. Soc. Sc. Fenn. 21048 (1846)] :-

"Femina: nitida cinerascenti sericea pilis brevibus rigidiusculis adspersa, fusca, pallescentia parum interlucente, partibus oris, antennis pedibusque obscure testaceo-pallescentibus ; capite paululum latiori quam thorax, palpis brevibus occipite, concaviusculo, oculis hirtulis; alis albescentihyalinis a basi fere ad medium fusco-umbratis, nervis fusco-brunnescentibus, stigmate obscure fusco ; squama petiolari subrectangulariter-ovali, apice late obtuse-angulatim emarginato."

$[\dagger \not+] \ddagger 0$ " $\not$. Long. 7 millimetr. - Fusca, ut in diagnosi dictum, pallescens, dense subtilissime cinerascenti-sericea sparse, breviter cinerascenti-pilosula. Caput dimidio majus quam in F. flava, circa os cum partibus ejusdem antennisque testaceo-pallescens, occipite conspicue concaviusculo; oculi sparse setulosi vel pilis rigidiusculis obsiti (in $F$. flava + pili in oculis sunt obsoletissimi). Alae anticae a basi fere trans aream discoidalem brunnescentes, stigmate fusco-brunneo, area discoidali solito majori h.e. ejusdem magnitudinis ac in $F$. flava, at dimidio majoris quam in $F$. nigra, rufa \&cet. ; posticae versus costam et basin dilutius brunnescentes; anticae longitudine $8 \frac{1}{2}$ milimetrorum (in $F$. flava fere $9 \frac{1}{4}$ millimetr., obsolete versus basin, fuscescentia tinctae). Squama proxime sicut in eadem, fusco-pallescens (nec pallida, tantum apice obsolete fuscescente). Abdomen teretiusculum longitudine capitis thoracisque oblongo-ovale, lat. $2 \frac{1}{2}$ millimetr., long. $3 \frac{1}{4}$ millimetr., fuscum pallescentia indistincte (magis tamen apud juniores) interlucente praesertim in ventre et ad insertionem petioli. (In $F$. flava o abdomen est mollius, depressius, corrugaturque saepissime et contrahitur post mortem). Ceteroquin haec est ut femina $F$. flavae, a qua, ut e jam dictis patet, colore pallido parciori, sordidiori, pilositate corporis uberiori, breviori, capite majori, occipite concaviusculo, oculis hirtulis, alis \&cet. satis distincta est.

Mas : subnitidus fusco-niger tenuissime cinerascenti sericeus et pilosulus, palpis, antennarum flagellis, pedum articulationibus tarsisque testaceopallescentibus ; capite sat magno paululum latiori quam thorax, flagellorum articulo primo crassiusculo, oculis hirtulis; alis albescenti-hyalinis a basi fere ad medium fusco-umbratis nervis brunnescentibus, stigmate fusco; squama petioli subovali apice subangulatim emarginato; vaginis genitalium fere aequali longitudine."

" o. Long. $4 \frac{1}{2}$ millimetr. ( $F$. flava $\hat{\sigma} 3 \frac{1}{2}$ millimetra est longus). Differt a mare $F$. flavae corpore duplo robustiore, multo magis opaco magisque nigro, capite majore, cruce frontis impressiuscula nulla, squama conspicue emarginata, alis distincte versus basin fumatis \&cet.-Corpus tenuissime cinerascenti-sericeum, breviter cinerascenti-pilosulum. Caput thorace fere latius occipite subintegro; mandibulae apice piceo-rufescentes subdenticulatae; clypeus infra medium linea transversa transeunte impressus; linea frontis longitudinalis distincta, transversalis vero nulla (etiam in $F$. flava ô saepe deficiens); flagellorum articulus primus parum crassior quam sequentes; oculi setulosi, (in $F$. flava ${ }^{\hat{~}}$ pilis interdum nonnullis parvis indistinctis microscopicis, minus erectis). Alae ut in femina coloratae, et dilutiores, area discoidali trapezoidea saltem dimidio majori quam in $F$. nigra $\hat{\sigma}$; anticae $5 \frac{1}{2}$ millimetra longae. ( $F$. flava ô easdem habet tantum obsoletissime versus basin fuscescentia tinctas vel saepissime totas albescenti-hyalinas, anticas $4 \frac{1}{2}$ millimetra longas areaque discoidali trapezoidea parva frequentissime carentes). Squama ut in diagnosi dictum. Abdomen thorace vix longius; vaginae externae fimbriatim pilosae."

\section{Habitat.}

Donisthorpea umbrata according to Wheeler ranges in the old World from England to Japan through northern and central 
Eurasia ${ }^{52}$, Ruzsky records it from the Caucasus, Siberia, and Finland, and in North America it is represented by four subspecies, not counting mixta which I regard as a good species.

The distribution in Britain is as follows :-

Cornwall, W. : Land's End (Bostock $)^{24}$; Cornwall, E. : Fowey ${ }^{41}$; Whitsand Bay (Donisthorpe) ${ }^{45}$.

Devon, S. : Exmouth Warren $(\text { Parfitt })^{18}$; Seaton $(\text { Crawley })^{63}$; Devon, N.: Morthoe (Dixey); Woolacombe (Pinkney) ${ }^{67}$.

Dorset : Swanage (Beck).

Isle of Wight : Landslip (Fowler) ${ }^{21}$; Sandown (Donisthorpe) ${ }^{66}$; Luccombe Chine (J. Taylor); Blackgang Chine (Bedwell); Shide

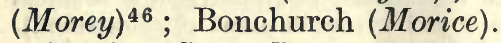

Hants, S.: Bournemouth $(F \text {. Smith })^{9}$; Hayling Island (Saunders) $^{19}$; Lymington (Donisthorpe) ${ }^{31}$; Hants, N.: Fleet (E. A. Butler).

Sussex, W.: Bognor (Guermonprez) ${ }^{40}$; Sussex, E. : Lewes $\left(\text { Dale }^{5} \text {; Brighton (Unwin }\right)^{40}$; St. Leonards (Piffard) ; Guestling ${ }^{40}$; 'Tilgate Forest (Donisthorpe) ${ }^{45}$.

Kent, E.: Deal (Hamm); Throwley ${ }^{44}$, and Huntingfield (Chitty) ; Kent, W. : Charlton (Farren-White) ${ }^{27}$.

Surrey : Shirley and South Norwood (Rothney); Richmond Park (Donisthorpe); Oxshott (E.A. Butler); Chobham (Saunders) ${ }^{19}$; Box Hill ${ }^{52}$, Mickleham ${ }^{45}$, Weybridge ${ }^{52}$, and Woking ${ }^{45}$ (Donisthorpe); Cobham (Nevinson); Camberley (E. E. Green).

Essex, N.: Colchester (Harwood).

Middlesex : Hampstead Heath (F. Smith) ${ }^{5}$; Chiswick (Sich).

Berks : Wellington College (Barnes) ${ }^{36}$.

Oxfordshire : Henley-on-Thames (H.Scott); Oxford (Hamm) ; Oddington (Crawley); Bletchington (Donisthorpe).

Suffolk, E. : Foxhall and Barren Heath, Ipswich (Morley) ${ }^{32}$; Suffolk, W. : Tostock ${ }^{32}$ and Bury St. Edmunds $(T u c k)^{52}$; Monk's Soham and Lakenheath ${ }^{32}$ (Morley); Brandon district (Perkins) ${ }^{32}$.

Norfolk, E. : Cromer $(\text { Tuck })^{38}$.

Gloucester, W.: Stonehouse (Farren-White) ${ }^{26}$; Tockington (Charbonnier).

Worcester: Bewdley (Blatch $)^{35}$; Bank of Severn, Lenchford (Fletcher) ${ }^{35}$; Malvern (Nevinson).

Warwick : Edgbaston ${ }^{29}$ and Harborne ${ }^{39}$ (Harrison).

Staffordshire: Colwich (Martineau) ${ }^{37}$.

Glamorgan: Worm's Head (T. $W$. Allen); Cwrt-yr-ala ${ }^{59}$, Portheawl, and Horton, Gower (Hallett).

Pembroke : Tenby (Donisthorpe ${ }^{6}$.

Nottinghamshire : Tollerton (Crawley).

Cheshire : Bowdon (B. Cooke $)^{17}$.

Yorks, Mid. W. : Pannal ${ }^{43}$.

Cheviotland: Sneer Hill ${ }^{10}$, Langleyford Vale ${ }^{10}$, Akeld ${ }^{16}$, and Brugh Law ${ }^{22}$ (Hardy). 
Haddington : Luffness Links ${ }^{58}$, near Gullane ${ }^{33}$ (Evans).

Kincardine : Stonehaven (Rothney).

Donisthorpea umbrata is widely distributed in Britain, but it is by no means a common ant; its occurrence is sporadic, and its colonies are generally more or less isolated.

It lives on sandy heaths, in fields, in the clearings of woods, in banks, on cliffs, and on sand-hills, etc., nesting in the earth, often in and at the roots of trees and old stumps, in decayed wood, and under stones. It is sometimes found in walls and houses, and occasionally makes earth mounds.

Forel mentions an immense colony he found in 1875 at Munich in the foundations of the front of a building, extending for a length of twenty paces ${ }^{15}$, and Morley records that Tuck discovered a colony in his house at Tostock in Suffolk ${ }^{32}$.

D. umbrata is a phlegmatic ant and is hardly ever to be seen above ground, being even more subterranean in habits than $D$. flava, and its food chiefly consists of the excreta of Aphidae and Coccidae, though it also kills and devours small insects, etc.

I found a number of workers of a large form of umbrata (?) walking about on the top of the sand-hills at Tenby in April, 1913, and much digging in the sand only produced more workers. Some of thesewhich somewhat resemble the continental $D$. affinis Schenck, though much more closely related to umbrata-were introduced into my mixto-umbrata and umbrata observation nest and were all killed by the latter ants, whereas workers of umbrata from Wellington College introduced into this nest in 1913, and from Woking and other places in 1912 , were all well received ${ }^{66}$.

D. umbrata will receive strange workers of their own species, but will kill workers of $D$. mixta when introduced into their nest, though I have found they will rear mixta larvae, when given to them in captivity. They will also readily rear pupae of $D$. fuliginosa.

On May 1st, 1910, I observed a large number of small empty land shells (Caecilioides acicula Müll.) in the galleries of a nest of umbrata situated under a stone at Box Hill; the ants appeared to have collected all the shells together and were resting on them as they do with their own brood ${ }^{53}$. It is however exceedingly doubtful that the ants were under the impression that the shells were pupae, or that they would serve as food.

Schenck mentions that umbrata possesses a much stronger odour than flava ${ }^{4}$-it is in fact similar to, though not so pronounced as, that possessed by fuliginosa-and as Brun points out, it is situated in the head ${ }^{64}$.

This ant also makes carton, though not to the same extent as fuliginosa. In December, 1910, Crawley and I dug up a nest of umbrata at Weybridge which I had known for some time, and 
which was situated in and at the roots of an old stump. As we took two specimens of a beetle (Myrmedonia humeralis Gr.) in this nestthe primary host of which is D. fuliginosa-and as some of the inner wood of the stump showed traces of the black colour caused by the latter ant in trees infested by it, I suggested that the stump had originally been inhabited by fuliginosa ${ }^{54}$. Subsequently when referring to this record I stated- "I now believe that this (the black colour of the wood) was caused by the umbratus themselves, as, this year (1912), I have found several nests in the ground under heather at Weybridge, with what were evidently black carton cells for the larvae, deep in the nest at the roots of the heather."60 In September, 1913, I dug up a nest of umbrata at Wellington College, which was situated in the ground at a spot where formerly a tree root or stump had been present, this being nearly entirely decayed. Cells of hard earthy carton were found attached to the roots of plants, which on analysis were found to be composed of :-

1. Numerous hyphae of a fungus, with spores, apparently.

2. A few fine root-fibres (?) of the plant supporting the cells.

3. The bark of the root (rhizome) (?) of the plant supporting the cells.

All these were much more numerous in the dark-coloured cells than in the paler ones.

4. Quartzite grains. These predominated.

Some of the root-fibres and bark were, no doubt, taken from the remains of the tree root or stump, and the presence of the fungus would be due to the "cement" used by ants for fastening the quartz grains, etc., together.

Similar cells, of a darker nature, which were again found at Weybridge, in 1913 , also contained fungus ${ }^{66}$.

On June 12th, 1914, in a bank at Woking I observed some neat carton cells fastened by carton nodules to roots in the centre of an umbrata nest,* and on July 16th I found some more dark carton in an umbrata nest at Weybridge, its blackish colour contrasting strongly with the light coloured sandy soil in which it was situated.

Farren-White undoubtedly describes the carton made by umbrata, though he evidently did not realize the nature of what he saw. He writes:- "Again, F. umbrata, as a rule, is found following the occupation of a miner. Lately, when cutting down what was once a magnificent willow adorning my paddock, but which for the last year or so had been gradually losing its beauty and hastening to decay, I was astonished at discovering in the very heart of the tree a strong colony of $F$. umbrata. It was here occupied as a carpenter as well as a miner. The work of destruction had been commenced, I believe, by a wood-boring beetle, but had been

* Again in 1915 I found at Woking on May 30th a similar nest to that described in the text above. On the following day my friend Mr. Morice accompanied me there and kindly photographed it (see Plate XII). 


\section{Plate XII.}

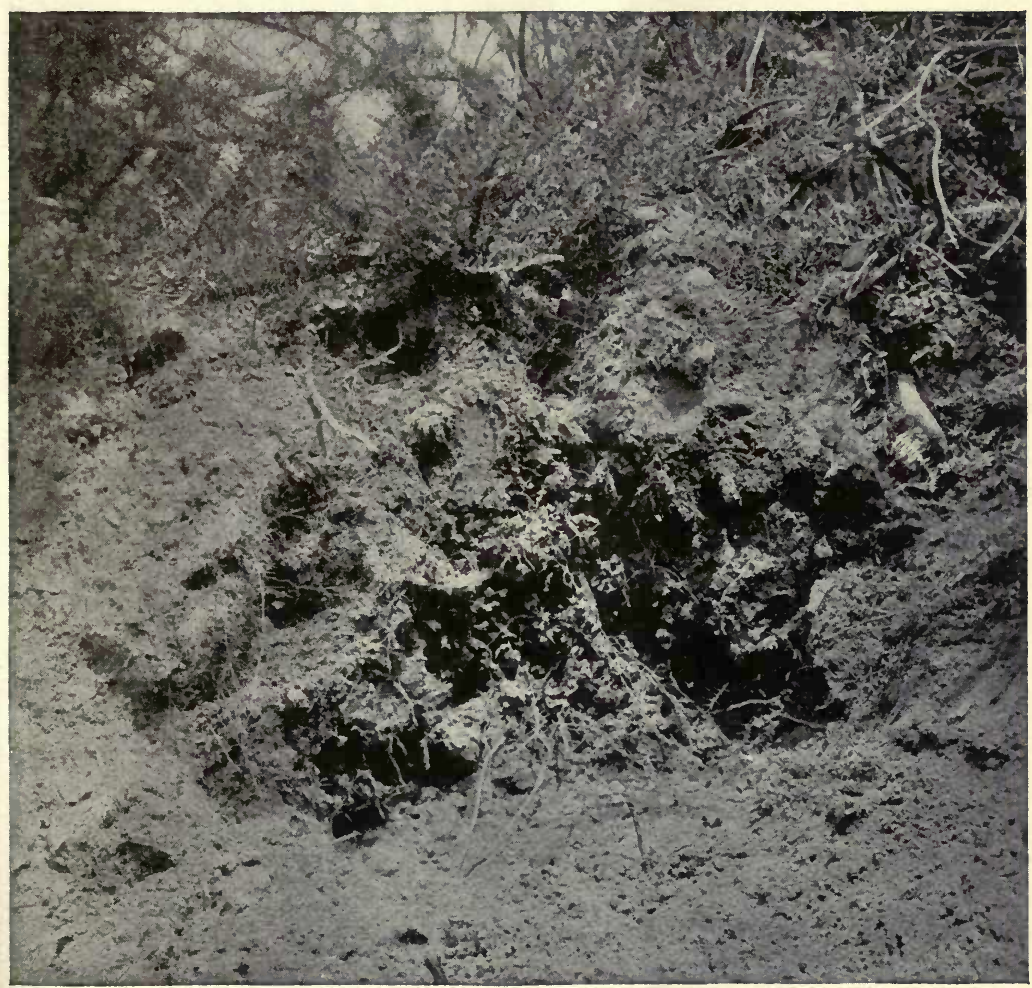

Nest of Donisthorpea umbrata in bank at Woking (31.V.15), showing carton nodules and cells on roots. (Morice.)

Face page 228. 

effectually continued and wellnigh completed by the little people, who had shown their wisdom in utilising the decaying wood and fine comminuted particles, which it had doubtless accumulated by its mandibles, which acted as sharp saws, to fashion its many chambers and accommodate the countless numbers of the rapidlyincreasing family. In fact the tree measured ten feet ten inches in circumference ; its centre, to the height of four feet six inches, was tenanted by a formic population of unnumbered thousands. The rich, brown, honeycombed, finely-wrought woody material occupied a space of about one foot four inches in diameter." 25

Adlerz writes in his recently published book on ants :- "Besides $L$. fuliginosus only one other ant was known in our part of the world, Liometopum microcephalum, which builds carton nests of somewhat more fragile quality in old decaying oaks, poplars, and apricot trees in S.E. Europe. But it is now proved that another of our species of Lasius, the yellow $L$. umbratus, has the same habit in Nordland. This species, which resembles our small, usually yellow, mound ant, but is larger and of a clearer yellow, builds in stumps, among roots, under stones, its carton nest of the same black colour as $L$. fuliginosus, but with stronger walls. This species also cultivates the fungus Cladotrichum (possibly a different species from myrmecophilum) on the walls of the cells, thus increasing their solidity. The carton which these two species of Lasius manufacture is more fragile and brittle than that which is used as building material in the nests of many tropical ants "65. Wasmann has recently shown that the European Donisthorpea emarginata Ol., also makes carton [Biol. Centralb. 33 264-266 (1913)].

I sent several samples of $D$. umbrata carton from different localities to Dr. Jessie Baylis Elliott, and after obtaining cultures and making a careful study of the fungus this carton contains, she has decided it is a new variety of Hormiscium pithyophilum which she has called $H$. pithyophilum var. myrmecophilum. ${ }^{69}$ Dr. Baylis Elliott tells me umbrata carton might almost be considered a pure culture of Hormiscium, and fuliginosa carton a pure culture of Cladosporium.

I have seen the winged sexes in numbers in the nests in July, August, and September, and the winged female in some numbers in a nest at Weybridge in December. Hamm found many winged females in a nest in the Museum grounds at Oxford in April, and Forel records the male in nests in Switzerland in June ${ }^{\mathbf{1 4}}$.

André gives July to September for the marriage flight ${ }^{20}$ and Saunders, August to September ${ }^{30}$.

Forel saw many males in the streets of Zurich on August 22nd, $1868^{14}$, and he noticed the same sex leaving the nest, before mentioned, at Munich in immense numbers from five to seven o'clock in the afternoon at the end of July, $1875^{15}$.

Tuck records the winged forms at Cromer in August, 190238, 
Morley observed males and females flying at Foxhall in September, $1892^{32}$, Crawley mentions a marriage flight at Seaton on September 15th, 1912, at 2 p.m. ${ }^{63}$, Charbonnier sent me a winged female to name, which was flying at Tockington on September 27th, 1914, and Beck took a male and female in copula at Swanage on October 6th, 1914. A marriage flight had evidently taken place at Weybridge on July 29th, 1913, as I saw many deälated females running about on the heath on each side of the railway station; several had been captured by workers of Formica rufa and F. sanguinea and were being dragged as prey to the nests of the latter ants, and a dead winged female was found in a nest of the last-named species. A marriage flight occurred at Sandown, Isle of Wight, on August 27th, 1913, males being observed in the late afternoon in the garden of my house there, and on the pavements near by, and a female was captured, which had already removed some of her wings ${ }^{66}$.

Wasmann has pointed out that-" On account of the concealment of the inner nest one almost never finds the old queens of L. umbratus, mixtus, brunneus, and emarginatus, whereas they are easily to be found with $L$. niger, alienus, and flavus." 42 This is certainly the case in my experience with umbrata, as, however carefully a colony of this ant has been dug up, I have never found the queen.

Barnes found nine deälated umbrata females when digging up a nest of Formica sanguinea at Wellington College on September 6th, $1902^{36}$, but it is probable they were only sheltering in the earth after the marriage flight. I have on several occasions found many $D$. umbrata workers when digging up $F$. sanguinea nests at Woking, but the two species were most probably not really living together ${ }^{53}$.

It has been demonstrated both by observations in nature and by experiments in captivity that the newly fertilized female of $D$. umbrata founds her colony in nests of $D$. nigra.

In the summer of 1895 Adlerz observed a colony of $D$. nigra in Sweden, containing a number of what he took to be $D$. flava workers, which assisted the nigra workers to carry off the brood ${ }^{28}$, but as suggested by Wasmann the yellow workers were most probably umbrata of the first brood ${ }^{48}$, which always consists of small ants. Adlerz's explanation of this mixed colony was that the nigra workers had pillaged some flava pupae and hatched them, but this is very improbable.

On August 1st, 1909, Wasmann discovered near Lippspringe, in Westphalia, a populous colony composed of about one thousand $D$. nigra workers, one hundred $D$. umbrata workers, and several males and one winged female of $D$. umbrata ${ }^{49}$.

On May 28th, 1914, Crawley found two mound nests near each other (in a field at Woking) belonging to the same colony, which contained workers of $D$. umbrata and $D$. nigra in about equal 
numbers, the former being uniformly small in size ${ }^{68}$; and on June 12th, 1914, also at Woking, I observed a few large dark nigra workers among the workers of a large colony of umbrata situated in a sandy bank. Several workers of both species were put into a small bottle and taken home; no fighting took place, and the ants lived together on friendly terms. In this latter case the nigra workers were evidently the survivors of the original nigra colony into which an umbrata female had been accepted.

On September 15th, 1912, after a marriage flight of $D$. umbrata at Seaton, Crawley observed a deälated female umbrata enter a hole under a wall which proved to be one of the entrances to a nest of D. nigra ${ }^{63}$.

On August 27th, 1913, after a marriage flight of $D$. umbrata at Sandown, Isle of Wight, I found a deälated female umbrata fighting with some nigra workers on the pavement near the entrance to a nest of the latter ${ }^{66}$; on August 10th, 1914, I noticed a deälated female umbrata, after a marriage flight at Weybridge, enter the nest of a large colony of $D$. nigra. She forced her way past some nigra workers standing at the entrance, and though I waited for some time, she did not appear again.

In August, 1896, Crawley proved by experiment that queenless colonies of $D$. nigra will accept fertile females of $D$. umbrata and bring up the offspring of the latter until the colony becomes a mixed one of the yellow and black ants. He placed a deälated female umbrata picked up near Oxford in a box with two nigra workerswhich she immediately killed-from a colony of the latter which he had in captivity, containing about four hundred workers, worker and female pupae, and a large quantity of eggs. She was then introduced to more of the nigra workers, and when they were found to be on friendly terms, they were placed near the door of the nigra nest. The workers immediately entered the nest and were followed in a few moments by the queen, swarms of ants collected round her and saluted her. A few days later the workers killed the young winged nigra females that had come to maturity in the nest. The queen began to lay on January 26th, 1897, but for two years only nigra workers were produced-from parthenogenetic eggs laid by the workers-so that the offspring of the umbrata queen must have been devoured in the egg or larval stage. In 1899 the eggs of the queen were at last allowed to reach the pupal stage, but it was not till 1900 that young umbrata workers were allowed to live and were unmolested, and by July 18th some twenty were present, and assisted the nigra workers to tend the brood ${ }^{34}$.

In 1908 similar results were obtained ${ }^{47}$, and as Lord Avebury found that workers of $D$. nigra will live seven years, or more, a colony of $D$. umbrata, therefore, founded by adoption in this manner, must take more than five years to become exclusively umbrata ${ }^{62}$. 
In 1913 Crawley made some nine more experiments, but in all but one the umbrata females were killed by the nigra workers. In the successful experiment, with a small queenless colony of $D$. nigra, the umbrata female though considerably attacked at first was eventually accepted.

It is conceivable therefore that in nature a female might enter an outlying part of a nest and be gradually accepted by most of the workers until she was able to enter the nest proper.

No cases are known of the host queen and the parasite living together in a nest, so, unless a female can only be adopted by a queenless colony, it must sometimes happen that a female is accepted by a colony already possessing a queen of its own species. In such a case the intruder must either kill the rightful queen herself, as the female of (non-British) Bothriomyrmex kills the queen of her host Tapinoma, or the workers of the host species must themselves assassinate their own queen, as do the workers of Tetramorium caespitum when they have accepted a female Anergates atratulus.

Crawley confined several queens of umbrata with queens of nigra, and the latter were always killed by the former, which, although a little the smaller, is stronger and possesses more powerful mandibles ${ }^{63}$.

On July 29th, 1913, I introduced a deälated fertile female umbrata, captured after a marriage flight at Weybridge, into a small queenless colony of $D$. aliena obtained at Weybridge on July 10th, 1912 - the queen of which, a D. mixta, had died on November 5th, 1912. The umbrata female was promptly attacked and nearly killed, so she was removed and died two days afterwards from the injuries she had received. A second umbrata female taken at the same time as the former was introduced into the aliena nest and was only slightly attacked; she killed three of the workers and by the next day she was accepted and has lived in the nest as queen ever since. On May 24th, 1914, she laid her first eggs, and by July 25th she laid a large number and her gaster was considerably swollen. On August 3rd a few workers hatched, which however proved to be aliena (from parthenogenetic eggs laid by the workers), but on August 27th the first umbrata worker appeared. A fair number hatched up to the end of September, all very small; every one, however, was killed after a few days by the aliena workers. The umbrata female laid many more eggs, and by November a large number of half-grown and small larvae (presumably umbrata) were present.

On September 15th, 1913, Pinkney introduced a deälated D. umbrata female taken just after swarming into a colony of D. aliena he had obtained at Woolacombe on August 27th, 1913. Only one worker appears to have attacked her, and she was finally accepted the same day, and was alive and well, living as the queen of the colony, on February 15th, 1914 ${ }^{67}$. 
On July 22nd, 1911, I dug up a nest of D. aliena at Weybridge which contained plenty of workers and small cocoons, some males, and a number of umbrata workers ${ }^{57}$, and on July 12th, 1913, I dug up a mixed colony of umbrata and aliena situated in a sandy bank, also at Weybridge, when both species picked up and carried off the small cocoons exposed by excavating. These two observations and the last two experiments show that $D$. aliena may also act as the host of $D$. umbrata females, and as aliena is not nearly so pugnacious an ant as nigra, the females may more easily accomplish their object.

The following myrmecophiles have been taken with Donisthorpea umbrata in Britain :-

Coleoptera: Myrmedonia humeralis Gr., and Homalota consanguinea Epp.

Formicidae : Stenamma westwoodi West.

Diptera : Pseudacteon (=Phora) formicarum Verrall.

Aphidae : Forda formicaria Heyd., Tycheoides setariae Pass., and Geoica formicina Buckton.

Collembola : Cyphodeirus (=Beckia) albinos Nic.

Araneina: Cryphoeca recisa Camb.

Acarina : Cillibano comata Leon., Urodiscella philoctena Trouess., Uroplitella minutissima Berl., Uropoda ovalis Kram., Trachyuropoda wasmanniana Berl., T. bostocki Mich., Antennophorus uhlmanni Hall., Laelaps cuneifer Mich., Sphaerolaelaps holothyroides Leon, and Tryoglyphus wasmanni Mon.

Crustacea : Platyarthrus hoffmanseggi Brdt.

\section{Donisthorpea umbrata Nyl., var. mixto-umbrata For.}

Lasius umbratus mixto-umbratus Forel Denkschr. Schweiz. Ges. Naturw. $2648(1874)^{1}$. Lasius mixto-umbratus André Spec. Hym. Europe 2196 $(1881)^{2}$. Lasius umbratus var. mixto-umbratus Dalla Torre Cat. Hym. 7 $192(1893)^{3}$. Lasius umbratus Farren-White Ants' Ways 84-85 (1895) (in part). Lasius umbratus var. mixto-umbratus Donisthorpe Ent. Rec. 25 $64^{5} 96^{6}$ (1913).

\section{Original description of $L$. mixto-umbratus Forel :-}

"Pilosité intermédiaire entre celle des deux races. Je n'ai pas encore trouvé d'autres fourmilières formant transition entre ces races, vu leur rareté et leur vie cachée (seulement des + isolées) ; mais leurs caractères distinctifs sont si peu solides, leurs mœurs, leur habitus, leur taille si identiques que je ne doute pas que ces transitions n'existent."'1

Wasmann points out that-"Between L. umbratus and mixtus intermediate varieties are more common than the pure race forms" [Archiv. Trim. Inst. Grand Ducal Luxemburg 111 (1906)].

This variety embraces forms which are intermediate between umbrata and mixta in size, colour, hairiness, and pubescence of the body and legs, etc.; it may be due in part to hybridism, and is 
not of a very satisfactory character. The typical forms however are very distinct, and it may be as well to tabulate how they may be distinguished here :-

\section{D. umbrata.}

$\Varangle$ Larger, clear yellow; hairs (bristles) longer and more abundant ; more pubescent.

Eyes a little smaller and flat.

Funiculus of antennae thin, with joints longer than broad.

Scale higher.

Tibiae with outstanding hairs.

o Lighter brown; hairs longer and more abundant; more pubescent.

Head larger, more emarginate posteriorly.

Funiculus thin, with joints longer than broad.

Scale emarginate at apex.

Tibiae with outstanding hairs.

Wings with dark colour not reaching so far across ; discoidal cell larger.

$\hat{o}$ More robust, less shining and more pubescent. teeth.

Mandibles with more distinct

Eyes with outstanding hairs.

Wings with dark colour not reaching so far across; discoidal cell a little larger.

\section{D. mixta.}

$\Varangle$ Smaller, brownish yellow ; hairs (bristles) shorter and less abundant; less pubescent.

Eyes a little larger and less flat.

Funiculus of antennae thicker, with joints broader than long.

Scale lower.

Tibiae without outstanding hairs.

ㅇ Darker brown; hairs shorter and less abundant; less pubescent.

Head smaller, less emarginate posteriorly.

Funiculus thicker, with joints not longer than broad.

Scale not emarginate at apex.

Tibiae without outstanding hairs.

Wings with dark colour reaching further across ; discoidal cell smaller.

to Less robust, more shining and less pubescent.

Mandibles with less distinct teeth.

Eyes without outstanding hairs.

Wings with dark colour reaching further across ; discoidal cell a little smaller.

I found several colonies of mixto-umbrata at Weybridge in 1912, males and winged females occurring with them in numbers in September ${ }^{5}$; Hallett has sent it to me from Porthcawl, and specimens I took at Bletchington in May, 1913, might be called this var., as the workers are somewhat intermediate in colour, etc., and the partly winged female has a few outstanding hairs on the tibiae. The two females which were taken in nests of $D$. aliena at Weybridge, and which will be mentioned under mixta, also have a few hairs on the tibiae. It appears probable that the colony recorded by Farren-White in his garden at Stonehouse would also come under mixto-umbrata; he writes, when speaking of specimens of D. mixta given to him by Bignell :- " He kindly furnished me with specimens-they are marvellously like Lasius umbratus or Formica umbrata; the workers and males especially so. The pubescence, however, is not so conspicuous upon the tibiae in the workers and females as in umbratus, and the colour of the females is of a dark sepia brown rather than of a reddish brown or mahogany tint, as in the typical specimens of umbratus. However, I have specimens of $L$. umbratus intermediate in its degree of pubescence 
and in its colouring between the two extremes. One with a reddish tinge, another of the pale yellowish brown kind, and a third of the dark sepia brown, precisely similar in its colouring to Mr. Bignold's (sic) specimens, from a very strong and long-established colony of umbratus in my garden. This colony for very many years has produced no females, males having been developed in their thousands, nay, tens of thousands, but not a single female having come within view. In 1882 , however, the species swarmed in the Vicarage, and must have come up through the foundations in some mysterious way. The males and females were accompanied by the workers, who seem to exercise over them a singular and controlling power. All the females were of the dark brown type with a fine,

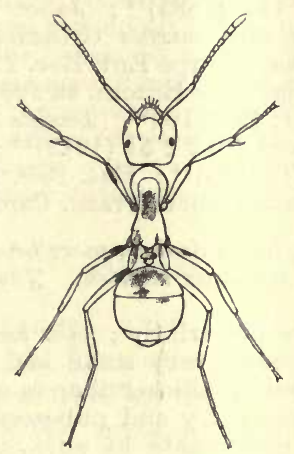

Fig. 86. D. mixto-umbrata ఫ̧ with patches of algae on body and legs.

silky sheen, and the pubescence I find more marked and clearly defined in some specimens than in others."4

By "pubescence" on the tibiae, etc., Farren-White means the outstanding hairs. It is evident that though the typical forms are quite distinct, these intermediate varieties are more confusing and difficult to deal with.

On August 11th, 1912, when at Weybridge in company with Professor Wheeler, we found two colonies of this variety, very many of the ants of both being infested with a curious dark brown warty growth in patches on parts of the body and legs-this Wheeler thought might be a fungus which was unknown to him.

I kept a number of these ants in captivity, and added uninfected workers of umbrata from other localities; the growth however did not increase nor spread to the new ants, but rather seemed to decrease. I sent some of the infested ants alive, and others in spirit, to Dr. Baylis Elliott, and she considered the patches were colonies of unicellular organisms growing on the outside of the 
ants $^{6}$; eventually she came to the conclusion that they were not fungoid growths, but probably colonies of an alga.

I have taken the Acari, Cillibano comata Leon., Antennophorus ulhmanni Hall., and Sphaerolaelaps holothyroides Leon., in nests of D. mixto-umbrata.

\section{Donisthorpea mixta Nyl.}

Formica mixta Nylander Acta. Soc. Sc. Fenn. $21050(1846)^{1}$; Schenck Jahrb. Ver. Naturk. Nassau $864-66^{2} 139^{3}$ (1852); Mayr Verh. Zool. Bot. Wien $5367(1855)^{4}$. Formica brunnea F. Smith Trans. Ent. Soc. Lond. (n.s.) $41857278(1858)^{5}$ : Proc. $88(1858)^{6}$ : Cat. Brit. Foss. Hym. $11^{7} 224^{8}$ (1858): Ent. Ann. 1858 399. Lasius mixtus Mayr Europ. Formicid. 50 $(1861)^{10}$. Lasius umbratus r. mixtus Forel Denkschr. Schweiz. Ges. Naturw. $2647^{11} 216^{12} 407^{13}$ (1874). Lasius mixtus Er. André Spec. Hym. Europe 2 $196(1881)^{14}$; Bignell Entom. $14262(1881)^{15}$ : Young Nat. $3191(1852)^{16}$; Dalla Torre Cat. Hym. $7187(1893)^{17}$; Janet Etudes. Fourmis 13 1-58 $(1897)^{18}$. Lasius umbratus race mixtus Grimshaw Ann. Scot. Nat. Hist. 1908 8919. Lasius mixtus Donisthorpe Ent. Rec. 23 236-238 (1911) ${ }^{20}$. Lasius umbratus subsp. mixtus Donisthorpe Entom. $44390(1911)^{21}$. Lasius umbratus race mixtus Evans Scot. Nat. 1912 10622. Lasius mixtus Crawley and Donisthorpe Int. Ent. Cong. Oxford 1912251 (1913) ${ }^{23}$; Donisthorpe Rep. LancsChesh. Ent. Soc. 36191240 (1913) ${ }^{24}$ : Ent. Rec. $2564^{25} 268^{26} 291^{27}$ (1913). Lasius umbratus subsp. mixtus Hallett Trans. Cardiff Nat. Soc. $453(1913)^{28}$.

$\Varangle$ Dirty yellow in colour, being darker, more brownish than umbrata, mandibles and funiculus of the antennae reddish. The whole body less hairy and pubescent than in umbrata.

Head scarcely emarginate posteriorly; eyes small, but a little larger and less flat than in umbrata; ocelli very small and indistinct; frontal furrow indistinct; funiculus of antennae thicker than in umbrata, with joints broader than long. Thorax much less hairy and pubescent than in umbrata. Scale narrowest, and somewhat emarginate at apex, not so high as in umbrata, but higher than in flava; gaster with fewer and shorter hairs than in umbrata. Tibiae without outstanding hairs. Long. $3 \cdot 5-4.5 \mathrm{~mm}$.

ㅇ Dark brown with mandibles, antennae, and legs reddish; darker and much less hairy and pubescent than umbrata.

Head as broad as thorax, but not so large, nor so emarginate posteriorly as in umbrata; funiculus of antennae thicker than in umbrata with joints not longer than broad. Thorax only slightly narrower than gaster, not so hairy nor so pubescent as in umbrata. Scale not emarginate at apex; gaster with fewer and shorter hairs than in umbrata. Tibiae without outstanding hairs. Wings infuscate at base, the colour slightly darker and reaching further across, and the discoidal cell smaller than in umbrata. Long. 6.5-8 $\mathrm{mm}$. (6-8 mm. teste André.)

ô Blackish brown, funiculus of antennae and tarsi yellowish; slightly less robust, a little more shining, and less pubescent than umbrata.

Head not quite so large as in umbrata; mandibles armed with five teeth, which are not as distinct as in umbrata; frontal furrow distinct ; eyes without outstanding hairs. Wings as in the female, the colour extending a little further across, and the discoidal cell a little smaller than in umbrata. Long.

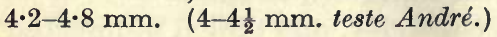

Original description of Formica mixta Nylander [Acta. Soc. Sc. Fenn. 21050 (1846)] :-

"Simillima est $F$. flavae, differt autem : operaria pilis parvis sparsis corporis brevioribus, flagellis antennarum submoniliformibus (h.e. articulis paulo magis discretis), antennis ipsis, ut videtur, nonnihil majoribus longiori- 
bus; femina paulo minor, pilositate sparsa fere obsoleta, pilis minutis hinc inde sparsis, pubescentia microscopica cinerascenti-sericea aeque densa ac in $F$. flava et umbrata, oculis hirtulis, alis albescenti-hyalinis a basi fere ad medium dilute brunnescenti-tinctis, nervis pallidis, apicalibus omnino dilutis, stigmate cinerascenti-pallido, area discoidali trapezoidea dimidio minori h.e. proportione eadem ac in $F$. nigra , anticis $8 \frac{1}{2}$ millimetra longis, squama subrectangulari supra integra, abdomine minori angustiori, pilis sparsis tantum minutissimis, multoque rarioribus, igitur longe nudiori (pube tamen sericea, ut dictum, in ambis aequali) ; mas corpore paulo minus nitido, pube sericea distinctiori, oculis parce microscopice hirtulis, lineola frontis impressa longitudinali distincta at transversa nulla, alis sicut in femina, nonnihil dilutius coloratis, area discoidali proportione ut in $F$. nigra $\hat{\sigma}$ (igitur dimidio minori quam in mare $F$. umbratae), anticis fere $5 \frac{1}{2}$ millimetra longis. Color alarum in specie praesente medium tenet inter $F$. umbratam et $F$. flavam, dilutior est quam in illa, obscurior quam in hac. His notis speciem eam solummodo indigitare valui. $F$. rubra Zett. Ins. Lapp. 450, 8 et Dahlb. mscrpt. probabiliter commixta est e speciebus tribus memoratis affinibus; sub hoc nomine etiam easdem tres a Cel. Dahlbom accepi. Maris varietas b., quae in Ins. Lapp. exponitur, verus est mas $F$. flavae nostrae; var a. ibid. et $F$. umbratae et flavae pertinere videtur. At observationibus ulterioribus praesertim in vivo nidoque factis termini naturales, quibus circumscribuntur hae species, clarius elucebunt. Forsitan haud inconvenienter simul cum $F$. nigra propriam constituere possint subdivisionem, parvitate marium proportione feminarum suarum, inter alia signa, dignotam."

\section{Habitat.}

Donisthorpea mixta ranges over North and Central Europe; Ruzsky records it from the Caucasus, Siberia, and Finland, and in North America it is represented by the var. aphidicola Walsh, which according to Wheeler is the most abundant form of the umbrata group in the Northern States,

It is distributed in Britain as follows :-

Devon, S. : Bickleigh (Bignell) ${ }^{\mathbf{1 5}}$; Devon, N. : Lundy Island (Donisthorpe) ${ }^{26}$.

Somerset, N. : Long Ashton and Leigh (Smallcombe).

Dorset: Glanvilles Wootton (Dale Coll.).

Isle of Wight : The Landslip (Dale Coll.).

Kent, E.: Deal (F. Smith) ${ }^{\mathbf{5}}$; Herne Bay (Rothney Coll.).

Surrey : Richmond Park (Dollman) ${ }^{20}$; Mickleham (Crawley and Donisthorpe) ${ }^{20}$; Box Hill ${ }^{27}$ and Weybridge ${ }^{20}$ (Donisthorpe).

Essex, N. : Colchester (Harwood $)^{25}$.

Oxfordshire : Shotover Hill (Hamm); Horsepath (Cambridge Mus. Coll.).

Bucks : Bourne End (Best Gardner) ${ }^{25}$.

Suffolk, E.: Pakefield (F. Smith $)^{8}$.

Gloucester, W. : Dursley (Smallcombe).

Glamorgan : Dinas Powis ${ }^{28}$, Cwrt-yr-ala ${ }^{25}$, Southerndown, Porthcawl, and Penarth (Hallett).

Edinburgh : Dalkeith Park (Evans) ${ }^{22}$.

Linlithgow : Dalmeny Park (Evans).

Fife and Kinross : Isle of May (Baxter and Rintoul) ${ }^{\mathbf{1 9}}$. 
Donisthorpea mixta was first recorded as British by Bignell, who discovered a colony at Bickleigh near Plymouth in September, $1881^{15}$, but no further capture was published till 1908 when Grimshaw pointed out that the Misses E. V. Baxter, and L. J. Rintoul had taken specimens on the Isle of May in September and October, $1907^{19}$. Evans had taken a female mixta on the Isle of May in September, 1888, and he found two nests there in 1910, and $1911^{22}$, but no further records occur till the latter year ${ }^{20}$.

The Formica brunnea F. Smith must be referred to Donisthorpea mixta, as $D$. brunnea Latr., which lives under the bark of trees on the Continent, has not been found in Britain.

Smith states that the brunnea of the Stephensian collection was represented by a female umbrata, but that he had taken a single female of the true brunnea on the Deal sand-hills, in $1856^{5}$.

Subsequently in his 1871 catalogue he sinks his brunnea as a synonym of umbrata, as also does Saunders, but as Smith describes the tibiae as being "without pile or pubescence " the specimen in question must have been $D$. mixta.

Donisthorpea mixta is not as abundant nor as widely distributed as D. umbrata ; it occurs on heaths, in sandy places, but also in clearings and copses, in chalky districts, and seems to like the shade.

The habits are similar to those of umbrata-though it is a more active species-it lives a subterranean life, and nests under stones, at and in the roots of trees, in stumps and banks, and its nests penetrate deep into the ground.

Janet records a very large colony which he observed for five years in the garden of the Villa des Roses near Beauvais, which was nesting in the ground in a shady place, the earth being of a fine vegetable mould, with violets, etc., growing on it. He dug a hole and inserted his arm, and at the depth of thirty centimetres below the surface, after passing through a thickening of the soil, rendered spongy by the galleries of the ants, his hand reached a vast excavation dug out by the ants in the soft soil, overrun with roots. $\mathrm{He}$ noticed a gentle heat in this cavity ${ }^{18}$.

In May, 1913, I found a number of colonies of mixta at Box Hill $^{27}$, one or two were situated under stones-the flinty nature of the ground beneath rendering excavation impossible - one in and under a fallen bough, but the majority in the roots of dead Juniper trees in thickets on each side of the valley. A number of species of ants occur in this valley and their nest are nearly all situated on the side facing the east, but the mixta nests were equally common on both sides. The ants had hollowed out the Juniper roots, channelling them with galleries partly filled with brittle earthen eells, which on analysis were found to contain some fungus. Most of the ants, and their brood, were inhabiting these roots, but a number of workers also occurred in the flinty ground round about.

The marriage flight takes place according to André from July to 
September ${ }^{14}$, but the latter month seems to be the more usual time. Forel noticed the males and winged females leaving a nest together at Zurich on September 20th, 1870, at half-past four in the afternoon ${ }^{13}$, Bignell observed a number of males and winged females on an old bramble stem at Bickleigh on September 2nd, 1881, the workers being on the ground below in great commotion ${ }^{15}$, Evans captured two winged mixta females with several winged flava females on September 22nd, 1903, from a big swarm on the banks of South Esk, Dalkeith Park ${ }^{22}$, and Misses Baxter and Rintoul took males, females, and workers on the Isle of May on September 10th, 11th, and 27th, and October 3rd, $1907^{19}$.

Forel found a large number of winged females, no males being present, in a colony at Morges, on March 16th, $1868^{13}$, which must have passed the winter in the nest.

On September 7 th, 1913, I found a great number of males and winged females in a nest in a juniper root at Box Hill ${ }^{27}$, in which some six or more young, freshly deälated, very active females also occurred. These young females may have already been fertilized in the nest, and as the females of this species do not lay till the following year, and as only one queen occurs in a nest, I would suggest that these young queens may leave the nests in the spring, which would account for the isolated females found on roads, etc., at that time.

On March 7th, 1910, I found a deälated female walking on the heath at Weybridge ${ }^{20}$, on February 17th, 1911, Dollman picked up a deälated female at large in Richmond Park ${ }^{20}$, in March, 1911, Hallett captured a deälated female walking on the Millbrook road at Dinas Powis ${ }^{28}$, and on April 22nd, 1911, Crawley and I took two deälated females on the road at Mickleham ${ }^{20}$.

As with umbrata, it is very rarely that the queen can be found in a mixta colony, but on May 23rd, 1913, I had the good fortune to find the queen in two nests of this species ${ }^{27}$. The whole colony was exposed by pulling up the juniper tree bodily, and shaking the roots, in which the ants were situated, over a sheet, and in each of these two nests the colony consisted of a single deälated female, with the gaster considerably swollen, packets of eggs, young larvae and a large number of workers.

Young females of D. mixta undoubtedly found their colonies in nests of D. aliena. As long ago as 1852 , Schenck recorded that he once found a female mixta in the earth with workers of aliena ${ }^{2}$, but he did not draw any conclusion from this remarkable fact; myrmecologists appear to have overlooked Schenck's record and its importance.

On July 18th, 1912, I dug up a colony of aliena which was nesting in a sandy bank at Weybridge, and contained a deälated female mixta, a number of aliena workers, and many large and small cocoons ${ }^{25}$, but the most careful search failed to produce any 
other female, and no eggs were present. The colony was taken home and established in a Janet nest, and when all the cocoons had hatched, the large ones proved to be aliena winged females, and the smaller ones aliena workers. The mixta female was very active, being exceedingly rapid in her movements, and very excited when first dug up. She laid eggs on August 7th, 1912, and was always treated as their queen by the aliena workers, who fed and cleaned her, and appeared to attend to her brood.

Crawley and I have suggested, as this female laid eggs in 1912, that " we should judge this $L$. mixtus female, therefore, to have been adopted last summer "23 -i.e. in 1911, but should this female have left the parent nest in the spring of 1912, and having found a nest of aliena have been accepted by the workers, it would account for her laying in the same year when accepted, but this would still be the year following fertilization.

On September 1st small larvae were present and a number were brought up, but as eventually only aliena workers were produced, the offspring of the mixta female must have been devoured and the aliena workers themselves have laid eggs, the result obtained being the same as in Crawley's experiments with umbrata and nigra.

On November lst the aliena workers killed some of their own winged females, and eventually destroyed and cut up all of them. The mixta female unfortunately died on November 5th; she gradually lost the use of her legs, and in the end could only move her antennae, which she kept waving backwards and forwards, but to the last the aliena workers carried her about, cleaning and attending to her.

A number of larvae are now present in this nest, and a female umbrata as queen, but it is almost certain that these larvae will prove to be the offspring of the workers.

On August 11th, 1912, when I had the pleasure of Professor Wheeler's company, we found, at Weybridge again, another mixta female, as queen in a nest of $D$. aliena ${ }^{25}$.

These are instances in nature where the mixta female has sought a nest of aliena in which to found her colony, and has been accepted by the workers. It is probable that either the latter then killed their own queen, if they possessed one, or the mixta female accomplished this act herself.

The following myrmecophiles have occurred with D. mixta in Britain :-

Coleoptera : Homoeusa acuminata Märk., and Claviger longicornis Müll.

Formicidae : Myrmecina graminicola Latr., Stenamma westwoodi West., and Leptothorax nylanderi Först.

Collembola : Cyphodeirus (=Beckia) albinos Nic.

Araneina : Cicurina cinerea Panz. 
Ácarina : Cillibano comata Leon., Trachyuropoda bostocki Mich., Antennophorus uhlmanni Hall., Laelaps cuneifer Mich., and Sphaerolaelaps holothyroides Leon.

Crustacea : Platyarthrus hoffmanseggi Brdt.

FORIMICA Linné.

(Formica, ant.)

Type : Formica rufa L. (Lamk., 1801).

The circumpolar genus Formica comprises a number of species of robust and intelligent ants which live an open-air life, hunting insects and other prey, and attending plant-lice on trees and shrubs. They are said not to rear Aphidae in their nests, but I have not infrequently found these insects domiciled with some of our Formicae, as will be seen later, when the different species are dealt with.

Many of these ants are very courageous and warlike-some of these possess the interesting habit of making slave-raids-whilst others are shy and cowardly, and are the ones chiefly exploited by the slave-makers.

The ants of this genus are rapid in their movements, have longer legs and stand higher on them than do the species of the genus Donisthorpea, and they do not follow each other in files over unknown territory. They use the eyes in finding their way, often leaving the trail and proceeding straight in the direction of the nest when a booty has been secured, and according to Wasmann can see resting objects on the ground at a distance of eight to ten centimetres.

These ants frequently carry their fellows beneath them; the ant carried packs its antennae and legs close to its body and grasps the mandible of its carrier, doubling itself up with its gaster bent under the head of the other ant.

They secrete a large amount of formic acid-possessing twice as much in proportion to their size as do the larger ants of the genus Camponotus. With this poison they spray an enemy, and some of the species can eject it to a considerable distance.

The males are about the same size as the females, the latter being generally larger than the largest workers, and sometimes a great many queens occur in a single colony.

The workers sometimes lay eggs, especially in queenless colonies; the queens lay eggs earlier in the year than do those of Donisthorpea, the larvae take much less time to develop, and are never present in the nests during the winter. The pupae are usually enclosed in cocoons of a pale buff colcur, but are sometimes naked, and both will occur at the same time in the same nest.

The nesting habits are various, some species build large hillocks 
of vegetable refuse, some construct earth mounds, others nest in the ground, or under stones, and occasionally in tree stumps.

The swarming of these ants is seldom seen, and some species found their colonies in the normal, others in the abnormal manners.

Their colonies are generally large, some species possess branch nests, and a great number of colonies in one area will all belong to the same vast community.

According to Wheeler Formica is "the most eurythermal" of the circumpolar genera Stenamma, Myrmica, Lasius, and Formica which are confined to the northern hemisphere, and it ranges in Europe, Asia, and North America from a latitude of $30^{\circ}$ to $60^{\circ}$ or $65^{\circ}$, and therefore nearly to the Arctic circle. In altitude the species range from sea-level to above timber-line, 12,000 to $12,500 \mathrm{ft}$.

Wheeler [Bull. Mus. Compar. Zoöl. 53385 (1913)] suggests that North America is the original home of the genus; he writes:- "If we divide the total number of the known Formicae (144) into Old and New World forms, we find that Eurasia possesses only fifty-two, whereas North America, though a much smaller land area, possesses ninety-three species, subspecies, and varieties (one of the species, $F$. fusca, is counted twice, because it occurs in both hemispheres). This would seem to indicate that the latter continent must be the original home of the genus, especially as it possesses representatives of all the Eurasian groups of species besides two peculiar to itself.

Unless we accept the view that the genus arose in the polar region during Mesozoic times and radiated its species out into Europe, Asia, and North America, we must suppose that Eurasia has received its species by immigration from the Nearctic region. That the latter view is the more probable is shown by a glance at the distribution of the forms in America. At least thirty-nine of our ninety-three forms, or nearly 42 per cent, occur in Colorado and the adjacent portions of New Mexico. Not only are these two states thus abundantly supplied with species, subspecies, and varieties but the colonies of the individual forms are unusually numerous and flourishing on the mountain slopes of this territory. We may therefore regard the southern ranges of the Rocky Mountains in the United States as the center of origin of the genus and of the dispersal of species to other portions of North America."

Five species of Formica, some of which are closely related to existing forms, have been described from the Baltic Amber.

Lamarck [Syst. An. sans. Vert. 268 No. 124 (1801)] adopts F. rufa L. as the type of Formica L.-Latreille [Cons. Gen. Crust. Ins. 311 No. 441, 437 (1810)] gives herculeana (L.) F., and rufa L., as the types, and the latter was definitely cited as the type by Curtis [Brit. Ent. 16 expl. Pl. 752 (1839)]-Westwood [Mod. Class. Ins. 2 
Syn. Gen. $83(1840)$ ] quotes Curtis, but cites fusca L., as type. In 1879 Girard [Traité Élém. Ent. 21011 (1879)] also states that rufa is the type, as does Bingham [Faun. Brit. India Hym. 2333 (1903)] -Wheeler [Ann. New York Acad. Sc. 21164 (1911)] adopts the last citation, but subsequently [Ann. New York Acad. Sc. 2379 (1913)] attributes the fixing of the type to Girard, overlooking the earlier citations.

Wheeler in 1913 divides Formica into five groups-sanguinea, exsecta, rufa, microgyna, and fusca [Bull. Mus. Compar. Zoöl. 53 381 (1913)], and Forel, when commenting on this arrangement, gives the subgeneric name of Raptiformica to the sanguinea-group, designating sanguinea Latr., as type, and Serviformica to the fusca-group, with fusca L., as type [Ann. Soc. Ent. Belg. $5^{\text {ry }} 361$ (1913)].

$\Varangle$ Head cordate; clypeus large, trapezoidal, convex, carinate; frontal carinae wide apart, subparallel, usually slightly diverging posteriorly ; frontal area triangular, distinctly defined, pointed posteriorly ; frontal furrow more or less distinct; mandibles broad, triangular, terminal border dentate; maxillary palpi six-jointed (rarely five-jointed), fourth joint slightly longer than fifth ; labial palpi four-jointed; antennae twelve-jointed, funiculus with joints gradually and slightly thickened towards the apex, but not forming a club; ocelli always present and distinct. Thorax narrower than head; pronotum rounded; suture between pronotum and mesonotum distinct; mesonotum rounded, suture distinct, and more or less deeply constricted, between mesonotum and epinotum; epinotum when seen in profile angled or rounded. Petiole furnished with an erect scale, which is compressed posteriorly and anteriorly; gaster short, globose.

o Characters, except thorax, as in the $\not$; wings ample, fore-wing with one discoidal cell, and one cubital cell which is always closed.

to Head triangular; clypeus, frontal area and palpi as in the $\not{\gamma}$; frontal carinae very short and indistinct; mandibles narrow, somewhat flat, terminal border short, armed with one, or five teeth; antennae thirteen-jointed, funiculus with first joint not broader than the rest, shorter than the second. Petiole with scale thicker and less compressed than in the $\Varangle$ and + , often emarginate at apex ; gaster flat and depressed above; external genital organs large. Wings as in the female.

Ovum : White, long oval, distinctly longer than broad.

Larva: Pale yellowish white, long, narrow, and curved anteriorly; head considerably narrower than the rest of the body; segments well defined, transversely striate, and gradually increasing in width till just before the distal end. The whole body covered with short straight hairs of equal length, which appear to be bifid at the apex, and are more abundant on the younger larvae.

Fupa : Usually enclosed in pale buff cocoons, but sometimes naked. The pupae do not acquire the complete adult coloration before they emerge.

Original description [Linnaeus Syst. Nat. Ed. 101343,579 (1758)] :-

"218 Formica. Aculeus obsoletus. Alae neutris nullae!" (p. 343).

" 218 Formica. Squamula erecta thoraci abdominique interjecta. Aculeus Feminis \& Neutris reconditus.

Alae Maribus \& Feminis ; sed Neutris nullae." (p. 579). 


\section{Table of the Species.}

\section{ళ}

1 Clypeus not emarginate . . . . . . . . . . . . 2

- Clypeus emarginate _. . . . . . . 4 sanguinea Latr.

2 f Head deeply excised posteriorly . . . . . . . . 3 exsecta Nyl.

(1) Head not excised posteriorly _ _ _ $\ldots \ldots \ldots \ldots$

3 Body robust; head evidently broader than thorax, in the largest individuals not, or scarcely, longer than broad; scale hexagonal; gaster much broader than the thorax . . . . . . . . . 4

Body more slender, head only a little broader than thorax, in the largest individuals longer than broad; scale rounded; gaster not much broader than thorax _ _ _ _ _ _ _ _ _ _ _ _ - 6

Gaster brown or black, often more or less red at the base ; eyes without or with less pronounced hairs . . . . . . . . . . . 5

(3) Gaster black; eyes with pronounced hairs - - -2 pratensis Retz.

5 (Head long and narrow, cheeks straight; thorax more slender . . . .

4) . . . . . . . rufa v. alpina Sant.

(4) Head short, cheeks more rounded; thorax more robust - _ - - _ _ _ _ - 1 rufa L., and rufa v. rufo-pratensis For.

6 (Body opaque . . . . . . . . . . . . . . 7

(3) Body shining - . $\ldots \ldots \ldots$. $\ldots \ldots$ - $\ldots$ picea Nyl.

7 j Body black . . . . . . . . . . . . 5 fusca L.

(6) Body at least in part red or brown - _ _ $\ldots$

8 Thorax chiefly dark in both large and small individuals . . .

(7) Thorax largely red in the larger individuals - fusca v. glebaria Nyl.

9 Thorax red in largest individuals only, without outstanding hairs ..

(8) ............ . fusca v. rubescens For.

(8) Thorax red generally, only infuscate in small individuals, with outstanding hairs . . . . . . . . . 6 rufibarbis F.

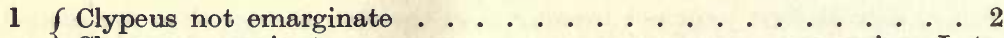

- Clypeus emarginate - $\ldots \ldots \ldots \ldots$ - $\ldots \ldots$ - $\ldots$ anguinea Latr.

2 Head excised posteriorly . . . . . . . . . . exsecta Nyl.

(1) Head not excised posteriorly _ $\ldots \ldots \ldots \ldots \ldots$

3 More robust ; head broader than thorax ; thorax higher, more rounded

above; gaster shorter, more spherical, much broader than thorax . 4

(2) Less robust; head not, or scarcely broader than thorax; thorax not so high, flatter above; gaster longer, not so much broader than thorax -6

4 Head long, narrow, cheeks straight ....... rufa v. alpina San.

(3) Head broad, cheeks more rounded _ _ _ . _ _ _ _ $\ldots-5$

5 Gaster smoother and shining, scarcely pubescent .... rufa L.

(4) Gaster duller, distinctly pubescent - - - - - - pratensis Retz.

6 Body all black .................. . . . .

(3) Body in part red _ $\ldots \ldots \ldots$

7 Less shining, more punctured and pubescent and less hairy - fusca L.

(6) More shining, less punctured and pubescent, more hairy - picea Nyl.

$8\left\{\begin{array}{c}\text { Thorax largely red; outstanding hairs on thorax more abundant and } \\ \text { distinct. }\end{array}\right.$

(6) Thorax mostly black ; outstanding hairs on thorax less abundant and

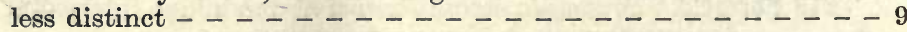

9 \{ Einotum almost entirely red ....... fusca v. rubescens For.

(8) Epinotum black or partly black _..... fusca v. glebaria Nyl. 
1 Mandibles armed with four, or five, teeth; clypeus emarginate . . .

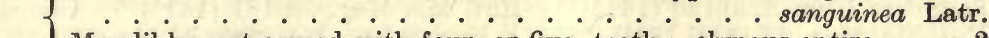

- Mandibles not armed with four, or five, teeth; clypeus entire - - - 2

2 Head excised posteriorly ............ exsecta Nyl.

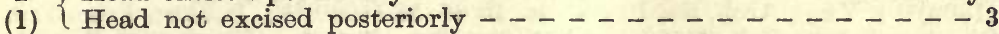

3 Robust, broad ; body much more hairy ; eyes hairy . . . . . . 4

(2) More slender, narrower; body less hairy; eyes without hairs - _ - 5

4 S Slightly more robust; body and eyes more hairy . . pratensis Retz.

(3) Slightly less robust; body and eyes less hairy _ _ _ _ - rufa L.

5 Gaster shining . . . . . . . . . . . . . . . 6

(3) Gaster dull - $\ldots \ldots \ldots \ldots \ldots \ldots \ldots$

6 Thorax with more, and longer, hairs and pubescence; gaster less strongly punctured, and with longer, and less close, pubescence . .

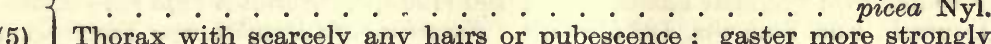
punctured, and with shorter and closer pubescence - _ fusca L. punctured, and with shorter and closer pubescence - - fusca L.
cale deeply emarginate . . . . fusca v. rubescens For.

7 (5) Scale deeply emarginate Scale widely but not deeply emarginate $-\ldots \ldots$ fusca v. rubescens For.

8 Legs mostly red; outstanding hairs on thorax shorter and sparser . .

(7) Femora and tarsi usually blackish; outstanding hairs on thorax longer and thicker $\ldots \ldots \ldots \ldots$ - $\ldots \ldots$ nubarbis $\mathbf{F}$.

\section{Formica rufa $L$.}

["The Hill Ant" Gould Account English Ants (1747)]". Formica rufa Linnaeus Syst. Nat. Ed. $101580(1758)^{2}$. Formica dorsata Panzer Faun. Ins. Germ. $541(1798)^{3}$. Formica rufa Latreille HN. Fourmis 143-150 $(1802)^{4}$. Lasius emarginatus Fabricius Syst. Piez. 416 (1804) $\delta^{75}$. ["La fourmi fauve dos rouge" Huber Mœurs Fourmis (1810)] ${ }^{6}$. Formica rufa Hill Mag. NH. 6476 (1833) $^{7}$; Conway Mag. NH. 7 266-267 (1834) ${ }^{8}$; Kirby Proc. Ent. Soc. Lond. 1 XXV $(1835)^{9}$; Lees Nat. $1154(1837)^{10}$; Clarke Mag. NH. (n.s.) 2393 (1838) ${ }^{11}$; Zetterstedt Ins. Lappon. $1448(1838)^{12}$. Formica obsoleta Zetterstedt Ins. Lappon. $1449(1838)^{13}$. Formica lugubris Zetterstedt Ins. Lappon $1449(1838)^{14}$. Formica rufa Curtis Brit. Ent. 16 expl. Pl. $752(1839)^{15}$; F. Smith Trans. Ent. Soc. Lond. 3 151-154 (1842) ${ }^{16}$; Plant Zool. 2 473-474 (1844) ${ }^{17}$; Nylander Acta. Soc. Sc. Fenn. 29021047 $1059(1846)^{18}$. ["The Large Wood Ant" Daniell Zool. 51931 (1847)]" Formica rufa Nylander Acta Soc. Sc. Fenn. $326(1849)^{20}$. Formica rufa v. major Nylander Acta. Soc. Sc. Fenn. $329(1849)^{21}$. Formica rufa Förster Hym. Stud. 1 13-15 (1850)22. Formica polyctena Förster Hym. Stud. 115 $(1850)^{23}$. Formica truncicola Förster Hym. Stud. 121 (1850) ఫ్ఫ24. Formica rufa Schenck Jahrb. Ver. Naturk. Nassau $823-25^{25} 136^{26}$ (1852). Formica polyctena Schenck Jahrb. Ver. Naturk. Nassau $825137(1852)^{27}$. Formica piniphila Schenck Jahrb. Ver. Naturk. Nassau 828138 (1852) ${ }^{28}$. Formica rufa F. Smith Trans. Ent. Soc. Lond. (n.s.) $3100(1855)^{29}$; Mayr Verh. Zool. Bot. Ver. Wien 5 328-331 (1855) ${ }^{30}$; F. Smith Cat. Brit. Foss. Hym. $4(1858)^{31}$. Formica apicalis F. Smith Cat. Hym. Brit. Mus. $649(1858)^{32}$. Formica herculanea Warner Sc. Gossip $1871198^{33}$. Formica rufa BuchananWhite Scot. Nat. 1 216-222 258-263 (1872) ${ }^{34}$. Formica rufa r. rufa Forel Denkschr. Schweiz. Ges. Naturw. $2652^{35} 203-204^{36} 219^{37} 408^{38}(1874)$. Formica rufa Forel Bull. Soc. Vaud. Sc. Nat. 14 59-60 (1875) ${ }^{39}$; Lubbock Mo. Mic. Journ. 18 Pf. 192 : 3.4.7 (1877) ${ }^{40}$; Bignell Ent. Mo. Mag. $16267(1880)^{41}$; Parfitt Trans. Devon Assn. Sc-Art $12513(1880)^{42}$; Saunders Trans. Ent. Soc. Lond. $1880204^{43}$; Er.André Spec. Hym. Europe $2184(1881)^{44}$; Lubbock Ants, Bees, Wasps $15(1882)^{45}$; Collett Ent. Mo. Mag. $2042(1883)^{46}$; 
Matthews Ent. Mo. Mag. 20 209-210 (1884) ${ }^{47}$; Darwin Life and Letters 3 $192(1887)^{48}$; Bowman Sc. Gossip $188932-34^{49} 198-200^{50}$; Dalla Torre Cat Hym. $7206(1893)^{51}$; Farren-White Ants' Ways $73^{52} 202^{53} 231^{54}$ (1895); Saunders Hym-Acul. $20(1896)^{55}$ : Ent. Mo. Mag. $32161(1896)^{56}$; Bignell Ent. Mo. Mag. $33141^{57} 183^{58}$ (1897) ; Morley Ent. Mo. Mag. $33158(1897)^{59}$; Janet C. R. Acad. Sc. Paris $130(1898)^{80}$; D. Sharp Camb. NH. Ins. 2148 $(1899)^{61}$; Yung Arch. Sc. Phys-Nat. 10 46-56 (1900) ${ }^{62}$; Poulton Proc. Ent. Soc. Lond. 1901 X XIII ${ }^{63}$; Donisthorpe Proc. Ent. Soc. Lond. 1901 XIII $^{64}$; Wheeler Bull. Amer. Mus. NH. 20 347-375 (1904) $)^{65}$; Wasmann Biol. Centralb. $25194-199$ (1905) ${ }^{66}$ : Tijds. Ent. 48 214-219 (1906) ${ }^{67}$; Joy Ent. Rec. 2019 $(1908)^{68}$; Donisthorpe Ent. Rec. 20 281-283 (1908) ${ }^{69}$ : Trans. Leicester LitPhil. Soc. 12 221-222 (1908) ${ }^{70}$; Wasmann Biol. Centralb. 28 258-260 (1908) ${ }^{71}$ : Arch. Tri. Inst. Grand-Ducal Luxemberg 4 3-12 (1909)72 : Naturwiss. Wochenschr. 8407 (1909) ${ }^{73}$; Wheeler Journ. New York Ent. Soc. 17 172-176 $(1909)^{74}$. ["The Large Wood Ant" Weiss New Phytol. 8 81-89 (1909) ${ }^{75}$ ]. Formica rufa Standen Lancs. Nat. $2190(1909)^{76}$. Formica rufa rufa Emery Deutsch. Ent. Zeitschr. 185 (1909) $)^{77}$. Formica rufa Donisthorpe Trans. Ent. Soc. Lond. $1910143-144^{78}$ : Ent. Rec. $2282-83(1910)^{79}$; Wheeler Ants 654 $(1910)^{80}$; Donisthorpe Ent. Rec. 2310 (1911) ${ }^{81}$ : Trans. Ent. Soc. Lond. $1911175-178^{82}$ : Entom. $44390(1911)^{83}$ : Ent. Rec. 24 7-9 (1912) ${ }^{84}$ : Marvels of Universe 27 1099-1104 (1912) $)^{85}$; Evans Scot. Nat. $1912105^{86}$; Rüschkamp Biol. Centralb. 32 213-216 (1912) ${ }^{87}$; Wasmann Zeitschr. Wissens. Zool. $101113(1912)^{88}$; Donisthorpe Ent. Rec. $2565(1913)^{89}$; Crawley and Donisthorpe Int. Ent. Cong. Oxford $1912237-47(1913)^{90}$; Brun Zeitschr. Wissens Insektenbiol 9 15-17 (1913) ${ }^{91}$; Kutter Biol. Centralb. 33 703-707 $(1913)^{92}$. Formica rufa rufa Wheeler Bull. Mus. Compar. Zoöl. 53 425-427 $(1913)^{93}$. Formica rufa Donisthorpe Ent. Rec. 2640 (1914) ${ }^{94}$; Morice and Durrant Trans. Ent. Soc. Lond. 1914430 (1915) ${ }^{95}$.

Zetterstedt, p. 450 sp. 8, writes " $F$.rufa" ; this is a misquotation, No. 1725 L. Fn. Suec.=Formica rubra L. Zetterstedt correctly refers to rufa on p. $448 \mathrm{sp} .3^{12}$.

४ Lighter or darker brick-red; front, vertex, antennae, legs, sometimes a line down the centre of clypeus, often a spot on the pronotum, which does not however reach the posterior border, and occasionally another on the mesonotum dark brown, or blackish brown; gaster blackish, or blackish brown, more or less red at the base.

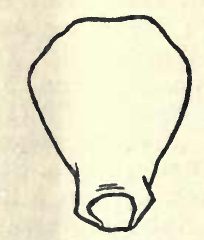

Fig. 87. Scale of Formica rufa ధ̧.

Head about as long as broad, not emarginate posteriorly, lateral border somewhat rounded; clypeus distinctly carinate, not emarginate anteriorly; frontal area shining, smooth, or slightly punctured; mandibles armed with eight teeth ; antennae stout, funiculus with apical joints longer and slightly narrower than penultimate joints; eyes without, or with indistinct hairs. Thorax narrower than head and gaster ; pro- and mesothorax convex ; strongly constricted between mesothorax and epinotum; epinotum seen in profile rounded but evidently angled. Scale large, broad, hexagonal, sometimes emarginate at apex, bare, or with a few hairs; gaster large and broad, rather 
dull, with very short fine pubescence, and suberect hairs more abundant than on the head or thorax. Legs long, robust, furnished with only decumbent pubescence, except the usual bristles. Long. 4-9.5 $\mathrm{mm}$.

o Red, vertex of head, clypeus, thorax above, except anterior portion of pronotum, some spots at the insertion of the wings, and epinotum; gaster except base, antennae, and legs except base of femora, black or blackish brown.

Head as in ఫ̧. Thorax robust, high. Scale without hairs; gaster shining, more or less smooth, without suberect hairs, and with pubescence wanting, or very scanty. Legs with only the usual bristles, and with very short and sparse decumbent pubescence. Wings somewhat infuscate, with brownish yellow pterostigma and veins. Long. 9.5-12 $\mathrm{mm}$. lighter.

ô Black; genitalia reddish yellow; legs reddish, or dark brown with knees

Head rather small, triangular, not excised posteriorly; clypeus carinate, convex, not emarginate anteriorly ; mandibles only toothed at apex ; frontal area dull, slightly punctured, or simply alutaceous; eyes with sparse hairs.

Thorax with rather abundant erect black hairs; mesonotum rugose and dull, with large, scattered, pit-like punctures; scutellum more shining. Scale thick, emarginate at apex, furnished with some scattered long hairs; gaster shining above, with erect hairs scarce, or wanting, and scanty, not close,

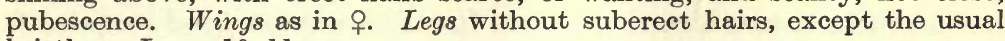
bristles. Long. 10-11 $\mathrm{mm}$.

Original description of Formica rufa Linnaeus [Syst. Nat. Ed. 10 $1580(1758)]$ :-

“F. thorace compresso toto ferrugineo, capite abdomineque nigris.

Fn. suec. 1020 Formica rufa.

Raj. ins. 69. Formica media rubra. Kalm."

Habitat in Europae acervis acerosis sylvaticis; in America septentrionali.

\section{Habitat.}

Formica rufa ranges over North and Central Europe as far south as the Pyrenees and the southern slopes of the Alps, occurring in the Caucasus and Siberia, and in the mountains only in South Europe ${ }^{93}$. In Britain it is widely distributed in England, but in Scotland its range is peculiar, and in Ireland it is scarce. Buchanan-White writes in 1872 :- " It does not appear to occur in Scotland south of a line beginning at Arran in the South-West, and then passing in a North-Easterly direction along the line of the Grampians, through Ben Lomond, Dunkeld, and Dee-Side, and reaching the East coast probably somewhere in Aberdeenshire."34 It is certainly very remarkable that it does not appear to occur between Dumbarton and Stirling, and the English border. It has been found in Ireland in Armagh, Wicklow, Wexford, East Galway, Waterford, and Kerry, and in Wales in Glamorgan, Merioneth, Carnarvon, Denbigh, and Anglesey. I have no records in England for East Cornwall, North Somerset, South Wilts, Herts, West Suffolk, West Norfolk, Bedford, Hunts, Northampton, East Gloucester, North Lincoln, South Lancashire, South, East, and North-West Yorks, Westmoreland, and in Scotland, north of the Forth, for Fife and Kinross, North Perth, Kincardine, North Aberdeen, Banff, West Ross, West Sutherland, and Caithness. 
Formica rufa is perhaps the most generally known ant in Britain, and has been called the "Wood Ant," "Hill Ant," "Fallow Ant," "Horse Ant," and in Germany, "Waldameise." D. Sharp refers to it as the "Red-ant," 61 but this is the name used for Myrmica rubra.

It is a hardy, fierce, and courageous species, being very strong, and able to lift very heavy weights in proportion to its size, and living chiefly an open-air life.

Its movements are abrupt, and it shows a want of individual initiative, single ants appearing to be rather stupid, as they will pass close by an object of which they are in search over a dozen times.

In warfare they attack' in serried masses, not exhibiting the strategy of $F$. sanguinea, nor sending out small troops to execute flank movements. They do not persistently pursue a flying foe, but endeavour to kill as many enemies as possible at once, and do not hesitate to sacrifice themselves for the common good in defence of their nests.

Warner states that in descending from a tree these ants drop from leaf to leaf to save themselves trouble in reaching the ground ${ }^{33}$, but this is by no means always the case.

They are indefatigable in working; Plant says they continue from sunrise till an hour after sunset ${ }^{17}$, but Kirby pointed out that they are at work at midnight ${ }^{9}$, and this I have often noticed in the observation nests I have kept of this species.

Sometimes they delight to bask in the sun, resting on a leaf, or on the top of the nest, and occasionally individuals will play together, chasing each other, rolling over, and pretending to fight.

These ants very frequently carry their fellows, and this act was mistaken by $\mathrm{Hill}^{7}$, and other early writers, and even by Bignell ${ }^{41}$, as an instance of making war, the carriers being supposed to have taken the carried prisoners.

Matthews describes a combat between two rufa colonies, which were situated on opposite sides of a ditch at Skellingthorpe, Lincs, on June 25th, 1850, when large numbers of both were said to have been destroyed, the whole of the space in the ditch being literally covered with the dead bodies of the combatants, which in some places lay more than an inch deep ${ }^{47}$.

This however is very unusual, for, as will be seen later, the nests in one area belong to the same large community. I have seen large numbers of dead ants in a cart-track near a large nest of $F$. rufa in Haye Woods near Knowle, which had been killed by a beetle, Myrmedonia humeralis. This beetle occurred in every crack and under every dead leaf in the cart-track, and every here and there little heaps of dead ants were to be seen, and these kept being added to by the Myrmedonias with specimens they had slain, thousands of the ants being killed ${ }^{69}$. 
Bowman says that the sense of hearing in this species is very acute; he instances the "clapping of hands" 49 and the "buzzing of a fly" 50 being noticed at once, and he gives some not very convincing experiments to prove his point. Clarke also mentions that when he kicked a fir tree on which were a number of rufa workers, instantly every vagrant ant suspended its operations and leant forward with the antennae porrect as though they were listening to discover the cause of the annoyance ${ }^{11}$. These cases do not illustrate hearing in our sense of the word, but rather reaction to material vibrations. I have tested $F$. rufa (and other ants) in captivity with the Galton-Edelmann whistle, up to its highest range, but the ants never appeared to notice anything.

$F$. rufa recognizes its fellows both from the same nest, and from the same community, after having been separated for long periods.

On April 2nd, 1901 (not "1907"78), I established a nest of Formica rufa, from Oxshott, in my study, containing twelve females and many workers, etc., and on April 12th I brought home from the same nest at Oxshott some more females and workers and introduced them into my observation nest, when they were at once recognized and received with pleasure, the females being cleaned and led into the nest. On April 26th I brought home a female and some workers from another nest at Oxshott, far removed from the first nest, and these also were well received by the ants in the observation nest. I have also been in the habit of obtaining ants in the spring from the same rufa nests from which I had previously taken specimens to form observation nests at home, and introducing them into the latter. I extract the following from one of my note-books-" May 19th, 1907. Took part of a nest of $F$. rufa at Weybridge"; then later on, "April 7th, 1908. Got some more débris from the same nest at Weybridge, 4 우우, $\not$ ants all well received." 78

As an instance of tenacity of life, an experiment made by Janet may be mentioned in which a rufa worker lived without a head for twenty-nine days ${ }^{60}$.

This species nests in woods in shady places, in clearings, and on the borders of woods and forests-but also in the interior-on heaths and commons, but never far from trees, being more generally associated with fir trees, though it also occurs in oak, birch, and other woods. Forel states that in the Alps it is intimately connected with the fir trees, occurring as high as the last of these, but never higher ${ }^{37}$.

F. rufa usually avoids the neighbourhood of human habitations, but will enter gardens in search of its prey and other food.

Its nests principally consist of the well-known mounds or hillocks forming a conical structure on the ground, covering an earth mound crater at the base, these structures being built up of pine needles, 
bits of stick, leaves, dried grass, or any other vegetable refuse, small shells, pebbles, etc.

In oak-woods they are chiefly composed of oak-twigs; at Nethy Bridge I have seen a nest formed entirely of Juniper leaves and twigs, at Weybridge of bracken, grass, and birch, and in Parkhurst Forest I found a small nest chiefly composed of small pebbles, which gave it a rather strange appearance-the ants must have experienced considerable difficulty in carrying some of the larger stones, and placing them in position on the top of the hillock ${ }^{81}$.

In Northumberland and Scotland these ants collect large quantities of yellow resin - "ant-amber"-from the fir trees; I have seen nests full of it, and Latreille states that in Sweden the inhabitants gather the resin of Juniper trees accumulated by $F$. rufa in its nests and burn it to purify the air ${ }^{4}$.

Under the hillock is a large central chamber, which is connected by galleries with other underground chambers and other parts of the nest. Numerous openings all over the structure form entrances to the nest; these are closed by the ants at night with twigs, etc., laid across each other, and sentinels are always stationed at these entrances. The habit peculiar to this ant and its allies of building hillocks shows their descent from a more ancient arctic life, as the heaping up of these mounds better attracts the rays of the sun and also concentrates the warmth in the nest.

Bignell in describing a large nest near Plymouth which he had known for ten years, and which he stated would measure forty feet in circumference at its base, writes :- "The extreme west side of it has been given up in consequence of receiving the beat of the weather" 58 - but the real reason for this was that, as we have before shown, ants prefer to face the east, and they would continue to build towards the east to obtain the most benefit from the sun.

The height and size of these hillocks varies according to the age of the nest, their situation and whether they have been disturbed or not. Latreille ${ }^{4}$, Daniell ${ }^{19}$, and Bignell ${ }^{41}$ record nests three feet high, Farren-White says he has found them full forty feet in circumference ${ }^{53}$, Forel gives one metre high and two metres in diameter, and Buchanan-White mentions nests four feet in height and twentyfive feet in circumference in Scotland ${ }^{34}$, but I have seen some narrow cone-shaped nests quite five feet high at Aviemore.

Joy records rufa nests situated in very thick undergrowth near Bradfield. He writes:- "The wood had been cleared two years before and small fir trees had been planted. It had not however been 'grubbed' and the stumps of the trees and briars were growing freely. It seemed rather a hopeless place to look for nests, but the keeper pointed out to me that when a nest was placed in thick undergrowth, the latter was evidently well nourished, as it was taller than the surrounding herbage and of a darker green. After this I had no difficulty in locating nests from some yards' distance, 


\section{Plate XIII.}

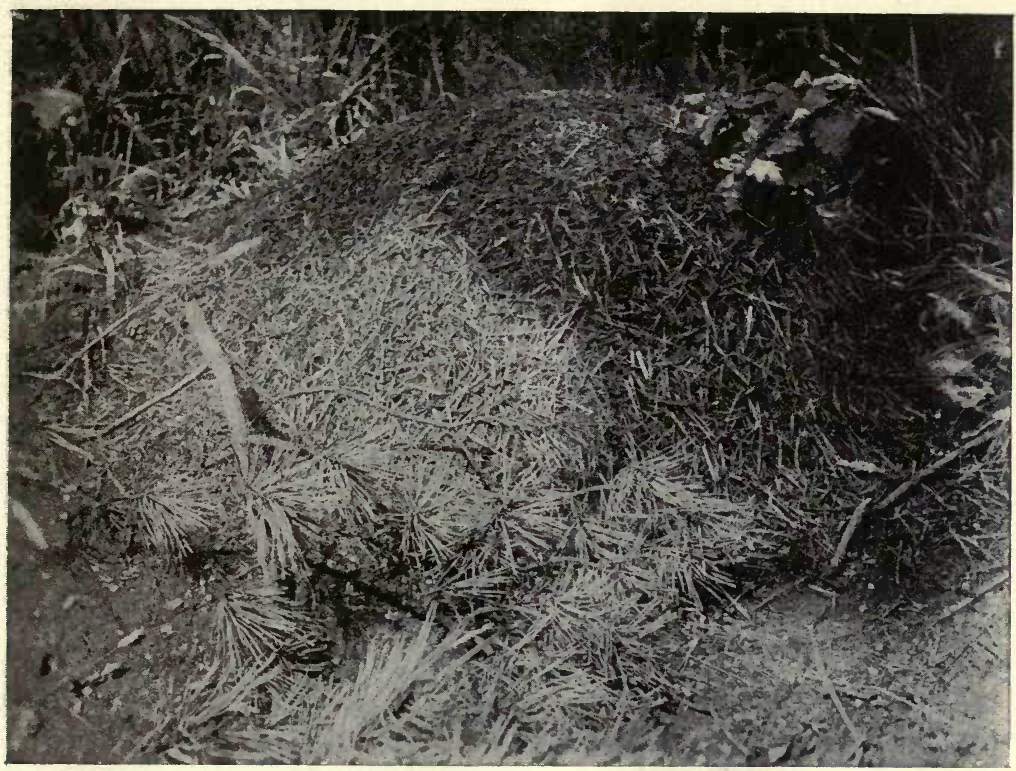

Nest of Formica rufa. Bournemouth, VIII.14. (Hamm.)

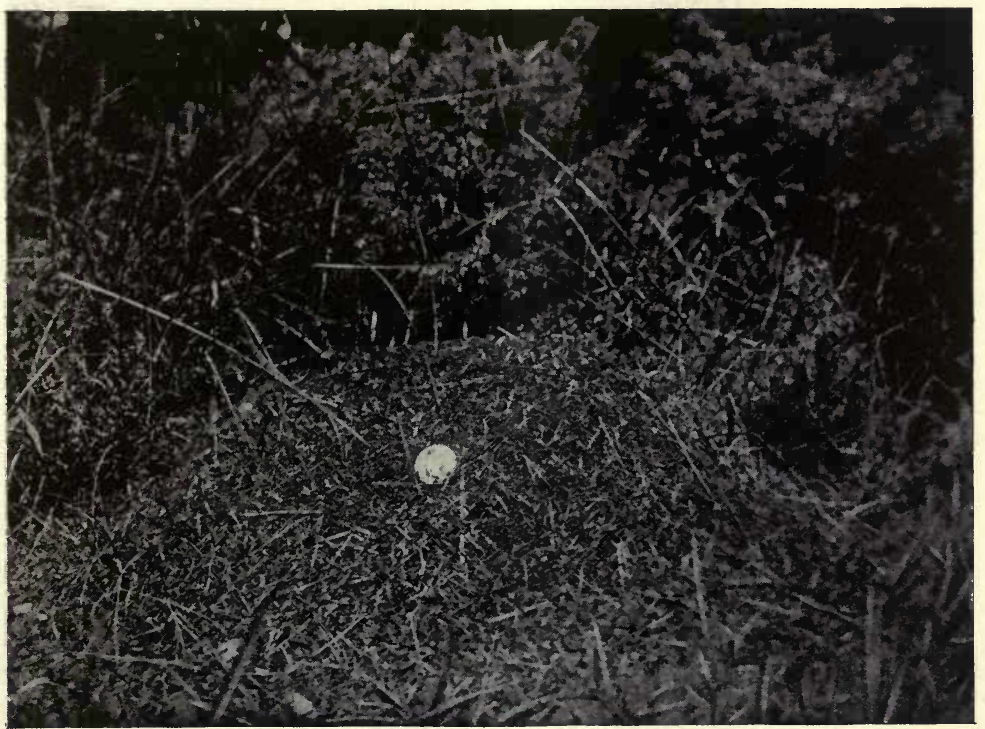

Nest of Formica rufa. Made of Juniper. Nethy Bridge, 20. VII.13.

(The white disc is a half-crown to show the size of the nest.) 

although they were always quite hidden from view ; but sometimes they proved to be uninhabited." 68

The reason why the undergrowth was better nourished in the neighbourhood of the nests is probably that the soil was loosened by the underground tunnels of the ants, which would have somewhat the effect of deep ploughing, and also because the vegetation would be freed from any caterpillars, etc.

When a rufa hillock has been overthrown, or disturbed, the workers soon build it up again, but if it is continually interfered with, the ants will move to another situation near by.

Morley asks :- " Why this species periodically deserts its nests in the late autumn and is found to possess a brand new one, with all parts complete, some twenty yards or so distant the next spring ?"59-but this is certainly not the usual habit of these ants. If they find for some reason that the situation they occupy is unsuitable, they will move, perhaps several times, and then they often take part of the nest itself with them. I have seen the ants of this species at Buddon Wood moving the whole nest to a spot near by, the pupae and entire contents of the nest, and most of the nest materials being carried bodily away, and many of the workers were carrying their fellows.

On the other hand, a nest in a suitable situation will, if undisturbed, remain on the same spot for a great many years-Conway pointed out in 1834 that the old habitations still remain in the same place from year to year ${ }^{8}$, Forel has known a nest (of $F$. pratensis) at Vaux for over forty years, Charles Darwin in a letter to Forel mentions that an old man of eighty noticed one very large rufa nest in the same place ever since he was a boy ${ }^{48}$, and I have known another at Weybridge for over twenty years.

$F$. rufa occasionally makes its nests in stumps and posts, carving out chambers in the wood, these stumps being often wholly or partly covered with vegetable refuse.

Forel mentions a curious nest he found near Munich, which was situated at the foot of two posts two metres eight centimetres high, belonging to a balustrade bordering a thick forest. The ants had heaped up materials to the top of one of these, and the interior of the post was entirely sculptured out ${ }^{39}$.

I have seen rufa colonies at Bagshot situated in tree stumps on a high bank; no materials were present over the stumps except a quantity of sawdust which the ants had accumulated in boring out their galleries in the stumps. A single colony may have a number of nests connected with one another by runs, paths, and tracks, thus forming a vast community, or ant-town, over a large area.

A certain proportion of a colony will emigrate and form a new nest with one or more queens, and a colony thus split is enabled to spread in the immediate vicinity where the conditions are favour- 
able and the same, rather than to send off swarms to less favourable localities.

A number of tracks, or open streets, extend to some distance from a nest-Forel gives eighty to one hundred metres ${ }^{36}$; these tracks often lead to trees infested by Aphides, or some other hunting ground, and the ants sometimes cut down the vegetation to clear a path.

Bignell says "that a new colony within a hundred yards, would, I feel certain, not be permitted by the old one " 58 , but now that we know how rufa founds a new colony, as will be shown later, it is clear that such a contingency would not arise.

In 1880 he records what he took to be a raid by a large colony on a smaller one two hundred feet away, the ants of the former carrying those of the latter by the mandibles ${ }^{41}$, but this was certainly a case of a branch nest, and no ant would allow a stranger to carry it quietly away from its nest in the manner he describes!

On June 12th, 1911, I observed a branch nest of rufa in the Black Wood at Rannoch. Two nests were found to be in connection one hundred and twenty-eight yards apart, one a large mound, about seventy-two inches in diameter and fifty-four inches in height, a few yards below the path, and the other a small hillock about the same distance from the path on the other side of it. The ants were going backwards and forwards along the path to the two nests, food being carried to the large nest, but the ants were carrying their larvae from the large nest to the smaller one. A deälated female was trying to get to the smaller nest; though often stopped by the workers, she persisted and gradually won her way to it. Some winged females were up on the top of the large mound ${ }^{84}$.

Colonies of these ants comprise a very large number of individuals -for a single nest Farren-White suggests ten thousand ${ }^{52}$, and Forel estimated (for a pratensis nest) ninety thousand to one hundred and fifty thousand. Yung, who actually counted the inhabitants of five rufa nests, gives for the one with the fewest ants-a nest $0 \mathrm{~m} 45$ high and $0 \mathrm{~m} 95$ in diameter, 47828 , and for the one with the largest number-a nest $0 \mathrm{~m} 65$ high and $1 \mathrm{~m} 40$ in diameter, 93694, and he thinks, making all due allowances for possible errors, that a single nest would not contain much over one hundred thousand ants ${ }^{62}$.

Formica rufa secretes a large amount of Formic acid (HCOOH), the Spiritus formicarum, and is the most capable of ejecting it into the air in defence of the nest, etc.; these ants partly paralyse their prey with acid discharges, and spray the liquid into a wound caused by their mandibles. When alarmed, or enraged, the workers stand up on the tips of their feet, with the gaster bent between their legs, and the acid is ejected to a considerable distance from the anal aperture. Forel says it is shot into the air to a height of five to six decimetres ${ }^{37}$, Daniell ${ }^{19}$ and Conway $^{8}$ give six and three inches respectively, but they both inaccurately state it is ejected 
from the mouth, André sixty centimetres ${ }^{44}$, Escherich $1 \frac{1}{4}-1 \frac{1}{2} \mathrm{~m}$., and Lubbock says a hand held as high as eighteen inches above the nest will be covered with acid ${ }^{45}$. I have noticed it shot by these ants to a distance of from six to twelve inches.

Latreille mentions that the people in Sweden employed this acid to give a taste of lemon to cream ${ }^{4}$, and Schenck says it was used in Germany in baths as a cure for gout and rheumatism ${ }^{25}$.

The fumes of this acid are so pungent as to induce coughing and take one's breath away if the head be held over a disturbed nest of this species.

It is also very corrosive, and Latreille pointed out that it produces pustules on the skin such as are produced by stinging nettles ${ }^{4}$. When working at nests of these ants for several days the skin has peeled off my hands, and when I have worn gloves as a protection they have been burnt by the discharges of formic acid ${ }^{64}$.

To determine the quantity of anhydrous acid contained in the liquid ejected by $F$. rufa, Poulton ${ }^{63}$ invented an apparatus, which consisted of a glass tube containing filter-paper fastened to a glass rod fixed in the tightly-fitting india-rubber cork. I obtained a number of these tubes and collected discharges from the ants; the percentage of anhydrous acid was found to fluctuate greatly in the various samples, strong samples containing from 60 to 70 per cent.

Mr. A. Vincent Briscoe of the Imperial College of Science, London, has kindly worked out for me the weight in grams of Formic Acid present per ant in a number of workers of Formica rufa which I obtained from Camberley; he obtained the following results :-

1. Ten ants were shaken in a stoppered bottle, which was rinsed out with water after the ants had been removed. The amount of acid found in the bottle was less than $002 \mathrm{gm}$.

2. Ten ants were dropped into boiling water to extract the acid from them-these 10 ants gave $\cdot 021 \mathrm{gm}$. (= $=0021 \mathrm{gm}$. per ant).

3. Fifteen ants (six dead and nine alive) were treated with boiling water-these 15 ants gave $\cdot 027 \mathrm{gm}$. (= $\cdot 0018 \mathrm{gm}$. per ant).

He therefore concludes that each ant, on an average, contains about $\cdot 002 \mathrm{gm}$. (2 milligrams) of formic acid.

$F$. rufa is an omnivorous feeder, devouring insects, carrion, honey of flowers, honey-dew, the excreta of Aphidae, caterpillars, etc. etc.

The workers drag home to their nests both living and dead insects, exploring every tree and bush in the neighbourhood, and are thus of great value in clearing woods and forests of insect pests. It is probable, considering how many insects, etc., the ants of a large colony may be seen to bring home per minute on favourable days, that they would bring in nearly one hundred thousand daily. Förster in 1850 states that the rufa nests near Aachen were nearly 
destroyed by the numbers of pupae taken from them to feed singing-birds 22, but according to Wheeler, "a German law passed in 1880, punishes with a fine of a hundred marks, or a month's imprisonment, any person who collects the cocoons of the fallow ant, Formica rufa, or wantonly disturbs its nests in the forest preserves." 80

They also bring home seeds; Weiss has shown that the large Wood Ant collects and helps to disperse the seeds of gorse and broom $^{75}$, and these seeds are provided with caruncles containing a large amount of oil, and resembling therefore the elaiosomes of other myrmecochorous plants.

On July 21st, 1908, I made a small collection of seeds from a nest of $F$. rufa at Chattenden, the seeds being obtained by taking them from the ants as they arrived at their nest. These seeds proved to belong to Viola sp ?, Carduus sp ?, Arrhenatherum avenaceum, false oat-grass, Holcus lanatus, soft-grass, and with them was a flower of the scarlet pimpernel ${ }^{69}$. The two first of these, the violet and thistle, are true myrmecochorous seeds, possessing food bodies, and were no doubt brought home for food, but the others are not, and were probably only picked up to add to the vegetable refuse on the nest.

Saunders records honey-bees being destroyed by Formica rufa; in 1896, he writes-" A friend of mine living at Long Cross, near Chertsey, has had two hives of bees entirely destroyed by these little creatures, and a third was only saved by the gardener opening the hive and taking the ants out with his hands."56 The ants no doubt raided the hives for the honey, and bee larvae, and would also carry off the bees themselves as prey.

$F$. rufa may frequently be seen milking Aphides on trees and shrubs, etc.; Lees in 1837 recorded seeing them attending plant-lice on thistle and brambles ${ }^{10}$, and Warner in 1871 on oak-twigs ${ }^{33}$, but they are not supposed to harbour these insects in their nests. F. Smith wrote :- "I have not detected Aphides in the nests of this species," 31 and Wasmann states that $F$. rufa does not keep any Aphidae or Coccidae in its nests ${ }^{88}$. I have, however, several times found species of both Aphidae and Coccidae in rufa nests.

Pseudogynes are sometimes abundant in colonies of this species; in September, 1908, I first found these curious forms in a nest of $F$. rufa at Nethy Bridge, a large proportion of the inhabitants of the nest consisting of them ${ }^{69}$, and subsequently other colonies in the same district were found to possess them, and in both 1911 and 1912 nearly all the rufa nests examined at Nethy Bridge contained pseudogynes. On May 18th, 1912, one large nest, in the shape of a perfect cone thirty-seven inches high and sixty-four inches in diameter, was found to contain. besides vast quantities of ordinary workers, many packets of eggs, larvae of all sizes in abundance, large numbers of worker and large cocoons, very many winged 
females, a very large number of deälated females, a few males, and pseudogynes in very considerable numbers.

Such a populous colony, apparently in a most prosperous condition, with plenty of both deälated females and ordinary workers, appears to entirely controvert the theory that pseudogynes have been brought about by the workers endeavouring to change female larvae into workers-or vice versa-to replace the scarcity of the latter caused by the presence of a beetle of the genus Atemeles. It may be added that pseudogynes occur in nearly every nest over the whole large area inhabited by $F$. rufa at Nethy Bridge, and that the most diligent search has never been rewarded by the discovery of an Atemeles, or its larva, there.

Of all the indigenous ants, as pointed out by Latreille in 1802 , the winged forms of this species appear first; he says the winged females are to be found towards the middle of spring, either on the nests or at some distance from them, or even in the interior of towns, running on the walls and often without wings ${ }^{4}$.

The winged sexes occur from April to August. Schenck records a winged female two hundred paces from a nest at Wiesbaden on April 26 th $^{26}$; the earliest date given by Forel for isolated winged females in Switzerland is May $10 \mathrm{th}^{38}$; Collett recorded that in 1883 the males began to appear at Guestling on May 21st and the females a week later ${ }^{46}$; and Bignell found winged females on a nest at Shaughbridge on April 22nd, $1897^{57}$.

On April 17th, 1912, I found rufa males out on fir posts, some distance from any nest, at Wellington College ${ }^{89}$, which is the earliest date of which I am aware for either of the winged sexes of this species. Plant states that swarming takes place from the end of July to the beginning of September ${ }^{17}$, but he does not say that he has actually seen a marriage flight, nor am I aware of any record of the actual mating of the sexes, other than the one to be mentioned shortly. Forel says he has seen the males and winged females of rufa ready to fly in the Engadine on July 10th, 187138, but he writes of the genus Formica- "One never sees the swarms formed by the $O$ and the $\hat{\sigma}$ of this genus; at least I do not know of any description, and I have never seen it. The coupling certainly does not take place in the air, but may probably be on the tops of trees or hills." Standen records seeing a number of specimens of $F$. rufa flying at Grange on August 15th, 1909, at four o'clock in the afternoon, the day being dead calm and very hot; a great many gulls were seen to be catching the ants in the air ${ }^{76}$.

On June 15th, 1911, I actually witnessed the coupling of the sexes at Aviemore in the middle of the afternoon. A number of rufa males and females were seen flying about in a timber yard, running about on a large mound of sawdust in the hot sunshine, flying off and settling on it, the males appearing to rise more easily than the females. Copulation took place on the mound; 
I never saw a single pair together in the air. Sometimes a female would rise and fly straight up into the air, whilst others ran about on the mound, and occasionally when a male had found a female, the latter would refuse to have anything to do with him. I picked up one pair in copulation, when the female turned round and bit the male, and they separated. I found this female afterwards refused any other male that approached her ${ }^{84}$.

These ants commence to stir about February, according to the weather, when on fine days the workers have a habit of massing in the sun on the top of the nest, large numbers all resting in a heap upon each other, and the queens start to lay about this time-in my observation nests they have begun to lay in December-and in nature these first eggs produce males and females, at least in large, or older, nests. On March 29th, 1912, Crawley and I found a very large rufa nest at St. George's Hill, Weybridge, which measured six feet in diameter, and it contained vast quantities of large (male and female) larvae and cocoons ${ }^{89}$, but in 1913 all rufa nests examined by me were very backward, only eggs and very small larvae occurring as late as May 4 th $^{94}$.

The worker larvae are reared next, and worker cocoons will be found in the nests up to October. I have found eggs in nests as late as August, and worker cocoons present in a nest at Wellington College on September 28th, 1912, but no eggs, larvae, nor pupae occur in the winter.

The pupae are generally enclosed in cocoons-the so-called " ants' eggs" which are used as food for singing birds, pheasants, etc., and robins are very fond of them, as, when a nest is disturbed, one of these birds will often sit near by, and flying down on to the nest, pick up a cocoon and fly off again.

The callows are helped by the workers to emerge from the cocoons, but they are also capable of liberating themselves.

Naked pupae also occur; many such pupae, which were evidently pseudogynes, were present in a nest at Nethy Bridge in June, $1911^{84}$, and on September 5th, 1913, I obtained a number of naked worker pupae in a rufa nest at Weybridge.

The Green Woodpecker is an enemy to $F$. rufa, as it devours these ants in the winter, making a long funnel-shaped hole in the hillock and extracting a number of individuals. I have seen these holes in a large nest at Pyrford, and the late Sir Charles Dilke, on whose property this colony occurred, told me that he had often seen the woodpecker at work on this hillock.

Bignell stated that a woodpecker will consume a small colony of rufa in the winter ${ }^{58}$, and Wasmann records the ravages caused by this bird in rufa and pratensis nests at Exaeten in Holland in December, 1894, and in 1898. On February 28th, 1899, he found near rufa nests fifty droppings of the Green Woodpecker, containing no less than ten thousand rufa workers ${ }^{67}$. 
The females of this species have lost the power of founding their colonies unaided; as we have seen their communities spread over a large area, and the success of the species is greatly helped by the habit of colony splitting and forming branch nests.

After the marriage flight large numbers of females are received back into the parent or other nests in the vicinity; some find nests of another race, or of their own species elsewhere, whilst a considerably smaller number, having flown to rufa-free ground, endeavour to enter a nest of Formica fusca.

Probably the fact that rufa queens are received back into nests of their own species over a large area, has caused them to lose the instinct of colony-founding alone.

The large size of rufa females in proportion to their workers may also be due to the same reason, and the occasions on which they actually need to found colonies with the aid of fusca are not sufficiently frequent to have caused them to become dwarfed in size, or to develop mimetic or myrmecophilous characters, as is the case with some of the American forms. Large numbers of queens often occur in rufa nests, and though an occasional nest may be found in which it is difficult to detect a queen, the general rule is for colonies of this species to possess a good many. Wasmann records that in March, 1884, he found sixty old queens in a rufopratensis nest at Exaeten ${ }^{66}$, and he subsequently mentions that he has several times found more than sixty queens in rufa nests in Dutch Limburg 72. In April, 1911, Crawley and I dug up a rufa nest at Porlock in which were considerably over one hundred queens, and as we only investigated part of the nest the number must have been much greater ${ }^{90}$. At Weybridge also, and elsewhere, I have frequently observed a very large number of queens in a single rufa nest, and this condition is evidently brought about by the acceptance, and readmission, of females after the marriage flight.

It is also certain that females of the allied races will be accepted into each other's nests in the same way; Wasmann often found in rufa or pratensis nests, and especially in that of the mixed form rufo-pratensis, both rufa and pratensis queens side by side. In April, 1904, at Luxemburg he observed seven queens in a pratensis nest, of which five were true pratensis, one a rufa, and one a truncicolo-pratensis ${ }^{72}$, and King has sent me to name from Nethy Bridge females of pratensis and rufo-pratensis from the same nest, the workers of this colony being rufo-pratensis, but much nearer to pratensis than rufa.

We now come to the founding of colonies by rufa queens in fusca nests. In 1904 Wheeler suggested that when more attention had been devoted to the incipient colonies of the European $F$. rufa (and $F$. exsecta), these ants would be found to be temporary social parasites in the colonies of $F$. fusca ${ }^{65}$. This he was led to predict, 
first, because he had found some of the North American allies of $F$.rufa ( $F$. consocians, microgyna, dakotensis, exsectoides, etc.) to be temporary parasites on $F$. incerta and subsericea; secondly, because Forel and Wasmann had recorded the occurrence of a few small, mixed colonies of fusca with allies of rufa ( $F$. pratensis, truncicola, exsecta, and pressilabris) ; and thirdly, because, notwithstanding the abundance of $F$. rufa in many parts of Europe, no one had ever seen one of its females in the act of establishing a colony independently.

His prophecy has since been fully justified, both by discoveries in the field and also by numerous experiments with observation nests in the laboratory.

In 1908 Wasmann records that in May, 1902, he discovered at Shötter-Marial an isolated rufa female under a stone over a fusca nest, but separated from it by a partition of earth ${ }^{71}$. This female was evidently awaiting her opportunity to enter the fusca nest.

On April 14th, 1906, Schmitz and Wasmann found at Luxemburg a small mixed colony of rufa and fusca, containing a rufa queen only; and in May of the same year they found another in a less advanced stage, containing a rufa female with eggs and about one hundred fairly large fusca workers ${ }^{71}$.

On July 20th, 1909, Wheeler found below the Turtmann Glacier a large nest of $F$. fusca under a pile of flat stones, which contained several hundred fusca workers, pupae and larvae, and in the midst was a rufa queen; and later on the same day, further down the Turtmann Valley, he found a second much smaller colony, comprising only fifty to eighty fusca workers, larvae, and a rufa queen, and lying close together in the centre of the nest were four dead but perfectly fresh rufa queens, each with her body cut in two. Evidently five rufa females had entered the nest, but only one had been successful in being adopted as the queen ${ }^{74}$.

On August 11th, 1909, Wheeler discovered near Zermatt under a small flat stone a little colony comprising about a dozen fusca workers, two dozen very small rufa workers, a rufa queen, and about fifty larvae and pupae of the latter species ${ }^{74}$.

On May 15th, 1910, when in Parkhurst Forest, Isle of Wight, in company with J. Taylor, I observed a rufa female actually making her way into a fusca nest. A marriage flight had evidently recently taken place, as many rufa females were noticed at large, some being winged and others deälated, and one of the latter was observed near an entrance to a fusca nest. There were several entrances into the ground in a sandy corner, whence fusca workers kept coming in and going out, and the rufa female made overtures to these workers and endeavoured to enter their nest. She had several fights with some of them, rolling over and over together on the ground, but eventually beat them off, and driving the more per- 
sistent ones away, she finally entered one of the doors of the nest and was lost to view ${ }^{82}$.

On August 21st, 1910, Taylor and I again visited Parkhurst Forest, and during the day we found in an enclosure of young fir trees a very small rufa nest, which consisted of a small mound only eight or nine inches in diameter and about three inches high, but built of rufa materials in the usual way. The nest, which was most carefully dug up, only reached a depth of about six inches into the earth, and contained about one hundred and fifty, mostly very small rufa workers, a rufa queen, some fifty fusca workers, and a number of cocoons, which hatched later and proved to be rufa workers, but no fusca female was present ${ }^{82}$.

On June 10th, 1911, in the Black Wood at Rannoch, I found a dead deälated rufa female in a fusca nest under a stone, which had evidently entered the fusca nest and had been killed by the workers, and on June 14th in the same locality, high up on a mountain where no rufa nests occur, I observed a deälated rufa female walking round a stone over a fusca nest. She eventually got under the stone and entered the nest, which contained a small fusca colony, but owing to lack of time I was unable to investigate further ${ }^{84}$.

In June, 1911, Rüschkamp found in a weak colony of $F$. fusca at Alt-Valkenburg, a deälated rufa queen; some fusca larvae and pupae were present, but no fusca queen occurred ${ }^{87}$.

On June 5th, 1912, R. Brun, having discovered a fairly strong colony of $F$. fusca under a stone near Glarus, proceeded to dig it up, but having unfortunately crushed the one fusca queen present, he replaced the workers and went away. Eight days later he revisited the spot, and found that the fusca workers had accepted a rufa female in place of their own dead queen ${ }^{91}$.

This list of natural mixed colonies and observations in nature leaves no doubt that Formica rufa is a temporary social parasite in $F$. fusca colonies, but numerous experiments have been carried out by Brun, Crawley, Donisthorpe, Kutter, Rüschkamp, Wasmann, Wheeler, and Viehmeyer, etc., with generally successful results. The females usually employ conciliatory methods to secure adoption, but where they meet with stubborn resistance they resort to force to secure their ends.

It is a remarkable fact that in no single instance, when a mixed rufa-fusca colony has been found in nature, has a fusca queen been present. It is evident that a rufa female either selects a queenless fusca nest, or, if a fusca queen is present, the latter is probably killed by the rufa queen.

$F$. rufa and pratensis females, if kept alone, either die without laying eggs, or pay no attention to them if laid, but leave them scattered about where they have fallen. I have made a number of experiments to test if it was possible for a rufa and fusca queen to 
join together to found a colony, but without success, as the rufa female has always died, after a longer or shorter period, without laying eggs, even in those cases where she has become quite friendly with the fusca female. The following experiments will serve to illustrate how a rufa female is accepted into a fusca colony.

On January 28th, 1910, I confined some forty workers of $F$. fusca v. glebaria, obtained at Whitsand Bay in July, 1909, in one chamber of a two-chambered Fielde-Janet nest, blocking the passage between the two chambers with cotton-wool, and in the empty chamber I placed a deälated $F$. rufa female from Nethy Bridge. After a few days to allow the female to get rid of her "nest aura," as would be the case in nature, the barrier was removed, when several workers entered her compartment, and she repeatedly entered their compartment, and returned, at first avoiding the workers. On February 2nd she was attacked, but regained her own compartment which now contained five workers, and the barrier was replaced, shutting her in with these five workers for the night. February 3rd she was again attacked, and she killed one persistent worker after first attempting to conciliate it by tapping and stroking it with her antennae; the remaining workers appeared more friendly and one fed the female. Other workers were now allowed to enter, which the female stroked with her antennae, but on February 6th she was again attacked by one, which she killed. The other workers were then introduced gradually, only one attacking her and being killed, and by February 9th all the workers were quite friendly; later she was again fed by a worker and was clearly adopted ${ }^{79}$. On March 1st she laid eggs, which came to maturity on June 20th; the eggs and larvae had been attended to by the glebaria workers; the callow rufa workers, however, were cripples. She laid again on November $20 \mathrm{th}, 1910^{82}$, and again on July 27th, 1911, and by August 16th, 1911, over twenty pupae were present, five of which hatched on September 25th, when there were over thirty pupae, all of which hatched by November 1st, being perfect, though small, rufa workers. The rufa queen, having lived in the nest for nearly two years, died on October 5th, 1911, from what cause is unknown, but it was certainly not through attacks by the glebaria workers ${ }^{84}$.

In an experiment made by Wasmann, in May, 1909, a rufa female, which had been accepted by a fusca colony which possessed a fusca queen, after a few days bit off the head of the latter ${ }^{73}$, and the following experiment also shows how when there is a fusca female present she may be got rid of.

On April 2nd, 1910, I brought home from Darenth Wood a number of fusca workers and three queens, which I had dug up out of a small sandy bank, and introduced them into a four-chambered Janet nest. On April 17th I placed a rufa female, taken at Welling- 
ton College the day before, into the last compartment of the nest, the fusca colony being in the second compartment. The next morning, April 18th, the rufa female was in the first compartment with three fusca workers; she was not being attacked and must have passed through the compartment containing the fusca during the night. During the day she was attacked by three other workers who entered her compartment, but she was not at all aggressive, and tried to conciliate them by stroking them with her antennae. Finally a worker dragged her by the jaws into the second compartment, where she was accepted by the fusca colony, and always remained with them. On June lst one of the fusca females was found bitten in two, and though this action was not actually witnessed, there is little doubt that it was the work of the rufa female, as she often rested with her head over one or the other of the three fusca females. Later there were eggs in the nest, but it was impossible to say whether the rufa female had laid any of them, and on June 20th she died, but not from violence. Up to November 26th the gaster of the dead rufa female was carried about by one of the fusca workers $^{82}$.

This experiment also shows that for a time, at any rate, $F$. rufa and $F$. fusca females may live amicably together.

I have also made a number of other experiments in which $r u f a$ females have been accepted into strange rufa and rufo-pratensis colonies, as well as fusca colonies, but the above will be sufficient to show the methods adopted by rufa queens under these circumstances.

The following myrmecophiles have been found with Formica rufa in Britain :-

Coleoptera: Aleochara ruficornis Gr., Microglossa pulla Gyll., Oxypoda formiceticola Märk., O. recondita $\mathrm{Kr}$., O. haemorrhoa Sahl., Thiasophila angulata Er., Dinarda märkeli Kies., Myrmedonia humeralis Gr., Drusilla canaliculata F., Notothecta flavipes Gr., $N$. confusa Märk., $N$, anceps Er., Homalota analis Gr., H. parallela Man., Heterothops sp ? (nigra $\mathrm{Kr}$ ?), Quedius brevis Er., Staphylinus stercorarius O1., Xantholinus atratus Gr., Leptacinus formicetorum Märk., Othius myrmecophilus Kies., Scydmaenus godarti Latr., Batrisodes venustus Reich., Trichopteryx montandoni All., Ptilium myrmecophilum All., Ptenidium myrmecophilum Mots., P. kraatzi Mat., Coccinella distincta Fald., Hetaerius ferrugineus O1., Dendrophilus punctatus Hbst., D. pygmaeus L., Myrmetes piceus Pk., Monotoma conicicollis Aub., M. formicetorum Th., Cetonia aurata L. (larvae and pupae), C. floricola Hbst. (larvae and pupae), and Clythra quadripunctata L. (larvae and pupae).

Formicidae: Formicoxenus nitidulus Nyl., Stenamma westwoodi West., and Leptothorax acervorum F.

Ichneumonidae : Microcryptus micropterus Gr., and Pezomachus vulpinus Gr. 
Braconidae : Elasmosoma berolinense Ruthe, Pachylomma buccata Nees., and Acoelius viator Först.

Proctotrupidae: Tropidopria fuliginosa Wasm., Conostigmus myrmecobia K., C. wasmanni K., C. testacipes K., C. formicarum K., Ceraphron myrmecophilus K., Lagynodes pallidus Boh., Baeus seminulum, Hal., Polynema albitarse K., Ashmedopria sociata K., Aphanogmus formicarius K., and Platygaster sp?

Cynipidae : Kleditoma formicaria K., K. myrmecophila K., and $K$. subintegra $\mathrm{K}$.

Lepidoptera : Myrmecozela ochraceella Tgstr.

Diptera : Ceratopogon myrmecophilus Egg., Phyllomyza formicae Collin, Pseudacteon (=Phora) formicarum Verrall, Apiochaeta (=Phora) pulicaria Fall., Scatopse infumata Hal., S. transversalis L., Limosina fungicola Hal., Trineura sp ?, Medeterus truncorum Mg., and Sciara sps?

Heteroptera : Alydus calcaratus L., Myrmecoris gracilis Sahl., Nabis lativentris Boh., Piezostethus formicetorum Boh., Pilophorus cinnamopterus Kirsch., and $P$. perplexus D. and S.

Aphidae : Lachnus formicophilus Buckt., Schizoneura corni F., and Aphis plantaginis Schr.

Coccidae : Newsteadia floccosa West, and Orthezia cataphracta Shaw.

Collembola : Cyphodeirus (=Beckia) albinos Nic.

Myriapoda : Polyxenus lagurus L., and Julus pulchellus Leach.

Araneina: Thyreosthenius biovata Camb., Tetrilus arietinus Thor., Cryphoeca recisa Camb., Microneta viaria Bl., M. innotabilis Camb., and Micarisoma festiva C. K.

Pseudoscorpionina : Chernes scorpioides Herm.

Acarina : Trachyuropoda coccinea Mich., Laelaps oophilus Wasm., and L. cuneifer Mich.

Crustacea : Platyarthrus hofmanseggi Brdt.

Formica rufa L., var. rufo-pratensis Forel.

Formica rufa rufo-pratensis Forel Denkschr. Schweiz. Ges. Naturw. 26 16-17' $53^{2} 56^{3}(1874)$. Formica pratensis var rufo-pratensis Dalla Torre Cat. Hym. 7205 (1893) $^{4}$. Formica rufa rufa var rufo-pratensis Emery Deutsch. Ent. Zeitschr. $1909186^{5}$. Formica rufa var rufo-pratensis Wasmann Arch. Trim. Inst. R. Grand-Ducal Luxemburg $413(1909)^{6}$. Formica rufo-pratensis Donisthorpe Ent. Rec. 21257 (1909)? . Formica rufa var rufo-pratensis Donisthorpe Entom. $44390(1911)^{8}$ : Ent. Rec. $2565(1913)^{9}$. Formica rufa rufa var rufo-pratensis Wheeler Bull. Mus. Compar. Zoöl. $53427(1913)^{10}$. Formica rufa var rufo-pratensis Donisthorpe Ent. Rec. 2640 (1914) ${ }^{11}$.

Original description [Forel Denkschr. Schweiz. Ges. Naturw. 26 ఛ̧ 53 우 56 (1874)] :-

ఫ̛ “F. rufo-pratensis (polyctena Först [?] et piniphila Schenk). Ces formes ont parfois un caractère un peu particulier, sont plus petites que les formes typiques, ont les couleurs moins nettes, etc. Elles se trouvent dans les clairières, au bord des bois et surtout dans les montagnes. Elles tiennent ordinairement plutôt de la $F$. rufa pour les poils et de la $F$. pratensis pour la couleur (rufa foncées et petites). Mais on en trouve aussi qui sont pratensis 
pour les poils et rufa pour la couleur. Il y a aussi des fourmilières intermédiaires en tout point. Les différences dans la longueur respective des faces du metanotum ( $F$. polyctena Först) n'ont aucune constance; elles varient énormément dans la même fourmilière." 2

우 "F.rufo-pratensis. Abdomen ni mat ni luisant partout, plutôt luisant." 3

Forel's var. rufo-pratensis embraces all the intermediate forms between $F$. rufa L. and $F$. pratensis Retz.; it is probable that the polyctena Förster and the piniphila Schenck, which are usually regarded as synonyms of rufa, both represent some one of these intermediate forms, but it is quite useless to try and fix a name to any particular form. Emery states:- "Old authors have distinguished several forms on account of the different condition of the erect hairs in the worker : the forms with hardly any bristles on the head and thorax embrace the $F$. rufa Foerst. and polyctena Foerst.; distinctly bristled make $F$. piniphila Schenck. The latter represents the first degree of a variety of intermediate forms going over to F. rufa pratensis which represent var. rufo-pratensis For.$\Varangle$,, , and $\sigma^{t}$ declare themselves in all their characteristic distinctions (colour, hairiness, shining of the gaster in the +, etc., which distinctions appear to combine together in every possible way and stage) as bringing together rufa rufa and rufa pratensis." 5

It is usual with transitional forms that all the individuals in one colony belong to the same form, and Forel gives a valuable table to illustrate the different zoological and embryological forms that may occur $^{1}$ :-

\begin{tabular}{|c|c|c|c|c|c|c|}
\hline & & $\begin{array}{c}\text { Fourmilière } \\
\text { I } \\
\text { F. rufa. }\end{array}$ & $\begin{array}{l}\text { Fourmilière } \\
\text { II } \\
\text { F. rufa } \\
\text { pratensoides. }\end{array}$ & $\begin{array}{l}\text { Fourmilière } \\
\text { III } \\
\text { F. rufo- } \\
\text { pratensis. }\end{array}$ & $\begin{array}{c}\text { Fourmilière } \\
\text { IV } \\
\text { F. pratensis } \\
\text { rufoides. }\end{array}$ & $\begin{array}{c}\text { Fourmilière } \\
\mathrm{V} \\
\text { F. pratensis. }\end{array}$ \\
\hline है & ro & & & & & \\
\hline 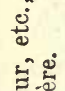 & ot & & & & & \\
\hline 范 & 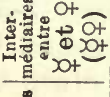 & & & & & \\
\hline 政 & 巡 & & & & & \\
\hline 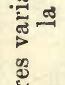 & : & & & & & \\
\hline 离 & 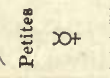 & & - & & & \\
\hline
\end{tabular}


The top line represents five different colonies, starting with rufa and gradually passing into pratensis, and it is understood that all the individuals in each colony belong to the same race, or form of variety, whichever it may be.

The side line represents the different embryological forms which may occur in each colony. Forel's intermediate forms between the worker and female are what are now called pseudogynes.

It is not however always the case with rufo-pratensis that only one variety is found in the same colony; Forel himself states that once or twice he has seen typical individuals and others distinctly passing to a neighbouring form in the same colony. He once sent two rufo-pratensis workers, taken in the same colony and mounted on the same pin, to an emerited myrmecologist, and the latter stood him out that the one was $F$.rufa and the other $F$. pratensis. Forel says:- "I hardly think that I have succeeded in convincing him of the fact."' 1

Wasmann says:- "It remains still to be settled whether the intermediates between the two races rest on direct variation, or rather on crossing between the pure races of rufa and pratensis. I am rather inclined to the latter opinion."6

I believe that in localities such as the Isle of Wight, where rufopratensis is found, but where pratensis does not, and has never been known to, occur, the former rests on direct variation from rufa proper, and in these cases the variety is found to be much nearer to rufa; whereas in the Highlands, where both rufa and pratensis are present, the varieties have chiefly sprung from crossing between rufa and pratensis males and females. We have already seen, under rufa, that colonies of rufa, pratensis, and rufo-pratensis will each receive the other's queens after the marriage flight, and a combination of all these facts will alone explain the contents of some of the nests I have seen from Nethy Bridge.

In 1909 I recorded rufo-pratensis from Nethy Bridge, the colouring of the ants being darker than that of rufa, but they did not possess the hairiness of pratensis, and I mentioned that the nests differed somewhat from those of rufa, being more compact, the domeshaped surface smoother and flatter, and the nest material not so loose-capable of being moved in layers. A point which struck me very much was the way in which many of the nests were being extinguished by the undergrowth. Moss starts to grow round the base of the nests, then "bilberry" and heather, which creep upwards all round the hillock, gradually driving the ants to the summit, and eventually extinguishing the colony. Most of the hillocks in the valley covered with dense undergrowth have once been ants' nests?

On September 8th, 1912, I found two nests of this variety at Parkhurst Forest, Isle of Wight, which were situated on a bank, constructed of finer materials than the rufa nests in the neighbourhood, 
and in fact looking more like exsecta nests. The workers were of a yellow-red colour with a neat, well-marked black spot on the pronotum, this is very distinct in some specimens, which also have another black spot on the mesonotum ${ }^{9}$. Several nests of rufopratensis, superficially like exsecta nests, were again found in Parkhurst Forest on June 29th, 1913, which were situated in clumps of grass (Aira caespitosa) ${ }^{\mathbf{1 1}}$. A deälated female was taken, but only worker eocoons were present, and in August another deälated female, and a male, were found in the same locality. The male appears to have the wings a little blacker than in rufa, probably only an individual variety, and the females have the gaster duller and more punctured than in rufa proper.

I have seen specimens of rufo-pratensis taken by Butler at Bexhill, by Best Gardner at Briton Ferry in Glamorgan, by W. Gardner at Deganwy and Crotnant near Denbeigh, by Rothney at Bournemouth, by H. Scott at Kingsteignton, South Devon, and Wheeler tells me he took it at Low Wood, on Lake Windermere, when he was in England in 1912.

The following myrmecophiles have been taken with $F$. rufa v. rufo-pratensis in Britain :-

Coleoptera : Oxypoda haemorrhoa Sahl., Thiasophila angulata Er., Notothecta flavipes Gr., N. anceps Er., Homalota parallela Man., Quedius brevis Er., Leptacinus formicetorum Märk., Dendrophilus pygmaeus L., Monotoma conicicollis Aub., and Clythra quadripunctata L. (larvae).

Braconidae : Pachylomma buccata Nees (large specimens).

Diptera : Phyllomyza formicae Collin.

Araneina : Thyreosthenius biovata Camb.

Acarina: Laelaps oophilus Wasm.

\section{Formica rufa L. var. alpina Sants.}

Formica rufa var alpina Santschi Bull. Soc. Ent. France $1911349^{1}$; Forel Rev. Suisse Zool. 19458 (1911) $^{2}$; Donisthorpe Entom. 44390 (1911) ${ }^{3}$ : Ent. Rec. $248(1912)^{4}$; Emery Deutschr. Ent. Zeitschr. $1912672^{5}$. Formica rufa rufa var. santschii Wheeler Bull. Mus. Compar. Zoöl. $53428(1913)^{6}$. Formica rufa var alpina Donisthorpe Ent. Rec. 2640 (1914) ${ }^{7}$.

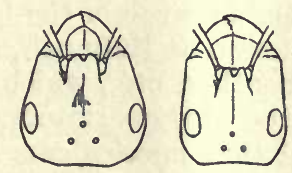

Fig. 88. 1. Head of Formica rufa ఫ్ .

2. Head of F. rufa v. alpina 暒.

$\Varangle$ Size and colour much as in rufa, but with closer and slightly more abundant pubescence, and distinctly more hairy in the Rannoch specimens.

Head long, narrow, with straight cheeks; frontal area duller and more 
punctured than in rufa; eyes with sparse hairs; scapes of antennae long and projecting further beyond the posterior corners of the head than in rufa. Thorax a little narrower with the pro- and mesonotum more convex. Scale with golden bristles, more abundant in the Rannoch specimens. Legs more hairy than in rufa, particularly so in the Scotch specimens. Long. 5.5-8.5 mm.

o Size and colour much as in rufa; but more pubescent and hairy.

Head long, narrow, with straight cheeks ; frontal area duller and more punctured than in rufa; eyes with sparse hairs; scapes of antennae projecting further beyond the posterior corners of the head than in rufa (this is brought about by the shape of the head, as the scapes, when measured, are not longer, and sometimes not so long, as in rufa). Thorax a little narrower, with mesonotum more convex anteriorly; meso- and metathoracic sternites and epinotum with some long golden hairs. Scale and anterior margin of gaster furnished with long golden hairs; gaster duller, more closely punctured than in rufa, with the red colour on the anterior portion of the first segment well marked. Legs more hairy than in rufa. Long. 9.5-10.5 mm.

I have not seen a male, nor a winged female; the worker is described from Continental and numerous Scotch specimens, the female from eight deälated specimens from Rannoch. The Scotch specimens only differ from the Continental ones in being more hairy.

Original description of Formica rufa var. alpina Santschi (Bull. Soc. Ent. France 1911 349) :-

“Taille, couleur et pilosité comme chez le type. La tête est beaucoup plus allongée et plus étroite en avant (un quart plus longue que large chez alpina et à peine un cinquième chez le type). Le scape dépasse davantage le bord occipital. Le thorax est plus étroit avec un promésonotum plus convexe. L'abdomen est légèrement plus large. Le reste semblable.

Montagne au Nord de Sondrio (Valteline). Reçue de M. le Pr. Galli Valerio."

Santschi says :- " To this form ants of other provinces connect themselves by the same character (the elongate head) but of variable colours. This is the case with examples from Munich sent to me by Professor Emery, which have the colour and pilosity of $F$.truncicola. This made me suspicious that this curious morphological modification might possibly be due to parasitism. Wheeler, Emery, Wasmann, Janet, etc., have already pointed out a dimorphism more or less constant with other ants infested either with entoparasites such as Mermis and Pelodera, which inhabit the abdomen or the pharyngeal glands of the adult, or by ectoparasites living as commensals at the expense of the larvae."

On June 11th, 1911, I found at Rannoch, on the edge of a moor, a small mound made of heather, etc., which was superficially very like a nest of $F$. exsecta, the workers running about on the mound, according to the habit of that species, were mostly small in size and very red in colour, and might have easily been taken for it, nor were there any tracks to and from the nest such as are found with $F$. rufa. On examining the workers they were at once seen not to belong to exsecta, and the nest being dug up four deälated females were found to be present. Having come to the conclusion that it was a form new to Britain I sent specimens to Forel and he wrote- 
Plate XIV.

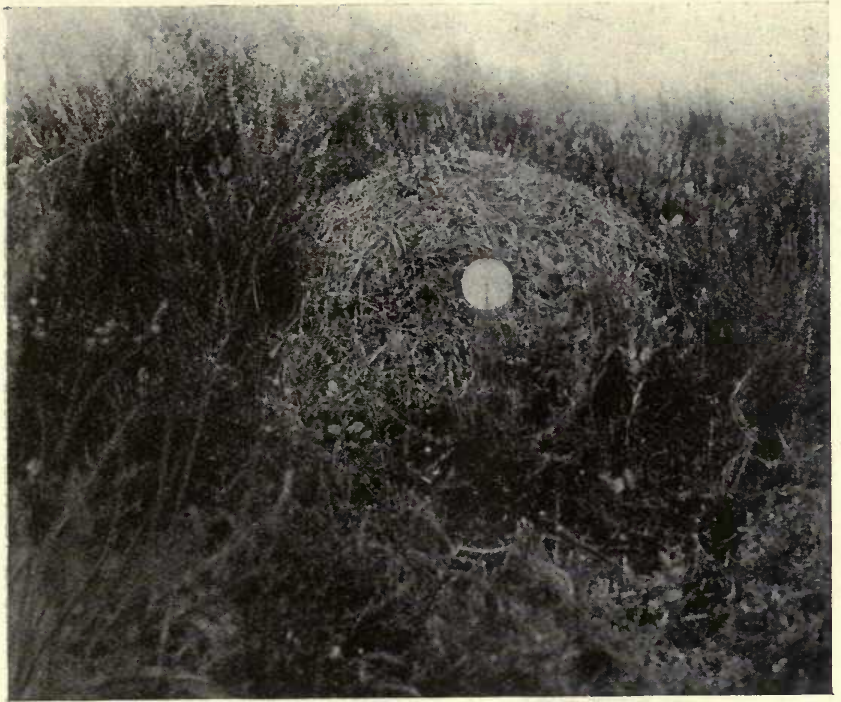

Nest of Formica rufa v. alpina. Rannoch, 16. VII.13.

(The white disc is a half-crown to show the size of the nest.)

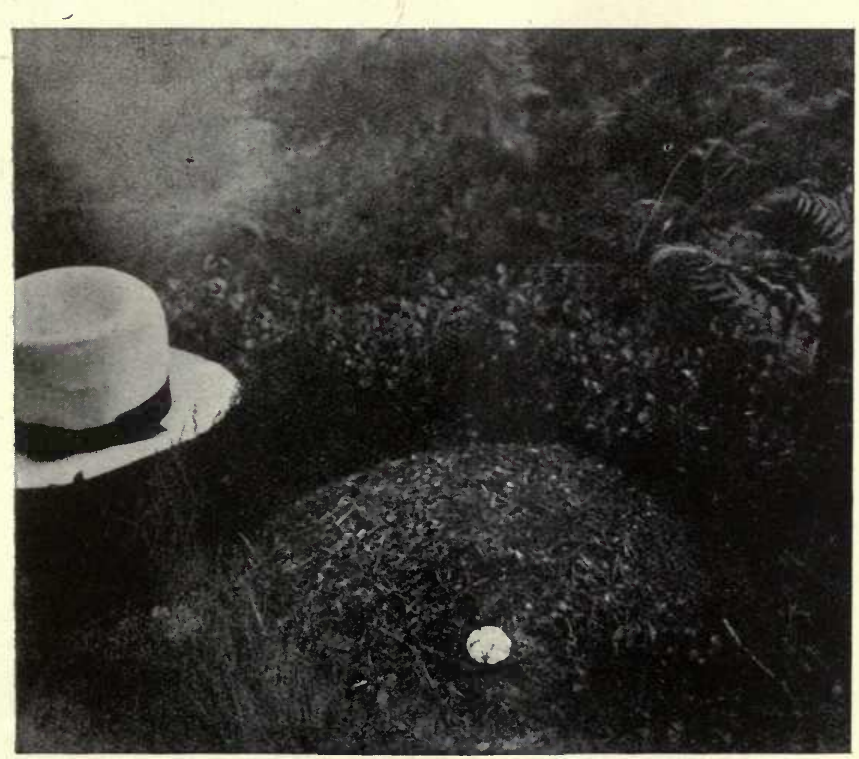

Nest of Formica pratensis. Rannoch, 17.VII.13.

(The white disc is a half-crown to show the size of the nest.) 

"Your ants belong to a group of varieties which I once called truncicolo-pratensis, they are nearly the colour of the var. dusmeti Emery from Norway and Spain, and recently Santschi has discovered and distinguished it in our Alps under the name of F. rufa var. alpina in litt. I myself have received it from Norway and the Black Forest, etc., and have also found it in Switzerland. It is distinguished above all by the more narrow head, as Santschi has shown. It has some erect hairs on the tibiae (hairs which fail in true $F$. rufa) and some sparse hairs on the eyes." 4

In July, 1913, when again at Rannoch, this time in company with Morice, we visited the same spot where I originally discovered alpina and some seven colonies were observed; deälated females were found, three in one nest, and two in others, and pseudogynes were present in one nest, but no winged ants were seen ${ }^{7}$. The nests were all small hillocks, chiefly composed of heather, and were distributed over a small area of the moor and its borders. Workers and larvae of a form of Myrmica scabrinodis (before mentioned under that species) and Leptothorax acervorum, were found in two of the nests and the beetle, Notothecta flavipes, also occurred.

Joy sent me some ants which he took, in July, 1913, at Loch Shin in Sutherland and among them I detected a few workers of the var. alpina.

As all the ants, both females and workers, in the colonies I have found possess the narrow-shaped heads, it does not seem probable that this is due to parasitism, as suggested by Santschi.

\section{Formica pratensis Retz.}

["Fourmi rousse des prés" De Geer Mém. Hist. Ins. 2 1080-81, 1173 Pf. 42.12-15 (1771)]1․ Formica pratensis Retzius Gen. Spec. Ins. De Geer 75 $(1783)^{2}$. Formica rufa Christ Naturg. Ins. 510-511 Pf. 60.7-8 (1791) 3. " [La fourmi fauve dos noir" Huber Mœurs Fourmis (1810) $)^{4}$. Formica congerens Nylander Acta Soc. Sc. Fenn. $2906(1846)^{5}$ : $327^{6} 30^{7}(1849)$; Förster Hym. Stud. 1 17-20 (1850) ${ }^{8}$; Schenck Jahrb. Ver. Naturk. Nassau $811^{9}$ $30-3^{10} 138^{11}$ (1852); Mayr Verh. Zool. Bot. Ver. Wien $5332-3(1855)^{12}$; F. Smith Cat. Brit. Foss. Hym. 6 (1858) ${ }^{13}$ : Trans. Ent. Soc. Lond. (n.s.) 4 $278(1858)^{14}$ : Ent. Ann. $185839^{15}$ : Ent. Mo. Mag. $229(1865)^{16}$ : Ent. Ann. $186585^{17} 87^{18}$ : $1866126-7^{19}$; Buchanan-White Scot. Nat. 1222 $(1872)^{20}$; H. Müller Berfrucht. Blumen $464(1873)^{21}$. Formica rufa r. pratensis Forel Denkschr. Schweiz. Ges. Naturw. $26 \quad 52^{22} 219^{23} 365-8^{24}$ $373^{25} 408^{26}$ (1874). Formica pratensis Forel Bull. Soc. Vaud. Sc. Nat. 14 $5861(1875)^{27}$. Formica congerens Saunders Trans. Ent. Soc. Lond. 1880 $205^{28}$; Parfitt Trans. Devon. Assn. Sc. Art. $12513(1880)^{29}$. Formica pratensis Er. André Spec. Hym. Europe $2184(1881)^{30}$. Formica congerens Bignell Young Nat. $3143(1882)^{31}$. Formica pratensis Forel Ann. Soc. Ent. Belg.

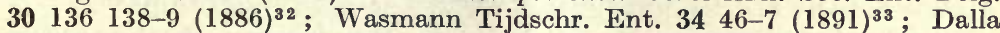
Torre Cat. Hym. $7204(1893)^{34}$. Formica congerens Farren-White Ants' Ways 202-3 $3^{35}$ 231-2 $2^{36}$ (1895). Formica rufa race pratensis Saunders Hym. Acul. $21(1896)^{37}$. Formica pratensis Forel Zool. Jahrb. Suppl. $7580(1904)^{38}$; Wasmann Biol. Centralb. 25 199-200 (1905) ${ }^{39}$ : Zeitschr. Wissens. Insektenbiol. $242(1906)^{40}$; Wheeler Journ. Psychol-Neurol. 13 426-427 (1908) ${ }^{41}$; Wasmann Arch. Trim. Inst. R. Grand-Ducal Luxemburg. 4 13-18 (1909) ${ }^{42}$. 
Formica rufa pratensis Emery Deutsch. Ent. Zeitschr. 1909 186-18743. Formica pratensis Wheeler Ants $222^{44} 445^{45}$ (1910). Formica rufa subsp. pratensis Donisthorpe Entom. 44390 (1911) ${ }^{46}$ : Ent. Rec. 249 (1912) ${ }^{4}$. Formica rufa pratensis Wheeler Bull. Mus. Compar. Zoöl. 53 428-429 (1913) ${ }^{48}$. Formica pratensis Donisthorpe Ent. Rec. $2640-41(1914)^{49}$.

\& Colour much as in rufa, but usually darker, with the black spot on the pronotum reaching the posterior border and often fusing with the black spot on the mesonotum; the anterior border of the scale is often black, and the gaster is all black; legs darker than in rufa, being chiefly brown, and the whole body considerably more hairy. In small specimens the greater part of the body is usually blackish.

Head : shape as in rufa; frontal area duller and more punctured than in rufa; eyes with short outstanding hairs. Thorax as in rufa, but with pronotum covered with outstanding hairs. Scale as in rufa, but furnished with abundant outstanding hairs; gaster with closer pubescence and with more abundant outstanding hairs than in rufa. Legs with decumbent pubescence closer than in rufa and furnished with suberect hairs as well as the usual bristles. Long. $4 \cdot 5-9 \cdot 5 \mathrm{~mm}$.

ㅇ Very like rufa, but more hairy and pubescent, and with the gaster distinctly pubescent.

Head: shape as in rufa, with frontal area more punctured; eyes sparsely hairy. Scale hairy ; gaster closely punctured, pubescent, and furnished with outstanding hairs, especially on the anterior border. Legs with closer and longer decumbent pubescence than in rufa, and with suberect hairs as well as the usual bristles. Wings as in rufa. Long. $9 \cdot 5-11 \mathrm{~mm}$.

$\hat{o}$ Very like rufa, but slightly more robust, and distinctly more hairy.

Head : shape as in rufa, but with more abundant outstanding hairs; eyes more hairy. Thorax considerably more hairy; mesonotum with pit-like punctures less distinct than in rufa, being more obscured by the hairs. Scale more hairy; gaster with more abundant erect hairs, and closer and more plentiful decumbent pubescence. Legs with suberect hairs besides the usual bristles, and with closer and more abundant decumbent pubescence than in rufa. Wings as in rufa. Long. $9 \cdot 5-11.5 \mathrm{~mm}$.

In Continental and Bournemouth specimens, the workers appear to run larger, and the colours are more distinct, the red being brighter, and the black more neatly defined.

\section{Original description of Formica pratensis Retz:-}

"Fourmi rousse des prés. 2. Fourmi rousse à tête et à ventre noirs, à écaille sur le filet du ventre " [De Geer Mém. Hist. Ins. 21080 (1771)].

" 325 . F. pratensis, rufa, capite abdomineque nigris, petiolo abdominis squamifero T. 2 p. 1080 " [Retzius Gen. Spec. Ins. De Geer 75 (1783)].

\section{Habitat.}

Formica pratensis ranges over Northern and Central Europe, Siberia, and is found on the island of Sakhalin; in Europe it extends southward to Southern Italy in the high mountains ${ }^{48}$.

British distribution-It is probable that some of the older British records of $F$. pratensis only refer to $F$. rufa, and possibly the var. rufo-pratensis-Farren-White credits Dale with the capture of pratensis at Holnest, Porlock, and Exmouth ${ }^{36}$, but there are no specimens labelled with these localities in the Dale collection, 


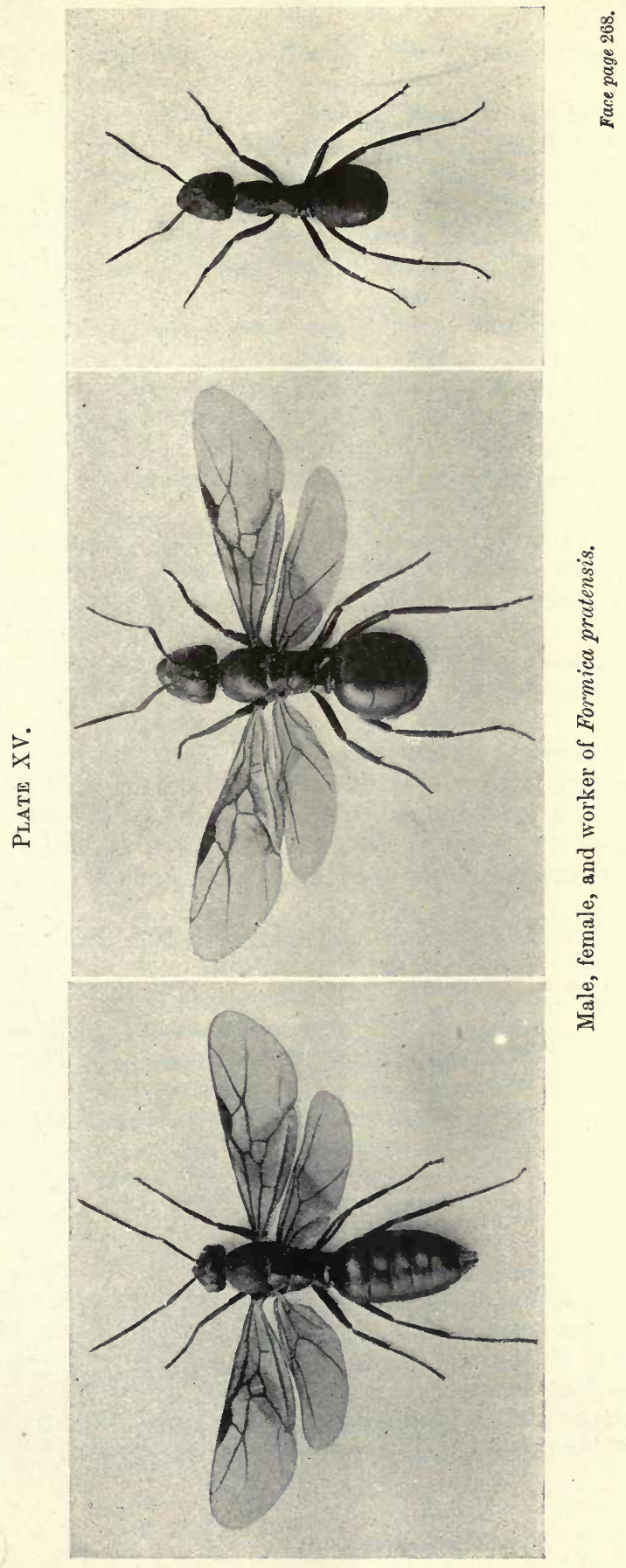



and I have examined the inhabitants of great numbers of wood-ants' nests at Porlock, all of which were pure rufa.

Parfitt says he met with two small nests of congerens in Stoke Wood near Exeter in September, $1879^{29}$, but I have seen no specimens in any collection from Devonshire, and neither Bignell nor Keys ever found it in that county; moreover I have had specimens of rufa sent to me from near Exeter with the remark that these ants are the commonest species in the woods in that neighbourhood.

$F$. pratensis certainly used to occur more commonly near Bournemouth, as there are many specimens in the Dale and F. Smith collections from that locality, but it had not been found there for many years, until I found a single colony in June, 1914. I have examined hundreds of wood-ants' nests in that neighbourhood all of which with the exception of the one just mentioned have proved to belong to $F$. rufa.

F. Smith writes (of pratensis) in 1866- "This is the common wood-ant at Bournemouth; I have not yet found $F$. rufa there "19 -but he had already recorded taking $F$.rufa (as well as $F$. pratensis) at Bournemouth in August, $1864^{17}$ !

Farren-White also states-"The former ( $F$. congerens) is the common wood-ant of Bournemouth ... the common wood-ant ( $F$. rufa) is very rare at Bournemouth." 35

Bignell in 1882 refers to Farren-White's remarks and says"Since the above was written, the writer had occasion to pass through Bournemouth, and having four hours to spare visited a pine-wood about a mile from the town, saw only one ant-hill, and brought away twenty-one workers from it, which are certainly F. rufa." "31

It would seem that the latter has nearly replaced $F$. pratensis in this locality.

It is best to regard the British distribution of $F$. pratensis as follows, until further records are forthcoming :-

Dorset: Morden near Bloxworth (Haines).

Hants, S. : Bournemouth (F. Smith) ${ }^{\mathbf{1 6}}$.

Northumberland, S. : Corbridge (Donisthorpe $)^{47}$.

Cumberland : Lodore, Derwent Water (Wheeler).

Mid Perth : Rannoch (Foxcroft) ${ }^{\mathbf{1 4}}$.

Easterness : Nethy Bridge ( $F . X . K i n g)$.

$F$. pratensis is very like $F$. rufa in many ways and has similar habits, but as Schenck pointed out in 1852, it is not quite so fierce, and does not spray its acid so easily ${ }^{\mathbf{1 0}}$, and Forel says it has more need of sun, and can put up with a greater degree of drought ${ }^{23}$.

On the Continent it prefers to nest in meadows, fields, and along the borders of woods and hedges, indeed De Geer stated pratensis only occurs in fields and not in woods ${ }^{1}$, and André also gives fields, 
borders of hedges, etc., though he says it is rarely found in clearings in woods ${ }^{30}$. Wasmann points out that in Holland pratensis occurs more commonly in woods and copses than it does in Luxemburg where it forms nests in more open places ${ }^{\mathbf{4 2}}$.

Mayr says this ant sometimes lives entirely underground, no hillock being constructed over the nest ${ }^{12}$, and Farren-White found it acting as a miner in a turf bank at Bournemouth ${ }^{35}$, and he says its nests though often seen in the pine-woods in that locality, are as often found on the open heath ${ }^{36}$. He discovered a large nest on a sloping bank of fern and heather and gorse, on the margin of a running stream, the depth at the crown of the nest measuring twelve inches, and eighteen inches down the slope of the bank seven inches across the nest; from the upper part to the base on the declivity seventy-two inches; and a foot from the crown, fifty-three inches across ; the circumference measuring eighteen feet and four inches ${ }^{35}$.

The colony I found at Bournemouth on June 15th, 1914, was situated in the grass by the side of a road. Their hillock, which was nine or ten inches high and fifteen to eighteen inches in diameter, was built at the foot of a small gorse bush, but not among trees, and was composed of coarse materials-long twigs, bits of straw, etc.-and the ants had collected a number of wooden matches, and small pebbles from the footpath near the road, which they had mixed with the other materials of the nest. These ants were mostly large in size and brightly coloured as in Continental specimens.

According to Forel, pratensis will live a little nearer to human habitations than rufa, and is sometimes found in gardens in villages in Switzerland ${ }^{23}$-when I was staying with him at Yvorne in 1912, he showed me a nest in a field quite close to his house.

The nests are similar to those of rufa, but smaller on the average, being not so high, flatter, and composed of coarser materials, and sometimes occur in old tree-stumps which are covered by the hillocks.

Nylander records nests in Finland made of bits of grass, birch twigs, etc. ${ }^{6}$, and Wasmann says that in Dutch Limburg they are generally covered with a layer of rabbits' excreta, this being very characteristic of pratensis in that region ${ }^{33}$, and on the other hand in Luxemburg where rabbits are scarce, this ant uses the droppings of hares in a similar way ${ }^{42}$. On June 28th, 1900, in the neighbourhood of Luxemburg he found a nest of pratensis which appeared to be covered with rabbits' droppings, but on closer observation he found that the layer consisted of the dry seed-heads of Centaurea pratensis ${ }^{40}$.

The colonies of this ant are usually smaller than those of rufa, and they may occur singly, or near to each other, Schenck says three or four nests will often be found close together ${ }^{10}$, and Wheeler mentions that pratensis often makes "tenuous paths" which are 
roofed over along much of their extent with vegetable detritus and connect the different nests of a colony with one another ${ }^{\mathbf{4 4}}$.

In June, 1911, I discovered two pratensis nests situated close to each other among the fir-trees near the Loch at Rannoch ${ }^{47}$, the one a small, rather flat hillock, the other considerably larger built over a pine stump, both being constructed of pine-needles, bits of heather, etc. On June 10th the smaller nest was dug up, and some workers were taken, but no queen was found, and on June 12th the inhabitants were found to have deserted the remains of their nest and to have amalgamated with those of the larger colony. It was found impossible to get at the bottom of the large nest, even with the help of a spade and axe on account of the deeply rooted pine stump, and again no queens were found.

In July, 1913, a number of colonies were found in this same spot ${ }^{49}$ - which consisted of rough, hilly ground, some parts of it swampy, with higher dry places and paths winding round the stumps of cut-down trees among the heather, with a number of large Scots Firs scattered about-the workers travelling long distances on the paths to some of the nests. The bottoms of these nests consisted of chambers and galleries constructed in the peaty ground beneath the hillocks, and in these galleries deälated females were found.

Forel observed a colony of $F$. pratensis migrating to a new nest, with a third nest serving as a magazine midway. He says the workers carry their fellows, and also the females, and males, by the mandibles, in the same manner as that employed by $F$. rufa, and the migrating of pratensis is distinguished from that of sanguinea and fusca, by their greater numbers together (plus grand ensemble $)^{24}$. It was during this migration that he made his calculation as to the numbers of the inhabitants of a nest (referred to under rufa), and he also observed the curious behaviour of a large worker, which was evidently unwell, stumbling on the old nest, with the tarsi and antennae drooping, with one mandible open and the other shut. He saw other workers approach her, lick, and tap her with their antennae, and endeavour to lead her gently, pulling her by the legs, into the interior of the nest. One more persistent worker tried hard to rouse her, and the suffering ant at last appeared to understand a little more what was wanted, tucking up her legs and antennae, and allowing herself to fall, but without grasping the mandible of the other worker. The latter at last seized hold of two of her legs and carried her towards the new nest. This couple was found a quarter of an hour later several paces along the route towards the new nest, the carrier persisting in conveying the sick ant forward in that direction. Forel says here is a case where an ant which was unwell was made the subject of special attentions by her companions; Ebrard and Huber cite some more touching but, perhaps, less certain cases. As Forel 
points out, this is not the usual practice, and ants which are unwell, are more often deserted, or thrown out of the nest, which has generally been my own experience. Forel has observed workers of pratensis playing together, performing gymnastics, etc., such as we have already seen to be performed by those of rufa.

The food of pratensis is similar to that of rufa, and Müller records finding workers of the former on flowers of Rosaceae and Compositae ${ }^{21}$.

There is no fixed time for the appearance of the winged forms, nor for the marriage flight of $F$. pratensis, indeed Forel states with regard to the swarming, that this is the most irregular of all ants in that respect. He has found the males and winged females in the nests in Switzerland in May, June, July, August, and September, the earliest date being May 2nd ${ }^{26}$.

Förster records the winged sexes at Aachen at the beginning of May, appearing most commonly in the early morning ${ }^{8}$.

Schenck found males in a colony at Weilburg on May 16th, 1882, this sex not having occurred until June 1st, in the same nest the year before ${ }^{11}$. He says they come up on to the top of the nest at from seven to nine, or ten o'clock in the morning, but do not appear later in the day ${ }^{10}$, and he has noticed that as soon as they show signs of leaving the nest, the workers take them back by force, even dragging them from the grass stems near by, into the nest ${ }^{9}$. He observed a double swarm, in June, and from the end of September to the beginning of October, in the same nest, in the same year ${ }^{9}$.

Wheeler writes-" At Vaud I had the pleasure of seeing the huge pratensis nest which Forel has had under observation for the past forty years. The colony inhabiting this nest has had a succession of queens during this period, showing that the colonies of these temporary parasites, when once established, may perpetuate themselves by adopting females of their own species and thus attain an extraordinary age. Just as Professor Forel and I approached the nest at about 10 a.m. on June 5th, the males and winged females were leaving it for their nuptial flight." 41

On June 3rd, 1906, I took a winged female pratensis at Corbridge, in Northumberland, near a rufa nest, and on June 11 th and 12th, 1911, I captured a very few males in, and also away from the nest, at Rannoch, but on July 17th, 1913, when I was in company with Morice, males and winged females were found to be abundant in one nest in that locality ${ }^{49}$, only sex pupae occurring in another.

The colony founding of pratensis is similar to that of $r u f a$, branch and twin nests occur, and females are received back into the nests after the marriage flight; and the latter also found their colonies in nests of $F$. fusca and its races. Wheeler says that in Southern Europe pratensis probably prefers the var. glebaria of fusca as a host ${ }^{48}$.

In small pratensis colonies usually only one queen occurs, but in 

Plate XVI.

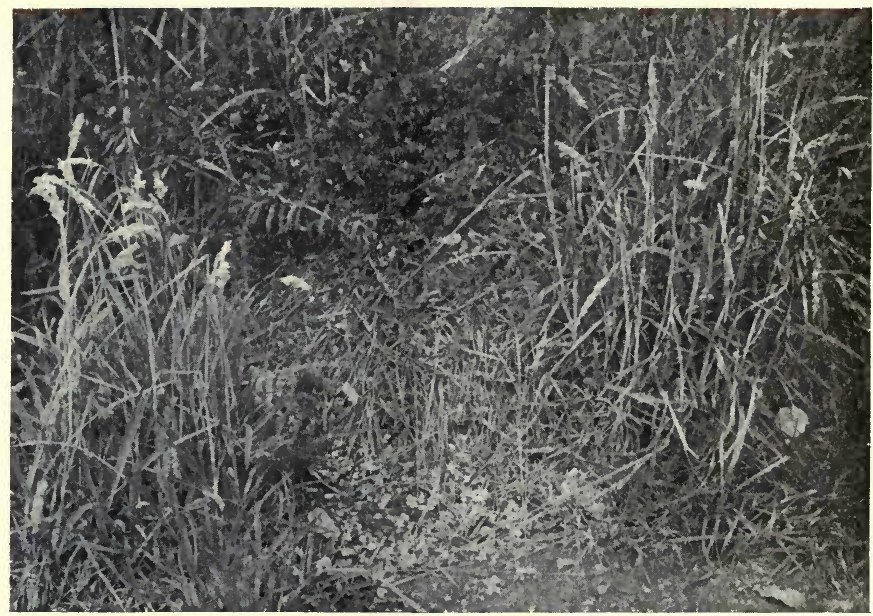

Nest of Formica pratensis. Bournemouth, 15. VI.14.

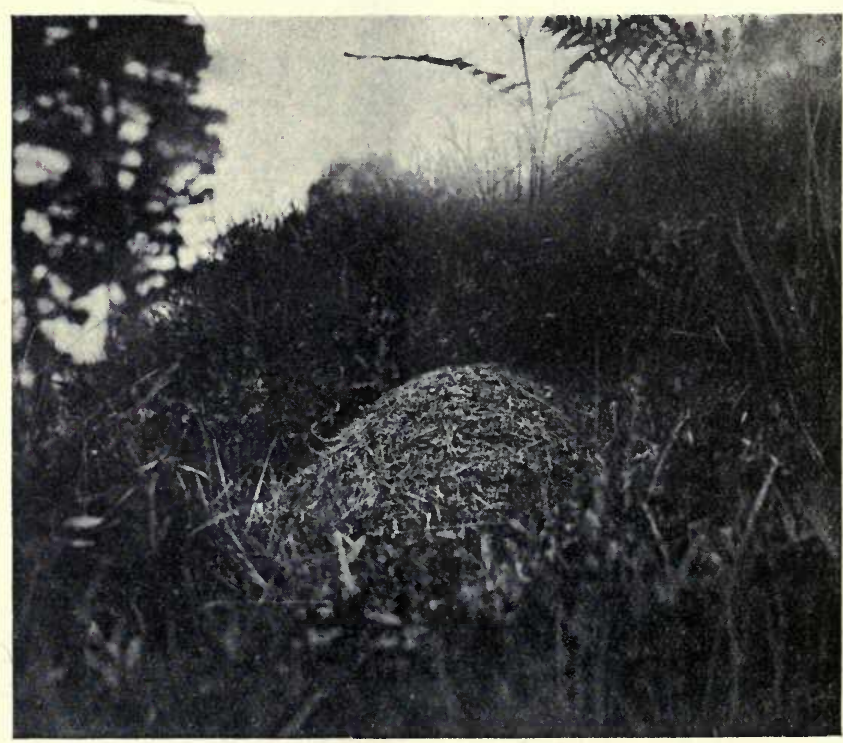

Nest of Formica exsecta. Rannoch, 16. VII.13.

Face page 273. 
larger and older ones more are generally to be found-Wasmann says six to eight queens are not at all rare in Luxemburg ${ }^{39}$, and I found four queens in one nest at Rannoch, in which nest pseudogynes were also present.

In 1906 at Shötter Marial Wasmann three times found young pratensis colonies which contained only a few hundred workers, no fusca being present ${ }^{42}$, which no doubt originated in a split from an older colony with a young queen.

On August 30th, 1871, Forel found near the summit of Mont Tendre a small mixed colony of pratensis and fusca which contained - worker pratensis cocoons ${ }^{25}$; on September 8th, 1887, Wasmann discovered near Exaeten, at the foot of an old oak stump another small mixed colony of the same two species ${ }^{39}$; and Wheeler records that in Switzerland during the summer of 1907 he found on two or three occasions a recently killed, but not mutilated, pratensis queen in the recesses of a fusca nest ${ }^{45}$.

All these discoveries in nature demonstrate the founding of colonies in fusca nests, by pratensis females.

The following myrmecophiles have been found with $F$. pratensis in Britain :-

Coleoptera : Cetonia floricola Hbst. (larvae).

Formicidae: Formicoxenus nitidulus Nyl., and Leptothorax acervorum $\mathrm{F}$.

Araneina : Thyreosthenius biovata Camb.

Acarina : Laelaps oophilus Wasm.

\section{Formica exsecta $\mathrm{Nyl}$.}

Formica exsecta Nylander Acta Soc. Sc. Fenn. 2 909-11 (1846) ${ }^{1}$ : 327 $(1849)^{2}$; Förster Hym. Stud. $123(1850)^{3}$; Schenck Jahrb. Ver. Naturk. Nassau $838(\mathbf{1 8 5 2})^{4}$; Mayr Verh. Zool. Bot. Ver. Wien $5340(1855)^{5}$; F. Smith Ent. Ann 1865 85, 87-88. Pf. [1] $2^{6}$ : $1866126^{7}: 186969-72^{8}$. Formica exsecta r. exsecta Forel Denkschr. Schweiz. Ges. Naturw. $2651^{9}$ $140^{10} 220^{11} 368^{12} 371^{13} 409^{14}$ (1874). Formica exsecta Saunders Trans. Ent. Soc. Lond. $1880206^{15}$; Er. André Spec. Hym. Europe $2178(1881)^{16}$; Dalla Torre Cat. Hym. $7195(1893)^{17}$; Farren-White Ants' Ways 57 $7^{18} 203-205^{19}$ $232^{20}$. Tf.36 (1895); Saunders Hym-Acul. 21 (1896) ${ }^{21}$; Bradley Ent. Mo. Mag. $3346(1897)^{22}$ : $3514(1899)^{23}$; Vic. Hist. Worcester $187(1901)^{24}$; Hamm Ent. Mo. Mag. $38266(1902)^{25}$; Holmgren Zool. Jahrb. 20 353-370; $(1904)^{26}$; Donisthorpe Ent. Rec. $17182(1905)^{27}$; Escherich Ameise 222 $(1906)^{28}$; Butler Ent. Mo. May. $43254(1907)^{29}$; Donisthorpe Trans. Leicester Lit. Phil. Soc. 12223 (1908) ${ }^{30}$; Wasmann Biol. Centralb. 28 298$306(1938)^{31}$ : Arch. Trim. Inst. R. Grand Ducal Luxemburg 4 39-44 $(1909)^{32}$; Formica exsecta exsecta Emery Deutsch. Ent. Zeitschr $1909190^{33}$. Formica exsecta Donisthorpe Ent. Rec. $21257-258(1909)^{34}$ : $2283(1910)^{35}$ : Entom. $44390(1911)^{36}$ : Trans. Ent. Soc. Lond. $1911179-180^{37}$ : Ent. Rec. $2310-11(1911)^{38}$ : $2410(1912)^{39}$; Emery Deutsch. Ent. Zeitschr $1912672^{40}$; Donisthorpe Ent. Rec. $2565(1913)^{41}$; Beare Ent. Rec. $25258(1913)^{42}$; Crawley and Donisthorpe Int. Ent. Cong. Oxford $1912 \quad 2 \quad 42-43(1913)^{43}$. Formica exsecta exsecta Wheeler Bull. Mus. Compar, Zoöl. $53489(1913)^{44}$. Formica exsecta Wheeler Psyche $2126(1914)^{45}$. 
$\Varangle$ Yellowish-red; head posteriorly, a more or less distinct patch on the pronotum, and sometimes a smaller one on the mesonotum, and the apex of the antennae brown; gaster brownish black, with base of first segment more or less reddish ; legs yellowish-red, tibiae and tarsi darker.

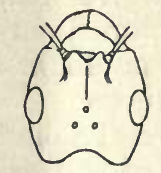

Fig. 89. Head of Formica exsecta ఫ్ధ.

Head narrower than long, narrowed anteriorly and posteriorly, the breadth at the anterior and posterior borders being equal, deeply excised posteriorly ; clypeus carinate, not emarginate anteriorly ; frontal area smooth and shining; mandibles with terminal border furnished with eight teeth, which are much blunter in some specimens than in others; maxillary palpi long, six-jointed. Thorax not very convex; constriction between mesonotum and epinotum shallow, broad; epinotum rounded. Scale not large, deeply excised. Long. $4 \cdot 5-7 \cdot 2 \mathrm{~mm}$.

우 Yellowish-red; head posteriorly, apex of antennae, thorax (except pronotum anteriorly, and epinotum) and gaster blackish brown; legs yellowish, or brownish, red.

Characters much as in $\not{ }$. Head deeply excised posteriorly; clypeus not emarginate anteriorly. Thorax: mesonotum flat. Scale larger and more deeply excised than in the $\Varangle$. Wings yellowish, with pale brownish yellow veins and pterostigma. Long. 8-9.5 $\mathrm{mm}$. lighter.

$\hat{\sigma}$ Black, genitalia and legs yellowish brown, articulations of the joints

Head dull, distinctly and widely excised posteriorly ; clypeus not emarginate posteriorly; mandibles not toothed on terminal border ; maxillary palpi as in $\zeta$ and $q$; eyes large, with sparse hairs. Thorax dull. Scale short, thick, with anterior border excised; gaster shining. Wings not as yellow as in the 으, with pale brownish yellow veins and pterostigma. Long. $6 \cdot 5-8 \mathrm{~mm}$. (6-9 mm. teste Wheeler.)

Original description of Formica exsecta Nylander [Acta. Soc. Sc. Fenn. 2 909-11 (1846)] :

"Operaria: ferrugineo-rufa parum nitida, abdomine castaneo-atro; palpis, antennarum flagellis et vertice fuscescentibus; occipite late emarginato; squama cordata, supra profunde exsecta ; pedibus sparse pilosis.

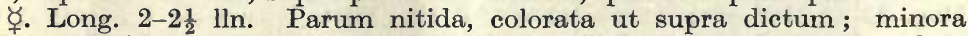
tamen individua verticem castaneo-fuscam, antennas fere totas et pedum saltem tibias fuscescentes habent. A $F$. rufa, cui leviter inspecta similis videtur, differt jam: mandibulis magis complanatis, occipite concavo, clypeo margine inferiori magis truncato, supra vestigio carinulae medianae, squama cordata h.e. ovata sursum parum latiori, supra semiovaliter excisa, colore abdominis atriori, pubescentia denique corporis conspicuiori (canitie sericeo-micante vix ulla). Palpi labiales articulo ultimo oblongo, longitudine 3 : tii. Metanotum a latere visum arcuatum. Pedes pilis sparsis obsiti ; tibiis latere interiori versus apicem sparse setulosis. Segmentum anale rufescens.

Femina : testaceo-rufa flavido-pubescens nitida; palpis, antennis, fronte cum vertice, thorace supra et abdomine castaneo-atris ; clypei disco, mesosterno et mesopleuris fuscescentibus; occipite late emarginato; squama 
cordata vel supra profunde exsecta; alis hyalinis obsoletissime fuscedine tinctis, nervis cinereo-flavidis, stigmate parum fusciori.

ㅇ. Long. $3 \frac{1}{4}$ lin. Sat longe flavido-pubescens valde nitida, capite fere ut in $\grave{\text {. }}$. Clypeus obsolete convexiusculus, margine infero tenui in medio rectâ late truncato; vestigio vix ullo carinulae. Linea frontalis elevatiuscula. Oculi parce pilosult, pilis his nonnullis parvis tenuibus apice flexis. Thorax mesonoto toto cum parte adjacente prothoracis, scutello, postscutello, mesopleuris et mesosterno obscurius vel dilutius infuscatis. Alae ut in diagnosi, stigmate pallide fusco; anticae $3 \frac{1}{2}$ lin. longae. Pedes pubescentes, tibiis cum tarsis saepe cinerascentibus vel obscurioribus. Squama ut in $\not{\gamma}$ valde compressa, profunde semiovaliter exsecta. Abdomen nitidum crebre subtiliter flavido pubescens, pubescentia ventris longiori. Basis abdominis truncata maculâ magnâ et segmentum anale rufa.

Mas : niger parum nitidus brevius pubescens, genitalibus et pedibus vel totis vel ad partem testaceo-pallescentibus; occipite parum emarginato; squama transversim subrectangulari crassa, supra late concaviuscula; alis hyalinis stigmate fusco.

o. Long. 3-31 iin. Similis mari F. rufae, sed magis nitidus, occipite concaviusculo alarumque colore nullo statim distinguitur. Brevius flavido pubescens quam $ᄋ$, abdominis pubescentia subtiliori decumbente. Oculi, ut in ㅇ, tenuissime pilosuli; ocelli in cacumine verticis elevatiusculi. Alae hyalinae ne minimis fere vestigiis fuscescentiae, nervis flavido-cinereis, stigmate fusco; anticae fere $3 \frac{1}{4}$ lin. longae. Pedes vel pallescenti-cinerei, coxis obscurioribus vel femoribus fere totis cum tibiis tarsisque pallide testaceis, pubescentiâ flavidâ cinerascentibus. Genitalia fere ut in $F$. rufa. Marginibus segmentorum certo situ magis nitidis, concoloribus."

\section{Habitat.}

Formica exsecta ranges over North and Central Europe ; Alps, Caucasus, Siberia, Altai Mountains ${ }^{44}$. Wheeler has recently described a new variety from Japan under the name of fukaii ${ }^{\mathbf{4 5}}$. In North America $F$. exsecta is represented by the well-known moundbuilding ant of the Alleghanies, Formica exsectoides Forel, which builds very large nests and establishes huge colonies-one of these studied by McCook comprising some one thousand six hundred nests !

Its British distribution is as follows:-

Cornwall, W. : Land's End (Isabell).

Devon, S.: Bovey Tracey $(\mathrm{Hamm})^{25}$.

Dorset : Lyme Regis (Nevinson); Poole (F. Smith $)^{7}$.

Isle of Wight : Parkhurst Forest (E. A. Butler) ${ }^{29}$.

Hants, S. : Bournemouth ${ }^{6}$ (F. Smith) ; Boscombe ${ }^{19}$ and Ringwood $^{18}$ (Farren-White); Parkstone (Saunders) ${ }^{21}$; New Forest $(\text { Bradley })^{23}$.

Worcester : Bewdley (Blatch $)^{24}$.

Mid Perth : Rannoch (Donisthorpe) ${ }^{39}$.

Aberdeen, S. : Braemar (Donisthorpe) ${ }^{38}$.

Easterness: Aviemore ${ }^{34}$ and Nethy Bridge ${ }^{41}$ (Donisthorpe); Boat of Garten (Beare) ${ }^{42}$.

Formica exsecta nests in sunny places, on the borders of woods, in clearings of woods and forests, in unsheltered places, on open heaths, by the sides of paths and roads, in clumps of grass, and 
rarely under stones. It does not like the neighbourhood of human habitations, and is fast disappearing from the heaths round Bournemouth, being driven away by building operations. The nests of exsecta are smaller, and are built of much finer materials than are those of rufa, being chiefly composed of grass and ling, but fern fronds, and bits of other plants, and sometimes a few pine-needles and other vegetable refuse are used-a typical exsecta nest can be recognized at a glance.

In 1907 Butler swept a single exsecta worker in Parkhurst Forest, Isle of Wight ${ }^{29}$, and, having told me whereabouts he thought he had taken it, on April 26th, 1909, I visited the locality in company with Taylor, and this spot having been drawn blank, we went further into the forest, when I found a small deserted nest. which I at once recognized as that of exsecta, and a little further on we came upon a very suitable situation for this species, being a clearing planted with young fir trees, when we immediately found four inhabited exsecta nests. A large nest near, which from its construction and materials had evidently belonged to exsecta was found to be inhabited by $F$. rufa, either the former having deserted, the latter had occupied this old nest, or else the latter had forcibly taken possession $^{34}$.

These nests are dome-shaped, or sometimes somewhat conical, their size about that of a football, seldom more than eight or ten inches in height, and often smaller. Galleries are excavated in the earth beneath the hillock, and when the latter is built over gorse, or tough grass-roots, etc., the nest is very difficult to dig up thoroughly, in consequence of which deälated females are not often obtained. Two or more nests will often be found close togetherI have found two nests so situated by the side of a road over the moor at Aviemoor, two large nests side by side near a path at Braemar, a number of nests near each other at Bournemouth, and in Parkhurst Forest four or five nests may be found in one clearing, several at intervals along a ride, and others scattered all over the Forest-I have counted over twenty rests in one day there.

Isolated nests often occur, and when a nest has grown to a large size, some of the workers will migrate with a young queen to a new situation near by.

Forel mentions an immense colony of $F$. exsecta he found in a clearing at the foot of Mont Tendre ${ }^{11}$, consisting of more than two hundred nests occupying a radius of over one hundred and fifty metres; all the nests being connected with each other by paths, and all the ants in the different nests on friendly terms with one another.

On the other hand, in Wasmann's experience, isolated nests are more usual with this ant, he neither saw in Vorarlberg and Tirol, nor in Rhineland and Westphalia nests connected with each other. He found that single nests belonged to single colonies, and that at 
Linz am Rhein where exsecta was common, the inhabitants of nests only three metres away from each other were enemies ${ }^{31}$.

I have, however, found these ants from the same locality to be friendly with each other, even after being separated for a long interval.

On April 26th, 1909, I took a small colony of exsecta in Parkhurst Forest, consisting of a deälated female and a number of workers, and established them at home in a combined "Fielde and Janet " nest, and on May 15th, 1910, I obtained about one hundred workers, some eggs and larvae (the queen was not found) from a colony near the same spot, and introduced them into my nest, which I wanted to strengthen, as many workers had died, only the queen and seven workers remaining. The new and old workers were quite friendly together, much excitement prevailed, and a great deal of tapping of antennae took place all round. The eggs and larvae were collected into a heap in one corner of the nest and the queen rested upon them; no fighting took place, no dead ants were present next day, and the nest was kept under observation for some years ${ }^{38}$.

F. Smith endeavoured in June, 1868, to establish a colony of exsecta in his garden at Islington, and he writes :- " On the morning of my leaving Bournemouth, I rose early, and, taking a spade and a tin box, I set out for the purpose of obtaining a nest of Formica exsecta. At the early hour of five o'clock, I found a nest with its inmates apparently in quiet repose, not an ant was to be seen...."

He dug up the nest without disturbing it and brought it bodily to London, where he established it in his garden at Islington.

" On the following morning I visited my ants' nest, when, what was my astonishment, on beholding a line of black ants extending from the nest to the root of a lilac tree in the corner of the garden; one troop of ants were on their way from the tree to the nest, whilst another was travelling in the opposite direction; each ant laden either with a larva or pupa of Formica exsecta."

At first he suggested that he had discovered Formica (i.e. Donisthorpea) nigra in the character of a slave-making ant-a quite impossible solution-but subsequently he realized the true state of affairs and he goes on-

"I was, however, doomed to be again disappointed; in a few days every larva, pupa, and worker was conveyed into the nest of Formica nigra, and from that time, the most careful watching failed to discover any trace of Formica exsecta; I have not any doubt of the whole contents of the nest having become the food of the colony of the black ants." 8

Forel, however, was more successful in Switzerland; on June 12th, 1871, he brought a large quantity of ants taken from the colony of exsecta at Mont Tendre, before mentioned, to Vaux, and 
placed them on the border of a small wood. The ants at once commenced to build a nest, and to attack two colonies of Donisthorpea nigra and one of $D$. flava which were situated in the neighbourhood, the siege lasting for two or three days, and numbers of the nigra and flava were killed and chased away. The exsecta workers in troops invaded the shrubs in the neighbourhood, and drove away workers of $D$. nigra and $F$. fusca, taking possession of the plant-lice belonging to these ants. They also attacked some Camponotus ligniperdus workers on a tree at some distance from the nest, but were eventually repulsed with heavy loss. After some days two nests were established on the borders of the wood, one being built over the nest of one of the vanquished nigra colonies. The exsecta workers never went out alone, at least for the first eight days, but always in bands, so that when one of their number was attacked, twenty other workers would come to the rescue, but they never went near the Camponotus nest again. This exsecta colony flourished and was still under observation in $1874^{12}$.

Holmgren has observed that the nests of $F$. exsecta in the bogs of Lapland are destroyed by the growth of a moss (Polytrichum strictum) which gradually invades the mounds of these ants, and covers them with a dense carpet. The moss is then replaced by a growth of sphagnum, and many other plants eventually take root in it, so that the ants are instrumental in the forming of these hillocks of moss, and hence helping the growth of peat-forming vegetation ${ }^{26}$.

$F$. exsecta is a very active and fierce ant, and when its nests are disturbed the workers rush out, swarm all over the invader, and bite most viciously.

They are somewhat abrupt in their movements; they possess good sight, but very little individual initiative. When the workers attack other species, they advance together in troops in fairly close formation and always try to avoid the grasp of an enemya number seizing the latter by its legs and antennae and pulling in different directions as hard as they can, whilst one of their number springs on to the back of the captive and endeavours to cut off its head.

Large nests are very populous, and a colony may consist of over one thousand, or, as Wasmann suggests, perhaps ten thousand, individuals. ${ }^{32}$

According to Escherich the marriage flight takes place in June and July without swarming ${ }^{28}$; André says the winged sexes appear in June and $\mathrm{July}^{16}$, Rothney found males and winged females at Bournemouth on July 14 th, $1868^{8}$, and I have taken them in abundance in nests in the same locality at the end of August and the beginning of September, 1905 ; sex pupae taken in June in Parkhurst Forest and in'July at Rannoch, 1913, hatched in the latter month. 
Forel captured an incomplete lateral ergatandromorph in a wild colony in Switzerland, which he briefly described :-

Worker with some portions of the left side male. Stature of ordinary worker. Male portions: a longitudinal black band under the head, left half of pronotum, a large V-shaped black blotch on mesonotum, a black protuberance (scutellum ?) and vestiges of alar articulations. All the rest worker. Epinotum malformed. ${ }^{10}$

Forel states the eggs are late in appearing and gives May 6th as the first date ${ }^{14}$, but, in captivity at any rate, the females lay earlier than that-Wasmann records that a female in a colony in his possession laid eggs in February, larvae being present in March ${ }^{31}$, and eggs were laid in my observation nest in the latter month. Worker cocoons are present in the nests up to late in the year. As we have seen, new exsecta nests are established and a colony spreads by means of branching, etc., some young queens are retained in the nests, and others would be accepted back after the marriage flight into the different nests of a large colony.

Young females of $F$. exsecta, however, also found their colonies in nests of $F$. fusca, and as the exsecta female is smaller in comparison with her workers than is rufa-being smaller than large fusca females-and dark in colour, she is more readily accepted into the fusca nests ; mimicry playing some part in the matter.

The reason why no very early stage of a mixed colony (a female exsecta, and fusca workers only) has been observed in nature is probably that an exsecta queen would easily be overlooked among the fusca workers, but later stages of mixed colonies have been found-in September, 1867, Forel discovered in a wood near Apples a very small mixed colony of $F$. exsecta var. rubens and F. fusca ${ }^{13}$; on April 26th, 1870, Bugnion found a mixed colony of exsecta and fusca near Lausanne, and in the following year at Ormonts another of exsecta-pressilabris and fusca under a stone ${ }^{13}$. In October, 1906, Wasmann dug up at Luxemburg an exsecta-fusca colony in a simple earth nest of the fusca type, containing an exsecta queen, several hundred exsecta and fusca workers, and pupae of the former, but no fusca female was present ${ }^{31}$.

On May 27th, 1910, I found an isolated nest on the borders of a wood at Bournemouth, of the usual exsecta type but very small, and on being examined it proved to contain both exsecta and fusca workers, the latter being in considerably greater numbers. It was impossible to properly dig up the nest, on account of the presence of gorse roots, etc., in the ground, and no female was found, but here undoubtedly was a new exsecta colony, founded by a young queen of that ant, which had entered a fusca nest, and been accepted by the inhabitants ${ }^{37}$. On August 26th, 1911, Hamm also found a mixed colony of exsecta and fusca at Bovey Tracey, in Devonshire ${ }^{43}$.

Some of the $F$. exsecta nests found by me in Parkhurst Forest, 
which were situated in the ground with very little nest materials built over them, were suggestive of a recent fusca origin, as was also an isolated nest, found by the side of a road at Aviemore, which was partly situated under a large stone, a heap of nest materials being built up on one side, whilst under the stone were galleries such as are constructed by $F$. fusca ${ }^{35}$.

The following myrmecophiles have been taken with $F$. exsecta in Britain :-

Coleoptera : Oxypoda haemorrhoa Sahl., Dinarda hagensi Wasm., Myrmedonia limbata Pk., Drusilla canaliculata F., Notothecta flavipes Gr., $N$. anceps Er., Homalota analis Gr., Othius myrmecophilus Kies., and Dendrophilus punctatus Hbst.

Formicidae : Leptothorax acervorum F.

Lepidoptera: Amphisbatis incongruella Staint.

Diptera: Ceratopogon myrmecophilus Egg., and Apiochaeta (=Phora) rata Wood.

Heteroptera : Ceratocombus coleopteratus Zett.

Collembola : Cyphodeirus (=Beckia) albinos Nic.

Myriapoda: Blanjulus guttulatus Gerv.

Araneina: Micaria pulicaria Sund.

Acarina: Laelaps cuneifer Mich.

Crustacea: Platyarthrus hofmanseggi Brandt.

\section{F. sanguinea Latr.}

Formica sanguinea Latreille Ess. Hist. Fourmis France $37(1798)^{1}$ : Hist. Nat. Fourmis $150(1802)^{2}$. ["La fourmi sanguine" Huber Mœurs Fourmis 275-288 (1810)] ${ }^{3}$. Formica sanguinea F. Smith Zool. 1 262-264 (1843)4. Formica dominula Nylander Acta. Soc. Sc. Fenn. $29051047(1846)^{5}: 326(1849)^{6}$. Formica sanguinea Förster Hym. Stud. $120(1850)^{7}$; Tischbein Stett. Ent. Zeitg. 12 295-297 (1851) ${ }^{8}$; Schenck Jahrb. Ver. Naturk. Nassau $811^{9} 14^{10}$ 36-3811 $139^{12} 145^{13}$ (1852); Mayr Verh. Zool. Bot. Ver. Wien 5 336-338 $(1855)^{14}$; F. Smith Trans. Ent. Soc. Lond. (n.s.) 3 101-103 (1855) 15 : Cat.

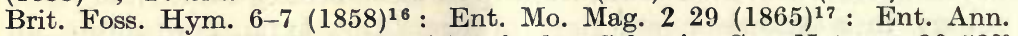
1868 93-94 18 : $187158^{19}$; Forel Denkschr. Schweiz. Ges. Naturw. $2652^{20}$ $219^{21} 261^{22} 324-330^{23} 358-364^{24} 408^{25}$ (1874): Bull. Soc. Vaud. Sc. Nat. 14 57-58 (1875) ${ }^{26}$; Saunders Trans. Ent. Soc. Lond. $1880205-206^{27}$; Er. André Spec. Hym. Europe $2180(1881)^{28}$; Lubbock Ants, Bees, and Wasps 41-4229 441 10 (1882); Rothney Ent. Mo. Mag. $18262(1882)^{31}$; Forel Ann. Soc. Ent. Belg. 30 139-140 (1886 $)^{32}$; Lubbock Journ. Linn. Soc. Lond. 20 $118(1888)^{33}$; Darwin Origin Species $1338-342(1888)^{34}$; Wasmann Tijdschr. Entom. $3446(1891)^{35}$ : zusam. Nest. gemischt. Kolon. Ameisen 46-52

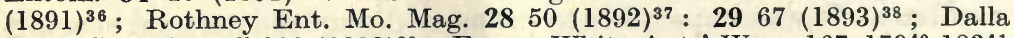

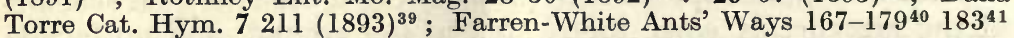

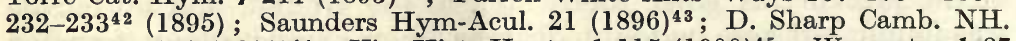
Ins. 2 149-150 (1899) ${ }^{44}$; Vic. Hist. Hants. $1115(1900)^{45}$ : Worcester 187 $(1901)^{46}$; Morice Ent. Mo. Mag. 3796 (1901 $)^{47}$; Barnes Ent. Mo. Mag. 38 $265(1902)^{48}$; Wasmann Verh. Deutsch. Zool. Gesell. $12100(1902)^{49}$ : Insektenbörse $20275-276(1903)^{50}$ : Biol. Centralb. $25200-210(1905)^{51}$; Wheeler Bull. Amer. Mus. NH. 21 1-16 (1905) $)^{52}$; Vic. Hist. Sussex 1131 $(1905)^{53}$ : Berks. $176(1906)^{54}$; Escherich Ameise $48^{55} 134^{56} 222^{57}$ (1906); Donisthorpe Ent, Record $19254(1907)^{58}$ : $20281(1908)^{59}$ : Trans, Leicester 
Lit-Phil. Soc. 12222 (1908) $^{60}$; Wasmann Biol. Centralb 28 369-376 (1908) ${ }^{61}$ : Arch. Tri. Inst. Grand Ducal Luxemb. 4 44-75 (1909) ${ }^{62}$; Donisthorpe Ent. Rec. $21257(1909)^{63}$ : Zool. 1909 463-466. Tf. 1, 264; Forel Arch. Sc. PhyNat. 28 Sept. 6-8 (1909) ${ }^{65}$; Viehmeyer Zeits. Wissens. Insektenbiol. 5 353-356 390-394 (1909) ${ }^{66}$; Emery Deutsch. Ent. Zeitschr. 1909 182-18467 ; Wasmann Biol. Centralb. $30481(1910)^{68}$; Wheeler Ants 454-458 (1910 ${ }^{69}$; Donisthorpe Ent. Rec. $2283(1910)^{70}$ : Trans. Ent. Soc. Lond. $1910142-150^{71}$ 1911 178-17972 : Entom. $44390(1911)^{73}$; Forel Int. Ent. Cong. Bruxelles 21910 101-104 (1911)74; Donisthorpe Ent. Rec. 24 9-10 (1912 $)^{75}$ : 2565 $(1913)^{76}$ : Rep. Lanes-Chesh. Ent. Soc. 361912 41-42 (1913) ${ }^{77}$; Crawley and Donisthorpe Int. Ent. Cong. Oxford 21912 55-63 (1913) ${ }^{78}$; Formica sanguinea sanguinea Wheeler Bull. Mus. Comp. Zoöl. 53 401-403 (1913) ${ }^{79}$; Formica sanguinea Rüschkamp Biol. Centralb. 33 668-675 (1913) ${ }^{80}$. Raptiformica (Formica) sanguinea Forel Ann. Soc. Ent. Belg. 57361 (1913) ${ }^{81}$. Formica sanguinea Donisthorpe Ent. Rec. $2641(1914)^{82}$; Crawley Ent. Rec. 26141 $(1914)^{83}$; Pinkney Ent. Rec. $26142(1914)^{84}$.

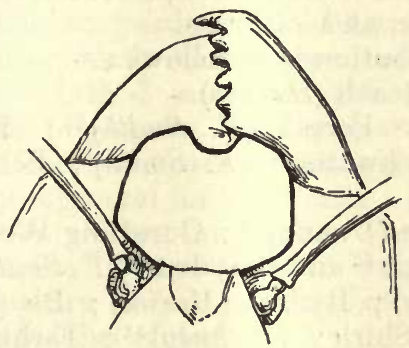

Fig. 90. Anterior portion of head of Formica sanguinea $\Varangle$ to show emargination of clypeus.

ఛ Head, thorax, petiole, antennae, and legs, lighter or darker red, gaster greyish black. Front and vertex of head darker, sometimes blackish; gaster sometimes reddish at base of first segment; hairs, and pubescence except. on gaster, sparse.

Head broad, slightly, but widely emarginate posteriorly; clypeus emarginate in centre of anterior border, not distinctly carinate except in some specimens ; frontal area finely shagreened; mandibles broad, furnished with strong teeth on terminal border. Thorax robust, the constriction between mesonotum and epinotum deep and angular; epinotum highest posteriorly, forming a rounded angle, descending in a rather flat straight surface to base. Scale broad, usually slightly emarginate at apex; gaster covered with thick grey pubescence. Long. 5-9 $\mathrm{mm}$.

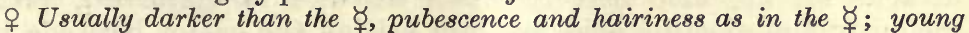
winged females are generally lighter in colour than old queens.

Head more blackish than in the $\not$, the red colouring more brown; clypeus emarginate in centre of anterior border. Thorax large; mesonotum flat above, with slight blackish patches at anterior border and insertion of the wings. Wings brownish with basal halves darker, veins and pterostigma pale yellowish brown. Long. 9.5-10.5 mm. (9-11 mm. teste Wheeler).

t Black, apex of antennae, legs and genitalia reddish yellow. Head dull, broad, with posterior border not emarginate; clypeus emarginate in centre of anterior border ; mandibles with four or five teeth on the terminal border. Thorax dull. Scale thick, widely but not deeply emarginate at apex; gaster somewhat shining, finely pubescent. Wings as in o, but with veins and pterostigma darker. Long. 6-10 $\mathrm{mm}$. 
Original description of Formica sanguinea Latreille [Ess. Hist. Fourmis France 37-38 (1798)] :-

"11. * F. sanguine. sanguinea. O. g. D'un rouge sanguin. Yeux et abdomen noirs. Trois petits yeux lisses. Ecaille ovée, un peu échancrée."

\section{Habitat.}

Formica sanguinea is distributed throughout the Palaearctic region, but in the southern portions of Europe and Asia it only occurs in hilly or mountainous country. In Europe it ranges south as far as Sicily, in Asia as far as the Himalayas (Cashmir) and Lahoul, on the frontier of Thibet. ${ }^{79}$

Four varieties have been described-from Siberia, the Caucasus, Andalusia, and Japan-and it is represented in North America by some five subspecies, and varieties.

The British distribution is as follows :-

Dorset : Parley Heath (Haines).

Hants, S. : New Forest $(F \text {. Smith })^{16}$; Hants, N.: Cove ${ }^{4}$, Hawley ${ }^{16}$, and Blackwater ${ }^{19}$ (F. Smith); Selborne (Dale Coll.); Fleet (E. A. Butler).

Sussex, E. : Hove (Unwin) ${ }^{53}$; Guestling Wood (Donisthorpe).

Surrey: Weybridge ${ }^{15}$ and Croydon ${ }^{17}$ (F. Smith); Chobham ${ }^{27}$ and Woking ${ }^{43}$ (Saunders); Byfleet (Morice); Blackheath, near Guildford (Champion); Shirley (Rothney) ${ }^{31}$; Ewhurst and Leith Hill (E. A. Butler) ; Hind Head (Donisthorpe).

Berks : Wellington College and Crowthorne (Farren-White) ${ }^{42}$; Burghfield (Barnes) ${ }^{54}$; Mortimer (Hamm).

Bedford: Heath-on-Reach, near Leighton Buzzard (G. Crawshay).

Worcester : Wyre Forest ${ }^{46}$ and Bewdley (Martineau).

Mid Perth : Rannoch (Donisthorpe) ${ }^{7 ?}$.

Easterness : Aviemore and Nethy Bridge (Donisthorpe) ${ }^{58}$.

Formica sanguinea, the blood-red Robber Ant, our only slavemaker, is one of the most interesting species, showing great intelligence in adapting its habits to varying circumstances. It is a restless, warlike, and courageous ant, running rapidly, and attacks an intruder fiercely when its nest is disturbed, biting viciously and ejecting acid, but not raising the gaster between the legs, as do rufa and pratensis, when angry. This species lives in clearings of woods, on heaths, and commons, on the borders of woods and hedges, by the sides of roads and paths, and loves heathy land near pine woods.

It prefers uncultivated places, sometimes dwelling in meadows, at a distance from human habitations, being driven away before cultivation, and shuns gardens, as pointed out by Forel ${ }^{21}$ _ although Schenck records its occurrence in such places ${ }^{11}$. The nests and nesting places, of sanguinea are very variable, being situated in 
banks, in rotten stumps, under stones, in clumps of grass, on and in mud walls, under and at the roots of heather, and sometimes small nests will occur under an old boot, or anything lying about.

In summer its nests are often covered with cut grass and other vegetable refuse (Schenck says especially the scales of beech buds) ${ }^{11}$ - the débris never forming a hillock, but only a carpet an inch or so high.

$F$. sanguinea is fond of a new nest ; in the summer it selects open sunny places, and in winter more sheltered spots; this change of nests takes place in very hot dry weather, and also at the approach of winter; but sometimes it only extends its nest deeper into the ground-this is generally the ease with colonies nesting in old stumps. On July 4th, 1914, I found a colony of this ant at Weybridge, situated in a hole in the turf; on August 3rd they had moved to a nest, about six yards from the former one, at the roots of heather with débris chiefly consisting of chopped heather laid over it. On August 24th I witnessed the ants moving again, carrying their fellows, pupae, etc., to a spot at the root of a gorsestem some six yards from the heather nest, and by September 15th, they had all gone underground for the winter.

Escherich has called the summer nests "work-nests," and the winter ones "rest-nests," 56 and I have found in Britain that sanguinea rarely appears above ground before May, and often retires in September for the winter.

A colony may possess three nests, and Forel says they will pass the winter in one of these one year and in another the next ${ }^{24}$. I have found these ants nesting in sandy banks, with or without a covering of vegetable detritus, in grass clumps, in old stumps, and at roots of gorse, etc. (at Woking); under and at the roots of heather and in fir-stumps (at Weybridge); simply emerging from a small hole in the turf (in Guestling Wood and at Hind Head); in the earth on the top of an old mud wall (in the New Forest); in large tree-stumps (near Leighton Buzzard); under rather loose small stones on a railway embankment, and in banks covered with thick layers of plant refuse, on the borders of hedges at the side of roads (at Bewdley); under large stones by the side of a wall, with a little vegetable débris scattered about (on a moor at Rannoch); and under one or two very large heavy stones by the side of a path (at Aviemore). Sometimes very large colonies may occur ; Wasmann records that at Exaeten in Holland four hundred and ten colonies were present, on an area of four square kilometres, consisting of over one thousand nests ${ }^{50}$, and at Luxemburg he found thirty-nine colonies in one spot two hundred metres in length and one hundred in breadth ${ }^{62}$. At Woking a dozen or so nests usually occur over a small area, most of which probably belong to the same colony, but at Bewdley, in 1909, a large number of colonies were present, nests being found all along the railway 
embankment, and by the sides of the roads, etc., in different parts of the Forest.

Formica sanguinea finds its way more by the sense of sight than that of smell.

When attacking other ants the slave-makers advance in small troops, sending out advance guards or couriers to spy out the movements of the enemy and ascertain where they are weakest; these couriers often fall to the rear-their places being taken by others-and call up reinforcements. They fight with great impetuosity, their object being to stampede the enemy, and they also send troops to attack in the rear. They appear to know at once when these manœuvres have thrown their opponents into a panic, but should they meet with too strong a resistance they instantly retire.

$F$. sanguinea will not attack a large ant, such as rufa, directly in front, but endeavours to take it by surprise from the side; when attacking smaller ants, however, these are usually seized at once, and quickly dragged backwards-tightly grasped to prevent the smaller ant from fixing on to the legs or antennae of its captor.

$F$. sanguinea understands well how to resist a siege by a numerous enemy; blocking up the entrances to its nest, removing the brood, etc., to safer quarters, and if necessary escaping from the opposite exits of the dwelling.

Ants of this species sometimes play together, pretending to fight. Individual ants live for a number of years; Lord Avebury kept some workers (sent to him by Forel), which lived for five years ${ }^{29}$; Wasmann tells me that a queen lived in one of his observation nests for thirteen years, and another in the same nest was eleven years old when she died; and I had ants which lived for four years, and then only died when the nest was allowed to get too dry, the whole colony unfortunately perishing.

The most interesting fact connected with the life-history of sanguinea is its habit of making slaves. This was first discovered and the meaning of these mixed colonies pointed out by Huber, who graphicly describes the slave-raids witnessed by him. After having found Ash-coloured ants mingled with the Sanguine ants, he was led to suspect that the former were procured by the latter much in the same way as by the Legionaries (Polyergus), and he watched their movements from day to day and at length witnessed several of their expeditions. He writes-"The following will convey a just idea of their tactics. On the 15th July, at ten in the morning, a small division of the Sanguine Ants was dispatched from the garrison, and arrived in quick march, near a nest of Negro Ants, situated twenty paces distant, around which they took their station. The inhabitants, on perceiving these strangers, rushed forth in a body to attack them, and led back several prisoners. The Sanguine Ants made no further advance; they appeared to be waiting some 
reinforcement. From time to time little companies of these insects came from the garrison to strengthen the brigade. They now advanced a little nearer, and seemed more willing to run the risk of a general engagement; but in proportion as they approached the Negro dwelling, the more solicitous did they seem to dispatch couriers to the garrison, who arriving in great haste produced considerable alarm, when another division was immediately appointed to join the army. The Sanguine Ants, although thus reinforced, evinced little or no eagerness for combat, and only alarmed the Ash-coloured Ants by their presence. The latter took up a position in front of their nest of about two feet square, where nearly their whole force was assembled to await the enemy. Frequent skirmishes take place all around the camp, the besieged always attacking the besiegers. The Negro Ants, judging from their number, announce a vigorous resistance; but distrusting their own strength, they look to the safety of the little ones confided to their care, and in this respect show us one of the most singular traits of prudence of which the history of insects can furnish an example. Even long before success is in any way dubious, they bring the pupae from the subterranean chambers, and heap them up on the side of their nest, opposed to that where the Sanguine army is stationed, in order to carry 'them off with the greater readiness should the fate of arms be against them. Their young females escape on the same side. The danger becomes more imminent; the Sanguine Ants, sufficiently reinforced, throw themselves in the midst of the Negroes, attack them on all points, and arrive to the very gates of their city. The latter, after a brisk resistance, renounce its defence, seize upon the pupae deposited on the outside and convey them to a place of safety. The Sanguine Ants pursue, and endeavour to steal from them their treasure. The whole body of Negro Ants are in flight; some few pass through the enemy's rank, and, at the hazard of their lives, enter once more their habitation, and expeditiously carry off the larvae, that would otherwise remain devoted to pillage. The Sanguine Ants descend into the interior, take possession of the avenues, and appear to establish themselves in the devastated city. Little bands of troops continually pour in from the garrison, and begin taking away the remainder of the larvae and pupae, establishing an uninterrupted chain from one ant-hill to the other : thus the day passes and night comes on, before they have transported all their booty. A considerable number of Sanguine Ants still remain in the Negro residence, and on the following morning, at break of day, recommence the transfer of the rest of its contents. When they have taken away all the pupae and larvae, they then carry each other to the garrison, a few only remaining behind."3

Huber goes on to say that eventually the raiders changed their residence, establishing themselves in that of the fusca colony, and 
he describes some other slave-making expeditions, etc. The accuracy of his observations has been confirmed and amplified by Forel and Wasmann in Europe, and by Wheeler with the subspecies sanguinea rubicunda in North America.

In Britain during all the years that the habits of ants have been studied, since the observations of Gould in 1747 to the present time, only four records occur of a slave-raid having been witnessed in our country ; it therefore seems advisable to reproduce them in detail. According to Farren-White, Frederick Smith was the first in England to witness the slave-making instinct in active exercise, when he observed a slave-making expedition at Blackwater in Hampshire. Farren-White gives the following account from an unpublished manuscript by F. Smith, in his possession.

"It was in the summer of 1843 I discovered a colony of this slave-making ant, and very closely I watched it, in the hope of witnessing what others had described. Three successive years passed without any satisfactory result. In the nests I found plenty of slaves, or, at least, plenty of a very different species to the $F$. sanguinea, all being black and smaller. One morning, on passing the nest, swarms of ants were spread over the bank in which the nest was situated. The larger ants, the soldiers, were very active, and constantly assuming the most threatening attitudes, standing erect, occasionally springing up on their hinderfeet, and snapping their jaws with great ferocity. The sun burst out, and the whole host rapidly retreated to their subterranean abode. Again, in the evening, I visited the spot, and to my delight I found the army again in battle array. Numbers of the largest ants at length separated from the rest, and formed the advanced guard or van, and the whole body was in motion. At a distance of about twenty yards was a nest of Formica fusca. This was the object of their attack. Without the slightest pause, the advanced warriors boldly entered the nest, and in poured swarms after them. After a few moments had elapsed numbers issued forth, each carrying their slaves in their jaws. Occasionally, a number of black ants rushed out of the nest and gallantly attacked their invaders, but they were quickly overcome, and carried off to the nest of the victors. Frequently, however, they were torn limb from limb, in which case their mangled bodies were borne off, no doubt as food, to the nest. In plundering a nest, although numbers of ants are carried off, by far the greater number convey the pupae, or young brood, of the black ants, and I have some suspicion that it is these which, being borm in the nest, become slaves from birth." 41

In this suspicion Smith was undoubtedly correct, but part of his account is contrary to the usual method of procedure, and it rather looks as if he had written it from memory sometime after the occurrence. Darwin was the next, and he saw what was evidently the finish of a slave-making expedition. He writes- 
"One evening I visited another community of $F$. sanguinea, and found a number of these ants returning home and entering their nests, carrying the dead bodies of $F$. fusca (showing that it was not a migration) and numerous pupae. I traced a long file of ants burthened with booty, for about forty yards back, to a very thick clump of heath, whence I saw the last individual of $F$. sanguinea emerge, carrying a pupa ; but I was not able to find the desolated nest in the thick heath. The nest, however, must have been close at hand, for two or three individuals of $F$. fusca were rushing about in the greatest agitation, and one was perched motionless with its own pupa in its mouth on the top of a spray of heath, an image of despair over its ravaged home." 34

Farren-White records that on July 3rd, 1877, when at Shirley with one of his sisters, he secured a nest of Formica sanguinea there and-" While carefully examining the sanguinea ground-for there were several nests besides the one I had secured-I was not a little interested in observing a worker of sanguinea carrying a pupa smaller than the pupae I had appropriated from the captured citadel, and I was still further interested in noticing another worker of sanguinea hastening along with a similar burden, and yet another and another, each laden with what evidently was a precious charge. The little carriers were hurrying forward with a jubilant and trumphant air, and a peculiar cantering motion, and nothing would turn them from their course. Soon we noticed that numbers of sanguinea were carrying burdens, a few being larvae, but almost all the burdens were pupae. The jocund little people seemed all eager to reach their home, which as usual was formed around a gorse stump. Some were marching quicker than the rest; their powers of endurance were evidently greater, and those who lagged behind were perhaps weary with their long journey and with the weight of their burdens, since we could see that they had come from far. I watched one worker, who travelled thirteen of my paces in three minutes, stopped a little to converse with a slave it met with on its way, and hastened on to its nest. I watched one worker of sanguinea travel twenty-three paces or yards, and carry the pupae to its nest. On its way it fairly outstripped two others who were journeying in the same direction and on the same errand. I was determined to trace back the scattered file of sanguinea to the spot from whence they had come, and so ascertain from whence they had obtained their precious burdens. I walked back forty-six paces, and discovered that they were filing out of a nest among the fern, and from this nest to their own there was constant motion, constant activity, and constant excitement. But what of the nest which was evidently being pillaged of its infant inmates? There were two workers of $F$. fusca running frantically about upon the surface, with pupae in their mandibles ; and, in order evidently to escape from the fell determination of the marauders who were 
desolating their home, they hurried into the fern, and so endeavoured to ward off from themselves and infant progeny the threatening danger. I opened a portion of the nest, and found a nursery crowded with pupae some depth below the surface of the nest; only one or two workers of fusca were left. The rest had evidently escaped with as many of the pupae as they could manage to take charge of and save. I noticed several wandering over the desolated nest with pupae and larvae in their mandibles. I watched a fusca carrying off a pupa from behind the entrance whence the sanguineae were issuing forth. Immediately it saw one of the enemy approaching, it dropped its charge and left it to its fate. The sanguinea then gave it a push, and drove it off in double quick time. I then saw another fusca wandering over the nest, and trying to escape, as it were, by the back door, with a larva in its mandibles, but it was seen and overtaken by a small worker of sanguinea, who seized the baby from its perturbed and luckless foster-mother, and bore it off in triumph. I noticed a sanguinea coming up out of the nest with a pupa ; and a fusca observing it, went up a fern-frond with the utmost expedition. My sister then observed a tussle between a fusca and a sanguinea. The fusca tried to force an entrance into its pillaged home; but meeting with an antagonist, thought discretion the better part of valour, and turned tail with all speed. These observations were made in the afternoon from 2.30 to 4.20 . I now noticed a sanguinea take off a pupa from the same entrance into which the fusca vainly endeavoured to force its way; and I noticed, further, another pupa within the same entrance ; hence was explained the persistence and anxiety of the fusca. It had most likely concealed these pupae in the hope that they would be saved from the general wreck. A sanguinea had evidently found these out, and the fusca was endeavouring to rescue them from their inevitable fate. Several fuscae were wandering over the disturbed nest. One took off a pupa and fled with it in a direction contrary to that taken by the marauders; at the same time I watched a sanguinea frighten off a fusca. Another fusca met a sanguinea on the nest, and ran away precipitately. Another fusca then appeared wandering over the nest with a pupa locked in its embrace, knowing not which way to turn for succour and safety. One thing was patent from our observations-that between the fuscae and the sanguineae there was a well-defined and clearly pronounced antagonism. In presence of the sanguineae the fuscae were terror-stricken. In fact, the depredators had it all their. own way, and were able in this instance, at least, to carry out their marvellous instincts without destroying a single life."40

On July 20th, 1908, I had the good fortune to witness a slaveraid, which was taking place early in the afternoon at Bewdley, and which I recorded as follows:-

"I found the ants belonging to a nest situated on a high cm- 
bankment of the railway in a great state of excitement, all running about outside the nest, and very active in the hot sunshine, some winged females being also present outside. I then noticed that a lot of sanguinea workers kept arriving, carrying pupae, whilst others were all hurrying off in the opposite direction. These I started to follow, and found they went along the embankment for a good many yards, and then descended the steep bank, crossed the railway-lines in a slanting direction, and mounted the bank on the opposite side. At the top I found them busily engaged in ravaging a nest of Formica fusca. Many workers, laden with pupae, were streaming off in the direction of their home; I had met specimens carrying pupae all the time I was tracking the outgoing ants. Others were attacking and killing solitary fusca workers. Several fusca workers were observed up the grass-stems, etc., holding pupae, and endeavouring to escape from the slave-raiders. I watched these proceedings for a considerable time, and accompanied some of the ants with pupae back to their nest, quite a distance off, though they covered the ground very quickly. Several trains passed, but the ants did not appear to be disturbed, as when I went on the lines after one had gone through, the ants continued to cross the railway as if nothing had happened. It was unfortunate that I did not witness the start of the expedition, only arriving after the proceedings were in full swing." 64

Also on July 15th, 1912, at Weybridge, I observed a number of sanguinea workers returning to their nest with fusca cocoons in their jaws. A few fusca workers were noticed in the neighbourhood in flight and on the top of grass-stems, some with their own cocoons in their jaws, so evidently a genuine slave-raid had taken place ${ }^{76}$.

These slave-making expeditions take place in July and August when the males and winged females of the slave species have usually left their nests, and only deälated females, workers, and worker cocoons are present. Both Huber ${ }^{3}$ and Darwin ${ }^{\mathbf{3 4}}$ assert that males and winged females of the slave species are never met with in sanguinea nests, but this is not absolutely the case, as Morice found four males and two winged females of fusca in a sanguinea nest at Weybridge on July 1st, $1900^{47}$, and Barnes dug up a winged fusca female in a sanguinea nest at Wellington College on September 6 th, $1902^{48}$.

According to Forel raids generally take place at eleven o'clock in the morning, but may occur at twelve, one, or two, and sometimes as late as three or four in the afternoon ${ }^{24}$, and not more than two or three expeditions are undertaken by one colony in one year.

The exact position of the slave nest must have been previously ascertained by single sanguinea workers, scouting independently, for when the expedition starts the leaders curiously enough keep falling to the rear, others taking their place, and as the ants proceed straight in the direction of the nest to be robbed, a number of 
workers must all know the way in order to be able to lead the others. They must also possess the necessary memory to find the exact spot again ; directions as to advancing, etc., appear to be given by antennae strokes. The workers of sanguinea only kill individuals of the raided nests when they meet with considerable hostile resistance, or when the defenders fasten on to their legs. The main idea seems to be to terrify and frighten away their opponents, and thus to obtain possession of as many pupae as possible. Since the number of slaves present in a sanguinea colony is never as large as the number of cocoons captured during the summer, it is evident that not all of the latter are allowed to hatch, a number being used as food. Forel has seen a sanguinea colony, after pillaging one slave nest, proceed to another eight paces away from the former and fifty from their own nest, robbing this also before returning home ${ }^{24}$.

Darwin attempted to explain the slave-making instinct in the following much criticized passage :-

" By what steps the instinct of $F$. sanguinea originated I will not pretend to conjecture. But as ants which are not slave-makers will, as I have seen, carry off the pupae of other species, if scattered near their nests, it is possible that such pupae originally stored as food might become developed; and the foreign ants thus unintentionally reared would then follow their proper instincts and do what work they could. If their presence proved useful to the species which had seized them-if it were more advantageous to this species to capture workers than to procreate them-the habit of collecting pupae, originally for food, might by natural selection be strengthened and rendered permanent for the very different purpose of raising slaves. When the instinct was once acquired, if carried out to a much less extent even than in our British $F$. sanguinea, which, as we have seen, is less aided by its slaves than the same species in Switzerland, natural selection might increase and modify the instinct-always supposing each modification to be of use to the species-until an ant was formed as abjectly dependent on its slaves as is the Formica rufescens." 34

In spite of opinions to the contrary this is an accurate statement of what does take place, for, as we have seen, other ants besides the slave-makers do raid strange nests and steal the pupae for food (Donisthorpea fuliginosa, Myrmica, etc.), and will occasionally actually bring them to maturity. F. sanguinea has not lost the instinct or power of working, both in the construction of their nests and in bringing up and attending to their brood, and indeed can live and prosper without slaves at all; hence they have been called facultative slave-holders. Wasmann has suggested that fewer slaves are present in the largest and oldest colonies, and that when a colony is old enough it ceases to make slave-raids ${ }^{62}$; but this is not proved to be always the case. 
D. Sharp says sanguinea very frequently lives without slaves ${ }^{44}$, but this is hardly the fact, at any rate in Europe. Forel mentions that in Switzerland he has seen a few colonies of sanguinea without slaves ${ }^{24}$, and Wasmann says that in Holland such slaveless colonies are very rare $^{35}$.

Forel, when recently describing a very large community of sanguinea without slaves, records that only three or four times in his life has he ever before found sanguinea without slaves. At the Chalet Boverat below Lausanne in a large meadow he discovered forty sanguinea nests, two to five metres distant from each other, over a length of over one hundred and fifty metres, all connected by chains of ants, and not a single slave occurred in any of them. He thinks it probable that the sanguinea had exterminated all the fusca species in the neighbourhood, as he was unable to find a single nest anywhere near ${ }^{74}$.

I have never found a sanguinea nest in Britain which did not contain slaves, and the suggestion that our species is less aided by its slaves than those in Switzerland appears to me to be very doubtful.

Wheeler points out that the normal slaves of $F$. sanguinea are members of the F. fusca group, namely, fusca, glebaria, rubescens, gagates, rufibarbis, and cinerea, but it occasionally enslaves members of the rufa group (rufa, pratensis, and their varieties). He says there can be no doubt that the typical fusca is the form most frequently enslaved in Northern Europe and at high elevations in the Alps, but in the valleys of Switzerland the varieties glebaria and rubescens and $F$. cinerea are the commonest slaves $^{69}$.

Wasmann found that in Holland fusca was the most common slave-species ${ }^{35}$, but that in Luxemburg rufibarbis was more generally used $^{62}$.

Two fusca forms may be present in one sanguinea nest, or even fusca and rufa forms together.

On July 27th, 1875, Forel observed a rufa-like nest on the side of a road near Laegern which on examination proved to contain both sanguinea and rufa workers, the latter being a little more numerous than the former, and generally small in size, and no fusca workers were present ${ }^{26}$. Wasmann on the other hand found a sanguinea colony at Exaeten in which ten per cent of the slaves were rufa, and five per cent fusca ${ }^{35}$.

In the summer of 1886 Forel discovered a sanguinea-pratensis colony at Fisibach in which the former were of large size and more numerous than the latter, which were small in stature ${ }^{32}$. Wasmann has also observed sanguinea colonies which contained only pratensis as slaves, as well as colonies with both fusca and pratensis as slaves; but a sanguinea-fusca-pratensis colony described by Rüschkamp is a rather more complicated affair. In April, 1911, he knew of a normal sanguinea-fusca colony, which was partly dug up May, 
1911, and February, 1912, and on each occasion a sanguinea queen, some workers, and slaves were taken for observation purposes. In August, 1912, pratensis workers were found to be present in the nest, and on completely digging up the same, a deälated pratensis female was found, which must have been adopted by the queenless sanguinea-fusca colony ${ }^{80}$.

In Britain F. fusca is undoubtedly the usual slave species utilized, indeed I have never found any other fusca form present in sanguinea nests in nature, and only once any other slave; when at Rannoch I took specimens of $F$. rufa var. alpina in company with fusca in a sanguinea colony situated in a locality where alpina nests occurred ${ }^{75}$.

F. Smith says he has found cunicularia in sanguinea nests in England ${ }^{16}$, though he gives no dates or localities for the same, but there is no reason why this should not be the case, for sanguinea enslaves the fusca species that happens to be living in the same district.

I have placed in my sanguinea observation nests worker cocoons of $F$. fusca, glebaria, rufibarbis, rufa, and pratensis, all of which have been taken into the nests, some of each having been allowed to come to maturity and act as slaves.

D. Sharp says that sanguinea "possibly utilizes Lasius flavus" as a slave in England ${ }^{44}$; he probably made this statement because F. Smith has published that he had found flava workers in sanguinea nests ${ }^{16}$. In 1843 the latter author records that one evening he saw some sanguinea workers pillaging nests of $D$. nigra and $D$. flava at Cove Common, carrying off their workers and pupae; this he concluded was a slave-raid ${ }^{4}$; and Schenck says he has found D. aliena workers and pupae in sanguinea nests at Nassau ${ }^{10}$. Forel criticizes the belief of Schenck and Smith that sanguinea makes slaves of aliena and flava pupae, remarking that this was a complete error, sanguinea always devouring the Donisthorpea pupae given to them ${ }^{24}$.

Forel further points out that sanguinea workers often attack nigra and flava nests and amuse themselves by killing the inhabitants ${ }^{24}$, and Wheeler writes:- "Even sanguinea shows a tendency to lapse into the ancient instinct of plundering the nests of different species of ants indiscriminately"; he describes as ridiculous a foray of a large sanguinea rubicunda colony on a woodland variety of Myrmica scabrinodis he witnessed in America ${ }^{52}$.

On July 10th, 1912, I myself observed an attack by sanguinea on a colony of $D$. umbrata at Weybridge, the nest of the latter being situated under a gorse root some twelve paces away from that of the former. A row of sanguinea workers stood outside the umbrata nest on guard, while others had penetrated under the root, and a large number of dead umbrata were lying about, and many of the sanguinea had dead workers of the attacked species fastened to their legs and antennae ${ }^{76}$.

Forel records that one fine day he saw a thick column of san- 
guinea workers march to a pratensis nest, drive off the latter and steal their large male and female cocoons, which they devoured, but, as he suggests, had they been worker cocoons some of them would probably have been taken home to be brought up as slaves ${ }^{22}$.

Various authors have recorded finding species of ants, other than slaves, in sanguinea nests, and Rothney took $D$. nigra, $D$. flava, $M$. scabrinodis, $M$. ruginodis, $M$. lobicornis, Leptothorax acervorum, L. nylanderi, and Tapinoma erraticum in such situations at Shirley ${ }^{18}$.

In some of these cases no doubt the alien species were living near to the sanguinea, and as Forel has pointed out, what appeared to be mixed nests were really only compound nests. I have twice found a Tapinoma nest quite close to a sanguinea nest at Weybridge, in fact the former might almost be described as being situated in the latter, but Tapinoma can well protect itself with its repugnant discharges, and the Formica would leave it strictly alone; and I have also several times found nests of Myrmica lobicornis situated beneath nests of $F$. sanguinea in the same locality; and species of Leptothorax, as we have seen, often associate with other ants, but none of these examples represent the phenomenon of dulosis in any way.

According to Hüber the slaves are better qualified than their masters to take care of the larvae, and to them is entrusted this important duty; he also says they close and open the doors of the nest $^{3}$, but we have already seen sanguinea is well able to carry out all these actions unaided. When migrating the masters carry their slaves, and if a nest be disturbed the largest sanguinea workers rush out to see what is happening, threatening with open jaws, the large specimens often acting as sentinels at the doors. I had a large sanguinea worker (recognizable because it had lost one of its antennae) which always undertook these duties.

The slave-owners spend a large part of their time attending Aphidae on trees and bushes and in hunting small ants and other insects; I have found amongst other remains in a sanguinea nest the body of a large "Humble Bee."

It has been suggested that the slaves do not leave the nest of their own free will, and Darwin says that Smith informed him he had never seen the slaves either leave or enter the nest ${ }^{34}$, but this is not always the case. Darwin himself records that during the month of July, 1860, he came across a community with an unusually large stock of slaves, and he observed a few slaves mingled with their masters leaving the nest and marching along the same road to a tall Scotch fir tree, twenty-five yards distant, which they ascended together, probably in search of aphides or $\mathrm{cocci}^{34}$. I have frequently seen fusca workers coming in and going out of their owners' nests, and foraging near.

The winged sexes of sanguinea may be found in the nests from 
May to September. Schenck records males as met with in a nest at Nassau on May 19th, $1852^{12}$, and both sexes in other nests from July 9 th to $18 \mathrm{th}^{11}$. Forel gives the middle of June to the end of $\mathrm{July}^{25}$, and Wasmann the middle of May to July, and he says males and females are seldom found in the same nest at the same time ${ }^{50}$, but Smith found all the sexes in the nest in August ${ }^{15}$. I have found males only in nests at Woking and Weybridge in July, August, and September, winged females in plenty in nests at Woking on June 29th, 1912, and males and winged females together in the nests at Bewdley on July 20th, 1909, etc. On September 5th, 1913, I took some micraners, only $6 \mathrm{~mm}$. in length, at Weybridge ; at Bewdley on July 20th, 1909 , micraners ${ }^{64}$ measuring $7 \mathrm{~mm}$., while the largest male met with in that locality was $10 \mathrm{~mm}$. in length. Escherich mentions sanguinea females with short wings ${ }^{55}$, which from what we know of such cases in Donisthorpea, etc., may be mermithogynes; Wasmann records workers of the size of normal females, but with broader thorax and shorter wings, which he classes as gynaecoid macropseudogynes ${ }^{50}$.

Three gynandromorphous specimens of sanguinea have been recorded. Tischbein ${ }^{8}$ found an ergatandromorph in a sanguinea nest on July 28th, 1851, at Herrstein, in which males but no winged females occurred. This may be described as follows :-

Nearly complete lateral ergatandromorph; male on left, worker on right side. In the head, the left mandible, outer third of clypeus, antenna, eye, median and lateral ocellus, are male, though the black colouring also covers the smaller right ocellus. Remainder of head red (worker). Thorax and petiole male on left, worker on right, the line of division being median on the dorsal surface, and the structure of the meso-, meta-, and epinotum correspondingly asymmetrical. Left half of thorax black, right half red, sharply divided above; on the ventral surface the dividing line is median only on the prothorax but passes outside the middle and hind coxa on the male side. Petiole sharply divided into a black male (left) and a red worker (right) half. Gaster black, with a large red blotch on the right side at the base of the first segment. The pilosity and sculpture of the left side are male, those of the right, worker. External male genitalia are present on the left side and the anal sternite is present only on this side. Remaining organs of this region quite malformed. All the legs, and the coxae of the male side, are red and hence of the worker type. Wings of the male (left) side of normal size, but their veins and stigma are paler. There are no wings on the worker (right) side.

This appears to be the first description of a gynandromorphous ant. When examining sanguinea nests at Bewdley I had the good fortune to meet with an ergatandromorph on July 20th, 1909, and a gynandromorph on the following day, both in the same colony ; these I described thus :-

"Nearly complete lateral ergatandromorph; male on right side, worker on left. Right antenna male, left worker. Right mandible, eye, lateral ocellus, and median ocellus male; left mandible, eye and lateral ocellus worker. The head is black, with the exception of the left mandible, left half of clypeus, a small patch before left eye, and left cheek, which are red. Thorax and petiole 
male on right, worker on left, the line of division not being quite straight however, the black colour on the right side of the mesonotum encroaching on the red colour of the left side. Petiole divided sharply, black on right, red on left side. Gaster black, the right half with male pilosity and sculpture, left half worker. External male genitalia are present on the right side, the anal sternite being present only on that side. The red and black colour is sharply defined beneath, but the coxae are all black and red as in the male, and the legs on both sides are somewhat infuscate, the tarsi on the right side being longer. Winged of course only on right side, the veins and stigma are pale, and more like those of the female. Long. $7 \mathrm{~mm}$." 64

"Lateral gynandromorph; male on left side, female on right. Both antennae female, head somewhat small, but female shape, left eye a little larger than right, ocelli female. Head black, with exception of clypeus and right mandible, which are red; greater part of thorax red and black, evenly divided laterally, only the top right corner of the epinotum being red. A bit of the scutellum and post-scutellum on the left side where the wing is joined, red. Petiole sharply divided, red on right side, black on left. Gaster black, the right side with female pilosity and sculpture, left side with that of male. Colour sharply defined underneath. Legs and coxae female on right side, male on left. External male genitalia are present on left-hand side. Fully. winged on both sides, the stigma and veins being darker, as in the male. Long. $9 \mathrm{~mm}$." 64

André gives June and July for the marriage flight of sanguinea ${ }^{28}$, and Schenck July ${ }^{11}$, while Smith suggests August ${ }^{17}$. Forel saw the males and winged females leaving a nest at Vaux from seven to eight o'clock in the morning on July $3 \mathrm{rd}, 1873^{25}$; I have found winged females away from their nests at Bewdley on July 20th, 1909.

Pseudogynes of sanguinea have been observed in numbers, and Wasmann attributes the occurrence of these entirely to the presence of the beetle Lomechusa strumosa in their nests.

I shall not discuss the subject fully now, hoping to deal with it at length on a future occasion, and shall therefore only give the results which Wasmann deduces from his observations on the occurrence of these forms, and my own experience, such as it is, with these curious individuals. He has studied and described numerous forms of them, in Holland and in Luxemburg, and he says :-

(a) The pseudogyne district always coincides with the Lomechusa district.

(b) The pseudogyne-holding colonies are always the centre of the Lomechusa district.

(c) Outside the Lomechusa district pseudogynes are never found in sanguinea colonies.

(d) In colonies where Lomechusa only dwells as an imago, pseudogynes are not produced, but rather only in those in which Lomechusa has brought up its larvae for many years ${ }^{49}$.

On May 22nd, 1908, I found pseudogynes in plenty in a colony of $F$. sanguinea in the New Forest, but after having dug up the 
whole nest, the most careful examination of it on a large white sheet failed to produce either Lomechusa or its larvaes9. This appears to be the first time a pseudogyne has been found in Britain, nor have I been able to detect such specimens in any of the British collections which I have examined. This is the more remarkable, as pseudogynes are very conspicuous objects, especially those of sanguinea, with their hunch-backs and usually lighter colour.

On May 25th, 1906, I discovered Lomechusa strumosa in a sanguinea nest at Woking, no pseudogynes being present, and I have observed this beetle every year since in various nests throughout the sanguinea area, which is not large in that locality. On May 17th, 1907 , I found over sixty specimens of the beetle in a single nest, and for several years I bred it in my large observation nest at home. During all this time, until 1913, not a single pseudogyne was observed at Woking, although specially searched for. In 1913 the beetle appeared to be very scarce, I only saw a single specimen, but on May 12th two nests of the ant situated near to each other contained pseudogynes, quite ten per cent of the ants in one of them consisting of this form ${ }^{82}$. These nests were most carefully dug up, but neither Lomechusa nor its larvae could be found, and the ants, and débris of the nests, were replaced in their original situations. On June 12th, 1914, two colonies of sanguinea were found, their nests occurring in almost the same spots as in the previous year; both contained pseudogynes, though not so plentiful as in 1913, and in one of them two or three Lomechusa larvae were present, in the other over a dozen.

For a number of years Wasmann kept statistical charts of very large colonies (consisting of many nests) of sanguinea, and every credit should be given to him for these exhaustive observations, although my experience which, after all, only consists of more or less negative evidence, does not appear altogether to support his theory. The number of deälated females of sanguinea present in any nest varies considerably at different times : in 1912 I was unable to find a wingless female, when badly wanted for experiments, though the winged females were abundant; but in 1913 deälated females were present in every nest-in one I counted no less than thirty-seven ${ }^{82}$.

Forel states that eggs are first laid by the queens in April ${ }^{25}$, but in captivity I have observed the latter to lay as early as January and February, no doubt on account of the higher temperature of my room.

In queenless nests the workers of $F$. sanguinea lay large quantities of eggs (at any rate in captivity) - the greater number of these eggs are devoured, but those which have come to maturity have (according to Forel, Lubbock, Wasmann, and Viehmeyer) only produced males. Crawley thinks that workers were produced in such a nest 
in his possession, but he is now making further more careful experiments.

In quite young colonies workers only are reared, the males and females only appearing when the colony has reached a certain age ; afterwards worker cocoons occur, chiefly from July to September, but they may occasionally be present, earlier or later, in June and October. Male and female cocoons which I collected in a nest of this species at Rannoch on July 16th, 1913, hatched during the same month. The pupae are usually enclosed in cocoons, but Schenck records finding naked pupae at Nassau ${ }^{9}$, and I found a number of the latter in a nest at Weybridge on July 22nd, 1911.

We have seen that females of the rufa and exsecta groups are unable to found their colonies alone-the females of the sanguinea group are equally incapable of founding such colonies. In 1909 I took a number of fertile females, from Woking, Aviemore, and Bewdley, and isolated them in bowls, with damp sponges and sand, where they remained for months without laying or excavating in the sand, and eventually died ${ }^{71}$; and again in 1910, under similar conditions, fertile females from Woking laid eggs which were left scattered about; these were never attended to, and did not hatch, the females dying ${ }^{73}$. Viehmeyer made similar experiments in 1909, with the same results ${ }^{66}$.

As we have seen, colonies of $F$. sanguinea often spread over a large area, branch and twin nests being formed, and young females are received back into the nests.

One of my observation nests of sanguinea was obtained from Woking in 1910, and when the queen died the next year I collected some more females at Woking and introduced one of them on May 5th, 1911. She was at once accepted by the sanguinea and their slaves, and having lost one antenna and two legs by injury when digging up the nest, was always recognizable. On May 27th, 1911, I introduced a second female, also from Woking but taken from another nest, this also was accepted, as was also another female taken at Woking in June, 1913, and introduced into the nest on December 30th, 1913. All these three females laid eggs every year and lived as queens in this nest until April, 1914, when the whole colony perished.

In 1905 Wheeler pointed out that although isolated sanguinea queens are often seen running about on the ground and seeking suitable nesting sites, no one had been able to show that these insects can found colonies without the assistance of alien workers, and he stated that a sanguinea queen very probably establishes her colony in a depauperate nest of an auxiliary species ${ }^{52}$. Subsequently in 1906, Wheeler proved the possibility of his suggestion by experiments, with the American subspecies rubicunda [Bull. Amer. Mus. NH. 22 33-105 (1906)], and in 1913 he says that in Europe 
"Viehmeyer, Donisthorpe, and Wasmann have shown that the female sanguinea establishes her colony by entering a fusca nest, appropriating some of the pupae and killing or driving away any of the fusca workers that venture to attack her or seek to deprive her of her booty. She guards the kidnapped young, and eventually helps them to hatch, thereby surrounding herself with a troop of nurses for her own brood as soon as she begins to lay. This method of colony formation in the typical sanguinea is the same as that first described by myself [W. Wheeler] for our American subspecies rubicunda and subintegra."79

Since Wheeler first suggested how sanguinea queens found their colonies, a number of observations in nature and experiments with captive ants of these species have been published, making us acquainted with the different stages of colony founding.

In the summer of 1898 Schmitz saw a female $F$. sanguinea endeavouring to enter the different doors of a $F$. fusca nest, near Exaeten, going in by one door, then coming out and re-entering by another, and so several times backwards and forwards; the numerous $F$. fusca workers about did not hinder her, but Schmitz is now unable to remember if she was finally accepted ${ }^{61}$.

Wasmann records that he once found at Exaeten in Holland a dead sanguinea female in a rufibarbis nest, held by the legs and antennae by a number of the rufibarbis workers ${ }^{61}$. On September 15th, 1887, he observed at Exaeten a small sanguinea-fusca colony in which the sanguinea workers were all small and not fully coloured, their numbers at the most not exceeding a hundred individuals, while the fusca workers to the number of about two hundred were all large and mature, the only queen present being a sanguinea female ${ }^{51}$. Again on May 23rd, 1889, in the same locality, he discovered a very small colony consisting of only ninety fusca workers, a sanguinea queen, and five freshly-hatched workers of the latter 5161 .

In the spring of 1909 Forel, when in company with Wheeler and Viehmeyer, found in Valais, under a stone, two fertile sanguinea females in the middle of a small heap of cocoons of $F$. rufibarbis and some workers of the latter, the little colony also containing a dozen small sanguinea workers, which were older than those of the rufibarbis. ${ }^{65}$

Viehmeyer also records the last observation, and in the middle of August of the same year, near Dresden, he found under a stone in a small earth-hole a sanguinea female, two very small sanguinea workers, and three equally small fusca workers. On searching further, a fusca female was discovered, two more fusca workers, and some pupae. This made him think of an alliance between the sanguinea and fusca females, as the workers of the former were certainly not younger than those of the latter. He put a sanguinea and fusca female together, and in four days they were quite friendly 
together, but subsequently the nest went wrong, and they both died on the same day 6 .

In 1911, 1912, and 1913 I tried numerous similar experiments, all of which were failures, for although the strange females generally become friendly, resting side by side and cleaning each other, etc., and often living together for months, before any results were obtained one or the other has died.

On July 3rd, 1913, Crawley found a sanguinea-fusca colony (situated in a tree-stump at Weybridge) consisting of an equal number of workers and cocoons of both species, the sanguinea all being small. He took as many of the pupae as he could obtain, which subsequently hatched and produced thirty-five sanguinea workers and thirty-four fusca workers. The situation of the nest prevented him from digging it up properly to ascertain if a fusca queen was present as well as a sanguinea ${ }^{83}$.

On May 1st, 1914, Pinkney discovered a small colony at Woking (situated in a bank) which consisted of a sanguinea queen, sixty to eighty very small sanguinea workers, and three fusca workers ${ }^{84}$. The six cases mentioned above are, as far as I am aware, all the incipient colonies of $F$. sanguinea that have been recorded in Europe.

In 1910 Wasmann enumerated the following six ways in which he suggests fertile sanguinea females may found their colonies :-

1. With the help of workers of their own colony : by branch nests.

2. With the help of workers of a strange colony of their own species : by the adoption of the female into a strange colony.

3 . With the help of grown-up workers of the auxiliary species : by the adoption of the sanguinea female into independent colonies of fusca or rufibarbis.

4. With the help of worker pupae taken by force from the auxiliary species: colony-founding by a pupa raid.

5. With the help of pupae of the auxiliary species, which sanguinea workers had left behind when plundering a slavenest: colony-founding with pupae found. [After a slave raid at Lippspringe which Wasmann observed on July 21st, 1909, he found a number of fusca pupae left behind which the sanguinea workers had either forgotten or intended to come back for, and in any case he suggests a sanguinea female wandering about after the marriage flight might easily have discovered them and appropriated them to bring up her brood when hatched. This is quite feasible, for when I introduced fusca pupae to some of my isolated sanguinea females they sometimes collected them and rested on the top.]

6. With the help of females of the auxiliary species, when a sanguinea and a fusca, or rufibarbis, female find themselves 
together after the marriage flight: colony-founding by Allometrose ${ }^{68}$. [Wasmann's allometrose $=$ an alliance between females of different species or races to found a mixed colony.]

A number of experiments have been carried out, in captivity, on the behaviour of $F$. sanguinea females, when introduced to colonies of $F$. fusca and its races, but only a few can be given here to illustrate what takes place.

In $1909 \mathrm{I}$ carried out some thirteen experiments, only two of which were successful, in all the others the sanguinea female was either killed at once by the fusca workers or died subsequently from injuries received from them. One difficulty in these experiments is that it is not possible to provide a means for the female to escape, as she could under natural conditions. In order to test this question in the most exhaustive manner, we require a young female just after her marriage flight, and also a small, or impoverished, fusca colony, both of which are exceedingly hard to find, especially just when wanted. I therefore made up small colonies of fusca, and its var. glebaria, by putting a limited number of workers and pupae into a combined "Fielde and Janet" nest, and introduced sanguinea females. I used both old deälated and doubtless impregnated females, and young winged virgin females, taken from sanguinea nests. From the latter I removed the wings, as Wheeler has shown that when the wings of a Formica female are removed, she acquires the instincts of an impregnated female.

No. 1. A small colony of $F$. fusca, consisting of workers and larvae taken at Sherwood Forest on June 13th, 1909.-June 24th, a sanguinea female, taken in a nest at Aviemore on May 17th, was introduced. She still retained one wing, which was removed. The fusca workers ran away when the female first approached them, but later attacked her. She retaliated by biting, and in the evening they were still fighting. The female did not pay any attention to the larvae, and did not try to conciliate the workers, but ran away from them.- June 25th, five workers had been killed by the female, and the remainder were in the passage between the two compartments with the larvae.-June 27 th the workers still occasionally attacked the female, several of them were killed.June 28th, the female appeared to be accepted by the workers, as they were all resting together, and several were cleaning the female. - July 2 nd, the female was dead, no doubt from injuries received in the previous encounters.

No. 2. July 4th, 1909, introduced deälated sanguinea female taken at Woking, May 5th, into a small fusca colony with pupae. The female approached the pupae, tapped them with her antennae, and was evidently much interested in them. The workers removed the pupae, but the female was only slightly attacked, and repulsed the workers. A little honey was given to the ants, and the female 
and workers fed side by side.-July 5th, the female had collected all the pupae into a corner and rested on them; two workers were with her, but several others were dead and injured.-July 6th, the female was on guard over all the pupae in one corner, and all but three of the workers had been killed. They tried to remove the pupae one by one, but the female brought them back again. Some pupae and larvae from a fusca nest from Weybridge were introduced, and the female collected them all together into her corner.July 15th, only two workers not killed, these were quite friendly with the female, all resting together on the pupae. All went well, and they all remained on friendly terms till the termination of the experiment.

No. 9. On July 12th, 1909, Hamm sent me a small fusca colony from Shotover, near Oxford, which contained many pupae and workers.-On July 23rd the wings were removed from a virgin sanguinea female (taken at Bewdley); she was first placed in a tin with some pupae, and afterwards introduced into this colony on July 24th. She killed two workers, which attacked her, and later captured some of the pupae, on which she rested in a corner, the workers collecting the remainder into another corner. Later she injured a worker, killed another which fastened on to her leg, and captured more of the pupae.-July 25 th, all the workers but one were killed, the female resting on all the pupae in a corner.July 26th the female carried the pupae about and arranged them all together. A few glebaria workers were introduced into the nest, and when these approached the pupae the sanguinea female sprang forward, seized and shook them, as a terrier shakes a rat, killing them all. This experiment differed slightly from the previous one in that the female killed all the workers, and took possession of all the pupae ${ }^{71}$.

In none of the thirteen experiments when a sanguinea female was introduced into a glebaria colony was she accepted by the workers; she was always killed by them, generally the same day.

In one of my experiments carried out in 1912 the result demonstrates how powerfully a female sanguinea can resist when attacked, and where if she had been living in nature she might possibly retire and escape. On July 10th a sanguinea female sent to me by Martineau from Bewdley was placed in the light chamber of a nest containing a strong colony of $F$. fusca from Porlock, and blocked in by herself with cotton-wool as I was going away for a couple of days. On my return on July 13th I found the fusca workers had forced an entrance, the sanguinea female was dead, and no less than fifteen dead fusca workers lay beside her. ${ }^{78}$

The next two experiments show that not only do artificially deälated virgin females exhibit the same instincts as newly fertilized self-deälated ones, but that they also lay eggs.

On July 2nd, 1912, I removed the wings from a young virgin 
sanguinea female taken at Woking in a sanguinea nest, in which no males were present. She was introduced into the light chamber of a small plaster-nest with two divisions, the dark chamber of which contained seven fusca females, three fusca workers, a few larvae and one cocoon. (This small brood had been brought up by these ants, which had been taken from a fusca colony at Hynish, Tiree, in April.) The sanguinea female soon entered the dark chamber; the fusca females and workers ran away and hid in corners, and later in the day all but one female had gone into the light chamber, taking the larvae with them, but the sanguinea female had captured the cocoon, which she held in her jaws. On July 3rd all the fusca workers had been killed and the sanguinea female was again holding the cocoon in her jaws, the fusca females being all huddled together in one corner with the larvae. July 4th, one of the fusca females had been killed, and the sanguinea female had collected the two largest larvae and the cocoon. Four of the fusca females were now removed, being required for other experiments. July 5th, the two remaining fusca females had been attacked, one having had both her antennae bitten off, and on July 7th both were dead and the sanguinea female was resting on the cocoon and the two larvae. July 8th, a naked pupa from a fusca nest from Porlock was introduced, and the sanguinea female added it to her collection. July 9 th, the female still resting on her heap, ten fusca cocoons were introduced; these she also collected and placed with the others. July 13th, the Tiree cocoon produced a callow, and the empty case had been carried into the next compartment. The largest larva had changed into a naked pupa, and the sanguinea female and the callow were resting together on the other cocoons and on the two naked pupae and the small larva.

July 14th, another empty pupa case was found in the light compartment, but as no second callow had hatched, the female must have eaten its contents. July 15 th, a second callow emerged, and on the 17th a third, whilst a single egg was present. July 18th, a fourth callow appeared, and the egg had vanished, the female was still helping to carry about the cocoons ${ }^{78}$, and by August 10th eleven fusca workers had hatched. During the whole of 1913 nothing of moment happened in this small colony; a fusca worker escaped on March 18th; one died on September 1st and two more on November 5th ; two more workers died before January 20th, 1914, three more in February and another in March. On April 4th the sanguinea female had laid a small packet of eggs, and on the 10th she was holding them in her jaws, the one remaining fusca worker resting beside her. On April 15th the eggs had disappeared, but on the 17th more were laid, and the worker carried them about. The number of eggs increased, but they did not hatch, and on May 25th they were found to be mouldy, so I transferred the Queen and the worker to a small "Crawley-Lubbock" earth-nest. On June 2nd, 
1914, when I introduced a few small fusca cocoons, hoping the queen might lay again and have a larger family of workers to look after her eggs, she was unfortunately crushed and died two days later.

On July 25th, 1912, Crawley placed an artificially deälated virgin sanguinea female in a glass-topped box containing two workers, a number of pupae, and a callow of glebaria from the New Forest, when the two adult workers each seized a pupa and fled to the top of the box, where they remained, holding the pupae for two days without having been observed to move. The sanguinea female took no notice of either workers or pupae until the next day, when she collected the pupae together and rested on them with the callow; more callows hatched from day to day; the two mature workers were found dead on July 28th. By the 31st there were ten callows with the female on the pupae and all were on good terms ${ }^{78}$. Crawley tells me that all the pupae hatched, and that the female laid eggs in the spring of 1914, and at the present time a pupa and some large larvae are alive; these are presumably the brood of the sanguinea female. Wasmann performed some experiments with young fertile sanguinea females and found that fusca workers adopted them readily, but Viehmeyer, and subsequently Wasmann himself, found that sanguinea females pillaged the cocoons and killed the fusca workers. It would therefore seem that this violent method is the more usual.

If Darwin had known, as we know to-day, that the queen sanguinea does not herself found her colony, but from the very first steals the fusca pupae, one of his greatest difficulties would have been removed, viz. why it is that workers, which do not normally breed, inherit the slave-making instinct ${ }^{2}$.

The following myrmecophiles have been taken with $F$. sanguinea in Britain :-

Coleoptera : Oxypoda recondita Kr., O. haemorrhoa Sahl., Dinarda dentata Gr., Lomechusa strumosa F., Myrmedonia limbata Pk., Drusilla canaliculata F., Notothecta flavipes Gr., Lamprinus saginatus Gr., Quedius brevis Er., Othius myrmecophilus Kies., and Hetaerius ferrugineus $\mathrm{Ol}$.

Formicidae : Leptothorax acervorum F., and L. nylanderi Först.

Ichneumonidae: Pezomachus intermedius Först.

Braconidae : Pachylomma baccata Nees.

Proctotrupidae : Proctotrypes gravidator L.

Diptera : Pseudacteon (=Phora) formicarum Verrall.

Heteroptera : Alydus calcaratus L. (larva and nymph), Nabis lativentris Boh. (larva), and Pilophorus perplexus D. and S.

Collembola : Cyphodeirus (=Beckia) albinos Nic.

Araneina: Evansia merens Camb., Micaria pulicaria Sund., Micarisoma festiva C.K., Dysdera cambridgei Thor., Harpactes hombergi Scp., and Theridium riparium Blkw. 
Acarina : Laelaps myrmecophilus Berl., and L. cuneifer Mich.

Crustacea : Porcellio scaber v. rufa Bagnall, and Platyarthrus hoffmanseggi Brdt.

\section{Formica fusca $L$.}

Formica fusca Linnaeus Syst. Nat. (Ed. 10) $1580(1758)^{1}$. ["Grande Fourmie noire" De Geer Mém. Hist. Ins. $\left.21082(1771)^{2}\right]$. Formica nigra major Retzius Gen. Spec. Ins. De Geer $75(1783)^{3}$. Formica flavipes Fourcroy Entom. Paris. $2452(1785)^{4}$. Formica fusca Fourcroy Entom. Paris. $2453(1785)^{5}$; Razoumowski Hist. Nat. Jorat. $1224(1789)^{6}$. Formica tristis Christ Naturg. Ins. $513(1791)^{7}$. Formica nigra Latreille Ess. Hist. Fourmis France 39

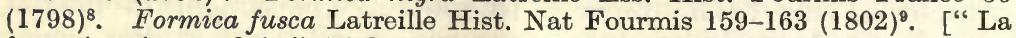
fourmi noire-cendrée" Huber Mœurs Fourmis 43-51 (1810)10]. Formica fusca Westwood Introd. Mod. Class. Ins. 2 Synops. $83(1840)^{11}$; Nylander Acta. Soc. Sc. Fenn. $2919(1846)^{12}$ : 327 (1849) $^{13}$; Schenck Jahrb. Ver. Naturk. Nassau $811^{14} 43-45^{15}$ (1852) ; Mayr Verh. Zool. Bot. Ver. Wien 5 346-347 $(1855)^{16}$; F. Smith Trans. Ent. Soc. Lond. (n.s.) 3104 (1855) ${ }^{17}$ : Cat. Brit. Foss. Hym. $9(1858)^{18}$; A. Müller Ent. Mo. Mag. $9120(1872)^{19}$. Formica fusca r. fusca Forel Denkschr. Schweiz. Ges. Naturw. $2654^{20} 165^{21}$ $217^{22} 357^{23} 399^{24} 408^{25}$ (1874). Formica fusca Forel Bull. Soc. Vaud. Sc. Nat. $1460(1875)^{26}$; Saunders Trans. Ent. Soc. Lond. $1880207^{27}$; H. Müller Alpenblumen $591(1881)^{28}$; Er. André Spec. Hym. Europe $2182(1881)^{29}$; Lubbock Journ. Linn. Soc. Zool. $15384(1881)^{30}$ : Ants, Bees, Wasps $34^{31}$ 38-3932 $91^{33}$ (1882) : Journ. Linn. Soc. Zool. $20133(1888)^{34}$; Dalla Torre Cat. Hym. 7196 (1893) $^{35}$; Wasmann Biol. Centralb. 15617 (1895) ${ }^{36}$; FarrenWhite Ants' Ways 233-234 253 (1895) ${ }^{37}$; Saunders Hym-Acul. $22(1896)^{38}$; Malloch Ent. Mo. Mag. $4042109(1904)^{39}$; Dalglish Ent. Mo. Mag. 4087 $(1904)^{40}$; Janet Obs. Fourmis 34-35 (1904) $)^{41}$; Wasmann Biol. Centralb. $25193(1905)^{42}$; Donisthorpe Trans. Leicester Lit-Phil. Soc. $12223(1908)^{43}$; Wasmann Biol. Centralb. $29663(1909)^{44}$ : Arch. Trim. Inst. R. Grand Ducal Luxemburg 4 75-81 (1909) ${ }^{45}$; Arnold Ent. Mo. Mag. 45278 (1909) ${ }^{46}$. For mica fusca fusca Emery Deutsch. Ent. Zeitschr. 1909 196. ${ }^{47}$. Formica fusca Silverlock Nat. $3513(1910)^{48}$; Wheeler Ants $174^{49} 654^{50}$ (1910); Donisthorpe Trans. Ent. Soc. Lond. $1910144^{51}$ : Ent. Rec. $2311(1911)^{52}$ : Entom. 44390 (1911) ${ }^{53}$ : Ent. Rec. 247 (1912) $)^{54}$ : $2566^{55} 268^{56}$ (1913); Crawley and Donisthorpe Int. Ent. Cong. Oxford 19122 31-34 (1913) ${ }^{57}$. Formica fusca fusca Wheeler Bull. Mus. Compar. Zoöl. $53494(1913)^{58}$. Serviformica (Formica) fusca Forel Ann. Soc. Ent. Belg. $57361(1913)^{59}$.

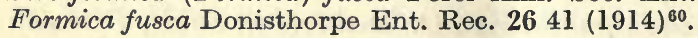

Dalla Torre ${ }^{35}$ queries $F$. barbata Razoumowski [Hist. Nat. Jorat. 1225 (1789)], and F. capsincola Schilling [Ubers. Arbeit. Schles. Ges. Vaterl. Kultur 1838 54, (1839)] as synonyms of $F$. fusca L. The description of the former does not agree with fusca, and the latter as pointed out by Roger [Berlin Ent. Zeitschr. 117 (1857)] more probably refers to Donisthorpea nigra L.

$\Varangle$ Black, mandibles, scape, base of funiculus, tibiae, tarsi, and articulations of the femora reddish brown; femora blackish brown; hairs short and sparse, pubescence white, more abundant, especially on gaster; puncturation fine and close, being somewhat shagreened, especially on the gaster.

Head longer than broad, narrowed anteriorly, not emarginate posteriorly ; clypeus entire, somewhat pointed anteriorly, carinate for its whole length; frontal area dull; eyes large, bare; mandibles armed with eight teeth; antennae slender, scape slightly thicker at apex, funiculus slightly thickened towards apex with joints two and three slightly narrower but not longer than the rest. Thorax narrow, depressed above, not very convex; con- 
striction between mesonotum and epinotum shallow; epinotum horizontal above and sloping at the base, both surfaces when seen in profile straight, and forming a distinct angle at their juncture. Scale rounded, gaster small. Long. $3 \cdot 8-6 \cdot 8 \mathrm{~mm}$.

+ Black somewhat shining, legs and antennae darker or lighter reddish brown. I possess a specimen from Scotland in which the mandibles, scapes, and legs are clear yellow. The colour and pubescence is much as in the worker.

Head, without mandibles, about as broad as long, somewhat rugosely punctured, the sculpture being rough and close, but formed of distinct, close punctures, without small scattered punctures; clypeus entire, carinate; frontal area dull and punctured. Thorax broader than head, with very sparse hairs, somewhat pubescent; mesonotum distinctly punctured, especially anteriorly, alutaceous between the punctures, with some scattered larger, and small, punctures; scutellum nearly smooth in centre, punctured at sides, somewhat shining. Scale broader than in the $\not{q}$, rounded; gaster almost without hairs except the bristles on the margins of the segments, distinctly punctured and pubescent. Wings slightly yellowish, pterostigma brown. Long. 7-10.6 mm.

o Black, scapes dark brown, tips of mandibles brownish yellow, legs and genitalia yellow, last joint of tarsi, and femora sometimes darker.

Head narrowed anteriorly, broad posteriorly; clypeus entire, convex, carinate; frontal area dull, punctured. Thorax broader than the head, with very sparse, short black hairs; mesonotum dull, closely punctured. Scale not or only slightly and widely emarginate at apex, glabrous; gaster long, narrow, shining, very finely punctured, with short, close pubescence, but without outstanding hairs. Wings greyish, a little darker than in the ㅇ. Long. 7-8.5 mm.

Original description of Formica fusca Linnaeus [Syst. Nat. Ed. $101580(1758)]$ :-

" F. cinereo-fusca, tibiis pallidis.

Fn. suec. 1022. Formica fusca.

Raj. ins. 69. Formica media, nigro colore splendens.

Habitat in Europae terra sabulosa."

\section{Habitat.}

Formica fusca is widely distributed through North and Central Eurasia; but in Southern Europe occurs only in mountainous country, and there often at considerable elevations (up to 2400 metres in the Alps, according to Forel). This form is also widely distributed through Boreal America. Wheeler states that on careful examination he is unable to detect any important differences between the form which he described as the var. glacialis from Maine and the true European fusca. The wings of the males and females in the American form are perhaps slightly darker, but the tint is variable in European specimens. The sculpture, colour, and pubescence are identical in the two forms. The specimens from Newfoundland, including in all probability those from St. Pierre and Miquelon, Newfoundland, mentioned by Emery [Zool. Jahrb. Syst. 7660 (1893)], and the specimens from Nova Scotia and New Brunswick agree very closely with the co-types from Maine. The western forms are often a little more like subsericea in pubescence 
and may be rrgarded as a transitional to that variety. Should it be possible or further study to detect any satisfactory differences between American and Eurasian specimens, the term glacialis would, of course, have to be reinstated ${ }^{58}$.

In Britain $F$. fusca is very widely distributed, but does not, as far as I know, range higher than an elevation of 2000 feet-in 1910 I found it in numbers on Beinn-a-Bhuird, a mountain at Braemar over 4000 feet high, with perpetual snow on the top, but the fusca colonies which were under stones, appeared to cease below 2000 feet ${ }^{52}$.

I have no records in England, from South Wilts, Herts, Hunts, Northampton, East Gloucester, Monmouth, Hereford, Salop, South-East Yorks, Isle of Man ; in Wales for Brecon, Cardigan, Montgomery, and Carnarvon; and in Scotland, Selkirk, Roxburgh, North Aberdeen, Banff, North Ebudes, East Ross, East and West Sutherland, Caithness, the Hebrides, the Orkneys, and the Shetlands. In Ireland I have records only from Antrim, Down, Armagh, Tyrone, Donegal, Fermanagh, Louth, Dublin, Kildare, Wicklow, Carlow, Westmeath, West Mayo, Clare, North Tipperary, South Cork, and Kerry.

Formica fusca, which according to Wheeler is indistinguishable by any satisfactory characters from the $F$. flori Mayr of the Baltic Amber ${ }^{49}$, is an abundant and widely distributed species, nesting in woods, meadows, and uncultivated places, but also occurs in gardens, under the steps and foundations of houses, in walls, etc. It prefers damp and shady places, but can also live in sunny and dry spots, and its nests are situated under stones and logs, in rotten tree stumps, and fallen branches, in banks and at the roots of herbage, etc. I have found it occupying the deserted nests of $F$. rufa and $F$. exsecta ${ }^{60}$, but it never, of its own accord, heaps any vegetable refuse over its nests, though it sometimes constructs an earthen mound. Its methods of building its chambers and galleries are not so elaborate nor so perfect as those of Donisthorpea nigra; Huber describes the architecture of $f u s c a^{10}$, but as Forel has pointed out this is not as regular nor as complete as stated by the former author ${ }^{21}$.

The colonies of fusca are usually only of medium size, and often very small ; very large ones being of rare occurrence.

In September, 1911, I observed a very small race of fusca, the nest of which was situated under a stone on the Isle of Eigg ${ }^{54}$; the ground beneath being too stony to allow the nest to be properly dug up, no female was found, but all the workers were exceedingly small, measuring little over $4 \mathrm{~mm}$. in length.

F. fusca is a shy and cowardly ant, fleeing before danger, and as it is abundant, it naturally lends itself to exploitation by other species. It is very agile and rapid in its movements, but possesses no tactics, not knowing how to effect a combined defence of its 
nests, and though the hidden entrances of the latter enable it to live close to and in the neighbourhood of other species, it is always liable to be raided by them. The workers do not forage together in troops, but go out singly hunting insects, attending Aphidae on bushes, etc., and visiting flowers - they may frequently be seen in the flowers of umbelliferae, and $H$. Müller records thirty-eight visits of fusca workers to different flowers, twenty-four to alpine plants alone ${ }^{28}$.

Dr. Chapman observed workers of $F$. fusca attending beetles (Larinus onopordi) on thistles at Gavarnie on July 29th, 1914, four or five ants being at work on a single beetle; they were not attacking the insect, and it would seem they were obtaining a secretion of some sort from it.

The workers may be seen returning to their nests, bringing in flies, remains of beetles and other insects, and they will attack the males and females of Donisthorpea nigra and flava, etc., after the marriage flight, and carry them off as food.

Lubbock writes of the hunting habits of this ant as follows :-

"Some species, such as Formica fusca, live principally on the produce of the chase; for though they feed partly on the honeydew of aphides, they have not domesticated these insects. These ants probably retain the habits once common to all ants. They resemble the lower races of men, who subsist mainly by hunting. Like them they frequent woods and wilds, live in comparatively small communities, and the instincts of collective action are but little developed among them. They hunt singly, and their battles are single combats, like those of the Homeric heroes." 33

It is not, however, correct to say that $F$. fusca has not domesticated aphides, as although Forel stated that the ants of the genus Formica never rear plant-lice in their nests, but only seek them on plants, on September 9th, 1874, he observed at Andermatt a number of large yellow root A phidae in a nest of $F$. fusca under a stone, and he saw the ants carry them into safety. He remarks that this is the only time he had seen these insects in a fusca nest, but he must modify his former statement ${ }^{26}$. I have frequently found aphides in fusca nests, comprising some six species, and on October 25th, 1908, I captured a fusca worker at Luccombe Chine, which was carrying an aphis in its jaws home to the nest situated in the side of the cliff.

Lubbock kept individual specimens of this ant alive for considerable periods; he possessed workers which were at least seven years old, and two queens which were much older. He says :-

"One of these queens, after ailing for some days, died on the 30 th July, 1887. She must then have been more than 13 years old. I was at first afraid that the other one might be affected by the death of her companion. She lived, however, until the 
8th August, 1888, when she must have been nearly 15 years old, and is therefore by far the oldest insect on record." 34

He also had, in 1880, five queens developed in one of his fusca nests, and as the nest had been under observation since April, 1879, the eggs must have been laid in captivity. He suggests that, as the nest had been richly supplied with animal food, this may possibly account for the fact, and that ants possess the power of developing a given egg into either a queen or a worker ${ }^{30}$.

As far as I am aware this is the only case in which a queen has been developed from eggs laid in captivity (see footnote p. 42).

Microgynes are often abundant in colonies of this species; Wasmann records such females in fusca nests at Exaeten in August, $1890^{36}$, and subsequently in plenty at Luxemburg ${ }^{45}$; Arnold found winged microgynes in three nests of fusca in the New Forest in July, 1909; he says no normal females occurred, but normal males were present in two of the nests ${ }^{46}$; and Mitford gave me a very small deälated microgyne, which he had taken in a colony of fusca at Rothes in Morayshire in 1912, this specimen being no larger than a medium-sized worker. ${ }^{55}$

I found these small females in abundance in fusca nests at Tenby in April, $1913^{60}$, all being deälated and in company with normal deälated queens, and again on Lundy Island in June of the same year, some specimens being winged and others with wing stumps ${ }^{56}$.

Wasmann describes a number of forms of $F$. fusca pseudogynes from Holland and Luxemburg ${ }^{44}$, but $I$ do not know of a single pseudogyne of fusca ever having been found in Britain.

Forel has found the males and winged females in the nests in Switzerland in June, July, and August ${ }^{25}$, and I have found them in the nests in Britain in the same three months, and also in September; sometimes they occur together, sometimes only one sex will be present in a nest.

Malloch records finding a winged female in a fusca nest in April ${ }^{39}$, Dalglish says he has seen them in March ${ }^{40}$, and Crawley and I observed twelve winged females in a fusca nest at Porlock on April 27th, 1911, but these are only cases where they have passed the winter in the nest, not having left for the marriage flight the year before.

Schenck says this species swarms in July and the beginning of August ${ }^{15}$, Mayr midsummer ${ }^{16}$, and André the middle to the end of the summer ${ }^{29}$. A. Müller records that at 8.50 in the morning of August 18th, 1872, he captured a female $F$. fusca which was flying across the road, at South Norwood, with a drooping flight, and he found that she was in simultaneous copulation with two males aside of each other ${ }^{19}$.

It appears to me more probable that the species Müller caught was really Donisthorpea nigra; it is doubtful whether any of the 
females of Formica carry the males, which are as large as the females, during the marriage flight, and it seems impossible that a female could fly, carrying two specimens at once. The early morning is certainly not the time for the marriage flight of $D$. nigra, but as the males were so fixed in the female that gentle pulling was not enough to sever them, they might well have remained in this condition since the evening before.

There does not appear to be any other record of the actual copulation of $F$. fusca, supposed, or otherwise.

I captured a female fusca on the wing at Oxshott on July 7th, $1912^{55}$, and found a winged female and several freshly deälated ones running on paths at Weybridge on July 29th, 1913-a marriage flight having probably taken place that day-and a male flying near Lake, Isle of Wight, on August 26th, 1913.

Wasmann suggests that the marriage flight takes place near the nest ${ }^{45}$, which would account for the number of deälated females often found in one nest, most of them having been received back into their own community, for, as we shall see presently, fusca colonies receive a strange fusca female with the greatest animosity.

Silverlock records finding eighteen deälated females in a fusca nest under a large stone near Halifax ${ }^{48}$, and I have frequently found many queens in a single fusca nest-in the County Meath, at Tenby, and on Lundy, etc.

It is a curious fact that fusca nests which contain a number of females are not as a rule more populous than those which possess only one.

The eggs are first laid in April, and worker pupae occur in nests up to the beginning of the winter.

Eggs laid by workers in queenless nests have, according to Lubbock ${ }^{32}$ and others, only produced males.

The pupae of this species are enclosed in cocoons, but naked pupae also occur-Schenck records finding them at Nassau ${ }^{14}$, I found naked female pupae in a fusca nest at Weybridge on July 18th, 191255, naked worker pupae in numbers at Box Hill on July 30th, 1913, and also in Parkhurst Forest on August 23rd, 1913 , in a nest under a fallen branch ${ }^{60}$.

The workers carry out the empty cocoons, after the ants have emerged from them, and scatter them outside the nest.

The females of the $F$. fusca group undoubtedly found their colonies unaided, incipient colonies having been observed in nature, and have also been brought up in captivity. As has been already stated, a fusca female will not be received into a strange fusca colony, the workers always attacking and killing her.

Forel says he has often seen fertile fusca females running in the neighbourhood of a strange nest of her own species, and when she has encountered workers of the latter they have at once killed 
her ${ }^{24}$; Lubbock records cases in which fertile females, introduced into queenless nests, were ruthlessly attacked ${ }^{31}$; Crawley made several experiments with fusca queens and colonies of fusca, both with and without queens, in all of which the strange females were attacked $^{57}$, and I have frequently endeavoured to introduce fusca females into observation nests containing strange colonies of their own species, but these queens have always been killed.

There are however a few cases on record in which fusca females have been accepted by strange races in observation nests.

On June 1st, 1909, I introduced some workers of Formica fusca var. glebaria taken in April at Whitsand Bay into a small glass bowl, which contained sand, and a deälated female $F$. fusca taken at Bradgate Park in May-the female had laid a few eggs in a small chamber underneath a piece of damp sponge. On June 27th the rest of the glebaria workers taken at Whitsand Bay were introduced, the queen was not attacked, and on July 4th all the workers had collected under the sponge with her ${ }^{51}$.

In October, 1909, Crawley introduced a number of $F$. subsericea workers obtained in the United States to a female $F$. fusca from England, and all were friendly with the queen. In 1912 the colony was still in existence, and a few subsericea workers were still alive, though a large number of fusca workers were present reared from eggs laid by the queen ${ }^{57}$.

It seems unlikely, however, that in nature a colony of fusca, or its races, would be founded in any other way than by the normal, viz. by one or more queens without workers.

On June 25th, 1906, Wasmann found at Shötter Marial two young fusca colonies under stones, the one containing a queen, with six small workers, and a dozen worker larvae and pupae, and the other two queens, six small workers, and a dozen half-grown larvae ${ }^{44}$. In the latter case two young queens must have joined together to bring up their family. For some years past I have experienced considerable difficulty in finding a single nest of $F$. fusca at Weybridge, which $I$ attributed to the fact that $F$. sanguinea had spread over the district and by continual raids had nearly exterminated the fusca colonies, but in June, 1914, I found a number of small colonies, under gorse roots and at the foot of fir stumps, etc., many of them being incipient colonies containing only a few small workers and brood. A number of males and females must have been reared in some isolated nest, or nests, and a fair proportion of the females, after the marriage flight, had successfully founded new colonies.

In the following cases broods have been brought up by females from their eggs laid in captivity.

Wasmann, in April, 1886, found a fertile female fusca running about at Exaeten, and placed her in a small glass with some damp earth and food. He did not look at it again till June 14th, when 
he saw the female resting in a small hole in the earth, with six worker cocoons and two full-grown larvae ${ }^{42}$.

Janet, in 1904, placed a fusca female, which had got rid of her wings on July 8th, in an observation nest, and in a few days a fairly large packet of eggs was laid, which soon hatched. On July 28th the first larva spun its cocoon, and on August 22nd the first callow made its appearance ${ }^{41}$.

On September 14th, 1910, I took five fusca females from a colony, nesting under the bark of a tree stump in a bog at Balrath, Co. Meath, which contained very many females. On September 17th, when I reached home, they were placed in a plaster nest, where they all laid eggs, which they carried about, but which all eventually disappeared. Three of these females were taken away for other experiments, and the remaining two lived together all through 1911. January 31st, 1912, one of them laid a few eggs, which she held in her mandibles-February 6th both females holding bunches of eggs : they were quite friendly and sometimes one alone carried all the eggs-February 27th eight larvae present, three of which pupated on March 2nd, the number increasing to seven by the 11th-March 24th a fresh batch of eggs laid-April 1st the first fusca callow hatched, carried about by one of the femalesApril 3rd a second callow appeared-April 4th another present, but it was dead-April 8th a third callow hatched, assisted by the other two-April 7th more eggs had been laid, carried about by the tiny workers-May 14th small bunch of larvae present carried by the workers-May 19th a fourth callow present. By June 6th one of the females had a swollen gaster, but the other, which had been ailing for some time and was of normal size, was dragged by an antenna by one of the workers, and as ants do not drag another by the antennae when their motives are friendly, this would seem to be a hostile act: at any rate this female was dead on June 7th, and put in the outside chamber ${ }^{57}$. The female with the swollen gaster and the four little workers lived together for some time, more eggs were laid, but no further brood was reared. One of the four workers died on November 26th, 1912, two more on January 27th, 1913, and the fourth on February 4th, 1913, the queen dying on March 4th, 1913.

On April 25th, 1913, I brought home a number of fusca females taken in nests at Tenby, June 9th microgynes from Lundy, and July 29th some rufibarbis queens taken in a nest at Weybridge, all of which were placed in the same small plaster nest. January lst, 1914, one fusca female, one microgyne, and one rufibarbis female were introduced into a small "Crawley-Lubbock" earth nestApril 2nd eggs present, each female carrying them about in turnMay lst small larvae present, carried equally by the large fusca, and the rufibarbis females (from this time forward the microgyne paid no further attention to the brood)-May 25th two cocoons 
and seven larvae present-June 1st all larvae in cocoons-June 8th the rufibarbis queen with a small packet of eggs in her jaws, only five cocoons and one empty case, but no worker, present-June 21st only four cocoons and a bunch of eggs present, the empty cocoons being buried in a small hole dug in the earth and filled up againJuly lst three small fusca callows hatched-July 4th a fourth callow present, four small larvae and three larger ones-July 10th four of the larvae in cocoons, only one other larva present-July 15th the rufibarbis female had her head bitten off. This would seem to show that fusca and rufibarbis females will not found colonies together, and in this instance the latter's brood was not allowed to develop.

The under-mentioned species of myrmecophiles have been taken with Formica fusca in Britain :-

Coleoptera: Homoeusa acuminata Märk., Aleochara ruficornis Gr., Atemeles emarginatus Pk., Myrmedonia limbata Pk., Drusillả canaliculata F., Lamprinus saginatus Gr., Neuraphes carinatus Muls., Batrisodes venustus Reich., Trichonyx märkeli Aub., and Hetaerius ferrugineus $\mathrm{Ol}$.

Formicidae : Ponera coarctata Latr., Myrmecina graminicola Latr., Stenamma westwoodi West., and Leptothorax acervorum F.

Braconidae: Spilomma falconivibrans Morley, and Chasmodon apterum Nees.

Proctotrupidae: Antaeon brevifilis K., Gonatopus striatus K., Lagynodes pallidus Boh., Plesiobaeus hospes K., Synopeas sp.?, Trichopria formicaria K., and Embolemus ruddi West.

Cynipidae : Rhoptromeris formicaria $\mathrm{K}$.

Diptera: Microdon mutabilis L. (larvae and pupae), Platyphora lubbocki Verrall, Aenigmatias blattoides Mein. var. highlandica Schm., and Limosina rufilabris Stnh.

Heteroptera: Alydus calcaratus L., Nabis lativentris Boh., Pilophorus perplexus D. and S., Systellonotus triguttatus L., and Ceratocombus coleopteratus Zett.

Aphidae: Trama radicis Kalt., Forda formicaria Heyd., Pentaphis marginata Koch., Lachnus nudus Retz., Brysocrypta ranunculi Kalt., Tetraneura uhlmi Geoff., and Schizoneura corni F.

Coccidae : Ripersia tomlini Newst., $R$. europaea Newst., and Newsteadia floccosa West.

Collembola: Cyphodeirus (=Beckia) albinos Nic., and Smynthurus caecus Tull.

Myriapoda : Polyxenus lagurus L.

Araneina: Thyreosthenius biovata Camb., Evansia merens Camb., Cryphoeca recisa Camb., Phrurolithus minimus C.K., Harpactes hombergi Scp., Micaria scintillus Camb., and M. pulicaria Sund.

Acarina : Discopoma pulcherrima Berl., Uroobovella notabilis Berl., Trachyuropoda coccinea Mich., T. coccinea var. sinuata Berl., T. laminosa C. and B., Laelaps myrmecophilus Berl., L. myrmophylus 
Mich., L. oophilus Wasm., L. cuneifer Mich., L. montanus Berl., and Tryoglyphus wasmanni Mon.

Crustacea : Armadillum pulchellum Brdt., and Platyarthrus hoffmanseggi Brdt.

Of the forms of the Formica fusca group in which the workers are not black, and the males and females are not shining, but dull or opaque, it is impossible to say what is actually intended by the older British records, the name $F$. cunicularia Latr. being used loosely for various forms, and not restricted to the species which is now known as rufibarbis F. (=cunicularia Latr.).

Most of the British references to cunicularia really mean (wholly, or in part), one, or both, of the vars. of fusca.

In 1880 Saunders mentions only cunicularia and fusca [Trans. Ent. Soc. Lond. 1880 206]; his description of the former agrees with rufibarbis, but he states it is "generally distributed and common in many localities," which is not the case with rufibarbis in Britain.

In 1896 he gives "race rufibarbis Fab.=cunicularia Latr.," and says rufibarbis is more local than fusca, but is widely distributed [Hym-Acul. 22 (1896)].

Saunders's records must include rufibarbis, fusca v. glebaria, and fusca v. rubescens, and most of the older records doubtless refer to one of these vars. rather than to rufibarbis.

It should perhaps be mentioned that specimens of glebaria taken at Weymouth in 1896, and of rubescens taken in the New Forest the same year, were both determined for me by Saunders as cunicularia.

In 1906 I introduced $F$. rufibarbis v. fusco-rufibarbis-teste Wasmann (=F. fusca v. fusco-rufibarbis Donis. nec Forel) as British [Ent. Rec. 18217 (1906)], and in 1911 Crawley brought forward F. fusca v. glebaria Nyl. [Ent. Rec. 2396 (1911)], but I now believe the insects in question are both glebaria; certainly I am unable to distinguish them. In $1909 \mathrm{I}$ introduced $F$. fusca $\mathrm{v}$. rubescens Forel as British [Ent. Rec. 21258 (1909)], and in 1911 pointed out that the varieties of Formica fusca have been quite inaccurately determined in this country-endeavouring to distinguish rubescens, glebaria, and fusco-rufibarbis by differences in the pubescence and their habitats [Entom. 44391 (1911)].

Subsequent researches however have shown that no reliance can be placed on the situations in which these ants occur [Ent. Rec. 2566 (1913)], and degrees of pubescence are of little value.

Forel when describing var. rubescens [Ann. Soc. Ent. Belg. 48 423-424 (1904)] says it is the var. "à thorax rougeâtre" in his Fourmis de la Suisse-this is F. fusca v. fusco-rufibarbis-and he points out that the var. rubescens has been frequently mistaken for F. rufibarbis $\mathrm{F}$.

Emery in his paper on the Palaearctic Species of Formica [Deutsch. Ent. Zeitschr. 1909 179-204] makes no mention of the 
var. fusco-rufibarbis, and neither does Wheeler in his monograph of the Genus Formica [Bull. Mus. Comp. Zoöl. 53 379-565 (1913)].

Recently I sent to Wheeler a large number of specimens, males, females, and workers, of what I had endeavoured to separate into rubescens, glebaria, and fusco-rufibarbis, and he was only able to detect rubescens and glebaria among them, and in these determinations I entirely concur.

Wasmann considers fusco-rufibarbis to be a variety of rufibarbis F., mainly because the beetles Atemeles paradoxus and Dinarda pygmaea are found with these two ants, and not with fusca; but having received from me specimens of what is called glebaria by Emery, Wheeler, and myself, he tells me this is his fusco-rufibarbis, and says-"Between these two forms (glebaria and rubescens) and the true rufibarbis, there are so many transitions, that it is hard to make them varieties of fusca instead of rufibarbis."

The smaller workers of glebaria and rubescens are alinost indistinguishable, and even of rufibarbis the small dark workers cannot be distinguished by their colour alone; this species can, however, always be recognized by the outstanding yellow hairs on the thorax - these are not present in fusca or its varieties. It may be stated emphatically that it is useless to take odd specimens of these varieties and expect to name them with any certainty. If however a number of specimens be taken, the habits of the ants and the nature of their nest noted, all sexes of the form (supposing that to be possible) collected, and the individuals from different nests not mixed, they can be accurately determined.

Under the Habitat of these forms I only give such British localities as I am personally acquainted with or from which $I$ have actually seen specimens, as no good purpose could be served by reprinting dubious records of ants under the names of "cunicularia," etc.

\section{Formica fusca L., var. glebaria Nyl.}

Formica glebaria Nylander Acta. Soc. Sc. Fenn. 2 917-919. Pf. 18·14 $(1846)^{1}$; Förster Hym. Stud. $131-32(1850)^{2}$. Formica cunicularia F. Smith Zool. 93249 (1851) ${ }^{3}$ : Trans. Ent. Soc. Lond. (n.s.) 3 102-104 (1855) [in part ?] : Cat. Brit. Foss. Hym. $8(1858)^{5}$ [in part ?]: Ent. Mo. Mag. 2 $29(1865)^{6}$ [in part ?] : Ent. Ann. $187028^{7}: 187295^{8}$ : Ent. Mo. Mag. 11 $111(1874)^{9}$. Formica fusca "des prés" Forel Denkschr. Schweiz. Ges. Naturw. $2654(1874)^{10}$. [Formica cunicularia Cooke Nat. $573(1879)^{11}$ ?] ; [Service Scot. Nat. $563(1879)^{12}$ ?] [Parfitt Trans. Devon Assn. Sc-Lit. 12 $513(1880)^{13}$ ?]; Fowler Ent. Mo. Mag. $2137(1884)^{14}$; Farren-White Ants' Ways $233(1895)^{15}$ [in part]. Formica rufibarbis Saunders Hym-Acul. 22 $(1896)^{16}$ [in part]. [Formica fusca race cunicularia Cuthbert Irish Nat. 6 $324(1897)^{17}: 767(1898)^{18}$ ?] ; Vic. Hist. Hants $1115(1900)^{19}$ [in part ?] ; [Vic. Hist. Essex $198(1903)^{20}$ ?] ; [Vic. Hist. Sussex $1131(1905)^{21}$ ?]; Vic. Hist. Devonshire $1187(1906)^{22}$; [Vic. Hist. Berks $176(1906)^{23}$ ?]. Formica rufibarbis var. fusco-rufibarbis (teste Wasmann) Donisthorpe Ent. Rec. $18217(1906)^{24}$. [Formica fusca race rufibarbis Vic. Hist. Yorks 1 $216(1907)^{25}$ ?]. Formica fusca race cunicularia Vic. Hist. Kent 1116 
$(1908)^{26}$ [in part]. Formica rufibarbis var. fusco-rufibarbis Donisthorpe Trans. Leicester Lit-Phil. Soc. 12 223-224 (1908) ${ }^{27}$ : Ent. Rec. 20281 $(1908)^{28}$ : $21287(1909)^{29}$. Formica fusca fusca var. glebaria Emery Deutsch. Ent. Zeitschr. 1909 196-198 ${ }^{30}$. Formica rufibarbis var. fusco-rufibarbis Donisthorpe Trans. Ent. Soc. Lond. $1910145^{31}$. Formica fusca glebaria Emery Deutsch. Ent. Nat. Bibliot. 2 4-5 (1911) ${ }^{32}$. Formica rufibarbis var. fusco-rufibarbis Donisthorpe Ent. Rec. $2362(1911)^{33}$. Formica fusca var. glebaria Crawley Ent. Rec. 2396 (1911) ${ }^{34}$; Donisthorpe Entom. 44 390-391 (1911) ${ }^{35}$. Formica fusca var. fusco-rufibarbis Donisthorpe Entom. 44 390-391 (1911)36. Formica fusca fusca subsp. glebaria Emery Deutsch. Ent. Zeitschr. $1912672^{37}$. Formica fusca var. fusco-rufibarbis Donisthorpe. Ent. Rec. $247^{37}(1912)^{38}$; $2566269(1913)^{39}$. Formica fusca var. glebaria Donisthorpe Ent. Rec. $2566(1913)^{40}$; Crawley and Donisthorpe Int. Ent. Cong. Oxford 1912232 (1913) $^{41}$. Formica fusca var. fusco-rufibarbis Crawley and Donisthorpe Int. Ent. Cong. Oxford 1912232 (1913) ${ }^{42}$. Formica fusca fusca var. glebaria Wheeler Bull. Mus. Compar. Zoöl $53497(1913)^{43}$. Formica fusca var. fusco-rufibarbis Donisthorpe Ent. Rec. 2641 (1914) ${ }^{44}$.

Schenck [Jahrb. Ver. Naturk. Nassau 843 (1852)] and Dalla Torre [Cat. Hym. ry 197 (1893)] incorrectly cite Formica glebaria Nyl. as a synonym of $F$. fusca L.

$\Varangle$ Blackish brown, with cheeks anteriorly, mandibles, scapes, base of funiculi, sutures of thorax, base of scale and legs brownish red.

In size and structure like fusca, but besides not being black like the latter, the pubescence is longer and closer, especially on the gaster, which gives the insect a silky appearance. Thorax without outstanding hairs. Long. $4 \cdot 5-7 \cdot 5 \mathrm{~mm}$.

ㅇ Brownish black, darker than the base of funiculi, thorax at the insertion of the wings, and legs reddish yellow, or reddish brown; scale lighter or darker brown.

It differs from fusca in colour and in being more pubescent, the whole insect having a more or less silky appearance ; epinotum entirely, or nearly entirely dark. Gaster opaque, much more pubescent than in fusca. Wings slightly infuscate. Long. 8-9.5 $\mathrm{mm}$.

$\hat{o}$ Black, like fusca, but duller and more pubescent, especially on the gaster, and the legs are more reddish.

Scale slightly, at any rate not deeply emarginate. Wings a little darker than in the o. Long. $7 \cdot 3-10 \cdot 3 \mathrm{~mm}$.

Original description of Formica glebaria Nylander [Acta. Soc. Sc. Fenn. 2 917-919 (1846)] :-

"Operaria : nigra nitida valde cinereo-micans; mandibulis, antennarum scapis flagellorumque basibus et pedibus vel totis vel tibiis tarsisque piceis seu piceo-rufescentibus ; ocellis parvis ; squama sursum late subtriangulariter subrotundata.

ఫ. Long. circa 2 lin. adeo similis praecedenti, ut omnia, quae de ea dicta sunt, in praesentem etiam speciem valeant, si addis tantum praecedenti nitorem cinereo-sericeam et demis ab abdomine ejusdem pilositatem longiusculam albidam. Palpi labiales articulo 3 : tio subtriangulari apice latiusculo. Color ut supra. Abdomen dense cinereo-sericeum, setulis brevibus flavidis parcis, marginibus segmentorum saepe membranaceo-pallescentibus, basibus saepe quoque politioribus.

Femina: nigra nitida valde cinereo-micans; mandibulis, antennarum scapis, coxarum apicibus, trochanteribus, geniculis tibiisque cum tarsis piceo-rufescentibus; alis albo-hyalinis parum fuscedine tinctis, nervis fuscis, stigmate obscure fusco ; squama late subtriangulari supra inaequali. 
ㅇ. Long. 3 lin. coloratus ut supra dictum. Caput quasi in $\Varangle$ formatum. Clypei carinula media sat distincta, parum infra aream frontis triangularem linea transversali abrupta; marginibus clypei externis buccalibus politis. Laminae frontalis margines ad radices antennarum parum sursum flexis. Thorax solitae in hac subdivisione structurae. Alae albo-hyalinae parum fuscedine tinctae, radice et tegula fuscis; alae anticae 3 lin. longae. Pedes fusco-nigri, trochanteribus, tarsis et articulationibus rufis, tibiis rufescentibus, tarsorum articulo ultimo fusco. Squama lata abdominis fere altitudine, sursum paullo latior quam infra, supra margine inaequali. Abdomen thoracis longitudine nitidissimum, totum pubescentia cinereo-micante subtili densa aequaliter vestitum, supra visum rotundato-ovale, pilis flavidis raris sparsis in ventre anoque pluribus ; marginibus segmentorum conspicuius quam in ఛ obscure membranaceo-pallescentibus."

\section{Habitat.}

Formica fusca var. glebaria is widely distributed in North, Central, and Southern Europe, also in Asia, and has been introduced into gardens in Algiers ${ }^{43}$. Emery states that it does not occur in the smaller southern islands in the Mediterranean, and that it is absent from Crete, ${ }^{30}$ but Wheeler points out that Krausse has recently taken it in Sardinia ${ }^{43}$.

British distribution :-

Cornwall, E.: Whitsand $\mathrm{Bay}^{27}$, Rame Head ${ }^{27}$, and Tregantle ${ }^{27}$ (Keys) ; St. Issey ${ }^{38}$ (Crawley and Donisthorpe); Trebetherick (Hallett).

Devon, S.: Plymouth and Meavy Valley (Keys); Seaton (Crawley) ; Devon, N. : Lundy Island ${ }^{9}$ (Donisthorpe) ${ }^{39}$.

Dorset : Weymouth (Donisthorpe); Swanage (Nevinson); Portland (Haines).

Isle of Wight: Chale, Blackgang ${ }^{39}$, Sandown ${ }^{28}$, and Landslip (Donisthorpe); Ventnor and St. Helens (Saunders Coll.).

Hants, S.: Bournemouth and Hayling Island (Saunders Coll.) ; New Forest (Crawley) ${ }^{34}$.

Sussex, E. : Hastings (Saunders Coll.).

Kent, E. : Folkestone (Donisthorpe) ; Kent, W.: Gravesend (Donisthorpe).

Middlesex : Hampstead (Brit. Mus. Coll.).

Essex, N. : Colchester (Piffard).

Oxford: Enslow Bridge (Collins).

Gloucester, W.: Stroud (W. B. Davis).

Glamorgan : Horton, Gower (Hallett).

Pembroke: St. David's (T. W. Allen).

Carnarvon: Abersoch (Nevinson).

Aberdeen, S.: Braemar (Donisthorpe).

Formica fusca v. glebaria occurs in fields, on cliffs, etc., on the Continent it lives in meadows and gardens, and Förster says it is often to be found on the borders of woods.

It nests under stones, in the sides of cliffs, etc., and frequently constructs earth-mounds, which in fields are covered with grass. 
This variety is abundant at Whitsand Bay, nesting under large stones all along the slopes by the sea; in the New Forest its nests consist of earth-mounds in open places, by the sides of enclosures, and also among scattered trees; and in the Isle of Wight I have found it under stones, in the sides of eliffs, and in small earthmounds. The habits of glebaria are similar to those of fusca, but it is not quite so cowardly.

Emery considers glebaria to be a subspecies of fusca, because the latter will not readily bring up the pupae of the former, and when nearly mature, treat them with hostility ${ }^{37}$.

Wheeler is not prepared to accept it as a subspecies ${ }^{43}$, and I do not consider the treatment of the pupae in captivity to be a sufficient test in this matter; Forel had a nest of Leptothorax tuberoaffinis which brought up two workers of Tetramorium caespitum from pupae he gave to the former (Fourmis Suisse 340), and I gave some eggs of Formica rufa to workers of $F$. fusca and F. glebaria, and they reared some of them to pupae (these eggs were taken in a nest of $F$. rufa at Bexhill, and the fusca and glebaria workers were slaves from my former sanguinea nest), but these occurrences do not make the Leptothorax and Tetramorium, or the $F$. rufa and $F$. fusca forms, more nearly related.

The colonies of glebaria at Whitsand Bay appear to belong to a common stock; at any rate Keys found that females and workers from different colonies in that locality agreed perfectly well together, and on July 14th, 1909, he sent me several different lots with pupae, which voluntarily mingled and formed a single colony ${ }^{31}$.

As with fusca, the pupae of glebaria are often naked; Keys found such pupae at Whitsand Bay in 1908, and I have found them in nests which also contained pupae in cocoons at Sandown, Isle of Wight, in 1908, and again, on August 13th, 1913.

I have found males and winged females in glebaria nests in July and August.

The females of glebaria of course found their colonies unaided; I found a small incipient colony consisting of a queen and about twelve workers, some of them being callows, in the top of an earth mound in the New Forest ${ }^{40}$, and Emery reared a small brood in captivity.

On June 25th, 1909, he isolated a deälated female without foodJuly 7th eggs were laid-July 30th four cocoons and two large larvae present-August 4th the larvae had disappeared-August 12th four very small workers emerged-August 14th more eggs laid and he then gave food to the small colony-September 2nd a naked pupa present, the others that appeared after this were all naked-October 5th an imago emerged, which was just as small as the first brood, as were all the other workers that subsequently appeared $^{32}$. 
The following myrmecophiles have been taken with $F$. fusca $\mathrm{v}$. glebaria in Britain :-

Coleoptera : Dinarda pygmaea Wasm., Atemeles paradoxus Gr., Drusilla canaliculata F., and Opatrum sabulosum L.

Formicidae : Solenopsis fugax Latr.

Braconidae : Blacus compar Ruthe.

Proctotrupidae : Gonatopus distinctus K.

Heteroptera : Nabis sp ? larva.

Aphidae : Tycheoides setariae Pass.

Coccidae : Ripersia subterranea Newst.

Collembola : Cyphodeirus (=Beckia) albinos Nic.

Araneina: Evansia merens Camb., Dysdera cambridgei Thor., Harpactes hombergi Scop., Micaria scintillus Camb., and M. pulicaria Sund.

Acarina : Uroplitella minutissima Berl., Laelaps myrmecophilus Berl., L. oophilus Wasm., and L. cuneifer Mich.

Crustacea : Platyarthrus hoffmanseggi Brndt.

\section{Formica fusca L., var. rubescens For.}

Formica cunicularia F. Smith Zool. $114080(1853)^{1}$. Formica fusca var. fusco-rufibarbis Forel Denkschr. Schweiz. Ges. Naturw. 26 54-55 (1874) ${ }^{2}$. Formica rufibarbis var. fusco-rufibarbis Dalla Torre Cat. Hym. $7210(1893)^{3}$. Formica fusca v. rubescens Forel Ann. Soc. Ent. Belg. 48423 (1904) ${ }^{4}$. [Formica fusca v. fusco-rufibarbis Schimmer Sitzung. Naturf. Ges. Leipzig 35 17-18 (1908) ${ }^{5}$ ?]. Formica rufibarbis Donisthorpe Ent. Rec. 20281 (1908) ${ }^{6}$ : Trans. Leicester Lit-Phil. Soc. $12223(1908)^{7}$ [in part]. Formica fusca var. rubescens Donisthorpe Ent. Rec. $21258(1909)^{8}$ : Zool. $1909466^{9}$. Formica fusca fusca var. rubescens Emery Deutsch. Ent. Zeitschr. $1909196^{10}$; Wheeler Bull. Mus. Compar. Zoöl. 53498 (1913)11. Formica fusca var. rubescens Donisthorpe Ent. Rec. $2566(1913)^{12}$ : $2641(1914)^{13}$.

$\Varangle$ The large workers have the head anteriorly (clypeus, cheeks, and frontal area), the mandibles, scapes, base of funiculi, thorax, scale and legs yellowish red. The head posteriorly, the apex of antennae, two patches on the thorax (one on the pronotum and the other on the mesonotum, almost fused as in F. pratensis), and the gaster are blackish brown.

The sculpture and pubescence is the same as in glebaria. The smaller workers are the same colour as glebaria, and are almost indistinguishable from the latter.

Thorax without outstanding hairs. Long. 5-7 mm. (4-6.5 $\mathrm{mm}$. teste Wheeler.)

o Similar to glebaria, but not so dark, with the epinotum and scale almost entirely red.

I possess a specimen from Fairlight, which has the gaster at the base, sides, and beneath, yellowish red.

Wings infuscate at base. Long. 8-9.5 mm. (7-9 mm. teste Wheeler.)

$\hat{0}$ Black; duller with legs more reddish than in fusca.

Scale deeply emarginate and appearing lunate. Wings darker than in the ㅇ. Long. 8.5-10 $\mathrm{mm}$.

Original description of Formica fusca v. rubescens Forel [Ann. Soc. Ent. Belg. 48 423-424 (1904)] :-

"Je donne ce nom à la grande variété, à thorax rougeâtre, dans mes Fourmis de la Suisse. Chez la $\Varangle$ major, le devant de la tête, le thorax, les 
scapes, le $1^{\mathrm{er}}$ article des funicules et les pattes sont d'un rouge jaunâtre, sauf deux taches brunes situées sur le pronotum et le mésonotum, taches qui ressemblent à celles de la $F$. pratensis et confluent à peu près. La petite ouvrière se distingue à peine de la var. glebaria Nyl (fusca des prés, Forel, Fourmis de la Suisse), la couleur rougeâtre y disparaissant à peu près. La grande $\not$ atteint près de 7 mill. ; c'est la plus grande variété de la $F$. fusca, dans nos parages. De même que la v. glebaria, elle vit dans les prés, où elle fait des dômes maçonnés, tandis que la fusca vera, qui est bien moins pubescente, un peu plus lisse et plus luisante, vit surtout dans les troncs pourris et sous les pierres. On a confondu encore très souvent la var. rubescens de la fusca avec la r. rufibarbis F., qui a des mœurs fort diffèrentes, et qui est surtout bien plus courageuse. La rufibarbis typique, $\not$ major, n'a pas les deux taches brunes sur le pronotum et le mésonotum; seule sa petite $\not{\gamma}$ a le thorax en partie brun."

\section{Habitat.}

According to Wheeler this variety is known only from Central Europe, and is common in Switzerland ${ }^{\mathbf{1 1}}$.

British distribution :-

Devon, S. : Seaton (Donisthorpe) ${ }^{\mathbf{1 2}}$; Sidmouth (Perkins).

Dorset: Lyme Regis (Nevinson).

Isle of Wight : Landslip (Donisthorpe) ${ }^{\mathbf{1 3}}$.

Hants, S. : New Forest (Donisthorpe) ${ }^{\mathbf{1 2}}$.

Sussex, E. : Fairlight (Donisthorpe).

Kent, E.: Rodmersham (Crawley).

Surrey : Box Hill (Bedwell); Caterham (Champion); Woking (Donisthorpe).

Essex : Southend ${ }^{1}$ (sub cunicularia F. Smith Coll.).

Middlesex : Crouch Hill (E. A. Butler).

Gloucester : Kilcot (Perkins),

Worcester: Bewdley (Donisthorpe) 6 8.

Glamorgan : Horton, Gower (Hallett).

Formica fusca var. rubescens has the same habits and lives in similar situations to glebaria, and in Switzerland it dwells in meadows and constructs earth-mounds.

In May, 1908, I discovered a fine colony of this variety on the side of the railway embankment at Bewdley, its nest being partly situated under a large heavy stone, partly in the bank, with earth built up round the stone ${ }^{8}$. In the New Forest it occurs in earthmounds, at Seaton under stones, in the Landslip, Isle of Wight, in the side of the cliff, and at Fairlight I found it both in the side of the cliff and in earth-mounds in the under-cliff-one of the nests being traced by tracking a worker which was carrying home a fly in its jaws. In 1908 no queen could be found in the Bewdley colony, and when the same nest was visited in July, 1909, many males were found to be present but no winged females, and again no queen was discovered.

It would appear that the queen had died in this colony, and the males had been reared from parthenogenetic eggs laid by the workers ${ }^{8}$. 
Many males occurred in the New Forest and Seaton nests in July, 1912, and on August 21st, 1913, a winged female and about a dozen males were found in a nest in the side of the cliff at the Landslip, Isle of Wight. Schimmer records a curious colony of rubescens (?), which he discovered at Rösertal, near Seeburg, on May 5th, 1908, consisting of fifteen deälated females, and only twenty to thirty workers. $\mathrm{He}$ is of the opinion that this was a queenless nest, which had adopted the deälated females after the marriage flight, as some of the females were typical rufibarbis, whilst others were varieties of fusca ${ }^{5}$.

Forel points out that rubescens has been frequently confounded with rufibarbis ${ }^{4}$, and it is probable that some of the British records of cunicularia and rufibarbis really refer to this variety.

I have taken Cyphodeirus albinos Nic., Laelaps myrmecophilus Berl., and Platyarthrus hoffmanseggi Brdt., in nests of rubescens.

\section{Formica rufibarbis $\mathrm{F}$.}

Formica rufa Fourcroy Entom. Paris 2452 (1785) ${ }^{1}$. Formica pratensis Olivier Encycl. Méthod Ins. $6504(1791)^{2}$. Formica rufibarbis Fabricius Ent. Syst. $2355(1793)^{3}$. Formica obsoleta Latreille Ess. Hist. Fourmis France $38(1798)^{4}$. Formica cunicularia Latreille Ess. Hist. Fourmis France 40 $(1798)^{5}$ : Hist. Nat. Fourmis 151-156 (1802) $)^{6}$. "La fourmi mineuse" Huber Mœurs Fourmis 324-325 (1810) ${ }^{7}$ ]. Formica cunicularia Nylander Acta. Soc. Sc. Fenn. 2 913-915 $1059(1846)^{8}$; Förster Hym. Stud. 125 $(1850)^{9}$. Formica stenoptera Förster Hym. Stud. $126(1850)^{10}$. Formica cunicularia F. Smith Proc. Ent. Soc. Lond. (n.s.) 182 (1851) $^{11}$; Schenck Jahrb. Ver. Naturk. Nassau $840-43^{12} 139^{13} 145^{14}(1852)$; Mayr Verh. Zool. Bot. Ver. Wien 5 342-344 (1855) $)^{15}$; F. Smith Trans. Ent. Soc. Lond. (n.s.) $3103(1855)^{16}$ [in part] : Cat. Brit. Foss. Hym. 8 (1858) ${ }^{17}$ [in part]. Formica fusca r. rufibarbis Forel Denkschr. Schweiz. Ges. Naturw. $2654^{18} 138^{19} 141^{20}$ $218^{21}$ 357-358 $8^{22} 408^{23}$ (1874). Formica cunicularia Saunders Trans. Ent. Soc. Lond. $1880206^{24}$ [in part]. Formica rufibarbis Er. André Spec. Hym. Europe $2182(1881)^{25}$; Lubbock Ants, Bees, Wasps $80(1881)^{26}$; Wasmann Stèt. Ent. Zeit. $51305(1890)^{27}$. Dalla Torre Cat. Hym. 7 209-210 (1893) ${ }^{28}$. Formica cunicularia Farren-White Ants' Ways 182199233 (1895) ${ }^{29}$ [in part]. Formica fusca race rufibarbis Saunders Hym-Acul. 22 (1896) ${ }^{30}$ [in part]. [Formica cunicularia Vic. Hist. Hants $1115(1900)^{31}$ ?] ;Vic. Hist. Surrey $184(1902)^{32}$. Formica rufibarbis Wasmann Mitt. Schweiz. Ent. Gesell. $1167-$ $69{(1905)^{33}}^{2}$ Frisby Proc. Holmesdale NH. Club. $190574(1906)^{34}$; [Vic. Hist. Kent $1116(1908)^{35}$ ?]. Formica fusca race rufibarbis Donisthorpe Trans. Leicester Lit-Phil. Soc. 12223 (1908) ${ }^{36}$ [in part]. Formica fusca rufibarbis Emery Deutsch. Ent. Zeitschr. 1909 19737. Formica rufibarbis Wasmann Archiv. Trim. Inst. R. Grand Ducal Luxemburg 4 81-88 (1909) ${ }^{38}$; [Silverlock Nat. $3513(1910)^{39}$ ?]. Formica fusca subsp. rufibarbis Donisthorpe Entom. $44390(1911)^{40}$ : Ent. Rec. 25 66-67 $(1913)^{41}$. Formica rufibarbis Wheeler Bull. Mus. Comp. Zoöl. 53 514-516 (1913) ${ }^{42}$; Donisthorpe Ent. Rec. $2641(1914)^{43}$.

$\Varangle$ The large $\not{q}$ has the clypeus, cheeks, frontal area, scapes and base of funiculi, whole of thorax, scale and legs clear pale red, or reddish yellow; head posteriorly and gaster blackish brown. The mandibles are red brown, tarsi with last joint slightly infuscate; the pubescence on gaster gives it a greyish appearance.

The medium and small workers possess brown patches on the pronotum 


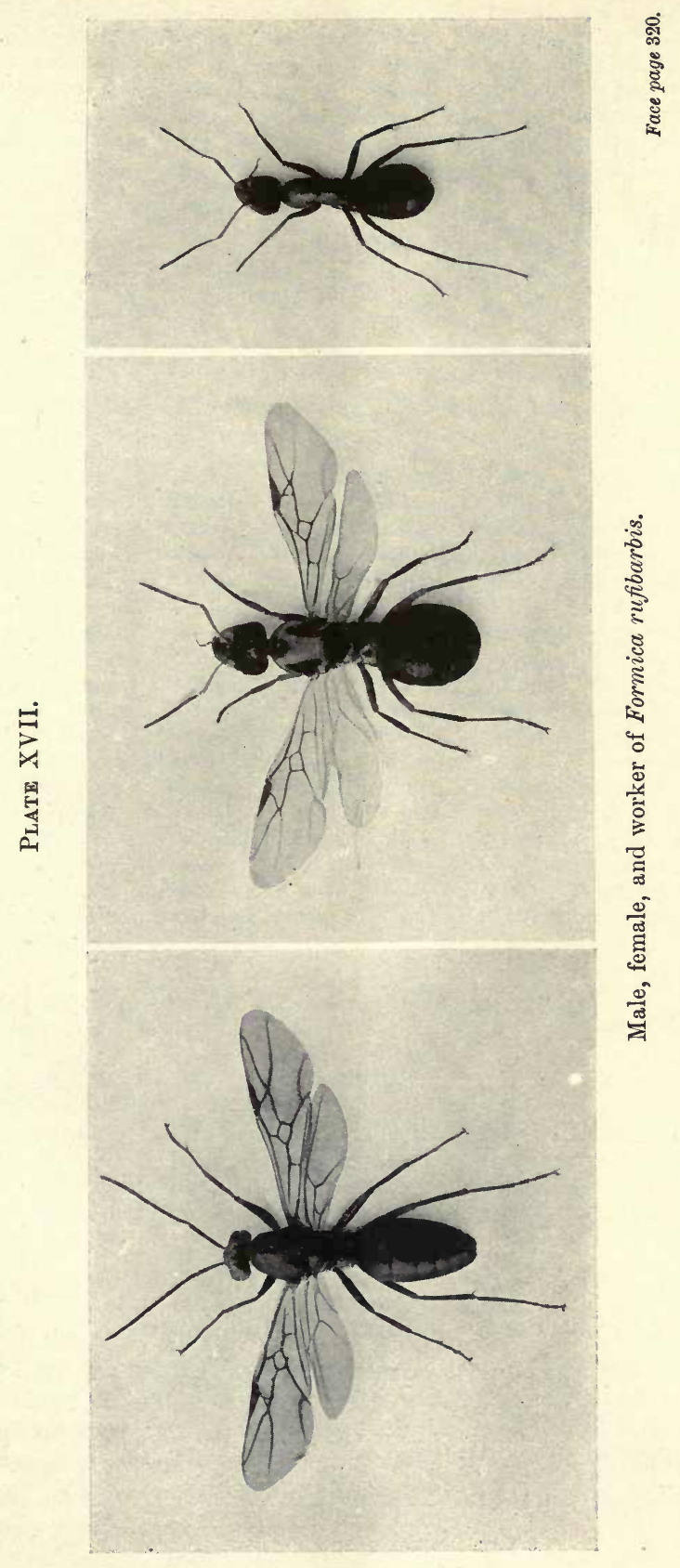


and mesonotum; and in the small workers the brown colour is sometimes spread over the whole body as in glebaria.

Structure and form much as in fusca, more hairy, and with longer and closer pubescence. Head opaque, not quite so dull as thorax; clypeus distinctly carinate ; frontal area punctured. Thorax opaque ; pronotum furnished with very distinct scattered outstanding yellow hairs, in both large and small specimens. Scale large, broad, rounded, sometimes with a fow

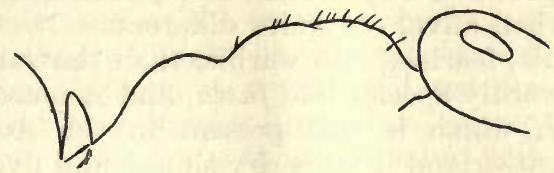

Fig. 91. Side view of thorax of Formica rufibarbis ఫ్ధ.

outstanding hairs; gaster with scattered outstanding yellow hairs. Long. $4 \cdot 6-7 \cdot 5 \mathrm{~mm}$. $(4-7 \cdot 5 \mathrm{~mm}$. teste Wheeler.)

o Cheeks, clypeus, frontal area, mandibles, scapes and base of funiculi, pronotum, mesonotum and scutellum in part, scale, apex of gaster and legs lighter or darker yellowish red; rest of head, mesonotum with three longitudinal patches, scutellum, post scutellum and gaster blackish brown.

Structure and form of fusca. Thorax with outstanding hairs, longer and more abundant than in the fusca vars. Wings greyish, veins brown yellow, pterostigma darker. Long. 9-10 $\mathrm{mm}$. (9-11 mm. teste Wheeler.)

$\hat{o}$ Black; legs yellow with nearly the whole of the tarsi, and base of femora blackish (sometimes only the extreme base of the femora, and the apex of the tibiae are dark, or the whole of the legs may be mostly blackish); genitalia reddish yellow. Shape and structure as in fusca; duller in appearance. Head with more distinct decumbent yellow hairs on cheeks and clypeus than in fusca or its vars. Thorax with distinct outstanding yellow hairs. Scale only slightly, or widely but not deeply emarginate, furnished with outstanding hairs; gaster more closely punctured than in fusca, with shorter closer pubescence, and some outstanding yellow hairs. Wings a little darker than in the o. Long. $8 \cdot 5-11 \cdot 8 \mathrm{~mm}$. $(9-10 \mathrm{~mm}$. teste Wheeler.)

Original description of Formica rufibarbis Fabricius [Ent. Syst. $2355(1793)]$ : 一

" F. oblonga nigra ore thoraceque rufis.

Habitat in Gallia.

Media. Antennae nigrae. Caput nigrum ore late rufo, qui color ad latera extenditur.

Mandibulae tamen nigrae. Thorax rufus, immaculatus.

Squama petiolaris ovata, obtusa. Abdomen ovatum, atrum, immaculatum. Pedes nigri.",

\section{Habitat.}

Widely distributed through Europe and Northern Asia, and occurring in Sardinia, though absent from the smaller Mediterranean islands. It is a distinctly xerothermal form and in the Alps does not reach such an elevation as the typical fusca. According to Ruzsky, however, it occurs at an altitude of $3000 \mathrm{~m}$. in the Caucasus, and according to Forel even higher in the Himalayas ${ }^{41}$. 
Six varieties of this species have been described, two of which live in North America.

British distribution:-

Surrey : Reigate $(\text { Frisby })^{34}$; Ripley $(\text { Arnold })^{36}$; Chobham (Saunders); Weybridge (Donisthorpe) ${ }^{41}$.

Wheeler considers Formica rufibarbis $\mathrm{F}$. to be a good species ${ }^{42}$, and not a subspecies of $F$. fusca L., as its habits, its instincts, and its behaviour when alive, are quite different.

It is more agile, fearless, and warlike than the varieties of fusca, not being a cowardly species like fusca, and it possesses a distinct aromatic odour, which is also present in the American forms. Forel says in Switzerland it loves dry slopes, and lives in meadows, on the borders of roads, in uncultivated places, very rarely in gardens; but it does not nest near houses, and never occurs in woods ${ }^{21}$.

This species is well called the mining ant by Huber ${ }^{7}$, as it nests in the ground; it has been recorded as living under stones, and sometimes constructing small earth-mounds, but I suspect the two latter situations really refer to the var. rubescens of fusca, and Emery distinctly states it nests under the ground without any earth construction above ${ }^{37}$.

I have found rufibarbis at Weybridge, nesting in sandy banks, on the borders of paths, and under turf and herbage.

The nest, which is often very difficult to find on account of its hidden nature, is situated about a foot below the surface of the ground, and the entrance consists of a small hole, sometimes concealed by a tuft of grass, or herbage.

A small chamber at the bottom of the nest contains the queen, or queens, and galleries all lead to the single entrance above ground.

This very active species lives an open-air life, and possesses more individual initiative than F.rufa; its workers hunt singly, catching flies and other insects, and they never forage in troops, nor execute joint excursions.

Frisby records their visiting flowers, and being especially partial to the flower-heads of Heracleum and other umbelliferous plants ${ }^{34}$, and I have seen workers basking in the sun on the leaves of brambles.

The workers are very audacious and will even endeavour to rob rufa of its prey-holding on and pulling-and the moment the rufa lets go, to get a better grip, or to attack the rufibarbis, the latter swiftly decamps with the prize; and should a rufa grasp it by a leg or an antenna, it remains quite still, and when its opponent loosens its grip, the better to kill it, it quickly slips away.

This species finds its way by sight alone, as it does not follow beaten tracks, and when it has captured a booty it returns in a straight line to the nest. Wasmann records that on May 10th, 1907, in a garden at Luxemburg, he observed two workers, the 
one carrying a fly-larva, the other a dead beetle (Silpha atrata), return in a straight line from different directions to their nest ${ }^{38}$.

On July 12th, 1913, having observed several rufibarbis workers running about on a path near a sandy bank at Weybridge, I endeavoured to find their nest, and commenced to pull up handfuls of herbage on the top of the bank, which I let fall on the slope. I then saw a worker approaching with a fly in its jaws and start to mount the bank, and as the scattered herbage was directly in its way, I feared the ant might be diverted from its nest, but when it reached the obstacle, it never hesitated for a moment, but running straight over it in a direct line, entered its nest on the top of the bank, which I was thus enabled to find.

Forel says the colonies of rufibarbis are sometimes small, but usually of medium size, and none that I have found have been large ; Wasmann, on the other hand, records large colonies at Luxemburg consisting of over one thousand workers, and says they are generally more populous than those of $f u s c a^{38}$. Schenck often found naked pupae in rufibarbis nests at Nassau ${ }^{12}$, and I have had such pupae produced in my observation nest from Weybridge.

Fore ${ }^{19}$ and Wasmann ${ }^{38}$ record pseudogynes of rufibarbis, and the former describes a mixed gynandromorphous specimen which he captured on the wing, flying with normal males and females at the summit of Monte Salvatore on July 1st, 1891 :-

Halves of head identical, but of such a character that it is impossible to say whether they are male or female; in form the head is exactly intermediate between the two sexes. Both antennae 13-jointed as in the male, but scapes too long in proportion to funiculi for this sex. Mandibles indistinctly denticulate, parti-coloured reddish black and brown, intermediate between male and female, as are also the size and conformation of the eyes and ocelli. Whole head more robust than that of the male, smaller than that of the female; black (hence male). Thorax indeterminate; right half of epinotum yellowish red, left half black, whereas the right half of the scutellum and petiole is black, the left half reddish yellow; hence the epinotum is female on the right, male on the left side; whereas the scutellum and petiole are male on the right and female on the left. The three pairs of legs are symmetrical, yellowish, and have rather the form of the female. The wings, being the same in both sexes, are indeterminate in the gynandromorph. Gaster apparently female, globular, very small, with five segments, excluding the petiole. Anus round, encircled by hairs as in the female, but it opens above into a transverse, eciliate slit, situated between the hypopygium and pygidium as if forming a second anus. The anus proper is cut into the hypopygium. ${ }^{20}$

On July 29th, 1913, I captured a curious individual, which was running rapidly among the workers in a nest of rufibarbis at Weybridge, and which I at first took to be a pterergate, as it had the general appearance of a large worker with wing stumps, but when set and studied more carefully it appears to be an ergatandromorphous specimen which may be described as follows:-

Head shape and size of large $\zeta$, black except mandibles and cheeks anteriorly, which are reddish yellow; median ocellus large, ô; lateral ocelli 
small $\not$; mandibles $\not{\gamma}$; antennae shape and size of $\Varangle, 12$-jointed, outer half of left scape blackish brown longitudinally, right scape with a blackish brown patch on outer anterior corner. Thorax $\forall$, reddish yellow, with larger and smaller blackish brown spots dotted irregularly about ; pronotum with distinct outstanding yellow hairs; metanotum furnished on left side with a short deformed wing, $2 \mathrm{~mm}$. in length, right side with only a small chitinous tubercle. Scale $\nvdash$; gaster long, but with sculpture, pubescence, and bristles of $\Varangle$; o genitalia, short, thick, and deformed, exposed at apex of gaster. Legs intermediate between $\hat{\sigma}$ and $\not \gamma$; coxae, femora, and tibiae of intermediate and posterior pairs infuscate, rest of legs and tarsi yellowish, left posterior leg with femora and tibia deformed, bowed. Long. $8 \mathrm{~mm}$.

Wasmann has found that gynaecoid workers occur, one, or more, acting as substitute queens in queenless nests of rufibarbis. At Luxemburg in 1904 he possessed two such workers which were treated as are true queens, being fed and cleaned and attended on by the workers; their gasters were swollen and they laid a number of eggs. He says this proves that it is possible for ants, by better feeding, to bring up ordinary workers, after they have hatched, as egg-laying individuals, and use them as substitutes in the place of true females ${ }^{33}$.

In his experience it is not usual to find many, or more than one deälated female in a rufibarbis nest; I have, however, found five, three, and two deälated females in single nests at Weybridge.

Nylander found the males and winged females in the nests in Finland from July 20 th to August 10 th $^{8}$; Schenck gives July 9th to 2lst at $\mathrm{Nassau}^{12}$, but he captured a male on October 3rd, and he says the winged females are much less abundant than the males, as he only once found the former, but frequently observed the latter in many nests ${ }^{12} \mathbf{1 4}$ - this has also been the case in my experience at Weybridge. Smith mentions a winged female which was captured in flight by .S. Stevens on April 18th, 1851 11_but this would probably be a specimen from the year before which had passed the winter in the nest-and Forel records the winged forms in the nests in Switzerland in June, July, and August. ${ }^{23}$

The occurrence of the sexes appears to be very erratic with this species, and I was never able to find any until 1914, having dug up rufibarbis nests for three years at Weybridge-in May, June, July, August, and September-and neither males or winged females, nor sex larvae or pupae occurred.

On June 5th, 1914, a nest was found which at last contained large (sex) larvae, a few of which I took home and introduced into my rufibarbis observation nest, but as the workers would not have anything to do with them-throwing them out of the nest every time I put them back-I returned them to their own nest at Weybridge, where they were taken in by the workers. On July lst I went down again, but found that my nest had been dug up and destroyed; however three more colonies were discovered, only one of which contained sex pupae. A few of these large cocoons were taken home, two of them were introduced into my observation 
nest, and the rest were placed in a tin with a little earth and some of their own workers.

On July 4th four more colonies were discovered, only two of which contained sex pupae, and a few of these were taken home from one of the nests and placed in the tin with the others.

Males emerged on July 9 th and 10th ; the ants in my observation nest having accepted the two cocoons, only one of which hatched however. On July 16th ten more nests were found, nearly all of which contained males in some numbers, but only one winged female was observed.

Forel states the marriage flight takes place in July at about seven o'clock in the morning, when he saw males and winged females flying at the summit of Mont Tendre ${ }^{23}$, as before mentioned, and André gives June and July ${ }^{25}$. On August 3rd, 1914, all the winged sexes had disappeared from the nests at Weybridge.

The queens found their colonies in the normal manner as, we have seen, do all the fusca group.

Wasmann records finding a small incipient colony at Shötter Marial on July 25th, 1906, which consisted of a deälated female, about fifty young small workers, and twelve naked worker pupae. The queen was resting in a small chamber about the size of a hazel nut, and empty cocoons were scattered about outside the nest, which he concluded had been removed from the pupae by the workers ${ }^{38}$.

My observation nest of this species was taken on July 10th, 1912, but the queen did not lay eggs till January 27th, 1913, and again on April 2nd and 17th, 1914; very few ants have died, and the colony - which is still under observation-is in good condition, but only a few workers have been brought up. Two very curious cripples with twisted legs and antennae were produced, which were quite unable to walk, but lived for some time in the nest.

I have never been able to find any beetles (which are the usual guests) with these ants, although Atemeles paradoxus and Dinarda pygmaea occur with them on the Continent, and the only myrmecophiles I have observed are one Leptacinus formicetorum Märk (a guest of F.rufa), Pachylomma buccata Nees., hovering over the ants, Platyphora dorni Ender., bred from the ant's pupae, and Cyphodeirus albinos Nic., in the nests.

\section{Formica picea Nyl.}

Formica picea Nylander Acta. Soc. Sc. Fenn $2917^{1} 1059-1060^{2}$ (1846) : $327(1849)^{3}$; Förster Hym. Stud. 1 30-31 (1850)4 ; Schenck Jahrb. Ver. Naturk Nassau $8126(1852)^{5}$. Formica gagates Mayr Verh. Zool. Bot. Ver.

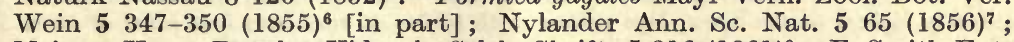
Meinert Kong. Danske. Vidensk. Selsk. Skrift. $5316(1861)^{8}$; F. Smith Ent. Ann. $1866127^{9}$; Sahlberg Meddel. Sco. Faun-Flora Fenn. $1134-136(1876)^{10}$; "Formica gagates Olivier-picea Nyl" Cornelius and v. Hagens Jahr. Nat. Elberfeld-Barmen $5104(1879)^{11}$. Formica gagates Saunders Trans. Ent. 
Soc. Lond. $1880207^{12}$; Stolpe Ent. Tidskr. 3133 (1882) ${ }^{13}$. Formica glabra Farren-White Ants' Ways $80^{14} 253^{15}$ (1883). Formica gagates Saunders Ent. Mo. Mag. 2016 (1885) ${ }^{16}$. Formica fusca race gagates Adlerz Bih. Sv. Vet-Akad. Handl. 11308 (1886) ${ }^{17}$. Formica transkaukasica Nassonow Imp. Obshch. Lyrrb. Est-Ant-Etn. Mosc. 58 (1) 62 [=Tr. Lab. Zool-Mus. 2 (1) 62] (1889) ${ }^{18}$. Formica gagates Dalla Torre Cat. Hym. 7 198-199 (1893) ${ }^{19}$ [in part]. Formica glabra Farren-White Ants' Ways (Ed. 2) $5^{20} 83-84^{21} 234^{22}$ (1895). Formica fusca race gagates Saunders Hym-Acul. $22(1896)^{23}$. Formica gagates Ruzsky Form. Imp. Ross. 378 (1905) ${ }^{24}$. Formica fusca transkaukasica Ruzsky Form.

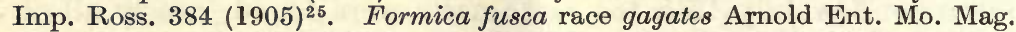
41 211-212 (1905) 26. Formica fusca subsp. gagates v. filchneri Forel Ann. Soc. Ent. Belg. 51208 (1907) ${ }^{27}$. Formica fusca picea Emery Deutsch. Ent. Zeitschr. $1909195^{28}$; Bondroit Ann. Soc. Ent. Belg. 53483 (1909) ${ }^{29}$. Formica fusca subsp. gagates Donisthorpe Entom. 44390 (1911) $^{30}$. Formica picea Reichensperger Bonn. Sitz. Ber. Nat. Ver. (E) $19111_{122^{31}}$; Bondroit Ann. Soc. Ent. Belg. $56352(1912)^{32}$; Donisthorpe Ent. Rec. 24306 (1912) ${ }^{33}$ : 25 67-68 Tf. 1-2 (1913) ${ }^{34}$. Formica fusca picea Wheeler Bull. Mus. Compar. Zoöl. $53512(1913)^{35}$; Bönner Biol. Centralb. 34 59-76 Tf. 1-6 (1914) ${ }^{36}$; Wasmann Biol. Centralb. 34 76-80 (1914) ${ }^{37}$; Adlerz Arkiv. Zool. 8 1-5 $(1914)^{38}$.

Dalla Torre ${ }^{19}$ incorrectly cites $F$. picea Nylander and $F$. glabra Farren-White as synonyms of $F$. gagates Latr.

$\Varangle$ Shining, lighter or darker blackish brown, mandibles, the greater part of the antennae, and legs pale reddish brown. In the lighter specimens only the head posteriorly and the apex of the antennae are dark, in the darker specimens the whole body and the apex of the antennae are blackish, and the femora are infuscate.

Head much smoother than in fusca, finely alutaceous; cheeks and frontal area more shining, being more finely shagreened. Thorax smooth, very finely shagreened, pubescence very scanty, scarcely visible except at sides of epinotum; pronotum and mesonotum furnished with outstanding yellow hairs-especially on the former, in which they are longer; epinotum seen in profile, distinctly angled. Scale rounded; gaster smooth and shining, finely alutaceous, pubescence very sparse and scattered, with outstanding yellow hairs or bristles. Long. 4.4-5.5 mm. (4-6.5 mm. teste Bönner.)

o Shining black, much smoother than in fusca, mandibles, legs, and scape brownish red.

Head (apart from the mandibles) about as broad as long, but a little shorter and broader than in fusca, the sculpture consisting of very close scratches (alutaceous puncturation) with some distinct small scattered punctures; clypeus entire, more sharply and distinctly carinate than in fusca, frontal area finely punctured but more shining than in fusca; eyes apparently a little smaller than in fusca, with facets somewhat smaller and closer. Thorax not so distinctly broader than head as in fusca, with more abundant, more distinct and longer hairs, pubescence almost nil, even on the epinotum; mesonotum simply alutaceous, with a few large and small scattered punctures; scutellum almost entirely smooth, very shining. Scale rounded much as in fusca; gaster very finely alutaceous transversely; almost impunctuate, and without pubescence, furnished with long outstanding yellow hairs, besides the bristles on the margins of the segments. Legs with less fine and close pubescence than in fusca. Long. 8-9 $\mathrm{mm}$.

t Black, more shining than in fusca, antennae all black, mandibles black, scarcely lighter at the apex, legs yellow with tibiae at base and last joint of tarsi darker, femora blackish, genitalia partly yellow, partly blackish.

Head narrow anteriorly; broad posteriorly, sculpture smoother and finer than in fusca; frontal area smoother and more shining; eyes not quite so convex; space at base of frontal furrow smoother and more shining. Thorax 
not as distinctly broader than the head, furnished with abundant, long, yellow hairs; mesonotum shining, alutaceous. Scale not, or scarcely, emarginate, thicker and blunter, with some outstanding hairs; gaster shining, alutaceous, with some outstanding hairs, and with longer, and more widely separated pubescence. Wings very pale brown, not as dark as in fusca, with pale brown veins and darker pterostigma. Long. 7-7.5 mm. (9-10 mm. teste Bönner.)

Original description of Formica picea Nylander [Acta. Soc. Sc. Fenn. 2917 (૪). 1059-1060 (ㅇ, ðో) (1846)] :-

"Operaria: piceo-nigra nitidissima; mandibulis, antennis pedibusque piceis; ocellis minutis; squama subtriangulariter rotundata; abdomine inprimis albo-pilosulo.

Hujus speciei neglectae hucusque tantum operariam parcius in sphagnosis ad Helsingfors et Uleåborg inveni ; diffusa igitur saltem per totam patriam videtur.

૪. Long. circiter 2 lin. Simillima sequenti. Nigra tota, mandibulis tantum et antennis piceo-rufescentibus, flagellis obscurioribus; pedibus quoque trochanteribus, geniculis et tarsis rufescentibus, tibiis femoribusque interdum ejusdem fere etiam coloris. Caput magnitudinis mediocris et formae sicut in $F$. rufa, pilis parcis albidis conspersum. Palpi maxillares atri ut in $F$. rufa constructi. Clypeus distincte carinulatus. Area frontalis sat distincte limitata, nitore reliquarum partium capitis. Oculi majores quam in praecedente ovales, paulo prominuli. Occiput (minime ut in praecedente emarginatum) aequaliter convexiusculum. Thorax nitidus subtilissime sparse adpresse albido pubescens, pilis nonnullis erectis in pronoto, depressione inter pulvinar pro- et mesonoti atque metanotum minori quam in $F$. rufa, aliis proportionibus fere iisdem ac in hac specie. Squama altitudine abdominis sursum paullo latior, angulis parum rotundatis, supra subtruncata vel margine convexiusculo. Abdomen nitidissimum nigrum (nitore cinereosericeo ne minimo quidem), supra visum rotundatum, capite latius, pilis longiusculis sparsis albidis solito more ante margines segmentorum serie et alibi rarius dispositis. Pedes adpresse subtiliter cinerascenti-pubescentes, tibiis latere interiori setulis nonnullis."

"Formica picea $\Varangle$ et $ᄋ$ exalata, e Sibiria. Femina (antea ignota) similis est $F$. glebariae + , at pili parvi corporis crebriores et rigidiusculi, pubescentia depressa subtilis obsoletissima, thorax contractior altior, longitudine abdominis, fere aeque altus ac longus (in glebaria o thorax altitudine sua duplo longior est); pedes obscure fusci articulationibus tarsisque rufescentibus similiter ac flagella antennarum; abdomen latiusculum, nigrum ut corpus ceterum (in glebaria i interdum parum aenescens). Mas. e Sibiria, qui forte $F$. piceae pertinet; similis est magnitudine et statura mari $F$. rufae, sed subnudus atro-niger totus, articulationibus pedum superioribus obsolete rufescentibus, squama paulo majori transversaliter (horizontaliter) rectangulari-oblonga supra integra; alae totae albescenti-hyalinae, versus basin solum obsoletissime brunnescenti-tinctae, nervis et stigmate fuscis, anticae $9 \frac{1}{4}$ millimetra longae. Area frontis triangularis (sicut caput ceteroquin et thorax) opaca."

\section{Habitat.}

Formica picea ranges over Northern Europe and Asia to East Siberia, and occurs in Britain, Belgium, Luxemburg, Holland, Germany, Sweden, Denmark, Finland, Russia, China, and Thibet, etc.

\footnotetext{
British distribution :-

Isle of Wight : ? (F. Smith Coll.).

Dorset: Wareham (Dale Coll.).
} 
Hants, S. : Bournemouth $(F \text {. Smith) })^{9}$; New Forest ${ }^{26}$ (Arnold and Piffard).

Glamorgan : Rhosilli (T.W. Allen).

Formica picea was described by Nylander in $1846^{1}$, in 1855 it was incorrectly sunk by Mayr as a synonym of $F$. gagates Latr. ${ }^{6}$, and curiously enough, Nylander, in 1856, followed Mayr in treating his own species as a synonym of gagates ${ }^{7}$. Nylander's species was again brought forward by Emery in 1909, who distinguishes it from gagates by the shape of the epinotum, and points out that the latter is a more southern and westerly form than picea ${ }^{28}$. I possess specimens of gagates from Vienna.

Its history as a British insect is as follows:-In $1866 \mathrm{~F}$. Smith added it to the British list, on specimens taken by his son at Bournemouth, under the name of gagates ${ }^{9}$, but he subsequently regarded it as distinct from that species and believed it to be a curious form of fusca, and in 1880 Saunders again brought it forward as a British insect as gagates ${ }^{12}$. In 1883 Farren-White rightly considered it to be distinct from that insect, and gave it the name of glabra $^{15}$, but Saunders in 1885, when criticizing Farren-White's views, again attributes it to gagates, and though he admits our specimens are undoubtedly smaller and paler than continental ones, he remarks that surely it is more likely to belong to a known form on the Continent than to a new species ${ }^{16}$. This was true enough, but it did not follow that our species must be gagates. In 1892 and 1893 Farren-White rediscovered picea at Bournemouth ${ }^{20}$, taking a female and many workers, and he says the differences between this species and continental gagates are most marked ${ }^{21}$, that it is sufficiently distinct to form a new species ${ }^{22}$, and he retains his name glabra for it; but in 1896 Saunders again refers to it as gagates ${ }^{23}$.

In 1905 Arnold and Piffard discovered picea in the New Forest, and Saunders having named these specimens gagates, they were recorded as such ${ }^{26}$.

In 1912 Crawley and I again found it in the New Forest, and I pointed out that the British species doing duty under the names of glabra and gagates was picea ${ }^{33}$; and in 1913 I reviewed the British captures to date, and published drawings to show how it differed from gagates both in the shape of the epinotum and of the scale ${ }^{34}$. In the same year I detected a specimen kindly sent to me among some ants from Rhosilli by Mr. T. W. Allen, and in 1914 I first discovered two, and subsequently five, colonies of picea in the New Forest, which will be mentioned again presently.

Bönner ${ }^{36}$, in an interesting paper on the history and habits of this ant, published in 1914, lists and discusses the literature of the subject, but he does not appear to be aware of the observations of Farren-White, Arnold, or Donisthorpe. He refers however to Saunders' record in 1880 of $F$. gagates as British, stating that he 
holds it for certain that Saunders' examples belong to $F$. picea, in which of course he is quite correct.

$F$. picea Nyl. is abundantly distinct from $F$. gagates Latr., both in structure and in habits. In the former the individuals are on the average smaller, the epinotum is angled and the scale is rounded (-at any rate it is never formed as in gagates, which has a scale similar in shape to that of $F$. rufa; I have called it hexagonal in this work, and Latreille himself describes it as "squama magna, ovata : margine supero medio elevato, truncato, subbidentato" [Hist. Nat. Fourmis 138 (1802)]-), in the latter the epinotum is quite rounded. $F$. picea dwells in sphagnum bogs; $F$. gagates lives in oak forests, nesting under large stones and at the roots of trees, and attending aphides on oak trees.

Wheeler regards gagates as an independent species, and not as a subspecies of fusca [Bull. Mus. Compar. Zoöl. 513 (1913)], and I
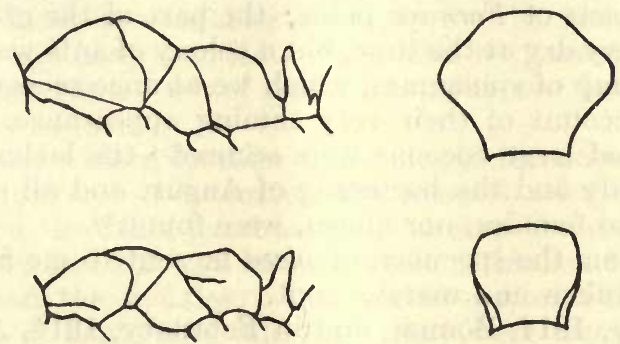

Fig. 92. 1. Thorax and scale of Formica gagates $\not$.

2. ", ", Formica picea

"(Donisthorpe.).

consider picea also to be a good species, as it is abundantly distinct from fusca in the worker, female and male, and its habits are quite different; Bondroit told me he also considered it to be a good species.

$F$. picea lives in wet places, and constructs small hillocks of bits of cut sphagnum, grass, etc., over its nests, the whole often soaked with water, and the ants and their brood living below the surface of the bog.

Nylander, as we have seen in the original description of picea, records it at Helsingfors and Uleåborg " in sphagnosis," 1 and again subsequently at Kuusamo " in sphagnosis."3

Farren-White only states he found the ants on the open heath ${ }^{22}$, but Arnold describes the nest found by him as follows:- "When collecting in the New Forest this July, a friend called my attention to a peculiarly shaped ants' nest in Matley Bog. In the part in which it was situated the ground was covered with tussock grass, each tussock forming a little hillock from one to two feet high, the ground between and below the tussocks being wet and mossy. On 
the top of one of these tussocks was a nest, in the shape of a cone, composed of very small bits of dried grass. It was about 9 inches high, and 4-5 inches wide at the base, the whole supported by the blades of tussock grass on the sides, while some of the blades sprang out from the top, forming a sort of pillar in the middle of the nest." 26

Arnold's "moss" between and below the tussocks would be sphagnum, and I suspect a part of the nest also consisted of sphagnum.

Saunders showed me a sketch of this nest which Arnold had made, but he unfortunately suggested that it was only constructed in this manner, on account of the nature of the ground in which it happened to occur, whereas these are the habits and situation peculiar to picea, and it is a splendid instance of the help that biology can give to the systematist.

On July 23rd, 1912, Crawley and I visited Matley Bog specially to hunt for nests of Formica picea; the part of the ground we explored was very dry at the time, but a colony of ants was discovered deep in a clump of sphagnum, which we at once recognized as this species on account of their very shining appearance. A number of workers and large cocoons were secured - the latter hatched at the end of July and the beginning of August and all proved to be males-but no females, nor queen, were found ${ }^{34}$.

Allen told me the specimen of picea he sent to me from Rhosilli in 1913 was taken in a marshy spot.

In January, 1914, Bönner, and in February, 1914, Adlerz, independently published papers on this interesting species, the one calling it a "Moorameise,"36 the other "Torfmossarnas Myra.", 38

On September 9th, 1912, the former author found an ants' nest in a "Torfmoor (Sphagnum)" at Lyngbymoor, two hours from Copenhagen, which he thought belonged to $F$. gagates, but Wasmann told him it was $F$. picea; and in July, 1913, they together visited the same locality.

This spot appears to be most admirably suited to picea, as Bönner says that at least one hundred and fifty nests occur in an area of two hundred metres long by eighty broad.

To get at the nests it is necessary to walk up to the ankles in water, the bog quaking, and if one stands still one sinks deeper, as where it is dry no nests occur, though they are not found in the very wettest parts where one would sink altogether; but the largest and most populous nests were often found on a higher and drier spot, which was merely surrounded by water.

The nests he found, which consisted of white hillocks composed of the leaves and stems of sphagnum collected together, varied from the size of a tennis-ball to half a "qm."-most nests measured one to two "dm." in diameter-and part of the nest was always situated five to seven "cm." below the surface. 
They were like a sponge, and when squeezed water ran out of them; only the chamber in the upper part of the dome and the entrances to the galleries being dry.

He often noticed grass stems growing through the nest, which at first he thought acted as pillars, in the same way as $D$. nigra uses grass stems to support its architecture, but he subsequently found that a number of black aphides were seated on these grass stems and sucking the juices from them; it is probable that the ants had built the nest round the stems on this account. In the hillocks he found cocoons, but rarely larvae, though in the hot weather most of the colony came up into them.

He says that not all nests are covered by a hillock, but that in such cases he never found the winged sexes nor brood in them. The colonies consisted of from fifty to one thousand individuals, but usually of six to eight hundred.

As he points out, the shining greasy ("fettige ") chitinous covering of these ants enables them to live in such wet places, but they always have wet feet, which can be proved by allowing them to walk over a pane of glass, when the wet marks made by their feet can be seen.

He found the winged females and males in the nests in July and August, but never in September, the females always being more abundant; on the other hand as we have seen Crawley and I only obtained males in 1912, and in $1914 \mathrm{I}$ found this sex to be far more abundant than the females. The worker pupae were usually in cocoons, but in September and later they were often naked, and he states he does not know how the colonies are founded.

On September 9th, 1912, he fixed up a small colony in a Lubbock nest, but the ants never worked in the earth, though they built a small wall with some sphagnum which had been introduced into the nest. Some larvae and cocoons of $F$. fusca were given to them, when they opened the latter and devoured the pupae, but accepted the former and covered them with bits of earth when ready to pupate.

He calls attention to the fact that Sahlberg ${ }^{10}$ found a mixed colony of this species and $F$. sanguinea in Finland, which was living in a sphagnum nest.

Wasmann, in commenting on this, suggests that either a sanguinea female had been accepted into a colony of picea after her marriage flight, or she had stolen some of their cocoons ${ }^{37}$.

The latter author also considers that the picea workers covering the larvae with bits of earth is a case of atavism, as this ant in normal conditions would not possess earth for this purpose ${ }^{37}$ - I have found however that ants in plaster nests where there is no earth present will use bits of plaster, cotton-wool, or anything they can get hold of for this purpose-and he points out that the white colour of these nests is caused by the fact that the sphagnum leaves 
possess large water-holding cells, between the green chlorophyl cells, and that when the leaves dry up the former cells fill with air, which gives a white appearance to the whole hillock ${ }^{37}$.

Adlerz ${ }^{38}$ says that $F$. picea appears to have completely adapted itself to a life in the sphagnum swamps of Nordland, outside of which he has never met with it, and he describes their nests as follows:- "In the sphagnum mounds inhabited by $F$. picea are passages and chambers dug out so compactly that their arrangement recalls that of the masonry nests of the species of Lasius. The excavated material is partly spread over the surface of the mound, thus increasing the size of the hillock, partly used for the partition walls between the chambers. These partitions are composed of a pliant, felted mass of shredded sphagnum interwoven and held together by a white, ramified fungus, which is of entirely different appearance to that of Cladotrichum myrmecophilum growing in nests of Lasius fuliginosus."

He says in fine weather the pupae are placed immediately under the outer covering of the chambers, and he has found the ants, their larvae, and pupae in the lower parts of the nest, which could be best compared to a completely saturated sponge, from which the water ran upon the slightest pressure; and that if the hillocks be opened, the ants often seek refuge by plunging under the surface of the water, holding firmly on to the moss, swaying it, evidently of set purpose, and pressing it down into the water until it closes over them, in order to hide in the already inundated chambers of the lower parts.

In his experience the pupae are as often naked as enclosed in cocoons, and if, as often asserted, the object of the cocoon is to protect the pupa against damp, then one would expect to find in these sphagnum nests, if anywhere, exclusively pupae in cocoons. Protection against dry weather appears to be unnecessary in these moss hillocks, so that the occurrence of cocoons among the picea pupae cannot be satisfactorily explained on these grounds.

Adlerz says that the males and winged females first appear at the beginning of August, and that he has found picea workers as slaves in sanguinea nests. He also found fly larvae (Microdon) in these nests.

On June 17th, 1914, I again visited Matley Bog in the hopes of finding nests of $F$. picea large enough to photograph for this work, but in this I was disappointed, though I was fortunate enough to find two incipient colonies of this most interesting species.

Search was first made in the spot where Crawley and I found the ant in 1912, but here it was all too dry, so proceeding further into the bog, I at last found a few workers, running about, and foraging on a patch of wet sphagnum some distance away. Some were on grass stems and others running on the surface of the sphagnum carrying flies, the body of a small bee, etc., and often when 



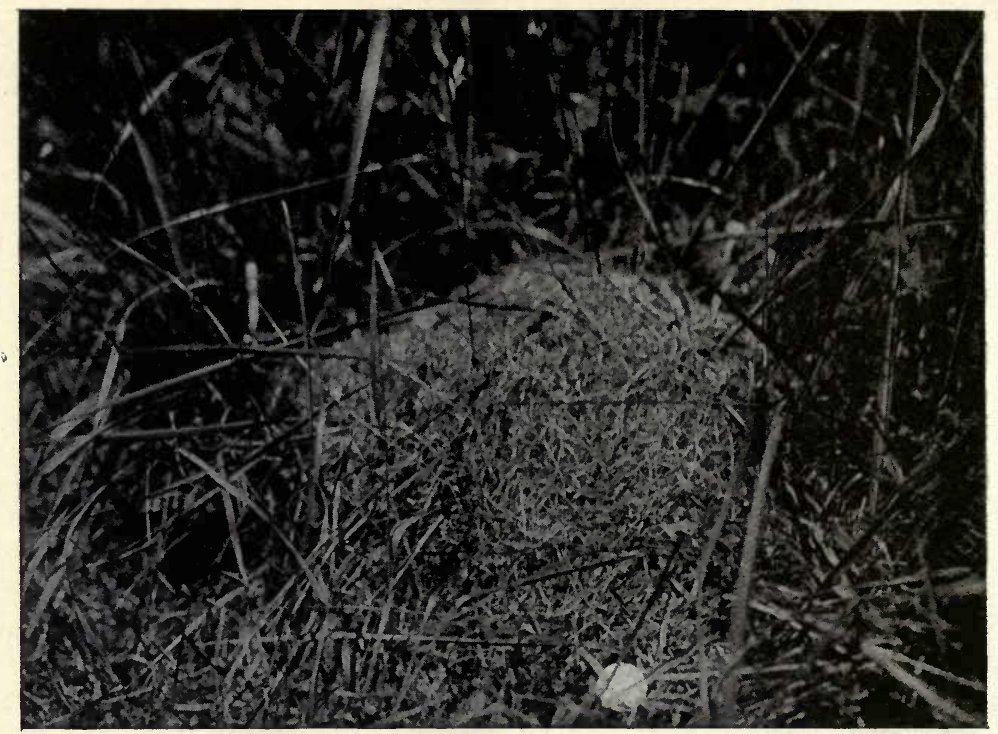

Nest of Formica exsecta. Parkliurst Forest, 29. VI.13.

(The white disc is a half-crown to show the size of the nest.)

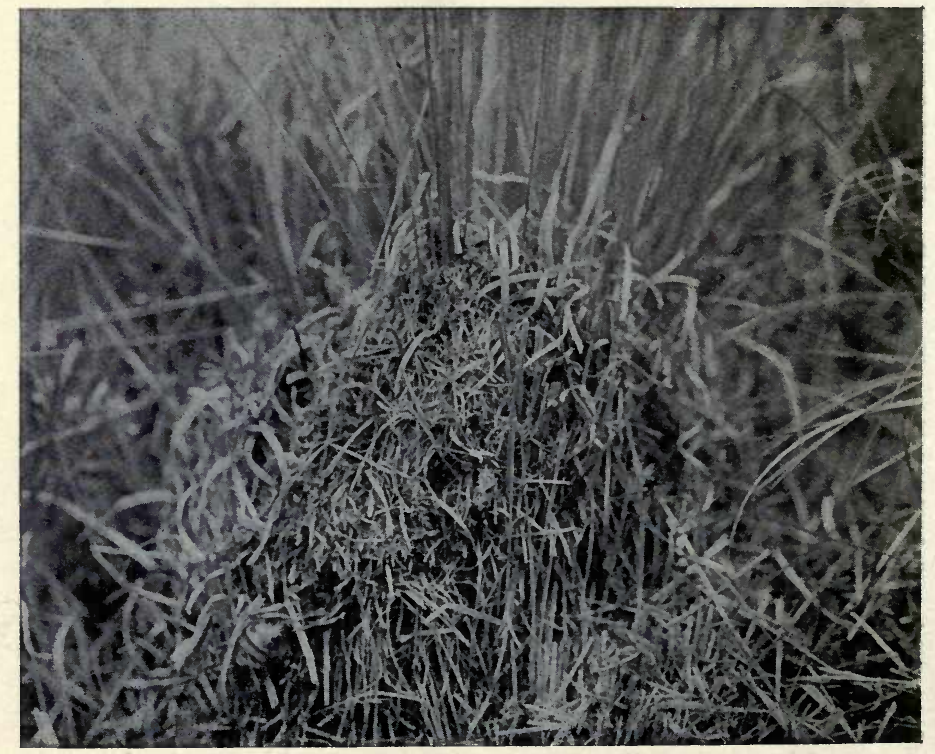

Nest of Formica picea. Matley Bog, New Forest, 23. VII.14. 
a worker was alarmed it seemed to vanish, disappearing into the sphagnum.

On carefully tracking some of the workers carrying prey I eventually discovered two nests (the workers were found to hunt at considerable distances from their dwellings), the one covered with a low layer of cut sphagnum, the other almost without any covering, being situated in the sphagnum itself, and when I knelt down to dig up the nests the knees of my trousers were quickly soaked with water. The nests were situated about a foot below the surface, some worker pupae, in cocoons, and a few workers being at the top, and below, in the very wettest part, a queen, a number of larvae, some more pupae, callows, etc., occurred in each. The one colony consisted of about one hundred individuals, the other perhaps of twice as many, and evidently in both these cases a young queen had found a suitable spot, after the marriage flight, and founded her colony alone.

Piffard has since given to me a plan of the place where he and Arnold found their nest; it was not on my spot, nor the 1912 locality, so that evidently $F$. picea ranges all over Matley Bog, though this locality is not so favourable as those in Denmark and Sweden.

I dug up a large block of sphagnum about a foot deep, with the wet peaty earth attached and a little heather and grass growing in it, which I brought home and fixed up in a large glass bowl, with water at the bottom. I introduced one of the above-mentioned colonies of picea into this observation nest. The queen and workers all disappeared into the sphagnum, carrying their brood. They soon established themselves in one corner of the clump, and now bits of sphagnum have been heaped above it. The ants feed on the honey which is placed in a lid fixed on the top of a pen-holder ; dead flies, other ant-larvae, etc., when put into a small tray, are very soon removed, but only one or two of the workers come up to get the food.

On July 14th I captured a specimen of the aberrant Phorid Aenigmatias blattoides Mein., which had climbed up to the honey and fallen in, and a day or two before I saw a winged Phorid, very like Platyphora lubbocki Verrall, running about, which disappeared into the sphagnum. My later captures, mentioned presently, prove these to be the female and male of the same species.

On July 23rd when again in the New Forest further search for nests of $F$. picea proved successful, five colonies being found, which had constructed nests of various sizes. The smallest of these nests was only about three inches high, consisting of bits of cut grass built round the stem of a small shoot of "Bog Myrtle"; the largest was about a foot in height and six inches in diameter, consisting of fine cut grass, bits of heather, some leaves of "Bog Myrtle," and sphagnum, these materials being closely woven 
together, with no visible opening on the outside. The other three nests were chiefly composed of bits of sphagnum and were situated on patches of that material. The large nest, and two of the mediumsized ones, were dug up and carefully investigated; a single deälated female was found in each of the two latter nests, and three occurred in the former. Naked pupae, as well as cocoons, of both sexes and workers were present, very many large cocoons occurring in the big nest. In these nests I found a number of small Dipterous pupae, the "spring-tail" Cyphodeirus albinos, and some pink coccids of the genus Pseudococcus, new to science, which E. Green has named $P$. sphagni.

Three of the deälated females, a number of workers, larvae, and pupae were brought home and introduced into the glass bowl, when they all disappeared into the sphagnum, being quite friendly with the older inhabitants of the nest.

A number of the large cocoons with a few workers were placed in tins with a little damp earth and sphagnum, and males and winged females commenced to emerge on July 26th-eventually over thirty hatched; only six of these were females, the last of which appeared on October 15th, 1914.

A number of the Dipterous pupae hatched, proving to be Platyphora and Aenigmatias, which are no doubt the male and female of Platyphora lubbocki Verrall.

\section{COSMOPOLITAN AND INTRODUCED SPECIES.}

Ants are continually being transported from land to land by commerce, in railway trains and ships, even the ships themselves becoming inhabited by some species.

Large numbers of ants, comprising single specimens, fecundated females, and even whole colonies, are carried about in fruit, vegetables, and plants of all kinds, sheltered in the leaves, earth, and moss adhering to the roots, etc.

Every botanical garden throughout the world receives annually numbers of species of ants from the tropics with orchids, etc., and by this means many of the species may become permanent inhabitants of the hot-houses; through the exchange of plants some of the ant-fauna of one botanical garden may be introduced into another.

Forel, in a paper on the geographical distribution of the Formicidae, read at the Entomological Congress at Brussels, enumerated eleven species of ants which have become cosmopolitan, being introduced everywhere by shipping, viz. :-

\section{Odontomachus haematodes L.}

2. Monomorium destructor Jerdon.

3. Monomorium floricola Jerdon. 
4. Monomorium pharaonis $\mathrm{L}$.

5. Solenopsis geminata F.

6. Pheidole megacephala F.

7. Tetramorium guineense $\mathrm{F}$.

8. Tetramorium simillimum F. Smith.

9. Tapinoma melanocephalum F.

10. Prenolepis longicornis Ltr.

11. Prenolepis vividula Nyl.

Of these all but the first, the third, and the fifth have been found in Britain, and some of them have become permanent inhabitants of hot-houses and dwellings.

Forel further gives four more species, which he says are actually becoming cosmopolitan at the present time, viz. :-

1. Plagiolepis longipes Jerdon.

2. Triglyphothrix striatidens Emery.

3. Iridomyrmex humilis Mayr.

4. Cardiocondyla emeryi Forel.

The second and third of these species have occurred with us. I give a list of every species (as far as is known to me) which has been introduced into Britain. The majority of these have not established themselves, and many of them have only been found in the plants, etc., in which they had just reached this country, but it seems advisable to enumerate them all, as it shows how and when they were or might have been introduced, should they obtain a footing here.

\section{PONERINAE.}

\section{Ectatomma regulare Mayr.}

Gnamptogenys regularis Mayr Verh. Zool. Bot. Ges. Wien $20965(1870)^{1}$. Ectatomma regulare Dalla Torre Cat. Hym. $726(1893)^{2}$. Ectatomma (Gnamptogenys) regulare Emery Gen. Ins. $11845(1911)^{3}$. Ectatomma regularis Donisthorpe Bull. R. Bot. Gard. Kew. 12368 (1911)

Habitat : Mexico, Central America, Brazil.

Two workers captured in the propagating pits, Kew Gardens, in $1911^{4}$.

\section{Diacamma rugosum Le Guill. subsp. vagans F. Smith var. indica Forel.}

Diacamma vagans Dalla Torre Cat. Hym. 729 (1893) ${ }^{1}$ [in part]; Bingham Faun. Brit. Ind. Hym. $281(1903)^{2}$. Diacamma rugosum race vagans var. indicum Forel Rev. Suisse Zool. $11400(1903)^{3}$. Diacamma vagans Bingham Bull. R. Bot. Gard. Kew (AS) 527 (1906)4. Diacamma rugosum subsp. vagans v. indica Emery Gen. Ins. $11867(1911)^{5}$.

Habitat : India.

Captured in a case from Calcutta, Kew Gardens, June, 1898. 
Neoponera theresiae Forel.

Pachycondyla theresiae Forel Biol. Centr. Amer. Hym. 313 (1899)1 . Neoponera theresiae Emery Gen. Ins. $11872(1911)^{2}$; Lucas Pro. Ent. Soc. Lond. $1911 \mathrm{XVI}^{3}$.

Habitat : Peru and Panama.

Three workers on bananas at Swanage (Tatchell) ${ }^{3}$.

Ponera coarctata Ltr. subsp. boerorum Forel.

Ponera coarctata r. boerorum Forel Rev. Suisse Zool. 9339 (1901) ${ }^{1}$; Donisthorpe Bull. R. Bot. Gard. Kew $3122(1908)^{2}$. Ponera *punctatissima subsp. boerorum Donisthorpe Trans. Leicester Lit-Phil. Soc. $12230(1908)^{3}$ : Ent. Rec. $2314(1911)^{4}$. Ponera coarctata subsp. boerorum Emery Gen. Ins. 118 $90(1911)^{5}$.

\section{Habitat: Natal.}

Kew Gardens : Winged female in Palm House, workers in fern house, January, $1908^{2}$; workers scarce in Fern House, common in palm house under flower-pots, November, 19104. Beresford sent me specimens to name from Dickson's nurseries, Newtownards, co. Dublin.

\section{Ponera opaciceps Mayr.}

Ponera opaciceps Mayr Verh. Zool. Bot. Ges. Wien $37536(1887)^{1}$; Dalla Torre Cat. Hym. $740(1893)^{2}$; Emery Gen. Ins. $11892(1911)^{3}$; Donisthorpe Bull. R. Bot. Gard. Kew. 12368 (1911) 4

Habitat: Brazil, Uruguay, Mexico, Porto Rico, Texas.

Two workers in propagating pits, Kew Gardens, May, $1911^{4}$.

\section{Anochetus mayri Emery.}

Anochetus mayri Emery Ann. Mus. Civ. Nat. Genova $21378(1884)^{1}$; Dalla Torre Cat. Hym. $748(1893)^{2}$; Emery Gen. Ins. $118110(1911)^{3}$.

Habitat : Antilles.

One worker under flower-pot in hot-house, Kew Gardens, 3.xi.11 (Crawley).

\section{MYRMICINAE.}

\section{Pseudomyrma gracilis $\mathrm{F}$.}

Formica gracilis Fabricius Syst. Piez. $405(1804)^{1}$. Pseudomyrma gracilis Dalla Torre Cat. Hym. $757(1893)^{2}$.

Habitat: South and Central America.

Three workers, Kew Gardens, 20,iii.12.

\section{Monomorium destructor Jerd.}

Atta destructor Jerdon Madras Journ. Lit-Sc. 171851105 (1853)1. . Monomorium destructor Dalla Torre Cat. Hym. $766(1893)^{2}$; Forel Int. Ent. Cong. Bruxelles $1910283(1911)^{3}$; Donisthorpe Bull. R. Bot. Gard. Kew $12368(1911)^{4}$.

Habitat : Cosmopolitan species.

Living and dead workers in numbers on a plant from Calcutta; Kew Gardens, May, $1910^{4}$. 


\section{Monomorium minutum Mayr.}

Monomorium minutum Mayr Verh. Zool. Bot. Ver Wien $5453(1855)^{\mathbf{1}}$; Er André Spec. Hym. Europe $2333(1881)^{2}$; Dalla Torre Cat. Hym. 767 $(1893)^{3}$. Monomorium minutum minutum Emery Deutsch. Ent. Zeitschr. $1908681^{4}$. Monomorium minutum Donisthorpe Trans. Leicester Lit-Phil. Soc. $12231(1908)^{5}$ : Bull. R. Bot. Gard. Kew $6251(1909)^{6}$; Wheeler Journ. New York Ent. Soc. $17183(1909)^{7}$.

Habitat: Italy, Corfu, Syria, Algeria.

Kew Gardens : On a plant from the Cambridge Botanic Gardens in $1908^{5}$, and in fern pits, February, $1909^{6}$.

\section{Monomorium pharaonis L.}

Cosmopolitan species (see p. 96).

\section{Pheidologeton diversus Jerd.}

Ocodoma diversa Jerdon Madras Journ. Lit-Sc. $171851109(1853)^{1}$. Pheidologeton diversus Dalla Torre Cat. Hym. $773(1893)^{2}$. Phidologiton diversus Bingham Faun. Brit. Ind. Hym. $2162(19) 3)^{\prime}$. Pheidologeton diversus Donisthorpe Bull. R. Bot. Gard. Kew 12368 (1911)4.

Habitat : India, Burma, extending into Malayan sub-region.

A deälated female and small workers in fern pits (the large queen was in the soil at the bottom of a flower-pot), Kew Gardens, November, $1909^{4}$.

\section{Cremastogaster scutellaris $\mathrm{Ol}$.}

Formica scutellaris Olivier Enc. Méth Ins. $6497(1791)^{1}$. Cremastogaster scutellaris Forel Denkschr. Schweiz. Ges. Naturw. $26 \quad 68223.386(1874)^{2}$; Er. André Spec. Hym. Europe $2392(1881)^{3}$; Billups Proc. Ent. Soc. Lond. $1884 \mathrm{XIV}^{4}$; Mason Proc. Ent. Soc. Lond. $1889 \mathrm{XXII}^{5}$; Dalla Torre Cat. Hym. $785(1893)^{6}$; Saunders Hym-Acul. $42(1896)^{7}$; Bingham Bull. R. Bot. Gard. Kew (AS) $528(1906)^{8}$; Vic. Hist. Cornwall $1182(1906)^{9}$; Vic. Hist. Devon $1188(1906)^{10}$; Vic. Hist. Stafford 183 (1908) ${ }^{11}$; Donisthorpe Trans. Leicester Lit-Phil. Soc. $12231(1908)^{12}$ : Bull. R. Bot. Gard. Kew $6251(1909)^{13}$. Crematogaster scutellaris scutellaris Emery Deutsch. Ent. Zeitschr. $1912653^{14}$.

Habitat: Europe, south-west, Mediterranean, etc.; North Africa, Tunisie, etc.

This ant has frequently been taken in England, being often imported in virgin cork; Billups captured workers running on the pavement in Church Street, Greenwich, near the premises of a firm of cork importers ${ }^{4}$; it occurred in abundance in the fernery of Mr. Baxter at Burton-on-Trent ${ }^{5}$; Bingham records it amongst virgin cork at Kew Gardens ${ }^{8}$; it occurred in greenhouses at Penryn, Cornwall $^{9}$; in imported apples on November 1st, 1892, in Devonshire $^{10}$; and in June of the same year E. A. Butler observed it in some numbers on virgin cork in a shop in North London ${ }^{12}$. In April, 1909, I found it in abundance, in company with Colobopsis truncata Spin., in cork at Kew Gardens ${ }^{13}$; and Pool sent me 
specimens of these two species which he had captured in the Insect House in the Zoological Gardens in July, 1914.

\section{Cremastogaster terminalis Shuck.}

Myrmica terminalis Shuckard Mag. Nat. Hist. (n.s.) 2627 (1838). ${ }^{1}$ Cremastogaster terminalis Dalla Torre Cat. Hym. 787 (1893). ${ }^{2}$

Taken by Abel Ingpen in hot-houses in Chelsea. ${ }^{1}$

\section{Pheidole gertrudae Forel.}

Pheidole gertrudae Forel Ann. Soc. Ent. Belg. 30 XLII (1886) ${ }^{1}$; Dalla Torre Cat. Hym. $790(1893)^{2}$; Donisthorpe Bull. R. Bot. Gard. Kew 12 $368(1911)^{3}$.

Habitat: Brazil ; Rio de Janeiro.

A winged female, numerous soldiers, and workers taken in propagating pits in Kew Gardens, May, 1911³.

\section{Pheidole megacephala F.}

Formica megacephala Fabricius Ent. Syst. $2361(1793)^{1}$ Oecophthora pusilla Heer Zurcher. Jung. Naturf. Ges. 54 1-24 (1852)2. Myrmica (?) laevigata F. Smith Trans. Ent. Soc. Lond. (n.s.) $3130(1855)^{3}$. Oecophthora pusilla Heer (trans. Lowe) Ann. Mag. Nat. Hist. (n.s.) 17 209-224, 322-333 Pf. III 1-4 (1856)4. Myrmica (Pheidole) pallidula F. Smith Trans. Ent. Soc. Lond. (n.s.) $41857282(1858)^{5}$. Myrmica (Pheidole) laevigata F. Smith Cat. Brit. Foss. Hym. $35225(1858)^{6}$ : Ent. Ann. 186270 Pf. [1] 4, 7-87. Pheidole laevigata F. Smith Ent. Mo. Mag. $229(1865)^{8}$ : Ent. Ann. $187161^{9}$. Pheidole pusilla Blackburn and Kirby Ent. Mo. Mag. $1789(1880)^{10}$. Pheidole pallidula Parfitt Trans. Devon. Assn. Sc-Lit. $12517(1880)^{11}$. Pheidole megacephala Saunders Trans. Ent. Soc. Lond. $1880223^{12}$; Er. André Spec. Hym. Europe $2383(1881)^{13}$; Dalla Torre Cat. Hym. $792(1893)^{14}$. Pheidole laevigata Farren-White Ants' Ways $60248(1895)^{15}$. Pheidole megacephala Saunders Hym-Acul. $42(1896)^{16}$; Donisthorpe Trans. Leicester Lit-Phil. Soc. 12230 $(1908)^{17}$; Forel Int. Ent. Cong. Bruxelles $1910283(1911)^{18}$.

Habitat : Cosmopolitan species.

This species was known as the house-ant of Madeira, where it was very abundant, and Heer wrote a very interesting paper on its habits $^{2}$. F. Smith records, in 1855, that this ant occurred some years ago at Battersea ${ }^{3}$; in 1858 , its capture on a wall at Hampstead, and in a hot-house at Exeter $(\text { Parfitt })^{5}$; and in 1862 he states it has been found in many conservatories, and in numbers in a baker's shop in the Borough (Farren-White) ${ }^{\text {? }}$. Parfitt records its occurrence in numbers in Mr. Veitch's nursery at Exeter ${ }^{11}$, Saunders at Greenwich ${ }^{\mathbf{1 2}}$, and Farren-White in an eating-house in the City as well as in the baker's shop in the Borough; he says it is undoubtedly naturalized ${ }^{15}$.

Typical Pheidole megacephala has not, however, been found in England for many years. 
Pheidole megacephala F. var. punctulata Mayr.

Pheidole punctulata Mayr Verh. Zool. Bot. Ges. Wien $16899(1866)^{1}$; Dalla Torre Cat. Hym. $795(1893)^{2}$.

Habitat: South Africa; Sierra Leone.

In February, 1913, Purser sent me workers and soldiers of this variety to name, which he had taken in the Cambridge Botanic Gardens. He tells me they attend "scales" and "mealy bugs," and build earthen chambers round the stems of small plants in flower-pots, up to about an inch above the soil. In January, 1914, Scott sent me more workers and males from the same locality; he says the ants have evidently been established for some time.

\section{Pheidole anastasii Emery var. cellarum Forel.}

Pheidole anastasii v. cellarum Forel Bull. Soc. Vaud. Sc. Nat. $4455(1908)^{1}$; Donisthorpe Bull. R. Bot. Gard. Kew $3122(1908)^{2}$ : Trans. Leicester LitPhil. Soc. $12231(1908)^{3}$; Bondroit Ann. Soc. Ent. Belg. $5514(1911)^{4}$.

Habitat : Guatemala (?) ; Costa Rica. (?)

Forel described this variety from specimens taken in hot-houses at Kew, Zurich, and Dresden'1.

In February, 1908, workers and soldiers were very abundant in the orchid house in Kew Gardens ${ }^{2}$, and again in 1913. In June, 1914, Cooper gave me specimens to name which he had captured in a hot-house at Bournemouth. Beresford has taken it in Dickson's nurseries, Newtownards, co. Dublin.

Bondroit found it in abundance in the hot-houses in the Botanic Gardens at Brussels ${ }^{4}$.

Forel wrote to me (27.xi.13) as follows:- "This form is so typical in all hot-houses in Europe, that it has almost become a race."

\section{Pheidole rhombinoda Mayr.}

Pheidole rhombinoda Mayr Verh. Zool. Bot. Ges. Wien $28678(1878)^{1}$; Dalla Torre Cat. Hym. $795(1893)^{2}$; Bingham Faun. Brit. Ind. Hym. 2 $250(1903)^{3}$.

Habitat: India; Ceylon.

A deälated female, soldiers, and workers, Kew Gardens, September, 1912 .

\section{Tetramorium guineense $\mathrm{F}$.}

Formica guineensis Fabricius Ent. Syst. 2357 (1793) ${ }^{1}$. Tetramorium kollari Mayr Verh. Zool. Bot. Ver. Wien $5425(1855)^{2}$. Myrmica reticulata F. Smith Trans. Ent. Soc. Lond. (3 S) $133(1862)^{3}$ : Ent. Ann. $187160^{4}$. Myrmica kollari F. Smith Ent. Ann. $187160^{5}$. Leptothorax reticulata Parfitt Trans. Devon Assn. Sc-Lit. $12516(1880)^{6}$. Tetramorium guïneense Saunders Trans. Ent. Soc. Lond. $1880223^{7}$; Er. André Spec. Hym. Europe 2288 $(1881)^{8}$; Dalla Torre Cat. Hym. $7133(1893)^{9}$. Tetramorium kollari FarrenWhite Ants' Ways $242(1895)^{10}$. Tetramorium guineense Saunders Hym-Acul. $34(1896)^{11}$; Thornley Nat. $18981^{12}$; Vic. Hist. Notts $191(1906)^{13}$; Godfrey Notes R. Bot. Gard. Edinburgh 17101 (1907) ${ }^{14}$; Donisthorpe Trans. 
Leicester Lit-Phil. Soc. $12230(1908)^{15}$; Emery Deutsch. Ent. Zeitschr. $1909695^{16}$; Donisthorpe Bull. R. Bot. Gard. Kew 12368 (1911) $)^{17}$ : Ent. Rec. $2314(1911)^{18}$; Forel Int. Ent. Cong. Bruxelles $1910283(1911)^{19}$.

Habitat: Cosmopolitan species.

F. Smith records this species, in 1862, from the Botanic Gardens at Exeter $(P a r f i t)^{3}$, and subsequently from Sheerness taken in 1866 $(\text { Brewer })^{5}$. Saunders gives Exeter and Greenwich as localities ${ }^{7}$; and Farren-White found it in great numbers in a hot-house at Stroud, and at Easting near Stonehouse, and in 1894 he captured it in the Botanic Gardens in Regent's Park ${ }^{10}$. Pegler took a worker at Retford, Notts ${ }^{12}$; and Godfrey describes it as the most abundant species in the Botanic Gardens at Edinburgh, winged specimens occurring from June to September ${ }^{14}$. Crawley observed this species in a conservatory at West Leake, Notts, in 1909, where he says it had been abundant for some years ${ }^{18}$. In December, 1910, it occurred in some numbers in a small hot-house in Kew Gardens, deälated females walking about freely among the workers ${ }^{17}$. In 1911 E. A. Butler captured specimens in a hot-house at Harrow. J. F. X. King took specimens in the Botanic Gardens at Belfast, and Halbert sent me specimens to examine from the Buckle Collection, also from Belfast-these were standing under the name Myrmica lippula. In the British Museum Collection specimens taken by R. S. Draper in hot-houses in Sunderland were doing duty for Myrmica lobicornis.

\section{Tetramorium simillimum F. Smith.}

Myrmica simillima F. Smith List. Brit. Anim. Brit. Mus. Acul. 118 (1851)1 ; Curtis Trans. Linn. Soc. Lond. $21216(1854)^{2}$; F. Smith Trans. Ent. Soc. Lond. (n.s.) 3129 (1855) ${ }^{3}$ : Ent. Ann. 1855 98. Myrmica (Leptothorax) simillima F. Smith Cat. Brit. Foss. Hym. $31(1858)^{5}$. Leptothorax simillima Parfitt Trans. Devon Assn. Sc-Lit. $12517(1880)^{6}$. Tetramorium simillimum Saunders Trans. Ent. Soc. Lond. $1880223^{7}$; Er. André Spec. Hym. Europe $2287(1881)^{8}$; Dalla Torre Cat. Hym. $7134(1893)^{9}$. Leptothorax simillimus Farren-White Ants' Ways $245(1895)^{10}$. Tetramorium simillimum Saunders Hym-Acul. $34(1896)^{11}$; Vic. Hist. Devon $1188(1906)^{12}$; Donisthorpe Bull. R. Bot. Gard. Kew $3122(1908)^{13}$ : Trans. Leicester Lit-Phil. Soc. 12230 $(1908)^{14}$; Emery Deutsch. Ent. Zeitschr. 1909 696 $6^{15}$; Forel Int. Ent. Cong. Bruxelles $1910283(1911)^{16}$.

Habitat : Cosmopolitan species.

F. Smith recorded that this ant was taken by Dale near his house at Glanvilles Wootton in Dorsetshire ${ }^{3}$, but subsequently that it had occurred in a greenhouse ${ }^{5}$. Parfitt observed it in large numbers, in June, 1876, in a hot-house at Exeter ${ }^{6}$; Saunders recorded it from Kew in $1880^{7}$; and Farren-White discovered it in a hot-house at Cheltenham ${ }^{10}$. In January and February, 1908, I found it present in some numbers in the Palm House at Kew Gardens ${ }^{13}$; a few deälated females were taken walking amongst the workers. 
Tetamorium mayitae Forel.

Tetramorium mayitae Forel in Escherich Termiten. Ceylon $224(1911)^{1}$; Donisthorpe Bull. R. Bot. Gard. Kew 12368 (1911)².

Habitat : Ceylon.

A number of workers on a plant from Java, Kew Gardens, January, $1911^{2}$.

Tetramorium lucayanum Wheeler var. sexdens Forel in lit.

Beresford sent me specimens of a Tetramorium to name, which he had taken in the Glasnevin Botanic Gardens, co. Dublin. Forel tells me it is a new variety of a species recently described by Wheeler from the Bahamas.

\section{Wasmannia auro-punctata Rog.}

Tetramorium (?) auro-punctatum Roger Berlin Ent. Zeits. 7182 (1863)¹. Tetramorium auro-punctatum Dalla Torre Cat. Hym. $7130(1893)^{2}$. Wasmannia auro-punctata Forel Trans. Ent. Soc. Lond. $1893383^{3}$; Donisthorpe Bull. R. Bot. Gard. Kew $3122(1908)^{4}$ : Trans. Leicester Lit-Phil. Soc. 12 $230(1908)^{5}$ : Bull. R. Bot. Gard. Kew 6251 Pf. [1]·7 (1909) ${ }^{6}$ : $12368(1911)^{7}$

Habitat : West Indies.

I first discovered this tiny little species in Kew Gardens in 19074; it is one of the commonest ants at Kew, being abundant in the propagating pits and some other houses. It nests in and under flower-pots, in the leaf-sheaves of Piper obliquum v. eximium, etc., and its males and females, which are very large in comparison with the workers, occur in December and January in the nests, and sometimes on the walls of the hot-houses. A small "wood-louse" somewhat like Platyarthrus hoffmanseggi, and the little spider Diblemma donisthorpei Camb., which is superficially very like the worker ants, are usually to be found in the nests.

\section{Triglyphothrix striatidens Emery.}

Tetramorium obesum razza striatidens Emery Ann. Mus. Civ. Gen. 27 $501(1889)^{1} \quad$ Triglyphothrix striatidens Dalla Torre Cat. Hym. $7136(1893)^{2}$; Bingham Faun. Brit. Ind. Hym. $2173(1903)^{3}$. Triglyphothrix obesa st. striatideus Bingham Bull. R. Bot. Gard. Kew (AS) $528(1906)^{4}$. Triglyphothrix striatidens Donisthorpe Bull. R. Bot. Gard. Kew $3122(1908)^{5}$ : Trans. Leicester Lit-Phil. Soc. 12231 (1908) ; ${ }^{6}$ Forel Int. Ent. Cong. Bruxelles $1910283(1911)^{?}$.

Habitat: India, Burma, Ceylon, Tunis, Sierra Leone, etc.

Bingham records this ant in the propagating pits 4 , and I have found it in plenty in the fern and palm houses in Kew Gardens 5 .

\section{Strumigenys rogeri Emery.}

Strumigenys rogeri Emery Bull. Soc. Ent. Ital. $2268(1890)^{1}$; Dalla Torre Cat. Hym. $7147(1893)^{2}$; Strumigenys incisa Godfrey Notes R. Bot. Gard. Edinburgh $17102(1907)^{3}$. Strumigenys rogeri Donisthorpe Bull. R. 
Bot. Gard. Kew $3122(1908)^{4}$ : Trans. Leicester Lit-Phil. Soc. $12231(1908)^{5}$ : Bull. R. Bot. Gard. Kew 6251 Pf. [1]·9 (1909) ${ }^{6}$.

Habitat: West Indies.

Several workers were taken in the propagating pits in 1904 (Godfrey) and again in 1905 (Stewart), Edinburgh Botanic Gardens ${ }^{3}$. There is a winged female from the same source in the British Museum Collection.

I captured a few workers under flower-pots in the propagating pits, Kew Gardens, December, $1907^{45}$, and a few have occurred since.

\section{DOLICHODERINAE.}

Iridomyrmex humilis Mayr.

Hypoclinea humilis Mayr Ann. Soc. Nat. Modena $3164(1868)^{1}$. Iridomyrmex humilis Dalla Torre Cat. Hym. $7169(1893)^{2}$; Carpenter Econ. Proc. R. Dublin Soc. $1155(1902)^{3}$; Donisthorpe Trans. Leicester Lit-Phil. Soc. $12229(1908)^{4}$; Foster Journ. Econ. Ent. $1289-293(1908)^{5}$; Woodworth Univ. Cal. Agri. Exp. Stn. Circ. 38 1-11 (1908)6 ; Newell Journ. Econ. Ent. 2 174-192 (1909) ${ }^{7}$; Wheeler Ants 153-155 (1910) ${ }^{8}$; Forel Int. Ent. Cong. Bruxelles $1910283(1911)^{8}$; Emery Gen. Ins. $13726(1912)^{10}$.

Habitat : Argentine; Brazil.

This species is known as the "Argentine Ant"; it is rapidly becoming cosmopolitan, and when once introduced into a new locality it may become a very serious pest. It displaces local species, and seems to have entirely exterminated Pheidole megacephala in Madeira ${ }^{8}$. It has been introduced into New Orleans ${ }^{5}$ and California ${ }^{6}$; in the former locality it now extends over fully five thousand square miles-from New Orleans to the Gulf of Mexico.

Newell has written an interesting account of the life history of this species?

Carpenter records its oceurrence in vast numbers in a house in Windsor Park, Belfast, in 1900, where it had been observed for eighteen months. The ants were present in the laundry, conservatory, and vinery, crossing the kitchen yard in great abundance. The ants were only got rid of with the greatest difficulty; the floors were taken up and eight large nests were found at a depth of three to four feet; they were also present in the walls. Waterston in 1912 sent me specimens of this ant to name, tåken in the Botanic Gardens in Edinburgh.

\section{Tapinoma melanocephalum F.}

Formica melanocephala Fabricius Ent. Syst. $2353(1793)^{1}$. Tapinoma melanocephalus Billups Proc. Ent. Soc. Lond. $1887 \mathrm{XXVII}^{2}$. Tapinoma melanocephalum Dalla Torre Cat. Hym. $7165(1893)^{3}$; Godfrey Notes R. Bot. Gard. Edinburgh $17102(1907)^{4}$; Forel Int. Ent. Cong. Bruxelles 1910 283 (1911); Emery Gen. Ins. 13741 (1912).

Habitat : Cosmopolitan species.

Billups eaptured this ant in September, 1886, on a palm in the palm house in Kew Gardens ${ }^{2}$; Godfrey records finding a nest in 
a pot containing an orchid from Hamburg, in June, 1904, in the Edinburgh Botanic Gardens, where the species was again found in August, 1904, and February, 1905 (Stewart) ${ }^{4}$. Hamm took it in some numbers on November 30th, 1908, on fruit in the Oxford market.

\section{Tapinoma minutum Mayr.}

Tapinoma minutum Mayr Verh. Zool. Bot. Ges. Wien 12703 (1862) Dalla Torre Cat. Hym. $7166(1893)^{2}$. Tapinoma *melanocephalum Donisthorpe Bull. R. Bot. Gard. Kew $12368(1911)^{3}$. Tapinoma minutum Emery Gen. Ins. 13741 (1912)4.

Habitat: New South Wales.

Workers in some numbers, Kew Gardens, $1911 .^{3}$

\section{Technomyrmex albipes F. Smith.}

Formica (Tapinoma) albipes F. Smith Journ. Pro. Linn. Soc. Zool. 638 $(1862)^{1}$. Technomyrmex albipes Dalla Torre Cat. Hym $7166(1893)^{2}$; Bingham Faun. Brit. Ind. Hym. $2301(1903)^{3}$ : Bull. R. Bot. Gard. Kew (AS) 528 $(1906)^{4}$; Donisthorpe Bull. R. Bot. Gard. Kew $3122(1908)^{5}$ : Trans. Leicester Lit-Phil. Soc. $12229(1908)^{6}$; Forel Bull. Soc. Vaud. Sc. Nat. $4421(1908)^{7}$; Donisthorpe Bull. R. Bot. Gard. Kew 6251 Pf. [1]•4, 8 (1909) ${ }^{8}$ : $12368(1911)^{9}$ : Ent. Rec. 2315 (1911) $^{10}$; Emery Gen. Ins. 13743 (1912) $^{11}$.

Habitat: India, Malay Isles, New Guinea, etc.

Bingham records this species from the palm house at $\mathrm{Kew}^{4}$; it is the commonest ant in the hot-houses in Kew Gardens, occurring in abundance in the fern and palm houses, propagating-pits, and other hot and some cooler houses. In $1908 \mathrm{I}$ discovered an apterous form of the male, which Forel has described ${ }^{7}$, and is sometimes abundant in company with the winged form. In $1910 \mathrm{I}$ found a short-winged male which I have suggested may be a mermithaner ${ }^{10}$. I never took the winged female, but on February 11th, 1909, I captured a deälated female walking on a rockery in the palm house.

I have received this ant from the Dublin Botanic Gardens (Halbert), and the Edinburgh Botanic Gardens (Bagnall).

Technomyrmex albipes F. Smith var. brunneipes Forel.

Technomyrmex albipes v. brunneipes Forel Journ. Bombay NH. Soc. $9466(1895)^{1}$; Bingham Faun. Brit. Ind. Hym. $2302(1903)^{2}$; Godfrey Notes R. Bot. Gard. Edinburgh $17101(1907)^{3}$; Emery Gen. Ins. 13743 $(1912)^{4}$.

Habitat: India.

Godfrey records this variety from the Botanic Gardens at Edinburgh; according to Stewart it builds earthen chambers ${ }^{3}$.

\section{CAMPONOTINAE.}

Plagiolepis alluaudi Emery.

Plagiolepis flavidula Er. André Spec. Hym. Europe 2 208. (1881)1 ; Dalla Torre Cat. Hym. $7172(1893)^{2}$. Plagiolepis alluaudi Emery Ann. Soc. Ent. 
France $189471^{3}$. Plagiolepis flavidula. Saunders Hym-Acul. $26(1896)^{4}$; Vic. Hist. Warwick $173(1904)^{5}$; Vic. Hist. Notts $191(1906)^{6}$. Plagiolepis alluaudi Donisthorpe Bull. R. Bot. Gard. Kew $3122(1908)^{7}$ : Trans. Leicester Lit-Phil. Soc. $12229(1908)^{8}$.

Habitat : Seychelles.

This little species has been found in the Botanic Gardens at Kew $^{4}$, Cambridge ${ }^{4}$, Edgbaston ${ }^{5}$, Dublin (Halbert $)^{8}$, Edinburgh (Bagnall $)^{8}$, Oxford (Hamm), and Belfast (J.F.X.King) ; in greenhouses at Bramcote, Notts ${ }^{6}$, and Beccles, Suffolk (Crowfoot). I found it in abundance in the palm house at Kew in December, $1907^{7}$, and Hamm captured winged females at Oxford on April 11th, 1903.

\section{Plagiolepis exigua Forel.}

Plagiolepis exigua Forel Journ. Bombay NH. Soc. 8417 (1894) ${ }^{1}$; Bingham Faun. Brit. Ind. Hym. $2323(1903)^{2}$; Godfrey Notes R. Bot. Gard. Edinburgh $17102(1907)^{3}$.

\section{Habitat : India.}

Godfrey records this species as abundant in the hot-houses at Edinburgh in 1904 ; nests were found in 1905, in the aroid house, in hollow metal rods ${ }^{3}$.

\section{Brachymyrmex patagonicus Mayr.}

Brachymyrmex patagonicus Mayr Ann. Soc. Nat. Modena $3164(1868)^{1}$; Dalla Torre Cat. Hym. $7174(1893)^{2}$; Donisthorpe Bull. R. Bot. Gard. Kew $6251(1909)^{3}$.

Habitat : Central America.

This species occurred in abundance in the Orchid house at Kew in $1909^{3}$, and again in 1910 .

\section{Prenolepis imparis Say subsp. nitens Mayr.}

Tapinoma nitens Mayr Ver Zool. Bot. Ver Wien $2144(1852)^{1}$. Tapinoma polita F. Smith Trans. Ent. Soc. Lond. (n.s.) $3112(1855)^{2}$ : Cat. Brit. Foss. Hym. $18(1858)^{3}$ : Ent. Mo. Mag. $229(1865)^{4}$. Tapinoma nitens Saunders Trans. Ent. Soc. $1880211^{5}$. Tapinoma polita Dale Ent. Mo. Mag. 17236 $(1881)^{6}$. Prenolepis nitens Er. André Spec. Hym. Europe $2204(1881)^{7}$. Tapinoma nitens Saunders Ent. Mo. Mag. $20270(1884)^{8}$. Prenolepis imparis var. nitens Dalla Torre Cat. Hym. $7178(1893)^{9}$. Tapinoma polita Farren-White Ants' Ways $237(1895)^{10}$. Prenolepis nitens Saunders HymAcul. 25 (1896) ${ }^{11}$; Bingham Bull. R. Bot. Gard. Kew (AS) 528 (1906) ${ }^{12}$; Donisthorpe Trans. Leicester Lit-Phil. Soc. $12228(1908)^{13}$. Prenolepis imparis subsp. nitens Emery Deutsch. Ent. Zeitschr. $1910128^{14}$.

Habitat: Krain, Balkan Peninsula, in Asia Minor, and the east coast of the Black Sea.

Dale captured a single specimen of this ant at Bournemouth, but $\mathbf{F}$. Smith ${ }^{2}$ and Saunders ${ }^{5}$ give Wales as the habitat, as the former read "Barmouth" for Bournemouth".

It is curious that Saunders appeared to consider this insect to be a British species; in $\mathbf{1 8 8 4}$ he says it should be looked for in the 
New Forest and Bournemouth districts ${ }^{8}$, and in his book he includes it in the British list, and not as introduced ${ }^{11}$. Bingham records it from the tropical fern house at Kew, and says it is introduced in England ${ }^{\mathbf{1 2}}$. There is no reason to suppose it was ever a native of this country.

\section{Prenolepis (Nylanderia) flavipes F. Smith.}

Tapinoma flavipes F. Smith Trans. Ent. Soc. Lond. $1874404^{1}$. Prenolepis flavipes Dalla Torre Cat. Hym. $7178(1893)^{2}$; Donisthorpe Bull. R. Bot. Gard. Kew $3122(1908)^{3}$ : Trans. Leicester Lit-Phil. Soc. $12229(1908)^{4}$. Prenolepis (Nylanderia) flavipes Emery Deutsch. Ent. Zeitschr. $1910132^{5}$.

\section{Habitat : Japan.}

A colony consisting of males, winged and deälated females, workers, pupae, and larvae was found amongst lily bulbs from Tokio in Kew Gardens ${ }^{3}$.

\section{Prenolepis (Nylanderia) steinheili For. var minuta For.}

Prenolepis steinheili v. minuta Forel Trans. Ent. Soc. Lond. $1893343^{1}$; Donisthorpe Bull. R. Bot. Gard. Kew $6251(1909)^{2}$.

Habitat : Antilles.

Workers were taken amongst palms from British Guiana in 1909, Kew Gardens ${ }^{2}$.

Prenolepis (Nylanderia) longicornis Latr.

Formica longicornis Latreille Hist. Nat. Fourm. $113(1802)^{1}$. Tapinoma gracilescens Fowler Ent. Mo. Mag. $21276(1885)^{2}$. Prenolepis longicornis Er. André Spec. Hym. Europe $2203(1881)^{3}$; Dalla Torre Cat. Hym. 7 $179(1893)^{4}$. Tapinoma gracilescens Farren-White Ants' Ways 65237 $(1895)^{5}$. Prenolepis longicornis Saunders Hym-Acul. 26 (1896) ${ }^{6}$; Bingham Bull. R. Bot. Gard. Kew (AS) $528(1906)^{7}$; Frisby Ent. Mo. Mag. 43 $159(1907)^{8}$; Assmuth Zeitschr. Wissens Insektenbiol. 3 301-309, 328-334, 357-368 $(1907)^{9}$; Donisthorpe Bull. R. Bot. Gard. Kew $3122(1908)^{10}$ : Trans. Leicester Lit-Phil. Soc. 12228 (1908)11 : Bull. R. Bot. Gard. Kew $6251(1909)^{12}$. Prenolepis (Nylanderia) longicornis Emery Deutsch. Ent. Zeitschr. 1910 12913. Prenolepis longicornis Forel Int. Ent. Cong. Bruxelles $1910283(1911)^{14}$; Crawley and Donisthorpe Int. Ent. Cong. Oxford 1911 $223(1912)^{15}$.

Habitat : Cosmopolitan species.

Farren-White says this species was established in a rectory in the heart of the City of London and occurred in large numbers in 1876 and 1878; he also records it from the Crystal Palace, the lily house at Kew, St. Leonards-on-Sea, Hastings, Exeter, and in a hot-house at Cheltenham ${ }^{5}$. Fowler observed this ant in some numbers in a cottage in the centre of Lincoln, and the old woman who inhabited it said they had been present for a great number of years past, and she had never been able to get rid of the plague ${ }^{2}$. Bingham records it in the propagating pits at Kew, and from Cam- 
bridge, etc. ${ }^{7}$; and Frisby found it to be common about several shops at Linkfield Corner, Redhill, in $1906^{8}$. It is represented in the Dale Collection by specimens from Little Stanmore; in the Rothney Collection from hot-houses at Tottenham; and Scott sent it to me to name from Warnham Court near Horsham. It is usually abundant at Kew, where I have found it in the propagating pits and other houses ; on one occasion I obtained a number of winged females ${ }^{11}$, and a colony situated in a flower-pot consisted of thirteen deälated females, a number of workers, larvae, etc. ${ }^{15}$.

\section{Prenolepis (Nylanderia) vividula Nyl.}

Formica vividula Nylander Acta. Soc. Sc. Fenn. 2900 (1846) ${ }^{1}$. Prenolepis vividula Er. André Spec. Hym. Europe 2204 (1881)²; Dalla Torre Cat. Hym. $7180(1893)^{3}$; Bignell Ent. Mo. Mag. $31132(1895)^{4}$; Malloch Faun. Flor. Geol. Clyde Área $219(1901)^{5}$; Butterfield Ent. Mo. Mag. $4463(1908)^{6}$; Donisthorpe Bull. R. Bot. Gard. Kew $3122(1908)^{7}$ : Trans. Leicester LitPhil. Soc. $12229(1908)^{8}$; Prenolepis (Nylanderia) vividula Emery Deutsch. Ent. Zeitschr. 1910 1319. Prenolepis vividula Forel Int. Ent. Cong. Bruxelles $1910283(1911)^{10}$.

Habitat : Cosmopolitan species.

On April 21st, 1895, Bignell captured two specimens of this ant in his house at Plymouth, which had undoubtedly escaped from a young palm, brought from London the day before ${ }^{4}$. Malloch records it from hot-houses at Queen's Park, and in the Botanic Gardens, Glasgow ${ }^{5}$; and Butterfield as abundant in greenhouses at Lister Park, Bradford, in $1907^{6}$. It is represented in the Dale Collection by specimens taken at Llanelly (Richardson); Haliday found it in hot-houses in Ireland ${ }^{7}$; and Wooley sent me specimens to name from a hot-house at Leicester Frith.

I captured specimens at Kew in the palm house on March 23rd, 1896, and in 1908 it occurred in the "Hospital" (house No. 18), where a nest, which was found under a flower-pot on October 28th, 1910, contained three males and one winged female. In March, 1914, Beck sent me specimens from Mogallon, near Newry, in Ireland, where he had found them in Mr. Wakefield Richardson's hot-house, attending scales (Lecanium hesperidum L.) on banana leaves. Beresford has sent me specimens from Clonsilla, co. Dublin, where, he tells me, a colony is established in a private house.

Prenolepis (Nylanderia) vividula Nyl. subsp. antillana For.

Prenolepis guatemalensis race antillana Forel Trans. Ent. Soc. Lond. $1893340^{1}$. Prenolepis vividula subsp. antillana Donisthorpe Bull. R. Bot. Gard. Kew $12369(1911)^{2}$ : Ent. Rec. $2315(1911)^{3}$.

Habitat : Antilles.

Workers occurred for some years in the Palm-house in Kew Gardens ${ }^{2}$. 
Prenolepis (Nylanderia) braueri Mayr subsp. donisthorpei For.

Prenolepis caeciliae Donisthorpe [teste Forel] Bull. R. Bot. Gard. Kew 3 $122(1908)^{1}$. Prenolepis (Nylanderia) braueri subsp. donisthorpei Forel Bull. Soc. Vaud. Sc. Nat. $4464(1908)^{2}$; Donisthorpe Trans. Leicester Lit-Phil. Soc. $12229(1908)^{3}$ : Bull. R. Bot. Gard. Kew 6250 Pf. [1].6 (1909) ${ }^{4}: 12$ $368(1911)^{5}$ : Ent. Rec. $2315(1911)^{6}$.

\section{Habitat : (?)}

I captured specimens of this ant in Kew Gardens as long ago as 1896 ; it has occurred in the fern, palm, and lily houses, but the former house is evidently its head-quarters, and there I found a male, on December 5th, $1910^{6}$. I sent Professor Forel a sketch of the genitalia of this specimen, and he tells me $P$. donisthorpei is probably a good species.

\section{* Donisthorpea brunnea Latr.}

Formica brunnea Latreille Ess. Hist. Fourmis France $41(1798)^{1}$. Lasius niger race brunneus Forel Denkschr. Schweiz. Ges. Naturw. $2647(1874)^{2}$. Lasius brunneus Er. André Spec. Hym. Europe $2193(1881)^{3}$; Dalla Torre Cat. Hym. $7182(1893)^{4}$. Lasius niger st. brunneus Bingham Bull. R. Bot. Gard. Kew (AS) $528(1906)^{5}$.

Habitat : Central Europe; Caucasus, etc.

Bingham records this species on a young dead sparrow near the Herbarium, Kew Gardens ${ }^{6}$. Bingham was probably in error, as he calls it a "common British species," and D. brunnea is not known to occur in Britain.

\section{Donisthorpea nigra L. subsp. lasioides Emery.}

Prenolepis lasioides Emery Ann. Acad. Aspiranti Nat. (SE) 26 (1869)1. Lasius niger alieno-brunneus Forel Denkschr. Schweiz. Ges. Naturw. 2647 $(1874)^{2}$. Lasius alienus var. lasioides Dalla Torre Cat. Hym. $7182(1893)^{3}$. Lasius niger subsp. lasioides Donisthorpe Bull. R. Bot. Gard. Kew 12369 $(1911)^{4}$.

Habitat : Italy.

A deälated female taken in orchid house, Kew Gardens, October, $1911^{4}$.

\section{Camponotus (Camponotus) herculeanus L.}

Formica herculeana Linnaeus Syst. Nat. Ed. $101579(1758)^{1}$; Berkenhout Outline NH. Gr. Brit. $1159(1769)^{2}$; Headwick, Don. Agri. Forfarshire Append. $53(1813)^{3}$. Formica herculanea Newman Entom. $3244(1867)^{4}$ : Proc. Ent. Soc. Lond. (S. 3) 5 LXXVI (1867) ${ }^{5}$. Formica herculeana Westwood Proc. Ent. Soc. Lond. $1871 \mathrm{XXVI}^{6}$; Dunning Pro. Ent. Soc. Lond. $1871 \mathrm{XXXVIII}^{7}$; Camponotus herculeanus $\mathrm{r}$. herculeanus Forel Denkschr. Schweiz. Ges. Naturw. $2639(1874)^{8}$. Formica herculanea Bridgman Trans. Norf. Norwich Nat. Soc. 2 276, $620(1877)^{9}$. Camponotus herculeanus Er. André Spec. Hym. Europe 2142 (1881) ${ }^{10}$; Dalla Torre Cat. Hym. 7233 $(1893)^{11}$. Camponotus herculanea Vic. Hist. Norfolk $199(1901)^{12}$. Camponotus herculaneus Stainforth Nat. $28456(1903)^{13}$. Camponotus herculeanus herculeanus Emery Deutsch. Ent. Zeitschr. 1908 184.14. Camponotus (Camponotus) herculeanus Forel Rev. Suisse Zool. $22266(1914)^{15}$. 
Habitat: North and Central Europe.

Berkenhout gives this species as British, but without any locality, ${ }^{2}$ and Headwick lists it in the plants and animals of Forfarshire ${ }^{3}$; both records are extremely doubtful.

Newman said he had been informed that this ant had been taken from pine stumps near Rannoch ${ }^{4}$, but F. Smith thought there was some mistake ${ }^{5}$. Westwood recorded on November 6th, 1871, that a Great Woodpecker (Picus martius), which was supposed to have been recently shot in Wytham Wood, Oxon, was found to have its crop crammed with perfect specimens of this ant $^{6}$; but Dunning pointed out that several of these birds, from Norway, were for sale at this time in Leadenhall Market?. Bridgman records females and workers running on some birch bark from New Brunswick (these would be one of the American forms of herculeanus), in a saw-yard at Norwich in April, $1876^{\circ}$, and Stainforth a live worker taken in the Western Dock Reserve at Hull in September, $1902^{13}$.

\section{Camponotus (Camponotus) herculeanus L. subsp. pennsylvanicus} Retz.

["Fourmi de Pensylvanie" Degeer Mém. Hist. Ins. $3603(1773)^{1}$ ]. Formica pennsylvanica Retzius Gen. Spec. Ins. Degeer $75(1783)^{2}$. Camponotus pennsylvanicus Er. André Spec. Hym. Europe 2141 (1881) $^{3}$. Formica pennsylvatica Sommerville Proc. NH. Soc. Glasgow (n.s.) 1 VII $(1883)^{4}$. Camponotus pennsylvanicus Dalla Torre Cat. Hym. $7246(1893)^{5}$. Camponotus herculeanus pennsylvanicus Wheeler Ann. New York Acad. Sc. 20 $335(1910)^{6}$. Camponotus (Camponotus) herculeanus subsp. pennsylvanicus Forel Rev. Suisse Zool. 22266 (1914)?

Habitat: North America.

Sommerville records living specimens nesting in a log of yellow pine on August 14th, 1883, received in Glasgow from Michigan, U.S.A. ${ }^{4}$

Camponotus (Camponotus) fallax Nyl. subsp. rasilis Wheeler var. pavidus Wheeler.

Camponotus fallax rasilis var. pavidus Wheeler Journ. New York Ent. Soc. $18228(1910)^{1}$ : Ann. New York Acad. Sc. $20342(1910)^{2}$.

Habitat : Texas; Louisiana; Florida ${ }^{2}$.

Males, winged females, and workers occurred in some numbers in a cooperage belonging to Messrs. Bulmer, Cider Merchants, Hereford, in April, 1911. The ants were living in the oak, used for binding the casks, which came from Texas.

Camponotus (Myrmoturba) maculatus F. subsp. sylvaticus Oliv.

Formica sylvatica Olivier Encycl. Méth. Ins. 6491 (1791)1․ Camponotus sylvaticus r. sylvaticus Forel Denkschr. Schweiz. Ges. Naturw. $2639(1874)^{2}$. Camponotus sylvaticus Er. André Spec. Hym. Europe 2144 (1881) ${ }^{3}$. Cam- 
ponotus silvaticus Dalla Torre Cat. Hym. $7252(1893)^{4}$. Camponotus sylvaticus Vic. Hist. Durham $195(1905)^{5}$. Camponotus maculatus silvaticus Emery Deutsch. Ent. Zeitschr. $1908199^{6}$.

Habitat: South of France ${ }^{6}$.

This species is recorded as being taken alive in bananas at Bishops Auckland ${ }^{5}$.

\section{Camponotus (Nyrmothrix) abdominalis F.}

Formica abdominalis Fabricius Sys. Piez. $409(1804)^{1}$. Camponotus abdominalis Dalla Torre Cat. Hym. 7219 (1893) ${ }^{2}$. Camponotus (Myrmothrix) abdominalis Forel Rev. Suisse Zool. 22268 (1914) $^{3}$.

Habitat : Central and South America.

Frisby found winged females of this species in a bunch of bananas at Gravesend; and Britten gave me workers also taken amongst bananas at Penrith, Cumberland, in 1906 (J.V.Smith.)

\section{Camponotus (Myrmothrix) abdominalis F. var. atriceps F. Smith.}

Formica atriceps F. Smith Cat. Hym. Brit. Mus. 644 (1858)1. Camponotus abdominalis Dalla Torre Cat. Hym. $7219(1893)^{2}$ [in part]. Camponotus abdominalis var. atriceps Donisthorpe Proc. Ent. Soc. Lond. 1912 CII $^{3}$.

Habitat: South America.

I captured a large worker of this variety in my flat on the evening of September 6th, 1912, having been at Weybridge during the day. It is probable that it came from the hotel at Weybridge, as I was told of the capture of other specimens there on my next visit ${ }^{3}$.

Camponotus (Myrmothrix) abdominalis F. subsp. stercorarius For.

Camponotus atriceps race stercorarius Forel Bull. Soc. Vaud. Sc. Nat. (2) $20340(1884)^{1}$. Camponotus stercorarius Dalla Torre Cat. Hym. 7253 $(1893)^{2}$. Camponotus abdominatis subsp. stercorarius Donisthorpe Bull. R. Bot. Gard. Kew 12369 (1911) $^{3}$.

Habitat: Central America.

A large worker was captured on a clump of imported Laelia gouldiana in the Orchid House at $\mathrm{Kew}^{3}$; Bedwell found another in an orchid house at Potters' Bar; and Hudd sent me a deälated female, large, and small workers taken on bananas at Cardiff in 1910.

\section{Camponotus (Myrmamblys) novogranadensis Mayr.}

Camponotus novogranadensis Mayr Sitz. Akad. Wiss. Wien 61 (1) 380 $(1870)^{1}$; Dalla Torre Cat. Hym. $7245(1893)^{2}$. Camponotus (Myrmamblys) novogranadensis Forel Rev. Suisse Zool. $22272(1914)^{3}$.

Habitat : Central America ; Columbia, Brazil.

Large and small workers were captured in orchids from Brazil, at Kew Gardens in December, 1912. 


\section{Camponotus (Colobopsis) truncatus Spin.}

Formica truncata Spinola Ins. Ligur. Spec. Nov. $2244(1808)^{1}$. Colobopsis truncata Forel Denkschr. Schweiz. Ges. Naturw $2644215387(1874)^{2}$; Er. André Spec. Hym. Europe $2160(1881)^{3}$. Camponotus truncatus Dala Torre Cat. Hym. $7255(1893)^{4}$. Camponotus (Colobopsis) truncatus Donisthorpe Bull. R. Bot. Gard. Kew 6251 Pf. [1]·1-2 (1909) ${ }^{5}$; Forel Rev. Suisse Zool. $22272(1914)^{6}$.

Habitat : South and Central Europe; North Africa.

In April, 1909, I found a number of soldiers and workers of this species in virgin cork in company with Cremastogaster scutellaris, in the fern house in Kew Gardens; a beetle Formicomus pedestris Ross., superficially very like the Colobopsis worker, occurred with them $^{5}$. Pool sent this ant to me to name, taken in cork in the insect house in the Zoological Gardens, Regent's Park, July, 1914. 


\section{BIBLIOGRAPHY.}

Addison, J. "Paper on Ants" The Guardian 2 334-348 (1713).

Adie, R. "On the Physical Power of Insects as Labourers and on their Architecture" The Naturalist 3 232-234 (1838).

Armit, W. E. "Agricultural Ants" Nature 18643 (1878).

Arnold, G. (1) "Formica fusca race gagates, in the New Forest" Ent. Mo. Mag. 41211 (1905) ; (2) "A large colony of Formicoxenus nitidulus Nyl. and microgynes of Formica fusca in the New Forest" Ent. Mo. Mag. 45278 (1909).

Bagnall, R. S. (1) "Formicoxenus nitidulus Nyl., in the Northumberland and Durham District" Ent. Mo. Mag. 42140 (1906) ; (2) "Note on some Myrmecophilous Beetles from the Northumberland and Durham District" Ent. Record 18 159-160 (1906) ; (3) "Formicoxenus nitidulus Nyl. $\widehat{\sigma}$ as British" Ent. Mo. Mag. 42 $210(1906)$.

Bailey, W. Whitman. "Habits of Ants" Nature 20244 (1879).

Ball, W. Platt. "Neuter Insects and Lamarckism" Natural Science 4 91-97 (1894).

Barnes, W. (1) "On a nest of Formica sanguinea and other Hymenoptera near Wellington College" Ent. Mo. Mag. 38265 (1902) ; (2) "Leptidia brevipennis in company with Formica sanguinea" Ent. Mo. Mag. 4014 (1904).

Baynes, E. S. A. "Ants appropriating old burrows of Clearwings" Ent. Rec. 2398 (1911).

Beare, T. H. "Myrmica ruginodis, a Marriage Flight;-Formica exsecta at Boat of Garten" Ent. Rec. 25258 (1913).

Bedwell, E. C. " Re-discovery of Hetaerius ferrugineus Ol." Ent. Mo. Mag. 45165 (1909).

Belt, T. "The Naturalist in Nicaragua" Ants 7, 17, 23, 26, 27, 71-84, $115,181,218,219,221,225,226,227,314,315$ (1874).

Bergroth, E. "On an Indian Ant-Mimicking Hemipteron" Ent. Mo. Mag. 28107 (1892).

Bignell, C. G. (1) "Formica rufa strengthening its nest by taking workers from other nests" Ent. Mo. Mag. 16267 (1880) ; (2) "Lasius mixtus Nyl. an Ant new to Britain" Entom. 14261 (1881); (3) "British Ants" The Young Naturalist 3 79-335 (1882) ; (4) “ Microdon mutabilis L." Ent. Mo. Mag. 2y 225 (1891); (5) "Myrmica ruginodis making war on its own species" Ent. Mo. Mag. 28135 (1892), ditto Brit. Nat. 2103 (1892); (6) " Preno- 
lepis vividula, an introduced Ant new to Britain " Ent. Mo. Mag. 31132 (1895) ; (7) "Early Appearance of Formica rufa" Ent. Mo. Mag. 33141 (1897); (8) "Habits of Formica rufa" Ent. Mo. Mag. 33183 (1897) ; (9) "Corsican Ants bred (Leptothorax angustulus Nyl., and Bothriomyrmex meridionalis Roger)" Ent. Mo. Mag. 37127 (1901) ; (10) “Corsican Ants, etc." Ent. Mo. Mag. 37 8 (1901).

Bingley, W. “Animal Biography” Ants 4 171-181 (1824).

Bold, T. J. " Myrmica lobicornis in Durham and Northumberland" Ent. Mo. Mag. 2234 (1865).

Bond, J. W. "Combat of Ants" Ent. Mag. 4221 (1837).

Bostock, J. "On the Domestic Habits of a minute Species of Ant" Trans. Ent. Soc. Lond. 2 65-67 (1837).

Bowman, J. "The Wood Ant (Formica rufa)" Science Gossip 1889 $32-34,198-200$.

Bridgman, J. B. "Occurrence of Myrmica lobicornis Nyl. in Norfolk" Trans. Norf. Norwich Nat. Soc. 4394 (1886).

Brock, S. E. “ Myrmica laevinodis Nyl., in West Lothian" Scot. Nat. 191447.

Brodie, P. B. " Tertiary Fossil Ants in the Isle of Wight" Nature 52 570 (1895).

Bryan, G. H. (1) "Harvesting Ants" Science Gossip $18 \% 9238$; (2) "Harvesting Ants" Nature 60174 (1899).

Buckton, G. B. "Aphides in Ants' Nests" Science Gossip 7 No. 81 (1901).

Butler, E. A. (1) "Our Household Insects" (1893) Ants 56-61 ; (2) "Two Rare Ants at Gomshall" Ent. Mo. Mag. 35290 (1899); (3) "Formica exsecta Nyl. in the Isle of Wight" Ent. Mo Mag. 43 254 (1907).

Cambridge, 0. Pickard. (1) "Thyreosthenius biovatus in nests of Formica rufa" Ent. Rec. 12138 (1900); (2) "Thyreosthenius biovatus in nests of Formica rufa, and Tetrilus arietinus in nests of F. rufa and Lasius fuliginosus" Ent. Rec. 12 163-164 (1900).

Cameron, P. "On the Occurrence of Microdon mutabilis Linn., in the West of Scotland" Proc. Nat. Hist. Soc. Glasgow (n.s.) 142 (1883).

Capron, E. “ Myrmecina Latreillei Curt., at Shiere " Ent. Mo. Mag. 22 $229(1886)$.

Carpenter [? W. B.]. "The Ants and the Aphis" Loudon's Mag. 1 66 (1829).

Carpenter, G. H. " "Some Recent Researches on Habits of Ants, Wasps, and Bees" Nat. Science 3 267-272 (1893).

Carrow, B. "Occurrence of Claviger foveolatus near Blandford" Zool. 18628084.

Carter, A. E. J. "Microdon mutabilis L., at Aberfoyle, Perthshire" Ent. Mo. Mag. 39303 (1903).

Champion, G. C. (1) "Note on the Occurrence of Coccinella labilis near Canterbury " Ent. Mo. Mag. 4187 (1868) ; (2) " Re-occurrence of Coccinella labilis" Ent. Mo. Mag. 545 (1868); (3) "Note on 
the Dinarda dentata Gr., of British collections " Ent. Mo. Mag. 35283 (1899) ; (4) "Coccinella distincta Fald., etc., at Woking" Ent. Mo. Mag. 39151 (1903) ; (5) "A New Locality for Lomechusa strumosa F." Ent. Mo. Mag. 48138 (1912).

Chapman, T. A. (1) "On the Larva of Liphyra brassolis Westw." Entom. 35 225-228; 252-255 (1902); (2) "Agriades coridon and Ants " Ent. Mo. Mag. 46215 (1910); (3) "The Mystery of Lycaena arion" Ent. Rec. 26245 (1914).

Charsley, R. S. (1) " New British Ant, Ponera ochracea?" Ent. Mo. Mag. 1469 (1877) ; (2) "A New Species of Ant found in Britain" Ent. Mo. Mag. 14162 (1877).

Chitty, A. J. (1) "Note on Cryptocephalus 6-punctatus L." Ent. Rec. 13250 (1901) ; (2) " Ponera contracta Ltr., at Charing Hill, Kent" Ent. Mo. Mag. 39283 (1903) ; (3) "Myrmecina Latreillei Curt., and Stenamma Westwoodi West., in East Kent" Ent. Mo. Mag. 39284 (1903) ; (4) "Cicindela campestris feeding on Myrmica rubra" Ent. Rec. 16206 (1904) ; (5) "Pseudisobrachium cantianum ; a species of Bethylinae (Prototrypidae) new to Science" Ent. Mo Mag. 42 148-151 (1906); (6) "Notes on the Habits of Ponera contracta Ltr." Ent. Mo. Mag. 42212 (1906) ; (7) "Notes on the Genus Gonatopus" (Dryininae) Ent. Rec. 19 79-82 (1907).

Clapton, J. F. " "Ants and Cocci " Science Gossip 1865234.

Clark, L. W. "Antennae of Insects" ( $F$. rufa) Charlesworth's Mag. 1838392.

Cockerell, T. D. A. "Hetaerius morsus Lec.; an entomological tragedy" Ent. Mo. Mag. 26158 (1890); (2) "Case-making coleopterous Larvae" Ent. Mo Mag. 27 190 (1891) ; (3) "The Use of Ants to Coccidae and Aphidae" Nature 67608 (1893); (4) "Coccidae associated with Ants" Science Gossip (n.s.) 3239 241 (1897).

Collett, E. P. (1) "Myrmecophilous Coleoptera in the Hastings District" Eint. Mo. Mag. 2040 (1883) ; (2) "Note on the appearance of $\delta$ and $ᄋ$ of Formica rufa" Ent. Mo. Mag. 2042 (1883) ; (3) "Coccinella labilis in the Hastings District" Ent. Mo. Mag. 20226 (1884).

Conway, C. "Ants conveying in their mouths other Ants of their own species ; and the courage of the Wood or Fallow Ant (Formica rufa)" Loudon's Mag. " 266 (1834).

Cooke, B. " Myrmica laevinodis" Nat. Yorkshire 830 (1882).

Cox, E. W. "Intellect in Brutes" Nature 20315 (1879).

Crawley, W. C. (1) “Alien Queen Ant" Science Gossip 6369 (1900) ; (2) "Queens of Lasius umbratus Nyl., accepted by colonies of Lasius niger L." Ent. Mo. Mag. 45 94-99 (1909) ; (3) " How Ants greet members of the same colony" Ent. Rec. 2243 (1910) ; (4) "Workers of Lasius flavus (? L. umbratus) among L. fuliginosus" Ent. Rec. 22 67-69 (1910) ; (5) "Ants and Platyarthrus hoffmanseggii" Ent. Rec. 22129 (1910); (6) "Summary of Experiments with fertile $\mathrm{O} s$ of several species of Ants" Ent. Rec. 22 152-156 (1910) ; (7) "Some Parasites of Lasius fuliginosus, L. niger, and 
L. flavus" Ent. Rec. 2322 (1911) ; (8) "Aphides of Lasius niger" Ent. Rec. 2323 (1911) ; (9) "Formica fusca L., var. glebaria Nyl., a form new to Britain " Ent. Rec. 2396 (1911) ; (10) " Parthenogenesis in Worker Ants, with special reference to two colonies of Lasius niger Linn." Trans. Ent. Soc. Lond. 1911 657-663 ; (11) See Donisthorpe, No. 55 ; (12) "Leptothorax tuberum Fab., subsp. corticalis Schenk, an Ant new to Britain" Ent. Rec. 24 63-65 (1912) ; (13) "Anergates atratulus Schenk, a British Ant and the acceptance of a $ᄋ$ by Tetramorium caespitum L." Ent. Rec. 24218 (1912); (14) See Donisthorpe, No. 60 ; (15) "Further experiments on the temporary social parasitism in Ants of the genus Lasius Fab. with a note on Antennophorus uhlmanni " Ent. Rec. 25 135-140 (1913) ; (16) "A revision of the genus Leptothorax Mayr. in the British Isles " Ent. Rec 26 89-96, 106-109 (1914) ; (17) "Natural Combined Colonies of Ants" Ent. Rec. 26 141-142 (1914).

Crotch G. R. "Coleoptera found in company with Formica fuliginosa" Zool. 18628139.

Crowther, H. " Clivina fossor myrmecophilous " Ent. Mo. Mag. 1519 (1878).

Cunningham, J. T. "Neuter Insects and Darwinism" Natural Science 4 181-289 (1894).

Curtis, J. "On the genus Myrmica, and other Indigenous Ants" Trans. Linn. Soc. Lond. 21 211-220 (1854).

Dale, C. W. (1) "Microdon mutabilis Lin." Ent. Mo. Mag. 2" 250 (1891) ; (2) " Ripersia Tomlinii Newstead" Ent. Mo. Mag. 28 219 (1892); (3) "Ants and their Companions" Entom. 28 97-100 (1895) ; (4) "Capture of Salticus formicarius in Dorsetshire" Ent. Mo. Mag. 40213 (1904).

Dalglish, A. A. "Formica fusca, winged females in spring " Ent. Mo. Mag. 4087 (1904).

Daniell, G. (1) "Note on the Large Wood Ant" Zool. 184 " 1931 ; (2) "Notice of the Habits of Myrmica domestica Shuck." Zool. 18533769 ; (3) "Notes on the Habits of the Common Garden Ant, Formica nigra L." Proc. Linn. Soc. 2 290-291 (1854).

Darwin, C. "Habits of Ants " Nature 8244 (1873) ; (2) "Instinct. Perception in Ants " Nature " 443 (1873); (3) "The Origin of Species" Ants 1223,359 ; 2336 (1888 Edn.); (4) "Descent of Man" Ants $181,94,104,112,136,227,448$ (1888 Edn.) ; (5) "Animals and Plants under Domestication" Ants 2238 (1890 Edn.).

Delpino, P. "On the Fondness of Ants for certain Homoptera" Ent. Mo. Mag. 1210 (1875).

Denning, W. F. "Swarming of Ants" Nature Notes 18 196, 225 (1907).

Dickson-Bryson, R. " "Instinct in Ants " Science Gossip (n.s.) 6 38-39 (1899).

Dodd, F. P. "Contribution to the Life History of Liphyra brassolis Westwood" Entom. 35 153-156 ; 184-188 (1902). 
Donisthorpe, H. St. J. K. (1) "Hints on Collecting Myrmecophilous Coleoptera" Ent. Mo. Mag. 32 44-50 (1896); (2) "Myrmecophilous Coleoptera in 1897" Ent. Rec. 9 246-247 (1897) ; (3) "Quedius mesomelinus Marsh, a Myrmecophilous Insect" Ent. Rec. 11266 (1899); (4) "Myrmecophilous Coleoptera" City of Lond. Ent-Nat. Hist. Soc. (Read Feb. 20th, 1900); (5) "Myrmecophilous Orthoptera" Ent. Rec. 12 162-163 (1900) ; (6) "Myrmecophilous Coleoptera" Leicester Lit-Phil. Soc. (Read Jan. 11th, 1900); (7) "The Guests of Ants and Termites," by E. Wasmann, S.J., translated by Horace Donisthorpe Ent. Rec. 12 41, 72, 87, 117, 147, and 204 (1900) (with plate); (8) "A Few Notes on Myrmecophilous Coleoptera, with a Table of all the British Species recorded with Ants" Ent. Rec. 12172 (1900); (9) "Myrmedonia collaris with Myrmica laevinodis at Wicken" Ent. Rec. $12263(1900)$; (10) "On the Origin of, and Progress in, the Study of Myrmecophilous Coleoptera" Trans. Leicester LitPhil. Soc. 6 3-15 (1901); (11) "On Some Experiments with Myrmecophilous Coleoptera, and an Observation Nest of Formica rufa" Ent. Rec. 13 351-352 (1901) ; (12) "Notes on the British Myrmecophilous Fauna (excluding Coleoptera)" Ent. Rec. 14 14-18, 37-40, 67-70 (1902) ; (13)." The Life History of Clythra 4-punctata L." Trans. Ent. Soc. Lond. 1902 11-23 (with plate); (14) "Some Speculations on Ants' Nest Beetles " Trans. Leicester Lit-Phil. Soc. 6 224-226 (1902); (15) "Further Experiments with Myrmecophilous Coleoptera, etc.” Ent. Rec. 15 11-12 (1903) ; (16) "Notes on the Myrmecophilous Habits of Cetonia aurata L." Ent. Rec. 16301 (1904) ; (17) "Dinarda hagensi Wasm., a species of Myrmecophilous Coleoptera new to Britain" Ent. Rec 17 181-182 (1905) ; (18) "Notes on Myrmecophilous Coleoptera in 1905" Ent. Rec. 17 271-272 (1905) ; (19) "The Myrmecophilous Coleoptera of Great Britain " the Vice-President's Address, Proc. Lancs-Ches. Ent. Soc. 1905 33-44 ; (20) "Dinarda pygmaea Wasm., a species of Myrmecophilous Coleoptera new to Britain" Ent. Rec. 18 217-218 (1906); (21) "A Re-discovered British Beetle (Lomechusa strumosa F.)" Zool. 1906 317; (22) " Myrmecophilous Notes for 1906 " Ent. Rec. 18 288-289, 317-319 (1906), 19 4-8 (1907) (with two plates); (23) "British Myrmecophilous Acarina" Hastings and East Sussex Nat. 1 65-67 (1907) ; (24) “ Myrmecophilous Notes for 1907 " Ent. Rec. 19 254-256 (1907); (25) "The Life History and Occurrence as British of Lomechusa strumosa F." Trans. Ent. Soc. Lond. 1907 415-520, (with woodcuts); (26) "The Evolution of Dinarda," by E. Wasmann, S.J., translated by Horace Donisthorpe Zool. 1908 68-71 ; (27) "The Myrmecophilous Coleoptera of Great Britain," "Coleoptera of the British Isles" Fowler and Donisthorpe, London, 6 320-330 (1913); (28) "Some New British Myrmecophilous Prototrupidae" Ent. Rec. 20106 (1908); (29) "The Ants at Kew " Bull. R. Bot. Gard. Kew. 3121 (1908); (30) "Notes on the Life History of two supposed Ants' Nest Beetles " Ent. Rec. 20108 (1908), with plate; (31) "Ants Found in Great Britain" Trans. Leicester Lit-Phil. Soc. 12 221-233 (1908); (32) "A few notes on Myrmecophilous Spiders" Zool. 1908 419-425; (33) 
“Myrmecophilous Notes for 1908" Ent. Rec. 20 281-284 (1908), 21 17-20 (1909) (with plate); (34) "On the Origin and Ancestral Form of Myrmecophilous Coleoptera" Trans. Ent. Soc. Lond 1909 397-411; (35) "On the Colonization of New Nests of Ants by Myrmecophilous Coleoptera" Trans. Ent. Soc. Lond. 1909 413-429 ; (36) "Ants at Kew " Bull. R. Bot. Gard. Kew $6250-251$ (1909) ; (37) "Pachylomma buccata Bréb., in the Isle of Wight" Ent. Mo. Mag. 45238 (1909) ; (38) "Formica sanguinea Ltr., at Bewdley, with an account of a Slave-raid and description of two Gynandromorphs, etc." Zool. 1909 463-466 (with two woodcuts); (39) "Some Experiments with Ants' Nests" Trans. Ent. Soc. Lond. $1910142-150$ (Read Dec. 1st, 1910) ; (40) "Myrmecophilous Notes for 1909 " Ent. Rec. 21 257-259, 287-291 (1909), 22 15-17 (1910); (41) "Lomechusa strumosa F., as a British Insect" Ent. Rec. 18159 (1906); (42) "On the Founding of Nests by Ants; and a few notes on Myrmecophiles" Ent. Rec. 22 82-85 (1910); (43) "Hearing in Ants" Ent. Rec. 22117 (1910) ; (44) " Fourmis et leurs hôtes" Trans. Int. Ent. Cong. Bruxelles, 1910, 2 199-208 (1911) (Read Aug. 4th, 1910); (45) "Further Observations on Temporary Social Parasitism and Slavery in Ants" Trans. Ent. Soc. Lond. 1911 175-183 (Read Dec. 7th, 1910) ; (46) "Myrmecophilous Notes for 1910 " Ent. Rec. 23 10-15, 58-63 (1911); (47) "Trichonyx sulcicollis Reich., and Amauronyx märkeli Aubé, as Myrmecophilous Insects" Ent. Mo. Mag. 4767 (1911); (48) "Microdon eggeri Mik, in nests of Formica sanguinea Latr., in the Luxemburg" Ent. Mo. Mag. 4743 (1911); (49) "Evolution of our Knowledge of Myrmecophilous Coleoptera" Ent. Rec. 13 51-56 (1901); (50) "Amphisbatis incongruella Stn., probably Myrmecophilous in the larval stage, and a few notes on some other Myrmecophiles" Ent. Rec. 23 169-170 (1911); (51) "Lasius mixtus Nyl. in Britain" Ent. Rec. 23 236-238 (1911); (52) "Ants at Kew" Bull. R. Bot. Gard. Kew 12 367-369 (1911) ; (53) "A Messmate of Ants" Marvels of the Universe 5 220-222 (1911), with photographs, London, Hutchinson and Co.; (54) "A Revised List of the British Ants " The Entom. 44 389-391 (1911); (55) (Joint paper with W. C. Crawley) "Experiments on the formation of Colonies by Lasius fuliginosus 우우 "Trans. Ent. Soc. Lond. 1911 664-672 (Read Nov. 15th, 1911) ; (56) "Myrmecophilous Notes for 1911 " Ent. Rec. 24 2-10, 34-40 (1912) ; (57) "A Fly that is born in Ants' Nests" (Microdon mutabilis) Marvels of the Universe 19 764-767 (1912) (with plate); (58) "Mites that live in Ants' Nests" Marvels of the Universe 19 778-780 (1912) (with plates); (59) "Dairying Ants" (Ants and Aphides) Marvels of the Universe 20 804-806 (1912) (with plates); (60) (Joint paper with W. C. Crawley) "The Founding of Colonies by Queen Ants" Trans. Int. Ent. Cong. Oxford, 1912, 2, 11-77 (1913); (61) "Ants as Honey Pots" (Myrmecocystus horti-deorum McCook) Marvels of the Universe 23 940-943 (1912) (with plates); (62) "The Wood Ant" (Formica rufa L.) Marvels of the Universe 27 1099-1103 (1912) (with plates); (63) "The Agricultural Ant of Texas" (Pogonomyrmex molificiens Buck) Marvels of the Universe 28 
1159-1162 (1912) (with plates); (64) "On Some Remarkable Associations between Ants of different Species" Rep. LancsChes. Ent. Soc. $36191238-56$ (1913); (65) "Some Races of Ants new to Britain" Ent. Rec. 24306 (1912); (66) "Some Notes on the genus Myrmica Latr." Ent. Rec. 25 1-8, 42-48 (1913) (with plate and woodcuts) ; (67) "Myrmecophilous Notes for 1912 " Ent Rec. 25 61-68, 89-97 (1913) (with woodcuts); (68) "Ants and Myrmecophiles on Lundy" (with plate) Ent. Rec. 25 267-269 (1913); (69) "Aenigmatias blattoides Meinert, captured in Scotland" Ent. Rec. 25 277-278 (1913) ; (70) "Notes on the Capture of Claviger longicornis Müll., and a Description of its Supposed Larva" (with plate) Ent. Rec. 25 290-294 (1913) ; (71) "Myrmecophilous Notes for 1913 " Ent. Rec. 26 37-45 (1914) ; (72) "Three Myrmecological Notes" Ent. Rec. 26 136-138 (1914); (73) "The Supposed Larva of Claviger longicornis Müll." Ent. Rec. 26228 (1914); (74) "Some Notes on the genera Platyphora and Aenigmatias, and a species new to Britain" Ent. Rec. 26 276-278 (1914).

Doubleday, E. "Note on the Capture of Claviger foveolatus" Zool. 1 200 (1843).

Douglas, J. W. (1) “Ants' Nest Beetles" Zool. 18586067 ; Ent. Week. Intell. 415 (1858); (2) "Beetles in Ants' Nests" Zool. 18586148 ; (3) "On the Occurrence of Systellonotus triguttatus in company with Formica fusca" Ent. Mo. Mag. 230 (1865) ; (4) "On the Resemblance to Ants among the Hemiptera" Ent. Mo: Mag. 11138 (1874); (5) "Note on Pilophorus perplexus Dougl. and Scot." Ent. Mo. Mag. 15253 (1879) ; (6) "Ants and Coccidae" Ent. Mo. Mag. 2318 (1886); (7) "Notes on some British and Exotic Coccidae" Ent. Mo. Mag. 27 244-247 (1891) ; (8) "Notes on some British and Exotic Coccidae" Ent. Mo. Mag. 28105 (1892) ; (9) "Dinarda dentata : a Reminiscence" Ent. Mo. Mag. 3611 (1900).

Eaton, A. E. "An Early Swarm of Formica nigra" Ent. Mo. Mag. 5 298 (1869).

Edmonds, E. M. "Ants and Cineraria maritima" Science Gossip 1865143.

Elliman, E. G. "Ilyobates glabriventris and Odontaeus mobilicornis in Bucks " Ent. Mo. Mag. 33279 (1897).

Ellis, H. Willoughby. (Joint paper with A. H. Martineau) "Midland Myrmecophilous Notes for 1907 " Ent. Rec. 20 56-57 (1908).

Elwin, E. T. (1) "Ants" Science Gossip $18 \% 0$ 241-246 ; (2) "Ants" Science Gossip 1871 245-248 ; (3) "A Chapter on Ants" Science Gossip 1874 58-60.

Emery, C. "On the Origin of European and North American Ants" Nature 52 399-400 (1895).

Evans, W. (1) "Platyarthrus hofmanseggii Brandt, in Fife," Ann. Scot. Nat. Hist. 1900 186; (2) "Ripersia subterranea Newst. in Forth" Ann. Scot. Nat. Hist. 1906241 ; (3) "A List of the Ants (Heterogyna or Formicidae) of the Forth Area" The Scot. Nat. 1912 104-108; (4) "Tetramorium caespitum (L.), an Ant new to 
Scotland-in the Forth Area" Scot. Nat. 1913 116; (5) "Ortheziola vejdovskyi Sulc.-a Coccid new to Scotland-in the Forth Area." Scot. Nat. 1913142.

Figuier, Louis. "The Insect World" Ants 377-393 (1867) (English Trans. N.D.).

Fletcher, J. E. "Fertile Eggs laid by Workers of Leptothorax tuberum F." Ent. Mo. Mag. 25 313-314 (1889).

Fowler, W. "Ants conveying in their Mouths other Ants of their own Species " Loudon's Mag. 6476 (1833).

Fowler, W. W. (1) "Solenopsis fugax at Sandown, Isle of Wight, etc." Ent. Mo. Mag. 19139 (1882) ; (2) "Atemeles paradoxus, etc., in the Isle of Wight" Ent. Mo. Mag. 2118 (1884); (3) "Solenopsis fugax, etc., in the Isle of Wight" Ent. Mo. Mag. 2137 (1884); (4) "Tapinoma gracilescens Nyl. at Lincoln" Ent. Mo. Mag. 21 276 (1885) ; (5) "Bythinus glabratus Rye at Sandown, Isle of Wight" Ent. Mo. Mag. 23236 (1887); (6) "Coccids in Ants' Nests" Ent. Mo. Mag. 2917 (1893).

Frisby, G. E. “Stenamma Westwoodi, etc., at Maidstone" Ent. Mo. Mag. 2682 (1890).

Frohawk, F. W. "Completion of the Life History of Lycaena Arion" Entom. 37145 (1906).

Gaskell, S. H. “The House Ant at Stockport" Ent. Mo. Mag. 13254 (1877).

Gardner, C. C. Best. "Experiments on the Capability of Ants to withstand drought and to recover from its effects when nearly dead" Ent. Rec 25 81-83 (1913).

Gillam, J. "Myrmica domestica" Entom. 583 (1870).

Godfrey, R. "Notes on the Animal Life of the Hot-houses of the Royal Bot. Gard. Edinburgh" Notes R. Bot. Gard. Edinb. 17 99-103 (1907).

Goodchild, J. G. (1) "Ants" Trans. Scot. Nat. Hist. Soc. 2 49-72 (1903); (2) "Ants in Relation to Flowers" Trans. Edinb. Field Nat-Mic. Soc. 5 1, 10-23 (1903).

Green, E. Ernest. (1) "Note on the Attractive Properties of certain Larval Hemiptera" Ent. Mo. Mag. 36185 (1900) (with fig) ; (2) " On Carnivorous Lycaenid Larvae" Entom. 35202 (1902) ; (3) " On a Coccid New to Great Britain, with Notes on Allied Species" Ent. Mo. Mag. 47 179-182 (1911); (4) "Ortheziola vejdovskyi (fam. Coccidae) in Scotland" Ent. Mo Mag 49138 (1913)

Gould, R. W. "An Account of English Ants" London, 1747

Guilding, B. A. L. "An Account of Margarodes, a new genus of Insects found in the neighbourhood of Ants' Nests " Trans. Linn. Soc. Lond. 16 115-119 (1829) (with plate).

Hadfield, H. "Remarks and Observations on the Red Ant" Zool. 18628211.

Haliday, A. J. " Dryinus pedestris" Ent. Mag. 2221 (1834).

Hall, C. G. "Swarms of Lasius niger L. var. alienus Först. near Dover " Ent. Mo. Mag. 2491 (1887). 
Hamm, A. H. (1) "Formica exsecta in South Devon" Ent. Mo. Mag. 38266 (1902); (2) "Notes on Cetonia aurata L., and C. floricola Herbst." Ent. Mo. Mag. 46137 (1910) (with photos).

Hardwick, T. "Observations on the Loves of the Ants and the Aphides" Zool. Jour. 4 113-115 (1829).

Hemsley, W. B. "Social Life of Ants and Plants" Gard. Chron. 20 71-72 (1883).

Hill, W. H. (1) “Ants and Aphides" Loudon's Mag. 2209 (1829) ; (2) "Ants conveying in their Mouths other Ants of their own Species" Mag. Nat. Hist. 6476 (1833).

Hislop, R. (1) "Note on Dinarda Maerkelii, etc." Zool. 18617330 ; (2) "Note on the Larval-case, etc., of Clythra 4-punctata" Ent. Mo. Mag. 8269 (1872).

Hogan, A. R. "On a New British Oniscoid found in Ants' Nests" Nat. Hist. Rev. 6109 (1859).

Holme, F. "Note on Beetles inhabiting Ants' Nests" Zool. 1844475.

Holt, R. B. "Ants at the Crystal Palace" Science Gossip 1868159.

Hope, F. W. (1) "Inquiries into the ground for the opinion that Ants lay up stores of food for the winter" Proc. Ent. Soc. Lond. 21837 XXXVII (1838) ; (2) "On some Doubts respecting the Economy of Ants" Trans. Ent. Soc. Lond. 3 211-213 (1844).

Howden, J. "Remarks and Facts on Ants" Mag. Nat. Hist. "y 269 (1834).

Huber, M. P. "The Natural History of Ants " English translation by J. R. Johnson, F.R.S., London, 1820.

Janson, E. W. (1) "Observations on the Myrmecophilous Coleoptera, or Ants' Nest Beetles of Britain" Ent. Ann. 1857 85-96; (2) "Notes on Ants' Nest Beetles" Ent. Ann. 1858 78-84; (3) "Myrmedonia plicata at Bournemouth" Entom. 344 (1866).

Jenner, J. H. A. "Claviger foveolatus at Lewes" Ent. Mo. Mag. 21 36 (1884).

Johnson, W. F. "A Tetratological Specimen of Myrmica rubra" Irish Nat. 2394 (1914).

Joy, N. H. (1) "Notes on Three Species of Microglossa" Ent. Mo. Mag. 41184 (1905) ; (2) "Searching for Nests of Formica rufa" Ent. Rec. 2019 (1908).

Keys, J. H. "A Note on the Pairing of Atemeles paradoxus" Ent. Mo. Mag. 50 61-62 (1914).

Kieffer, J. J. "Gonatopus sociabilis, n.sp. and a Table of the British Species" Ent. Rec. 197 (1907).

Kinahan, J. R. "On the genus Platyarthrus Brandt" Nat. Hist. Rev. 6125 (1859).

King, Edmund. "Observations concerning Emmets, or Ants, their eggs, production, progress, coming to maturity, use " Philosoph. Trans. 2425 (1667).

Kirby and Spence. "An Introduction to Entomology" (Ants' Nests) 1 479-484; (Ants) 2 44-106 (1823). 
Kirby, W. "History, Habits, and Instincts of Animals " Bridgwater Treatises, Ants 2 339-349 (1835).

Kirby, W. F. (1) "Mental Status of Ants" Evolution and Nat. Theol. 149-150 (1883); (2) "Marvels of Ant Life" London, 1898.

Lees, Edwin. " Days in the Woods and Fields" The Nat. 1154 (1837).

Lewis, D. M. " "Sound-producing Ants" Nature 25266 (1882).

Lewis, G. (1) "On a New Species of Hetaerius" Ent. Mo. Mag. 2183 (1884); (2) "On a new Species of Hetaerius from Tangier" Ent. Mo. Mag. 24164 (1887); (3) "On Sternocoelis and Hetaerius and Notes on the Geographical Distribution of the Species" Ent. Mo. Mag. 27 161-162 (1891) ; (4) "On a New Species of Sternocoelis" Ent. Mo. Mag. 3262 (1896).

Livingstone. "Missionary Travels" 328 (1857).

Lloyd, R. W. "Note on Cetonia floricola Herbst." Ent. Mo. Mag. 28 310 (1892).

Lubbock, Sir J. (Lord Avebury). (1) "Observations on Ants, Bees, and Wasps "Jour. Linn. Soc Zool. 12 110-139 (1874); (2) 12 227-251 (1875) ; (3) 12 445-513 (1876); (4) 13 217-258 (1877); (5) "On some Points in the Anatomy of Ants" Month. Micr. Journ. Sept. 1st, 121-142, pts. 189-192 (1877) ; (6) "The Habits of Ants" Roy. Inst. Grt. Brit. Jan. 26th (1877); (7) "Obs. on Ants, Bees, and Wasps" Journ. Linn. Soc. Zool. 14 265-290 (1878). (8) "On the Habits of Ants, etc.' Sc. Lect. London 11879 ; (9) “ On the Anatomy of Ants" (abstract) Journ. Linn. Soc. Zool. 14 738-739 (1879) ; (10) "On the Anatomy of Ants" Trans. Linn. Soc. Zool. 2 141-145 (1879) ; (11) "Obs. on Ants, Bees, and Wasps" Journ. Linn. Soc. Zool. 14 607-626 (1879) ; (12) 15 167-187 (1880); (13) $15362-387$ (1881); (14) "Obs. on Ants, Bees, and Wasps" Nature $23255-258$ (1881) ; (15) "Ants, Bees, and Wasps" London, 1882 ; (16) "Obs. on the Habits of Ants" Entom. 15 33-36 (1882); (17) "Obs. on Ants, Bees, and Wasps" Journ. Linn. Soc. Zool. 16 110-121 (1882); (18) 17 41-52 (1883); (19) "Longevity of Ants" Am. Nat. 20 170-171 (1885) ; (20) "Obs. on Ants, Bees, and Wasps" Journ. Linn. Soc. Zool. 20 118-136 (1888) ; (21) "On the Senses, Instincts, and Intelligence of Animals with special reference to Insects" London 292 (1888); (22) "Ants, Bees, and Wasps" 1894, Revised Ed. Internat. Sc. Ser. N.Y. Appleton and Co.

Luff, W. A. "Lecanium distinguendum Doug., on broom in Guernsey " Ent. Mo. Mag. 29139 (1893).

Malloch, J. R. " Formica fusca, Winged Female in Spring" Ent. Mo. Mag. 40109 (1904).

Martineau, A. H. See H. Willoughby Ellis.

Matthews, A. (1) "Capture of Claviger foveolatus in Oxfordshire" Zool. 51804 (1847) ; (2) "The Wars of the Ants" Ent. Mo. Mag. 20209 (1884)

Matthews, G. F. "New Locality for Claviger foveolatus" Zool. 22 9077 (1864). 
Meade, R. H. "On the Occurrence of Aphides in an Ant's Nest" Zool. 93221 (1851).

Merrin, J. "A Plague of Ants" Entom. 3299 (1866-1867).

Mesmin, L. "Habits of Myrmedonia collaris" Ent. Mo. Mag. 1364 (1876)

Michael, A. D. (1) "On the Hypopi Question" Journ. Linn. Soc. Zool. 17 371-394 (1884); (2) "On the Association of Gamasids with Ants" Proc. Zool. Soc. Lond. 4 638-653 (1891); (3) "Notes on the Uropodinae" Journ. Roy. Mic. Soc. 1894289.

Moffat, C. B. " Formica rufa in Co. Wexford" Irish Nat. 5143 (1896).

Moggridge, J. T. " Harvesting Ants and Trap-door Spiders" London, 1873, Pt. 1 Harvesting Ants 1-69, and Supplement 158-179.

Morice, F. D. "Hymenopterological Notes ( 010 and $ᄋ$ 우 of $F$. fusca in a nest of $F$. sanguinea)" Ent. Mo. Mag. $3^{\text {ry }} 96$ (1901).

Morley, C. (1) "Early Appearance of Formica rufa" Ent. Mo. Mag. 33 158 (1897) ; (2) "On the Pachylommatinae, with descriptions of New Species" Ent. Mo. Mag. 45209 (1909); (3) "Synonymy of Euphorus bistigmaticus Morl. and Neoneurus halidaii Marsh." Ent. Mo. Mag. 5016 (1914); (4) "Synonymy of Neoneurus Marsh., with Elasmosoma berolinense Ruthe" Ent. Mo. Mag. 5093 (1914).

Morris, C. H. "Coccinella labilis Muls. attached to the Nests of Formica rufa" Ent. Mo. Mag. 2536 (1888).

Müller, Albert. "Formica fusca : two ơ in copulâ with one ${ }^{\top}$ " Ent. Mo. Mag. 9120 (1872).

Nevinson, E. B. "Note on the Behaviour of Leptothorax tuberum" Ent. Mo. Mag. 4122 (1905).

Newbery, E. A. "Machaerites glabratus Rye, at Charing, Kent" Ent. Mo. Mag. 37281 (1903).

Newman, E. (1) "Dinarda mürkelii and Hetaerius sesquicornis" Zool. 18596580 : (2) "Formica herculanea, a British Insect" Entom 3244 (1867).

Newstead, R. (1) "On new, or little known Coccidae, chiefly English" Ent. Mo. Mag. 28 141-148 (1892); (2) "New, or little known Coccidae, chiefly English" Ent. Mo. Mag. 2977 (1893) ; (3) "Paracletus cimiciformis in Ants' Nests in North Wales" Ent. Mo. Mag. 29115 (1893) ; (4) "A New Coccid in an Ant's Nest" Ent. Mo. Mag. 29138 (1893) ; (5) "Observations on Coccidae" Ent. Mo. Mag. 29 205-210 (1893) ; (6) " Obs. on Coccidae" Ent. Mo. Mag. 30 204-207 (1894) ; (7) Ent. Mo. Mag. 33 165-171 (1897) ; (8) "Obs. on Coccidae" Ent. Mo. Mag. 36 247-251 (1900).

Nicholson, C. "Swarming of Ants" Nature Notes 18214 (1907).

Osten Sacken, C. R. "A remarkable instance of deliberation observed in an American Ant" Ent. Mo. Mag. 38172 (1902).

Parfitt, E. " "Hypopus parasitic on Ants " Ent. Mo. Mag. 1843 (1881).

Parrot, F. H. "Ants " Science Gossip 1882237.

Pawson, C. "Recognition of Ants" Science Gossip 1893183.

Payne, G. H. " "Instinct in Ants " Science Gossip 1875238. 
Perkins, R. C. L. "Male and Worker characters combined in the same individual of Stenamma Westwoodi" Ent. Mo. Mag. 27123 (1891).

Pinkney, D. W. (1) "Fertile Queen of Lasius umbratus accepted by Queenless Colony of Lasius alienus" Ent. Rec. 26 98-99 (1914); (2) "Incipient Colony of $F$. sanguinea-fusca" Ent. Rec. 26142 (1914).

Plant, J. "Note on Formica rufa" Zool. 1844473.

Poulton, E. B. " Formic Acid-Apparatus to determine the Strength" Proc. Ent. Soc. Lond. 190110.

Power, J. A. "Notes on Myrmecophilous Coleoptera" Zool. 1858 6287.

Praeger, R. L. " A Plague of Ants " Irish Nat. "y 254 (1898).

Quintin, St., W. H. "Ants and Lycaenid Larvae" Ent. Rec. 2272 (1910).

Rayward, A. L. (1) "Larvae of Lycaena corydon and their Association with Ants" Entom. 39197 (1906); (2) "Larvae of Lycaena bellargus and their Association with Ants" Entom. 39219 (1906).

Reading, J. J. "Myrmecophilous Coleoptera captured in the neighbourhood of Plymouth" Zool. 1858 5929-5930.

Rennie, J. "Amazon Ant (Formica rufescens Latr.)" The Field Nat. 2 203-208 (1834).

Richardson, N. M. "Solenopsis fugax Latr., etc., near Weymouth" Ent. Mo. Mag. 30213 (1894).

Roebuck, W. Denison. "Leptothorax acervorum in North-East Yorkshire " Naturalist 1912252.

Romanes, G. J. (1) "Animal Intelligence" Intern. Scient. Series (1882) Ants 3 31-142; (2) "The Use of Ants to Aphids and Coccidae" Nature 4854 (1893).

Rothney, G. A. J. (1) "Formica sanguinea at Shirley" Ent. Mo. Mag. 2850 (1892); (2) “Formica sanguinea, etc., at Shirley " Ent. Mo. Mag. 2967 (1893).

Rothschild, N. C. "An Entomological Riddle" Ent. Rec. 2340 (1911).

Rye, E. C. (1) "Description of a Species of Oxypoda new to Science" Ent. Mo. Mag. 1212 (1865) ; (2) "Note on Thiasophila inquilina Märk." Ent. Mo. Mag. 3189 (1867); (3) "Description of a New Species of Bythinus from Great Britain "Ent. Mo. Mag. 733 (1870).

Saunders, E. (1) "Notes on British Ants" Ent. Mo. Mag. 2016 (1883); (2) "Coleoptera from the Vicinity of Ants' Nests, Chobham" Ent. Mo. Mag. 2018 (1883); (3) "The ô of Formicoxenus nitidulus Nyl." Ent. Mo. Mag. 2342 (1886); (4) "Ponera punctatissima Rog., at Bromley, Kent" Ent. Mo. Mag. 2368 (1886); (5) "Rare Hemiptera at Chobham and Surbiton" Ent. Mo. Mag. 28290 (1892); (6) "Hymenoptera Aculeata" London (1896) British Ants 16-42; (7) "Honey Bees destroyed by Wood Ants (Formica rufa)" Ent. Mo. Mag. 32161 (1896); (8) "Myrmecoris gracilis Sahlb., an addition to the British Hemiptera" Ent. Mo. Mag. 39269 (1903) ; (9) "Wild Bees, Wasps, and Ants " London, 1906 ; (10) "Myrmecoris gracilis in the nest of Formica rufa" Ent. Mo. Mag. 45271 (1909). 
Scott, J. “Ants' Nests and their Inhabitants " Zool. 1860 7024-7026.

Sharp, D. "Claviger foveolatus" Ent. Week. Intell. 1861140 ; (2) "On Stridulation in Ants" Trans. Ent. Soc. Lond. 1893 199-213 (with plate); (3) "Heterogyna or Formicidae-Ants" Cambridge Nat. Hist. Ins. 2 130-183 (1899).

Shipp, J. W. "Claviger testaceus in Wychwood Forest" Ent. Mo. Mag. 29144 (1893).

Shuckard, W. E. (1) "Description of a New Species of Myrmica which has been found in houses both in the Metropolis and Provinces" Charlesworth's Mag. Nat. Hist. 2626 (1838) ; (2) "Monograph of the Dorylidae, a family of Hymenoptera Heterogyna "Ann. Nat. Hist. or Mag. Zool. Bot. Geol. 5 202-258 Append. 396-398 (1840); (3) "Differences of Neuters in Ants" Ann. Mag. Nat. Hist. " 525 (1841) ; (4) "The Red House Ant (Diplorhoptrum molesta) " Science Gossip 1866272.

Silverlock, O. C. "The Senses of Ants as regards Heat and Light" Nature Notes 17 165-169 (1907); (2) "Ant Colonies" Nature Notes 18225 (1907).

Smallcombe, W. A. "Observations on Ants" Proc. Bristol Nat. Soc. $476-81$ (1914).

Smith, F. "Notes on the Habits of Various Species of British Ants" Trans. Ent. Soc. Lond. 3 151-154 (1842) ; (2) "Notes on Entomological Captures in Hampshire " Zool. 1 262-265 (1843) ; (3) "Notes on the Capture of Claviger foveolatus and other Coleopterous Insects inhabiting Ants' Nests" Zool. 1 266-269 (1843); (4) "Economic Habits of Ants" Zool. 1844405 ; (5) "Essay on the Genera and Species of British Formicidae" Trans. Ent. Soc. Lond. (n.s.) 3 95-135 (1855); (6) "Notes on the Myrmicidae and Formicidae, Family Myrmicidae (Formica, pt. Linn.)" Ent. Ann. 1855 97 ; (7) "Revision of an Essay on the British Formicidae" Trans. Ent. Soc. Lond. (n.s.) 4 274-284 (1858) ; (8) "Capture of Dinarda dentata at Weybridge" Ent. Week. Intell. 910 (1860) Zool. 1860 7291 ; (9) "British Species of Ants at Bournemouth" Entom. 2 303 (1864-1865) ; (10) "Notes on British Formicidae" Ent. Mo. Mag. 228 (1865); (11) "On Hermaphroditism in Ants" Ent. Ann. 1874147.

Smith, W. W. (1) "On the Origin of Ants' Nests" Ent. Mo. Mag. 28 60 (1892); (2) "Coccids in Ants' Nests" Ent. Mo. Mag. 28307 (1892) ; (3) "Large Colonies of Ants in New Zealand" Ent. Mo. Mag. 367 (1900); (4) "Ants displaced by Wood-lice in New Zealand" Ent. Mo. Mag. 38132 (1902).

Southcombe, H. W. "Note on the Formation of a new Nest of Lasius niger" Proc. Ent. Soc. Lond. 1906 75-77.

Spencer, J. B. " "Ants store the Seeds of Violets " Zool. 18596697.

Stainforth, T. " Camponotus herulaneus at Hull " The Naturalist 1903 456.

Standen, R. (1) "Gulls and Ants " The Lancashire Nat. 2190 (1909) ; (2) "On the Distribution and Habits of Platyarthrus hofmanseggi Brandt" The Lancashire Nat. 2 239-242 (1909). 
Step, E. (1) "Plants and Insects-especially Ants" Messmates, London, 127-160 (1913); (2) "Ants as Hosts" Ditto 163-206.

Stone, J. Harris. " A Natural Ant Trap" Nature 25 151-152 (1882).

Stopes, Marie C., and C. Gordon Hewitt. "On the Tent-building of the Ant Lasius niger Linn. in Japan" Proc. Manchester Lit-Phil. Soc. 53 1-6 (1909).

Sulc, K. "Coccids Associated with Ants" Ent. Mo. Mag. 3087 (1894).

Swinton, A. H. "Note on the Stridulation of Myrmica ruginodis and other Hymenoptera" Ent. Mo. Mag. 14187 (1878).

Taylor, B. "Ant Hills" Science Gossip 186888.

Temple, Miss E. G. "Sundew and Ants" Science Gossip (n.s.) 2198 (1895-1896).

Theobald, F. V. "First List of Aphides found with Myrmica" Ent. Rec. 25 48-51 (1913).

Thomas, T. H. "Note upon an Ant's Nest in a Cardiff Garden" Rep. Trans. Cardiff Nat. Soc. 20 106-109 (1888).

Tomlin, J. R. le B. (1) “ Occurrence of a Species of Ripersia (europaea Newstead) New to Britain at Swanage, Dorset" Ent. Mo. Mag. 40282 (1904); (2) "Atemeles emarginatus Pk. and Claviger testaceus Preys. in N. Wales" Ent. Mo. Mag. 4120 (1905) ; (3) "Myrmecophilous Coleoptera in Herefordshire" Ent. Rec. 22189 (1910).

Tutt, J. W. "The Connection between Ants and Lycaenid Larvae" Ent. Rec. 20 89-90 (1908).

Wakefield, R. "Note on the Economy of Ants" Zool. 1843335 ; (2) "On some Habits of Ants" Proc. Linn. Soc. Lond. 2 293-294 (1854).

Walker, A. 0. "The Use of Ants to Aphides and Coccidae" Nature 48 54 (1893).

Walker, J. J. (1) “Notes on Ants' Nest Beetles at Gibraltar and Tangier; with especial reference to the Histeridae" Ent. Mo. Mag. 25 374-378 (1889); (2) "Capture of Trichonyx sulcicollis Reich, and T. märkeli Aubé" Ent. Mo. Mag. 46213 (1910): (3) "Claviger longicornis Müll., a British Insect" Ent. Mo. Mag. 48100 (1912); (4) "The host of Claviger longicornis Müll.; in England" Ent. Mo. Mag. 49136 (1913); (5) "Quedius puncticollis Thoms. accompanying Lasius fuliginosus Latr." Ent. Mo. Mag. 50247 (1914).

Ward, F. H. "Concerning Ants" Science Gossip 1868 177-180.

Warner, W. H. (1) "Yellow Ant (Formica flava)" Science Gossip 18 "1 183 ; (2) "Large Wood Ant (Formica herculanea)" Science Gossip 1871198.

Waterston, J. "Monomorium pharaonis L., in Kincardineshire" Scot. Nat. 1912280.

Weiss, F. E. (1) "The Dispersal of Fruits and Seeds by Ants" The New Phytologist " 23-28 (1908); (2) "The Dispersal of the Seeds of the Gorse and Broom by Ants "The New Phytologist 8 81-89 (1909). 
Wenham, F. H. "The Instincts of Ants" Science Gossip 1872 201.

Westwood, J. 0. (1) "Introduction to Modern Classification of Insects" Formicidae 2 217-236 (1840); (2) "The House Ant" Gardener's Chron. 10 No. 22340 (1850).

White, F. Buchanan. "The Nest of Formica rufa and its Inhabitants" Scott. Nat. 1 216-222, 258-263 (1871-1872).

White, Farren-. "Ants and their Ways" London (1883); 2nd. Ed. Revised (1895).

Wilkinson, T. "Ants' Nest Beetles at Scarborough" Ent. Mo. Mag. 214 (1865).

Winder, T. "Intelligence in Ants" Science Gossip 1879262.

Wollaston, T. V. (1) "Capture of a Coleopterous Genus new to the British Fauna" Zool. 18565178 ; (2) "Coleoptera" Ent. Week. Intell. 2 85-86 (1857).

\section{"ANONYMOUS."}

"Amator Naturae." “Flies and Ants" Science Gossip 188844. Anon. "Ants and Precious Stones" Science Gossip 18 "3 92. "G. C." "The Large Wood Ant" Science Gossip 1866150. "G. E. C." " Ants and the Taint of the Hand " Nature 8303 (1873).

"E. D. H. D." "Ants and Aphides" Science Gossip 1868190.

“E. L. R." "Beetles and Ants" Science Gossip 186689.

"J. D." (1) "A Battle between Ants of the Species Myrmica rubra and Ants of the Species Myrmica caespitum" Mag. Nat. Hist. "y 267 (1834) ; (2) "Ants and their Carnivorous Habits" Mag. Nat. Hist. r 268 (1834); (3) "A Mode of Destroying Ants in Gardens" Mag. Nat. Hist. 7269 (1834).

"H. G. K." "The House Ant" Science Gossip 1865170.

“L. F. C." "Ants and Aphides" Loudon's Mag. 3148 (1830).

"O." "A Battle of Ants" Loudon's Mag. 4149 (1831).

“W. E. G.” (Bristol). “ Ants and Aphides " Science Gossip 1889214. 
$x=$ 


\section{INDEX (SYSTEMATIC).}

\section{ANTS.}

(Genera are spelt with a capital letter, species otherwise. synonyms are in italics, asterisks $\left(^{*}\right)$ signify errors, sections (§) homonyms, and daggers ( $\dagger$ ) errors in spelling, for which Author disclaims all responsibility.)

abdominalis, Camponotus, 349 acervorum, Leptothorax, 147 Aecophthora, 96

affinis, Donisthorpea, 227

affinis, Leptothorax, 155, 159

*affino-tuberum, Leptothorax, 166

albipennis, Stenamma, 155

*albipennis, Stenamma, 162

albipes, Technomyrmex, 343

aliena, Donisthorpea, 212

alieno-nigra, var., Donisthorpea, 211

alluaudi, Plagiolepis, 343

alpina, var., Formica, 265

americana, subsp., Myrmecina, 80

americana, var., Donisthorpea, 213

androgyna, Ponera, 71, 72

Anergates, 87

antiguensis, Formica, 96

antillana, subsp., Prenolepis, 346

aphidicola, var., Donisthorpea, 237

apicalis, Formica, 245

arduennæ var., Myrmica, 134, 135

argentata, Formica, 219

Asemorhoptrum, 139

atavia, Ponera, 69

*atratula, Myrmica, 171

atratulus, Anergates, 89

atriceps, var., Camponotus, 349

auro-punctata, Wasmannia, 341

barbata, Formica, 304

bidens, Myrmica, 76

binodis, Formica, 170

boerorum, subsp., Ponera, 336

brevicornis, Donisthorpea, 208

brevispinosa, var., Myrmecina, 80

brunnea, Donisthorpea, 230, 238

*brunnea, Donisthorpea, 347

*brunnea, Formica, 236

brunneipes, var., Technomyrmex, 343

caerulescens, Formica, 179

caespitum, Myrmica, 125 caespitum, Tetramorium, 90, 170

Camponotinae, 184, 343

capsincola, Formica, 304

cellarum, var., Pheidole, 339

chamberlini, Symmyrmica, 84

cingulata, Myrmica, 155

clypeatus, Leptothorax, 144

coarctata, Ponera, 67

collina, Tapinoma, 179

Colobopsis, 350

congerens, Formica, 267

consocians, Formica, 258

contracta, Formica, 67

corticalis, Leptothorax, 155, 160

crassinoda, Formica, 65

cunicularia, Formica, 313, 314, 318, 320

dakotensis, Formica, 258

debilis, Myrmica, 139

denticornis, Myrmica, 134

destructor, Monomorium, 334, 336

diluta, Myrmica, 115

Diplorhoptrum, 96, 102

diversus, Pheidologeton, 337

Dolichoderinae, 178, 342

domestica, Myrmica, 96

domesticum, †Ciphlorophum, 96

dominula, Formica, 280

Donisthorpea, 184

donisthorpei, subsp., Prenolepis, 347

dorsata, Formica, 245

dufourii, Micromyrma, 179

dusmeti, var., Formica, 267

eduardi, Ponera, 74

emarginatus, Donisthorpea, 229, 230

*emarginatus, Lasius, 245

emeryi, Cardiocondyla, 335

erraticum, Tapinoma, 179

exigua, Plagiolepis, 344

exsecta, Formica, 273

exsectoides, Formica, 258, 275 
filchneri, var., Formica, 326

flava, Donisthorpea, 216

flavidula, Myrmica, 102

flavidula, Plagiolepis, 343

flavipes, Formica, 304

flavipes, Prenolepis, 345

*flavus, Lasius, 223, 224

flori, Formica, 306

floricola, Monomorium, 334

Formica, 241

Formicoxenus, 82

*fugax, Diplorhoptrum, 96

fugax, Solenopsis, 102

*fugax, Solenopsis, 116

fukaii, var., Formica, 275

fuliginosa, Donisthorpea, 188

fusca, Formica, 304

*fusca, Formica, 170, 200

fusco-rufibarbis, var., Formica, 313, 314,318

fuscula, Myrmica, 90, 170

gagates, Formica, 328, 329

*gagates, Formica, 325

geminata, Solenopsis, 101, 335

gertrudae, Pheidole, 338

glabra, Formica, 326

glabrella, Formica, 179

glacialis, Formica, 305

glebaria, var., Formica, 313, 314

gracilescens, Tapinoma, 345

gracilis, Pseudomyrma, 336

graminicola, Formica, 147

*graminicola, Formica, 139

graminicola, Myrmecina, 76

guineense, Tetramorium, 335, 339

haematodes, Odontomachus, 334

hammi, var., Tetramorium, 178

*herculanea, Formica, 245

herculeanus, Camponotus, 347

humilis, Iridomyrmex, 335, 342

impura, Myrmica, 171

incisa, Strumigenys, 341

incompleta, Myrmica, 110

indica, var., Diacamma, 335

inserta, Formica, 258

interruptus, Leptothorax, 155, 166

kollari, Tetramorium, 339

lacteipennis, Myrmica, 147

laevigata, Myrmica, 338

laevinodis, Myrmica, 110

laeviuscula, Myrmica, 83

*laeviuscula, Myrmica, 139.

lasioides, subsp., Donisthorpea, 347
$\S$ Lasius, 184

latreillei, Myrmecina, 76

Leptothorax, 144

lippula, Myrmica, 139

lobicornis, Myrmica, 134

longicornis, Prenolepis, 335, 345

longipes, Plagiolepis, 335

longiscapus, Myrmica, 110

lucidula, Myrmica, 83

lugubris, Formica, 245

maculipes, Myrmica, 90, 171

major, var., Formica, 245

mandibularis, Solenopsis, 101

Manica, 162

mayitae, Tetramorium, 341

mayri, Anochetus, 336

megacephala, Pheidole, 335, 338

melanocephalum, Tapinoma, 335, 342

mellea, Formica, 217

microcephalum, Liometopum, 229

microgyna, Formica, 243, 258

minkii, Myrmica, 139

minuta, Atta, 96

minuta, var., Prenolepis, 345

minutum, Monomorium, 95, 337

minutum, Tapinoma, 343

mixta, Donisthorpea, 236

*mixta, Formica, 223

mixto-umbrata, var., Donisthorpea, 233

modesta, Myrmica, 171

*molesta, Myrmica, 96

molesta, Solenopsis, 97

Monomorium, 95

mutica, Myrmica, 84

Mychothorax, 145, 147

Myrmamblys, 349

Myrmecina, 75

Myrmica, 107

Myrmicinae, 74, 336

myrmicoxena, Myrmica, 138

Myrmothrix, 349

Myrmoturba, 348

nearcticus, Donisthorpea, 217

neonigra, Donisthorpea, 215

*niger, Lasius, 216, 219

nigerrima, Formica, 200

*nigra, Formica, 304

nigra, Donisthorpea, 200

nigra major, Formica, 304

nipponensis, var., Donisthorpea, 190

nitens, subsp., Prenolepis, 344

nitidula, Formicoxenus, 83

*nitidula, Myrmica, 139

*nitidulus, Formicoxenus, 139

†nodicornis, Myrmica, 134 
novogranadensis, Camponotus, 349 nylanderi, Leptothorax, 155

Nylanderia, 345-347

obsoleta, Formica, 245, 320

*ochracea, Ponera, 71

opaciceps, Ponera, 336

pallescens, Formica, 200

* pallidula, Pheidole, 338

pallitarsis, Formica, 213

patagonicus, Brachymyrmex, 344

pavidus, var., Camponotus, 348

pennsylvanicus, subsp., Camponotus,

348

perelegans, Myrmica, 122

pharaonis, Monomorium, 96, 335, 337

picea, Formica, 325

picea, var., Formicoxenus, 81

piniphila, Formica, 245, 263

polita, Tapinoma, 344

polyctena, Formica, 245, 263

Ponera, 66

Ponerinae, 65, 335

pratensis, Formica, 267

*pratensis, Formica, 320

pressilabris, Formica, 279

punctatissima, Ponera, 71

punctulata, var., Pheidole, 339

pusilla, Oecophthora, 338

pygmaea, Micromyrma, 178

Raptiformica, 243

ravouxi, Formicoxenus, 85

regulare, Ectatomma, 335

reticulata, Myrmica, 339

rhombinoda, Pheidole, 339

rogeri, Strumigenys, 341

rubens, var., Formica, 279

rubescens, var., Formica, 313, 318

rubicunda, Formica, 297, 298

rubida, Myrmica, 84

rubra, Formica, 108, 110

rufa, Formica, 245

*rufa, Formica, 220, 267

rufibarbis, Formica, 313, 320

*rufibarbis, Formica, 314

ruficornis, Formica, 217

rufo-pratensis var., Formica, 262

ruginodis, Myrmica, 115

ruginodo-laevinodis, var,, Myrmica, 115 sabuleti, var., Myrmica, 132

sanguinea, Formica, 280

santschii, var., Formica, 265

scabrinodis, Myrmica, 125

schiefferdeckeri, Donisthorpea, 202

schmidti, var., Tetramorium, 178

scutellaris, Cremastogaster, 337

semilaeve, var., Tetramorium, 178

Serviformica, 243

sexdens, var. Tetramorium, 341

simillimum, Tetramorium, 335, 340

simpliciuscula, Myrmica, 166

Solenopsis, 101

Stenamma, 138

stenoptera, Formica, 320

stercorarius, subsp., Camponotus, 349

striatidens, Triglyphothrix, 335, 341

strictula, Myrmica, 76

subintegra, Formica, 298

subsericea, Formica, 258, 305, 310

sulcinodis, Myrmica, 122

sulcinodo-ruginodis, var., Myrmica, 121

sylvaticus, subsp., Camponotus, 348

Tapinoma, 178

tarda, Ponera, 71

terminalis, Cremastogaster, 338

Tetramorium, 169

texana, subsp., Myrmecina, 80

theresiae, Neoponera, 336

transkaukasica, Formica, 326

tristis, Formica, 304

truncatus, Camponotus, 350

*truncicola, Formica, 245

truncicolo-pratensis, var., Formica, 267

*tubero-affinis, Leptothorax, 166

tuberosa, Formica, 162

tuberum, Leptothorax, 154, 162

*tuberum, Leptothorax, 160

*tuberum, Myrmica, 155

umbrata, Donisthorpea, 223

*unifasciata, Formica, 96

* unifasciata, Leptothorax, 162

unifasciatus, Leptothorax, 154, 155

vagans, Myrmica, 115

vividula, Prenolepis, 335, 346

westwoodii, Myrmica, 83

westwoodi, Stenamma, 139

*westuondi, Stenamma, 116 


\section{MYRMECOPHILES.}

(The term is used in its widest sense here.)

\section{COLEOPTERA}

acuminata, Homoeusa, 199, 210, 223, 240,312

analis, Homalota, 131, 199, 223, 261, 280

anceps, Notothecta, 261, 265, 280

angulata, Thiasophila, 199, 261, 265

atratus, Xantholinus, 199, 261

aurata, Cetonia, 261

bennetti, Ilyobates, 199

bicolor, Medon, 223

brevis, Quedius, 199, 261, 265, 303

canaliculata, Drusilla, 70, 114, 121 ,

$125,131,154,177,199,210,216$,

$223,261,280,303,312,318$

carinatus, Neuraphes, 312

cognata, Myrmedonia, 199

collaris, Myrmedonia, 114

confusa, Notothecta, 199, 261

conicicollis, Monotoma, 261, 265

consanguinea, Homolota, 199, 233

dentata, Dinarda, 303

distincta, Coccinella, 261

emarginatus, Atemeles, 114, 121, 125,

$131,134,312$

exarata, Homalota, 199

ferrugineus, Hetaerius, 223, 261, 303. 312

flavipes, Notothecta, 261, 265, 267, 280,303

floricola, Cetonia, 261, 273

formiceticola, Oxypoda, 261

formicetorum, Monotoma, 261

formicetorum, Leptacinus, 261, 265, 325

funesta, Myrmedonia, 199

gentilis, Microglossa, 199

glabratus, Bythimus, 70

glabriventris, Ilyobates, 199

godarti, Scydmaenus, 261

gressneri, Ptenidium, 199

haemorrhoa, Oxypoda, 199, 261, 265, 280,303

hagensi, Dinarda, 280

haworthi, Myrmedonia, 199

humeralis, Myrmedonia, 199, 228, 233,261

inquilina, Thiasophila, 199

kraatzi, Ptenidium, 261

laticollis, Myrmedonia, 199

limbata, Myrmedonia, 131, 199, 210 , $223,280,303,312$ longicornis, Claviger, 210, 240

lugens, Myrmedonia, 199

marginata, Amphotis, 199

märkeli, Dinarda, 261

märkeli, Trichonyx, 199, 223, 312

montandoni, Trichopteryx, 261

myrmecophilum, Ptenidium, 199, 261

myrmecophilum, Ptilium, 261

myrmecophilus, Othius, 132, 199, 223

$261,280,303$

nigra ? Heterothops, 196, 261

nigricollis, var., Atemeles, 115

nitidula, Homalota, 199

onopordi, Larinus, 307

paradoxus, Atemeles, 114, 314, 318, 325

parallela, Homalota, 261, 265

pedestris, Formicomus, 350

piceus, Myrmetes, 261

plicata, Myrmoecia, 184

pulla, Microglossa, 199, 261

punctatus, Dendrophilus, 199, 261, 280

pygmaea, Dinarda, 314, 318, 325

pygmaeus, Dendrophilus, 261,265

quadripunctata, Clythra, 261, 265

recondita, Oxypoda, 261, 303

ruficornis, Aleochara, 199, 261, 312

sabulosum, Opatrum, 210, 318

saginatus, Lamprinus, 70, 121, 134, $223,303,312$

stercorarius, Staphylinus, 114, 121, $132,177,223,261$

strumosa, Lomechusa, 295, 303

testaceus, Claviger, $210,216,223$

venustus, Batrisodes, 132, 199, 261, 312

vittata, Oxypoda, 199

\section{HYMENOPTERA PARASITICA}

albitarse, Polynema, 262

anthracinus, Pezomachus, 210

apterum, Chasmodon, 199, 312

aquisgranensis, Pezomachus, 121, 132

berolinense, Elasmosoma, 262

brevifilis, Antaeon, 312

buccata, Pachylomma, 121, 132, 138,

$184,210,216,223,262,265,303$, 325

cantianum, Pseudisobrachium, 70

compar, Blacus, 318 
cynipseus, Litus, 211

distinctus, Gonatopus, 114, 318

donisthorpei, Loxotropa, 223

donisthorpei, Tetramopria, 177

donisthorpei, var., Exallonyx, 132

erythromera, Spalangia, 199

falconivibrans, Spilomma, 312

femoralis, var., Tetramopria, 177

formicaria, Kleditoma, 262

formicaria, Rhoptromeris, 312

formicaria, Trichopria, 312

formicaria, var., Belyta, 199

formicarius, Aphanogmus, 262

formicarius, Bethylus, 199

formicarum, Loxotropa, 199

fuliginosus, Tropidopria, 199, 262

gravidator, Proctotrypes, 303

hospes, Plesiobaeus, 312

hyalinus, var., Amblyaspis, 199

intermedius, Pezomachus, 303

lasiophila, Aclista, 199

lasiophilus, Amblyaspis, 199

myrmecobia, Conostigmus, 262

myrmecobius, Hoplogryon, 199

myrmecobius, Teleas, 199

mymecophila, Kleditoma, 199, 262

myrmecophilus, Ceraphron, 262

myrmecophilus, Exallonyx, 199

myrmecophilus, Gonatopus, 210

myrmecophilus, Leptorhaptus, 199

myrmecophilus, Paragryon, 223

myrmicarum, Ceraphron, 121

neeisij, var., Pezomachus, 114

nervosa, Aspilota, 199

nigro-cinetus, Microcryptus, 114, 261

pallidus, Lagynodes, 199, 262

pedestris, Planopria, 210

ruddi, Embolemus, 312

rufo-petiolatus, var., Amblyaspis, 199

seminulum, Baeus, 262

sociabilis, Gonatopus, 177

sociabilis, var., Exallonyx, 199

sociata, Ashmedopria, 262

striatus, Gonatopus, 223, 312

subcyaneum, Pseudisobrachium, 81

subintegra, Kleditoma, 262

subterranea, Loxotropa, 210, 223

testaceipes, Conostigmus, 262

tritoma, Loxotropa, 177

viator, Acoelius, 262

vulpinus, Pezomachus, 261

wasmanni, Conostigmus, 262

wasmanni, Exallonyx, 199

\section{LEPIDOPTERA}

arion, Lycaena, 134

bellargus, Lycaena, 206 corydon, Lycaena, 220

eros, Polyommatus, 124

incongruella, Amphisbatis, 280

ochraceella, Myrmecozela, 262

\section{DIPTERA}

aequalis, Apiochaeta, 199

aterrima, Trineura, 200

brachyptera, Peyerimhoffia, 216

ciliata, Apiochaeta, 199

conformis, Apiochaeta, 121

curtiventris, Limosina, 200

dorni, Platyphora, 325

femorata, Apiochaeta, 121

formicae, Phyllomyza, 262, 265

formicarum, Pseudacteon, 138, 184,

$199,211,216,223,233,262,303$

fungicola, Limosina, 200, 262

highlandica, var., Platyphora, 312

infumata, Scatopse, 199, 262

lasiae, Phyllomyza, 199

longicostalis, Apiochaeta, 199

lubbocki, Platyphora, 312, 333, 334

ludens, Milichia, 199

mutabilis, Microdon, 121, 211, 312

myrmecophilus, Ceratopogon, 262, 280

pulicaria, Apiochaeta, 262

rata, Apiochaeta, 280

rufilabris, Limosina, 312

sp ?, Phyllomyza, 199

transversalis, var ?, Scatopse, 199

transversalis, Scatopse, 262

\section{HETEROPTERA}

calcaratus, Alydus, 211, 262, 303, 312 cinnamopterus, Pilophorus, 262

coleoptrata, Myrmedobia, 114, 200, 211

coleopteratus, Ceratocombus, 280, 312

formicetorum, Piezostethus, 262

gracilis, Myrmecoris, 211, 262

lativentris, Nabis, 211, 262, 303, 312

perplexus, Pilophorus, 200, 211, 262, 303,312

triguttatus, Systellonotus, 211, 312

\section{APHIDAE}

alienus, Aphis, 216

carnosa, Geoica, 211, 216, 223

cimiciformis, Paracletus, 177, 223

corni, Schizoneura, 114, 121, 131, 211 , $223,262,312$ 
donisthorpei, Trama, 177

formicaria, Forda, 114, 121, 131, 177, $211,216,223,233,312$

formicarium, Macrosiphum, 223

formicina, Geoica, 211, 233

formicophilus, Lachnus, 262

furcata, Forda, 114

hexagona, Forda, 223

hirsutum, Tycheoides, 223

lactucaria, Brysocrypta, 121, 131

leontodoniella, Aphis, 223

marginata, Pentaphis, 177, 211, 312

nudus, Lachnus, 312

pellucida, Geoica, 223

plantaginis, Aphis, 121, 211, 223, 262

radicis, Trama, 131, 211, 216, 223, 312

ranunculi, Aphis, 223

ranunculi, Brysocrypta, 121, 131, 312

setariae, Tycheoides, 121, 223, 233, 318

setulosa, Tycheoides, 114, 223

sp ?, Macrosiphum, 211

subterranea, Aphis, 216

trivialis, Pentaphis, 114, 177, 211, 223

troglodytes, Trama, 131, 211, 216, 223

ulmi, Tetraneura, 121, 131, 177, 216, 223,312

viridana, Forda, 131, 216, 223

\section{COCCIDAE}

aceris, Pseudococcus, 195

cataphracta, Orthezia, 262

donisthorpei, Ripersia, 70

europaea, Ripersia, 312

floccosa, Newsteadia, 200, 262, 312

formicarii, Ripersia, 211, 223

formicarum, Lecanopsis, 211

hesperidum, Lecanium, 205, 346

rubi, Lecanium, 195

sphagni, Pseudoccus, 334

subterranea, Ripersia, 177, 211, 216, 223,318

tomlini, Ripersia, 211, 223, 312

vejdovskyi, Ortheziola, 132, 211, 223

vitis, Coccus, 205

\section{COLLEMBOLA}

albinos, Cyphodeirus, 70, 114, 121, $125,132,134,138,177,184,200$, $211,216,223,233,240,262,280$, $303,312,318,320,325,334$ caecus, Smynthurus, 121, 312

cavernarum, Lepidocyrtus, 200

\section{MYRIAPODA}

guttulatus, Blanjulus, 280

lagurus, Polyxenus, 262, 312

pulchellus, Julus, 200, 262

\section{ARANEINA}

arietinus, Tetrilus, 200, 211, 262

biovata, Thyreosthenius, 262, 265, 273,312

cambridgei, Dysdera, 200, 303, 318

cinerea, Cicurina, 200, 240

diversa, Cryphoeca, 200

donisthorpei, Diblemma, 341

festiva, Micarisoma, 200, 211, 262, 303

formicarius, Myrmarachne, 132

helvola, Hahnia, 200

hombergi, Harpactes, 134, 200, 211, $303,312,318$

innotabílis, Microneta, 200, 262

merens, Evansia, 211, 303, 312, 318

minimus, Phrurolithus, 132, 312

pulicaria, Micaria, 177, 211, 280, 303,

312,318

recisus, Tetrilus, 200, 233, 262, 312

riparium, Theridium, 303

scintillus, Micaria, 312, 318

scurrilis, Acartauchenius, 177

troglodytes, Drassus, 200

viaria, Microneta, 200, 262

\section{PSEUDOSCORPIONINA}

scorpioides, Chernes, 262

\section{ACARINA}

acutus, Laelaps, 132

bostocki, Trachyuropoda, 200, 233, 241

celtica, Trachyuropoda, 223

coccinea, Trachyuropoda, 262, 312

comata, Cillibano, $211,223,233,236$, 241

cuneifer, Laelaps, 200, 233, 241, 262 ,

$280,304,318$

equitans, Laelaps, 177

excavata, Trachyuropoda, 200, 211

foreli, Antennophorus, 211

formicarius, Urotrachytes, 223

grandis, Antennophorus, 200

holothyroides, Sphaerolaelaps, 233, 236,241 
laevis, Laelaps, 177

laminosa, Trachyuropoda, 177, 211, 223,312

minutissima, Uroplitella, 200, 211, 233,318

montanus, Laelaps, 313

myrmecophilus, Laelaps, 121, 304, $312,318,320$

myrmophilus, Laelaps, 132, 177, 312

notabilis, Uroobovella, 312

obovata, Uroobovella, 223

oophilus, Laelaps, 262, 265, 273, 313, 318

ovalis, Uropoda, 233

ovatula, Uroplitella, 114, 223

philoctena, Urodiscella, 223, 233

pubescens, Antennophorus, 223

pulcherrima, Discopoma, 312

ricasoliana, Urodiscella, 200

sinuata, var., Trachyuropoda, 211, 312

styliferus, Laelaps, 223

uhlmanni, Antennophorus, 233, 236, 241

vacuus, Laelaps, 132, 211

wasmanni, Tryoglyphus, 233,313

wasmanniana, Trachyuropoda, 233

\section{CRUSTACEA}

hoffmanseggi, Platyarthrus, 114, 121, $125,132,134,154,177,200,203$, $211,216,223,233,241,262,280$, $304,313,318,320$ pulchellum, Armadillum, 313

rufa, var., Porcellio, 304

\section{MYRMECOCHOROUS SEEDS}

aparine, Galium, 206

avenaceum, Arrhenatherum, 254

broom, 254

Carduus, sp. ?, 254

Cerastium, 175

cyanus, Centaurea, 119

flexuosa, C. (Cardamine), 175

gorse, 254

hirsuta, C. (Cardamine), 175

hirta, Viola, 195

lanatus, Holcus, 254

Mercurialis, 175

odorata, Viola, 195, 206

Paniscum, 175

uniflora, Melica, 195

Viola sp. ?, 254

\section{FUNGI}

Laboulbeniaceae, 154

myrmecophilum, Cladosporium, 193

*myrmecophilum, Cladotrichum, 193

*myrmecophilum, Macrosporium, 193

*myrmecophilum, Septosporium, 193

myrmecophilum, var., Hormiscium, 229

pithyophilum, Hormiscium, 229 



\section{LIST OF SUBSCRIBERS.}

Adams, Fredk. C., F.Z.S., F.E.S., 50 Ashley Gardens, Westminster, S.W.

Adkin, Robert, F.E.S., 4 Lingards Road, Lewisham, S.E. (2 copies.)

Avebury, The Right Honble. Lord, High Elms, Orpington.

Bagnall, Richard S., F.L.S., F.E.S., Penshaw Lodge, Penshaw, Co. Durham.

Balfour, Miss, Whittingehame, Prestonkirk, Scotland.

Beare, T. Hudson, Regius Professor of Engineering, B.Sc., F.E.S., F.R.S.E., 10 Regent Terrace, Edinburgh.

Beck, R., F.E.S., 49 Portchester Road, Bournemouth.

Beresford, Denis R. Pack, D.L., Fenagh House, Bagnalstown, Ireland.

Bethune-Baker, G. T., F.L.S., F.Z.S., Past-Pres. Ent. Soc., Lond., 19 Clarendon Road, Edgbaston. (2 copies.)

Bishop, Thos. G., Dalmore, Helensburgh, Dumbartonshire. (2 copies.)

Bostock, E. D., F.E.S., Oulton Cross, Stone, Staffs.

Bouskell, Frank, F.R.H.S., Market Bosworth, Nuneaton.

Bowles, E. Augustus, M.A., F.E.S., Myddelton House, Waltham Cross, Herts.

Boycott, A. E., Red Friars, Radlett.

Bristol Museum and Art Gallery (H. Bolton, Director.)

Brun, R., Dr. Med., Zollikerstrasse 106, Zürich 8, Switzerland.

Bryant, G. E., F.E.S., Fir Grove, Esher.

Buchan-Hepburn, Sir Archibald, Bt., J.P., D.L., F.E.S., Smeaton-Hepburn, Prestonkirk, East Lothian.

Butler, Edward A., B.A., B.Sc., F.E.S., 56 Cecile Park, Crouch End, London, $\mathrm{N}$.

Cameron, M., M.B., R.N., F.E.S., 7 Blessington Road, Lee, London, S.E.

Cardiff Libraries Committee (Harry Farr), Central Library, Cardiff.

Carr, Prof. J. W., M.A., F.L.S., University College, Nottingham. (2 copies.)

Chapman, T. A., M.D., F.Z.S., F.E.S., Betula, Reigate. (2 copies.)

Crawley, W. C., B.A., F.E.S., 29 Holland Park Road, London, W.

Donisthorpe, Lieut. de Aulâ, Intelligence Corps, General Headquarters, British Expeditionary Force, France.

Druce, Hamilton H. C. J., F.Z.S., F.E.S., Trefusis Lodge, 3 Norfolk Road, London, N.W.

Dulau and Co., Ltd., 37 Soho Square, W. (4 copies.)

Eales-White, Captain J. C., F.F.S., 49 Chester Terrace, Eaton Square, S.W.

Edwards, Stanley, F.L.S., F.Z.S., F.E.S., 15 St. Germans Place, Blackheath, S.E.

Elliot, Andrew, 17 Princes Street, Edinburgh.

Elliott, Mrs. Jessie Bayliss, D.Sc., B.Sc., F.B.M.S., Arden Grange, Tanworthin-Arden, Warwickshire. 
Elliott, Ernest A., F.E.S., 16 Belsize Grove, London, N.W. (2 copies.)

Ellis, H. Willoughby, F.E.S., 3 Lancaster Place, Belsize Park, London, N.W.

Elwes, H. J., J.P., F.R.S., etc., Past-Pres. Ent. Soc., Lond., Colesborne Park, nr. Cheltenham.

Entomological Society of London, The, 11 Chandos St., Cavendish Square, W. Evans, Wm., F.R.S.E., F.E.S., 38 Morningside Park, Edinburgh.

Fontenelle, Paul de Peyerimhoff de, 78 Boulevard Bon-Accueil, Alger.

Foster, Nevin H., F.L.S., M.R.I.A., Hillsborough, Co. Down, Ireland.

Foxall, W. H., Birmingham Natural Hist. and Philosophical Soc., Avebury House, 55 Newhall Street, Birmingham.

Frisby, George E., F.E.S., 40 Windmill Street, Gravesend, Kent.

Frohawk, F. W., M.B.O.U., F.E.S., Stanley House, Park Road, Wallington, Surrey.

Gardner, Charles C. Best, F.E.S., R.N. Flying Corps, Rookwood, Neath, S. Wales.

Gardner, Willoughby, F.L.S., F.S.A., F.E.S., Deganwy, N. Wales.

Gimingham, C. T., F.I.C. (University of Bristol), Long Ashton, nr. Bristol.

Green, E. Ernest, Vice-Pres. Ent. Soc., Lond., Way's End, Camberley, Surrey.

Haines, F. H., Brookside, Winfrith, Dorchester.

Hall, Thomas Wm., F.E.S., Stanhope, The Crescent, Croydon.

Hallett, H. M., F.E.S., 102 Merchants Exchange, Cardiff.

Hamilton, Lord Claud, M.P., 28 Cambridge Square, London, W.

Hamm, A. H., 22 Southfield Road, Oxford.

Heath, Ernest, F.R.M.S., Froyle, Penylau, Cardiff.

Horne, Arthur, F.E.S., 60 Gladstone Place, Aberdeen, N.B.

Hudd, Alfred E., F.E.S., 108 Pembroke Road, Clifton.

Image, Selwyn, M.A., F.E.S., Slade Prof. of Arts, Oxford, 20 Fitzroy Street, London, W.

Imms, A. D., M.A., D.Sc., F.L.S., F.E.S., Dept. of Agricultural Entomology, University of Manchester.

Imperial Entomologist, Agricultural Research Institute, Pusa, Bihar, India. Institutions of Science and Art, Kildare Street, Dublin.

Jackson, A. Randell, M.D., D.Sc., Westcote, Hoole Road, Chester.

Jackson, W. Hatchett, D.Sc., Pen Wartha, South Road, Weston-super-Mare. Janson, O. E., F.E.S., 44 Gt. Russell Street, W.C.

Johnson, Rev. W. F., M.A., F.E.S., Acton Glebe, Poyntzpass, Co. Armagh, Ireland.

Jones, Albert Hugh, Treasurer Ent. Soc., Lond., Shrublands, Eltham, S.E.

Kew, H. Wallis, 3 Herndon Road, Wandsworth.

Keys, James H., F.E.S., 7 Whimple Street, Plymouth.

King, James J. F. X., F.E.S., I Athol Gardens Terrace, Kelvinside, Glasgow.

Laboratorio di Zoologia, R. Scuola Superiore di Agricoltura, Portici (Napoli).

Latter, Oswald H., M.A., F.E.S., Charterhouse, Godalming, Surrey.

Levett, Rev. T. P., F.E.S., F.Z.S., Frenchgate, Richmond, Yorks.

Linnean Society of London, The, Burlington House, W.

Lloyd, Robert Wylie, F.E.S., 1, 5 \& 6 Albany, Piccadilly, W. 
Longstaff, G. B., M.A., M.D., Vice-Pres. Ent. Soc., Lond., Highlands, Putney Heath, London, S.W.

Lowe, E. E. (Curator for Leicester Museum), Leicester.

MacDougall, Prof. R. Stewart, M.A., D.Sc., F.R.S.E., F.E.S., University, Edinburgh.

McGowan, Bertram, Linwood, Dumfries.

Manchester Museum, The University, Manchester (W. M. Tattersall).

Manchester, University of, Dept. of Agricultural Entomology.

Martineau, Alfred H., F.E.S., 54 Holly Lane, West Smethwick, Staffs.

Meade-Waldo, Geoffrey, M.A., F.E.S., 20 Douglas Mansions, Cromwell Road, London, S.W., and British Museum (Natural History).

Merrifield, F., Fast-Pres. Ent. Soc., Lond., 14 Clifton Terrace, Brighton.

Mitford, R. S., C.B., F.E.S., Thornlea, Weybridge, Surrey.

Monk, Lt.-Col., Burlton Lodge, Station Road, Barnes, London, S.W.

Morey, Frank, F.L.S., Wolverton, Newport, Isle of Wight.

Morford, Augustin, The Friary, Saltash.

Morice, Rev. F. D., M.A., Fellow of Queen's College, Oxford, Past-Pres. Ent. Soc., London, Brunswick, Mount Hermon, Woking. (2 copies.)

Morton, Kenneth J., F.E.S., 13 Blackford Road, Edinburgh.

Moulton, J. C., F.E.S., The Hall, Bradford-on-Avon, Wiltshire.

Municipal Museum and Art Gallery, Tavistock Place, Plymouth.

Nevinson, E. B., F.Z.S., F.E.S., Morland, Cobham, Surrey.

Nicholson, C., F.E.S., 35 The Avenue, Hale End, Chingford, Essex.

Page, H. E., F.E.S., Bertrose, Gellatly Road, New Cross, London, S.E.

Parkin, T., M.A., F.L.S., F.Z.S., Fairseat, High Wickham, Hastings.

Percival Pearse, Ltd., 8 Sankey Street, Warrington.

Perry, Rev. J. F., Stonor Park, Henley-on-Thames.

Pinkney, D. Ward, 9 Burgess Hill, Hampstead, N.W.

Plymouth Institution (per C. W. Bracken, B.A,, F.E.S., Joint Hon. Sec.), The Athenaeum, Plymouth.

Porritt, Geo. T., F.L.S., F.E.S., Elm Lea, Dalton, Huddersfield.

Poulton, E. B., D.Sc., M.A., F.R.S., etc., Pres. Linn. Soc., Past-Pres. Ent. Soc., Lond., Hope Prof. Zoology, Wykeham House, Oxford.

Pugh, Miss C., 45 Lancaster Gate, Hyde Park, W. (2 copies.)

Pugh, Miss Laura, 45 Lancaster Gate, Hyde Park, W. (3 copies.)

Radcliffe Library, Museum, Oxford.

Reid, Percy C., Feering Bury, Kelvedon, Essex.

Richardson, Henry, Librarian, Lit. and Phil. Society, Newcastle.

Robinson-Douglas, W. D., M.A., F.L.S., F.E.S., Orchardton, Castle Douglas, N.B.

Robinson, Lady, F.E.S., The Manor, Worksop, Notts.

Rothney, G. A. James, F.E.S., Pembury, 1 Tudor Road, Upper Norwood, London, S.E.

Rothschild, The Hon. N. Charles, M.A., F.L.S., F.Z.S., Pres. Ent. Soc., Lond., Arundel House, Kensington Palace Gardens, W.

Rothschild, The Right Honble, Lord, D.Sc., F.R.S., etc., Trustee Brit. Museum, Zoological Museum, Tring, Herts. (2 copies.)

Routledge, G. B., J.P., F.E.S., Tarn Lodge, Headsnook, Carlisle. 
Saltren-Willett, Mrs. A. E., Manor House, Padworth, Reading.

Scott, Hugh, M.A., F.E.S., University Museum of Zoology, Cambridge.

Sennett, Lieut. Noël S., F.E.S., 32 Bolton Gardens, S. Kensington, S.W.

Sheldon, W. G., F.E.S., Youlgreave, South Croydon.

Sich, Alfred, F.E.S., Corney House, Chiswick, London, W.

Smallcombe, Wm. A., 62 Greenbank Road, Lower Easton, Bristol.

Steck, Dr. Theod., Museum of Nat. History, Berne, Switzerland.

St. Quintin, W. H., F.E.S., Scampston Hall, Rillington, York.

Taylor, S. O., 26 Nelson Street, Leicester.

Theobald, Prof. F. V., M.A., F.E.S., Wye Court, Wye.

Thornley, Rev. A., M.A., F.L.S., F.E.S., "Hughenden," Coppice Road, Nottingham.

Turner, H. J., F.E.S., 98 Drakefell Road, New Cross, London, S.E.

Under Secretary of State, Ministry of Agriculture, Cairo.

Walker, Commander James J., R.N., M.A., F.L.S., Sec. Ent. Soc., Lond., Aorangi, Lonsdale Road, Summertown, Oxford.

Wallace, Dr. Wm., 15 Hainton Avenue, Grimsby.

Walsingham, The Right Honble. Lord, M.A., LL.D., F.R.S., etc., High Steward of the University of Cambridge, Trustee Brit. Museum, etc., Past-Pres. Ent. Soc., Lond., etc., Cromwell Road, S.W.

Waterhouse, C. O., I.S.O., Past Pres. Ent. Soc., Lond., Ingleside, Avenue Gardens, Acton, W.

Watkins and Doncaster, 36 Strand, W.C. (3 copies.)

Webb, E. H., 12 Ashburton Road, Southsea.

Wesley and Son, Wm., 28 Essex Street, Strand, W.C. (4 copies.)

Wheeler, Prof. W. M., Bussey Institution of Harvard University, Forest Hills, Boston, Mass.

Wheldon and Co., John, 38 Great Queen Street, Kingsway, London, W.C. ( 2 copies.)

Whittaker, Oscar, F.E.S., Ormidale, Ashlands, Ashton-upon-Mersey, Cheshire.

Whittle, F. G., 7 Marine Avenue, Southend-on-Sea.

Wilkins, Col. W. H., Indian Army, c\% Messrs. Thos. Cook and Son, Ludgate Circus, London, E.C.

Williams, C. B., F.E.S., The Horticultural Institution, Mostyn Road, Merton, Surrey.

Wilson, A. Gordon, M.D., F.R.C.S., 1 Philbeach Gardens, South Kensington, London, S.W.

Wood, H. Worsley, 31 Agate Road, Hammersmith, W.

Woodruff-Peacock, Rev. E. Adrian, F.L.S., F.E.S., F.G.S., Cadney Vicarage, Brigg, Lincs.

Wyman and Sons, Ltd., Government Collecting Dept., Ireland Yard, St. Andrew's Hill, London, E.C.

Zoological Society of London, The, Regent's Park, London, N.W. 
SUBSCRIPTIONS RECEIVED TOO LATE FOR ALPHABETICAL ARRANGEMENT.

Allen, J. W., 266 Willesden Lane, Cricklewood, London, N.W.

Library of the Royal Swedish Academy of Sciences (Dr. J. A. Bergstedt, Librarian), Stockholm. 


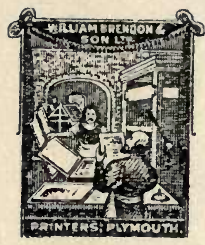



THIS BOOK IS DUE ON THE LAST DATE STAMPED BELOW

AN INITIAL FINE OF 25 CENTS WILL BE ASSESSED FOR FAILURE TO RETURN THIS BOOK ON THE DATE DUE. THE PENALTY WILL INCREASE TO 50 CENTS ON THE FOURTH DAY AND TO $\$ 1.00$ ON THE SEVENTH DAY OVERDUE.

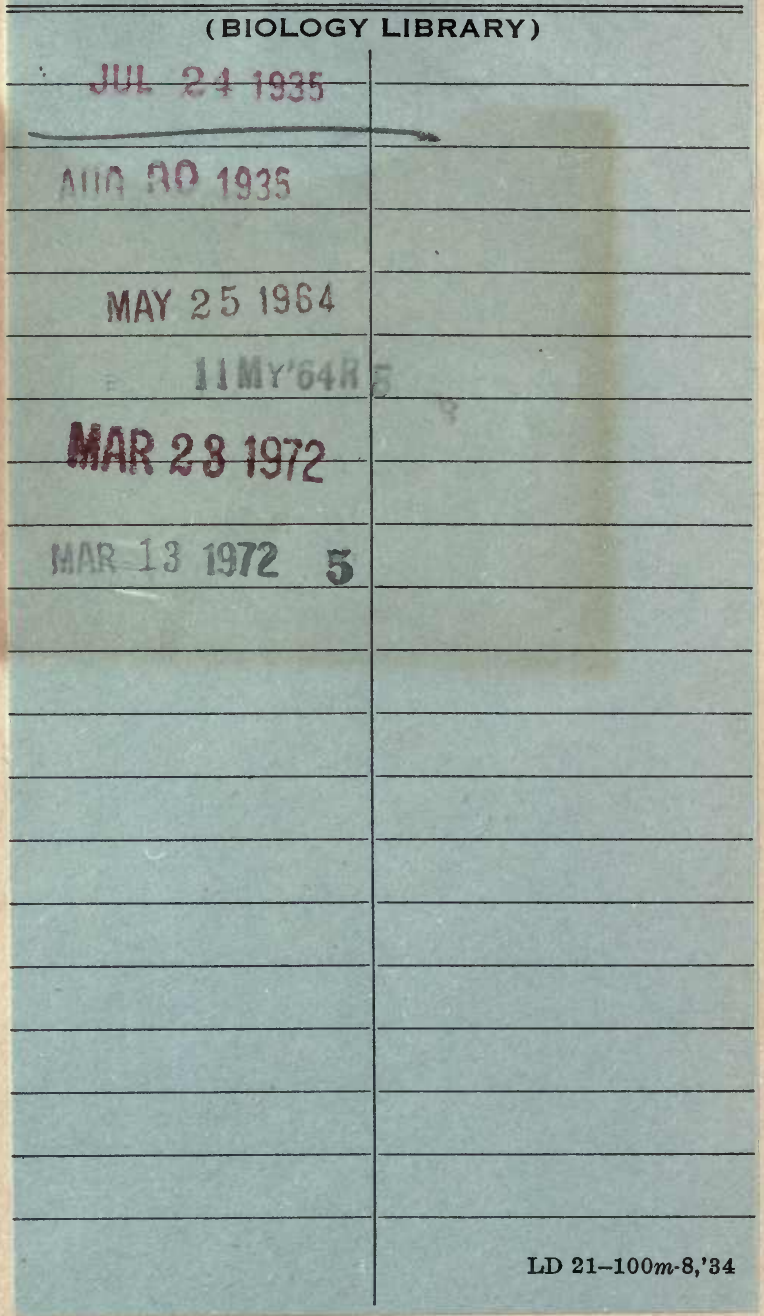




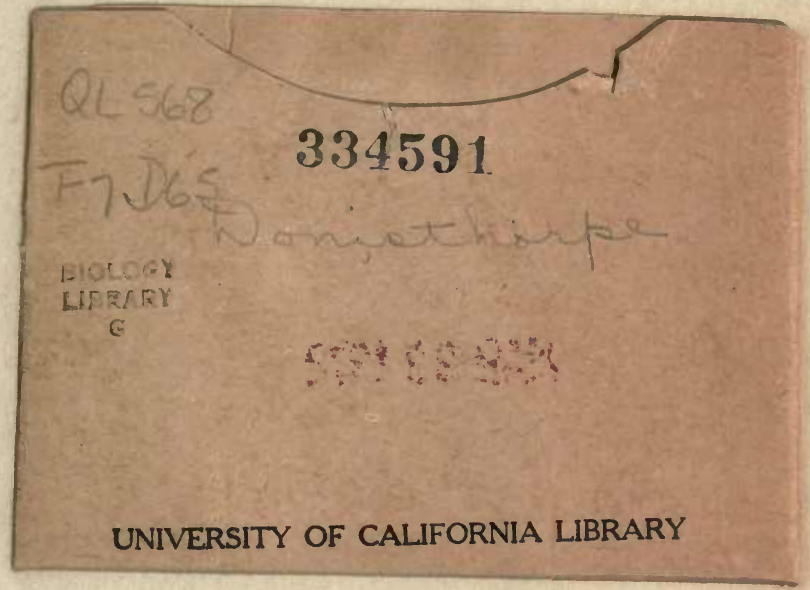


